Cenozoic Geology of the Granite Mountains Area, Central Wyoming

GEOLOGICAL SURVEY PROFESSIONAL PAPER 495-G

Prepared in cooperation with the Geological Survey of Wyoming and the Department of Geology of the University of Wyoming as part of a program of the Department of the Interior for development of the

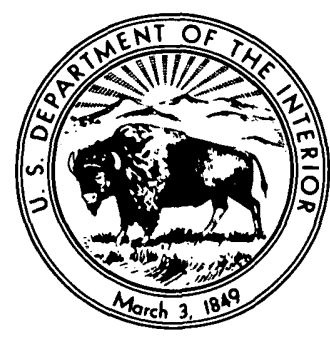
Missouri River basin 
CENOZOIC GEOLOGY OF THE GRANITE MOUNTAINS AREA, CENTRAL WYOMING 


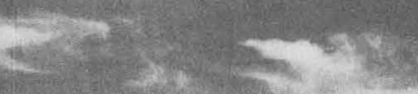

\section{L}

K

I

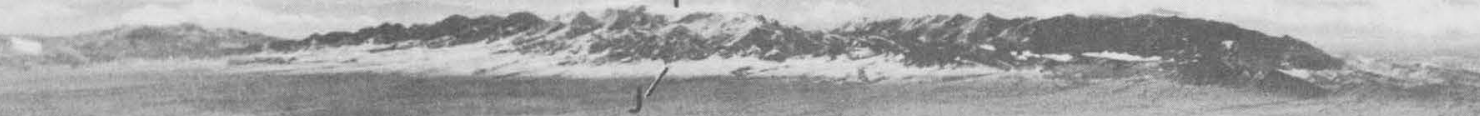
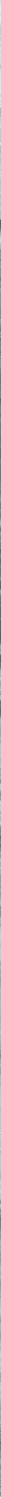

Granite Mountains, the only major uplift in Wyoming composed of Precambrian igneous and metamorphic rocks that are still largely buried by Miocene and Pliocene strata. View southeast toward gentle dip slope of Agate Flats in Split Rock Formation (A); type section of Moonstone Formation on White Ridge (B); two Precambrian granite peaks, Lankin Dome (C) and MeIntosh Peak (D); highest and youngest remnant of Moonstone Formation (E); surface beveling Precambrian rocks, which probably mark uppermost limit of burial of mountains (F); "soda lake" on upper part of Split Rock Formation (G); broad flat underlain by Split Rock syncline $(H)$; Ferris Mountains (I) bounded on the north by a major post-Miocene normal fault at break in slope $(\mathrm{J})$; Medicine Bow Mountains (K); Park Range, Colo. (L); and partially exhumed ridge of Precambrian igneous and metamorphic rocks (M). Oblique aerial photograph by $\mathrm{P}$. T. Jenkins and L. P. House. 


\section{Cenozoic Geology of the Granite Mountains Area, Central Wyoming}

By J. D. LOVE

GEOLOGY OF THE WIND RIVER BASIN, CENTRAL WYOMING

GEOLOGICAL SURVEY PROFESIONAL PAPER 495-C

Prepared in cooperation with the Geological

Survey of Wyoming and the Department of

Geology of the University of Wyoming as

part of a program of the Department of

the Interior for development of the

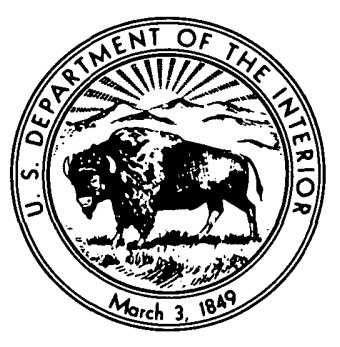

Missouri River basin

Cenozoic history of a major mountain range and

its influence on stratigraphy and economic

resources in adjacent sedimentary basins

UNITED STATES GOVERNMENT PRINTING OFFICE, WASHINGTON : 1970 
UNITED STATES DEPARTMENT OF THE INTERIOR

WALTER J. HIGKEL, Secretary

\section{GEOLOGIGAL SURVEY}

William T. Pecora, Director

For sale by the Superintendent of Documents, U.S. Government Printing Office Washington, D.C. 20402 


\section{CONTENTS}

Abstract.

Introduction

History of investigation.

Acknowledgments.

Problems of nomenclature of geologic features........

Granite Mountains versus Sweetwater uplift. ..... -

Great Divide basin versus Red Desert basin ......

Economic geography

Topography and drainage.

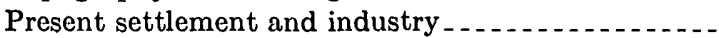

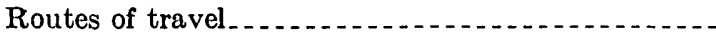

History of settlement and development.

Climate. - _. -

Precambrian rocks

Stratigraphy of pre-Tertiary sedimentary rocks.

Stratigraphy of Tertiary sedimentary rocks.

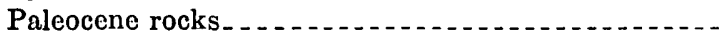

Fort Union Formation.

Name and definition . .

Distribution and thickness. . . .

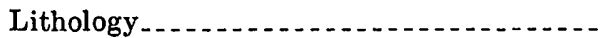

Stratigraphic and structural relations......

Age and correlation. .....

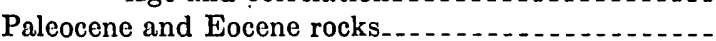

Wasatch and Battle Spring Formations.......

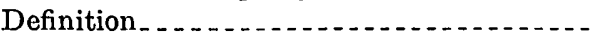

Distribution and thickness.

Lithology . . . . . . . .

Stratigraphic and structural relations.....

Age and correlation. . .

Eocene rocks.....

Crooks Gap Conglomerate.....................

Name and definition.

Distribution and thickness. . . . . . . . . .

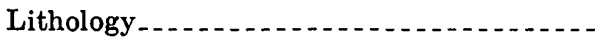
Stratigraphic and structural relations.....Age and correlation.....

Tongues of Wasatch and Green River Formations in Great Divide basin......... Cathedral Bluffs Tongue of Wasatch

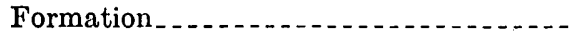
Laney Shale Member of Green River Formation . . .

Indian Meadows Formation

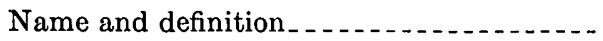

Distribution and thickness.......

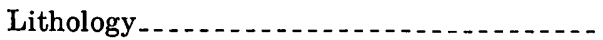
Stratigraphic and structural relations...... Age and correlation...........................

Wind River Formation. Name and definition. . . . . Distribution and thickness. Lithology - . _:_-_. Stratigraphic and structural relations......

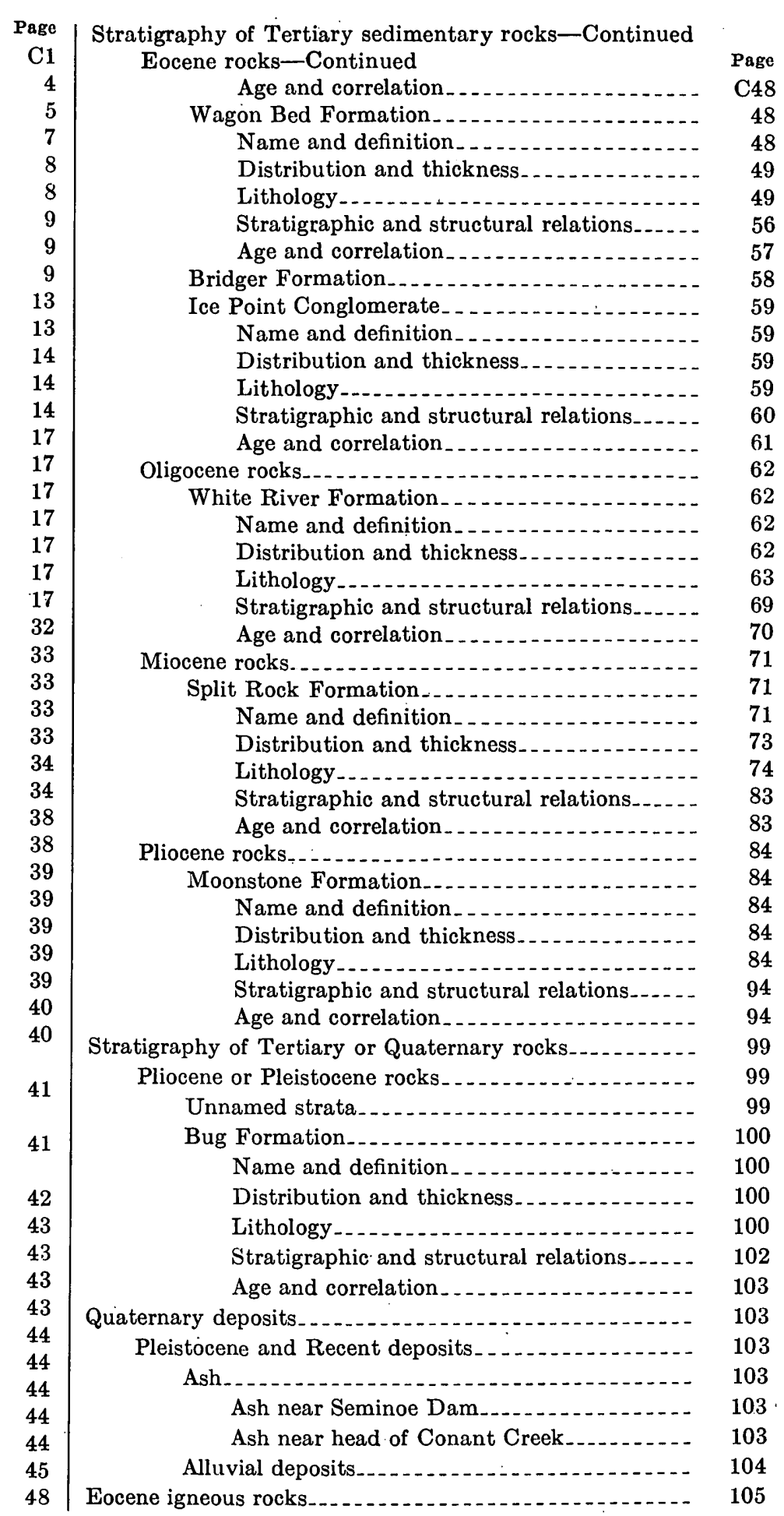


Summary description of structural features-as

Bare Ring Butte graben -106

Beaver Creek thrust fault......................... 106

Bison Basin-Antelope-Bare Ring (Barren) Butte anticlinal complex.

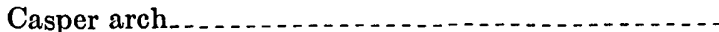

Continental normal fault. . . . . . . . . .

Cyclone Rim syncline............................

Emigrant Trail thrust fault. . .

Flattop fault. .

Granite Mountains.

Great Divide basin

Mormon Trail fault............................

North Granite Mountains fault system ...........

Rattlesnake Hills volcanic field and associated structures.....................................

South Granite Mountains fault system . . . . . . . . .

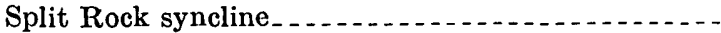

Sweetwater Crossing anticline.....................

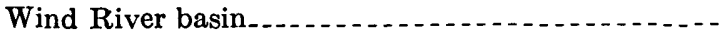

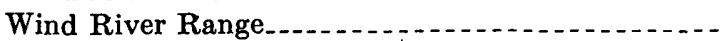

Wind River thrust fault system . .................

Geologic history and its relation to economic potential - -

Late but not latest Cretaceous. . . . . . . . . . . . . .

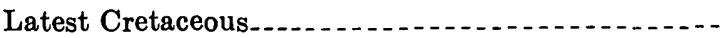

Paleocene

Earliest Eocene.....

Early Eocene............

Transition from early to middle Eocene........

Middle Eocene. . . .

Late Eocene. . . . . . . . . . . .

Oligocene

Miocene
Geologic history and its relation to economic potentialContinued

Early to middle(?) Pliocene-

Late Pliocene or early Pleistocene............. 120

Middle Pleistocene to Recent.................. 121

Summary of structural phases in the development of the Granite Mountains.......................... 122

Deposits of economic or scientific interest. . .

Uranium . . . . . . . . 123 Gas Hills district. Crooks Gap district. . . .

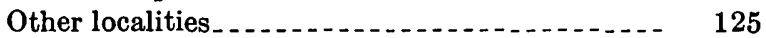
Origin of uranium deposits................ 129 Areas warranting further exploration......... 133

Thorium............. 134

Oil and gas.

Oil-saturated sandstone..................... 135

Coal. ..............

Pumicite and ash........................... 137

Zeolites and other clay minerals.

Soda lakes........... 137

Jade

Agates.

Rubies, sapphires, and colorless corundum . . . . . . 140

Spodumene. . . .

Chromium. . .

Iron

Gold, silver, lead, copper, and molybdenum...... 140

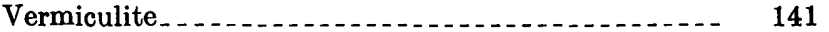

Sand and gravel.

Ground-water potential . . . . . . . . . 141

References cited...... 142

Index

\section{ILLUSTRATIONS}

[Plates are in separate map case]

Frontispiece. Photograph of the Granite Mountains, the only major uplift in Wyoming composed of Precambrian igneous and metamorphic rocks that are still largely buried by Miocene and Pliocene strata.

Plate 1. Geologic map and sections $A-A^{\prime}$ to $D-D^{\prime}$, Granite Mountains area.

$A-A^{\prime}$, Interpretive restoration of the relations of Eocene and Paleocene rocks to older rocks at the end of Eocene deposition.

$B-B^{\prime}$, Eocene and Paleocene rocks from Great Divide basin to Flattop Buttes.

$C-C^{\prime}$, Relations of Tertiary rocks in the Happy Springs-Soap Holes area.

$D-D^{\prime}$, Interpretive restoration showing relations of Tertiary rocks on opposite sides of South Granite Mountains fault system at Happy Springs oil field prior to post-Miocene faulting and erosion.

2. Topography and drainage of the Sweetwater River valley and adjacent areas.

3. Stratigraphic and structure sections, $E-E^{\prime \prime}$ to $N-N^{\prime}$, in the Granite Mountains area.

$E-E^{\prime \prime}$, From Crooks Mountain to Bare Ring Butte.

$E^{\prime \prime \prime}-E^{\prime}$, From Crooks Peak to well 157.

$F-F^{\prime}$, South margin of Granite Mountains at east end of Green Mountain.

$G-G^{\prime}$, From Granite Mountains south across Split Rock syncline and Ferris Mountains.

$H-H^{\prime}$, From Granite Mountains to southeast arm of Wind River basin.

$I-I^{\prime}$, From Great Divide Basin to Horsetrack anticline.

$J-J^{\prime}$, Across South Granite Mountains fault north of Crooks Gap.

$K^{\prime}-K^{\prime \prime}$, Across Long Creek arm of Wind River basin and Emigrant Trail thrust fault.

$L-L^{\prime}$, Across Emigrant Trail thrust fault near Sweetwater River.

$M-M^{\prime}$, Across Emigrant Trail thrust fault.

$N-N^{\prime}$, Across Emigrant Trail thrust fault. 
Plate 4. Stratigraphic and structure sections, $K-K^{\prime \prime}$ to $W-W^{\prime}$, in the Granite Mountains area.

$K-K^{\prime \prime}$, From Sweetwater Crossing anticline northeastward across Long Creek arm of Wind River basin to Granite Mountains.

$L-L^{\prime}$, Across Emigrant Trail thrust fault near Sweetwater River.

$M-M^{\prime \prime}$, Across western part of Split Rock syncline and Emigrant Trail thrust fault.

$N-N^{\prime}$, Across Emigrant Trail thrust fault.

$O-O^{\prime}$, Between Beaver Divide and Crooks Mountain.

$P-P^{\prime}$, Near west end of Crooks Mountain.

$Q-Q^{\prime}$, Split Rock syncline north of Crooks Mountain and Green Mountain.

$R-R^{\prime}$, From Sweetwater River valley around west end of Crooks Mountain to Great Divide basin.

$S-S^{\prime}$, Between the Great Divide basin and the Sweetwater River valley.

$T-T^{\prime}$, Tertiary rocks northeast of Crooks Mountain.

$U-U^{\prime}$, Across northwestern part of Split Rock syncline.

$V-V^{\prime}$, From South Sand Draw oil and gas field southeast across Beaver Divide to Long Creek gas field.

$W-W^{\prime}$, Tertiary rocks across North Granite Moutains fault system in southwestern part of Gas Hills area.

5. Thickness maps of some Tertiary formations in the Granite Mountains area.

6. Structure contour maps of some Tertiary formations in the Granite Mountains area.

7. Generalized geologic map of western part of Granite Mountains showing outcrops of Paleocene Fort Union Formation and older rocks and major existing faults during early Eocene time.

8. Electric-log characteristics of Split Rock, White River, and Wagon Bed Formations.

9. Tectonic sketch map of Granite Mountains area.

10. Maps of Granite Mountains area during successive stages of structural development.

Figun: $\quad$ 1. Map of Wyoming showing location of Granite Mountains area

2. Map of Wyoming showing relation of Granite Mountains area to major structural basins containing Eocene and Paleocene rocks and to major Eocene and younger uplifts

3. Photograph of relief map of Granite Mountains area

4. Photograph, view northeast from east end of Green Mountain

5. Photograph, view east from east end of Green Mountain

6. Oblique aerial photograph, view northwestward across Ferris Mountains

7. Oblique aerial photograph, view south across Gas Hills area

8. Oblique aerial photograph showing relation of Moonstone Formation to Precambrian core of Granite Mountains........

9-16. Photographs showing:

9. Surface of the Moonstone, a Precambrian massive granite monolith

10. Lankin Dome from the south. . .

11. East side of Lankin Dome.....

12. Split Rock, a pioneer landmark on the Oregon Trail

13. Fort Union Formation, east side of Crooks Gap

14. Structural relations of Upper Cretaceous, Paleocene, Eocene, and Oligocene rocks along north margin of Great Divide basin . . . .

15. Angular unconformity between Crooks Gap Conglomerate and the Wasatch and Battle Spring

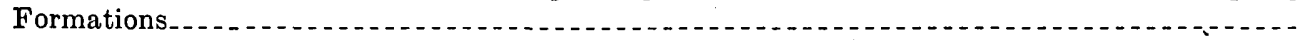

16. Coarse-grained gray arkosic sandstone in the Wasatch and Battle Spring Formations...........

17. Oblique aerial photograph, view east showing western part and north face of Crooks Mountain ........ 18-34. Photographs showing:

18. Basal part of Crooks Gap Conglomerate on the north face of Sheep Mountain . . . . . . . . . . . .

19. View southwest from Rogers Mountain

20. Type section of Halfway Draw Tuff Member of the Wind River Formation.

21. Lower part of Wagon Bed Formation................

22. Physical appearance and contact relations of Split Rock, White River, and Wagon Bed Formations.

23. Roadcut along abandoned route of U.S. Highway 287, Beaver Divide escarpment. . . . . . . . .

24. Green Cove classic section of Tertiary rocks on Beaver Divide

'25. Structural relations of Pennsylvanian and lower, middle, and upper Eocene rocks along the north margin of the Great Divide basin . . . . . . . . .

26. View east across Alkali Creek, showing relations of Cretaceous, Eocene, and Oligocene rock units.-

27. Contact between basal conglomerate of Split Rock Formation and White River Formation......

28. Outcrop of Beaver Divide Conglomerate Member of White River Formation . . . . . . . . . . .

29. Andesite boulders in Beaver Divide Conglomerate Member of White River Formation.........

30. Sweetwater moss agates from the lower porous sandstone sequence in the Split Rock Formation at type locality . . . .

31. View north at fossil locality 14P, showing upper part of Split Rock Formation at type locality ....

32. Type locality of Split Rock Formation

33. Algal limestone reefs in Split Rock and Moonstone Formations

34. Bluish-gray pumicite marker bed in upper porous sandstone sequence in Split Rock Formation .... 

in Oligocene and younger strata contrasted with those of the Pierre Shale and other marine Cretaceous shales.

36-43. Photographs showing:

36. Nearly vertical contact between soft sandstone of the Split Rock Formation and hard unweathered Precambrian granite

37. Type section of Moonstone Formation

38. Thin-bedded strata in type section of Moonstone Formation

39. Agates weathering out of tuff in lower part of Moonstone Formation .

40. Interlaminated white shale and dark-brown chalcedony in type section of Moonstone Formation - -

41. Bulbous masses of brown sandy tuffaceous rock, possibly algal reefs, interbedded with white tuff, in type section of Moonstone Formation . . .

42. Pliocene strata half a mile south-southeast of well 225

43. Section of black shale member of Moonstone Formation

44. Oblique aerial photograph showing type section of Moonstone Formation

45. Photograph of type section of Bug Formation.

46. Oblique aerial photograph, view east across Seminoe Dam

47. Photograph of Pleistocene ash bed near Seminoe Dam

48. Photograph of Pleistocene ash bed in south wall of Conant Creek phosphate trench

49. Oblique aerial photograph, view southwest toward northeast margin of Crooks Gap.

50. Photograph of North Granite Mountains fault system along south margin of the Rattlesnake Hills... ...

51. Oblique aerial photograph, view west along South Granite Mountains fault system

52. Photograph showing Black Canyon cut by the North Platte River through the Seminoe Mountains.....53-56. Oblique aerial photographs showing:

53. Complexly faulted west end of Crooks Mountain

54. View south in T. 28 N., R. 94 W. . . . . .

55. View east along East Diamond Springs segment of North Granite Mountains fault system .......

56. View northeast showing uranium strip mines in Wind River Formation

57. Photograph showing Precambrian rocks at portal of Little Man uranium mine

58. Photograph showing Cheyenne Mining Co. uranium strip mine in upper part of Wagon Bed Formation...-

59. Photograph showing oil-saturated arkosic sandstone comprising the uranium ore bed in the Cheyenne Mining Co. strip mine.

60. Map showing outcrop of white shale uranium marker bed and of thorium- and uranium-bearing limestone in Moonstone Formation.

61. Photograph showing wind-faceted nephrite jade boulders

\section{TABLES}

1. Summary description and correlation of pre-Tertiary sedimentary rocks in the Granite Mountains area...-

2. Data on numbered wells and core holes in the Granite Mountains area

3. Summary description and correlation of Cenozoic sedimentary rocks in the Granite Mountains area.. In map case

4. Paleocene pollen from drill cuttings.

5. Potassium-argon ages of Oligocene and Eocene rocks in the Granite Mountains area, along the north margin of the Wind River basin, and in the Absaroka Range.

6. Semiquantitative spectrographic analyses of ash, pumicite, tuff, and tuffaceous claystone of Cenozoic age and Precambrian granite.

7. Rock analyses of pumicite and other tuffaceous strata of Cenozoic age, and of the Eocene and Precambrian age igneous rocks in central and northwestern Wyoming _.....

8. Names and ages of Oligocene and younger Cenozoic rock units in the Granite Mountains and Wheatland areas, Wyoming, and in western Nebraska

9. Numbered localities, other than fossil, indicated on geologic map and discussed in text

10. Numbered fossil localities indicated on geologic map and discussed in text

11. Uranium analyses of samples from Bug and Moonstone Formations

12. Diatoms in the Split Rock, Moonstone, and Bug Formations.

13. Pollen from black shale member of Moonstone Formation. 


\title{
GEOLOGY OF THE WIND RIVER BASIN, CENTRAL WYOMING
}

\section{GENOZOIG GEOLOGY OF THE GRANITE MOUNTAINS AREA, GENTRAL WYOMING}

\author{
By J. D. Love
}

\begin{abstract}
The Cenozoic history of the Granite Mountains of central Wyoming was one of growth, burial, subsidence, and partial exhumation. These events affected the stratigraphy and economic resources in the Wind River basin to the north and the Great Divide basin to the south.

The Granite Mountains are unique in Wyoming because they remain partly buried by upper Cenozoic sedimentary deposits, whereas other mountain ranges have been almost entirely exhumed and their Cenozoic sedimentary record thus destroyed. Preservation of the sedimentary strata on the Granite Mountains was made possible by collapse of almost the entire uplift during late Cenozoic time, either prior to or contemporaneously with the epeirogenic uplift that launched the present cycle of regional degradation.

Most of the clastic debris in the lower Eocene rocks and some of that in younger sequences were derived from Precambrian rocks which are 1,450-2,900 million years old and which form the core of the Granite Mountains. The Precambrian rocks consist mainly of pink and gray granite and, in the western and northern parts of the area, of a thick sequence of metasedimentary rock; they also include some granite gneiss and mafic dike rock, and they are the source of the nephrite jade boulders found in the Eocene and younger rocks of the area.

Tertiary rocks surround and overlap the Granite Mountains on all sides. The Fort Union Formation of Paleocene age is farthest from the mountain core and consists of as much as 3,000 feet of dark-gray-brown largely noncalcareous shale and claystone, fine-grained gray and brown sandstone, and lenticular chert-pebble conglomerate. Many coal beds are present in the thickest sections. The Fort Union Formation rests unconformably on Cretaceous rocks. The Precambrian core of the Granite Mountains was exposed during Paleocene time but furnished much less arkosic debris than it did in the Eocene.

The most violent movements of the Laramide Orogeny in central Wyoming came during earliest Eocene time. The Granite Mountains rose as a block 90 miles long and $\mathbf{3 0}$ miles wide, and their western part was thrust west and southwest over the Long Creek a rm of the Wind River basin. This arm is a syncline that connects with the Great Divide basin. West of the Long Creek syncline is the Sweetwater Crossing anticline which is 20 miles long and 4 miles wide. It was folded, thrust southwest onto Cretaceous rocks, and eroded to its Precambrian core during earliest Eocene time. Still farther west, the rising Wind River Range, even larger than the Granite Mountains, was thrust southwest over the Great Divide and Green River basins.
\end{abstract}

The Wasatch and Battle Spring Formations of early Eocene and Paleocene age extend southward from the Granite Mountains into the Great Divide' basin and reflect this spasm of the orogeny. This flood of clastic debris, consisting of 4,500 feet or more of arkosic conglomerate, sandstone, and mudstone derived from the mountain uplift, was deposited unconformably across all rocks from Precambrian to Paleocene in age near the Granite Mountains. Farther south in the Great Divide basin, the unconformity has not been recognized. In the Crooks Gap area, the sequence is the host rock for uranium deposits and in many places contains coal beds of minable thickness.

The overlying Crooks Gap Conglomerate is a fan of giant granite boulders, in places nearly 1,500 feet thick, that spread southwestward from a mountain block that was raised vertically as much as 3,000 feet during the initial movement along the South Granite Mountains fault system at about the time of transition from early to middle Eocene. This fault system parallels the eastern part of the Emigrant Trail thrust but diverges westward from it at Crooks Gap.

Intertonguing with and overlying the upper part of the Wasatch and Battle Spring Formations are tongues of the Green River Formation. All are of early or middle Eocene age. From oldest to youngest, these subdivisions are the Luman Tongue of the Green River, the Niland Tongue of the Wasatch, the Tipton Tongue of the Green River, the Cathedral Bluffs Tongue of the Wasatch, and the Laney Shale Member of the Green River Formation. The tongues of the Green River consist chiefly of oil shale, thin limestone, and gray lacustrine shale. The tongues of the Wasatch are composed of gray and brown arkosic sandstone and conglomerate and variegated mudstone; the Niland Tongue and older strata in the Wasatch Formation contain numerous coal beds. A hitherto unrecognized unconformity at or slightly below the base of the Cathedral Bluffs Tongue in the southwestern part of the Granite Mountains area suggests that this tongue originally lapped northward across the older parts of the Wasatch and Battle Spring Formations.

At the south end of the Wind River Range, the Laney Shale Member laps northward onto the basal beds of the Wasatch Formation.

Above the Laney Shale Member is the Bridger Formation of middle Eocene age; it is a green tuffaceous lacustrine and fluviatile sequence of 'mudstone, limestone, and sandstone as much as 500 feet thick in places.

North of the Granite Mountains, lower Eocene rocks are represented by the Indian Meadows Formation of earliest Eocene age and by the Wind River Formation of early Eocene age. Like the Wasatch and Battle Spring Formations, they were derived by erosion of the adjacent uplifted mountain core. The 
Indian Meadows is exposed only in the southeast arm of the Wind River basin - in the northeast corner of the Granite Mountains area. This formation, which thins and disappears southward from a thickness of more than 6,000 feet in the deep part of the basin, consists of conglomerate made up of Paleozoic and Precambrian rock fragments and of sandstone and variegated mudstone. Most of this debris came from the Granite Mountains. Unconformably overlying the Indian Meadows and older rocks is the Wind River Formation, which is present along the entire north flank of the mountains. It consists of as much as 5,000 feet of conglomerate, arkosic sandstone and variegated mudstone. In the upper part is the felsic Halfway Draw Tuff Member, which is the oldest mappable unit of Cenozoic pyroclastic rock to be deposited in this area. The Wind River Formation is the host for large uranium deposits in the Gas Hills area.

At about the time of transition from early to middle Eocene, the North Granite Mountains fault system developed, probably contemporaneously with the initial movement on the South Granite Mountains fault system. Displacement of 1,000-5,000 feet along the northern fault system was vertical, and the mountain block was uplifted. This movement caused almost complete stripping of lower Eocene rocks from the Granite Mountains and partial stripping from the area to the west as far as the Wind River Range. The debris was incorporated in the Cathedral Bluffs Tongue and the Crooks Gap Conglomerate on the south side of the mountains and in the uppermost conglomeratic beds in the Wind River Formation and the overlying reworked basal conglomeratic strata of the Wagon Bed Formation on the north side. By this time the Granite Mountains were outlined in approximately their present form.

The Flattop fault probably originated during early Eocene time. Some movement occurred shortly after deposition of the Cathedral Bluffs Tongue. The north block was uplifted 1,0002,500 feet, and this unit and most of the Wasatch and Battle Spring Formations were stripped off before the final expansion of Gosiute Lake into the southwest corner of the Granite Moun tains area. By this time, the top of the Precambrian on the north side of the fault was approximately 20,000 feet above that on the south side. The Laney Shale Member was deposited in Gosiute Lake which, at the southeast margin of the Wind River Range, extended well across the temporarily quiescent fault. Next came deposition of the Bridger Formation, after which, during late Eocene time, the southern part of Wind River Range was uplifted. This caused a flood of coarse debris, the Ice Point Conglomerate, made up chiefly of Paleozoic rock fragments, to spread east and southeast of the Wind River Range in a series of fan deposits as much as 200 feet thick. Extensive erosion followed this episode of deposition and preceded the accumulation of the first Oligocene rocks.

Major Laramide compressional movements had ceased by middle Eocene time, and, as a consequence, the Wagon Bed Formation of middle and late Eocene age is the oldest Tertiary unit to be preserved on three sides of the newly shaped Granite Mountains. The formation consists of as much as 700 feet of green and yellow'soft bentonitic fluviatile and lacustrine deposits composed largely of felsic to maflc pyroclastic rock debris. The chief source of this debris in the western part of the area was the Absaroka Range. During middle and late Eocene time igneous and pyroclastic rocks composed principally of quartz latite, trachyte, and phonolite were extruded from about 35 vents in the Rattlesnake Hills. Before Oligocene time these vents became inactive and were then deeply eroded.
During the Oligocene, a powerful river that flowed southeast from the Absaroka Range, 90 miles northwest of the report area, deposited as much as $\mathbf{1 5 0}$ feet of coarse andesitic pyroclastic debris that makes up the volcanic facies of the Beaver Divide Conglomerate Member of the White River Formation. The rest of the White River consists of as much as 800 feet of white and grayish-orange tuffaceous siltstone that represents slightly reworked airborne debris.

The east-trending Split Rock syncline developed during Miocene time along what had formerly been the crest of the Granite Mountains. The Split Rock Formation, a vast sheet of windblown and waterlaid sand nearly 3,000 feet thick, accumulated in and adjacent to this downwarp and buried all but the highest parts of the mountains. Peaks of massive granite that projected above the sand plain weathered to remarkably smooth domeshaped knobs.

Events of great magnitude and significance occurred in central Wyoming during early to middle(?) Pliocene time. The area south of the Granite Mountains, extending from the Great Divide basin to the Hanna basin, was uplifted and tilted northward and was stripped of post-Eocene rocks by northwardflowing streams. In the Hanna basin, Upper Cretaceous rocks were exposed, and black shale of that age containing marine fossils was transported northward across the buried Seminoe Mountains and deposited on the Precambrian core of the Granite Mountains. The Split Rock syncline continued to sag, and the western part of the South Granite Mountains fault system was reactivated, but movement was in a direction opposite to that in Eocene time, for the mountain block dropped at least 1,000 feet.

Moonstone Lake formed in the Split Rock syncline. More than 1,000 feet of tuffaceous strata, making up the Moonstone Formation, accumulated in and adjacent to this lake. The presence of diatoms of saline habitat and of salt concentrations and the absence of mollusks suggest that the lake had little or no external drainage. Some lacustrine strata in this sequence are unusually rich in uranium and thorium and are believed to be source rocks for part of the uranium present in the Gas Hills and Crooks Gap uranium districts.

Regional uplift during late Pliocene and early Pleistocene time started the present cycle of degradation in most of central Wyoming. In the Granite Mountains area, however, reactivation of movement along the North Granite Mountains fault system and more widespread movement along the South Granite Mountains fault system caused the mountain block to drop farther, and the regional effect of a lowered base level was thus reduced. The easterly course of the Sweetwater River was established along the trough line of the Split Rock syncline, but the continued sagging of the Granite Mountains reduced the ability of this stream to erode. Thus, only 1,000 feet of the buried crest of the mountains was exhumed. The sluggish river was trapped along a superimposed course across granite knobs. Recurrent movement at this time along the southeastern part of the Flattop fault was in the same direction as movement in Eocene time.

Elsewhere in Wyoming many other normal faults developed, commonly along or slightly on the mountainward side of buried Eocene thrust faults and almost invariably the mountain block collapsed. The south end of the Wind River Range dropped along the Continental fault. At least one highly saline lake was present south of the Rattlesnake Hills, and the Bug Formation accumulated in it. This sequence contains thin beds of uraniumand thorium-rich limestone and clastic debris from the adjacent volcanic cones. The North Platte River cut an antecedent course across the rising Seminoe Mountains. A broad east-trending up- 
warp in the southern part of the Wind River basin caused the Wind River to divert northward and its gradient to increase to several times that of the eastward-flowing Sweetwater River. Headward erosion by vigorous tributaries to the Wind River was responsible for development of the Beaver Divide. In the Gas Hills uranium district, tilting of the south flank of this broad young flexure in the Wind River basin was sufficient to reverse the normal northward downdip movement of uraniumcharged ground water. As a consequence, ground water in some places became static and in others moved southward down the new dip and was trapped against faults and other barriers. Many of the smaller uranium ore bodies were probably formed or modified at this time.

From middle Pleistocene to Recent, the Split Rock syncline, because of recurrent subsidence, remained the dominant feature that influenced erosion and deposition in the Granite Mountains area. Northward-flowing streams that crossed the synclinal trough line had difficulty maintaining their courses to the Sweetwater River; some, including Crooks Creek, did not maintain their courses and became ponded. Small-scale movement occurred on both the North and the South Granite Mountains fault systems.

The structural development of the Granite Mountains can be divided into eight phases:

1. Gradual vertical uplift of mountain arch, coinciding with subsidence of paralleling basins to north and south.

2. Increase in magnitude of vertical uplift of mountain arch and decrease in amount of subsidence of flanking basins.

3. Uplift of Granite Mountains predominating over subsidence of flanking basins, development of subsidiary folds with northwest trends, and development of thrust faults along steep flanks of mountains and anticlines.

4. Vertical uplift of the west-trending central part of the Granite Mountains and of the anticlinal and synclinal complex to the west along normal faults.

5. Relative stability of mountains and basins alike for 20 million years.

6. Subsidence of Granite Mountains arch and anticlinal and synclinal complex to the west and initial development of the east-trending Split Rock syncline across both the complex and the highest part of the Granite Mountains.

7. Epeirogenic uplift concomitant with downfaulting of the core of the Granite Mountains and areas to the west along the reactivated North and South Granite Mountains fault systems and continued subsidence of the Split Rock syncline.

8. Continued sinking of the Split Rock syncline, development of a broad east-trending arch in the southern Wind River basin, establishment of antecedent drainage across the Seminoe Mountains, and superposition of principal streams elsewhere. Major uranium deposits are present in lower Eocene rocks in the Gas Hills and Crooks Gap districts, and minor deposits and occurrences of mineralization are known in other places in Precambrian, lower, middle, and upper Eocene, Oligocene, Miocene, Pliocene, and Pleistocene strata. The broad geographic and stratigraphic distribution of the minor occurrences, and the origin of the major ones, can be explained by the interpretation that most of the uranium was leached from lacustrine tuff beds, containing syngenetic uranium, in the middle part of the Moonstone Formation. One 12-inch-thick bed still retains about 200 tons uranium per square mile. Eight somewhat more extensively leached zones are known. Ground water in the Moonstone has three times the uranium content of that in other formations outside the uranium districts.
High-sulfur oil from Paleozoic and Mesozoic rocks was introduced along porous and permeable Tertiary strata in both the Gas Hills and the Crooks Gap districts during the interval of maximum Cenozoic sedimentary load in post-Split Rock time. This oil migration could have been triggered by subsidence of the Granite Mountains, and elsewhere in central Wyoming, by epeirogenic uplift. The occurrence of oil staining in Eocene, oligocene, and Miocene rocks, and chiefly near uranium deposits, has received little attention. Secondary pyrite is commonly associated with the oil, and its presence would have created a favorable environment for deposition of uranium that had been leached from the Moonstone Formation. Uraniumbearing water from this formation moved laterally and downward along permeable channelways and faults in older rocks until it reached the lower Eocene host rocks in the Gas Hills area. It was prevented from spreading northward and being dissipated in the broad, deep part of the Wind River basin by the newly formed barrier of the gentle east-trending arch in the southern part of the basin. It could not escape eastward because of the upland barrier of pre-Wind River rocks, or westward because of permeability pinchouts in the host rocks. Late Pleistocene faulting and southward tilting locally modified the ore bodies, and some movement of uranium is still continuing.

The following areas may be worth additional prospecting for uranium : (1) An east-trending area 30 miles long and 10 miles wide in the northern part of the Great Divide basin south of Crooks Gap; (2) a structurally closed basin in the vicinity of well 269 ; (3) both sides of the North Granite Mountains fault system west of the Rattlesnake Hills and from the faults north to the Beaver Divide; (4) an area of oil-stained upper Eocene sandstone about 5 miles east of the Big Sand Draw oil and gas field; (5) the deep part of the Split Rock syncline.

The possibility of accumulation of oil and gas in facies traps, below unconformities, and in structural traps, or in a combination of all three, is especially good on and near the AntelopeBare Ring Butte anticlinal complex and also between the Lost Soldier oil field and Green Mountain. Small areas of lesser promise are the northwestern part of the Long Creek arm of the Wind River basin and the unnamed syncline north of Bison Basin.

One area of oil-saturated sandstone is worth further study. It is in the Wagon Bed Formation in the northwest half of $T$. 32 N., R. 94 W.

More than a billion tons of coal of unknown quality are present in Paleocene and lower Eocene rocks in the subsurface along the southwest margin of the Granite Mountains area. Many million tons of pumicite are present; the thickest and most abundant beds occur in the upper part of the Split Rock Formation in the central part of the Granite Mountains area and in the Moonstone Formation in the southeastern part. Thorium, oil shale, zeolites and clay minerals, soda lakes, jade, agates, rubies, sapphires, colorless corundum, spodumene, chrom. ium, iron, gold, silver, lead, copper, molybdenum, and vermiculite also occur. Sand and gravel are present in enormous quantities in various parts of the area.

The ground-water potential of the Split Rock Formation is excellent throughout a large part of the area, although in some places the water table is deep. Arkosic facies of lower Eocene rocks near the Granite Mountains have good ground-water potential. As the rocks become finer grained in the basins to the north and south, the potential decreases, and the total dissolved

${ }^{1}$ This report was submitted for publication in 1965 ; beginning in 1967, extensive exploration for uranium was carried on in parts of areas 1 and 3 . 
solids increase. Water resources of other formations are only of local significance.

\section{INTRODUCTION}

The Granite Mountains trend west-northwest across south-central Wyoming and make up a major upwarp whose partly exposed Precambrian core is 90 miles long and 20-35 miles wide (figs. 1-3, pls. 1-4). The area of this report comprises 3,000 square miles and includes all but the southeast end of the uplift.

This chapter is the third in a series of topical and areal studies that represent the final phase of the Wind River basin ${ }^{\prime}$ project. Published chapters are those by

\footnotetext{
2 Throughout this report, basin is used in the sense of a structural basin and is not capitallzed. The Wind River drainage basin does not include the southeastern arm of the structural basin; this arm drains
} into the Powder River and into the North Platte River.
Keefer (1965) and by Keefer and Van Lieu (1966). The Wind River basin project was launched in the mid1940 's as a long-range research study of the surface and subsurface stratigraphy, structure, geologic history, and economic resources of a large intermontane downwarp and its associated marginal uplifts. This particular basin was selected because a wide range of surface and subsurface geologic data are available for it and because it is in the middle of a region of many mountains and basins. The geological principles and the structural patterns, as well as the research techniques used to determine them, should be useful in adjacent areas where the record is either not as complete or not as well exposed.

About 150 man years were devoted to this project. It was conceived and directed by me for the first 13

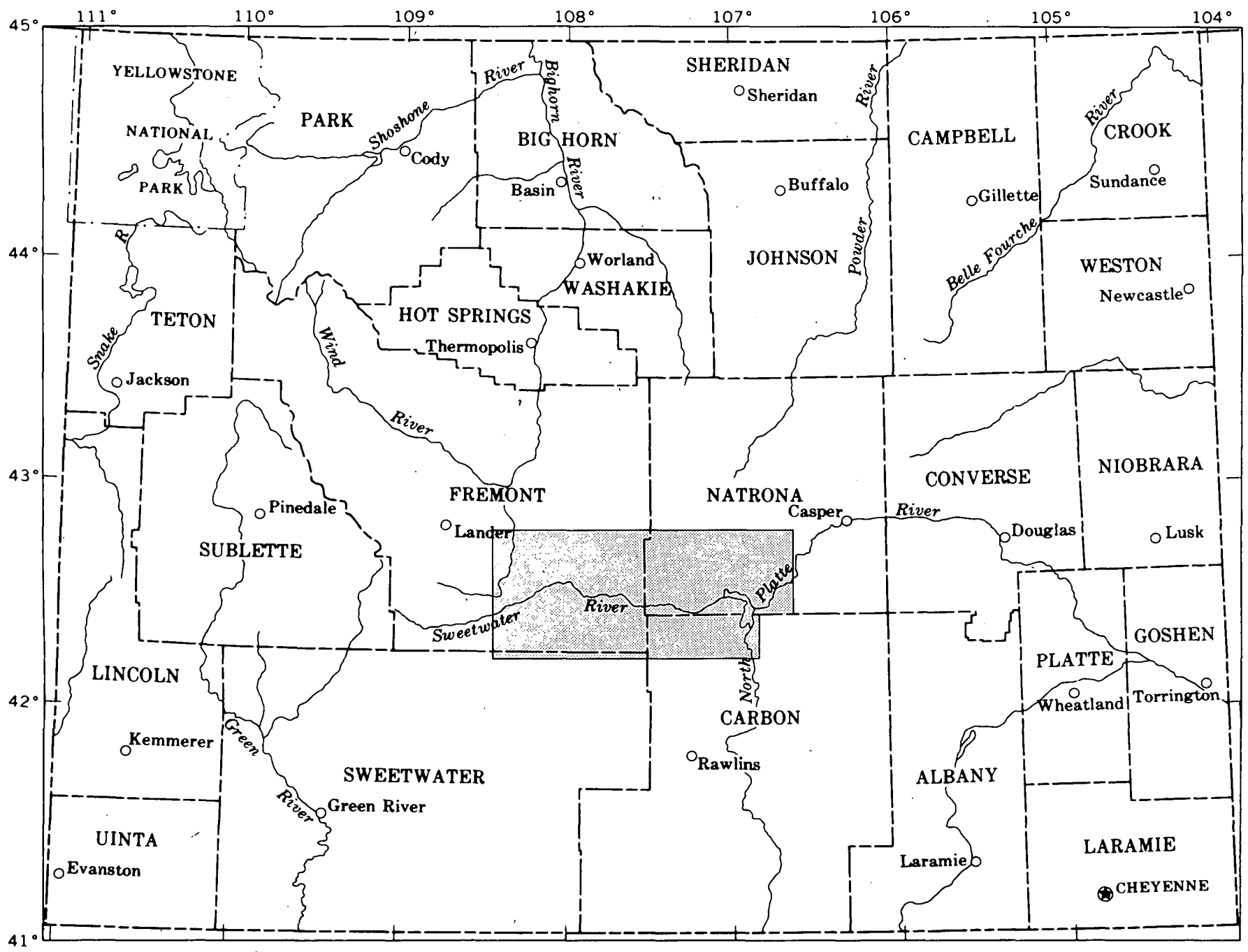

$\underbrace{50}_{1,150} 100$ MILES

FIGURE 1.-Location of Granite Mountains area (shaded). 
years and afterward was under the supervision of $W$. R. Keefer.

The Granite Mountains are unique in Wyoming because they remain partly buried by upper Cenozoic sedimentary deposits (see frontispiece), whereas other mountain ranges have been almost entirely exhumed and the Cenozoic sedimentary record thereby destroyed. Preservation of these strata on the Granite Mountains was made possible by subsidence of almost the entire uplift during late Cenozoic time, either prior to or contemporaneously with an epeirogenic uplift that launched the present cycle of regional degradation. The record of progressive burial of this mountain range during the last 60 million years is a classic example of what must have happened to the adjacent mountains. When information on the devel- opment of this mountain range is integrated with fragmentary data elsewhere in the State, a reconstruction of regional history of Cenozoic sedimentation and tectonism will be made possible

\section{HISTORY OF INVESTIGATION ${ }^{3}$}

An earlier study of the Miocene and Pliocene rocks of the Granite Mountains area (Love, 1961b) mentioned most of the previous reports on upper Tertiary strata. Eocene and Oligocene rocks along the northern margin of the area have been described by Van Houten (1964) and Love (1964). Uppermost Cretaceous, Paleocene, and lower Eocene rocks of the

3 The cutor date for incorporation of published references was 1965 when thls manuscript was submitted for publication. Data from a few wells drilled in 1966 were later included.

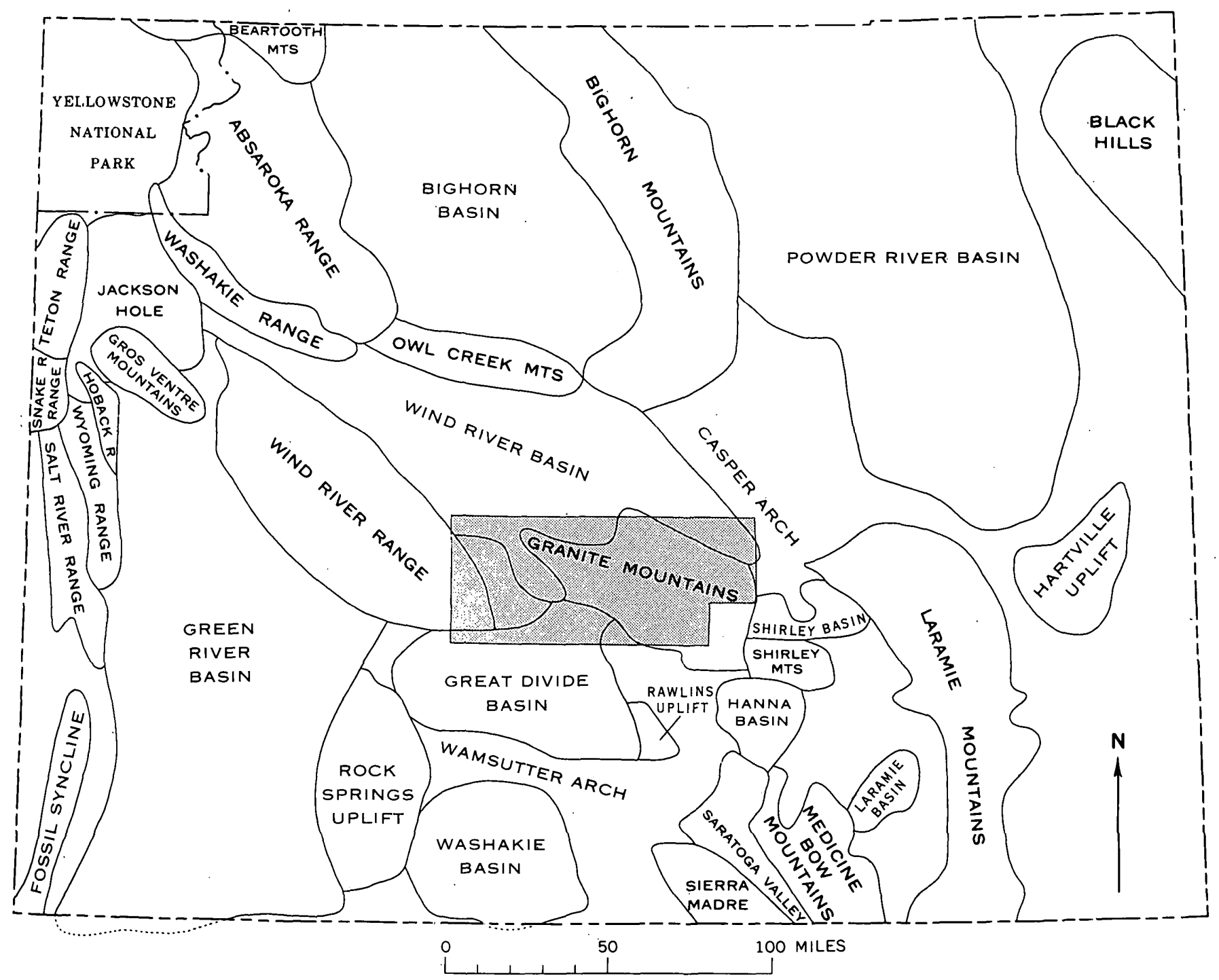

FIGUre 2.-Relation of Granite Mountains area to major structural basins containing Eocene and Paleocene rocks and to major Eocene and younger uplifts. Unnamed blank areas are neither major uplifts nor major basins. 


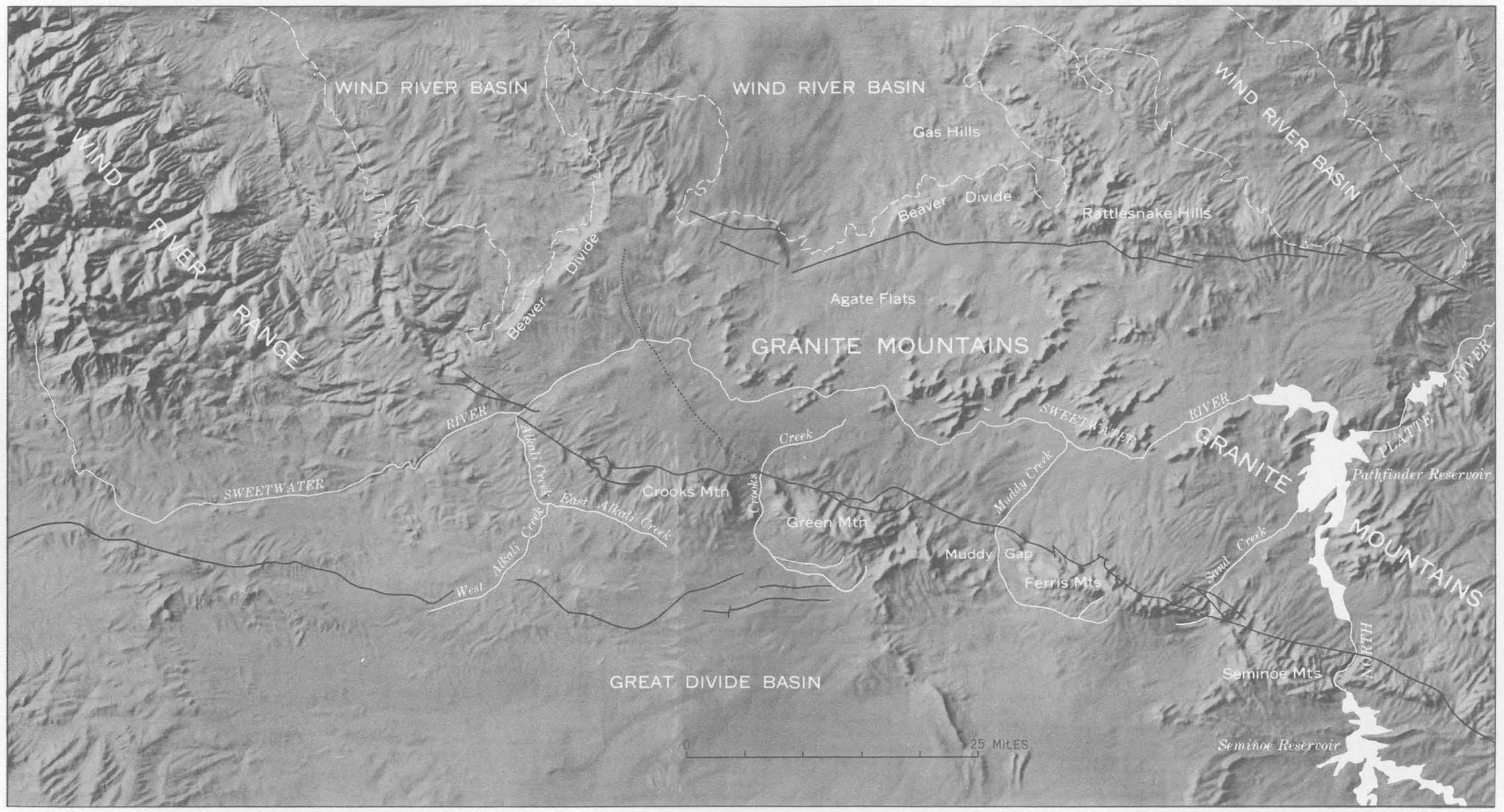

FIGURE 3.-Relief map of Granite Mountains area and surrounding vicinity showing major geographic features, major faults, and south boundary of Wind River Formation in the Wind River basin. Photograph of reverse sides of Casper and Lander $2^{\circ}$ quadrangles of U.S. Army Map Service relief maps. 
Wind River basin have been discussed by Keefer (1965).

Oil and gas production along the margins of the Granite Mountains (pl. 1) has been a sufficient economic incentive for oil companies to drill more than 275 wells and core holes through the Tertiary rocks in this area (table 2). Subsurface data obtained from these drillings were supplemented by information secured from many geophysical studies. The discovery of major quantities of uranium in the Gas Hills and Crooks Gap areas, on opposite flanks of the Granite Mountains (pl. 1), stimulated at least 100 man years of work on the Tertiary rocks by individuals and private, State, and Federal groups.

My studies and those by my associates included surface geologic mapping, measuring and sampling of many surface sections, microscopic examination of approximately 250,000 feet of drill cuttings, and correlation of electric logs on about 275 wells. Heavy-mineral separates, thin sections, size analyses, and specificgravity determinations, as well as spectrographic, rapid-rock, uranium and other analyses, were made of surface sample and drill cuttings. Water from many springs and wells in the region was analyzed for uranium by the U. S. Geological Survey. Collections of fossil vertebrates, mollusks, ostracodes, diatoms, and plants, including leaves, wood, pollen, spores and algae, were studied by specialists.

\section{ACKNOWLEDGMENTS}

This study has been made possible by the cooperation, encouragement, assistance, criticism, and contribution of data by many people during a period of 2.0 years. Studies around the margins of the Granite Mountains were aided by the collaboration of many U.S. Geological Survey colleagues. Especially helpful were the constant challenges supplied by N. M. Denson. W. R. Keefer, who assumed much of the responsibility for the Wind River basin program after 1956 , has been a valuable friend and counselor in both field and office studies. I also acknowledge with thanks and appreciation the help of D. E. Beardsley, W. G. Bell, D. L. Blackstone, Jr., Frank Byrne, John Chase, M. L. Dickey, Cotter Ferguson, C. K. Fisher, R. H. Guess, Leon Hetherington, L. P. House, Mr. and Mrs. Walter Irvin, J. E. Keenan, Charles Kortes, Halsey Kortes, John Kortes, A. L. Lyth, G. T. Mathers, P. O. McGrew, M. C. McKenna, Dan Meschter, Antonie Paap, E. I. Rich, R. L. Sielaff, M. F. Skinner, P. E. Soister, A. G. Speight, J. G. Stephens, H. A. Tourtelot, F. B. Van Houten, D. W. Wiger, H. B. Young, and H. D. Zeller.
R. G. Coleman generously furnished me with unpublished data on the mineralogy and geochemistry of the Gas Hills uranium deposits.

Isotope studies of carbon and sulfur in several limestones were made by E. S. Cheney, and carbon-oxygen isotope studies were done by MacKenzie Keith.

Ted Graham supplied data on old gold mines and prospects in Precambrian rocks of the Granite Mountains. P. T. Jenkins combined his geologic and photographic skills by generously using his personal plane piloted by L. P. House, to make many of the photographs used in this report.

U.S. Geological Survey paleontologists studied the fossils : K. E. Lohman and G. W. Andrews, the diatoms; D. W.Taylor, the mollusks; E. B. Leopold, the pollen; J. A. Wolfe, the leaves; R. A. Scott, the wood; G. E. Lewis, R. W. Wilson, F. C. Whitmore, and M. J. Hough, the vertebrates; and Richard Rezak, the algae. C. C. Black made available a list of fossil vertebrates he had identified from the Split Rock Formation. H. D. MacGinitie provided field identifications of middle Eocene floras that were too fragmentary and too fragile to be collected with the equipment available. E. L. Reid supplied pollen samples from drill cuttings in the northern part of the Great Divide basin.

R. S. Houston studied the thin sections and heavy mineral separates. R. F. Gantnier made mechanical analyses and specific-gravity determinations and prepáred heavy-mineral separates. Analytical data were obtained through cooperation of L. B. Riley, L. F. Rader, and W. W. Niles. J. N. Rosholt made extensive studies of thorium and associated elements in the Moonstone Formation. Theodore Botinelly made many X-ray determinations of claystone samples throughout the Tertiary section. Pumicites were studied by $\mathbf{H}$. A. Powers as part of his program of regional investigation of upper Cenozoic volcanic debris.

Mr. and Mrs. Bert A. Rhoads and Ralph Rhoads provided a photograph of jade boulders as well as information on the history of exploration for jade in central Wyoming.

This investigation has benefited greatly from the counsel of W. H. Bradley, whose studies showed for the first time how the fine-grained rocks in the Eocene basins of southwestern Wyoming can be directly related to events in the Granite Mountains and the Wind River Range.

The cooperation of S. H. Knight and D. L. Blackstone, Jr., of the Dapartment of Geology, University of Wyoming, and H. D. Thomas, State Geologist, through the years of this study has been of inestimable value. 
Between 1951 and 1955 that part of the investigation relating to uranium was done on behalf of the Division of Raw Materials of the U.S. Atomic Energy Commission and results have been published elsewhere. Some work along the south margin of the Wind River basin was done as part of the program of the Department of the Interior for development of the Missouri River basin.

\section{PROBLEMS OF NOMENCLATURE OF GEOLOGIC FEATURES}

The origin and definition of many names pertaining to the geography and geology of the Granite Mountains area are given in other parts of this report. However, two controversial names closely involved in this study must be defined to avoid possible confusion.

\section{GRANITE MOUNTAINS VERSUS SWEETWATER UPLIFT}

An unfortunate dual nomenclature has evolved for the mountain arch that is the subject of this study, largely because it no longer resembles an arch. In late Cenozoic time it was warped into a syncline and downfaulted so that its flanks in many places are higher than the crest (fig. $3 ;$ pl. 2), and most of the former arch is buried by Cenozoic strata. Some geologists use the term "Granite Mountains" both for the granite knobs that project above the Cenozoic deposits and for the major structural upwarp of which these knobs are the exposed part. Other geologists restrict the term "Granite Mountains" to the granite knobs and identify the upwarp variously as the Sweetwater uplift, arch, anticline, or mountains. A review of the evolution of the nomenclature shows that the most logical name for the entire arch is "Granite Mountains."

Maps of the trans-Mississippi West, compiled for the years 1540-1861 by Wheat (1958), show the history of names for various geographic features in this area. Maps by Franklin in 1845, Fremont in 1846, Fremont and Preuss in 1848, Bruff in 1849, Watson in 1850, and Stansbury in 1852, place the "Sweetwater Mountains" or "Sweetwater Hills" south of the Sweetwater River, in the position of Crooks Mountain, Green Mountain, and the Ferris Mountains (fig. 3). Fremont's 1846 map was the first to show "ridges and masses of naked granite destitute of vegetation" along and north of the Sweetwater River and to distinguish these granite masses from the "Sweetwater Mountains." Fremont and Preuss in 1848 called these granite masses the Rattlesnake Mountains, a name later restricted to a range of hills along the north margin of the area (fig. 3).

Hayden (1869, p. 77-78) casually mentioned the "Sweetwater Mountains," but the name does not appear on his colored geologic map of the area. Later he was more specific (Hayden, 1871, p. 29-30) :

Indeed, the Sweetwater valley is a sort of anticlinal, with the Seminole and Sweetwater hills on the south side, and the divide between the Wind River and Sweetwater on the north. The northern portion of the anticlinal is seen only for ten to twenty miles near the Three Crossings, where the lower Silurian and carboniferous beds are shown over a restricted area. The numerous granite ridges which are scattered all through this valley are most probably remnants of a vast mountain nucleus, from which the unchanged rocks inclined on either side.

Comstock (1875) likewise placed the "Sweetwater Mountains" south of the Sweetwater River.

Endlich, in the first comprehensive report on the Sweetwater district $(1879$, p. 5-158), specifically defined both the "Sweetwater Hills" and the "Granite Hills" (p. 43-45). He stated, "The Sweetwater Hills and their eastern extension, the Seminole Group, have a trend of nearly east and west, forming the last range from the Sweetwater [River] southward to the Union Pacific Railroad." He used this name in a structural as well as a physiographic sense, for on page 95 he commented, "We may essentially consider the Sweetwater Hills as a small anticlinal range, forming a continuation of the anticlinal upheaval east of the Wind River Mountains." With respect to the "Granite Hills," Endlich stated (p. 45):

Nearly the whole mass of these hills remains north of the Sweetwater, and only small isolated fragments of the granite make their appearance south of the river until we reach the Devils Gate.*** [See pl. 1, this report.] On several maps the inscription Granite Hills or Granite Ridges may be found. It is to be presumed that these names were put on rather to convey some definite information than to represent the appellation given to the group. The first name, however, is a descriptive one and $I$ have adopted it for these granitic exposures.*** So far as we could determine from a distance, the Granite Hills eventually connect with the eastern extension of the Seminole (sic) Mountains.

That he considered the "Granite Hills" in a structural sense is evident both from his cross-sections and from his statement (p. 97) :

Connecting the three exposures which I regard as belonging to one series, we obtain an old granitic range of considerable length. It shows a slight S-shaped curve upon horizontal projection. Between the eastern end of the subsidiary range and the western beginning of the Sweetwater Hills there was a decided depression, permitting the granites to be hidden from sight by the succeeding sedimentary formations. A similar depression existed in the space intervening between the lastnamed outcrop and the Granite Hills.

Endlich's geologic map (Hayden, 1883) used the name "Granite Mountains," as shown on plate 1 of this report, and the name "Sweetwater Mountains" for the Crooks Mountain-Green Mountain-Ferris Mountains uplift. 
W. C. Knight (1900), on the first geologic map of Wyoming, subdivided Endlich's "Sweetwater Mountains" into Green Mountain and the Ferris Mountains but used "Sweetwater Mountains" for Endlich's "Granite Mountains." From this time on, the terminology became less and less consistent. Hares (1916, p. 249) stated: "The Granite Mountains, viewed broadly, are in the middle of a great upfold, which will be referred to as the Sweetwater anticline," but on his geologic map (pl. 23) he shows only the "Granite Mountains." Lovering (1929, p. 208-209) coined a new name: "An uplift extends more than 100 miles west-northwestward through Carbon, Natrona, and Fremont Counties from Difficulty to Hailey, and midway of its length, near the Pathfinder Reservoir, is about 30 miles wide. For convenience it will be referred to in this report as the Pathfinder uplift." The name "Pathfinder" was later applied to an uplift of Pennsylvanian age in the same general area (Mallory, 1962).

Bell (1956, p. 83) gave the name "Sweetwater anticline" (pl. 7, this report) to a separate uplift, eroded to the Precambrian, between his "Sweetwater arch" (identical with the "Sweetwater anticline" of Hares) and the Wind River Range. In brief, about half the publications dealing with central Wyoming during the last 15-25 years use the name "Granite Mountains," and half use "Sweetwater uplift," "Sweetwater arch," "Sweetwater mountains," or "Sweetwater anticline." The tectonic map of the United States by King (1944) uses "Sweetwater uplift," but that by Cohee (1961) has "Sweetwater uplift," with "Granite Mountains" in parentheses.

All my pertinent publications during the last 25 years have consistently used "Granite Mountains" in the structural and physiographic senses defined by Endlich and have avoided the name "Sweetwater uplift." It is quite unnecessary to have two names for one uplift just because it was not entirely exhumed as adjacent mountains were. "Granite Mountains" has been used in all previously published reports connected with the Wind River basin project, and this usage is continued here. The terms "Sweetwater uplift," "Sweetwater arch," "Sweetwater mountains," "Sweetwater anticline," and "Pathfinder uplift" are discarded.

\section{GREAT DIVIDE BASIN VERSUS RED DESERT BASIN}

The major structural downwarp and topographic basin lying south of the western part of the Granite Mountains has been called both the Great Divide basin and the Red Desert basin. A review of the history of nomenclature (Love, 1961a) shows that the name "Great Divide basin" should be used (fig. 2).

\section{ECONOMIC GEOGRAPHY}

\section{TOPOGRAPHY AND DRAINAGE}

The topography of the Granite Mountains area is shown in the frontispiece and figures 4-8 and on plate 2. McIntosh Peak $(8,058 \mathrm{ft})$ is the highest in the western part of the Granite Mountains (frontispiece; fig. 7), and Pyramid Peak (8,316 ft) is the highest in the eastern part. Other maximum elevations in the area are Ferris Mountains, 10,037 feet (figs. 3-6); Garfield Peak in the Rattlesnake Hills, 8,244 feet (pls. 1, 2); Whiskey Peak, 9,225 feet (figs. 4-7); Green Mountain, 9,081 feet (figs. 3, 7) ; and Crooks Mountain 8,310 feet (fig. 17). The broad gentle valley of the Sweetwater River has â general elevation of 6,000-7,000 feet, and the Sweetwater Plateau north of the river, 6,500-7,500 feet (pl. 2).

The drainage of the Granite Mountains area is peculiar, partly because of late Cenozoic faulting and warping and partly because streams have been superimposed across buried masses of resistant rock. The Sweetwater River flows almost the entire east-west length of the Granite Mountains (fig. 3) at an average gradient of considerably less than 10 feet per mile (figs. 4, 12). Streans flowing into the river from the north have more or less conventional patterns and an average gradient of about 45 feet per mile (frontispiece; pl. 2; fig. 55). Major streams that flow north from the Great Divide basin and join the Sweetwater River near the present crest of the Granite Mountains, however, show a segmented pattern. Gradients of segments of these drainages south of the South Granite Mountains fault system (pls. 1, 2; figs. 3, 5, 51, 53) average more than 200 feet per mile; gradients of the segments from the fault to the trough of the Split Rock syncline (figs. 4, 51, 54) are about 85 feet per mile and about 35 feet per mile from the trough line to the river. Several major streams, such as Crooks Creek (fig. $3 ;$ pl. 2), which at one time had sufficient vigor to erode a valley (Crooks Gap) through 1,000 feet of conglomerate south of the fault, lose so much gradient north of the synclinal trough line that they become ponded; water soaks into the underlying porous sandstone, and not even a flood channel reaches the Sweetwater River (pls. 1, 2; fig. 3). The profile of section $O-O^{\prime}(\mathrm{pl} .4)$ illustrates the asymmetry of the river valley.

The courses of all streams in the Granite Mountains area, both north and south of the Beaver Divide, show an extremely sensitive response to late Cenozoic crustal movement. Some of the seemingly anomalous drainage patterns (for example, those of Sand, Muddy, Crooks, 


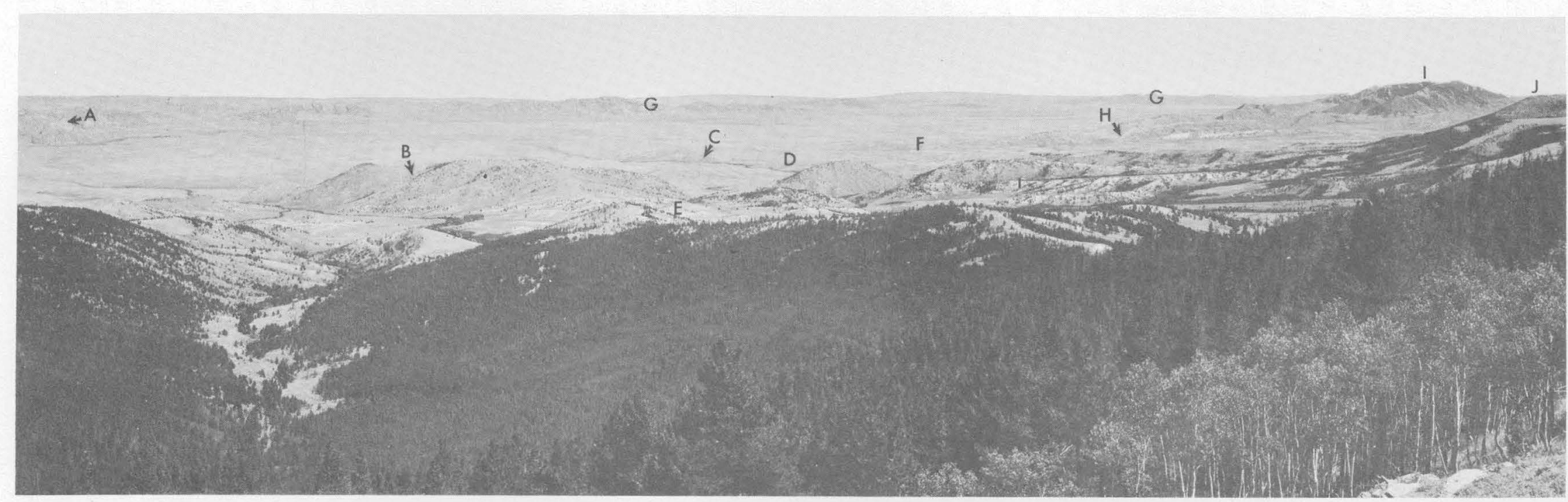

FrguRE 4.-View northeast from east end of Green Mountain. A, Split Rock and the Sweetwater River flowing along its south margin. B, Position of Emigrant Trail thrust fault (Cambrian rocks overlie Wasatch and Battle Spring Formations). C, Intersection of Emigrant Trail thrust fault (Precambrian granite overlies Cody Shale) and South Granite Mountains fault system (Split Rock Formation on north side is down against both granite and Cody Shale). D, Rolling hills of Cody Shale. E, White arkose facies in Wasatch and Battle Spring Formations. F, Broad flat underlain by Split Rock syneline. G, Knobs of Precambrian granit
of Granite Mountains projecting above Split Rock Formation. H, Muddy Gap through which U.S. Highway 287 passes. I, Ferris Mountains. J, Whiskey Peak. (See also fig. 5 for panorama farther to right.) 


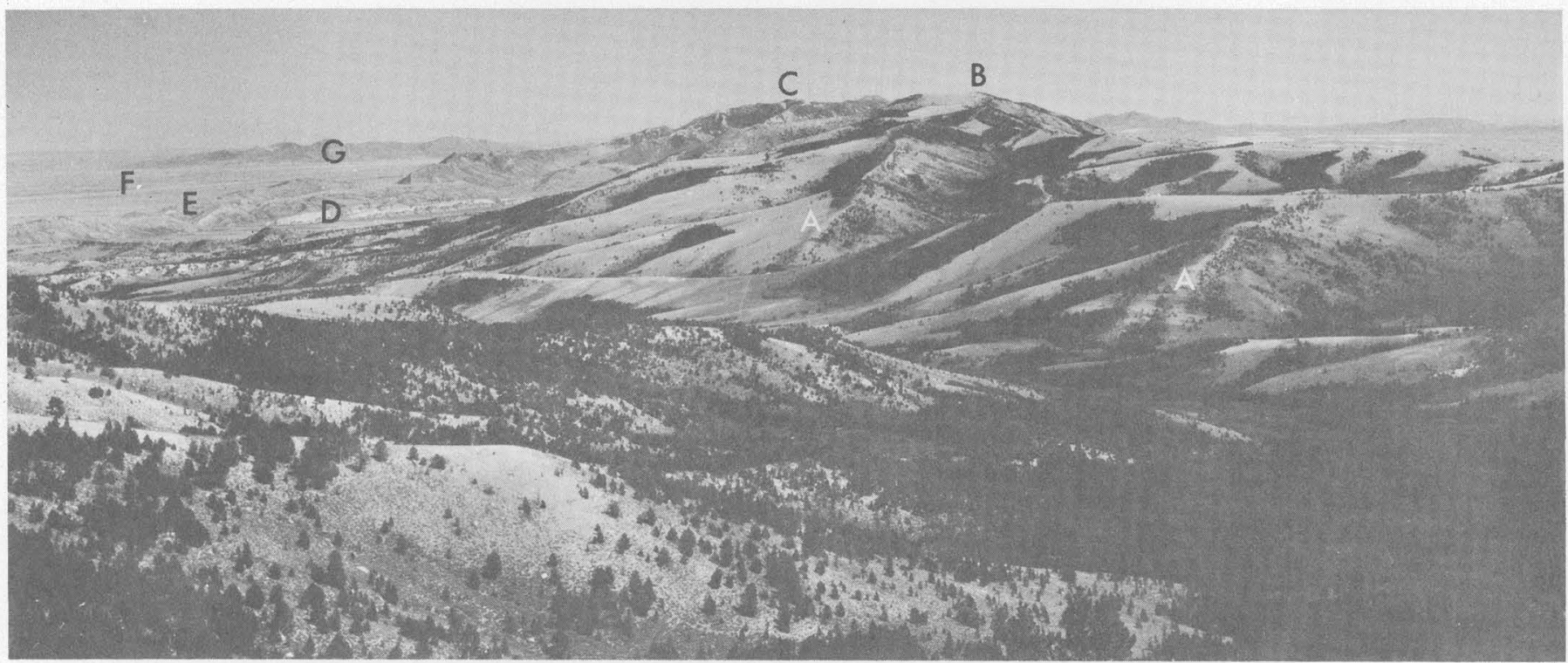

FIGURE 5.-View east from east end of Green Mountain, across Cooper Creek valley. A, North-dipping conglomerate beds in Wasatch and Battle Spring Formations B, Whiskey Peak. C, Ferris Mountains. D, Dip slope of sandstone in Frontier Formation. E, Muddy Gap traversed by U.S. Highway 287. F, Plains underlain by Split Rock Formation. G, Partly exhumed granite knobs of Granite Mountains.

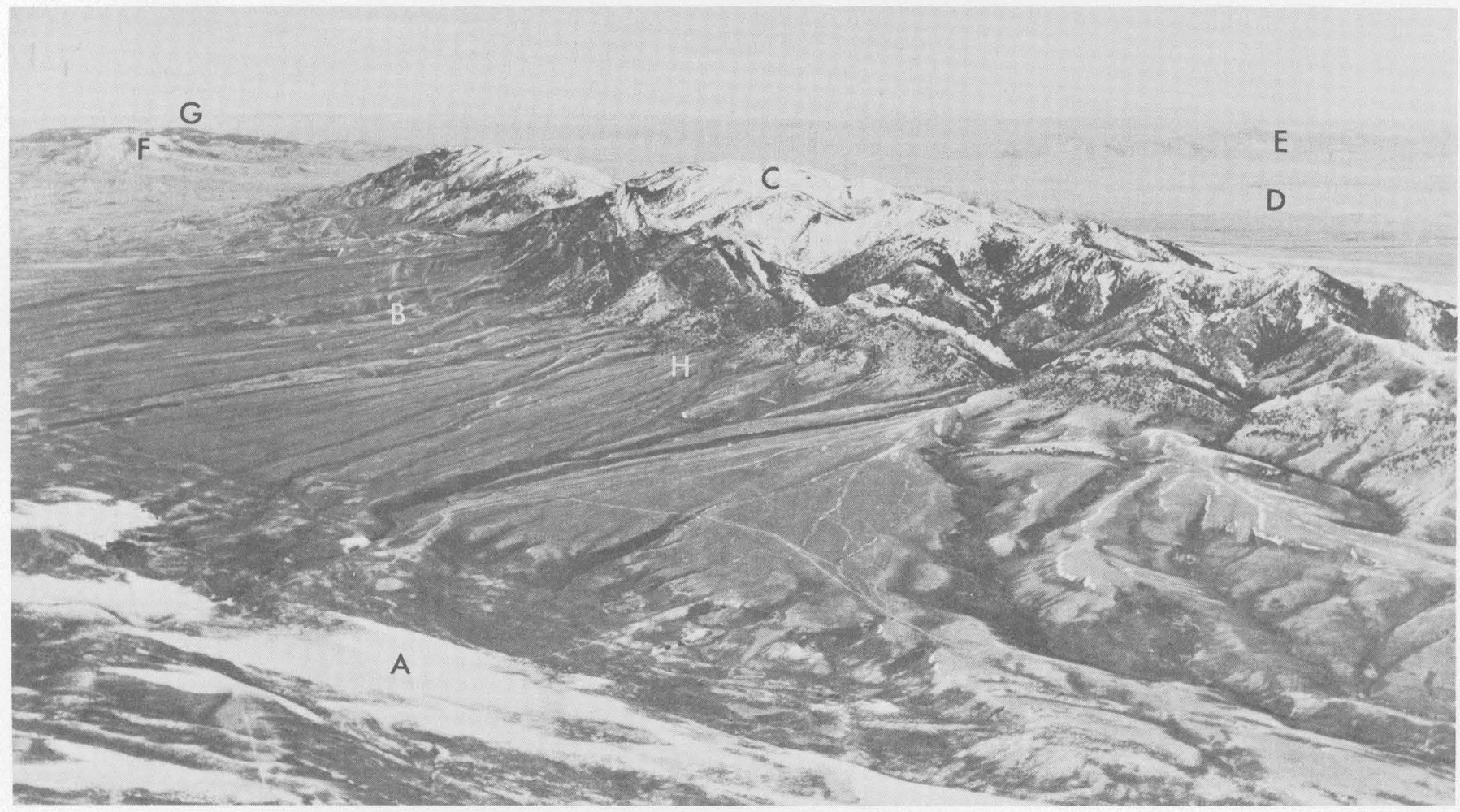

FIGURE 6.-Oblique aerial photograph northwestward across Ferris Mountains, showing relation of downdropped Precambrian core of the Granite Mountains to sedimentary rocks along the south flank of the mountains. A, Recent sand dunes. B, Steeply dipping Mesozoic rocks. C, Ferris Mountains, composed chiefly of folded and faulted Paleozoic rocks. D, Miocene and younger rocks. E, Granite core of Granite Mountains. F, Whiskey Peak, composed of Wasatch and Battle Spring Formations derived from the down-faulted granite core, which is now much lower. G, Snow-capped Wind River Range in distance. H, South end of section $G-G^{\prime}$, plate 3. Photograph by P. T. Jenkins and L. P. House. 


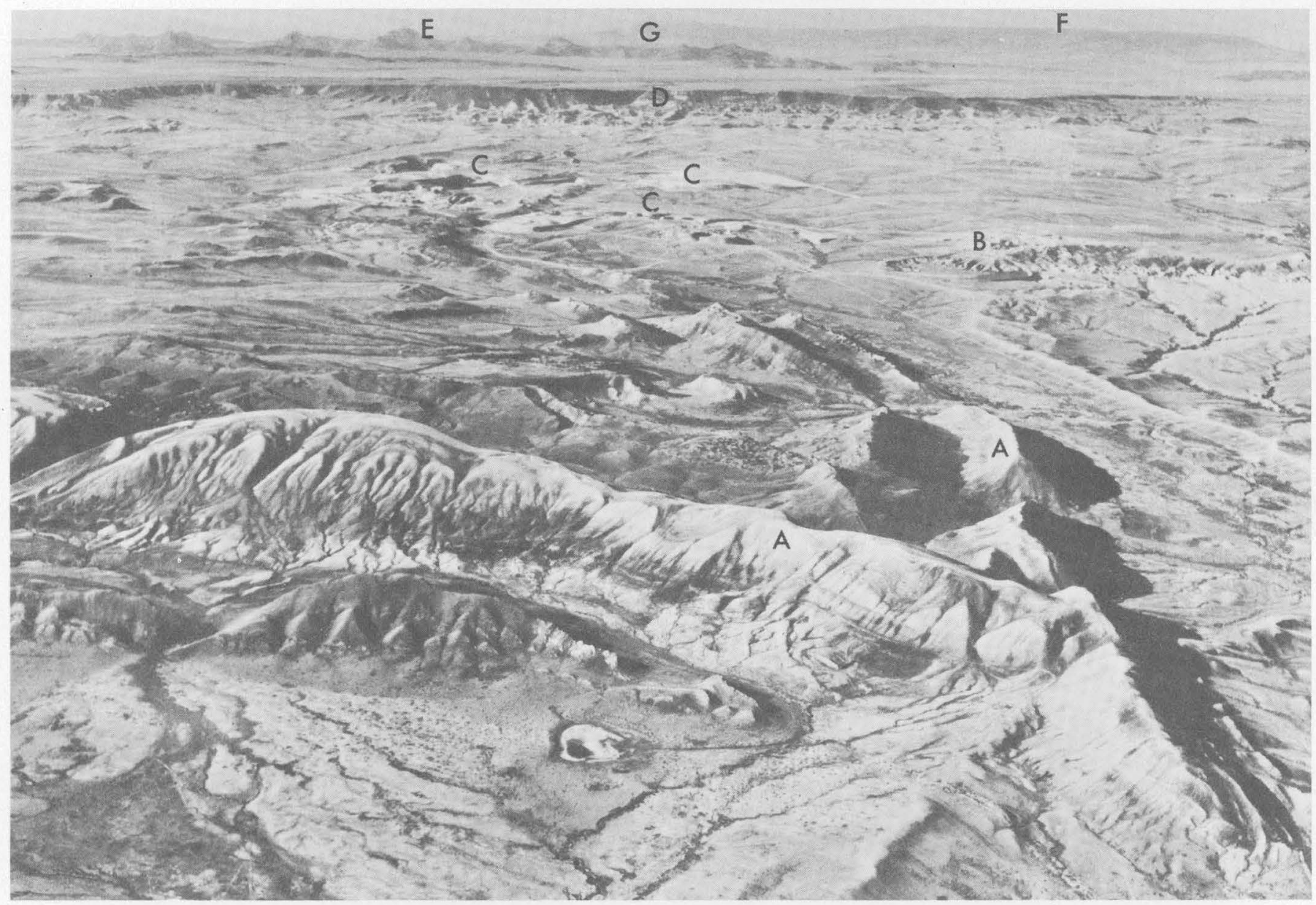

Figure 7.-Oblique aerial photograph south across Gas Hills area. A, Partly exhumed Mowry Shale ridges marking northwest-plunging Dutton Basin anticline. B, Lucky Mc uranium mill. C, Uranium strip mines in Wind River Formation. D, Beaver Divide, composed of Wagon Bed and White River Formations, capped by basal conglomerate of Split Rock Formation. E, McIntosh Peak. F, Green Mountain. G, Whiskey Peak. Photograph by P. T. Jenkins and L. P. House.

and Alkali Creeks, figs. 3, 37, 55) are discussed in connection with Pleistocene tectonic history.

The Sweetwater River valley differs from others in Wyoming because most of it is underlain by porous and permeable sandstone and conglomerate. As a consequence, runoff is easily absorbed and springs and perennial streams are few. The water, however, except in the vicinty of "soda lakes," is less alkaline than in the basins to the north and south-hence, the name "Sweet Water" applied to the river by pioneers.

For nearly 100 miles along the north margin of the Granite Mountains area, except locally near the Rattlesnake Hills, the gently rolling topography of the Sweetwater Plateau and the unnamed plateau east of the Rattlesnake Hills ends abruptly at the north-facing irregular escarpment, the western part of which is known as the Beaver Divide (figs. 3, 7, 22, 24; pl. 2; pl. $3, H-H^{\prime}$; pl. $4, O-O^{\prime}, V-V^{\prime}, W-W^{\prime}$.) The divide is also locally known as Beaver Rim. North of the escarpment, the headwaters of northward-flowing streams have gradients of $500-1,000$ feet per mile, and the streams drain either into the Wind River (west of the Rattlesnake Hills) or into the Powder River and the North Platte River (east of the Rattlesnake Hills). These streams, cutting southward into the Sweetwater Plateau, have beheaded several tributaries to the Sweetwater River, but only in a few places have they exposed the pre-Tertiary rocks composing the north flank of the Granite Mountains.

The pre-Miocene Tertiary rocks north of Beaver Divide erode into badlands on which very little soil has developed; there, the lower altitude $(1,000 \mathrm{ft}$ lower), the completely different type of bedrock, the poor water, and the lack of soil have caused the establishment of vegetation markedly different in type and abundance from that in the plateau area south of the escarpment. Compare, for example, the vegetation on impervious claystone (figs. 20-22) with that on porous sandstone (fig. 31). 


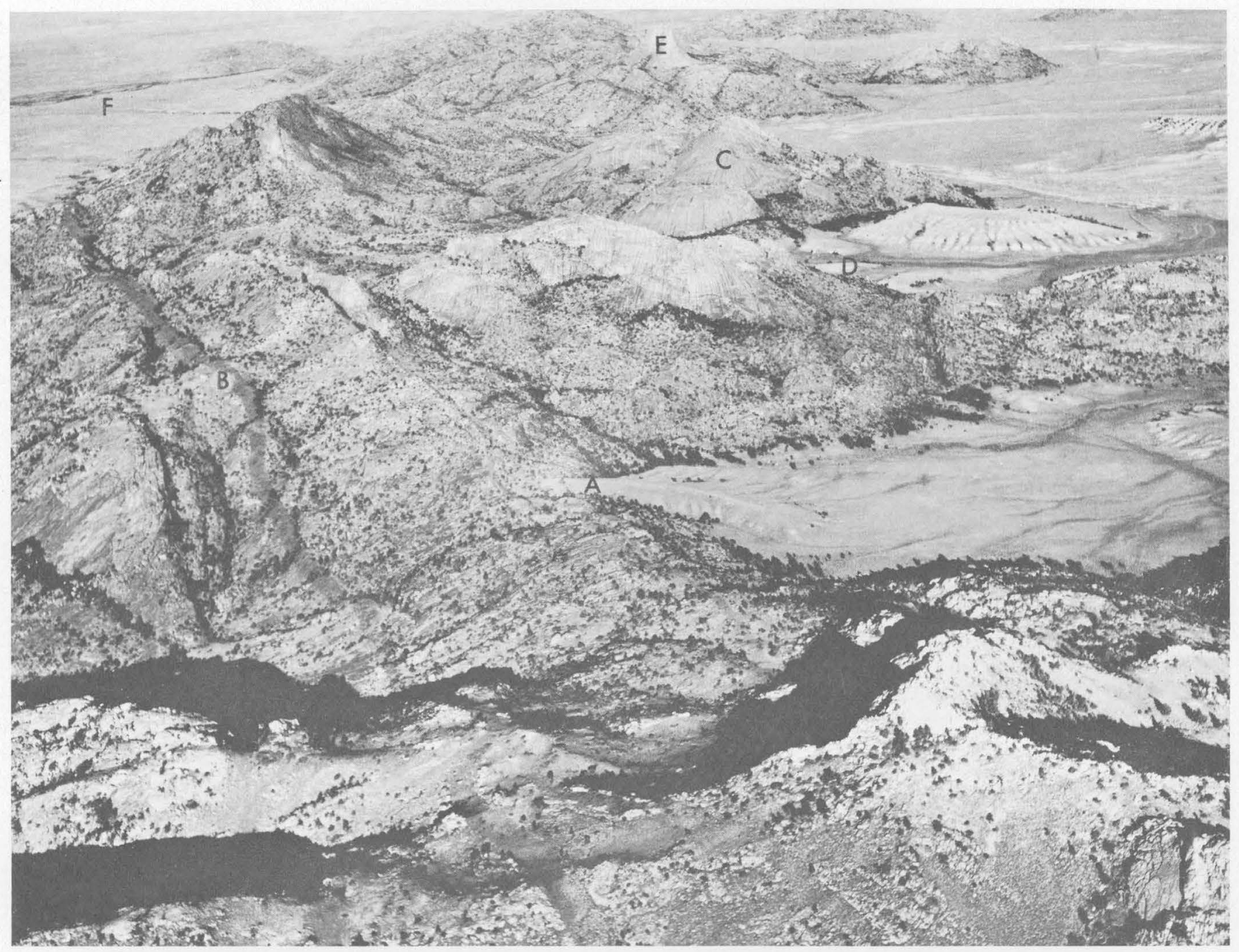

FIGURE 8.-Oblique aerial photograph showing relation of Moonstone Formation to Precambrian core of Granite Mountains. A, Uppermost beds in type Moonstone Forma tion, representing approximate stage of maximum burial of mountains. B, Precambrian mafic dike, which cuts granite. C, Moonstone Peak, a monolith of massive granite. D, Strata in Moonstone Formation containing fossil wood. E, Lankin Dome, composed of massive granite. F, Split Rock Formation along Sweetwater River. View is toward west. Photograph by P. T. Jenkins and L. P. House.

\section{PRESENT SETTLEMENT AND INDUSTRY}

The Granite Mountains area is sparsely settled. As a result of the uranium industry, Jeffrey City, chiefly a trailer town with a fluctuating population of several hundred people, was established in 1955 . Two additional settlements large enough to have post offices are Lamont (pl. 2) and Alcova (pl. 1). Several uranium camps (fig. 56) inhabited by a trailer-dwelling populace are present near uranium mills and strip mines in the Gas Hills area. Maintenance eamps are at the Lost Soldier, Crooks Gap, Happy Springs, Sig Sand Draw, and Grieve oil fields. The remainder of the population of this 3,000-square-mile area consists of several hundred cattle and sheep ranchers.

The only year-around industries are oil, gas, uranium, and livestock. Occurrences of oil and gas, uranium, and other potentially economic deposits are discussed separately.

\section{ROUTES OF TRAVEL}

The area has no railroads and no officially maintained airports. Private landing strips are maintained at Jeffrey City, at various localities in the Gas Hills, at Crooks Gap, and at several oil camps and ranches. U.S. Highway 287 and State Highway 220 are the only paved roads (pls. 1,2); they traverse the southern part of the area. The remainder of the area is accessible by improved and unimproved roads to uranium mines and mills, oil fields, and ranches.

\section{HISTORY OF SETTLEMENT AND DEVELOPMENT}

The Sweetwater River valley has been a key area in the exploration and development of the West. Easy 
access to the valley from all sides (fig. 3 ) and abundant rich grass, water, and game made it a favorite hunting ground and migration route, first for Indians, and later for whites. Archaeological records of cultures in sites north and south of the river date back more than 10,000 years (Renaud, 1932; McGrew, 1961; Irwin and others, 1962). According to legend, Spaniards came north and prospected the Spanish mine area in the Ferris Mountains in the 16th century. Sieur de la Verendrye, in 1744 , explored as far south as the Wind River basin. In 1812-13, Robert Stuart discovered South Pass at the south end of the Wind River Range. During the 1820's, many trappers and explorers passed through the area, and from that time traffic increased. In the late 1840's when the Oregon Trail was established, and into the 1850 's, as many as 50,000 people per year passed through the valley. The Pony Express route, 1860-61, followed the Sweetwater River. Gold was discovered in the southern part of the Wind River Range in 1842 , but extensive mining was not done until the 1860 's and 1870 's. Settlement of the Sweetwater River valley has been more or less permanent since the 1840 's.

\section{CLIMATE}

The four weather stations within or along the margins of the Granite Mountains area are situated at low altitudes; no data are available for the mountains. Mean annual precipitation at these stations averages from 8 to 12 inches. Mean maximum temperature in July is $84^{\circ} \mathrm{F}$, and the minimum is from $48^{\circ} \mathrm{F}$ to $52^{\circ} \mathrm{F}$. Mean maximum temperature in January is $28^{\circ} \mathrm{F}$, and the minimum is from $4^{\circ} \mathrm{F}$ to $12^{\circ} \mathrm{F}$ (U.S. Weather Bureau, 1960). Destructive cloudbursts, which have caused flash floods, occur in areas of steep topography along the north and south margins of the area; elsewhere the danger of flood damage is lessened because of the porous sandy character of the soil and bedrock and the low stream gradients. The area is windy, with predominant wind direction from the west and southwest; wind-faceted boulders are abundant. (For example, see fig. 61.) Windy conditions have existed in the past also, for wind-faceted stones are incorporated in Miocene conglomerate. These stones are difficult to distinguish from those being faceted today.

\section{PRECAMBRIAN ROCKS}

A detailed investigation of the Precambrian rocks is not within the scope of this report, but these rocks have been so closely involved in the Tertiary sedimentary, structural, physiographic, and economic history of the region that a summary description is presented.

Very little specific information is available on the
Precambrian rocks. Endlich (1879, p. 96-101; also his geologic map in Hayden, 1883) subdivided the Precambrian into three units: "metamorphic" granite, "prozoic" granite, and "basalt" dikes. Hares (1916; $1946 \mathrm{a}, \mathrm{b})$ distinguished granite and schist and mafic dikes but gave no descriptions. Beeler (1907) gave a brief description (but no map) of mineralized schists and diorite and of quartz dikes in the Black RockLong Creek locality 8-15 miles northwest of Jeffrey City (pl. 1). W. C. Knight (1901), Trumbull (1914), Spencer (1916) and Bayley $(1960,1963)$ described Precambrian rocks in the South Pass-Atlantic City district at the south end of the Wind River Range west of the area shown on plate 1. Carey (1954) mapped but did not describe the granite gneiss and hornblende schist in the Rattlesnake Hills.

The Precambrian rocks in the Granite Mountains area are of at least three ages and types. The oldest rocks are, in part, a metasedimentary sequence of black and green schist, slate, phyllite, quartzite, and diorite(?), which is extensively exposed in the Black Rock-Long Creek district (locs. 12G, 13G, C, 14J, and 15J, R, pl. 1). These rocks strike northeast, dip moderately southeast, and make up a section several thousand feet thick. They have yielded small amounts of gold, copper, and black, dark-green, and light-green nephrite jade, as well as corundum, pale-blue sapphires, rubies, and asbestos. Guilinger (1963) postulated that the uranium in the Gas Hills area had been derived from uraniferous vein deposits in the Precambrian rocks of the Granite Mountains. No modern petrographic or structural study, even of a reconnaissance nature, has been made of these rocks. They resemble part of the igneousmetasedimentary complex in the Atlantic City-South Pass district, but no correlation has been established. Lead-alpha age determinations from Atlantic City (Cannon, 1957; Jaffe and others, 1959, p. 128) suggest a long and complex Precambrian history, as galena from gold-bearing quartz veins is 2,700-2,900 m.y. (million years) old, zircon from graywacke in the metasedimentary sequence is $1,950 \mathrm{~m} . \mathrm{y}$. old, and zircon from quartz diorite cutting the metasediments is 1,450 m.y. old.

A somewhat similar sequence of metasedimentary rocks, likewise unstudied, occurs along the south margin of the Rattlesnake Hills. Some of these rocks are cut by pegmatite dikes, one of which, on Black Mountain (secs. 1 and 2, T. 32 N., R. 89 W.), contains spodumene. Hanley, Heinrich, and Page (1950, p. 121) gave a brief description of this deposit and the enclosing rocks.

The major part of the Granite Mountains consists of granite that is younger than the metasedimentary 
sequence but is possibly of more than one age. The most conspicuous physical expression of the granite is a series of massive knobs and peaks that Endlich (1879, p. 96) described as follows: "The absolute nakedness of these hills is truly remarkable. Without any definite

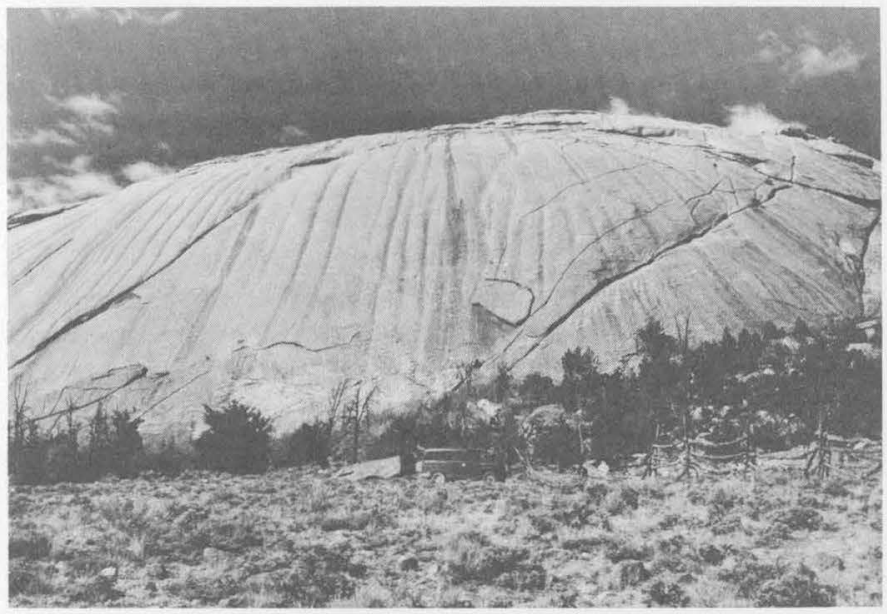

FIGURE 9,-Surface of the Moonstone, a Precambrian massive granite monolith. Height of face is approximately 400 feet. Surface was formed prior to burial by Moonstone Formation (foreground) and is being exhumed. rock structure they rise directly from the plain, presenting their bald, gray and red forms, which rise to a relative elevation of 300 to 1,100 feet. Smooth, rounded surfaces of considerable extent render the ascent of some of the higher peaks almost an impossibility". The excellence of this description is indicated by the actual appearance of the knobs and peaks shown in figures 8-12. Other masses of granite in the area are highly fractured and are cut by joints of several different ages. (See aerial photographs of Split Rock reproduced in Ray, 1960, p. 132-133.) The relation between the massive and the highly fractured granite has not been determined.

Kieslinger (1960) and Bradley (1963) discussed the development of exfoliated smooth surfaces on granite and other massive rocks in various parts of the world and attributed this phenomenon to relaxation of residual stress after initial exposure by erosion. Relief of stress began when the Granite Mountains were first exposed during Eocene time, and the domes probably are of that age or slightly younger. Those of lower elevation, such as Moonstone Peak and Split Rock, were largely buried by Miocene and Pliocene strata and only

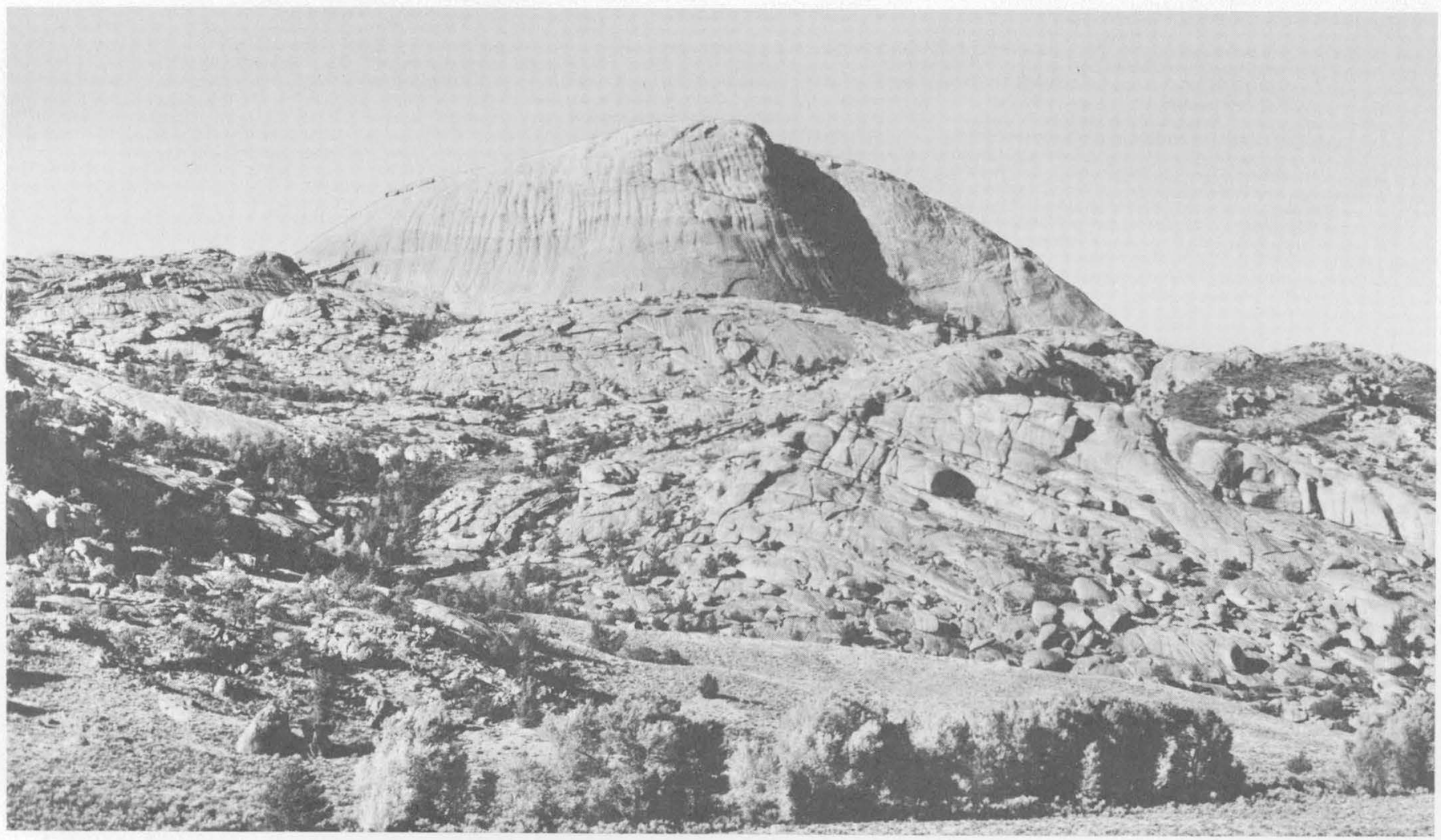

FIGURE 10.-Lankin Dome from the south, 1,400 feet above Moonstone Formation on valley floor. Note layering in massive granite. Compare with figure 11 , a view from the east. 


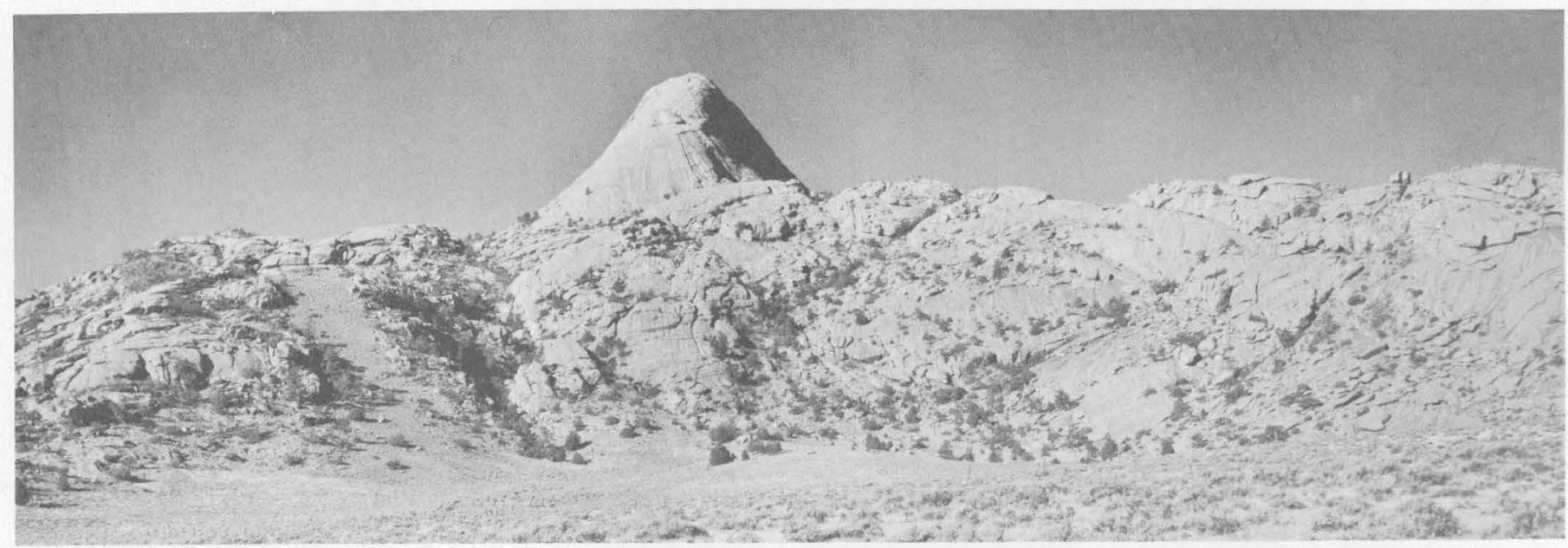

FIgURE 11.-East side of Lankin Dome, a monolith of Precambrian granite. Top of peak is 1,400 feet above flat in foreground, which is underlain by Moonstone Formation. Accordant knobs comprising foothills of peak probably represent upper limit of burial of Granite Mountains during Pliocene time when the abrupt break in slope at base of Lankin Dome was formed. Exhumed topography is virtually unmodified. Smooth vegetated stripe extending over hill at left marks Precambrian mafic dike, which cuts granite.

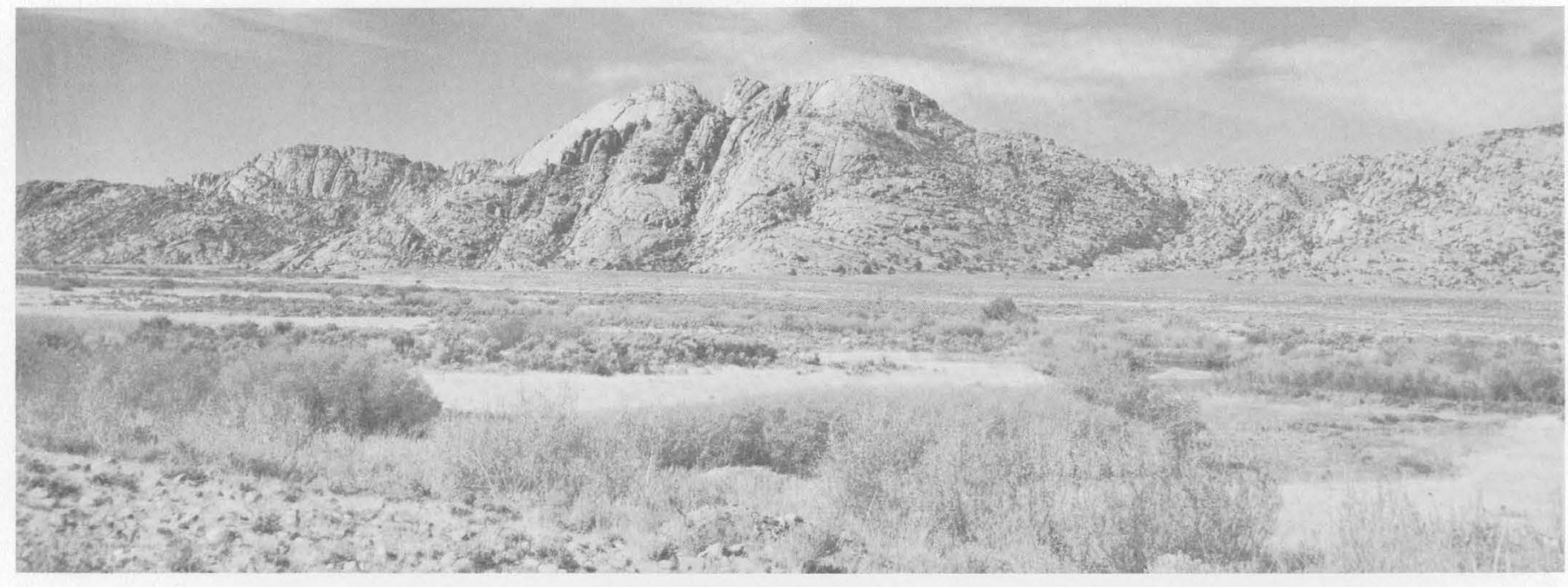

Figure 12.-Split Rock, a pioneer landmark on the Oregon Trail, displays nearly unmodified Miocene and Pliocene topography of the Granite Mountains, exhumed during Quaternary time. View is west across the Sweetwater River. Valley floor is underlain by Split Rock Formation; smooth rock surfaces are on granite; and bottom of slot on Split Rock is a soft mafic Precambrian dike intruded along a fracture in the harder granite.

recently have been exhumed; their subsequent modification has been insignificant. The upper parts of the higher domes, such as Lankin Dome and McIntosh Peak, may have been continuously exposed since Eocene time.

A specimen of granite from the $\mathrm{SW}^{1 / 4}$ sec. 2 , T. 29 N., R. 92 W., has a lead-alpha of $2,000 \pm 225$ m.y'. (Coleman and Erd, 1961, p. C299). In the eastern part of the Granite Mountains, at the Little Man mine (Love, 1954a), on the south side of Heath Peak (loc. $28 \mathrm{U}, \mathrm{L}$, pl. 2 and table 9 ), NW1/4 NE $1 / 4 \mathrm{SE}^{1} / 4$ sec. $14, \mathrm{~T}$. 27 N., R. 84 W., a layer of uraninite-bearing graphite surrounded by gray and brown granite has a lead-alpha age of 1,800 m.y. (T. W. Stern, oral commun., 1957).
The relation of the granite in the Granite Mountains to dated Precambrian rocks in the Atlantic City district has not been determined.

Numerous black mafic dikes ranging in width from a few feet to more than 500 feet and in length from several hundred feet to at least 5 miles cut both massive and fractured granite in the Granite Mountains (figs. 8, 11). They were truncated before the first Cambrian sandstone was deposited in this area. Most, but not all, have an easterly trend. Their petrography has not been studied, and it is not known whether they are composed of the same rock types or whether they are all of the same age. 


\section{STRATIGRAPHY OF PRE-TERTIARY SEDIMENTARY ROCKS}

The pre-Tertiary sedimentary rocks are not of primary concern to this study of the Granite Mountains area. A summary description of them, however, is presented in table 1 , because they furnished clastic debris to the Tertiary formations and, in addition, were involved in folds and faults that developed during Tertiary and Quaternary times. The references listed on plate 1 contain discussions of the Paleozoic and Mesozoic stratigraphy around the flanks of the Granite Mountains. Outcrops of some formations are shown in figures 4-7 and 19 .

Detailed descriptions of the pre-Tertiary sedimentary rocks in the Wind River basin to the north are given by Keefer (1965); Keefer and Rich (1957); Keefer and Troyer (1964); Keefer and Van Lieu (1966) ; Love, Thompson, and others (1945); Love, Tourtelot, and others (1945); Love, Johnson, and others (1945); Love, Tourtelot, and others (1947); Love (1948) ; Rich (1962) ; Thompson, Love, and Tourtelot (1949); Yenne and Pipiringos (1954).

\section{STRATIGRAPHY OF TERTIARY SEDIMENTARY ROCKS}

Tertiary strata surround the Granite Mountains and were deposited on a surface of low to high relief that truncated Mesozoic, Paleozoic, and Precambrian rocks comprising the flanks and core of the uplift. This is not an example of simple overlap, however, for largescale thrust faults and normal faults, reversal of direction of movement on some high-angle faults, stripping of uplifted blocks and redeposition on adjacent downdropped blocks, and regional downwarp of the mountain arch have resulted in a very complex history of - sedimentation. Because of these complexities, stratigraphic discussion of rocks of a given age is presented as much as possible by localities. The regional relations are summarized graphically (pl. 10) and described in the section on geologic history. Stratigraphic data from wells are summarized in table 2.

\section{PALEOCENE ROCKS FORT UNION FORMATION NAME AND DEFINITION}

The Fort Union Formation was named and described by Meek and Hayden (1862, p. 433) from exposures in North Dakota. Hayden (1869) later applied the name to similar rocks in central Wyoming. For many years the formation was one of several involved in the "Laramie Problem" and was called Cretaceous by some geologists and Tertiary by others. In the Granite Mountains area the name Fort Union Formation is currently applied to a sequence of gray and brown fluviatile and lacustrine conglomerate, sandstone, shale, and thin coal beds containing fossil plants and vertebrates of Paleocene age. The formation was deposited across truncated edges of Upper Cretaceous rocks and in turn was overlapped by Eocene rocks.

\section{DISTRIBUTION AND THICKNESS}

At outcrops in the Bison Basin area. (loc. $4 \mathrm{~V}$, table 10 and pl. 1), the Fort Union Formation is about 800 feet thick, but this thickness increases in subsurface sections to more than 2,000 feet 10 miles to the south, and 3,000 feet 15 miles to the east (pl. 5A). In the Crooks Gap area about 700 feet is exposed (fig. 13), but 1 mile downdip from the outcrop a well (No. 148) penetrated a section nearly 1,000 feet thick. North of the Big Sand Draw oil and gas field (T. 33 N., R. 95 W.) is a unique remnant about 200 feet thick containing abundant fossil fruits and nuts (Keefer, 1965). In the northeastern part of the area, the thickness in outcrop is about 1,000 feet, but it increases northward in subsurface sections in the Wind River basin to a maximum of more than 8,000 feet (Keefer, 1965). Northeast and northwest of Whiskey Peak in the southern part of the Granite Mountains area, the thickness of surface sections is about 1,500 feet.

\section{IITHOLOGY}

Generalized lithologic descriptions of the Fort Union Formation in various parts of the report area are given in table 3 (in map case). Detailed descriptions and measured sections of Fort Union rocks along the north margin of the Granite Mountains are presented by Keefer (1965). The lithology of the formation on both the north and the south flanks of the Granite Mountains is very similar.

At Bison Basin (loc. 4V, table 10 and pl. 1), the lower third of the formation consists of gray and brown sandstone and dark-gray to brown siltstone and claystone. The upper two-thirds has many lenticular beds of conglomerate containing rounded pebbles 1-6 inches in diameter, chiefly of siliceous Paleozoic and Mesozoic rocks. Few carbonate rocks or granite fragments are present. The principal lithology of beds between the conglomerates is gray to brown soft claystone that forms smooth drab slopes. Highly calcareous sandstones, elsewhere rare in the Fort Union Formation, are common at this locality. Carbonaceous plantbearing siltstone and claystones occur throughout the section. 
$\mathrm{T}_{\mathrm{ABLE}}$ 1.-Summary description and correlation of pre-Tertiary sedimentary rocks in the Granite Mountains area

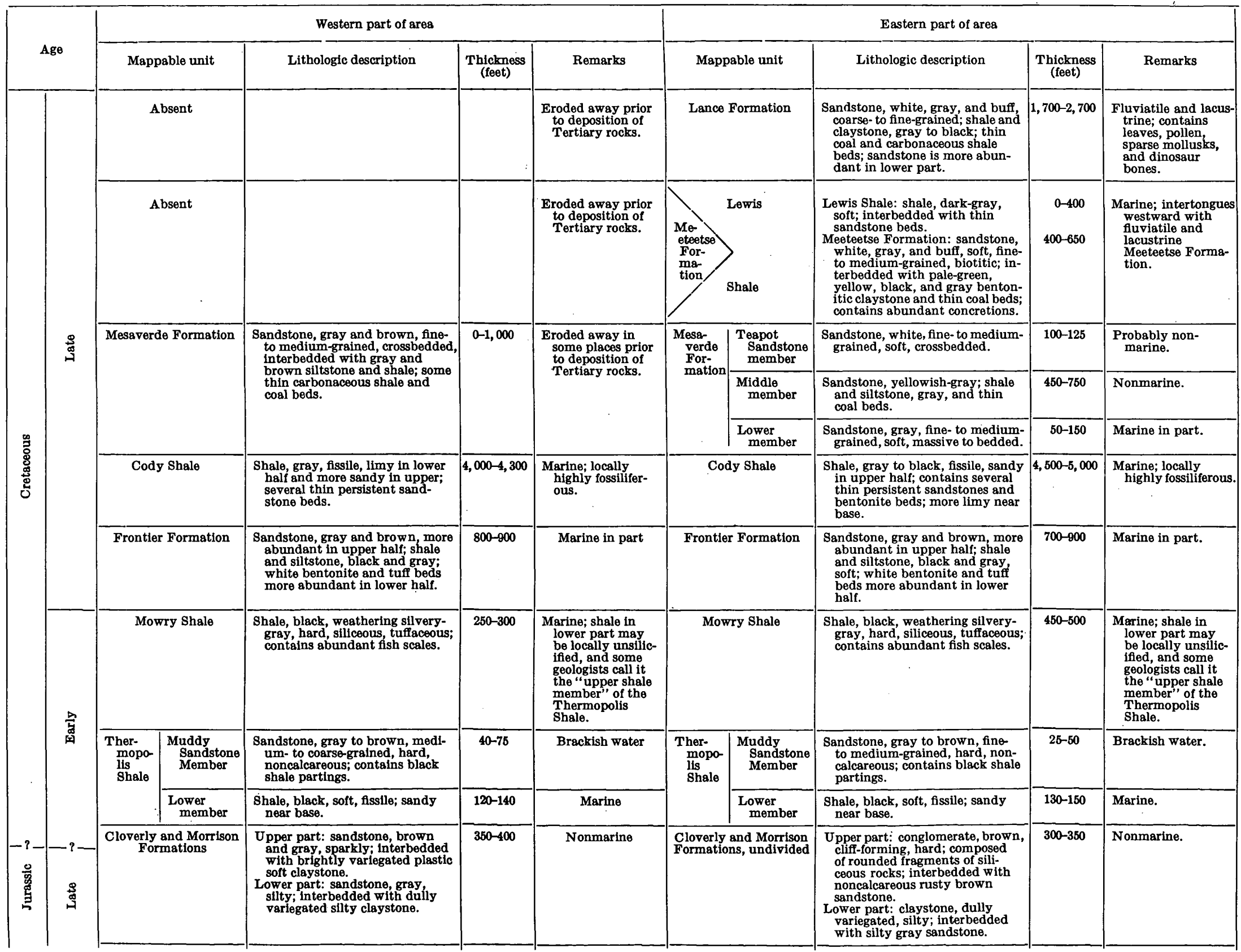




\begin{tabular}{|c|c|c|c|c|c|c|c|c|c|c|c|c|}
\hline \multirow{3}{*}{\multicolumn{2}{|c|}{ 㤣 }} & \multirow{2}{*}{ 岸 } & \multirow{2}{*}{\multicolumn{2}{|c|}{ Sundance Formation }} & \multirow{2}{*}{$\begin{array}{l}\text { Upper part: sandstone, pale- } \\
\text { green and brown, highly glan- } \\
\text { conitici interbedded with sandy } \\
\text { highly glauconitic limestone. } \\
\text { Lower part: sandstone, gray, with } \\
\text { pink zones, very fine-grained; } \\
\text { interbedded with thin gray } \\
\text { fossiliferous limestone beds. }\end{array}$} & \multirow{2}{*}{$\frac{116-150}{75-100}$} & \multirow{2}{*}{$\begin{array}{l}\text { Marine } \\
\text { Marine }\end{array}$} & \multirow{2}{*}{\multicolumn{2}{|c|}{ Sundance Formation }} & \multirow{2}{*}{$\mid \begin{array}{c}\text { Opper part: sandstone, siltstone, } \\
\text { and shale, pale-green, highly } \\
\text { glauconitic, some beds of gray } \\
\text { sandy limestone. } \\
\begin{array}{c}\text { Lower part: sandstone, pink and } \\
\text { white, in upper half, lower half } \\
\text { is palo-green soft fissile limy } \\
\text { shale. }\end{array} \\
\end{array}$} & \multirow{2}{*}{$\frac{115-140}{180-200}$} & \multirow{2}{*}{$\begin{array}{l}\text { Marine. } \\
\text { Chiefly marine. }\end{array}$} \\
\hline & & & & & & & & & & & & \\
\hline & & 旁 & \multicolumn{2}{|c|}{$\underset{\text { Formation }}{\text { Gypsum Spring }}$} & $\begin{array}{l}\text { Gypsum, white, massive; over- } \\
\text { lain by red shgle and siltstone } \\
\text { interbedded with gray earthy } \\
\text { dolomite; gypsum leached away } \\
\text { in many surface sections. }\end{array}$ & $0-150$ & $\begin{array}{l}\text { Marine in part; re- } \\
\text { moved by pre- } \\
\text { Late Jurassic } \\
\text { erosion from } \\
\text { eastern part of } \\
\text { area. } \\
\end{array}$ & \multicolumn{2}{|c|}{ Absent } & & & $\begin{array}{l}\text { Eroded away prior } \\
\text { to deposition of } \\
\text { Upper Jurassic } \\
\text { rocks. }\end{array}$ \\
\hline & \multirow{6}{*}{. } & \multirow{2}{*}{ 岛 } & \multicolumn{2}{|c|}{ Nugget Sandstone } & $\begin{array}{l}\text { Sandstone, salmon-red, fine- to } \\
\text { medinum-grained, highly cross- } \\
\text { bedded in upper part; abun- } \\
\text { dant frosted rounded quartz } \\
\text { grains. }\end{array}$ & $400-525$ & $\begin{array}{l}\text { Formation in this } \\
\text { area is belifeved to } \\
\text { be entirely of } \\
\text { Triassic age (Love, } \\
\text { 1957; Reeside and } \\
\text { others, 1957). } \\
\end{array}$ & \multicolumn{2}{|c|}{ Absent } & & & $\begin{array}{l}\text { Eroded away prior } \\
\text { to deposition of } \\
\text { Upper Jurassic } \\
\text { rocks. }\end{array}$ \\
\hline & & & \multirow{4}{*}{$\begin{array}{c}\text { Chug- } \\
\text { water } \\
\text { For- } \\
\text { ma- } \\
\text { tion 1 }\end{array}$} & $\begin{array}{r}\text { Popo-Agle } \\
\text { Member }\end{array}$ & $\begin{array}{l}\text { Siltstone, claystone, and shale, } \\
\text { orange, purple, and red, anal- } \\
\text { citic; lenticular purplish-gray } \\
\text { limestone pebble conglomerate } \\
\text { beds. }\end{array}$ & $235-300$ & Nonmarine & \multirow{4}{*}{$\begin{array}{c}\text { Chug- } \\
\text { wattor } \\
\text { For- } \\
\text { mation }\end{array}$} & \begin{tabular}{|c} 
Popo Agle \\
Member
\end{tabular} & $\begin{array}{l}\text { Siltstone, claystone, and shale, } \\
\text { orange, purple, and red, anal- } \\
\text { citicic purplish-gray limestone } \\
\text { pebble conglomerates. }\end{array}$ & $0-350$ & $\begin{array}{c}\text { Completely removed } \\
\text { in places prior to } \\
\text { deposition of Up- } \\
\text { per Jurassic rocks. }\end{array}$ \\
\hline & & \multirow{4}{*}{ 窟 } & & $\begin{array}{l}\text { Crow Moun- } \\
\text { tain Sand- } \\
\text { stone } \\
\text { Member } \\
\end{array}$ & $\begin{array}{l}\text { Sandstone, salmon-red, fine-to } \\
\text { mediumangrained, crossbedded; } \\
\text { abundant frosted rounded } \\
\text { quartz grains. } \\
\end{array}$ & $50-100$ & $\begin{array}{l}\text { Probably non- } \\
\text { marine. }\end{array}$ & & $\begin{array}{l}\text { Crow Moun- } \\
\text { tain Sand- } \\
\text { stone } \\
\text { Member } \\
\end{array}$ & $\begin{array}{l}\text { Sandstone, salmon-red, fine- to } \\
\text { medium,-grained, crossbbedded; } \\
\text { abundant frosted rounded } \\
\text { quartz grains. }\end{array}$ & $50-100$ & $\begin{array}{l}\text { Probably non- } \\
\text { marine. }\end{array}$ \\
\hline & & & & $\begin{array}{c}\text { Alcova } \\
\text { Limestone } \\
\text { Member } \\
\end{array}$ & $\begin{array}{l}\text { Limestone, purplish-gray, thln- } \\
\text { bedded, hard. }\end{array}$ & $2-10$ & Probably marine & & $\begin{array}{c}\text { Alcova } \\
\text { Limestone } \\
\text { Member } \\
\end{array}$ & $\begin{array}{l}\text { Limestone, purplish-gray, thin- } \\
\text { bedded, hard. }\end{array}$ & $10-25$ & Probably marine. \\
\hline & & & & $\begin{array}{r}\text { Red Peak } \\
\text { Member }\end{array}$ & $\begin{array}{l}\text { Siltstone, silty sandstone, and } \\
\text { shale, brick-red, soft. }\end{array}$ & $800-900$ & $\begin{array}{c}\text { Environment of } \\
\text { deposition not } \\
\text { known. }\end{array}$ & & $\begin{array}{r}\text { Red Peak } \\
\text { Member }\end{array}$ & $\begin{array}{l}\text { Siltstone, silty sandstone, and } \\
\text { shale, brick-red, soft. }\end{array}$ & $700-800$ & $\begin{array}{l}\text { Environment of } \\
\text { deposition not } \\
\text { known. }\end{array}$ \\
\hline & & & \multicolumn{2}{|c|}{ Dinwoody Formation } & $\begin{array}{l}\text { Siltstone, brown, highly dolomitic, } \\
\text { fne-gradned, hard; slightly } \\
\text { gypsiferous. }\end{array}$ & $50-100$ & Marine & \multirow[t]{2}{*}{$\begin{array}{c}\text { Goose } \\
\text { Egg } \\
\text { For- } \\
\text { mation }\end{array}$} & Opper part & $\begin{array}{l}\text { Shale, red, sandy, anhydrite, } \\
\text { gypsum; thin sandy limestone } \\
\text { in upper part. }\end{array}$ & $50-100$ & Marine in part. \\
\hline & \multirow{2}{*}{ 兽 } & 超 & \multicolumn{2}{|c|}{$\begin{array}{l}\text { Permlan rocks, } \\
\text { undifferentiated }\end{array}$} & $\begin{array}{l}\text { Dolomite, tan, petroliferous, } \\
\text { cherty in interbedded with thin } \\
\text { sandstones and shales; phos- } \\
\text { phoritte beds in upper and } \\
\text { lower parts. }\end{array}$ & $275-325$ & Marine & & Lower part & $\begin{array}{l}\text { Shale, red, gypsiferous; with } \\
\text { gypsum beds in middle; three } \\
\text { prominent limestone beds in } \\
\text { upper, middle, and lower parts. }\end{array}$ & 300 & Marine in part. \\
\hline & & 票 & \multicolumn{2}{|c|}{ Absent? } & & & $\begin{array}{l}\text { Removed by pre- } \\
\text { Phosphoria ero- } \\
\text { sion. }\end{array}$ & \multirow{3}{*}{\multicolumn{2}{|c|}{ Casper Formation }} & 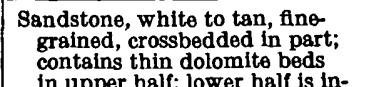 & $400-500$ & Marine. \\
\hline & \multirow[b]{2}{*}{ 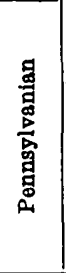 } & Late & \multicolumn{2}{|c|}{ Absent } & & & $\begin{array}{c}\text { Removed by pre- } \\
\text { Phosphoria ero- } \\
\text { sion. }\end{array}$ & & & $\begin{array}{l}\text { terbedded red and green shale, } \\
\text { white dense dolomite, and thlin } \\
\text { sandstone beds. }\end{array}$ & & \\
\hline & & 递 & \multicolumn{2}{|c|}{$\begin{array}{l}\text { Tensleep Sandstone } \\
\text { and Amsden } \\
\text { Formation }\end{array}$} & $\begin{array}{l}\text { Sandstone, white to tan, fine } \\
\text { gralned, hard, crossbedded in } \\
\text { part; contains thind dolomite } \\
\text { beds, in upper half; lower half } \\
\text { is red and green shale, dense } \\
\text { white dolomite, and a soloot } \\
\text { thick relod and gray sandstone } \\
\text { at base. } \\
\end{array}$ & $600-700$ & Marine & & & & & \\
\hline & \multicolumn{2}{|c|}{ Mississippian } & \multicolumn{2}{|c|}{ Madison Limestone } & $\begin{array}{l}\text { Limestone and dolomite, white to } \\
\text { bluish-gray, hard, cherty. }\end{array}$ & $400-500$ & Marine & \multicolumn{2}{|c|}{ Madison Limestone } & $\begin{array}{l}\text { Limestone, bluish-gray, massive } \\
\text { in part, hard. }\end{array}$ & $200-300$ & Marine. \\
\hline & \multicolumn{2}{|c|}{ Devonian } & \multicolumn{2}{|c|}{ Darby (?) Formation } & $\begin{array}{l}\text { Dolomite, brown, fetid, shaly, } \\
\text { and sandy. }\end{array}$ & $0-20 ?$ & $\begin{array}{l}\text { Possibly a thin } \\
\text { remnant present. }\end{array}$ & & Absent & & & $\begin{array}{c}\text { Removed by pre- } \\
\text { Madison erosion. }\end{array}$ \\
\hline & \multicolumn{2}{|c|}{ Ordovician } & Bigho & n Dolomite & $\begin{array}{c}\text { Dolomite, gray, hard, slliceous, } \\
\text { massive. }\end{array}$ & $0-50$ & Marine & & Absent & & & $\begin{array}{c}\text { Removed by pre- } \\
\text { Madison erosion. }\end{array}$ \\
\hline & 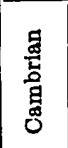 & 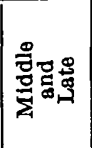 & Undi & ferentiated & $\begin{array}{l}\text { Limestone, brownish-gray, glau- } \\
\text { contitic, hard, slabby, in upper } \\
\text { part; green fissile shale in mid- } \\
\text { dle; sandy limestone grading } \\
\text { down to red and brown sand- } \\
\text { stone in lower part. }\end{array}$ & $900-1,000$ & Marine & Undiff & fferentiated & $\begin{array}{l}\text { Sandstone and fine-grained con- } \\
\text { glomerate, brown to dark-red, } \\
\text { hard. }\end{array}$ & $200-300$ & Probably marine. \\
\hline
\end{tabular}


TABLE 2.-Data on numbered wells and [Most wells are shown on pl. 1. Measurements

Explanation of abbreviations: n.d:, no data; CH, core hole.
Location: SNL, south of north line; WEL, west of east line; NSL, north of south line; EWL, east of west line; C, center, etc.

Elevation: T, elevation from modern topographic map; DF, derrick floor, KB, kelly base on drill rig; $G$, ground elevation at well site.

Source of data: E, electric log; GRN, gamma-ray-neutron log, G RS, gamma-ray-sonic log, DM, dip-meter log.

Formation: Tm, Moonstone Formation; Tpm, Plocene and Miocene rocks undifferentiated; Tsr, Split Rock Formation; Tmo, Miocene and Oligocene rocks undifferentiated; Twr, White River Formation; Twb, Wagon Bed Formation; Tb, Bridger Formation; Tgl, Laney Shale Member of Green River Formation; Tc, Crooks Gap Conglomerate;

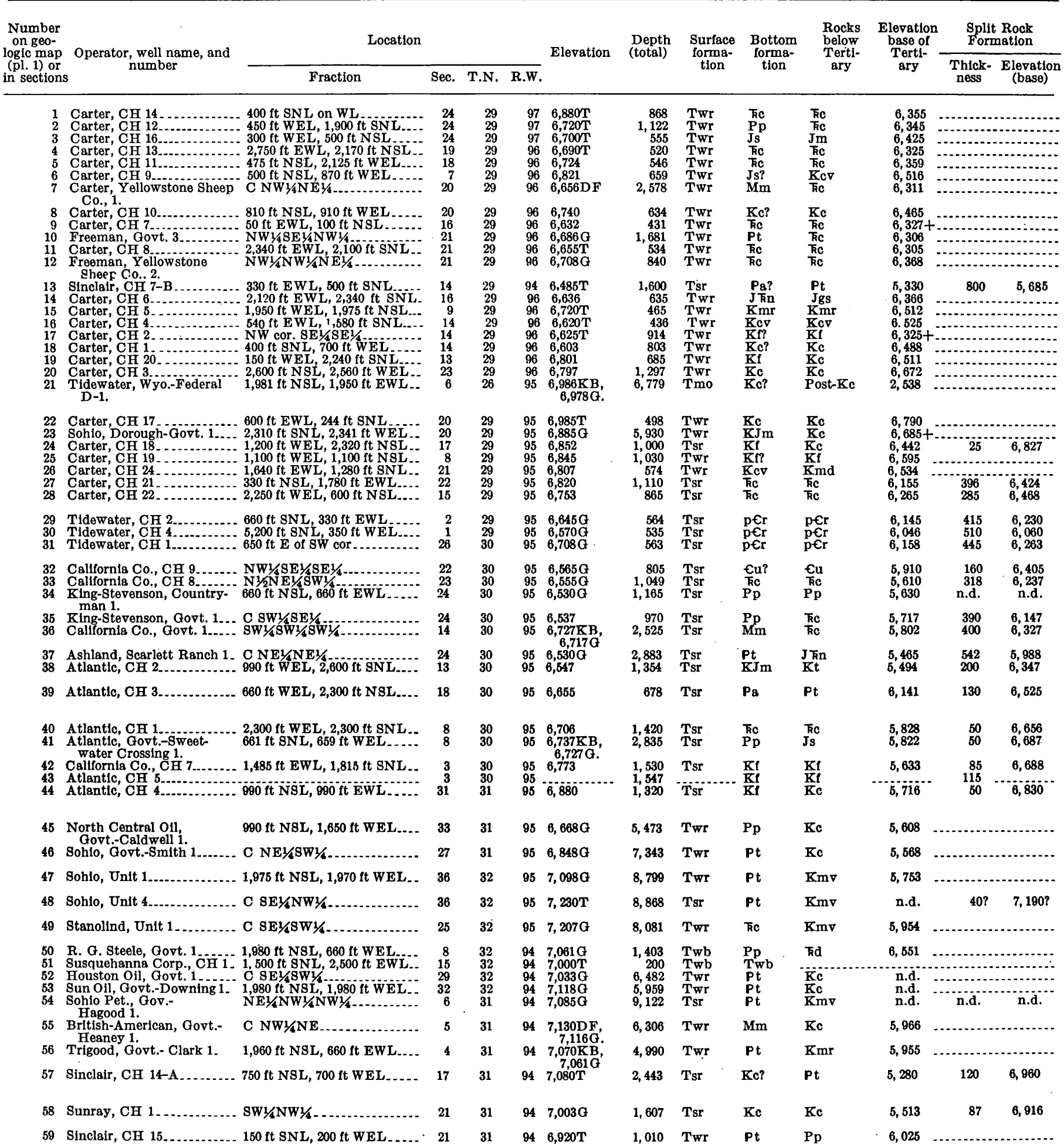


core holes in the Granite Mountains area

of altitude, depth, and thickness are in feet]

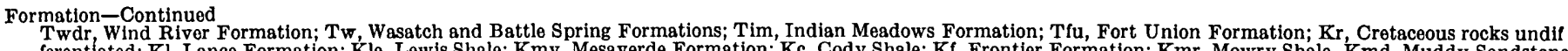
ferentiated; Kl, Lance Formation; Kle, Lewis Shale; Kmv, Mesaverde Formation; Kc, Cody Shale; Kf, Frontier Formation; Kmr, Mowry Shale, Kmd, Muddy Sandstone Momber of Thermopolis Shale; Kt, Thermopolis Shale; Kcv, Cloverly Formation; KJm, Cloverly and Morrison Formations undifferentiated; Jm, Morrison Formation; Js, Sundance Formation; Jgs, G ypsum Spring Formation; Jkn, Nugget Sandstone; Kc, Chugwater Formation; Kd, Dinwood y Formation; Pp, Permian rocks; Pt, Tensleep
Sandstone; Pa, Amsden Formation; Mm, Madison Limestone; Cu, Cambrian rocks undifferentiated; per, Precambrian rocks.

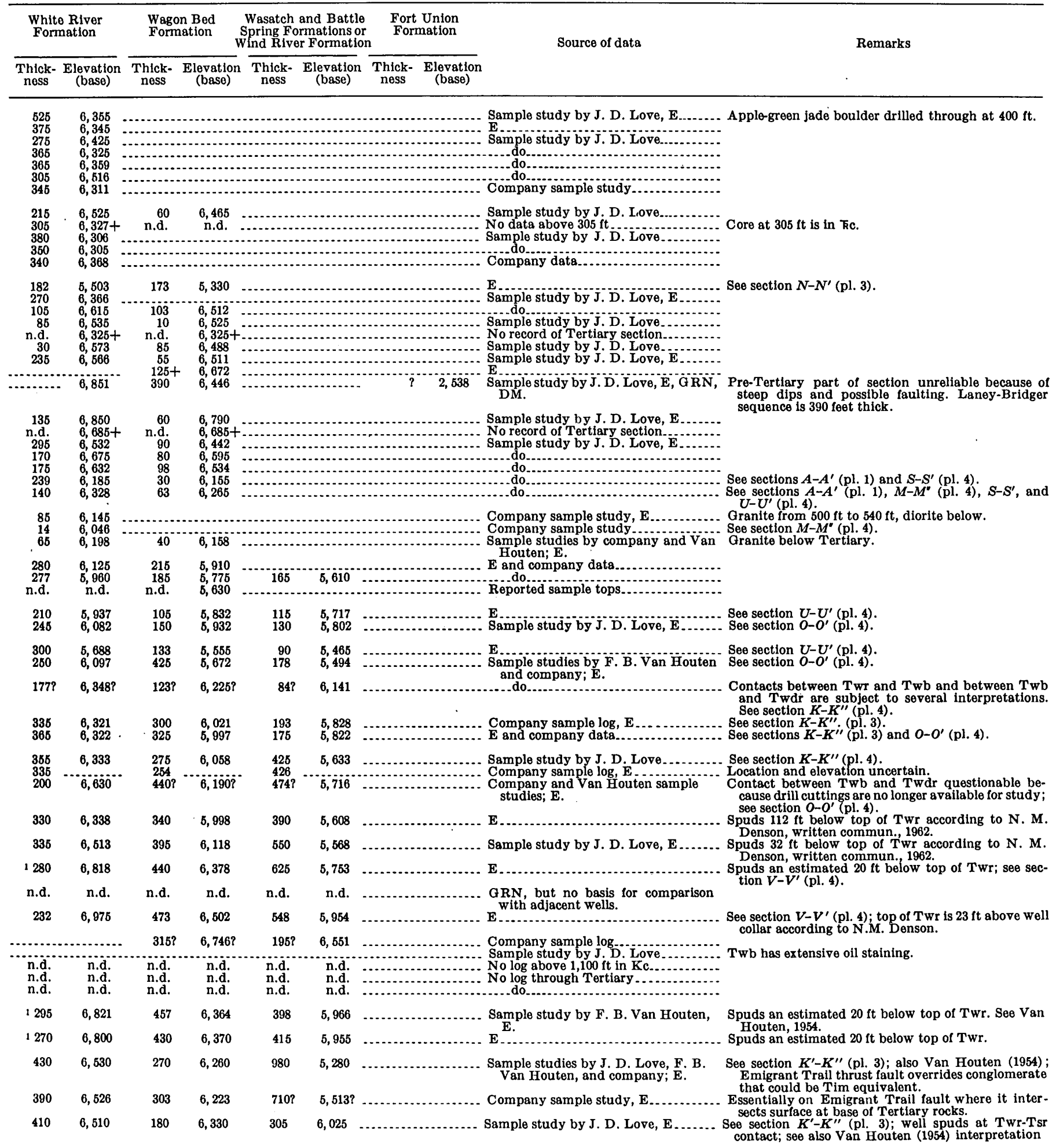


TABLE 2.-Data on numbered wells and core holes

\begin{tabular}{|c|c|c|c|c|c|c|c|c|c|c|c|c|c|}
\hline \multirow{2}{*}{$\begin{array}{l}\text { Number } \\
\text { on geo- } \\
\text { logic map } \\
\text { (pl. 1) or } \\
\text { in sections }\end{array}$} & \multirow{2}{*}{$\begin{array}{l}\text { Operator, well name, and } \\
\text { number }\end{array}$} & \multicolumn{4}{|l|}{ Location } & \multirow{2}{*}{ Elevation } & \multirow{2}{*}{$\underset{\text { Depth }}{\text { (total) }}$} & \multirow{2}{*}{$\begin{array}{l}\text { Surface } \\
\text { forma- } \\
\text { tion }\end{array}$} & \multirow{2}{*}{$\begin{array}{l}\text { Bottom } \\
\text { forma- } \\
\text { tion }\end{array}$} & \multirow{2}{*}{$\begin{array}{l}\text { Rocks } \\
\text { below } \\
\text { Terti- } \\
\text { ary }\end{array}$} & \multirow{2}{*}{$\begin{array}{l}\text { Elevation } \\
\text { base of } \\
\text { Terti- } \\
\text { ary }\end{array}$} & \multicolumn{2}{|c|}{$\begin{array}{l}\text { Split Rock } \\
\text { Formation }\end{array}$} \\
\hline & & Fraction & Sec. & T.N. & R.W. & & & & & & & $\begin{array}{l}\text { Thick- } \\
\text { ness }\end{array}$ & $\begin{array}{c}\text { Elevation } \\
\text { (base) }\end{array}$ \\
\hline 60 & Stanolind, Scarlett Ranch & SW1/4SW1/4NE1/4 & 22 & 31 & 94 & $6,881 G$ & 8,000 & Twr & p€r & $\mathrm{Pp}$ & 6,261 & & \\
\hline 61 & Sinclair, $\mathrm{CH} 8 \ldots \ldots$ & $900 \mathrm{ft}$ WEL, $1,000 \mathrm{ft}$ SNL.... & 22 & 31 & 94 & $6,840 \mathrm{G}$ & 600 & Twr & Pp & $\mathrm{Pp}$ & 6,300 & & \\
\hline 62 & Sunray, $\mathrm{CH} 2 \ldots . .$. & C NE1/4NW1/4 & 29 & 31 & 94 & $6,961 \mathrm{~KB}$ & 2,010 & Tsr & $\mathbf{K c}$ & $\mathbf{K c}$ & 5,291 & 200 & 6,781 \\
\hline 63 & Sunray, CH 3............ & $720 \mathrm{ft}$ SNL, 2,850 ft WEL & 31 & 31 & 94 & $6,755 \mathrm{~KB}$ & 1,805 & Tsr & Kc & Kc & 5,570 & 90 & 6,665 \\
\hline 64 & Champlin Oil Ref. Co., & $660 \mathrm{ft}$ NSL, $1,980 \mathrm{ft}$ EWL.... & 29 & 31 & 94 & $\begin{array}{l}6,863 \mathrm{~KB} \\
6,856 \mathrm{G}\end{array}$ & 7,021 & $\mathrm{Tsr}$ & Kc & $\mathrm{Kc}$ & 5,523 & 115 & 6,748 \\
\hline $\begin{array}{l}65 \\
66\end{array}$ & $\begin{array}{l}\text { Atlantic, } \mathrm{CH} 6 \\
\text { Sunray, } \mathrm{CH} \\
4\end{array}$ & $\begin{array}{l}1,320 \mathrm{ft} \text { SNL, } 990 \mathrm{ft} \text { WEL } \\
\mathrm{C} \text { NE1/4NW1/4. }\end{array}$ & $\begin{array}{l}6 \\
5\end{array}$ & $\begin{array}{l}30 \\
30\end{array}$ & $\begin{array}{l}94 \\
94\end{array}$ & $\begin{array}{l}6,680 \mathrm{~T} \\
6,655 \mathrm{~KB} \\
6,650 \mathrm{G}\end{array}$ & $\begin{array}{l}1,546 \\
1,470\end{array}$ & $\begin{array}{l}\text { Tsr } \\
\text { Tsr }\end{array}$ & $\begin{array}{l}\mathrm{Kc} \\
\mathrm{Kc}\end{array}$ & $\begin{array}{l}\mathbf{K} \mathbf{c} \\
\mathbf{K} \mathbf{c}\end{array}$ & $\begin{array}{l}5,597 \\
5,637\end{array}$ & $\begin{array}{r}122 \\
85\end{array}$ & $\begin{array}{l}6,558 \\
6,570\end{array}$ \\
\hline 67 & Sinclair, CH 13... & $330 \mathrm{ft}$ SNL, 1,570 ft WEL.... & 4 & 30 & 94 & $6,680 \mathrm{~T}$ & 1,406 & Tsr & $\mathbf{K c}$ & $\mathbf{K c}$ & 5,752 & 70 & 6,610 \\
\hline $\begin{array}{l}68 \\
69\end{array}$ & $\begin{array}{l}\text { Sinclair, CH } 9 \\
\text { Columbian Fuel Corp., } \\
\text { Scarlett } 1 .\end{array}$ & $\begin{array}{l}2,200 \mathrm{ft} W E L, 400 \mathrm{ft} \text { SNL } \\
656 \mathrm{ft} \text { SNL, } 1,936 \mathrm{ft} \text { WEL of } \\
\text { SE1 }\end{array}$ & $\begin{array}{r}3 \\
11\end{array}$ & $\begin{array}{l}30 \\
30\end{array}$ & $\begin{array}{l}94 \\
94\end{array}$ & $\begin{array}{l}6,665 \mathrm{~T} \\
6,559 \mathrm{~KB}\end{array}$ & $\begin{array}{l}484 \\
690\end{array}$ & $\begin{array}{l}\text { Tsr } \\
\text { Tsr }\end{array}$ & $\begin{array}{l}\text { Pa? } \\
\text { n.d. }\end{array}$ & $\begin{array}{l}\text { Pa? } \\
\text { n.d. }\end{array}$ & $\begin{array}{l}\text { 6, } 195 \\
\text { n.d. }\end{array}$ & $\begin{aligned} 20 \\
\text { n.d. }\end{aligned}$ & $\begin{array}{l}\text { 6, 645 } \\
\text { n.d. }\end{array}$ \\
\hline 70 & $\begin{array}{l}\text { Columbian Fuel Corp., } \\
\text { Scarlett 1-A. }\end{array}$ & $2,430 \mathrm{ft}$ NSL, $2,430 \mathrm{ft}$ WEL. & 11 & 30 & 94 & $\begin{array}{l}6,572 \mathrm{~KB} \\
6558 \mathrm{G}\end{array}$ & 6,033 & Tsr & $p \in r$ & $\mathbf{P a}$ & 6,102 & 40 & 6,532 \\
\hline $\begin{array}{l}71 \\
72 \\
73\end{array}$ & $\begin{array}{l}\text { Sinclair, CH } 2 \\
\text { California Co., CH } 1 . . . \\
\text { Arnold-Utah Southern, } \\
\text { Besore 1. }\end{array}$ & $\begin{array}{l}\text { C SE1/4NW1/4 } \\
2,244 \mathrm{ft} \text { NSL, } 2,244 \text { ft EWL.. } \\
\text { NW1/4NW1/4NE1/4 }\end{array}$ & $\begin{array}{l}16 \\
18 \\
30\end{array}$ & $\begin{array}{l}30 \\
30 \\
30\end{array}$ & $\begin{array}{l}94 \\
94 \\
94\end{array}$ & $\begin{array}{l}6,510 \mathrm{~T} \\
6,532 \\
6,666 \mathrm{~KB} \\
6,655 \mathrm{G}\end{array}$ & $\begin{array}{l}1,260 \\
1,159 \\
1,952\end{array}$ & $\begin{array}{l}\text { Tsr } \\
\text { Tsr } \\
\text { Tsr }\end{array}$ & $\begin{array}{l}\mathrm{Kc} \\
\mathrm{Kmr} \\
\mathrm{Pt}\end{array}$ & $\begin{array}{l}\mathbf{K c} \\
\mathbf{K} \mathbf{m r} \\
\mathbf{K} \mathbf{c}\end{array}$ & $\begin{array}{l}5,595 \\
5,437 \\
5,676\end{array}$ & $\begin{array}{r}50 \\
340 \\
555\end{array}$ & $\begin{array}{l}6,460 \\
6,192 \\
6,111\end{array}$ \\
\hline 74 & Utah Southern, Ames 2.... & $230 \mathrm{ft} \mathrm{SNL}, 430 \mathrm{ft} \mathrm{EWL} . .$. & 29 & 30 & 94 & $6,656 \mathrm{~KB}$ & 2,470 & Tsr & Pt & he & 5,746 & 500 & 6,156 \\
\hline $\begin{array}{l}75 \\
76\end{array}$ & $\begin{array}{l}\text { Arnold, Ames } 1 \\
\text { Utah Southern, Besore } 2 . .\end{array}$ & $\begin{array}{l}\text { C SE1/4NW1/4 } \\
\text { C NE1/4SE1/4 }\end{array}$ & $\begin{array}{l}29 . \\
30\end{array}$ & $\begin{array}{l}30 \\
30\end{array}$ & $\stackrel{94}{94}$ & $\begin{array}{l}6,600 \mathrm{G} \\
6,571 \mathrm{~KB} \\
6,560 \mathrm{G}\end{array}$ & $\begin{array}{l}2,609 \\
2,108\end{array}$ & $\begin{array}{l}\text { Tsr } \\
\text { Tsr }\end{array}$ & $\stackrel{\text { Pt? }}{\mathrm{Mm}}$ & $\begin{array}{l}\text { Kc } \\
\text { Pp }\end{array}$ & $\begin{array}{l}5,510 \\
5,647\end{array}$ & $\begin{array}{l}510 \\
490\end{array}$ & $\begin{array}{l}6,090 \\
6,081\end{array}$ \\
\hline $\begin{array}{l}77 \\
78 \\
79 \\
80 \\
81 \\
82 \\
83 \\
84 \\
85\end{array}$ & $\begin{array}{l}\text { Shell, CH 3. } \\
\text { California Co., CH } 6 . \\
\text { California Co, CH } 5 . \\
\text { Sinclair, CH } 6 . \\
\text { Shell, CH 1 } \\
\text { Tidewater, } \mathrm{CH} 3 \\
\text { Shell, CH } 2 \text {. } \\
\text { Tidewater, } \mathrm{CH} 5 \\
\text { Preston Assoc., Govt. } 1 . .\end{array}$ & 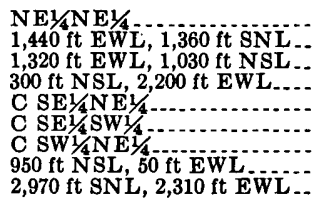 & $\begin{array}{r}32 \\
35 \\
24 \\
36 \\
5 \\
5 \\
7 \\
8 \\
11\end{array}$ & $\begin{array}{l}30 \\
30 \\
30 \\
30 \\
29 \\
29 \\
29 \\
29 \\
29\end{array}$ & $\begin{array}{l}94 \\
94 \\
94 \\
94 \\
94 \\
94 \\
94 \\
94 \\
94\end{array}$ & $\begin{array}{l}6,545 \mathrm{~T} \\
6,600 \mathrm{~T} \\
6,628 \mathrm{~T} \\
6,485 \mathrm{~T} \\
6,520 \mathrm{~T} \\
6,545 \mathrm{~T} \\
6,580 \mathrm{~T} \\
6,645 \mathrm{~T} \\
6,508 \mathrm{~K} \mathrm{~B}, \\
6,501 \mathrm{G}\end{array}$ & $\begin{array}{r}1,407 \\
1,380 \\
1,340 \\
1,270 \\
1,025 \\
994 \\
705 \\
571 \\
3,095\end{array}$ & $\begin{array}{l}\text { Tsr } \\
\text { Tsr } \\
\text { Tsr } \\
\text { Tsr } \\
\text { Tsr } \\
\text { Tsr } \\
\text { Tsr } \\
\text { Tsr } \\
\text { Tsr }\end{array}$ & $\begin{array}{l}\mathrm{Kc} \\
\mathrm{Kt} \\
\mathrm{Kc} \\
\mathrm{Kcv} \\
\mathrm{Pa} \\
\in \mathrm{u} \\
\mathrm{p} \in \mathrm{r} \\
\mathrm{p} \in \mathrm{r} \\
\mathrm{Mm}\end{array}$ & $\begin{array}{l}\text { Kc } \\
\text { Kmr } \\
\text { Kc } \\
\text { Kmr } \\
\text { Pa? } \\
\text { Eu } \\
\text { p } \mathbf{r} \\
\text { pEr } \\
\text { kc }\end{array}$ & $\begin{array}{l}5,400 \\
5,500 \\
5,558 \\
5,690 \\
5,595 \\
5,790 \\
5,895 \\
6,084 \\
5,378\end{array}$ & $\begin{array}{l}510 \\
460 \\
195 \\
400 \\
550 \\
510 \\
630 \\
510 \\
772\end{array}$ & $\begin{array}{l}6,035 \\
6,140 \\
6,433 \\
6,085 \\
5,970 \\
6,035 \\
5,950 \\
6,135 \\
5,736\end{array}$ \\
\hline 86 & California Co., Govt. 3... & 1,848 ft SNL, 2,208 ft EWL.- & 2 & 28 & 94 & $\begin{array}{r}6,726 \mathrm{~KB} \\
6,717 \mathrm{G}\end{array}$ & 3,095 & Tsr & €u? & Ka & 4,596 & 1,660 & 5,066 \\
\hline 87 & $\begin{array}{l}\text { British American, Boesel- } \\
\text { Govt. } 1 .\end{array}$ & $990 \mathrm{ft}$ NSL, $990 \mathrm{ft}$ EWL & 2 & 28 & 94 & $6,913 \mathrm{~KB}$ & 2,850 & $\mathbf{T w b}$ & Mm & ke & 6,313 & & \\
\hline $\begin{array}{l}88 \\
89\end{array}$ & $\begin{array}{l}\text { Sinclair, CH } 22 \\
\text { Sinclair, CH } 20\end{array}$ & $\begin{array}{l}1,200 \mathrm{ft} \text { EWL, } 1,120 \mathrm{ft} \text { NSL.. } \\
1,300 \mathrm{ft} \text { SNL, 1,280 ft WEL.. }\end{array}$ & $\begin{array}{r}1 \\
12\end{array}$ & $\begin{array}{l}28 \\
28\end{array}$ & $\begin{array}{l}94 \\
94\end{array}$ & $\begin{array}{l}6,830 \mathrm{~T} \\
7,005 \mathrm{~T}\end{array}$ & $\begin{array}{l}1,340 \\
2,055\end{array}$ & $\begin{array}{l}\text { Twr } \\
\text { Twr }\end{array}$ & $\begin{array}{l}\mathrm{Kc} \\
\mathrm{Kc} ?\end{array}$ & $\begin{array}{l}\text { JKn } \\
\text { Kc }\end{array}$ & $\begin{array}{l}5,975 \\
5,965\end{array}$ & 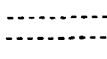 & \\
\hline 90 & $\begin{array}{l}\text { Natural Gas \& Oil, } \\
\text { Govt.-Boos 1. }\end{array}$ & NW1/4NW1/4SE1/4.................. & 12 & 28 & 94 & $7,026 \mathrm{~KB}$ & 6,219 & $\mathrm{Tw}$ & Kc & $\mathbf{K c}$ & 6,151 & 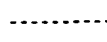 & 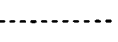 \\
\hline 91 & Sinclair, $\mathrm{CH} 23$ & $1,590 \mathrm{ft}$ WEL, $850 \mathrm{ft}$ NSL.... & 6 & 28 & 93 & $6,970 \mathrm{~T}$ & 1,682 & Tsr & $\mathbf{K} \mathbf{f}$ & $\mathrm{Kc}$ ? & 5,750 & 60 & 6,910 \\
\hline $\begin{array}{l}92 \\
93\end{array}$ & $\begin{array}{l}\text { Sinclair, CH 18. } \\
\text { True \& Brown, Fremont } \\
\text { Sheep 1. }\end{array}$ & $\begin{array}{l}1,430 \mathrm{ft} W E L, 1,000 \mathrm{ft} \mathrm{NSL} . . \\
225 \mathrm{ft} \text { NSL, } 1,700 \mathrm{ft} \text { WEL.... }\end{array}$ & $\begin{array}{l}6 \\
6\end{array}$ & $\begin{array}{l}28 \\
28\end{array}$ & $\begin{array}{l}93 \\
93\end{array}$ & $\begin{array}{l}6,960 \mathrm{~T} \\
7,005 \mathrm{~KB} \\
6,995 \mathrm{G}\end{array}$ & $\begin{array}{l}1,870 \\
5,115\end{array}$ & $\begin{array}{l}\text { Tsr } \\
\text { Tsr }\end{array}$ & $\begin{array}{l}\mathrm{Kf} \\
\mathrm{Kmr} ?\end{array}$ & $\begin{array}{l}\mathbf{K} \mathbf{c} \\
\mathbf{K} \mathbf{c}\end{array}$ & $\begin{array}{l}5,740 \\
5,762\end{array}$ & $\begin{array}{l}370 \\
(3)\end{array}$ & ${ }_{(2)}^{6,590}$ \\
\hline 94 & $\begin{array}{l}\text { Sinclair, Happy Springs } \\
\text { Unit } 30 \text {. }\end{array}$ & $990 \mathrm{ft}$ SNL, $990 \mathrm{ft}$ EWL. & 4 & 28 & 93 & $7,045 \mathrm{~T}$ & 6,378 & Tsr & $\mathrm{Pp}$ & $\mathbf{K c}$ & 5,375 & 1,260 & 5,785 \\
\hline 95 & $\begin{array}{l}\text { Sinclair, Happy Springs } \\
\text { Unit } 36 \text {. }\end{array}$ & $330 \mathrm{ft}$ WEL, 1,650 ft N SL.... & 5 & 28 & 93 & 6,994 KB & 5,276 & Tsr & J页n & Ki & 5,564 & 950 & 6,044 \\
\hline 96 & $\begin{array}{l}\text { Sinclair, Happy Springs } \\
\text { Unit } 37 .\end{array}$ & 2,310 ft NSL, 1,650 ft EWL.. & 4 & 28 & 93 & 6,994 KB & 7,065 & Tsr & Mm & $\mathbf{K} \mathbf{f}$ & 4,984 & 1,612 & 5,382 \\
\hline 97 & Sinclair, $\mathrm{C} H$ 2-A......... & $\begin{array}{l}240 \mathrm{ft} \text { NSL, } 380 \mathrm{ft} \text { WEL of } \\
\text { NW1/4. }\end{array}$ & 4 & 28 & 93 & $6,938 \mathrm{~T}$ & 2,560 & Tsr & $\mathbf{K} \mathbf{f}$ & $\mathbf{K} \mathbf{f}$ & 4,758 & 1,790 & 5,148 \\
\hline 98 & $\begin{array}{l}\text { Sinclair, Happy Springs } \\
\text { Unit 23. }\end{array}$ & $1,650 \mathrm{ft}$ NSL, $2,310 \mathrm{ft}$ EWL.. & 4 & 28 & 93 & $6,984 \mathrm{G}$ & 6,502 & Tsr & Pt & $\mathrm{Kc} ?$ & 5,004 & 1,510 & 5,474 \\
\hline 99 & $\begin{array}{l}\text { Sinclair, Happy Springs } \\
\text { Unit } 27\end{array}$ & $1,650 \mathrm{ft}$ NSL, $1,650 \mathrm{ft}$ WEL... & 4 & 28 & 93 & $6,950 \mathrm{~T}$ & 6,340 & Tsr & Pp & $\mathbf{K c}$ & 4,930 & 1,650 & 5,300 \\
\hline 100 & $\begin{array}{l}\text { Sinclair, Happy Springs } \\
\text { Unit i3. }\end{array}$ & $330 \mathrm{ft}$ NSL, $990 \mathrm{ft}$ EWL..... & 4 & 28 & 93 & $7,110 \mathrm{~T}$ & 4,632 & $\mathbf{T w}$ & $\mathbf{K J m}$ & $\mathbf{K c}$ & 6,110 & & \\
\hline 101 & $\begin{array}{l}\text { Sinclair, Happy Springs } \\
\text { Unit 15. }\end{array}$ & 330 ft $\mathrm{BNL}, 1,680 \mathrm{ft}$ EWL.... & 9 & 28 & 93 & $7,186 \mathrm{G}$ & $-4,760$ & $\mathbf{T w}$ & $\mathrm{Kev}$ & $\mathrm{Kc}$ & 6,141 & & \\
\hline 102 & Sinclair, Jade Unit 1..... & $\begin{array}{l}330 \mathrm{ft} \text { NSL, } 330 \mathrm{ft} \text { WEL of } \\
\mathrm{SW} / 4 .\end{array}$ & 3 & 28 & 93 & $\begin{array}{l}7,036 \mathrm{~KB} \\
7,027 \mathrm{G}\end{array}$ & 5,100 & Tw & $\mathrm{Jm}$ & $\mathbf{K c}$ & 5,946 & & \\
\hline 103 & $\begin{array}{l}\text { Sinclair, Happy Springs } \\
\text { Unit } 28 \text {. }\end{array}$ & NW $1 / 4$ SE $1 / 4$ NW $1 / 4$ & 9 & 28 & 93 & $7,391 \mathrm{G}$ & 4,190 & Tc & $\mathbf{K f}$ & $\mathbf{K c}$ & 6,531 & & \\
\hline 104 & $\begin{array}{l}\text { Sinclair, Happy Springs } \\
\text { Unit 19. }\end{array}$ & $330 \mathrm{ft}$ NSL, 2,310 ft EWL...- & 8 & 28 & 93 & 7,834 KB, & 5,407 & Tc & $\mathbf{K f}$ & $\mathrm{Kc}$ & 6,534 & & \\
\hline 105 & $\begin{array}{l}\text { Sinclair, Happy Springs } \\
\text { Unit } 6\end{array}$ & $330 \mathrm{ft}$ WEL, 2,250 ft SNL... & 8 & 28 & 93 & $8,111 \mathrm{G}$ & 6,625 & Tc & $\mathbf{K t}$ & $\mathbf{K c}$ & 6,893 & & \\
\hline 106 & $\begin{array}{l}\text { Sinclair, Happy Springs } \\
\text { Unit 4. }\end{array}$ & $330 \mathrm{ft}$ WEL, $1,650 \mathrm{ft}$ NSL... & 17 & 28 & 93 & $8,176 \mathrm{G}$ & 6,954 & Tc & $\mathbf{K J m}$ & $\mathbf{K c}$ & 7,031 & & \\
\hline 107 & $\begin{array}{l}\text { Sinclair, Happy Springs } \\
\text { Unit } 38 \text {. }\end{array}$ & $990 \mathrm{ft}$ NSL, $1,650 \mathrm{ft}$ EWL.... & 16 & 28 & 93 & $8,188 \mathrm{G}$ & 9,225 & Tc & kc & $\mathbf{K c}$ & 7,198 & & \\
\hline 108 & $\begin{array}{l}\text { Sinclair, Happy Springs } \\
\text { Unit 5. }\end{array}$ & $330 \mathrm{ft}$ NSL, $330 \mathrm{ft}$ WEL.... & 17 & 28 & 93 & $8,099 \mathrm{G}$ & 6,500 & Tc & $\mathrm{Kmr}$ & $\mathbf{K c}$ & 6,999 & & \\
\hline 109 & $\begin{array}{l}\text { Sinclair, Happy Springs } \\
\text { Unit } 3 \text {. }\end{array}$ & $990 \mathrm{ft}$ SNL, 1,650 ft EWL... & 21 & 28 & 93 & $8,064 \mathrm{G}$ & 6,675 & Tc & Kt & $\mathbf{K c}$ & 7,064 & & \\
\hline 110 & Phelps Dodge, $\mathrm{CH}$ 58-2... & $2,200 \mathrm{ft}$ WEL, $850 \mathrm{ft}$ SNL..- & 27 & 28 & 93 & 7,936 & 1,000 & Tc & Tw & & & & \\
\hline $\begin{array}{l}111 \\
112 \\
113\end{array}$ & $\begin{array}{l}\text { Phelps Dodge, CH 58-5. . } \\
\text { Sinclair, CH 1-B } \\
\text { Sinclair, CH 3-B (2 of }\end{array}$ & $\begin{array}{l}370 \mathrm{ft} \mathrm{NSL}, 705 \mathrm{ft} \text { WEL } \\
1,700 \mathrm{ft} \mathrm{NSL}, 1,950 \mathrm{ft} \text { WEL. } \\
1,400 \mathrm{ft} \text { WEL, } 2,300 \mathrm{ft} \text { NSL.. }\end{array}$ & $\begin{array}{r}22 \\
1 \\
-\quad 1\end{array}$ & $\begin{array}{l}28 \\
28 \\
28\end{array}$ & $\begin{array}{l}93 \\
93 \\
93\end{array}$ & $\begin{array}{l}8,060 \\
6,625 \mathrm{~T} \\
6,601\end{array}$ & $\begin{array}{l}1,000 \\
2,175 \\
2,250\end{array}$ & $\begin{array}{l}\text { Tc } \\
\text { Tsr } \\
\text { Tsr }\end{array}$ & $\begin{array}{l}\mathbf{T w} \\
\mathbf{K f} \\
\mathbf{K} \mathbf{c}\end{array}$ & $\begin{array}{l}\mathrm{K} \mathbf{K} \\
\mathbf{K c}\end{array}$ & & $\begin{array}{r}630 \\
-\quad 1,055\end{array}$ & $\begin{array}{l}5,995 \\
5,546\end{array}$ \\
\hline 114 & $\begin{array}{l}\text { Phelps Dodge, CH } \\
\text { Nettie } 9\end{array}$ & $1,800 \mathrm{ft}$ SNL, on WL... & 1 & 27 & 93 & $6,920 \mathrm{~T}$ & 1,000 & $\mathrm{Tw}$ & & & & & 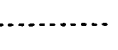 \\
\hline 115 & Phelps Dodge, $\mathrm{CH}$ 58-12... & $1,900 \mathrm{ft} \mathrm{NSL}$, on WL.... & 1 & 27 & 93 & $6,940 \mathrm{~T}$ & 1,008 & $\mathbf{T w}$ & & & & & \\
\hline
\end{tabular}


in the Granite Mountains area-Continued

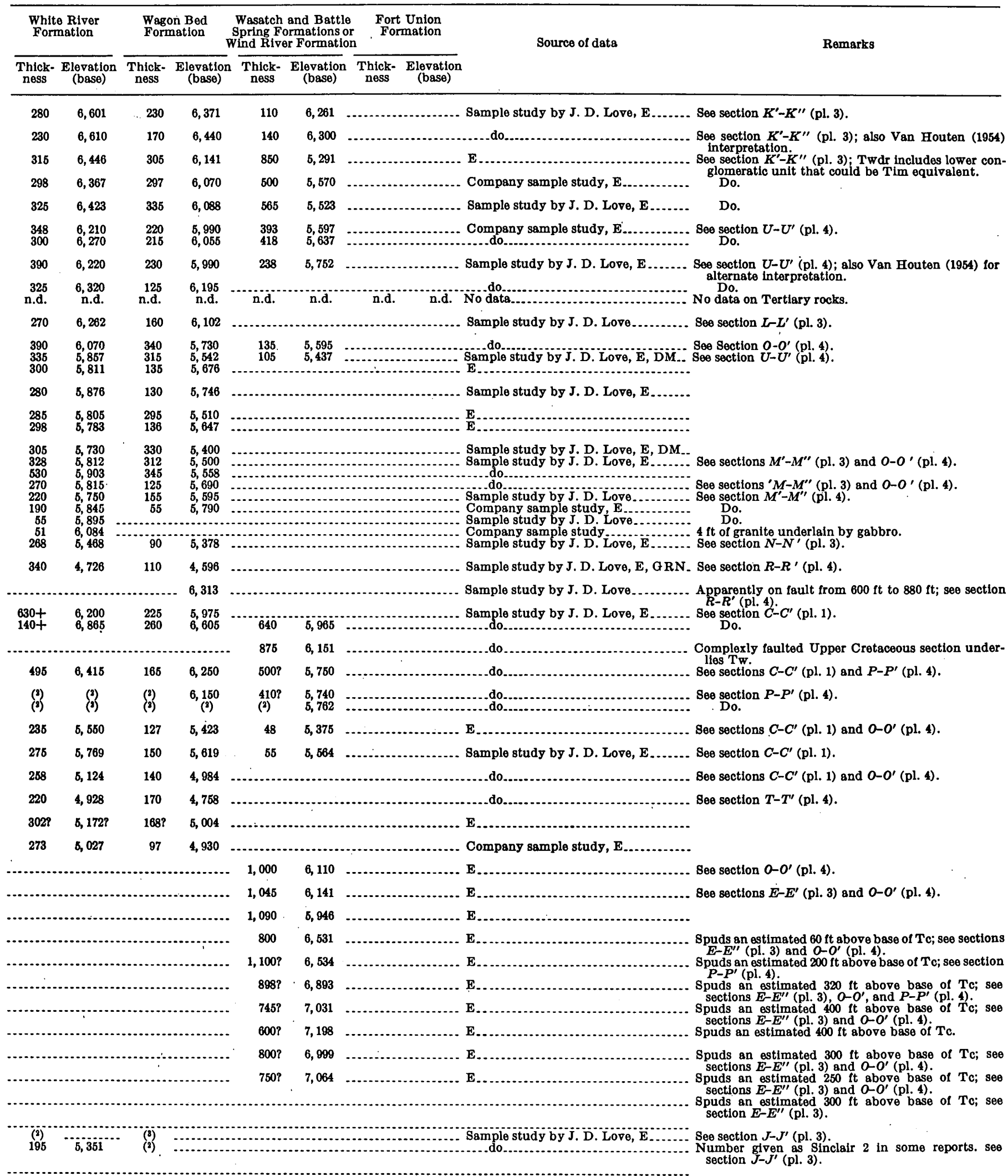


$\mathrm{T}_{\mathrm{ABLE}}$ 2.-Data on numbered wells and core holes

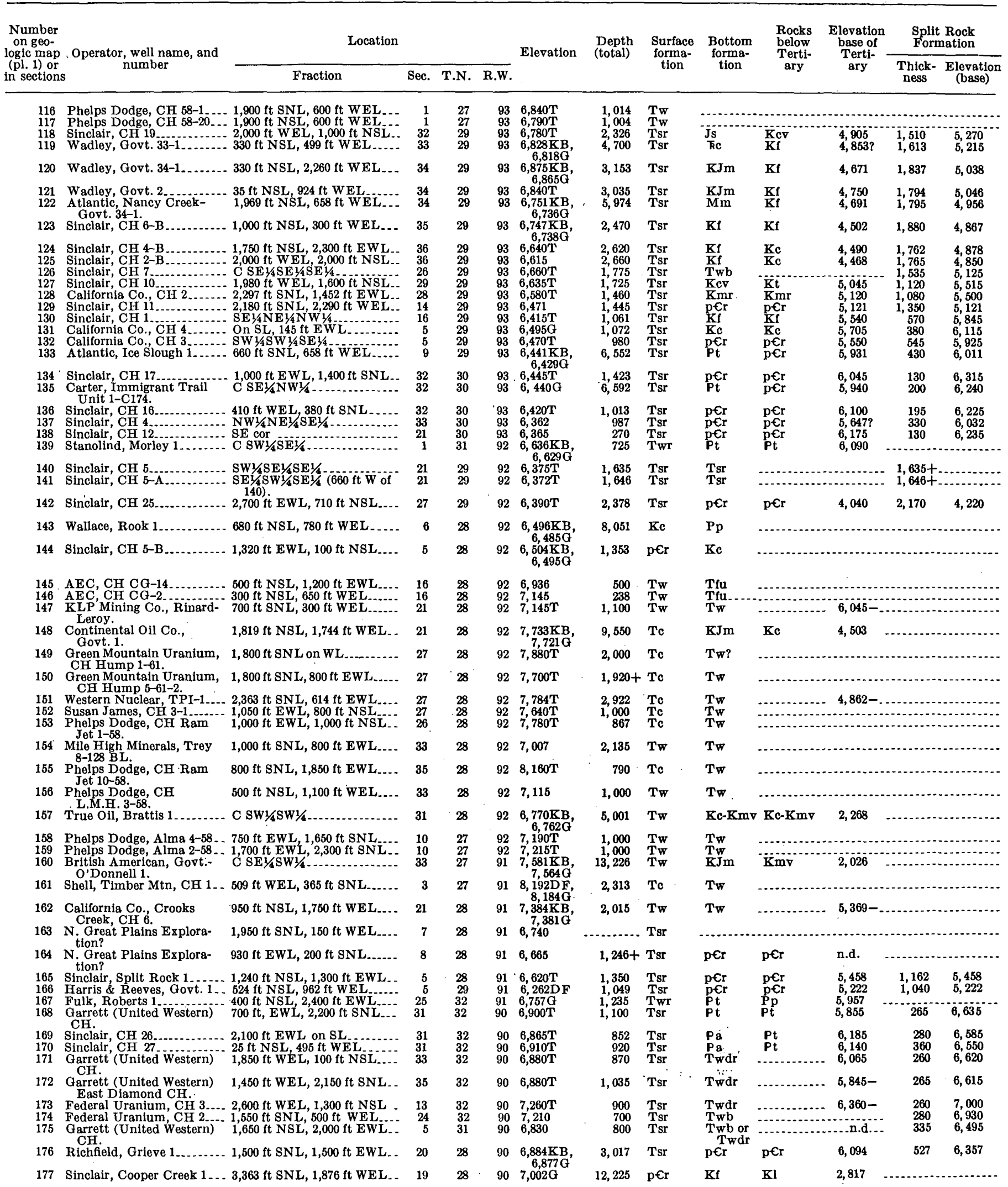

See footnotes at end of table. 
in the Granite Mountains area-Continued

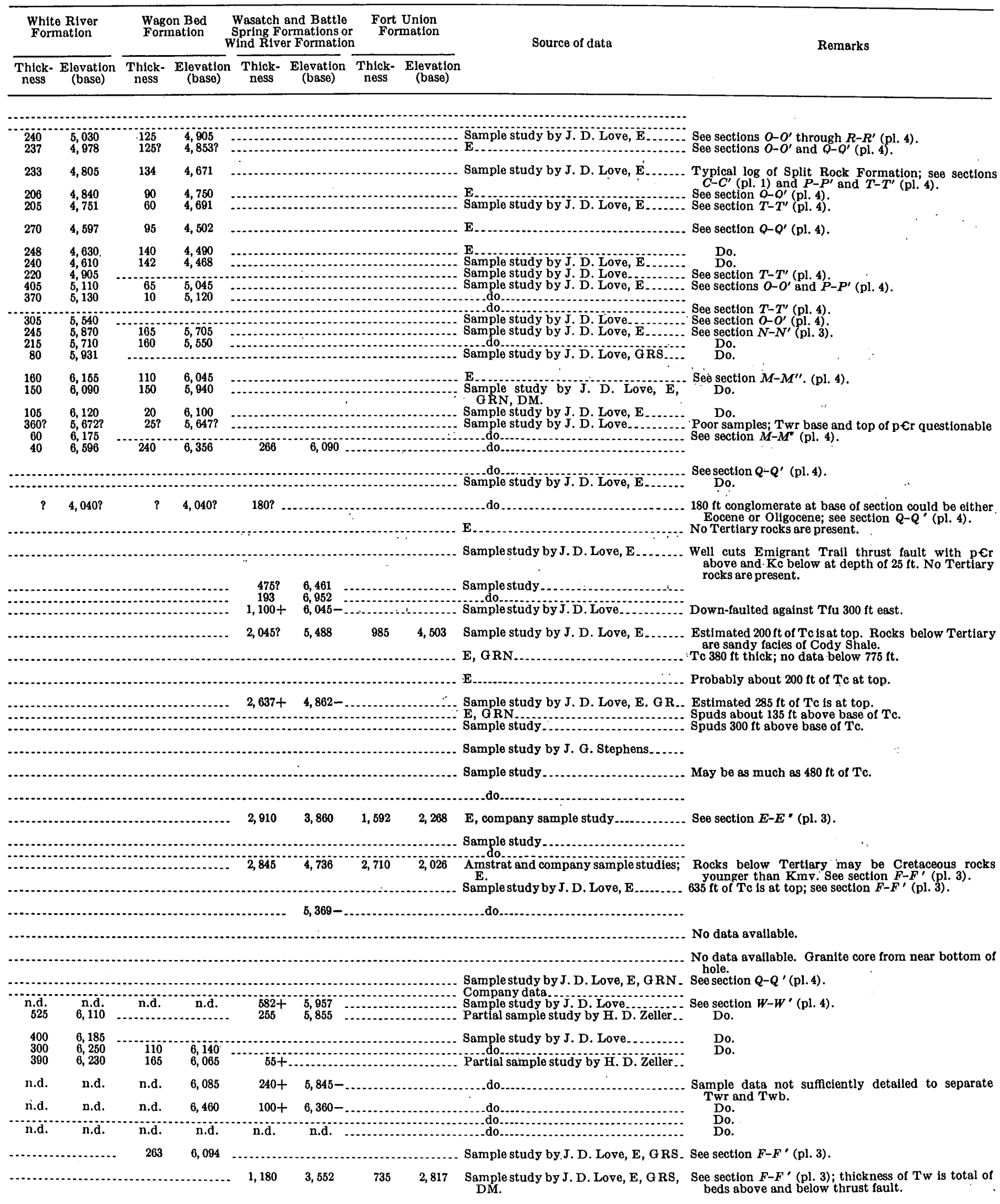


TABLE 2.-Data on numbered wells and core holes

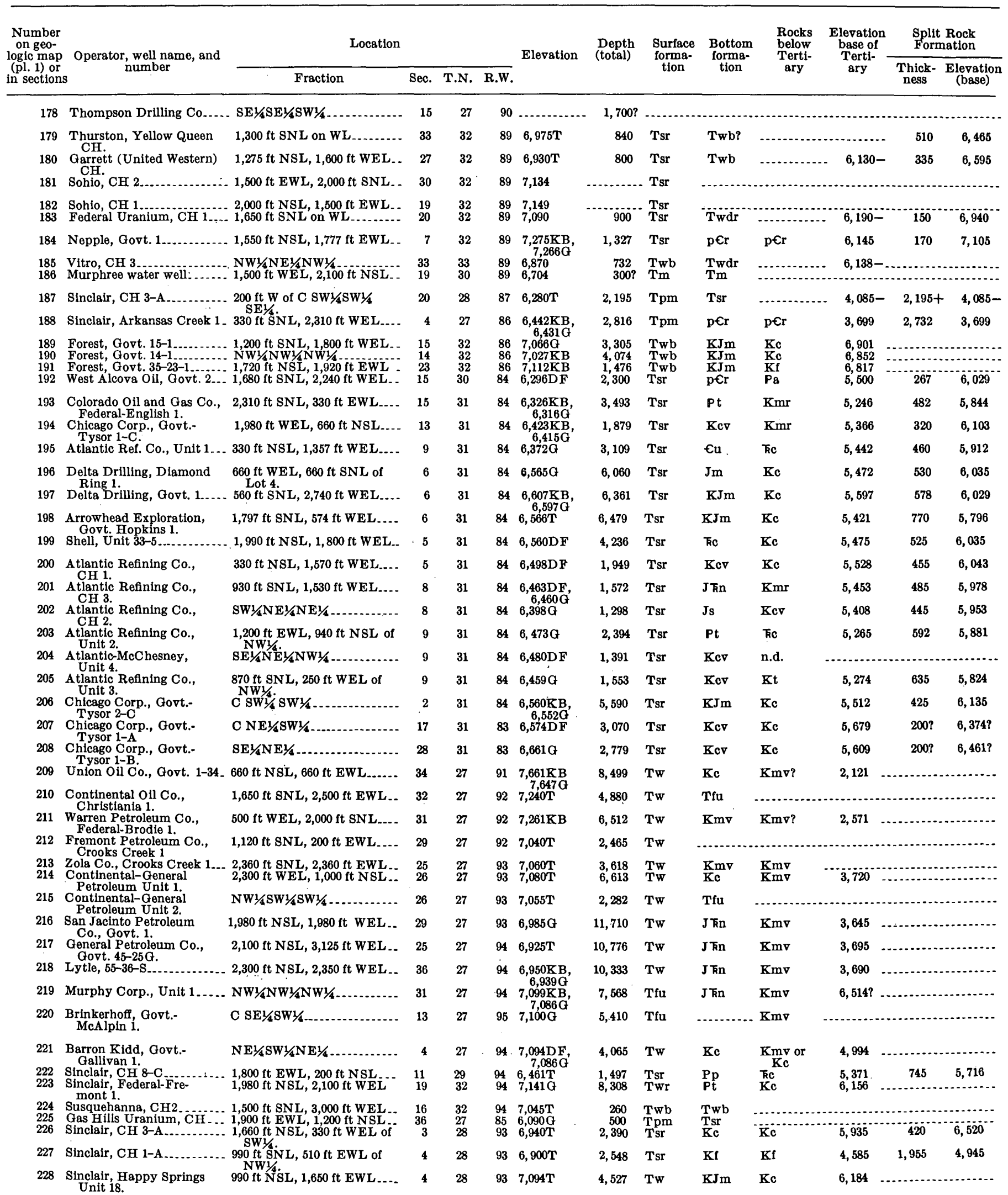

See footnotes at end of table. 
in the Granite Mountains area-Continued

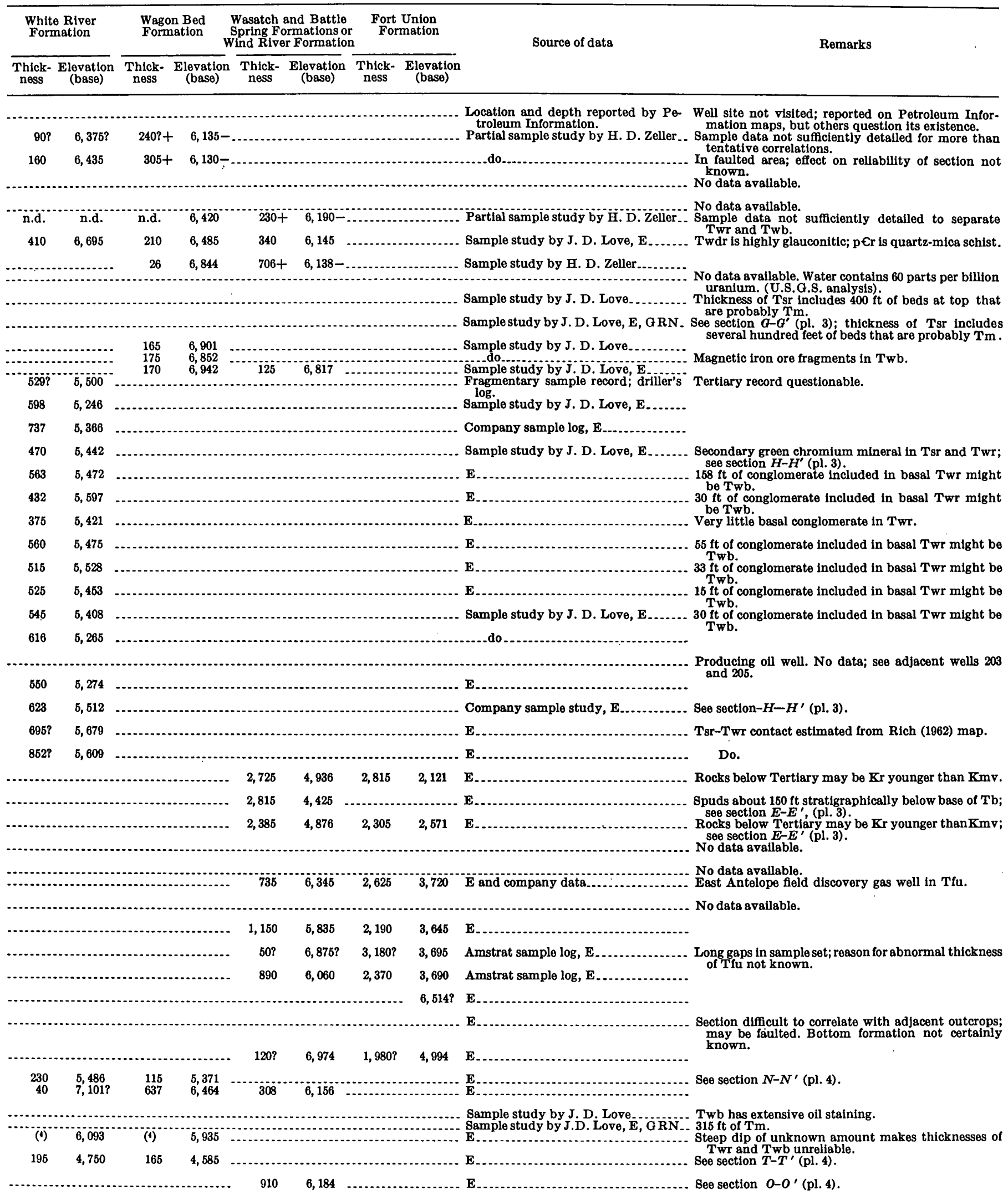


TABLE 2.-Data on numbered wells and core holes

\begin{tabular}{|c|c|c|c|c|c|c|c|c|c|c|c|c|c|}
\hline \multirow{2}{*}{$\begin{array}{l}\text { Number } \\
\text { on geo- } \\
\text { logic map } \\
\text { (pl. 1) or } \\
\text { in sections }\end{array}$} & \multirow{2}{*}{$\begin{array}{l}\text { Operator, well name, and } \\
\text { number }\end{array}$} & \multicolumn{4}{|l|}{ Location } & \multirow{2}{*}{ Elevation } & \multirow{2}{*}{$\begin{array}{l}\text { Depth } \\
\text { (total) }\end{array}$} & \multirow{2}{*}{$\begin{array}{l}\text { Surface } \\
\text { forma- } \\
\text { tion }\end{array}$} & \multirow{2}{*}{$\begin{array}{l}\text { Bottom } \\
\text { forms- } \\
\text { tion }\end{array}$} & \multirow{2}{*}{$\begin{array}{l}\text { Rocks } \\
\text { below } \\
\text { Terti- } \\
\text { ary }\end{array}$} & \multirow{2}{*}{$\begin{array}{c}\text { Elevation } \\
\text { base of } \\
\text { Terti- } \\
\text { ary }\end{array}$} & \multicolumn{2}{|c|}{$\begin{array}{l}\text { Split Rock } \\
\text { Formation }\end{array}$} \\
\hline & & Fraction & Sec. & T.N. & R.W. & & & & & & & $\begin{array}{c}\text { Thick- } \\
\text { ness }\end{array}$ & $\begin{array}{l}\text { Elevation } \\
\text { (base) }\end{array}$ \\
\hline 229 & Sinclair, Happy Springs & $330 \mathrm{ft}$ SNL, $405 \mathrm{ft}$ EWL & 8 & 28 & 93 & $7,140 \mathrm{~T}$ & 4,675 & $\mathrm{Tw}$ & $\mathbf{K c v}$ & $\mathbf{K c}$ & 5,740 & & \\
\hline 230 & $\begin{array}{l}\text { Sinclair, Happy Springs } \\
\text { Unit } 7 \text {. }\end{array}$ & 1,425 ft SNL, $480 \mathrm{ft} \mathrm{EWL} \ldots$ & 8 & 28 & 93 & $7,326 \mathrm{~KB}$ & 5,402 & $\mathbf{T w}$ & J Fn & $\mathbf{K} \mathbf{c}$ & 5,784 & & \\
\hline 231 & $\begin{array}{l}\text { Sinclair, Arapahoe Creek, } \\
\text { Unit 1. }\end{array}$ & $1,980 \mathrm{ft} \mathrm{NSL}, 1,980 \mathrm{ft}$ WEL & 10 & 26 & 94 & $6,891 \mathrm{~KB}$ & 5,500 & Tw & $\mathbf{K c}$ & $\mathbf{K m} \nabla ?$ & 4,131 & & \\
\hline $\begin{array}{l}232 \\
233 \\
234\end{array}$ & $\begin{array}{l}\text { Carter, Murphy } 1 \\
\text { Carter, Great Divide- } \\
\text { Govt. } 1 \text {. } \\
\text { AEC, CH } 7 . . . . . . .\end{array}$ & $\begin{array}{l}660 \mathrm{ft} \text { SNL, } 656 \mathrm{ft} \mathrm{EWL} \\
4,650 \mathrm{ft} \mathrm{EWL}, 650 \mathrm{ft} \mathrm{SNL} . . . \\
1,250 \mathrm{ft} \mathrm{SNL}, 2,650 \mathrm{ft} \text { EWL.- }\end{array}$ & $\begin{array}{r}17 \\
13 \\
1\end{array}$ & $\begin{array}{l}26 \\
26 \\
32\end{array}$ & $\begin{array}{l}94 \\
93 \\
90\end{array}$ & $\begin{array}{l}6,822 \mathrm{G} \\
7,245 \mathrm{~KB} \\
7,232 \mathrm{G} \\
6,960 \mathrm{G}\end{array}$ & $\begin{array}{r}9,728 \\
8,551 \\
810\end{array}$ & $\begin{array}{l}\text { Tw } \\
\mathbf{T w} \\
\mathbf{T w r}\end{array}$ & $\begin{array}{l}\mathbf{K J m} \\
\mathbf{K} \mathbf{c} \\
\mathbf{T w d r}\end{array}$ & $\begin{array}{l}\mathrm{K} m \mathbf{v} \\
\mathbf{K} \mathbf{m} v ?\end{array}$ & 3,712 & & \\
\hline $\begin{array}{l}235 \\
236 \\
237\end{array}$ & $\begin{array}{l}\text { AEC, CH } 6 \\
\text { Cities Service, Govt. } 1-\mathrm{CC}_{--} \\
\text {Shell Oil Co., Dry Lake } \\
\text { Unit 12-28. }\end{array}$ & 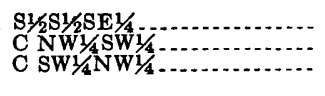 & $\begin{array}{r}2 \\
12 \\
28\end{array}$ & $\begin{array}{l}32 \\
32 \\
27\end{array}$ & $\begin{array}{l}90 \\
85 \\
95\end{array}$ & $\begin{array}{l}6,920 \mathrm{G} \\
6,455 \mathrm{G} \\
7,165 \mathrm{~KB} \\
7,157 \mathrm{G}\end{array}$ & $\begin{array}{r}690 \\
11,284 \\
3,613\end{array}$ & $\begin{array}{l}\text { Twr } \\
\text { Twdr } \\
\text { Tfu }\end{array}$ & $\begin{array}{l}\mathrm{Kc} \\
\mathrm{Jm} \\
\mathrm{Kmr}\end{array}$ & $\begin{array}{l}\mathrm{Kc} \\
\mathrm{Kl} \\
\mathbf{K c}\end{array}$ & $\begin{array}{l}6,295 \\
3,365 \\
6,805\end{array}$ & & \\
\hline $\begin{array}{l}238 \\
239 \\
240\end{array}$ & $\begin{array}{l}\text { G. G. Travis, Govt. 1... } \\
\text { British American, CH } 3 . \\
\text { Pioneer Oil and G. C. }\end{array}$ & $\begin{array}{l}1,980 \mathrm{ft} \text { NSL, } 1,962 \mathrm{ft} \text { EWL. } \\
\text { NW1/4SE1/4 } \\
1,650 \mathrm{ft} \text { SNL, } 1,805 \mathrm{ft} \text { WEL.. }\end{array}$ & $\begin{array}{r}29 \\
5 \\
26\end{array}$ & $\begin{array}{l}30 \\
31 \\
32\end{array}$ & $\begin{array}{l}94 \\
94 \\
95\end{array}$ & $\begin{array}{l}6,553 \mathrm{G} \\
7,132 \mathrm{G} \\
6,751 \mathrm{G}\end{array}$ & $\begin{array}{l}1,573 \\
1,739 \\
8,999\end{array}$ & $\begin{array}{l}\text { Tsr } \\
\text { Tsr } \\
\text { Twb }\end{array}$ & $\underset{\mathrm{Pt}}{\mathrm{Pp}}$ & $\begin{array}{l}\text { Kc } \\
\text { Kc } \\
\text { Kc }\end{array}$ & $\begin{array}{l}5,481 \\
5,875 \\
6,321\end{array}$ & n.d. & n.d. \\
\hline $\begin{array}{l}241 \\
242 \\
243\end{array}$ & $\begin{array}{l}\text { Carter, CH 23... } \\
\text { Carter, CH 15.... } \\
\text { Federal Uranium, CH } \\
\text { B-5. }\end{array}$ & $\begin{array}{l}\mathrm{C} \mathrm{sW1} / 4 \\
1,400 \mathrm{ft} \\
700 \mathrm{ft} \mathrm{SNL}, 750 \mathrm{ft} \mathrm{EWL} \\
\mathrm{E}\end{array}$ & $\begin{array}{l}11 \\
24 \\
23\end{array}$ & $\begin{array}{l}29 \\
29 \\
32\end{array}$ & $\begin{array}{l}95 \\
97 \\
91\end{array}$ & $\begin{array}{l}\text { 6,610T } \\
6,720 \mathrm{~T} \\
6,635\end{array}$ & $\begin{array}{l}927 \\
640 \\
440\end{array}$ & $\begin{array}{l}\text { Tsr } \\
\text { Twr } \\
\text { Twdr }\end{array}$ & $\begin{array}{l}\text { Tsr } \\
\text { kc } \\
\text { Twdr }\end{array}$ & ha & $\begin{array}{l}5,683- \\
6,470 \\
6,195-\end{array}$ & $927+$ & $\begin{array}{r}5,683- \\
\end{array}$ \\
\hline 244 & $\begin{array}{l}\text { Federal Uranium, } \mathrm{CH} \\
\mathrm{B}-6 .\end{array}$ & $1,600 \mathrm{ft}$ EWL, $1.500 \mathrm{ft}$ SNL & 23 & 32 & 91 & 6,760 & 520 & $\mathbf{T w b}$ & Twdr & $\ldots .$. & $6,240-$ & $\ldots$ & .. \\
\hline 245 & $\begin{array}{l}\text { McElroy Ranch, State } \\
1-36 \text {. }\end{array}$ & $1,320 \mathrm{ft}_{\mathrm{j}} \mathrm{SNL}, 1,320 \mathrm{ft}$ WEL.. & 36 & 31 & 84 & $6,349 \mathrm{~KB}$ & 868 & Tsr & $\mathbf{P a}$ & Pt & 5,807 & n.d. & n.d. \\
\hline 246 & $\begin{array}{l}\text { Champlin Oil and Refin- } \\
\text { ing Co., Govt.-Tysor. }\end{array}$ & $200 \mathrm{ft} \mathrm{W}$ of $\mathrm{C} \mathrm{SW} 1 / 4 \ldots$ & 9 & 31 & 83 & $\begin{array}{r}6,464 \mathrm{~KB} \\
6,454 \mathrm{G}\end{array}$ & 4,426 & Tsr & $\mathbf{K} \mathbf{c v}$ & $\mathbf{K} \mathbf{c}$ & 5,474 & $250 ?$ & $6,214 ?$ \\
\hline 247 & $\begin{array}{l}\text { Tidewater, Poison Spring } \\
\text { Creek 1. }\end{array}$ & $\begin{array}{l}1,497 \mathrm{ft} \mathrm{NSL}, 990 \mathrm{ft} \mathrm{EWL} \\
\text { of NE } 14 .\end{array}$ & 31 & 32 & 83 & $6,326 \mathrm{DF}$ & 13,130 & Twdr & $\mathbf{K} \mathbf{f}$ & K1 & 126 & & \\
\hline 248 & $\begin{array}{l}\text { Huber Corp., Govt.- } \\
\text { Sanford 1. }\end{array}$ & $660 \mathrm{ft}$ NSL, 1,980 ft EWL.- & 33 & 32 & 84 & $6,690 \mathrm{G}$ & 7,575 & Tsr & $\mathbf{K e v}$ & $\mathbf{K} \mathbf{c}$ & 5,900 & $240 ?$ & $6,450 ?$ \\
\hline $249 ?$ & True and Fulton, Ritter 1. & C SE1/4SE $1 / 4$ & 32 & 32 & 84 & $6,723 \mathrm{DF}$ & 6,521 & Tsr & $\mathbf{K J} \mathbf{m}$ & Post-Kc & 6,008 & $100 ?$ & $6,623 ?$ \\
\hline $250 ?$ & True, Ritter 3.............. & C SE1/4SW1/4 & 32 & 32 & 84 & $6,684 \mathrm{G}$ & 6,820 & Tsr & $\mathbf{K J m}$ & Post-Kc & 5,826 & $50 ?$ & $6,634 ?$ \\
\hline 251 & $\begin{array}{l}\text { Schieck, Govt. 37-32-1-... } \\
\text { Davis Oil Co., Federal- } \\
\text { Diamond Ring 1. }\end{array}$ & $\begin{array}{l}1,650 \mathrm{ft} \text { SNL, } 330 \mathrm{ft} \text { EWL } \\
1,251 \mathrm{ft} \text { NSL, } 3,490 \mathrm{ft} \mathrm{EWL} \\
\text { of Lot 4. }\end{array}$ & $\begin{array}{l}32 \\
19\end{array}$ & $\begin{array}{l}32 \\
32\end{array}$ & $\begin{array}{l}84 \\
84\end{array}$ & $\begin{array}{l}6,916 \mathrm{~KB} \\
6,667 \mathrm{~KB}\end{array}$ & $\begin{array}{l}7,280 \\
8,477\end{array}$ & $\begin{array}{l}\text { Twdr } \\
\text { Twdr }\end{array}$ & $\mathbf{J m}_{\mathbf{K} \mathbf{m}}$ & $\begin{array}{l}\mathbf{K} \mathbf{m} \nabla \\
\mathbf{K} l\end{array}$ & $\begin{array}{l}6,256 \\
5,732\end{array}$ & & \\
\hline 253 & $\begin{array}{l}\text { Davis Oil Co., Govt.- } \\
\text { Diamond Ring } 1 .\end{array}$ & $\begin{array}{l}654 \mathrm{ft} \text { NSL, } 1,026 \mathrm{ft} \text { EWL } \\
\text { of Lot } 4 .\end{array}$ & 18 & 32 & 84 & $\begin{array}{r}6,541 \mathrm{~KB} \\
6,530 \mathrm{G}\end{array}$ & 9,357 & Twdr & $\mathbf{K} \mathbf{c r}$ & $\mathbf{K} \mathbf{l}$ & 5,361 & $\ldots$ & \\
\hline $\begin{array}{l}254 \\
255 \\
256 \\
257 \\
3\end{array}$ & $\begin{array}{l}\text { True, Govt.-Ritter } 2 \\
\text { Schieck, Govt. 33-36-1.... } \\
\text { Forest, Grieve Unit 24 } \\
\text { Forest, Grieve Unit 22- } \\
\quad 26-3 \text {, }\end{array}$ & $\begin{array}{l}\text { C SE1/4 SW1 } 144 \\
1,900 \mathrm{ft} N S L, 988 \mathrm{ft} \text { EWL } \\
500 \mathrm{ft} \text { SNL, } 2,150 \mathrm{ft} \text { EWL } \\
1,980 \mathrm{ft} \text { NSL, } 1,080 \mathrm{ft} \text { EWL.- }\end{array}$ & $\begin{array}{l}31 \\
36 \\
35 \\
26\end{array}$ & $\begin{array}{l}32 \\
32 \\
32 \\
32\end{array}$ & $\begin{array}{l}84 \\
85 \\
85 \\
85\end{array}$ & $\begin{array}{l}6,609 \mathrm{G} \\
6,740 \mathrm{G} \\
6,990 \mathrm{G} \\
7,327 \mathrm{G}\end{array}$ & $\begin{array}{l}6,681 \\
6,305 \\
6,880 \\
7,269\end{array}$ & $\begin{array}{l}\text { Tsr } \\
\text { Twr } \\
\text { Twdr } \\
\text { Twr }\end{array}$ & $\underset{\mathbf{J m}}{\mathbf{K t}}$ & $\begin{array}{l}\text { Post-Kc } \\
\text { Kmv? } \\
\text { Kmv? } \\
\text { Kmv? }\end{array}$ & $\begin{array}{l}6,004 \\
6,390 \\
6,286 \\
6,427\end{array}$ & $\begin{array}{c}50 ? \\
-\end{array}$ & $\begin{array}{c}6,559 ? \\
\end{array}$ \\
\hline 2581 & $\begin{array}{l}\text { Hiawatha, } 1 \text { Federal- } \\
\text { Fremont 215. }\end{array}$ & $330 \mathrm{ft}$ SNL, $330 \mathrm{ft}$ EWL..... & 15 & 32 & 94 & $7,018 \mathrm{G}$ & 1,932 & $\mathrm{Twb}$ & $\mathrm{Mm}$ & Kc & 16,768 & & \\
\hline 2591 & $\begin{array}{l}\text { Newman Bros., Federal } \\
1-14 .\end{array}$ & $330 \mathrm{ft}$ SNL, $330 \mathrm{ft}$ EWL... & 14 & 30 & 94 & $\begin{array}{r}6,676 \mathrm{~KB} \\
6,664 \mathrm{G}\end{array}$ & 4,300 & Tsr & $\mathbf{P t}$ & Kc & 5,176 & 150 & 6,526 \\
\hline 260 & $\begin{array}{l}\text { Newman Bros., State } \\
1-16 .\end{array}$ & $1,200 \mathrm{ft}$ NSL, 1,700 ft WEL.. & 16 & 29 & 95 & $6,769 \mathrm{~KB}$ & 3,763 & Tsr & Pt & $\mathbf{K} \mathbf{m r}$ & $\ldots$ & $\ldots$ & \\
\hline 261 & $\begin{array}{l}\text { Newman Bros., Federal } \\
1-21 .\end{array}$ & $2 \mathrm{ft}$ SNL, 2 ft WEL & 21 & 29 & 95 & $6,721 \mathrm{~KB}$ & 3,353 & Tsr & $\mathbf{P t}$ & J辰 & 6,321 & 1220 & 16,501 \\
\hline $262 V$ & Western Nuclear, SH-1... & 500 ft EWL, 1,800 ft SNL.... & 10 & 28 & 94 & $6,920 \mathrm{~T}$ & 800 & Twb & $\cdots$ & & & & \\
\hline 263 & Western Nuclear, SH-3..... & $1,275 \mathrm{ft} \mathrm{SNL}, 125 \mathrm{ft} \mathrm{WEL} . .$. & 15 & 28 & 94 & $7,300 \mathrm{~T}$ & 900 & Tw & Tfu & $\cdots+$. & $6,400-$ &.- & - \\
\hline $\begin{array}{l}264 \\
265 \\
266\end{array}$ & $\begin{array}{l}\text { Western Nuclear, SH-2.... } \\
\text { Western Nuclear, KL-1 } \\
\text { Sinclair, } 1 \text { Federal-Fre- }\end{array}$ & 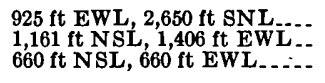 & $\begin{array}{l}12 \\
22 \\
17\end{array}$ & $\begin{array}{l}28 \\
28 \\
27\end{array}$ & $\begin{array}{l}94 \\
92 \\
94\end{array}$ & $\begin{array}{l}6,950 \mathrm{~T} \\
7,484 \\
\mathbf{7 , 0 4 4 G}\end{array}$ & $\begin{array}{l}1,112 \\
2,416 \\
3,479\end{array}$ & $\begin{array}{l}\text { Twr } \\
\text { Tw } \\
\text { Tfu }\end{array}$ & $\begin{array}{l}\mathbf{K c} \\
\mathbf{T w}\end{array}$ & $\mathbf{K c}$ & 5,857 & $\ldots$ & \\
\hline 267 & $\begin{array}{l}\text { mont 855. } \\
\text { Sinclair, Arapahoe Creek } 2 \text {. }\end{array}$ & $1,980 \mathrm{ft} \mathrm{SNL}, 660 \mathrm{ft} \mathrm{EWL}$ & 16 & 26 & 93 & $\begin{array}{l}7,059 \mathrm{~KB}, \\
7,048 \mathrm{G}\end{array}$ & 7,500 & $\mathbf{T w}$ & Kc & Kmv? & $2,089 ?$ & & \\
\hline 268 & $\begin{array}{l}\text { Sunray-Mid-Continent } \\
\text { O1l, Wyo.-Federal-D, } 1 .\end{array}$ & $660 \mathrm{ft}$ NSL, $660 \mathrm{ft}$ EWL..... & 22 & 26 & 95 & $\begin{array}{r}6,808 \mathrm{~KB} \\
6,793 \mathrm{G}\end{array}$ & 8,989 & Tcb & $\begin{array}{l}\text { Post- } \\
\mathbf{K} \mathbf{c ~ K r}\end{array}$ & $\underset{\mathbf{K} \mathbf{r}}{\text { Upper }}$ & -442 & & \\
\hline 269 & $\begin{array}{l}\text { Oil Corp. of America, } \\
\text { Govt. } 1 \text {. }\end{array}$ & SW1/4SW1/4SW1/4... & 7 & 25 & 94 & $6,717 \mathrm{~T}$ & 8,777 & $\mathrm{Tt}$ & Kle? & Kl & 67 & & \\
\hline 270 & $\begin{array}{l}\text { Continental Oil Co., Chain } \\
\text { Lakes Unit 1. }\end{array}$ & $560 \mathrm{ft}$ NSL, $560 \mathrm{ft}$ WEL & 35 & 23 & 94 & $\underset{6,658 \mathrm{G}}{6,671 \mathrm{~KB}}$ & 11,475 & Tw & Kle? & $\mathbf{K l}$ & -429 & & \\
\hline 271 & $\begin{array}{l}\text { Carter and Amerada Cos., } \\
\text { Ruddy } 1 .\end{array}$ & C sW1/4NW1/4. & 14 & 24 & 90 & $\begin{array}{l}7,095 \mathrm{~KB} \\
7,083 \mathrm{G}\end{array}$ & 6,006 & $\mathbf{T w}$ & Tfu? & & & & \\
\hline 272 & $\begin{array}{l}\text { National Coop. Ref. Co., } \\
\text { Govt.-Taffs } 1 .\end{array}$ & 1,988 ft NSL, 1,977 ft EWL.- & 21 & 25 & 90 & $7,069 \mathrm{~KB}$ & 7,064 & $\mathrm{Tw}$ & $\mathrm{K} \mathbf{l} ?$ & $\mathrm{~K} 1 ?$ & $259 ?$ & & \\
\hline $273 I$ & Newman Bros., CH-1.... & $1,400 \mathrm{ft} \mathrm{EWL}, 2,300 \mathrm{ft}$ SNL.. & 15 & 30 & 94 & $\begin{array}{l}\text { 6,675DF, } \\
6,667 \mathrm{G}\end{array}$ & 1,385 & Tsr & $\mathbf{K c}$ & $\mathbf{K} \mathbf{c}$ & 5,500 & 175 & 6,500 \\
\hline 274 & $\begin{array}{l}\text { Newman Bros., CH-2...... } \\
\text { Newman Bros., CH-3..... }\end{array}$ & $\begin{array}{l}1,100 \mathrm{ft} \text { NSL, } 2,200 \mathrm{ft} \mathrm{WEL} \\
1,003 \mathrm{ft} \mathrm{SNL}, 1,960 \mathrm{ft} \text { EWL.- }\end{array}$ & $\begin{array}{l}10 \\
14\end{array}$ & 30 & $\begin{array}{l}94 \\
94\end{array}$ & $\begin{array}{l}6,496 \mathrm{G} \\
6,654 \mathrm{~KB} \\
6,647 \mathrm{G}\end{array}$ & $\begin{array}{l}1,495 \\
1,465\end{array}$ & $\begin{array}{l}\text { Twr } \\
\text { Tsr }\end{array}$ & Kc & $\mathbf{K} \mathbf{c}$ & $\begin{array}{l}5,571 \\
5,679\end{array}$ & 150 & 16,604 \\
\hline 276 & Newman Bros., CH-4..... & $350 \mathrm{ft}$ SNL, 1,600 ft WEL.... & 10 & 30 & 94 & $6,568 \mathrm{~KB}$ & 1,350 & Tsr & & & 5,978 & 40 & 16,528 \\
\hline 277 & $\begin{array}{l}\text { Newman Bros., CH-5....- } \\
\text { Murphy Oil Corp., Trans- } \\
\text { mountain Federal } 1 .\end{array}$ & $\begin{array}{l}1,100 \mathrm{ft} \text { SNL, } 2,195 \mathrm{ft} \text { EWL... } \\
1,980 \mathrm{ft} \text { SNL, } 660 \mathrm{ft} \text { WEL... }\end{array}$ & $\begin{array}{l}10 \\
10\end{array}$ & $\begin{array}{l}30 \\
22\end{array}$ & $\stackrel{94}{93}$ & $\begin{array}{l}6,580 \mathrm{~T} \\
6,766 \mathrm{~K} \mathrm{~B} \\
6,755 \mathrm{G}\end{array}$ & $\begin{array}{l}1,480 \\
7,140\end{array}$ & $\begin{array}{l}\text { Tsr } \\
\text { Tw }\end{array}$ & $\begin{array}{l}\text { Kc? } \\
\text { Kle? }\end{array}$ & $\begin{array}{l}\mathrm{Kc} \\
\mathrm{K} 1 ?\end{array}$ & $\begin{array}{l}5,860 \\
-380\end{array}$ & 150 & $\begin{array}{l}16,530 \\
1 \ldots . . . .\end{array}$ \\
\hline
\end{tabular}

1 Estimate. ${ }^{2}$ Faulted. 3 Faulted out. 1 Steep dip. 
in the Granite Mountains area-Continued

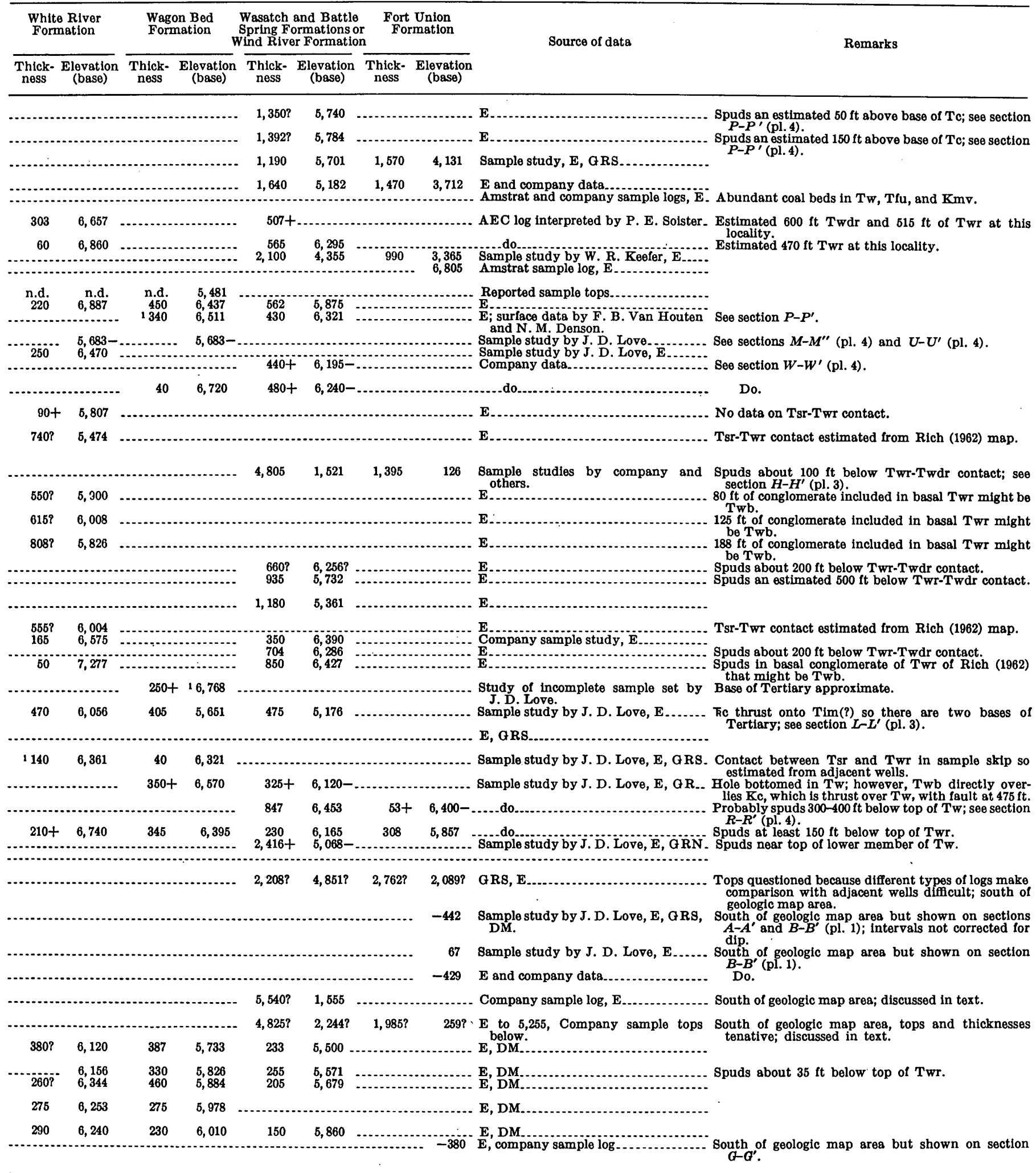




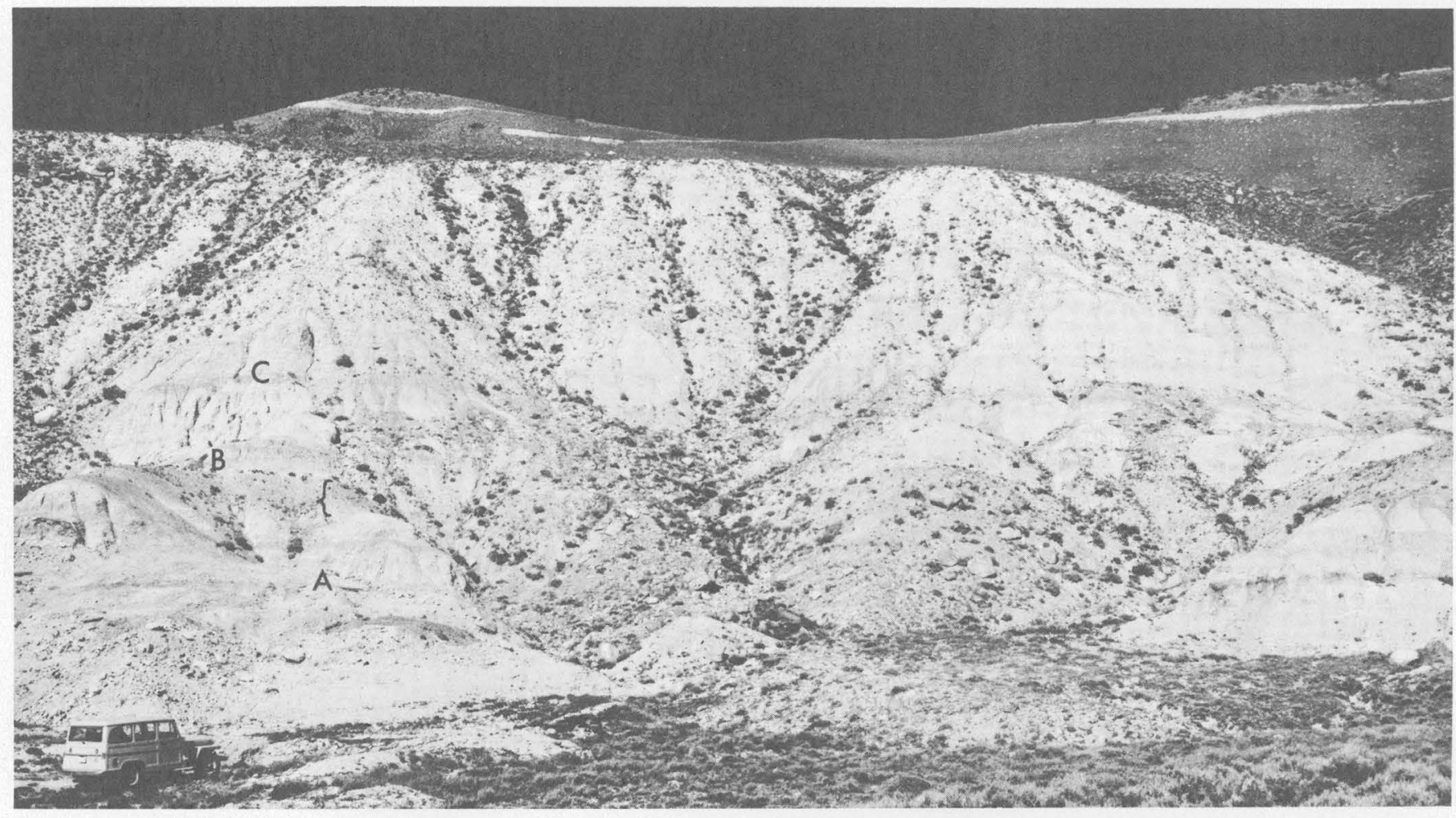

Figure 13.-Fort Union Formation, east side of Crooks Gap, in SW1/4NW1/4NE1/4 sec. 17, T. 28 N., R. 92 W. Positions of pollen samples A, B, and C are indicated. Stratigraphic interval between $A$ and $C$ is 38 feet. Brace indicates chert pebble conglomerate. Wasatch and Battle Spring Formations are exposed in uranium-prospect cuts near skyline.

South and east of Bison Basin the Fort Union Formation thickens to several thousand feet in subsurface sections, and the contact between it and the overlying Wasatch and Battle Spring Formations is subject to various interpretations. Some of the problems are shown graphically on plate 1 , section $B-B^{\prime}$. All wells that penetrated the Fort Union Formation within 30 miles south and southeast of well 21 were studied. The information they yield merits some discussion. For example, a suite of samples from well 278 and from another well 1,320 feet east of it yielded a pollen assemblage of Paleocene age (table 4). The stratigraphic positions of these collections is shown in section $B-B^{\prime}$. The highest one is 2,000 feet above a marker zone of mudstone, coal, and sandstone (hereafter, for the sake of brevity, this is called the mudstone marker zone). Concerning this assemblage, E. B. Leopold (written commun., 1967) stated: "The presence of Carya, Aquilapollenites spinulosus, Pistillipollenites, and Momipites (with three polar scars) indicates a late Paleocene age for samples 1 and 2. Carya along with miscellaneous forms from stratigraphically older samples are either middle (post-Ludlow) or late Paleocene in age."

As is shown graphically in section $B-B^{\prime},(\mathrm{pl} .1)$, this age assignment means that not only is the mudstone
TABLE 4.-Paleocene pollen from drill cuttings, sec. 10, T. 22 N., R. 93 W., Sweetwater County, Wyo.

[Samples 1, 2, and 3 taken from Murphy Oil Co. Transmountain-Federal 2 well, 1,320 [Samples 1,2 , and 3 taken from Murphy Oil $\mathrm{Co}$. Transmountain-Federal 2 well, 1,320
ft west of well 278 ; sample 4 taken from well 278 . Samples furnished by E. L. Reid, identified by E. B. Leopold]

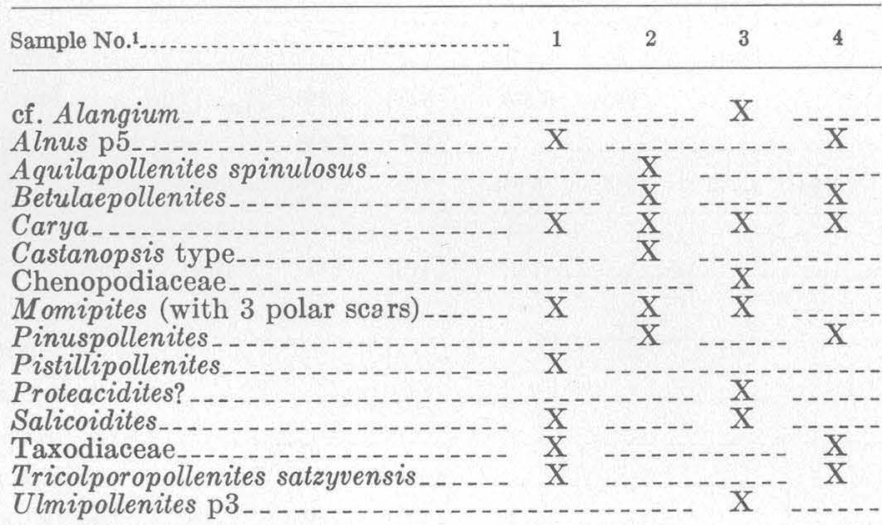

1 Depth of drill cuttings sampled: $1,2,500-2,510 \mathrm{ft} ; 2,3,140-3,150 \mathrm{ft} ; 3,3,150-3,155 \mathrm{ft}$; $4,3,700-3,710 \mathrm{ft}$.

marker zone Paleocene but so is a considerable thickness of arkosic sandstone and conglomerate (described later) above and below it. These arkosic strata have been considered by previous workers to be part of the Wasatch and Battle Spring Formations in the Flattop Buttes area. 
'The basal beds of the Fort Union Formation in well 21 are conglomeratic sandstone containing chert, quartzite, and quartz pebbles, but they become finergrained southeastward. The interval between the basal sandstone and the mudstone marker zone includes many coal beds. For example, in well 21 the lower coal zone has six coal beds 5 feet or more in thickness and the upper zone has 11 coal beds 5-30 feet thick. Four miles downdip (on the coal-bearing beds, not on the surface rocks, pl. 1, section $\left.B-B^{\prime}\right)$ to the southeast, the upper and lower coal zones combined contain 29 coal beds ranging in thickness from 5 to 50 feet. Well 269 has 20 coal beds $5-30$ feet thick in this interval. This same general part of the section in well 233,15 miles to the east, contains about 25 coal beds 5-20 feet thick. Lesser amounts of coal are present in well 160, still farther east. The general pattern of coal distribution is one of thinning and disappearance of beds toward the ancestral Granite Mountains uplift. Only a few thin coal beds are present in outcrops.

Abundant arkosic conglomerates and sandstones and variegated mudstones are present between the upper and lower coal zones in wells 21 and 268. These strata resemble those in lower Eocene rocks to the north. Variegated mudstone, however, is conspicuous in the vertebrate-fossil-bearing lower 800 feet of the Fort Union Formation at Bison Basin (loc. $4 \mathrm{~V}$, pl. 1 and right-hand margin of section $B-B^{\prime}$ ); arkose is less common. The base of the arkosic sequence rises in the section from north to south, as is shown on plate 1 , section $B-B^{\prime}$, wells 21,268 , and 269 ; in well 269 the base is above the mudstone marker zone. This zone and the overlying rocks are discussed in connection with the Wasatch and Battle Spring Formations.

In summary, south of the Flattop fault, arkosic sandstone and conglomerate, variegated mudstone, and coal are apparently present in the Fort Union, Wasatch, and Battle Spring Formations; so the criteria used for separating these formations in outcrops farther north are not reliable in the southern subsurface sections. Therefore, until a detailed study of these rocks in the deep part of the basin is made, they are lumped as Wasatch, Battle Spring, and Fort Union Formations.

About 8 miles northeast of Bison Basin, the lower part of the Fort Union Formation contains abundant rounded boulders of hard siliceous Paleozoic and Mesozoic rocks as much as 2 feet in diameter (fig. 14). Soft variegated claystone beds are present in the upper part of this section.

Outcrops in the Crooks Gap area (fig. 13) and drill cuttings from well 1481 mile south of the outcrops show a lithology nearly identical with that at Bison Basin. Dully variegated pink, red, purple, yellow, and green siltstone and claystone occur about 600 feet above the base of the formation on the east side of Crooks Gap. These and other fine-grained strata contain ironstone concretions. Conglomerates in Crooks Gap are lenticular, are rarely more than 30-50 feet thick, and are composed of roundstones of black chert, quartzite, hard sandstone, and siliceous Mowry Shale ranging in size from a fraction of an inch to several inches. Sparse granite fragments are also present and almost invariably are deeply weathered.

On the east side of Whiskey Peak the conglomerate beds in the Fort Union Formation overlap Mesozoic rocks and are much thicker (as much as $500 \mathrm{ft}$ ) and coarser grained than the beds at Crooks Gap. They contain cobbles and boulders of sandstone from the Cloverly Formation as much as 8 inches in diameter and slabs of Mowry Shale (Weimer and Guyton, 1961, p. 142).

The Fort Union Formation north of the Big Sand Draw oil and gas field and farther east along the north flank of the Granite Mountains was described by Keefer (1965). In general, the lithology is similar to that at Bison Basin except that the sandstones are more arkosic, have very little calcareous cement, and some sections contain abundant glauconite.

In the northeast corner of the area (around the margins of the southeast arm of the Wind River basin), the Fort Union Formation consists of chalkywhite to bluish-white sandstone and claystone interbedded with lenticular beds of harder dark-brown ferruginous sandstone, soft dark-gray claystone and siltstone, and some carbonaceous shale and coal. Few beds contain calcareous cement. Conglomerates are sparse and thin and consist chiefly of small rounded pebbles of siliceous Mowry Shale, black chert, hard sandstone, and quartzite. Deeply weathered granite pebbles occur sporadically, and some sandstone beds are arkosic.

Rock fragments in the conglomerates in the eastern part of the area were derived from the rising Granite Mountains, but in the western part some came from the Wind River Range. Most of the rock types can be readily identified. Mowry Shale, sandstone from the Cloverly Formation, and black and gray Permian and Mississippian chert are the most abundant. Limestone fragments were not observed, but some pebbles of dense white dolomite, probably of Ordovician age, were found. The coarse clastic debris decreases rapidly in size basinward, and, only a few miles from the source areas, conglomerates merge with grit and coarse-grained sandstone.

During Paleocene time, both the Wind River Range and the Granite Mountains were eroded deeply enough 


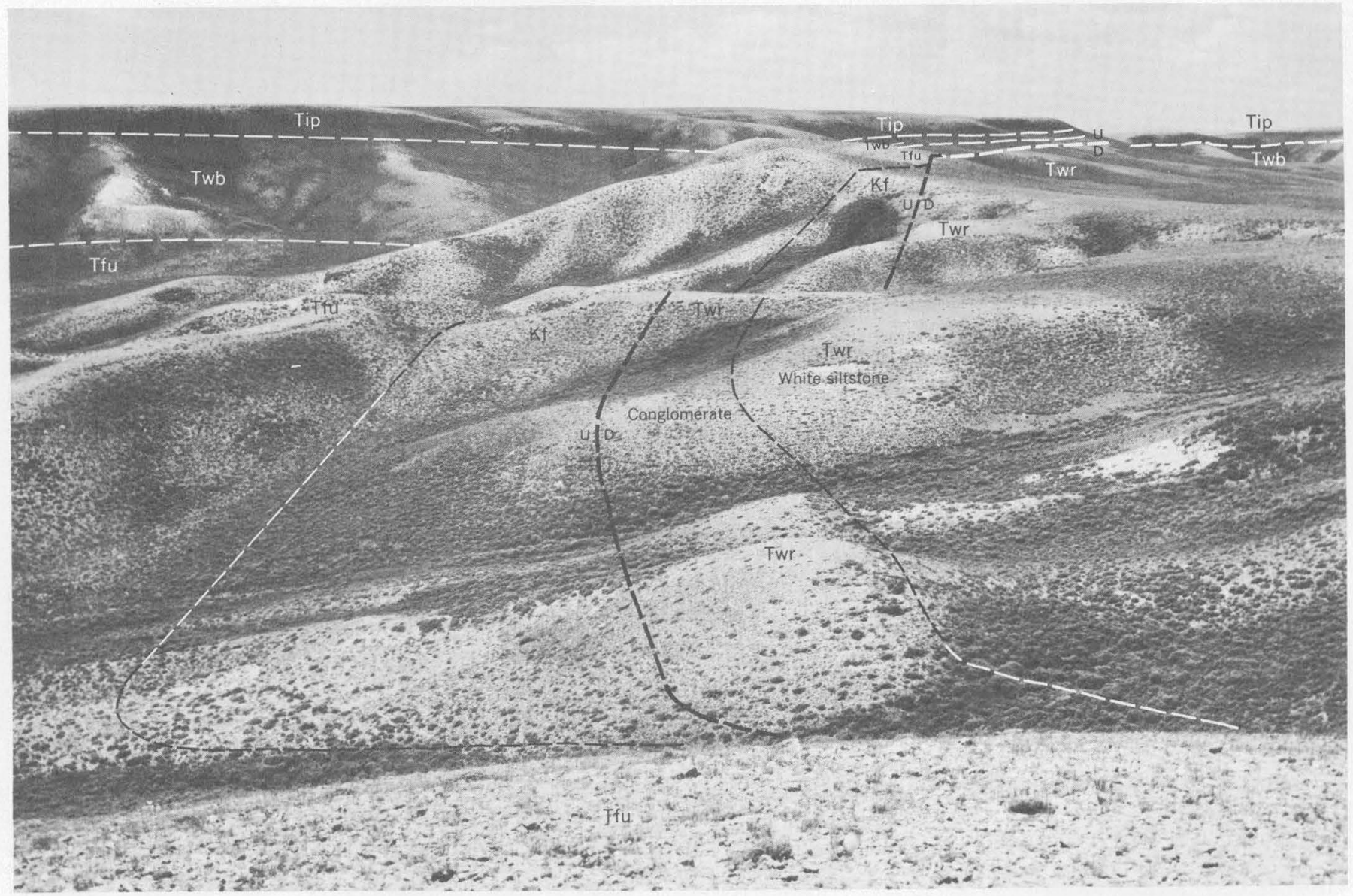

FigurE 14.-Structural relations of Upper Cretaceous, Paleocene, Eocene, and Oligocene rocks along north margin of Great Divide basin. Frontier Formation (Kf) is vertical and is overlapped by coarse conglomerate of Fort Union Formation (Tfu), which dips about $45^{\circ} \mathrm{S}$. This formation is overlapped by the nearly horizontal Wagon Bed Formation (Twb), and it, in turn, is overlain by the Ice Point Conglomerate (Tip). The north-dipping White River Formation (Twr), with a basal conglomerate facies overlain by white siltstone, is down faulted at least 500 feet. View is west-northwest in N3í sec. 13, T. 28 N., R. 95 W. Note boulders in Fort Union Formation in foreground.

to expose Precambrian rocks. A regional interpretation of areas of uplift and sedimentation has been presented by Love (1961b) ; Love, McGrew, and Thomas (1963); and Keefer (1965).

The origin of the glauconite in both the Wind River and Great Divide basins is being investigated, but no conclusions have been reached. The glauconite is too abundant and too unaltered to have been derived from the glauconite-bearing Cambrian, Permian, Jurassic, and Cretaceous rocks. It probably could not have been selectively preserved as discrete grains without the concomitant preservation of the more resistant distinctive minerals associated with it. The absence of invertebrate fossils, limestone pebbles, and carbonate cement suggests that extensive chemical weathering of the source areas occurred during Paleocene time.

Conditions of deposition and geologic history are discussed more fully later in this report.

\section{STRATIGRAPHIC AND STRUCTURAL RELATIONS}

The base and top of the Fort Union Formation on both flanks of the Granite Mountains are marked by regional unconformities (pl. $1, A-A^{\prime}, B-B^{\prime}, D-D^{\prime}$; pl. $3, \mathrm{E}-\mathrm{E}^{\prime}, E^{\prime \prime \prime}-E^{\prime}, F-F^{\prime \prime}$; pl. $\left.4, S-S^{\prime}\right)$. Local unconformities occur within the Fort Union Formation (Keefer, 1960, p. B235) ; these resulted from progressive growth of some anticlines during Paleocene time. The amount of angular discordance and the contrast in rock types on opposite sides of the interformational unconformities differ from place to place. Thus, in some localities, even in a few that are close to the mountains, continuation of similar environments of deposition, reworking of older strata, and lack of conspicuous discordance make the contacts difficult to determine. The magnitude of the unconformities at top and bottom decreases basinward, and the lithologically distinctive features of various parts of the Fort Union Formation become more subtle. 
In the Bison Basin area, the discordance in dip between the Fort Union Formation and the underlying Cody Shale and Mesaverde Formation is $10^{\circ}-20^{\circ}$, and discordance in strike is as much as $90^{\circ}$ (Bell, 1954; 1956, p. 84). The thickness of the Cretaceous. section cut out from south to north by the unconformity at the base of the Fort Union Formation can be determined by data from wells in section $G-G^{\prime}$. The base of the Fort Union in well 270 is about 4,000 feet above the "L-datum" of Barlow (1961) in the Lewis Shale, and this "L-datum" in turn is between 1,000 and 2,000 feet above the Cody Shale equivalent in wells farther south. Thus, if thicknesses remained constant between well 270 and Bison Basin, 5,000 feet or more of postCody Cretaceous rocks would have been eroded away from the Bison Basin area prior to deposition of the basal strata of the Fort Union Formation.

Eight miles northeast of Bison Basin, the difference in dip between the Fort Union and Frontier Formations is about $45^{\circ}$ (fig. 14), and the Mesaverde Formation and Cody Shale were removed by pre-Fort Union erosion. Comparable discordances were mapped by Stephens (1964) in the Crooks Gap area. Along the north flank of the Granite Mountains, the Fort Union Formation commonly overlies Cretaceous rocks with a much smaller angular unconformity than it does on the south flank. North of the Rattlesnake Hills, the angle of discordance is $8^{\circ}$, but in many other places it is much less or not locally measurable. On neither flank of the Granite Mountains does the Fort Union now overlap rocks older than the Frontier Formation, but prior to Eocene uplift and renewed erosion of the mountain arch, Paleocene sediments probably extended onto the Precambrian core (pl. 10C).

\section{AGE AND CORRELATION}

The middle and upper parts of the 800-foot section at Bison Basin yielded an abundant late Paleocene (Tiffanian provincial age) vertebrate fauna (Gazin, 1956a; McGrew, P. O., 1957). No identifiable mammals have been found in other Fort Union outcrops on either flank of the Granite Mountains, although leaves are common. Leaves and pollen assemblages from the north flank of the Granite Mountains are listed by Keefer (1965). No mollusks have been found in any section on the south side of the mountains, but a few are present on the north side (D. W. Taylor, written commun., 1965).

Keefer $(1961$, p. 1315; 1965; and Gazin, 1961, p. 51) discovered a large and varied vertebrate fossil assemblage of late Torrejonian to early Tiffanian provincial age in the upper part of the Fort Union Formation on the north side of the Wind River basin, 50 miles north of the Granite Mountains area. Seventyfive miles south of the Granite Mountains area, Swain (1.957; McGrew and Roehler, 1960, p. 158) found a mammal fauna of Torrejonian provincial age about 1,000 feet above the base of a 1,500- to 1,700-foot section of the Fort Union Formation. The stratigraphic and geographic relations of these three faunas suggest that strata in the Granite Mountains area represent at least part of the latter half of Paleocene time.

PALEOCENE AND EOCENE ROCKS

\section{WASATCH AND BATTLE SPRING FORMATIONS} DEFINITION

Prior to 1955, most of the lower Eocene rocks south of the Granite Mountains were called Wasatch Formation (Love and others, 1955). Pipiringos (1955) named the Battle Spring Formation from exposures in the Great Divide basin; the name was derived from Battle Spring Flat, which lies between wells 269 and 270 (pl. 1, section $B-B^{\prime}$, and table 2). Amplified descriptions and a geologic map were added later by Pipiringos (1961). The name Battle Spring Formation was applied to a thick sequence (inferred to be as much as $3,300 \mathrm{ft}$ ) of unfossiliferous arkosic sandstone. With reference to the source, Pipiringos stated (1961, p. 34): "The sediments that make up this formation appear to have been deposited in deltaic sheets; the source of the sediments appears to have been the Granite Mountains north and northeast of the area." Concerning the stratigraphic relations, he stated: "The Battle Spring formation intertongues with all the subdivisions of the Green River and Wasatch formations described in preceding parts of this report [these are the Red Desert, Niland, and Cathedral Bluffs Tongues of the Wasatch Formation and the Luman and Tipton Tongues and Laney Shale Member of the Green River Formation]."

No measured type section was given and no base was indicated in, or reference made to, wells 21 and 269 , which were drilled several years prior to publication of Pipiringos' report. Regarding the top of the formation, he stated (1961, p. 34) : "In the Cyclone Rim area the lithologic character of the Bridger formation is unlike that of the underlying rocks, so the deposition of the Battle Spring formation probably ceased within or at the end of Laney time."

Masursky, who studied part of the area shown on plate 1 , section $B-B^{\prime}$, had this to say regarding the Battle Spring Formation (1962, p. 10-11):

Having been formally adopted, the name is used here reluctant1y. This name is undesirable on both local and general grounds. First, these thick-bedded coarse-grained rocks are a mountainward fluviatile facies of the main body of the Wasatch forma- 
tion that grades basinward into a fine-grained thin-bedded coalshale-sandstone facies deposited in alternating lake, swamp, and stream environments. To assign the sandstone facies formational name and rank deemphasizes the intimate lateral gradation of the sandstone and coal-bearing facies that in turn weak. ens recognition of the genetic tie between these lateral changes and uranium distribution.

Second, even if a formation name were appropriate, Battle Spring is not a desirable one. The term is not well defined, largely owing to poor exposures in the type locality. Neither the top nor bottom is present there or exposed nearby and, therefore, the thickness is indefinite. In addition, the age range in the type area is unknown. The lower part of the sequence is presumably of early Eocene (Wasatch) age, but the upper part might be of middle or even late Eocene age. It is, therefore, premature to name these rocks formally. Probably, naming should be reserved, at least, until the sandstone facies can be studied in the northeast part of the Great Divide Basin, where critical relations are likely to be revealed in good and abundant exposures.

The Granite Mountains area includes the northern part of the Great Divide basin alluded to by Masursky, and my study tends to support his conclusions about the undesirability of the term Battle Spring. Oriel recognized a comparable situation farther west and discussed it as follows (1962, p. 2163): "The conglomerate member of the Wasatch Formation is a peripheral facies formed along the western margin of the Green River Basin; it is, therefore, analogous with the Battle Spring Formation which forms a peripheral facies in the Great Divide basin of Wyoming." He did not name his peripheral facies.

Section $B-B^{\prime}$ (pl. 1) demonstrates graphically some of the problems encountered in trying to distinguish the Wasatch, Battle Spring, and Fort Union Formations as mappable units in the northern part of the Great Divide basin. Compare, for example, the relations shown in this section with the following statement by Pipiringos $(1961$, p. 35$)$ :

In summary, the pre-Bridger Eocene rocks of this area may be thought of as products of three environments. The Green River formation is of lacustrine origin. It interfingers with the Wasatch formation of fluviatile and paludal origin. The Battle Spring formation of deltaic-fluviatile origin interfingers with both. In general, the Laney shale member of the Green River formation thins northeastward, whereas the Tipton and Luman tongues of the Green River formation, the Niland and Red Desert tongues of the Wasatch, and the Battle Spring formation thin southwestward.

The outcrop terminology, the stratigraphic and structural relations, and the subsurface data on coal beds to a depth of about 900 feet in section $G-G^{\prime}$ between wells 278 and 268 were taken from maps by Masursky and Pipiringos. The section below 900 feet is based on my studies of drill cuttings, electric, gamma-sonic, and dipmeter logs, and oil and uranium company records. These data provide the third dimension of the stratigraphy that has not been considered in previous studies of this area. Worthy of note, with reference to Pipiringos' statement quoted above, are the following items in section $B-B^{\prime}$ (pl. 1) : (1) The drastic northward-thinning of the lower Eocene and Paleocene section, (2) the distribution of arkosic sandstone far down in the coal-bearing section in wells 21 and $268,(3)$ the unconformities shown by dipmeters in wells 21 and 268 in the section above the mudstone marker zone, and (4) the relation of tongues of the Green River Formation to older, younger, and laterally equivalent strata.

Deep drilling is constantly adding new information; so in due time a logical terminology for the various facies of Paleocene and lower Eocene rocks may be established. For the present, however, the Wasatch, Battle Spring, and Fort Union Formations are considered as one unit in the area south of that on plate 1, and the Wasatch and Battle Spring Formations are not differentiated within the area on plate 1.

\section{DISTRIBUTION AND THICKNESS}

Thicknesses of the Wasatch, Battle Spring, and Fort Union Formations south of the Flattop fault are shown in section $B-B^{\prime}$ (pl. 1). Thicknesses north and northeast of this fault are indicated on plate $5 B$. Inasmuch as the top of the sequence was eroded from most of the area shown on the isopach map, the original thickness cannot be determined, but it probably exceeded 4,500 feet. Sections $A-A^{\prime}$ through $D-D^{\prime}$, (pl. 1) ; $E-E^{\prime}, E^{\prime \prime \prime}-E^{\prime}, F-F^{\prime}, I-I^{\prime}$ (pl. 3) ; and $O-O^{\prime}, P-P^{\prime}$, $R-R^{\prime}, S-S^{\prime}$, and $T-T^{\prime}$ (pl. 4) show local details of thickness and relations to older and younger rocks.

Well 177 (section $F-F^{\prime}$ ), which was drilled through a Precambrian granite thrust plate, encountered the Wasatch and Battle Spring Formations at a depth of 2,150 feet and the Fort Union Formation at 3,450 feet. A thrust wedge of 120 feet of Tensleep Sandstone within this interval indicates that only a partial section was penetrated.

\section{LITHOLOGY}

The lithology of the Wasatch and Battle Spring Formations is described from southwest to northeast, and that in the northern part of the Great Divide basin is presented first. Pipiringos (1961) and Masursky (1962) discussed the Red Desert and Niland Tongues of the Wasatch Formation and the Luman and Tipton Tongues of the Green River Formation in the area of section $B-B^{\prime}$; so their statements are not repeated here.

The mudstone marker zone is a persistent subsurface unit (section $B-B^{\prime}$, pl. 1) characterized by low resistivity and spontaneous potential curves on electric logs. 
It consists of gray mudstone, fine-grained sandstone, and thin coal beds in the southeasternmost sections and dully variegated mudstone in the northern sections. It has a relatively constant thickness of slightly more than 200 feet. In most wells, the zone maintains an approximately parallel position with respect to the base of the Fort Union Formation below and, in wells 270 and 278 , with the Transmountain sandstone of oil companies above.

The Transmountain sandstone, named after one of the companies participating in drilling well 278 , has been penetrated in wells south, east, and north of wells 270 and 278. It is a sequence, ranging in thickness from an edge to 200 feet, of gray fine-grained lenticular sandstone beds intercalated with mudstone. Oil was produced from it in well 278. Pollen indicates that it is of Paleocene age (table 4).

The succession above the mudstone zone south of well 268 contains major coal beds. Those above a depth of 900 feet were described by Masursky (1962) and Pipiringos (1961); those below have not previously been mentioned in any publication. One of these coal-bearing sequences is in well 278 and north, south, and east of it. The sequence is 1,000-1,500 feet thick, the top is $1,500-2,000$ feet below the surface, and 10-17 coal beds $5-40$ feet thick are present. The quality of coal is not known.

Near well 269 and below the Tierney 5 coal that was a structure-contour horizon used by Pipiringos (1961, pl. 1) is an additional 800 feet of coal-bearing rocks. The upper 250 feet of this sequence may be equivalent to Pipiringos' Dune coal zone and his "unnamed coal zone"; the lower beds have not been described. Some are significantly radioactive, and these are discussed in connection with uranium deposits.

Wells 21 and 268 contain no coal above the mudstone marker zone. The strata are coarse-grained arkosic gray sundstone interbedded with finer-grained sandstone, siltstone, and variegated nudstone. As is indicated in section $B-B^{\prime}$ (pl. 1), dipmeter surveys show a rightangle change in direction of dip from north above to west below in well 268 ; this change occurs about 650 feet above the mudstone marker zone. In well 21, the dip changes from northeast above to southwest below in the section above the marker zone. The lithology of strata above and below the dip changes is similar. This similarity might be expected, even where a major unconformity is present, if the younger sequence was locally derived from the older.

Well data show that coal beds gradually decrease in number and thickness from southwest to northeast, toward the Granite Mountains. Associated carbonaceous gray mudstones become variegated to the north and northeast, and many, but not all, grade mountainward into arkosic gray sandstone and conglomerate.

The lithology of the Wasatch and Battle Spring Formations in the Crooks Gap area was described by Stephens (1964) in his study of uranium deposits. Strata are soft and poorly cemented, so even in localities of high relief, good exposures are rare. In addition, a thick accumulation of lag boulders (figs. 15-17, $51,53)$ from the overlying Crooks Gap Conglomerate contributes to the difficulty of lithologic studies and mapping. The description presented here is based on a combination of data from outcrops, uranium mines and prospect pits, drill holes; and electric and gamma ray-neutron logs.

The dominant rock type is coarse arkosic white to tan sandstone (fig. 16) interlayered with some beds of small granite boulders. Less common are coarse boulder conglomerate, carbonaceous siltstone, and green claystone. In the valley west of Whiskey Peak (figs. 4, 5, 15), 1,000 feet or more of white soft crossbedded arkose is exposed; it is interbedded with only minor amounts of claystone and contains a few lenses of very large granite boulders. The arkose consists chiefly of angular fragments of white quartz and gray feldspar, some of which are fresh and some deeply weathered. Similar white arkosic sandstone is conspicuous all along the south flank of Crooks Mountain and Green Mountain. Elsewhere, the color tends to be gray to tan and brown both on outcrops and in subsurface sections. In several localities, especially near Whiskey Peak, zones of coarse- and fine-grained sandstone and siltstone distributed through 1,500 feet or more of section contain abundant grains of bright-green glauconite. Its occurrence as soft grains in thick arkosic sandstone and its abundance do not suggest derivation from older marine rocks or from the Fort Union Formation.

In the lower part of the Wasatch and Battle Spring Formations on the east side of Crooks Gap, SE $1 / 4$ sec. 8, T. 28 N., R. 92 W., is a remarkable exposure of strata resulting from rapid stripping of the rising Granite Mountains. This is an unusual display of the geologic column in reverse (Knight, 1937). Angular fragments of hard siliceous Mowry Shale are at the bottom of the section, then hard sparkly sandstone from the Cloverly Formation, then Triassic red beds, and then Paleozoic sandstone, limestone, and shale. Fresh angular chunks of green soft Cambrian shale near the top are, in places, so abundant that this part looks almost like Cambrian outcrops. Overlying the shale are fragments of the basal sandstone in the Cambrian section, and on top is a flood of granite boulders. 


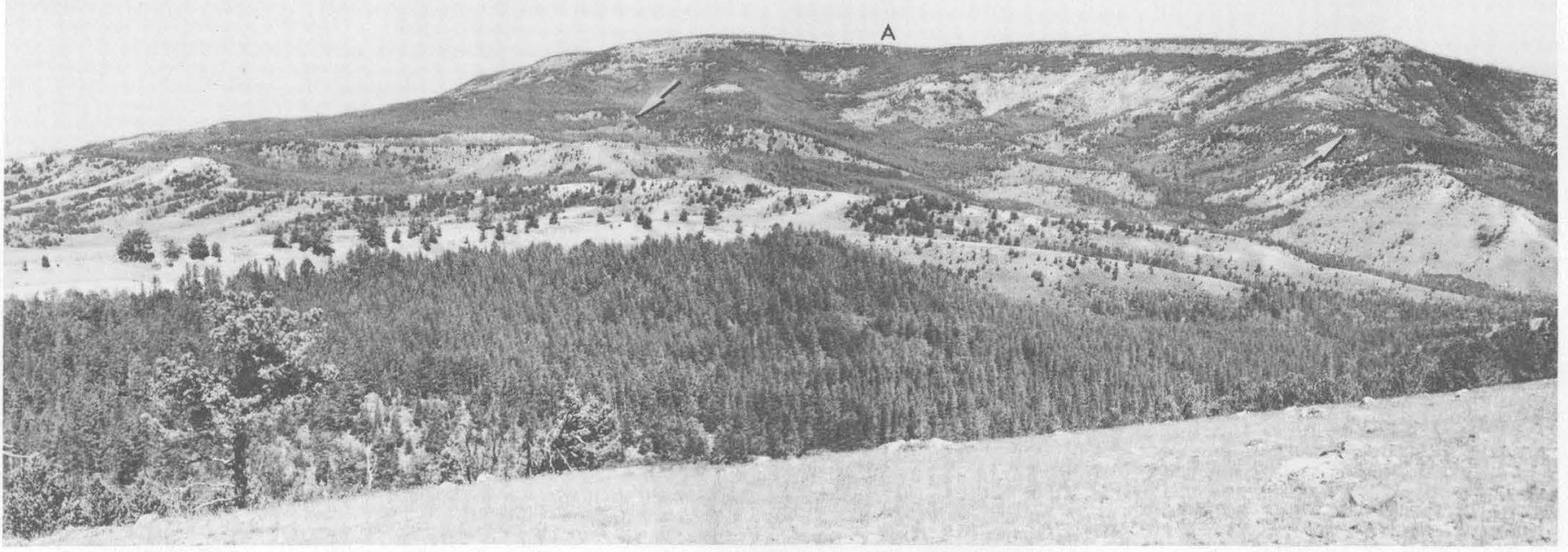

FIGURE 15.-Angular unconformity (marked by arrows) between Crooks Gap Conglomerate and the Wasatch and Battle Spring Formations on prominent bench in upper middle of photograph. The Wasatch and Battle Spring dip $15^{\circ}-20^{\circ} \mathrm{N}$. (right), whereas the Crooks Gap Conglomerate is nearly flat. View, which is northwest across valley of Willow Creek, shows east end of Green Mountain in secs. 2, 3, and 10, T. 27 N., R. 91 W. Structure section $F-F^{\prime}$ (pl. 3 ) extends through this area. Camera point for figure 5 is indicated by $A$.

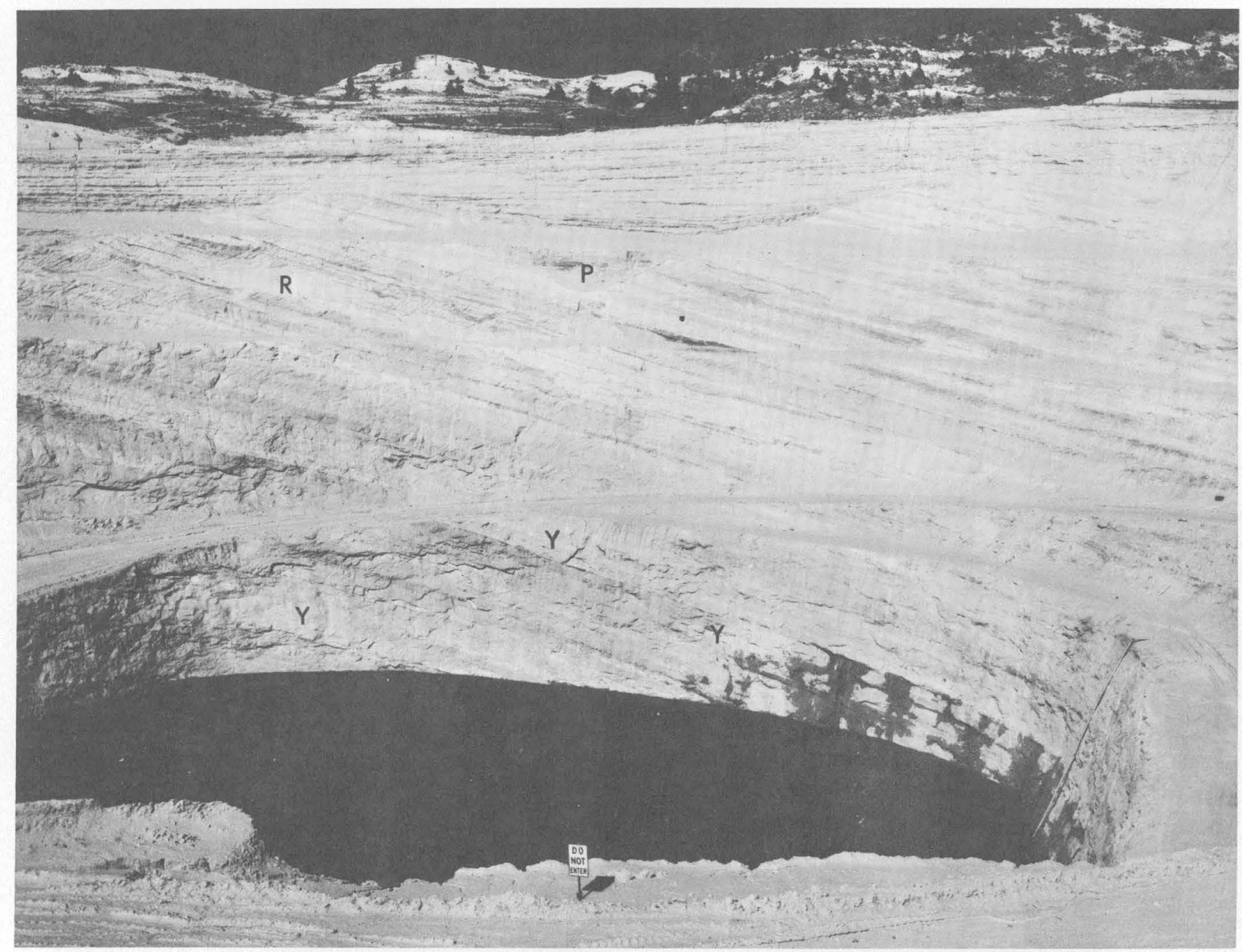

FIGURE 16,-Coarse-grained gray arkosic sandstone in the Wasatch and Battle Spring Formations in Western Nuclear Corp. uranium strip mine. View toward east ou east side of Crooks Gap, NW 1/4 sec. 21, T. 28 N., R. 92 W. R, Red zone within arkose. Y, Yellow uranium oxide discoloration. P, Channel fill of Pleistocene loess. 


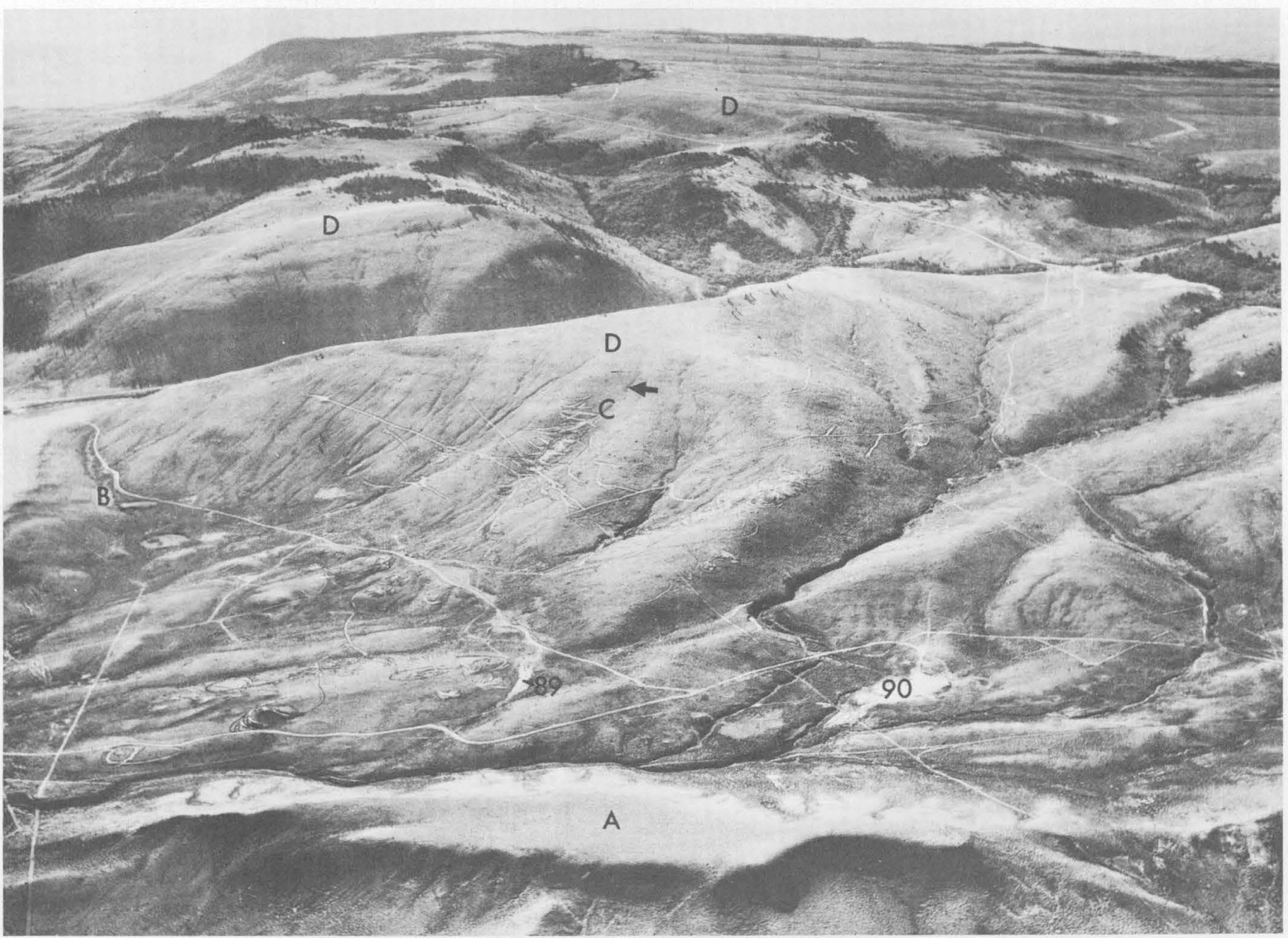

FIGURE 17.-View east showing western part and north face of Crooks Mountain. A, White River Formation makes up mesa in foreground. Well 89 spuds in White River on north side of a branch of the South Granite Mountains fault system, and well 90 spuds in Wasatch and Battle Spring Formations on south side. B, Fault trace to east follows road at break in slope. C, Scarified area in the Wasatch and Battle Spring Formations where boulders of nephrite jade occur. D, Strata above arrow are the Crooks Gap Conglomerate. Photograph by P. T. Jenkins and L. P. House.

Adjacent to the south flank of the Granite Mountains, siltstone is common only in the lower part of the formation; probably it was derived from similar strata of Cretaceous and Paleocene ages. In the rest of the section the size of clastic fragments decreases rapidly southward, and conglomerate is sparse $3-5$ miles south of the Precambrian source. Green and brown siltstone takes the place of much of the arkosic and sandy section. Thin lenticular beds of carbonaceous sandstone, siltstone, shale, and coal and some dully variegated red and green strata are present in several areas. No persistent coarse- or fine-grained marker beds were observed, although beds of coal and carbonaceous shale are sufficiently continuous to be locally useful in correlating uranium ore zones in the Crooks Gap area. Mica is common in most types of strata.

All the major uranium deposits in the Crooks Gap uranium district (pl. 1) occur in the Wasatch and
Battle Spring Formations ; they were described in some detail by Stephens (1964). Except in the oxidized zone near the surface, most of the ore is uraninite $\left[\left(\mathrm{U}^{+4}{ }_{1-\mathrm{x}} \mathrm{U}_{\mathrm{x}}^{6}\right) \mathrm{O}_{2 \mathrm{x}}\right]$, which impregnates arkosic sandstone (fig. 16), fine-grained conglomerate, and carbonaceous siltstone along lenses and beds to depths of at least 1,400 feet. These deposits are discussed in connection with uranium resources.

West of Crooks Gap, apple-green nephrite jade occurs as boulders in the upper part of the sequence (figs. 17, 53, 61). The jade was formed during Precambrian time, exposed in early Eocene time, and then eroded from the Granite Mountains along with other coarse clastic debris that makes up the Wasatch and Battle Spring Formations.

The environment of deposition near the mountains was markedly different from that prevailing during Fort Union time. The Granite Mountains rose rapidly, 
and, along their south flank, torrential streams deposited gigantic fans of coarse clastic debris (pl. 10). There was little time for chemical decomposition of rocks exposed in the mountain core, and limestone, shale, and sandstone, as well as Precambrian rocks, were ripped loose, transported, and redeposited as fresh angular to subrounded fragments. Many boulders of Precambrian crystalline and metamorphic rocks have, however, subsequently rotted in place. The origin of the thick somewhat weathered white arkosic sequence in the valley west of Whiskey Peak and along the south side of Crooks Mountain and Green Mountain has not been determined. It may represent the product of erosion of a source area containing white granite that contrasts with the pink granite most common in the Granite Mountains, or unusual environmental conditions may have caused bleaching of the feldspars from pink to white. The upper 500 feet of granite in well 177 and several zones in well 176 (section $F-F^{\prime}, \mathrm{pl} .3$ ) is gray and coarsely crystalline. Farther northwest at well 133 (section $N-N^{\prime}$, pl. 3 ), about 700 feet of snowywhite highly quartzose granite is underlain by nearly 2,000 feet of dark-brownish-green more mafic Precambrian rock. These light-colored granites may be the sources of the white arkose.

\section{STRATIGRAPHIC AND STRUCTURAI RELATIONS}

The stratigraphic and structural relations of the Wasatch and Battle Spring Formations to older and younger rocks are shown in sections $A-A^{\prime}$ through $D-D^{\prime}$ (pl. 1) ; $E-E^{\prime \prime}, E^{\prime \prime \prime}-E^{\prime}, F-F^{\prime}$, and $I-I^{\prime}$ (pl. 3 ) ; and $O-O^{\prime}, P-P^{\prime}, R-R^{\prime}, S-S^{\prime}$ and $T-T^{\prime}$ (pl. 4). Along the north margin of the Great Divide basin, the sequence rests with angular unconformity across the truncated edges of Upper Cretaceous and Paleocene rocks, and originally it overlapped northward onto the Precambrian core of the Granite Mountains (pl. 10). South of the mountains, however, the unconformity at the base of the sequence becomes progressively less pronounced and probably disappears within the area of section $B-B^{\prime}$ (pl. 1).

Plate 7 shows a reconstruction of the outcrop pattern of Precambrian, Paleozoic, and Mesozoic rocks in the western part of the Granite Mountains area at the time of initial deposition of the Wasatch and Battle Spring Formations. The mountain ranges and major anticlines, synclines, and thrust and reverse faults must have developed rapidly after deposition of the Fort Union Formation. Erosion of the uplifted areas and deposition in adjacent depressed areas was likewise rapid during this period of crustal disturbance. These factors contributed to the complex relations of the peripheral coarse clastic facies to the paludal and lacustrine facies farther south in the basin.

Section $I-I^{\prime}$ (pl. 3) shows the magnitude of uplift and erosion along the southeast margin of the Wind River Range prior to deposition of the Laney Shale Member of the Green River Formation. The top of the Precambrian rocks below this member on the north side of the Flattop fault is 20,000 feet higher than the top on the south side.

The relation of the Cathedral Bluffs Tongue of the Wasatch Formation to older and younger rocks is discussed in connection with that tongue. Where the tongue is not present, there is an unconformity at the top of the Wasatch and Battle Spring Formations. These strata were overridden along the Emigrant 'Trail thrust fault by Precambrian, Paleozoic, and Mesozoic rocks (pls. 6A, 10), and then were folded and deeply eroded prior to deposition of the Crooks Gap Conglomerate (sections $E-E^{\prime}, E^{\prime \prime \prime}-E^{\prime}, F-F^{\prime}$, pl. 3).

\section{AGE AND CORRELATION}

Carbonized wood and leaf fragments are common in the Wasatch and Battle Spring Formations; however, no diagnostic forms have been identified. Uranium-impregnated agatized trees are present on the south side of Crooks Mountain, but the cell structure of the wood has been so thoroughly destroyed that identification is not possible. No bones or invertebrate fossils have been found in the Granite Mountains area, but collections from exposures to the south and southwest give some clues as to age.

The Red Desert Tongue of the Wasatch Formation (section $B-B^{\prime}$, pl. 1) contains vertebrate fossils of earliest Eocene (Gray Bull of Granger, 1914, and Indian Meadows) age. This fossil collection (in sec. 12, T. 23 N., R., 100W.) was estimated by Pipiringos (1961, table 2) to be 200 feet above the base of the Red Desert Tongue. The sections in four wells near the site of this collection suggest that the fossils are 1,500 feet or more above the base. The Niland Tongue (section $B-B^{\prime}$ ) contains vertebrate fossils of late early Eocene (Lost Cabin) age (McGrew and Roehler, 1960, p. 158; Love, 1964). Inasmuch as the Red Desert and Niland Tongues of the Wasatch intertongue with the Battle Spring Formation (section $B-B^{\prime}$ ) the entire sequence apparently represents much of early Eocene time. Thus, the sequence is equivalent to at least part of the Indian Meadows Formation, and to the Lysite and to part of the Lost Cabin Members of the Wind River Formation in the Wind River basin (table 3). The age of the Cathedral Bluffs Tongue of the Wasatch Formation is discussed in connection with that unit. 
The relation of strata in well 278 containing Paleocene pollen to the mudstone marker zone and to adjacent coal and arkosic sequences (section $B-B^{\prime}$ ) indicates that the lower part of the Wasatch and Battle Spring Formations in the northern part of the Great Divide basin is of Paleocene age, the same as the Chappo Member of the Wasatch Formation farther west in the Green River basin (Oriel, 1962, p. 2167).

\section{EOCENE ROCKS \\ CROOKS GAP CONGLOMERATE NAME AND DEFINTIION}

Giant boulders that litter the tops and flanks of Crooks Mountain and Green Mountain were noted by all the early workers in this area, and some of these workers considered the boulders to be of glacial origin. Bauer (1934, p. 680) put these boulder beds in his Sweetwater Member of the White River Group of Oligocene age. Knight (1937) related the boulders to the rising thrust block of the Granite Mountains. This unit was mapped later (Love and Weitz, 1951) as "Wasatch conglomerate of petroleum geologists." It is shown on the geologic map of Wyoming (Love and others, 1955) as "Conglomerate beds."

Bell (1956, p. 84) considered this unit to be a postBridger conglomerate, and other workers (for example, Smith, 1909) mapped it merely as Wasatch. Stephens (1964) called it member B of the Battle Spring Formation. Marshall (1959a, b, c) and Dickey (1962) mapped a contact between this conglomerate and the underlying Battle Spring Formation and called them the upper unit and the lower unit.

For many years, the informal term Crooks Gap conglomerate has been used by local geologists for these rocks; it is here proposed that this unit be called formally the Crooks Gap Conglomerate. The name is taken from Crooks Gap, on both sides of which the formation is exposed. Crooks Mountain is designated the type locality. The conglomerate is poorly cemented, and this characteristic plus its slumped and deeply weathered outcrops, all of which occur only on topographically high areas, make good natural exposures a rarity; therefore, no type section is designated. All the wells in the South Happy Springs oil field were drilled through the conglomerate, but cuttings were not saved so there is no record of detailed lithology. The conglomerate overlies the Wasatch and Battle Spring Formations with an angular unconformity. No younger rocks have been recognized in the type locality.

\section{DISTRIBUTION AND THICKNESS}

The Crooks Gap Conglomerate is present only in the Crooks Mountain-Green Mountain area (pls. 1, 6) and along the extreme east margin of the Great Divide basin. The original southward extent of this unit is not known because erosion has completely removed it south and southwest of Crooks Mountain (E-E', pl. $3 ; D-D^{\prime}$, pl. 1). Boulder conglomerates extending 20 miles south of the east end of Green Mountain may be remnants of this formation, but they have not been studied in sufficient detail to permit definite correlation. On Green Mountain the lower 635 feet was penetrated in well 161 (section $F-F^{\prime}$, pl. 3) and an estimated 850 feet of beds is present above the well site (not in the line of the section), making a total of nearly 1,500 feet. On Crooks Mountain, fragmentary records from wells in the South Happy Springs oil-field area suggest that about 400 feet of the conglomerate is present $\left(O-O^{\prime}\right.$ pl. 4 ; $E-E^{\prime}$, pl. 3 ).

\section{LITHOLOGY}

The Crooks Gap Conglomerate consists largely of giant granite boulders embedded in pink to gray arkosic sandstone and siltstone. A pink color predominates in the upper part of the section penetrated in well 161 and likewise in some of the younger beds cropping out above the well site. The size of the boulders is phenomenal. One has exposed dimensions of 30 by 16 by 10 feet; another, at the west end of Green Mountain, is 40 by 25 by 20 feet. Even larger ones may exist. Many are several miles from the nearest Precambrian outcrops and, because of late Cenozoic movement, are now at elevations more than 1,000 feet above the source area. Few natural exposures of this conglomerate (fig. 18) are present because the surface lag concentration of large boulders inhibits erosion and causes the development of rounded slopes (figs. 5, $17,53)$. Nowhere is there any decrease in boulder size in the uppermost beds.

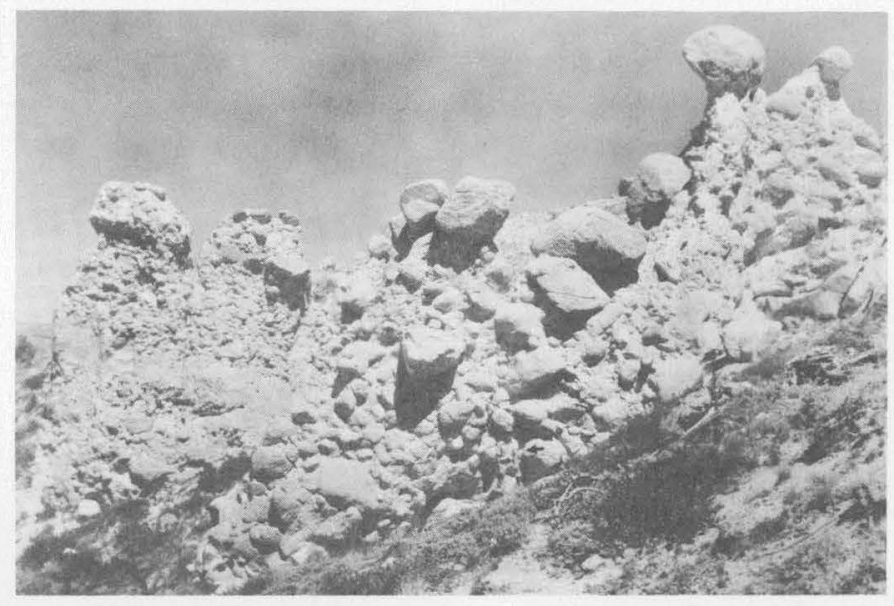

FIGURE 18.-Basal part of Crooks Gap Conglomerate on the north face of Sheep Mountain, east side of Crooks Gap. Boulders are of Precambrian rocks; largest are more than 20 feet in diameter. Man (lower center, arrow) shows scale. View north east in NE $1 / 4$ sec. 21, T. 28 N., R 92 W. Photograph by S. H. Knight, July 1933. 
The lag boulders on outcrop appear fresh, and subrounded, but this is in part, at least, the result of weathering after exhumation. Nearly all of those on the surface are gray and pink coarsely crystalline granite. Artificial cuts, however, have exposed partly or completely decayed subrounded highly fractured boulders, not only of granite but also of mafic igneous and metamorphic rocks.

The matrix of the conglomerate was examined in many fresh cuts and under the microscope for evidence of volcanic ash or bentonitic claystone, but none was found. The absence of volcanic debris distinguishes this conglomerate from those of middle and late Eocene and Oligocene age in areas to the north and west.

'The conglomerate is so coarse and thick that it must have been deposited as giant fans in front of a precipitous mass of Precambrian granite that was rising rapidly. Section $L-L^{\prime}$ (pl. 3 ) shows that the Emigrant Trail thrust cuts a pre-Wind River conglomerate but does not cut the Wind River Formation 10 miles north of Crooks Mountain; this part of the Wind River is believed to be somewhat younger than that part of the Wasatch and Battle Spring Formations which is overridden by the Emigrant Trail thrust at section $F-F^{\prime}$ (pl. 3). Sections $O-O^{\prime}, P-P^{\prime}$ (pl. 4), and D-D' (pl. 1) show that between the time of deposition of the Wasatch and Battle Spring Formations and that of the middle and upper Eocene Wagon Bed Formation, the Granite Mountains rose 1,000-3,000 feet along the newly-formed South Granite Mountains normal fault system. This fault system is nearly parallel to the Emigrant Trail thrust east of Crooks Gap and to the Mormon Trail thrust west of the gap.

The Crooks Gap Conglomerate was derived from the Precambrian rocks rising along this normal fault system east of Crooks Gap. West of the gap, however, the debris was secondarily derived from conglomerate in the Wasatch and Battle Spring Formations as it was stripped from the rising block in the area where no Precambrian rocks were present at the surface (pls. 7,10$)$. The boulder fans spread south and southwest from the normal fault scarp for an unknown distance, but individual fragments are still of spectacular size in remnants 5 miles south of the fault. No carbonaceous shale and coal beds have been observed in the Crooks Gap Conglomerate, which may account in part for the absence of any significant amount of uranium mineralization. Apple-green nephrite jade boulders are present but not abundant.

\section{STRATIGRAPHIC AND STRUCTURAL RELATIONS}

The Crooks Gap Conglomerate was deposited across the truncated edges of more than 2,000 feet of the Wasatch and Battle Spring Formations on the east end of Green Mountain (fig. 15; pl. 3, section $F-F^{\prime}$ ) and along the south margin of Crooks Mountain (section $E-E^{\prime \prime}$, pl. 3 ). On the west end, it laps onto the Cody Shale. The amount of angular discordance in dip between the conglomerate and the underlying lower Eocene rocks varies from place to place, up to a maximum of at least $25^{\circ}$; there is commonly a marked divergence in strike. On Crooks Mountain, the unconformity is less conspicuous than on Green Mountain (figs. 17, 51, 53); the magnitude is illustrated by a comparison of the divergent structure contour pattern on the base of the Wasatch and Battle Spring Formations (pl. 6A) with that on the base of the Crooks Gap Conglomerate (pl. 6E).

Although in no place have younger rocks been identified on top of the Crooks Gap Conglomerate, regional relations of possibly correlative and younger strata elsewhere indicate the presence of a major structural and stratigraphic break at the top of the formation. (See section $D-D^{\prime}$, pl. 1, for interpretation of these relations.)

\section{AGE AND CORRELATION}

No identifiable fossils have been found in the Crooks Gap Conglomerate. Apparently neither lithology nor environment has been conducive to preservation of fossils. As is indicated in the discussions of the Wasatch and Battle Spring Formations, the Cathedral Bluffs Tongue of the Wasatch Formation, and the Wind River and Wagon Bed Formations, the tectonic event that caused the deposition of the Crooks Gap Conglomerate could hardly have been so localized that the sediments of adjacent areas were unaffected. Therefore, tentative correlations are based on regional patterns of sedimentation and structural history. These suggest that the conglomerate is of latest early and perhaps early middle Eocene age.

The conglomerate is probably the northern coarse clastic equivalent of the Cathedral Bluffs Tongue of the Wasatch Formation. The lower part may be equivalent to the upper conglomerate facies of the Lost Cabin Member of the Wind River Formation along the south margin of the Wind River basin. The arkosic conglomeratic reworked beds at the base of the Wagon Bed Formation may be equivalent to the upper part. However, the Crooks Gap Conglomerate cannot be as young as the fine-grained facies of the Wagon Bed Formation because, as is shown in section $D-D^{\prime}$ (pl. 1), north of Crooks Mountain and Green Mountain the Crooks Gap Conglomerate is separated from its source area by this 
facies of the Wagon Bed. The conglomerate was stripped off the 3-6 mile intervening area (pl. 7) prior to deposition of the fine-grained facies of the Wagon Bed Formation. No boulder beds comparable with those in the Crooks Gap Conglomerate are present in subsurface sections north of the South Granite Mountains fault system.

The conglomerate cannot be the basal part of the Oligocene White River Formation as postulated by Bauer (1934). Such an age would require the South Granite Mountains fault system to have developed in Oligocene time. Sections $D-D^{\prime}$ (pl. 1), $O-O^{\prime}, P-P^{\prime}$, and $Q-Q^{\prime}$ (pl. 4), and others show that this is not possible. Abundant well data indicate that within a few hundred feet of the fault at the Happy Springs oil field the basal conglomerate of the White River, where present (in places there is none), is less than 50 feet thick, fine grained, and tuffaceous, whereas directly south of the fault and still farther from the source area the Crooks Gap Conglomerate consists of several hundred feet of coarse boulders in a nontuffaceous matrix. Well data from other areas along the west margin of the Granite Mountains (pl. 1; table 2) are sufficiently abundant that the areal distribution of the coarse facies of the White River Formation can be reconstructed. The distribution pattern of the coarse facies shows that it is completely unrelated to the Crooks Gap Conglomerate.

\section{TONGUES OF WASATCH AND GREEN RIVER FORMATIONS IN GREAT DIVIDE BASIN}

CATHEDRAL BLUFFS TONGUE OF WASATCH FORMATION

The Cathedral Bluffs Tongue of the Wasatch Formation was named by Schultz (1920) from exposures along the south margin of the Great Divide basin. The tongue has been eroded from the central part of the basin, but it was mapped by Pipiringos in the northern part where, west of well 268 , it consists of brightly variegated blue-green, red, and white claystone and siltstone and lesser amounts of sandstone, all weathering into badlands. Pipiringos recognized that as the outcrop area of the Cathedral Bluffs narrowed eastward, many beds of arkosic sandstone and some cobble conglomerate appear and the variegated claystone and siltstone become subordinate.

Regarding thicknesses and stratigraphic relations, Pipiringos stated (1961, p. A32) :

In the Cyclone Rim area west of Lost Creek, the Cathedral Bluffs tongue is estimated to be 1,100 to 1,300 feet thick. It includes a body of arkosic sandstone at the base, 300 feet thick (locally assigned to the upper part of the Tipton, as shown on fig. 2 , because it contains some beds of brown low-grade oil shale), and underlies the Laney shale member of the Green River formation. The contact with the Laney is not exposed in the northern part of the area, but it is probably conformable and intertonguing. The thinness of the Laney and the increased thickness of the Cathedral Bluffs tongue suggest that the upper several hundred feet of the Cathedral Bluffs tongue in the Cyclone Rim area are equivalent to the lower part of the Laney.

Sheridan, Maxwell, and Collier (1961, p. 402-404) described in considerable detail the stratigraphy of the Cathedral Bluffs Tongue and underlying rocks southeast of well 268 because they are hosts for small amounts of uranium. The thickness of the tongue and that part of the Battle Spring Formation that is interbedded with it was given as 1,650 feet. In well 21 , however, the thickness is only about 400 feet (section $B-B^{\prime}$, pl. 1). This requires some explanation.

The Cathedral Bluffs Tongue in the well is arkosic sandstone and pebble conglomerate interbedded with a lesser amount of variegated mudstone. Inasmuch as the underlying rocks have similiar lithology for the most part, the question arises as to the basis $I$ have used for separating the Cathedral Bluffs Tongue from underlying rocks. The reasons are as follows:

1. A comparison of electric logs for wells 21 and 268 , 4 miles apart, shows a good correlation of the mudstone marker zone, fair correlation of individual units, and characteristic spontaneous potential and resistivity curves in the section from above the marker zone up to a depth of 910 feet in well 21 . Above that horizon there is no similarity of curves in the two well sections. A comparable break in pattern in well 21 is shown on the gamma ray-sonic logs. The gamma ray curves are much less pronounced above this horizon, and the interval transit time increases conspicuously above it.

2. The dipmeter survey of well 21 shows a change in direction of dip from northeast above this horizon to southwest below, as is indicated in section $B-B^{\prime}$ (pl. 1).

3. A reconstruction based on projection of outcrop sections of the Cathedral Bluffs Tongue, Laney Shale Member, and Bridger Formation from $\mathrm{Cy}$ clone Rim to well 21, plus the correlation of the mudstone marker and base of the Fort Union Formation, shows that there is more than 2,000 feet of thinning northward of the lower Eocene and Paleocene section in 4 miles and that most of it occurs somewhere between the Laney Shale Member and the mudstone marker zone.

Pipiringos (1961) and Sheridan, Maxwell, and Collier (1961) stressed the intertonguing relations of the Battle Spring Formation and Cathedral Bluffs 'Tongue, but this intertonguing would not explain the thin sections of either or both sequences. Two possible interpretations are: (1) a southward-dipping normal 
fault that cut out 2,000 feet of section in well 21 or (2) the presence of an unconformity at or a short interval below the Cathedral Bluffs Tongue.

No evidence of a fault of the necessary magnitude was found on outcrop by any workers in the area (Bell, 1955; Wyant and others, 1956; Sheridan and others, 1961; Pipiringos, 1961). The Flattop fault, a mile northeast of well 21 would have to have a low dip to the southwest to cut the well section above the mudstone marker bed, but all surface evidence suggests that the fault is nearly vertical. None of the criteria listed above for determining the base of the Cathedral Bluffs Tongue can be considered as conclusive evidence that the base is precisely at the horizon indicated on section $B-B^{\prime}$ (pl. 1), or that the base necessarily is marked by an unconformity. Nevertheless, an unconformity seems to be the most logical explanation for the observed thinning of the underlying section. The lithologic similarity of beds both above and below the postulated unconformity can be explained by local reworking of the older beds and deposition of this debris in the younger. From a regional genetic standpoint, an unconformity could be expected at the base of the Cathedral Bluffs Tongue because the sudden flood of coarse granitic debris was almost certainly in response to an uplift of the Wind River Range and the Granite Mountains. Similar movements in these areas at other times have resulted in unconformities.

None of this reasoning about the unconformity accounts for the thinning of the Cathedral Bluffs Tongue itself in the vicinity of well 21 . Intertonguing does not explain the relations shown in section $B-B^{\prime}$ (pl. 1$)$.

The Laney Shale Member of the Green River Formation has been presumed to overlie conformably the Cathedral Bluffs Tongue (Pipiringos, 1961) in the Cyclone Rim area. However, an investigation of the relations of these rocks in six wells on and near the Horsetrack anticline north of the west end of Cyclone Rim (pl. 9), in the vicinity of the middle Eocene (Bridger Formation) vertebrate fossil locality $1-\mathrm{V}$ ( pl. 1 ; table 10 ), shows that a major unconformity is actually present at the base of the Laney Shale Member (section II', pl. 3). The pre-Laney Tertiary rocks on the anticline are a moderately thin remnant of green and gray arkosic conglomeratic sandstone in all wells. This sequence rests unconformably on rocks ranging in age from Cambrian in the northernmost well (Sohio) to Pennsylvanian in Shell 2 well.

Three miles east of section $I-I^{\prime}$ (pl. 3) is the Sohio Petroleum Co. East Horsetrack 2 well, SE $1 / 4$ sec. 24, T. 27 N., R. 97 W., less than $21 / 2$ miles north of the Cathedral Bluffs mapped by Pipiringos in sec. 6, T. $26 \mathrm{~N}$., R. $96 \mathrm{~W}$. This well penetrated a combined thick- ness of about 400 feet of the Bridger Formation and Laney Shale Member and then drilled 660 feet of green and gray arkosic sandstone, containing 150 feet of coaly sandstone in the upper middle, before Triassic red beds were reached. Compare this thickness and lithology with Pipiringos' 1,100-1,300 feet of brightly variegated mudstone, sandstone, and conglomerate. It is hardly likely that the entire variegated section of Cathedral Bluft's would change to green and gray in $21 / 2$ miles, especially toward an easily available source of red beds. In addition, 6,000 feet or more of older Eocene and Paleocene rocks known to underlie the Cathedral Bluffs 'Tongue in nearby wells to the southeast (well 268) and southwest (Gulf Oil Corp., Picket Lake-Federal 1 shown in section $I-I^{\prime}$ ) must be accounted for.

It seems almost certain that the 440-1,200 feet of green and gray sandstone in the Horsetrack wells represents part of the Wasatch Formation (the term Battle Spring has not previously been extended to this area and so is not used). After deposition of the Cathedral Bluffs Tongue, renewed uplift of the block on the north side of the Flattop fault (earlier movement in the same direction had resulted in erosion of at least $15,000 \mathrm{ft}$ of Mesozoic and Paleozoic rocks from this part of the north block) caused complete stripping of the Cathedral Bluffs and most of the underlying Wasatch Formation prior to expansion of Gosiute Lake over the Horsetrack area and deposition of the Laney Shale Member of the Green River Formation.

North of the Flattop fault and south of the Granite Mountains, no beds have been specifically correlated with the Cathedral Bluffs Tongue. As mentioned previously, the Crooks Gap Conglomerate may be a partial correlative. On the north side of the mountains, the reworked arkose and conglomerate in the basal part of the Wagon Bed Formation may represent contemporaneous or perhaps slightly younger deposits. Vertebrate fossils indicate that the Cathedral Bluffs is transitional in age between early and middle Eocene (McGrew and Roehler, 1960).

\section{LANEY SHALE MEMBER OF GREEN RIVER FORMATION}

The Laney Shale Member was named by Schultz (1920) from exposures in the northern part of the Washakie Basin (fig. 2). Correlative beds in a narrow outcrop along the north margin of the Great Divide basin were mapped by Pipiringos (1961). The member is characterized by brown oil shale, green ostracodebearing papery shale, sandy mollisk-bearing limestone, limy sandstone, and arkosic sandstone. In well 21 the member is 190 feet thick and has oil shale at top and bottom and arkosic granule conglomerate in the middle. Twelve miles east-southeast, the Laney is about 225 
feet thick and is dark-gray soft shale and claystone. Northeast toward Bare Ring Butte (section $E-E^{\prime}$, pl. 3), no lithology similar to that of the Laney Shale Member has been recognized. In the Horsetrack area (section $I-I^{\prime}$, pl. 3), the Laney consists of about 300 feet of soft brown and green siltstone, shale, and claystone. Here it lies unbroken across the buried trace of the Flattop fault. Southeast of Flattop Buttes, however, the Laney has been cut out by later movement along this segment of the fault.

The member unconformably overlies a stratigraphic sequence extending from the lower part of the Wasatch Formation (section $I-I^{\prime}$ ) to the Cathedral Bluffs Tongue and is conformably overlain by the Bridger Formation. Fossils from other areas indicate that the Laney is of middle Eocene age.

\section{INDIAN MEADOWS FORMATION} NAME AND DEFINTTION

The Indian Meadows Formation was named and described from exposures in the northwestern part of the Wind River basin (Love, 1939, p. 58-63), about 85 miles northwest of the Granite Mountains area. In the type locality it contains vertebrate fossils of earliest Eocene age. This formation has been recognized in surface and subsurface sections in the northern and eastern parts of the Wind River basin (Keefer, 1965). Keefer's studies show that it is continuous in the subsurface as far as the southeast end of the Wind River basin, where it crops out again (pl. 1). At this locality, the Indian Meadows Formation unconformably overlies the Fort Union and is unconformably overlain by the Lysite Member of the Wind River Formation. Rich (1962) called it the "umnamed sequence" and included it in the Wind River Formation.

\section{DISTRIBUTION AND THICKNESS}

The only outcrop of the Indian Meadows Formation in the Granite Mountains area is in its northeast corner (pl. 1), where about 120 feet (Rich, 1962) is exposed on Clarkson Hill (sec. 9, T. 31 N., R. 82 W.). The formation thickens to more than 6,000 feet in subsurface sections to the northwest (Keefer, 1965; Keefer and Love, 1963 , pl. 3 ; pl. $5 B$, this report). The formation may possibly also occur in two wells (57 in section $K$ $K^{\prime}$ and 259 in section $L-L^{\prime}$, pl. 3) at the west end of the Granite Mountains where, under typical strata of the Wind River Formation that overlap unbroken across the Emigrant Trail thrust plate, there are conglomeratic beds preserved beneath the thrust. The formation is believed to have been eroded away else- where in the mapped area prior to deposition of the overlying Wind River Formation.

\section{LITHOIOGY}

In outcrops at Clarkson Hill, the Indian Meadows Formation consists of white to yellowish-gray conglomeratic sandstone and lenticular gray and brown carbonaceous siltstone, claystone, and shale. The sandstone is composed of coarse and fine angular grains of clear and milky quartz and white feldspar in a white to yellowishgray claystone matrix. Granite pebbles and cobbles as much as 1 foot in diameter occur in the upper half. The claystone and siltstone beds are very irregular; some are contorted, and contain carbonized wood, poorly preserved macerated plant fragments, and pods of coal. The finer grained and more carbonaceous strata are host rocks for small amounts of uranium.

At the thick subsurface section 25 miles northwest of Clarkson Hill, Keefer (1965) described the Indian Meadows Formation as consisting chiefly of arkosic white sandstone that is fresh near the top but progressively more altered toward the base. The sandstone is interbedded with lesser amounts of variegated red, purple, and greenish-gray, gray, and black shale, claystone, and siltstone. The appearance, thickness, and lithologic succession are similar to those of the dominantly white sequence in the Wasatch and Battle Spring Formations south of Green and Crooks Mountains.

In wells 57 and 259 (pl. 3, section $L-L^{\prime} ;$ pl. 4, section $K-K^{\prime \prime}$, Paleozoic and Mesozoic rocks comprising the overriding plate of the Emigrant Trail thrust fault are on gray and pink arkosic sandstone and conglomerate containing many fragments of Paleozoic and Triassic rocks. The coarse clastics are interbedded with a few gritty silty variegated claystones. Dipmeter logs were not run on either well, so true thickness of the sequence are not known. In well 57 about 200 feet was penetrated and in well 259 more than 1,000 feet, but dips may be steep, especially in the latter well. The Wind River Formation is umbroken in overlap across the trace of the Emigrant Trail thrust in the vicinity of both wells. The lithology of the overridden conglomerate is unlike that in the Fort Union Formation 10 miles west and northwest of well 57. Thus, the arkosic and conglomeratic sandstone beds below the thrust plate are tentatively considered to be a remnant of the Indian Meadows Formation that was once much more extensive in the western part of the Granite Mountains area.

Although the record of regional deposition during Indian Meadows time is very incomplete in the Granite Mountains area, it can be reconstructed from the remnants described above and from data in the deeper part of the Wind River basin and in the Powder River basin 
to the northeast (fig. 2). As mentioned in the discussion of the Wasatch and Battle Spring Formations, extensive uplift of the Granite Mountains during earliest Eocene time resulted in a large and high source area that furnished an enormous amount of arkosic debris. Powerful streams carried part of this debris south into the Great Divide basin, where the Wasatch and Battle Spring Formations were deposited. Other streams flowed northeast across the site of the present southeast arm of the Wind River basin and on into the Powder River basin. These streams laid down an enormous fan of arkosic debris that was 6,000 feet thick northeast of the Rattlesnake Hills (Keefer, 1965, pl. 10D). The thickness decreases progressively to less than 3,000 feet in the Pumpkin Buttes area of the Powder River basin, 75 miles to the northeast (Iove and others, 1963, fig. 7), and comprises all but the uppermost 200 feet of the Wasatch.

\section{STRATIGRAPHIC AND STRUCTURAI RELATIONS}

The angular discordance between the Indian Meadows and Fort Union Formations at Clarkson Hill ( $T$. $31 \mathrm{~N} .$, R. $82 \mathrm{~W}$.) is about $5^{\circ}$, and this decreases northward into the Wind River basin (Rich, 1962). At the top, the amount of discordance with the overlying Wind River Formation is $5^{\circ}$ or less; but to the northwest, on the opposite side of this arm of the Wind River basin, in the area of faulting along the Casper arch (fig. 2), the discordance is nearly $90^{\circ}$ in places (Keefer and Love, 1963). Regional relations indicate that if the Indian Meadows Formation was ever deposited in extensive areas west of the Rattlesnake Hills along the north flank of the Granite Mountains, it was largely, and perhaps entirely, removed by erosion prior to deposition of the Wind River Formation. The only remnants that may have survived this erosion interval at the west end of the Granite Mountains are those previously mentioned that occur under the Emigrant Trail thrust plate.

\section{AGE AND CORRELATION}

The type locality of the Indian Meadows Formation is dated as earliest Eocene on the basis of vertebrate fossils. Nondiagnostic pollen was collected from the section on Clarkson Hill ; no other fossils were obtained from the Indian Meadows Formation in the Granite Mountains area.

Regional correlations in the Wind River basin are based on lithology and structural relations. For example, in the vicinity of the Casper arch the Indian Meadows unconformably overlies the Fort Union Formation and is unconformably overlain by the Lysite Member of the Wind River Formation, which is dated by vertebrate fossils as early Eocene. The Indian Mead- ows equivalent in the Powder River basin (all but the upper $200 \mathrm{ft}$ of the Wasatch) is dated by abundant vertebrate fossils (my unpub. notes; fossil identifications by M. J. Hough and C. L. Gazin, written commun., 1952) of earliest Eocene age.

Successive stages of development of the Wind River basin on the north side of the Granite Mountains during Paleocene and early Eocene time have been described (Keefer and Love, 1963, pl. 4; Keefer, 1965). It is logical to expect that any major uplift of the Granite Mountains would have produced comparable sediments on opposite flanks. The fan of arkosic sandstone extending northeast from the Granite Mountains to the Powder River basin has been discussed. Its southern counterpart on the south side of the Granite Mountains, directly opposite the source area of the northern fan, is believed to be the thick arkosic sandstone in the Wasatch and Battle Spring Formations.

\section{WIND RIVER FORMATION NAME AND DEFINITION}

The Wind River Formation was named by Meek and Hayden (1862,'p. 434) from exposures in the general area of the Wind River basin, and no subsequent major problems of nomenclature have developed, although the top and base are not everywhere agreed upon. Granger (1910, p. 241-246) divided the Wind River Formation on the basis of both fauna and lithology into the Lysite Member and the overlying Lost Cabin Member. These were discussed in some detail by Keefer (1965). As far as is now known, only the Lost Cabin Member is exposed in the Granite Mountains area, but the Lysite Member may be represented in the thicker subsurface sections.

\section{DISTRIBUTION AND THICKNESS}

The Wind River Formation is present north of the segment of the North Granite Mountains fault system that is east of the Rattlesnake Hills (pl. 3, section $H-$ $H^{\prime}, \mathrm{pl} .5 B$ ) and is on both sides of the fault system along the western segment. The formation wedges out southward and westward against preexisting uplands in the northwestern part of the Granite Mountains area and is not known south of U.S. Highway 287 except along the Beaver Divide. Because the formation was deposited on a surface of considerable local relief, its thickness differs markedly from place to place (pl. $5 B$; table 3$)$. North of the western part of the Beaver Divide it is $0-2,500$ feet thick; in the Gas Hills area, $0-$ 1,000 feet thick; and east of the Rattlesnake Hills 0$\tilde{5}, 000$ feet thick. In the Long Creek arm of the Wind River basin (pl. 7), 1,000 feet or more of the Wind River Formation is preserved (pl. $5 B$ ). 


\section{LTTHOLOGY}

Because most of the Wind River Formation was locally derived from adjacent uplands, its lithology is directly related to the types of source rocks and to the gradients of streams flowing from the source areas to the sites of deposition. Thus, along the west margin of the Granite Mountains area, the Wind River Formation contains abundant large boulders of Paleozoic and Precambrian rocks interbedded with locally derived red and green sandstone, siltstone, and claystone.

Several wells drilled into the deepest part of the Long Creek arm of the Wind River basin (pl. 7; pl. 4, section $K-K^{\prime \prime}$ ) penetrated as much as 400 feet of conglomeratic sandstone, which contained much more rubble of Paleozoic rocks than is typical in the Wind River Formation. Electric log characteristics of this sandstone are likewise quite different from those of the overlying strata of the Wind River. This sequence may be a remnant of the Lysite Member of the Wind River Formation. Although the strata contain abundant fragments of Paleozoic rocks, as does the Indian Meadows in the Wind River basin, they overlap unbroken across the Emigrant Trail thrust fault at localities where the Indian Meadows(?) Formation is overridden by the thrust. Therefore, they are provisionally included in the Wind River Formation.

The Wind River Formation in the Gas Hills area has been studied in considerable detail (Zeller and others, 1956; Zeller, 1957; Soister, 1958) because it contains some of the largest uranium deposits in Wyoming and has been exposed in enormous strip mines (fig. 56). Here the formation can be subdivided into two sequences, a fine-grained facies overlain by a coarse-grained facies.

The fine-grained facies consists of 0-200 feet (average about $130 \mathrm{ft}$ ) of light-gray fine-grained sandstone, siltstone, and claystone, variegated green and red siltstone and claystone, and thin carbonaceous shale and coal. The unit wedges out south ward on the north flank of the Granite Mountains. In some places, however, it was removed by erosion prior to deposition of the coarse-grained unit. Only small amounts of uranium ore have been found in the fine-grained facies.

The coarse-grained facies consists of conglomeratic arkosic sandstone and granitic granule to boulder conglomerate. These beds are interbedded with siltstone and claystone and with several moderately persistent beds of carbonaceous shale and coal. On outcrop, the facies is light yellowish gray, and in artificial cuts and drill holes it is greenish gray to bluish gray.

A sequence in the northeastern part of the Granite Mountains area is similar to that in the Gas Hills (Rich 1962). A lower, fine-grained facies is overlain by a coarse-grained facies. The fine-grained facies, in turn, is subdivided into a lower, variegated sequence overlain by a greenish-gray and drab sequence. The lower, variegated sequence consists of 250-800 feet of red, purple, green, and gray siltstone and claystone interbedded with lenses of gray to yellow sandstone that contain numerous fragments of Paleozoic and Mesozoic sedimentary rocks. It rests with angular unconformity on the Indian Meadows and Fort Union Formations and on Mesozoic rocks. The variegated strata grade up into the greenish-gray and drab siltstone and claystone sequence, which is lithologically similar except for the lack of variegated color and the presence of more arkose in the lenticular sandstones. The thickness of the drab sequence ranges from an eroded edge to perhaps 4,000 feet.

The upper, coarse-grained facies rests with erosional unconformity on the fine-grained facies and consists of $0-1,000$ feet of poorly consolidated light-yellowishgray crossbedded arkosic sandstone and granitic pebbleto-boulder conglomerate. The sandstone is medium to coarse grained and is interbedded with minor amounts of dark-gray carbonaceous siltstone (commonly radioactive), claystone, and shale. The upper two-thirds of the sequence is much more conglomeratic than the lower third. Roundstones are chiefly gray coarsely crystalline granite; fragments of Paleozoic and Mesozoic rocks are rare.

Neither the upper nor the lower facies of the Wind River Formation is found south of the North Granite Mountains fault system east of Rattlesnake Hills because of pre-Oligocene (probably pre-middle Eocene) erosion (pl. 3, section $H-H^{\prime} ;$ pl. $5 B$ ). The Granite Mountains certainly were the source of nearly all the coarse clastic debris, and the deposits must have originally extended southward several miles onto the Precambrian core.

The widespread distribution of conglomerate and coarse-grained sandstone in the upper part of the Wind River Formation along most of the north flank of the Granite Mountains is the result of a major uplift in late early Eocene time. Movement may have continued into the earliest part of middle Eocene time. This event was probably the same as that which caused deposition of the Crooks Gap Conglomerate on the south flank. The tuffaceous fine-grained strata in the Big Sand Draw area probably are the youngest in the Wind River Formation, as they overlie the conglomerate facies and overlap the Emigrant Trail thrust fault (pl. 4, sections $K-K^{\prime \prime}$ and $\left.U^{-} U^{\prime}\right)$.

North, northwest, and east of the Big Sand Draw oil and gas field (T. 32 N., R. 95 W.), 10 miles or more nortl of the Granite Mountains, the youngest beds in 
the Wind River Formation consist of brightly variegated claystone and siltstone, lesser amounts of sandstone, and very little conglomerate. This basinward facies is somewhat unusual in that it is very tuffaceous and bentonitic and weathers to bare puffy-surfaced, rounded variegated badland hills (fig. 19). There are also several widespread beds of white felsic tuff, one of which (fig. 20) has been mapped (Thompson and White, 1954) and described in some detail (Sinclair and Granger, 1911, p. 93-94). This tuff, which represents a unique volcanic episode in the record of sedimentation during early Eocene time in central Wyoming, is useful in stratigraphic and structural studies.

IIALFWAY DRAW TUFF MEMBER

The name Halfway Draw Tuff Member is here proposed for the white felsic tuff that is exposed on the north, east, and south sides of the Beaver Creek oil and gas field, about 3 miles north of the mapped area on pl. 1. The name is taken from Halfway Draw, an intermittent stream, on both sides of which the member is exposed. The type section of the tuff and associated beds is presented below and shown in figure 20 .
Type section of Halfway Draw Tuff Member, 200 feet east of west line and 1,900 feet north of south line of sec. 2, T. 33 N., R. 96 W., Fremont County, Wyo.

[Measured with steel tape by J. D. Love, 1962]

Wind River Formation (part):

\section{Thick-} ness
$($ feet $)$

12. Sandstone, light-tan, soft; interbedded with hard ledge-forming arkose; composed of angular fragments of Precambrian rocks; makes up lower part of widespread tawnycolored unit which caps ridges on east side of Beaver Creek oil and gas field and which is at least $100 \mathrm{ft}$ thick ............

11. Claystone, soft, plastic, waxy; interbedded red and green layers; puffy on weathered surfaces_..............................

Halfway Draw Tuff Member:

10. Tuff, grayish-white, hard, tough, very thin bedded, evenly bedded; weathers to fissile slabs; most is very fine grained, sparkly, and biotitic, but some is crystal tuff containing pumice chunks as much as $1 \mathrm{in}$. in maximum diameter, and plagioclase phenocrysts $1 / 4$ in. in diameter; contains euhedral biotite erystals; uppermost $2 \mathrm{ft}$ has greatest concentration of biotite, and this was sampled for rapid-rock analysis (table 7); thin section Wyo-903, $3 \mathrm{ft}$ above base; Wyo-904, $5 \mathrm{ft}$ above base; Wyo-905, 390, and 391, $2 \mathrm{ft}$ below top.--

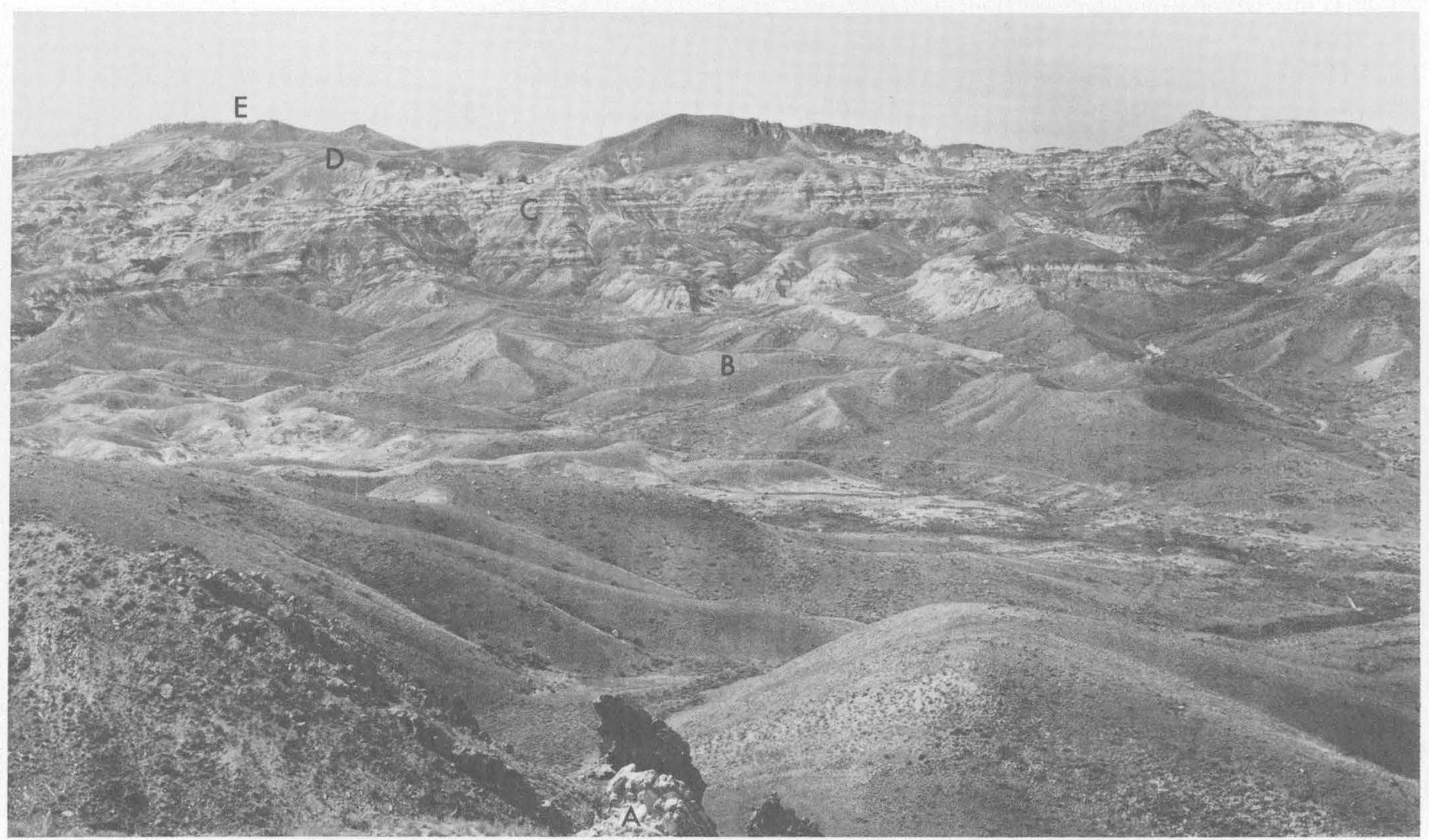

Figure 19.-View southwest from Rogers Mountain. A, Steeply dipping sandstone in Frontier Formation. B, Cody Shale. C, Variegated tuffaceous strata in Lost Cabin Member of Wind River Formation. D, Wagon Bed Formation, in horizontal position and, E, vertical in landslide mass in secs. 24 and 25 , T. 33 N., R. 95 W. 


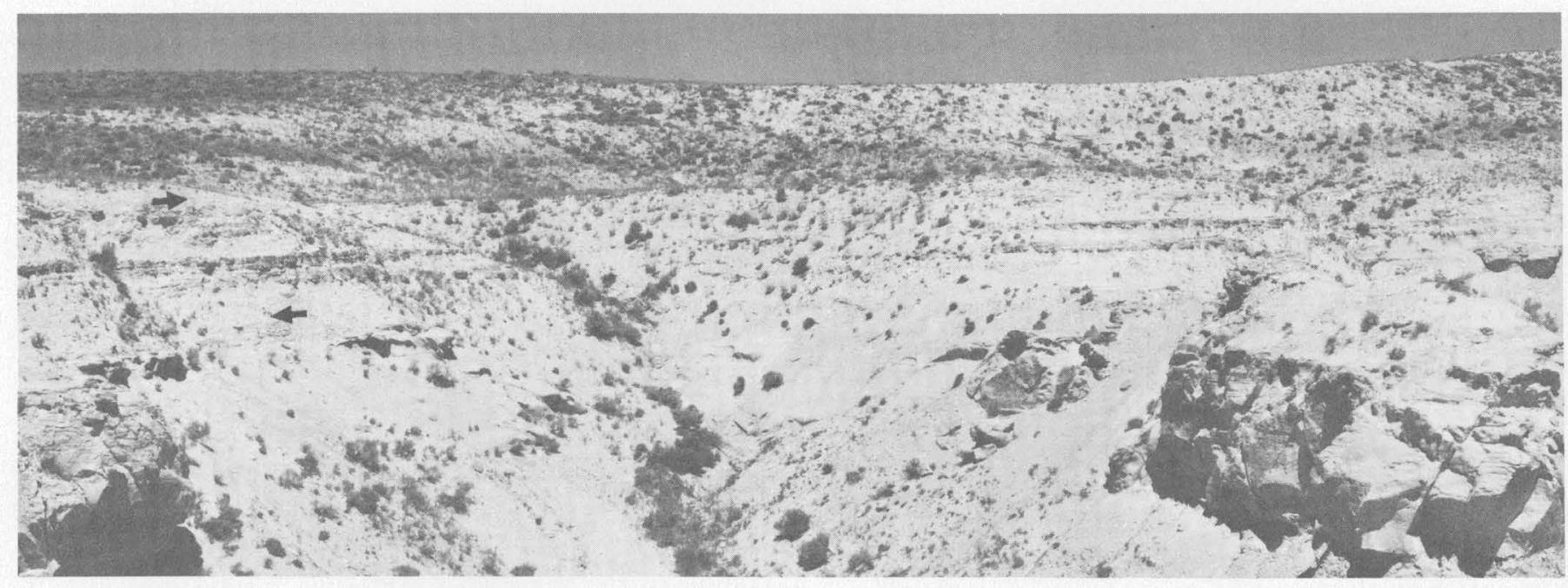

Figure 20.-Type section of Halfway Draw Tuff Member (between arrows) of the Wind River Formation, NW14SW14 sec. 2, T. 33 N., R. 96 W. Note abundant vegetation on variegated claystone (unit 11 in measured section) above bare tuff in upper center.

Type section of Halfway Draw Tuff Member, 200 feet east of west line and 1,900 feet north of south line of sec. 2, T. 33 N., R. 96 W., Fremont County, Wyo.-Continued

Wind River Formation (part) - Continued Base of Halfway Draw Tuff Member.

9. Sandstone, light-tan to gray, very fine grained, very thin bedded; contains abundant finely disseminated biotite.....

8. Sandstone, brown, hard; medium grained near top; conglomeratic in lower $1 \mathrm{ft}$ and contains pebbles and granules of gray porphyry as much as $1 / 2$ in. thick but more commonly $1 / 10$ in.; thin section Wyo-902 of pebble bed; forms conspicuous cliff below Halfway Draw Tuff Member........

7. Sandstone, gray, hard, medium-grained, clayey highly tuffaceous, biotitic; clayey near top; forms reentrant within tan cliff

6. Sandstone, tan, massive, soft, biotitic, tuffaceous, medium-grained; forms lower conspicuous sandstone on cliff face; grades up into unit 7 .....................

5. Sandstone; lower half has irregular brown roll-shaped concretions; upper half has two thin conspicuous irregular hard sandstone beds; forms a distinctive unit below lower massive brown sandstone; has abundant biotite and pumice fragments; thin section Wyo-901 from upper part.........

4. Sandstone, brown, medium grained in lower $3 \mathrm{ft}$, gray in middle, brown and cliff forming near top; highly biotitic and tuffaceous; along strike, entire unit forms cliff_-

3. Sandstone, gray; lower $3 \mathrm{ft}$ is soft, highly biotitic, tuffaceous, and medium grained, and grains are angular; remainder is more clayey sandstone interbedded with darkgreen soft puffy sandy claystone and, near top, very fine grained waxy claystone and some brown flaky shale................
Thickness
(feet)
Type section of Halfway Draw Tuff Member, 200 feet east of west line and 1,900 feet north of south line of sec. 2, T. 33 N., R. 96 W., Fremont County, Wyo.-Continued

Thickness
(feet)

Wind River Formation (part) - Continued

2. Claystone, pale green and red near base, dark green in remainder; soft, puffy, bentonitic, sandy near top; has shiny waxy fracture $\ldots . . . . . . . . . . . . . . . . .$.

1. Claystone, brick-red, soft; has shiny waxy fracture; contains turtle bones; grades up to unit $2 \ldots 5+$ Total thickness of measured section ... $102+$

Chemical analyses of samples of the Halfway Draw Tuff Member taken by Sinclair and Granger (1911, p. $94)$ and by me are given in table 7.

Sinclair and Granger (p. 93) published a petrographic description of the Halfway Draw. Their work and the thin sections made for the present study indicate that the tuff has a rhyolite quartz latite composition.

Thickness of the Halfway Draw Tuff Member ranges from 10 to 20 feet near the type section. Similar tuffs are known farther north in the Wind River basin (Keefer, 1965), but not to the east along the margin of the basin; in fact, tuffaceous debris is very sparse farther east.

Overlying the variegated strata in the Wind River Formation along Beaver Divide is a sequence of yellowish-gray to pale-green tuffaceous arkosic and conglomeratic sandstone with a green plastic bentonitic claystone matrix. These beds have been described as Bridger (?) Formation by Sinclair and Granger (1911) and as Wind River by Van Houten $(1954,1964)$. In my 
report, they are discussed in connection with middle Eocene rocks.

\section{STRATIGRAPHIC AND STRUCTURAL RELATIONS}

The Wind River Formation was deposited on a rough topographic surface underlain by rocks ranging in age from Precambrian to earliest Eocene. The amount of angular discordance varies with the distance from major Laramide folds and faults and is, therefore, less conspicuous in gently warped parts of the Wind River basin. Regional relations of the Wind River Formation to older and younger rocks are shown in sections $H-H^{\prime}$ (pl. 3) and $K-K^{\prime \prime}, O-O^{\prime}, U-U^{\prime}$, and $V-V^{\prime}$ (pl. 4). Plate 7 is a generalized geologic map showing structures and pre-Eocene rocks exposed at about the time of deposition of the oldest strata in the Wind River Formation in the broadest part of the Long Creek arm of the Wind River basin. There is no record of the original northern extent of the Wasatch and Battle Spring Formations north of Crooks Mountain. The Indian Meadows (?) Formation had already been completely stripped away except possibly for small remnants (not shown) partially trapped under the Emigrant Trail thrust at wells 57 and 259. The Granite Mountains, the Sweetwater Crossing anticline, and other major folds had already developed, been faulted, and been deeply eroded. Some structures continued to grow (compare pls. $6 A$ and $6 E$ ), and movement was renewed on several faults; but these were declining spasms of the Laramide orogeny.

Keefer (1965) discussed the folding and erosion that occurred between deposition of the Lysite and Lost Cabin Members of the Wind River Formation in the Wind River basin. Certainly, the Granite Mountains were involved, but, inasmuch as no strata of Lysite age have been identified on either flank of the mountains, the record of events in areas of most extensive uplift is obscure. It may be that the angular unconformity between the Crooks Gap Conglomerate and the Wasatch and Battle Spring Formations represents part of this episode.

Overlying the Wind River Formation west of the Rattlesnake Hills is a sequence of arkosic sandstone and conglomerate that is believed to have been reworked from the Wind River and older rocks. This unit, the transition beds of Van Houten $(1954,1964)$, is discussed in connection with middle Eocene rocks. A distinctive green decrepitating bentonitic claystone matrix distinguishes it from the Wind River Formation.

\section{AGE AND CORRELATION}

Fossils from the Wind River Formation near the Big Sand Draw oil and gas field and farther southwest along the Beaver Í)ivide (Granger, 1910; Sinclair and Granger, 1911) and from the same formation elsewhere along the north flank of the Granite Mountains, have been listed by Keefer (1965, table 2). Strangely enough, despite intensive work, no diagnostic fossils have been reported from the Wind River Formation in the Gas Hills area, but the lithologic succession seems to be comparable with that east of the Rattlesnake Hills where Lambdotherium popoagicum, a guide fossil to the Lost Cabin Member, was found in the upper part of the variegated sequence (Rich, 1962); these strata are in the lower third of Rich's lower, fine-grained facies. It is concluded, therefore, that the overlying drab sequence and the coarse clastic facies in both areas probably are also of Lost Cabin age. The Niland Tongue of the Wasatch Formation in the Great Divide basin likewise contains a large vertebrate fauna of Lost Cabin age (Love, 1964, fig. 3 ).

Hay (1956, p. 1890) reported Lambdotherium from a bed less than 1 foot below the Halfway Draw Tuff Member near the type section, and Sinclair and Granger found the same fossil genus stratigraphically above the tuff. Evernden, Savage, Curtis, and James (1964) determined the potassium-argon age of the tuff to be 49.2 m.y. (table 5). The published location of their sample, and likewise that of Hay's Lambdotherium, conflict with the position of outcrops of the tuff as mapped by Thompson and White (1954), but probably both localities are about 2 miles south-southeast of the type section. Inasmuch as Evernden, Savage, Curtis, and James also reported an age of $49 \mathrm{~m} . \mathrm{y}$. for a sample in the Wagon Bed Formation (loc. $4 \mathrm{KA}$, tables 5 and 9 ; pl. 1), from a stratigraphic horizon considerably above the Halfway Draw Tuff Member, the age of one of these samples probably is in error.

The volcanic-rich strata containing the Halfway Draw Tuff Member may correlate with the tuffaceous Tipton Tongue of the Green River Formation, likewise of Lost Cabin age (McGrew and Roehler, 1960). The upper conglomeratic facies of the Wind River Formation along the north flank of the Granite Mountains may be contemporaneous with at least part of the Crooks Gap Conglomerate on the south flank.

\section{WAGON BED FORMATION}

\section{NAME AND DEFINTTION}

The Wagon Bed Formation was named and defined by Van Houten (1964) from exposures of tuffaceous strata near Wagon Bed Spring, about 2 miles west of the South Sand Draw oil and gas field (pl. 1), along the northwest margin of the Granite Mountains. This unit was originally subdivided into the "Bridger(?)" and "Uinta" Formations by Granger (1910) and Sin- 
clair and Granger (1911). The lower part was named "Green Cove beds" by Wood (1934, p. 245-249; 1948, p. 38). The entire sequence was called "middle and upper Eocene rocks" by Van Houten $(1950,1954,1955)$, Van Houten and Weitz (1956), and Love, Weitz, and Hose (1955). The middle Eocene part has been called the Aycross equivalent and the upper Eocene part the Tepee Trail equivalent (Love, 1964).

\section{DISTRIBUTION AND THICKNESS}

The Wagon Bed Formation is exposed along almost the entire Beaver Divide (pl. 1) and as far east as the east margin of the Rattlesnake Hills. From there to the east and southeast as far as the Shirley basin, unfossiliferous erosion remnants with comparable lithology have been tentatively identified (fig. $2 ; \mathrm{N}$. M. Denson, oral commun., 1960; E. N. Harshman, 1964a-h; not mapped in the field by me or indicated on pl. 1). South of the Granite Mountains, in the southwestern part of the report area, the Wagon Bed Formation crops out as far as the Flattop fault (pl. 1).

The Wagon Bed Formation laps out against Paleozoic and Precambrian rocks on the north, west, and southwest flanks of the Granite Mountains, as well as against the southeast margin of the Wind River Range (sections $F-F^{\prime}, K^{\prime}-K^{\prime \prime}, M-M^{\prime}, N-N^{\prime}$, pl. 3 ; sections $Q-Q^{\prime}, T-T^{\prime}, U-U^{\prime}, W-W^{\prime}$, pl. 4), and nearly surrounds the Sweetwater Crossing anticline. (See pl. 7 for configuration of this uplift; also pls. $5 C, 10 F$.)

Volcanic centers in the Rattlesnake Hills contributed a significant amount of locally derived tuff to the Wagon Bed Formation. One of the two thickest sections $(600 \mathrm{ft})$ is in that area. The other $(700 \mathrm{ft})$ is near the Big Sand Draw oil and gas field. (pl. $5 C$ ) and represents accumulated pyroclastic debris from the Absaroka Range, 90 miles to the northwest, in addition to locally derived sediments.

In the southwestern part of the map area (pl. 1), north of the Flattop fault, the Wagon Bed ranges in thickness from 0 to more than 200 feet.

\section{LITHOLOGY}

The Wagon Bed Formation exhibits a new feature the first locally derived volcanic debris - in the record of sedimentation of the Granite Mountains area. The debris came from a swarm of 35 or more volcanic vents clustered in an area of about 125 square miles in the Rattlesnake Hills. Other features of the Wagon Bed Formation are thin beds of uraniferous phosphate; laminated organic-rich shale like that in the Green River Formation; oil-saturated sandstone, some of which contains a commercial amount of uranium; zeolites such as erionite, clinoptilolite, and heulandite; uncommon elements such as dysprosium, erbium, and gadolinium; and the oldest known fresh-water diatoms.

The lithology of the Wagon Bed Formation has been studied in detail from the west end of Beaver Divide to the Rattlesnake Hills (Van Houten, 1954, 1955, 1964; Van Houten and Weitz, 1956; Love, 1964). Within the Rattlesnake Hills, the formation is associated with igneous rocks; both have been mapped by Carey (1954, 1959).

The Wagon Bed Formation is divisible into several lithologic units. Above the variegated strata of the Wind River Formation and below the pale-green and drab tuffaceous rocks that compose the bulk of the Wagon Bed Formation at the base of the escarpment along most of the Beaver Divide is a sequence of strata that has been classified in several ways. This unit consists of a few feet to nearly 300 feet of lenticular soft yellow to gray conglomeratic arkosic sandstone with a distinctive green decrepitating clayey matrix that is interbedded with evenly layered light-greenish-gray and yellowish-green tuffaceous mudstone, siltstone, and claystone (figs. 21-24).

These strata were included in the "Bridger(?)" Formation by Granger (1910; compare his pl. 20 with fig. 24 of this report) and by Sinclair and Granger (1911), and in the "Green Cove beds" by Wood (1934, p. 245249 and pl. $24 ; 1948$, p. 38), who described and illustrated an erosional unconformity at the base. No such unconformity was observed by Van Houten. Regarding the mappability of these strata, Van Houten (1954) stated:

East and north of Big Sand Draw anticline conspicuous grayishyellow coarse arkose and arkosic mudstone 25 feet thick at the base of the zone support a discontinuous belt of evergreen trees. Because the basal beds of the overlying formation are poorly exposed and usually difficult to locate, the base of the transitional zone has arbitrarily been mapped as the top of the Wind River formation in this area.

He nevertheless considered this sequence to be part of the Wind River Formation, but I include the sequence in the Wagon Bed Formation. My reasons are: (1) Its lithology, especially the green bentonitic matrix, is identical with that in the Wagon Bed and is not typical of the Wind River; (2) its coarse clastic debris is believed to reflect in part the orogenic uplift of the Granite Mountains that stripped the Wind River Formation from the mountain core (fig. 10E) prior to and contemporaneously with deposition of the lower part of the Wagon Bed Formation; and (3) its areal distribution, in my opinion, corresponds closely to that of the Wagon Bed Formation and is markedly different from that of the Wind River. 


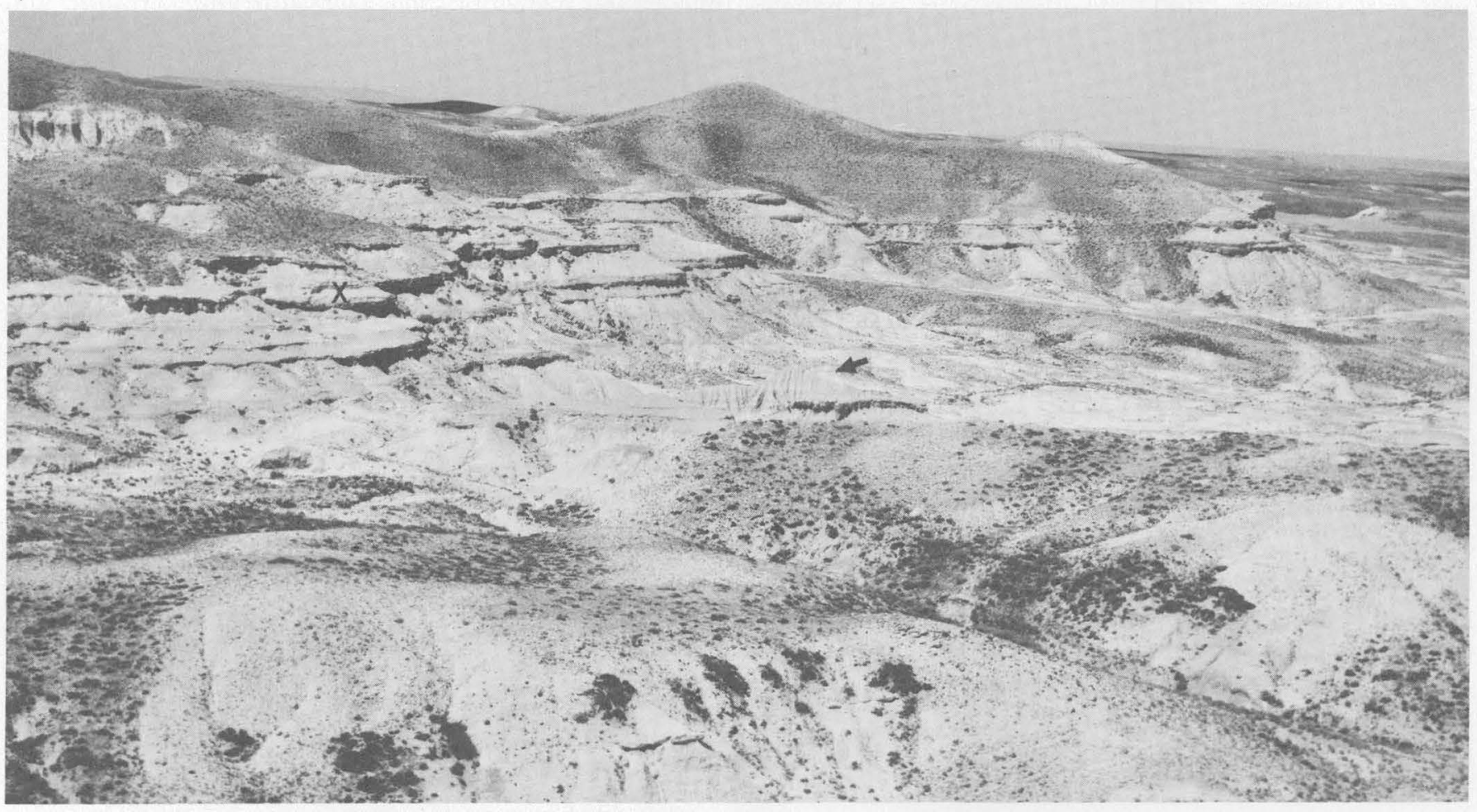

FIGURE 21.-Lower part of Wagon Bed Formation. $X$, siliceous marker bed underlain by beds containing green uraniferous claystone (arrow). View west in NW1/4SE1/4NE1/4 sec. 10, T. 32 N., R. 90 W., Gas Hills area.

The regional data suggest that, rather than being a transition facies between the Wind River and Wagon Bed Formations, this sequence is a reworked zone and that its predominantly arkosic debris was derived in large part from the Wind River Formation that was being rapidly stripped from the rising Granite Mountains several miles to the south.

In the Green Cove locality (fig. 24), the reworked beds weather to pale-green hard bare fluted badlands (Sinclair and Granger, 1911, pl. 6; Van Houten, 1964, fig. 5) consisting of coarscly bedded tuffaceous claystone, siltstone, and sandstone with secondary red and brown spots. In the upper part are some beds of boulder conglomerate composed of rounded fragments of Paleozoic sandstone and limestone as much as 5 feet in diameter (fig. 23) embedded in a green plastic bentonitic decrepitating clayey matrix that is not at all like the silty gritty matrix in the conglomerate of the underlying Wind River Formation. This sequence is locally radioactive, but the uranium and phosphate content is low. For example, in the Green Cove section, samples taken 4 and 60 feet above the base of the reworked beds contain 0.005 and 0.004 percent uranium and 0.15 and 0.08 percent phosphate, respectivèly (Love, 1964, table 11, lab. no. 285750 and 285749$)$.
In the western part of the Beaver Divide area the strata above the reworked beds and below the White River Formation have been subdivided by Van Houten (1954, 1964) into five units. The summary presented here is drawn largely from his descriptions. Unit 1, which is recognized from the western part of the Beaver Divide to the Rattlesnake Hills except in localities where it laps out against uplands of resistant preTertiary rocks, is a marker ledge (or a sequence of marker ledges) as much as 30 feet thick composed of hard bluish- greenish- and yellowish-gray gnarlyweathering mudstone that is locally siliceous. It crops out as a single ledge or as a series of conspicuous ledges (figs. 21, 23, 24) which are separated by softer, very fine grained green clayey beds. Sinclair and Granger (1911, p. 89-97, and unit 4, pl. 6) described this unit and placed it in the "Bridger(?)" Formation. Greenbrown and blue-green hornblende are very common; no pyroxenes, however, were noted by Van Houten (1954). The unit apparently grades into the underlying reworked beds. It is lithologically identical with beds in the Bridger Formation south of Crooks Mountain on Bare Ring Butte (pl. 1; section $E-E^{\prime}$, pl. 3). 


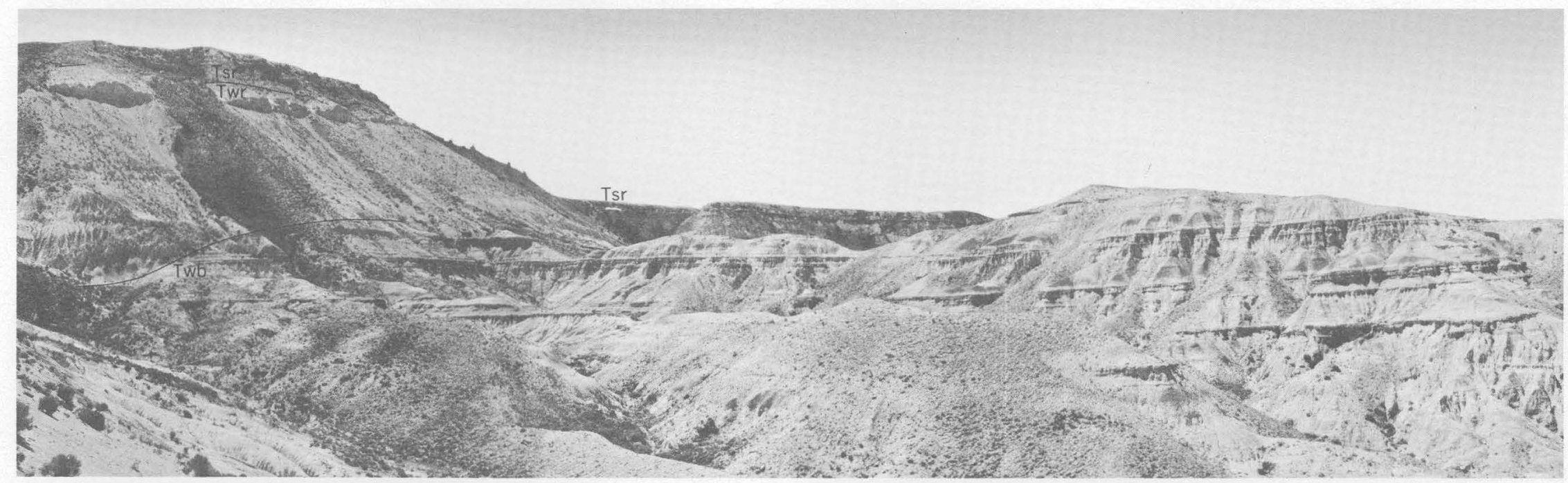

FIGURE 22,-Physical appearance and contact relations of Split Rock Formation (Tsr), White River Formation (Twr), and Wagon Bed Formation (Twb) on Beaver Divide escarpment in Gas Hills area. View southwest in SE1/4 sec. 10, T. $32 \mathrm{~N}$., R, $90 \mathrm{~W}$, shows west margin of major channel cut in Wagon Bed Formation and filled with tuffaceous claystone of the White River Formation. All beds in center and at right are believed to be units 2 and 3 of Van Houten (1955). Some thin hard layers are algal(?) limestone. 
Evernden, Savage, Curtis, and James (1964) determined the potassium-argon age of unit 1 in the Green Cove area (Van Houten, 1950, sec. 7 ; loc. $4 \mathrm{KA}$ on pl. 1 and in table 5) to be 49.0 m.y. (table 5). This age is remarkably close to the 49.2 m.y. obtained from the Halfway Draw Tuff Member. The member, however, is believed to be several hundred feet stratigraphically lower than unit 1 and, on the basis of the record of tectonic events in the Granite Mountains, considerably

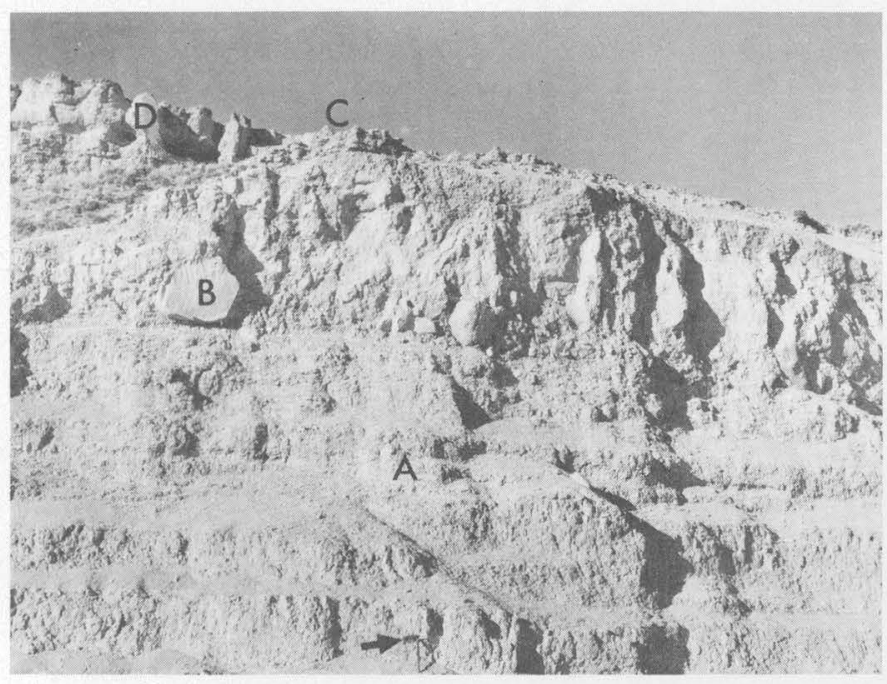

FIGURE 23.-Roadcut along abandoned route of U.S. Highway 287 , Beaver Divide escarpment, NW1/4 sec. 10, T. 30 N., R. 96 W., at site of measured section 1 of Van Houten (1950). A, Green tuffaceous claystone, siltstone, and sandstone with red and brown spots in reworked beds. B, Bed of Paleozoic boulders. C, One of several siliceous marker ledges in lower part of Wagon Bed Formation. D, Cliff of pale-green clayey sandstone in Wagon Bed Formation. Arrow at bottom of photograph points to shovel for scale. older. Additional age determinations are needed to clarify this discrepancy.

Unit 2 consists of coarsely bedded greenish-gray to yellowish-gray arkosic sandstone and sandy mudstone that weather to soft slopes. Near the Big Sand Draw oil and gas field, the upper part of unit 2 is massive yellowish-gray to pale-brown and olive soft bentonitic mudstone grading to soft tuffaceous sandstone; these beds crop out as conspicuous "elephant-back" badlands. In this locality, some sandstones are as much as 40 feet thick and contain granules and rounded pebbles up to 3 inches in diameter of dark-gray and reddish-brown augite hypersthene andesite. This composition contrasts with that of the more felsic volcanic debris in older and younger units.

Unit 3 consists of yellowish-orange to yellowish-gray fine-grained tuff and tuffaceous siltstone that is as much as 200 feet thick southwest of the Big Sand Draw oil and gas field. Hard limonite-stained slabby sandstone and thin carbonaceous shale beds are present, as well as several uraniferous phosphatic zones (Love, 1964, table 11). The maximum content of uranium is 0.042 percent and of phosphate 5.67 percent in a bed that contains the uncommon elements dysprosium, erbium, and gadolinium (Love, 1964, table 17). The volcanic material is chiefly brown and greenbrown biotite and green-brown hornblende. Fossil vertebrates of middle Eocene age were collected from about 20 feet above the base of the unit at Green Cove (Van Houten, 1954, section 7; 1964, loc. 1, p. 50; this report, fig. 24 (sequence marked by D)).

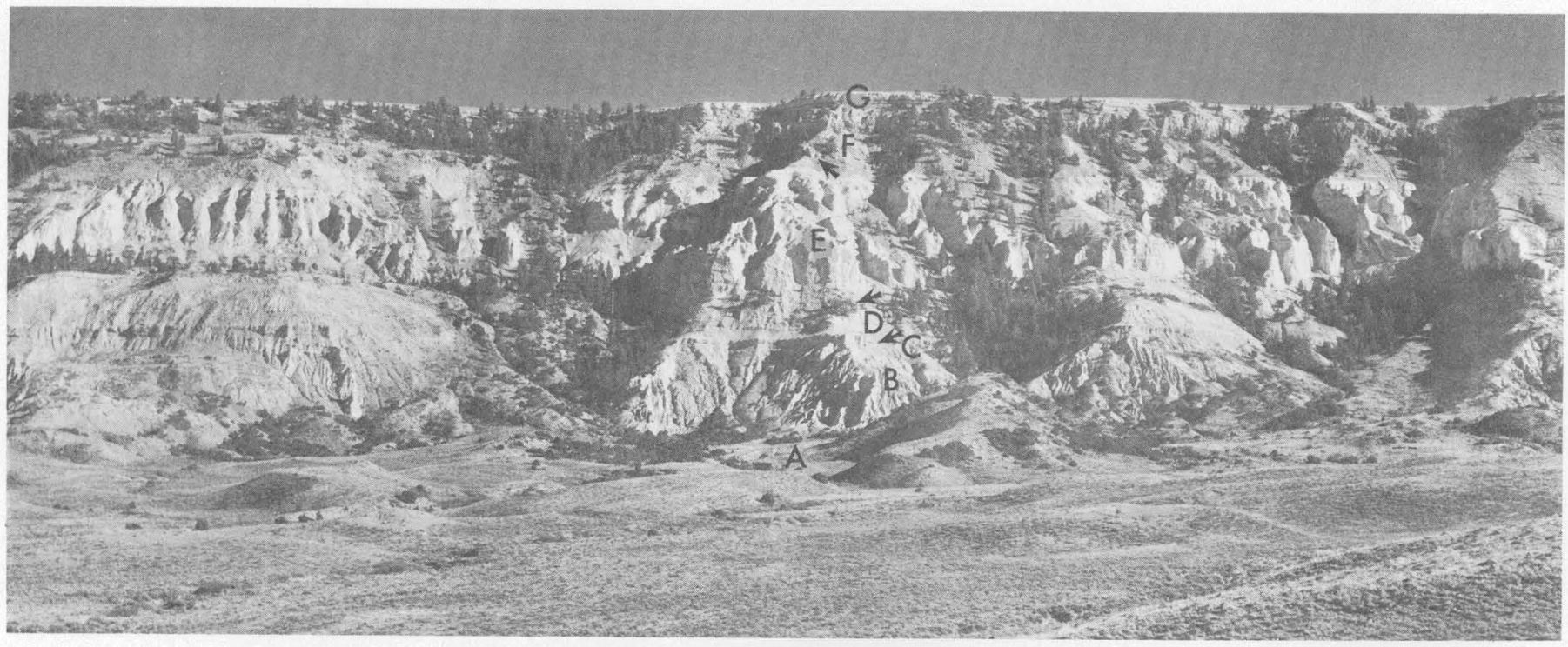

FIGURE 24.-Green Cove classic section of Tertiary rocks on Beaver Divide directly west of north end of section $0-O^{\prime}$ (pl. 4). View south toward escarpment 850 feet high. A, Variegated claystone and arkose of Wind River Formation. B, Pale-green reworked beds. C, Siliceous marker bed in lower part of Wagon Bed Formation. D, Upper part of Wagon Bed Formation. E, White River Formation. F, Basal conglomerate in lower porous sandstone sequence in Split Rock Formation. G, Sandy limestone in Split Rock Formation. 
TABLE 5.-Potassium-argon ages of Oligocene and Eocene rocks in the Granite Mountains area, along the north margin of the Wind River basin, and in the Absaroka Range

\begin{tabular}{|c|c|c|c|}
\hline $\begin{array}{l}\text { Locality and number } \\
\text { on goologic map (pl. 1) }\end{array}$ & $\begin{array}{l}\text { Age (millions } \\
\text { of years) }\end{array}$ & Formation and age & Locality data and reference \\
\hline Ellis Ranch; 2KA.... & 32. $2( \pm 2.0)$ & $\begin{array}{c}\text { White River; } \\
\text { Oligocene. }\end{array}$ & $\begin{array}{l}\text { White biotitic tuff about } 300 \mathrm{ft} \text { above base of White River Formation; } \\
1,300 \mathrm{ft} \text { east of west line, } 2,300 \mathrm{ft} \text { north of south line sec. 4, T. } \\
29 \text { N., R. } 96 \text { W., Fremont County, Wyo. Sample collected by } \\
\text { J. D. Love; analyzed by Geochron Laboratory (Houston, 1964). }\end{array}$ \\
\hline $\begin{array}{l}\text { Lone Tree Gulch; } \\
\text { 29KA. }\end{array}$ & 31. 6-35. 7 & $\begin{array}{l}\text { White River; early } \\
\text { Oligocene. }\end{array}$ & $\begin{array}{l}\text { Six samples representing four beds of white tuff within a stratigraphic } \\
\text { interval of about } 500 \mathrm{ft} \text { (Chadronian provincial age of Wood and } \\
\text { others, 1941), SE } 14 \text { sec. } 23 \text {, to E1/2 sec. } 22 \text {, T. } 31 \text { N., R. } 83 \text { W. (cor- } \\
\text { rected location), Natrona County, Wyo. Samples collected and } \\
\text { analyzed by Evernden, Savage, Curtis, and James (1964, samples } \\
\text { KA895, 897-900, and 1032, p. 185; 190). }\end{array}$ \\
\hline Irish Rock........ & 33. $9( \pm 3.4)$ & $\begin{array}{l}\text { Basal white tuff in } \\
\text { Wiggins; Oligo- } \\
\text { cene. }\end{array}$ & $\begin{array}{l}\text { White pumicite in basal part of Wiggins Formation, SW14SW14SE14 } \\
\text { sec. 15, T. } 47 \mathrm{~N} \text {., R. } 104 \mathrm{~W} \text {. (unsurveyed), Park County, Wyo.; } \\
\text { (not shown on map). Sample collected by C. R. Dunrud, analyzed } \\
\text { by Geochron Laboratory (Houston, 1964). }\end{array}$ \\
\hline Badwater ............ & 145.0 & Tepee Trail; Eocene_ & $\begin{array}{l}\text { Limy tuff at approximate stratigraphic position of upper Eocene } \\
\text { vertebrate fossils, Badwater locality, NEY, sec. 29, T. } 39 \text { N., R. } \\
88 \text { W., Natrona County, Wyo.; (not shown on map). Sample col- } \\
\text { lected and analyzed by Evernden, Savage, Curtis, and James } \\
\text { (1964, sample KA1024, p. 189). }\end{array}$ \\
\hline Hawks Butte_...... & $146.2( \pm 1.5)$ & $\begin{array}{l}\text { Tepee Trail equiva- } \\
\text { lent; Eocene. }\end{array}$ & $\begin{array}{l}\text { White biotitic tuff in unit 7, Hawks Butte, measured section of } \\
\text { Tepee Trail equivalent on Lysite Mountain, SEY4SW14N W14 sec. } \\
\text { 36, T. } 42 \text { N., R. } 90 \text { W., Hot Springs County, Wyo.; (not shown on } \\
\text { map). Sample collected by J. D. Love, analyzed by Geochron } \\
\text { Laboratory (Houston, 1964). }\end{array}$ \\
\hline $\begin{array}{l}\text { Wagon Bed Spring; } \\
\text { 32KA. }\end{array}$ & 145.4 & $\begin{array}{l}\text { Wagon Bed; } \\
\text { Eocene. }\end{array}$ & $\begin{array}{l}\text { Biotitic tuff in middle Eocene part of Wagon Bed Formation (Van } \\
\text { Houten, 1954, section } 26 ; 1964) ; 1 \text { mile north of Wagon Bed Spring, } \\
\text { SE1/4 sec. 28, T. } 32 \text { N., R. 95 W. (corrected location), Fremont } \\
\text { County, Wyo. Sample collected and analyzed by Evernden, Savage, } \\
\text { Curtis, and James (1964, sample KA1018, p. 189). }\end{array}$ \\
\hline Green Cove; 4KA...- & 49. 0 & do & $\begin{array}{l}\text { Bentonitic tuff in lower part of Wagon Bed Formation (Van Houten, } \\
1950 \text {, section } 7 ; 1964) \text {, center SEY4 sec. } 35 \text {, T. } 31 \text { N., R. } 96 \text { W., } \\
\text { Fremont County ,Wyo. Sample collected and analyzed by Evern- } \\
\text { den, Savage, Curtis, and James }(1964 \text {, sample KA1021, p. 189). }\end{array}$ \\
\hline Beaver Creek ....... & 49. 2 & Wind River; Eocene_ & $\begin{array}{l}\text { Biotite-rich bed in type locality of Halfway Draw Tuff Member, } \\
1,000 \mathrm{ft} \text { above base of Wind River Formation and directly over- } \\
\text { lying beds containing Lambdotherium, SE cor. SE1/4 NE1/4 sec. 14., } \\
\mathrm{T} .33 \mathrm{~N} ., \mathrm{R} .96 \mathrm{~W} \text {. (location corrected from that given by Evernden } \\
\text { and others, 1964), Fremont County, Wyo. Sample collected and } \\
\text { analyzed by Evernden, Savage, Curtis, and James (1964, sample } \\
\text { KA1012, p. 188). Not shown on map. }\end{array}$ \\
\hline
\end{tabular}

1 Vertebrate fosslls and lithologic composition suggest that the Badwater and Hawks Butte samples are nearly contemporaneous and that the Wagon Bed Spring sample is older than the Hawks Butte sample.

Evernden, Curtis, Savage, and James (1964) reported a potassium-argon age of $45.4 \mathrm{~m} . \mathrm{y}$. (loc. $32 \mathrm{KA}$, table 5 and pl. 1) for a sample from the middle of unit 3 in the Wagon Bed Spring Area (Van Houten, 1954, sec. 26).

Unit 4 consists of 100-200 feet of yellowish-gray to pale-olive soft tuffaceous claystone, siltstone, and sundstone. Bright-green claystone beds, chert, siliceous claystone, and siliceous nodules are conspicuous features. Some strata are thin bedded and a few are laminated. X-ray analysis of several of these beds indicates the presence of the zeolite heulandite (variety clinoptilolite), montmorillonite, and erionite (Van Fouten, 1964; Deffeyes, 1959a, b). One bed resembles the varved fish-bearing oil shale in the Green River: Formation (Van Houten, 1964, p. 41 and fig. 8) of southwestern Wyoming, but it yielded only 2.4 gallons of oil per ton (Love, 1964, Sand Draw pipeline-road section, unit 4).
About 6 miles south of this pipeline-road locality, directly below the top of the formation, well 4.6 , at a depth of 335 f'eet, penetrated 25 feet of laminated brown organic-rich shale that may be correlative and that certainly represents a comparable depositional environment. Similar organic-rich shale is present in the approximately correlative Aycross(?) equivalent in the Lysite Mountain area of north-central Wyoming (Love, 1964).

A widespread cherty sindstone and limestone composes the upper part of unit 4 southwest and east of the Big Sand Draw oil and gas field. A green plastic bentonitic claystone 60 feet below the top at Green Cove ('T. 31 N., R. 96 W.) is radioactive. The most radioactive 2 inches contains 0.009 percent uranium and 0.07 percent phosphate (Love, 1964, table 12, lab. No. 285748). Volcanic minerals in the unit are greenbrown hornblende, blue-green hornblende, and sodic plagioclase. 
Unit 5 along the western part of the Beaver Divide consists of $0-120$ feet of massive greenish-yellow to yellowish-gray tuffaceous sandstone and siltstone containing lenses and beds of silica-cemented arkose and arkosic conglomerate. The coarser grained beds are more common in, but not confined to, the upper parts of the thicker sections. Farther east along the Beaver Divide the upper beds were stripped away before the beginning of Oligocene deposition. Many pebbles and a few cobbles and boulders in the conglomerate are dark-gray and red-brown porphyritic hypersthenehornblende-biotite andesite, probably derived from the Absaroka Range, 90 miles northwest.

Unit 5 contains much more augite, hypersthene, and red-brown hornblende than units 3 and 4 . About 5 miles east of the Big Sand Draw oil and gas field, the lower part of the unit contains gastropods (Van Houten, 1964, fossil loc. 13); near this locality and elsewhere along the divide, this unit yielded vertebrate fossils of late Eocene age. In and near sec. 3, 'T. $32 \mathrm{~N}$., R. $94 \mathrm{~W}$., these rocks are impregnated with oil containing commercial amounts of uranium (figs. 58, 59). This deposit is discussed in connection with uranium deposits.

Rock analysis of one unit in the Wagon Bed Formation is given in table 7 .

Van Houten $(1954,1964)$ observed that in the western part of the Beaver Divide area unit 5 overlies an unconformity cut about 200 feet into the underlying middle Eocene rocks.

In the Gas Hills, 30 miles east of Wagon Bed Spring, the reworked beds in the lower part of the formation are commonly 50-200 feet thick and overlie the upper, coarse-grained facies of the Wind River Formation. As in the western part of the Beaver Divide area, the lower strata in the unit contain yellow to white arkose in a bentonitic clayey matrix; these beds support a sparse growth of pine and juniper. The overlying strata in the reworked beds are dull gray, yellowishgreen, and greenish-gray evenly bedded soft bentonitic mudstone and claystone (fig. 21) that weather to bare badlands. These fine-grained rocks are similar to those in the overlying part of the Wagon Bed Formation, whereas the arkoses, except for the bentonitic matrix, are like those in the Wind River Formation. A radioactive carbonaceous shale about 60 feet below the top of the reworked beds in sec. 27, T. 33 N., R. 89 W., yielded leaves of Green River type (Van Houten, 1955, p. 6 ; this report, table 10 , loc. $20 \mathrm{P}$ ). An analysis shows 0.062 percent uranium and 0.16 percent phosphate (Love, 1964, table 11, lab. No. D-99211). In this same general area, a 1-foot-thick bed of pale-green clayey sandstone, 17 feet below a 5-foot-thick bed of puffysurfaced pale-green bentonitic claystone and 50 feet below the top of the reworked beds (fig. 21), is moderately radioactive, but samples from two localities contain only 0.001 percent uranium and 0.03 and 0.05 percent phosphate (Love, 1964, table 10, lab. Nos. 285744 and 297259$)$. The source of the radioactivity has not been determined.

Between the Gas Hills and Rattlesnake Hills, the Wagon Bed Formation, exclusive of the reworked beds, has been subdivided into six units (Van Houten, 1955, 1964), each of which has a distinctive lithology that reflects a significant stage in the history of the area. Unit 1 is probably the approximate equivalent of unit 1 southwest of Big Sand Draw, 50 miles to the west, for both have the same general appearance (fig. 21 ), composition, and stratigraphic relation to the reworked beds. Unit 1 consists of 30 feet of tough gnarly ledge-forming greenish-gray to olive mudstone and claystone containing many secondary cavities. These beds are almost identical in physical appearance with those in the lower part of the Bridger Formation on Bare Ring Butte south of Crooks Gap (pl. 7 ; section $E-E^{\prime}$, pl. 3). One or more beds of soft felsic tuff in the eastern Beaver Divide area are believed to represent the first episode of volcanic activity in the adjacent Rattlesnake Hills volcanic field.

Unit 2 along the eastern Beaver Divide consists of 75-120 feet of pale-olive to greenish-yellow, yellowishgray, and brownish-gray puffy-surfaced biotitic soft mudstone and claystone, with some arkose, capped by an arkosic sandstone and conglomerate that weathers to fluted ledges. The roundstones, commonly small, are chiefly Precambrian gneiss and schist, but a few are pebbles of white and bluish-gray sodic trachyte lava. Volcanic debris, in addition to the trachyte, includes hexagonal biotite, shards, and bentonite. One 4-footthick pale-olive-drab siltstone at the base of the uppermost sandstane is radioactive, but analyses show only 0.001 percent uranium and 0.03 percent phosphate (Love, 1964, table 10, lab. No. 297260). The source of the radioactivity has not been determined. The relation of unit 2 in this area to unit 2 in the western part of the Beaver Divide has not been definitely established.

Unit 3 is coarse grained in localities close to the Rattlesnake Hills and becomes progressively finer grained farther west. Van Houten (1955, p. 8 and pl. 1, sections $A$ and $B ; 1964$, p. 47) described a deposit 2550 feet thick of giant boulders of Precambrian gneissic rock as much as 12 feet in diameter (I have found some, however, that are $20 \mathrm{ft}$ ) in the lower part of unit 3, in sections 26 and 27, T. 33 N., R. $89 \mathrm{~W}$. He suggested 
that the large size, angularity, and limited vertical distribution may indicate derivation from a fault scarp in the Rattlesnake Hills 5 miles to the east rather than from the somewhat closer peaks in the Granite Mountains to the south. Neither the isopach map (pl. $5 C$ ) nor the structure contour map (pl. $6 B$ ) shows any evidence of such a scarp. The boulders decrease in size to the west and disappear within 5 miles. In addition to the boulders, the coarse-grained facies contains lithic fragments of sodic trachyte porphyry, vitrophyre containing white feldspar phenocrysts, lapilli tuff, and abundant fibrous shards. These were transported westward from the Rattlesnake Hills volcanos. Apparently the magnitude, violence, and frequency of eruptions were progressively increasing during middle Eocene time. The finer grained facies west of Rattlesnake Hills consists of 50-100 feet of soft evenly bedded tuffaceous greenishyellow to olive bentonitic claystone and mudstone and of thin persistent layers of algal (?) limestone (fig. 22). Blue-green hornblende, apparently derived from Precambrian schist in the Rattlesnake Hills, is more abundant in unit 3 than in any other unit. Correlation of unit 3 in this area with units 3 and 4 in the western Beaver Divide is uncertain, but probably they are at least partly equivalent.

Unit 4 consists of 40-60 feet of light-gray to yellowish-gray cliff-forming coarse-grained lapilli tuff and fine-grained vitric tuff and a few lenses of conglomerate containing both volcanic and Precambrian rock fragments from the Rattlesnake Hills. Pebbles and cobbles of pumice and pumiceous tuff are abundant, and some of sodic trachyte occur; all contain a suite of light- and dark-green pyroxenes that has not been found in the underlying units.

Unit 5 consists of approximately 130 feet of lightolive-gray to pale-olive and yellowish-gray poorly sorted bentonitic tuffaceous mudstone, sandstone, and conglomerate (Van Houten, 1955, p. 9). Both Precambrian metamorphic rocks and hard brown-weathering gray pyroxene andesite porphyry fragments are present in the conglomerate. The finer grained part is soft tuffaceous sandstone containing abundant lithic fragments of pumice and some silicified beds. This unit has more magnetite, pale-green augite, and medium-green clinopyroxene than any underlying unit, and the rock fragments are andesine andesite in contrast with those of sodic trachyte in the older units.

Unit 6, the youngest, coarsest grained, and most conspicuous unit in the Wagon Bed Formation between the Gas Hills and Rattlesnake Hills, crops out in prominent cliffs and dip slopes. It consists of as much as 140 feet of boulder conglomerate of brown-weathering gray pyroxene andesite porphyry fragments embedded in a coarse unsorted crystal tuff and tuffaceous gray mudstone matrix. It laps out against knobs of Precambrian rocks in the Granite Mountains. Van Houten postulated that some of this coarse debris may have been transported as mudflows from volcanos in the Rattlesnake Hills. On some of the dip slopes, however, the abundance of coarse angular slabs suggests that they are lag fragments from a lava flow that disintegrated in place.

The volcanic vents and the igneous and related pyroclastic rocks in the Rattlesnake Hills have been described and mapped by Carey $(1954,1959)$. As is expected, the section of pyroclastic rocks becomes thicker and coarser grained toward the vents. The thickest exposed section near a vent is above 550 feet of volcanic breccia and coarse-grained tuff in sec. 35, T. 33 N., R. 88 W. Parental rock types included in these deposits in the Rattlesnake Hills are discussed with the Eocene igneous rocks.

East of the Rattlesnake Hills, no detailed studies of the middle and upper Eocene rocks have been made. Drill cuttings of wells 189,190 , and 191, which begin in the Wagon Bed Formation, show 165-175 feet of dark-green tuffaceous conglomerate, sandstone, and siltstone. These strata directly overlie Cretaceous rocks in wells 189 and 190, but in well 191, 125 feet of the Wind River Formation is present. Both the Wind River and Wagon Bed Formations lap out against uplands of preTertiary rocks in this area. Still farther east and southeast, along the escarpment extending from the Rattlesnake Hills to Alcova Reservoir and along the north and east margins of the Shirley basin (fig. 2), thin erosion remnants of unfossiliferous green arkosic sandstone, siltstone, and claystone have been observed by N. M. Denson (oral commun., 1960) and mapped by Harshman (1964a-h) in places at the base of the Oligocene section. These may be either reworked debris from the Wagon Bed Formation incorporated in the Oligocene rocks or remnants of formerly more extensive deposits of the Wagon Bed. Other than these possible occurrences and a few on the west flank of the Laramie Mountains (Love and others, 1955), no middle and upper Eocene rocks are known from that part of Wyoming east of the 107th meridian (Love, 1960, p. 209).

Strata between the Wind River Formation and the Oligocene rocks in subsurface sections south of the Beaver Divide, in the western part of the Granite Mountains area, resemble the middle Eocene part of the Wagon Bed Formation. Plate 8 shows electric-log characteristics of these rocks. Except in the sections near or lapping directly onto Precambrian rocks, the lower 50-100 feet of the formation is commonly green to brick-red soft highly bentonitic claystone. Shards 
and crystals of sanidine are common in some wells. The red color is typical of sections moderately close to outcrops of Triassic red beds. The thicker sections and those farthest east, near the Emigrant Trail fault, contain abundant gray to white arkose with green to creamy-tan bentonitic claystone matrix.

West and northwest of the Bison Basin oil field are extensive outcrops of the Wagon Bed Formation. These were mapped by Bell (1955) but have not been studied in detail. They consist of variegated bentonitic claystone interbedded with gray arkosic sandstone and lenticular conglomerate (fig. 26).

Strata here assigned to the Wagon Bed Formation crop out in fault blocks for 12 miles along the South Granite Mountains fault system east of Crooks Gap. They were called White River by Stephens (1964), White River(?) by Riva (1959), and middle and upper Eocene by Dickey (1962). The strata are chiefly pink and green waxy bentonitic claystone and gray soft arkosic sandstone but include some lenticular coarse granite boulder conglomerate. One characteristic common to all outcrops is the abundance of very fine grained almost colloidal claystone which is the matrix in coarse-grained strata and the dominant lithology in the finer grained beds. The nearest outcrops of the White River Formation northwest of the Happy Springs oil field, as well as drill cuttings of the White River sequence in 24 wells 2-10 miles from Crooks Gap, show this type of lithology to be rare or absent. However, it is characteristic (containing 25 percent or more of montmorillonite in the samples examined) of the underlying Wagon Bed Formation.

Stephens (1964, table 3) emphasized the close similarity of rapid-rock analyses of the definitely identified White River Formation with the one analysis from the disputed beds. He did not compare his analysis with rapid-rock analyses of the Wagon Bed Formation or with correlative middle and upper Eocene rocks. Analyses of three samples of middle and upper Eocene rocks are given in table 7 and show that Stephens' analysis (1964, lab No. 14771, his table 3) has just as many differences from and similarities to the Bridger Formation and Tepee Trail equivalent as it has to the White River. Heavy minerals are not diagnostic, for much of the suite reported by Stephens $(1964$, table 2$)$ in the beds in question is locally derived from adjacent older rocks, as is that in both the White River and Wagon Bed Formations. There is little similarity to the volcanic suites from either the Wagon Bed or White River (Van Houten, 1964, table 5 and pl. 7). On the basis of physical appearance, weathering characteristics, presence throughout of a flood of bentonitic claystone, and similarity to all adjacent subsurface sections of the
Wagon Bed Formation, these strata are here considered as part of the Wagon Bed rather than as the White River.

The chemical and elemental compositions of the volcanic constituents in the Wagon Bed Formation are inadequately known, but the few analyses show some intriguing patterns. For example, of all the Cenozoic rocks in the Granite Mountains area, individual samples of the Wagon Bed have the highest concentrations (not the weighted average in table 6) of the following elements (percentages determined by chemical or spectrographic analyses) :
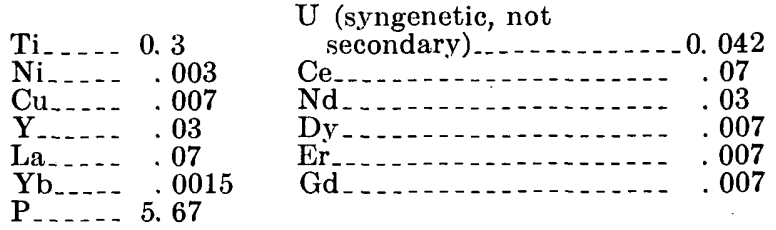

The Wagon Bed has concentrations, equal to the highest in the area, of the following elements:

$$
\begin{array}{ll}
\mathrm{Sc} \ldots \ldots & 0.0015 \\
\mathrm{Fe}_{\ldots} \ldots \ldots & 3.0 \\
\mathrm{Ba}_{\ldots} \ldots . & 2
\end{array}
$$

The Wagon Bed has concentrations, equal to the second highest, of the following elements:

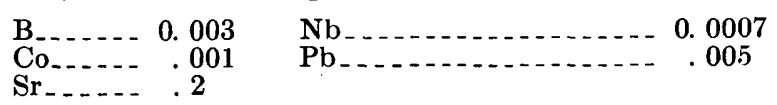

On the basis of these values, I think a systematic sampling of the Wagon Bed Formation in the Granite Mountains area would yield fundamental data on an apparent regional pattern of elemental excesses (and possible deficiencies) that occurred only from the latest early (in the Green River basin) through late Eocene times. These excesses and deficiencies may reflect an unusual composition of contemporaneous volcanic debris.

\section{STRATIGRAPHIC AND STRUCTURAI RELATIONS}

Wood $(1934,1948)$ described an erosional unconformity at the base of the reworked beds in the western part of the Beaver Divide area, but this was not mentioned by other geologists studying those exposures or additional ones farther east. In subsurface sections between the Beaver Divide and Precambrian rocks on the north flank of the Granite Mountains, the Wagon Bed Formation unconformably overlies pre-Tertiary rocks, and no intervening Wind River Formation is present except in the northernmost sections (pl. 1, $A-A^{\prime}, C-C^{\prime}, D-D^{\prime} ;$ pl. $3, F-F^{\prime}, N-N^{\prime} ;$ pl. $4, K-K^{\prime \prime}$, $M-M^{\prime \prime}, O-O^{\prime}$ through $W-W^{\prime} ;$ pl. $\left.10 F^{\prime}\right)$.

An erosional unconformity between the middle and the upper Eocene rocks in the western part of the Beaver Divide area, along which more than 200 feet 
TABLE 6.-Semiquantitative spectrographic analyses of ash, pumicite, tuff, and tuffaceous claystone of Cenozoic age and Precambrian granite in the Granite Mountains area

Rapld-rock analysos (table 7) were made of most of these samples. Values are reported in percent to the nearest number in the series $7,3,1.5$, 0.7 , etc.; at least 60 percent of results are expected to be the correct range; none found, ..... Elements look ed for but not found, $\mathbf{A g}, \mathbf{A s}, \mathbf{A u}, \mathbf{B i}, \mathrm{Cd}, \mathrm{Eu}, \mathrm{Ge}, \mathrm{Hl}, \mathrm{Hg}, \mathrm{Ho}, \mathrm{In}, \mathrm{Ir}, \mathrm{Lu}, \mathrm{Os}, \mathrm{Pd}, \mathrm{Pr}, \mathrm{Pt}$ Ro, Rh, Ru, Sb, Ta, Tb, Te, Tl, Tm, W, Zn. Elements not looked for: Cs, F, Rb. Values given are weighted averages for all samples in each formation Analysts: N. M.
Conklin, J. C. Hamilton, J. L. Harris, R. G. Havens, K. V. Hazel, A. L. Sutton, Jr., and Barbara Tobin]

\begin{tabular}{|c|c|c|c|c|c|c|c|c|c|c|c|c|c|c|c|c|c|c|}
\hline Formation or lithology & $\begin{array}{l}\text { Number } \\
\text { of } \\
\text { samples }\end{array}$ & Si & Al & $\mathrm{Fe}$ & $\mathbf{M g}$ & $\mathbf{K}$ & $\mathrm{Na}$ & $\mathrm{Ca}$ & $\mathbf{T i}$ & $\mathbf{B a}$ & $\mathrm{v}$ & Mn & $\mathrm{Sr}$ & $\mathrm{Zr}$ & B & $\mathrm{Cr}$ & $\mathrm{Cu}$ & $\mathrm{Ni}$ \\
\hline 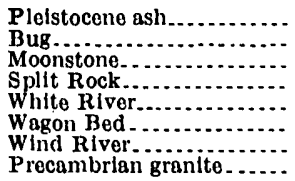 & $\begin{array}{r}1 \\
2 \\
19 \\
4 \\
2 \\
5 \\
1 \\
11\end{array}$ & $\begin{array}{l}>10.0 \\
>10.0 \\
>10.0 \\
>10.0 \\
>10.0 \\
>10.0 \\
>10.0\end{array}$ & $\begin{array}{r}>10.0 \\
1.0 \\
7.0 \\
5.0 \\
7.0 \\
5.0 \\
>10.0 \\
7.0\end{array}$ & $\begin{array}{l}1.0 \\
.7 \\
1.5 \\
1.5 \\
1.5 \\
1.5 \\
1.5 \\
1.0\end{array}$ & $\begin{array}{l}0.2 \\
1.5 \\
1.0 \\
1.0 \\
1.5 \\
2.0 \\
.7 \\
.5\end{array}$ & $\begin{array}{l}5.0 \\
2.0 \\
5.0 \\
3.0 \\
5.0 \\
5.0 \\
2.0 \\
5.0\end{array}$ & $\begin{array}{r}3.0 \\
1.0 \\
1.5 \\
2.0 \\
2.0 \\
-2.0 \\
3.0 \\
3.0\end{array}$ & $\begin{array}{l}0.5 \\
3.0 \\
5.0 \\
5.0 \\
1.5 \\
3.0 \\
3.0 \\
.3\end{array}$ & $\begin{array}{l}0.1 \\
.05 \\
.1 \\
.1 \\
.2 \\
.1 \\
.15 \\
.07\end{array}$ & $\begin{array}{l}0.07 \\
.02 \\
.07 \\
.03 \\
.1 \\
.1 \\
.2 \\
.1\end{array}$ & $\begin{array}{l}0.007 \\
.007 \\
.003 \\
.007 \\
.005 \\
.005 \\
.002\end{array}$ & $\begin{array}{l}0.02 \\
.015 \\
.03 \\
.03 \\
.05 \\
.03 \\
.02 \\
.02\end{array}$ & $\begin{array}{l}0.01 \\
.1 \\
.07 \\
.03 \\
.07 \\
.1 \\
.5 \\
.03\end{array}$ & $\begin{array}{l}0.015 \\
.005 \\
.015 \\
.01 \\
.015 \\
.01 \\
.007 \\
.007\end{array}$ & $\begin{array}{l}\cdots \ldots \ldots . \\
0.0015 \\
.0015 \\
.0002 \\
.0007 \\
\ldots \ldots \ldots . .\end{array}$ & $\begin{array}{l}0.0007 \\
.002 \\
.0015 \\
.0015 \\
.0003 \\
.003 \\
.005 \\
.0003\end{array}$ & $\begin{array}{l}0.0005 \\
.002 \\
.001 \\
.0015 \\
.0015 \\
.003 \\
.0007 \\
.0005\end{array}$ & \begin{tabular}{r}
0.0007 \\
.0005 \\
.0005 \\
\hdashline .0015 \\
.0015
\end{tabular} \\
\hline
\end{tabular}

\begin{tabular}{|c|c|c|c|c|c|c|c|c|c|c|c|c|c|c|c|c|c|c|}
\hline & $\mathbf{L a}$ & $\mathbf{Y}$ & $\mathrm{Sc}$ & Co & $\mathbf{P b}$. & Ga & $\mathrm{Nb}$ & $\mathbf{Y b}$ & Be & Mo & $\mathrm{LI}$ & $\mathrm{Ce}$ & Nd & $\mathrm{Th}$ & Sn & Dy & Er & Gd \\
\hline Pleistocene ash.............. & 0.007 & 0.005 & 0.0005 & 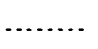 & 0.005 & 0.003 & 0.005 & 0.0005 & 0.0005 & 0.0005 & & 0.02 & 0.007 . & 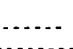 & 0.001 & & & \\
\hline 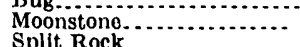 & .005 & .001 & $.0007^{\circ}$ & 0.0001 & .002 & .0015 & .0015 & .0005 & .0002 & .0003 & 0.002 & .006 & 003 & $\ldots$ & .0002 & & & \\
\hline $\begin{array}{l}\text { Split Rock } \\
\text { White River................................ }\end{array}$ & .003 & $\begin{array}{l}.003 \\
.002\end{array}$ & .0005 & (n.... & $\begin{array}{l}.003 \\
.003\end{array}$ & .003 & .0002 & $\begin{array}{l}.0003 \\
.0003\end{array}$ & $\begin{array}{l}.00015 \\
.0002\end{array}$ & .0002 & .005 & .005 & 003. & & & & & \\
\hline $\begin{array}{l}\text { Wagon Bed } \\
\text { Wind RIver... } \\
\text { preambrinn }\end{array}$ & . 015 & $\begin{array}{l}.007 \\
.001\end{array}$ & .0007 & .0005 & .002 & .002 & . & .0005 & .00015 & .00015 & & .015 & $.007^{-1}$ & 0.007 & $\ldots$ & .0015 & 0.0015 & 0.0015 \\
\hline
\end{tabular}

1 Random sample (see rock analysis 162633 , table 7 ) from core in well 164 at depth of about $1,245 \mathrm{ft}$. Other analyses of granite are from mineralized areas and not representativo so are not listed.

of southwestward beveling can be seen has already been mentioned. Eastward from this area as far as the Rattlesnake Hills, no conspicuous consistent structural break has been found in this part of the section (Van Houten, 1964 p. 50), but a lithologic break does appear to be present between the felsic rocks and the overlying mafic rocks. The structural significance of the giant granite boulders in unit 3 has not been determined.

While the Crooks Gap Conglomerate was being deposited, the South Granite Mountains normal fault system developed, and the Granite Mountains and the Long Creek arm of the Wind River basin rose vertically as a single block. This normal fault system paralleled the Emigrant Trail thrust fault east of Crooks Gap, diverged westward at the gap, and followed the west-trending trace of the older Mormon Trail fault (pl. 7). Maximum throw on this system is not known, but it may have ranged from 1,000 feet (section $D-D^{\prime}$, pl. 1) to 3,000 feet. Between the Sweetwater River and the South Granite Mountains fault system, north of the Happy Springs oil field, nearly all the lower Locene rocks, at that time 1,000 feet or more thick, were eroded before deposition of the Wagon Bed Formation (fig. 10E'). This episode of uplift and erosion probably accounts for part of the coarse-grained debris in the reworked beds on the north flank of the Granite Mountains.

Along the eastern part of the North Granite Mountains fault system, tectonic events were comparable to, and probably more or less synchronous with, those involving the South Granite Mountains fault system. West of the Rattlesnake Hills, however the history of the northern system is imperfectly known. Section $H-H^{\prime}$ (pl. 3) shows that the Granite Mountains block was uplifted about 5,000 feet, with respect to the Wind River basin block, after deposition of the Wind River Formation and before deposition of the White River Formation. As a result of the faulting, the Wind River was stripped from the south block (pls. $5 B, 6 A$ ), possibly in part before deposition of the Wagon Bed Formation.

This orogenic episode is discussed more fully in connection with the history of the North Granite Mountains fault system. A conspicuous erosional, and in places angular, unconformity is present between the Wagon Bed Formation and Oligocene rocks.

\section{AGE AND CORRELATION}

Many fossil localities in the Wagon Bed Formation have been described and identified forms listed (Granger, 1910; Sinclair and Granger, 1911; Van Houten, 1954, 1955, 1964; Wood, 1948; and Gazin, 1955, p. 7-8). Wood gave a historical summary and bibliography pertaining to fossil collecting along the Beaver Divide. Table 10 includes data on some of the more pertinent fossil assemblages.

The reworked beds yielded one leaf collection (table 10) from a carbonaceous radioactive shale in the Gas Hills area. R. W. Brown (in Van Houten, 1955, p. 6) 356-301 0-60-5 
considered these species to be characteristic of the Green River Formation. Because the strata containing the flora are crumbly, H. D. MacGinitie identified fragile specimens in the field. He reported (written commun., 1963) : "The Zelkova is a slender late Green River type; the 'Quercus' leaf is an elongate variety; and Liquidambar is sparse. Pollen samples taken at the same time from the leaf bed contain abundant Carya, Quercus, and Zelkova-Ulmus, lesser amounts of Platycarya, Juglans, Nymphaea, and sparse Rhus." He said that this flora is definitely not early Eocene and is probably later than early middle Eocene.

The reworked beds overlie the Lost Cabin Member of the Wind River Formation and, as previously mentioned, are lithologically more like other dated middle Eocene rocks than like those of early Eocene age. Because of the lithology, middle Eocene flora, and relation of these strata to post-Wind River regional orogenic events involving the west end of the Granite Mountains, the reworked beds are here included in the Wagon Bed Formation.

Unit 3 along the western part of Beaver Divide yielded vertebrate fossils of middle Eocene (Bridger B, Wood and others, 1941) age (Van Houten, 1954, 1964). The Aycross Formation 80 miles northwest of the Beaver Divide yielded vertebrate fossils of Bridger $A$ age near the base and of Bridger $C$ age near the middle (Love, 1939), both ages of Wood and others (1941). Thus, that part of the Wagon Bed Formation below the unconformity in the western part of the Beaver Divide area probably is equivalent to all or part of the Aycross Formation.

Correlation of the Wagon Bed Formation with rocks south of the Flattop fault (section $A-A^{\prime}$, pl. 1) is discussed in the section on the Bridger Formation.

Unit 5 yielded a vertebrate fauna of late Eocene (Uinta) age southwest of the Big Sand Draw oil and gas field. These rocks also contained a mollusk assemblage, concerning which D. W. Taylor (written commun., 1962) stated:

Fossil localities in Wagon Bed Formation, Beaver Divide

\begin{tabular}{|c|c|c|}
\hline Freshw & 8256 & 20089 \\
\hline Lymnaea aff. $L$. similis Meek & $X$ & $\Lambda$ \\
\hline sp & $\mathrm{X}$ & $\mathrm{X}$ \\
\hline pseudoammonius (Schlotheim) & $\mathbf{X}$ & $\mathrm{X}$ \\
\hline
\end{tabular}

Land snails:

Gastrocopta ?.2.

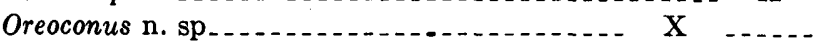

USGS 8256 (14). Fremont Co., Wyo. About sec. 8, T. 32 N., R. 94 W. A. J. Collier and Harvey Bassler, 1918.

USGS 20089. Fremont Co., Wyo. SE $1 \frac{1}{4}$; sec. 5 , T. 32 N., R. $94 \mathrm{~W}$. One mile east of Asbell triangulation station, and 50 feet below top of Beaver Rim. F. B. Van Houten; 1950.
So far as determinable, all species occur also in the Tepee Trail Formation of the northeastern Wind River basin. Correlation of these units accords well with the molluscan data, but in the absence of adequate middle Eocene collections from the Wind River basin the fossil mollusks do not strongly indicate such a correlation.

Along with the mollusks are some poorly preserved diatoms - the earliest record of fresh-water diatoms in North America (K. E. Lohman, written commun., 1965).

A primitive titanothere, Eometharhinus ervayensis was found in unit 5 in the Gas Hills area by J. F. Rachou (Van Houten, 1955, p. 9), but inasmuch as it is a new species and structurally intermediate between middle and late Eocene species of the genus, it is of little help in dating the enclosing rocks.

The type section of the Tepee Trail Formation 90 miles northwest of the Beaver Divide yielded a specimen of Metarhinus of late Eocene aspect (Love, 1939) and Parahyus vagus (collected and identified by G. E. Lewis). Neither fossil is definitely diagnostic of late Eocene, but the stratigraphic, structural, and petrographic data suggest the sequence is probably of that age. Upper Eocene fossils occur near the top of a thick section of similar-appearing rocks that overlie strata containing middle Eocene fossils on Carter Mountain, 35 miles northeast of the type Tepee Trail Formation (E. L. Simons, written commun., 1964).

The lower part of the Hendry Ranch Member of the Tepee Trail Formation, about 35 miles north of the Rattlesnake Hills, contains a large vertebrate fauna of Uinta C age (Tourtelot, 1957; Gazin, 1956b ; Robinson and others, 1964). These fossiliferous strata are probably equivalent to the part of the Wagon Bed Formation above the unconformity in the western part of the Beaver Divide area from which upper Eocene fossils were collected. The upper part of the Hendry Ranch Member is of late Oligocene or Miocene age (C. C. Black, oral commun., 1965).

\section{BRIDGER FORMATION}

The Bridger Formation is exposed in the Cyclone Rim syncline south of the Flattop fault (section B-B', pl. 1), on the Horsetrack anticline (section $I-I^{\prime}$, pl. 3), and in a graben in the Bare Ring Butte area (pl. 1; section $E-E^{\prime \prime}$, pl. 3). The western outcrops consist of pale-green to blue-green and lemon-yellow siliceous bentonitic claystone and shale containing thin beds of ostracode-bearing limestone and green silicified algae. Fossil tree stumps, waterworn fragments of silicified wood, and dark-gray and brown agates are common. The formation is 300 feet or more thick on the Horsetrack anticline, 200 feet thick in well 21, and 500 feet 
thick in a fault trough at Bare Ring Butte (section $\left.E^{\prime}-E^{\prime \prime}\right)$. At the last locality, the basal beds are snowy white pumicite and arkose set in a bentonitic claystone matrix; they overlie gray. soft arkose with a silty claystone matrix and, in places, thin beds of variegated claystone in the Wasatch and Battle Spring Formations. Above the basal beds of the Bridger Formation are silicified green arkosic sandstones that cap Bare Ring Butte and form conspicuous strike ridges for several miles. Overlying these are hard ragged-weathering concretionary drab-blue-green and yellow blocky siliceous claystones interbedded with tuff. The upper beds are arkosic green sandstone and claystone. A distinctive feature of the claystone, both in individual beds and as matrix in arkose, is its extraordinary fine grained waxy almost colloidal appearance. Some of the gnarly siliceous claystone beds are identical in appearance with the "siliceous marker bed" of Van Houten (1954) in the lower part of the Wagon Bed Formation on the north side of the Granite Mountains (figs. 21, 23).

The light-mineral fraction is largely angular grains of potash feldspar and lesser amounts of quartz, plagioclase, and shards. The clay is predominantly montmorillonite. More than half the heavy fraction is composed of opaque minerals, and the remainder, in order of abundance, is hornblende, clinopyroxene, zircon, biotite, and garnet.

The Bridger Formation conformably overlies, and may intertongue with, the Laney Shale Member of the Green River Formation. The relation of the Bridger on the south side of the Flattop fault to the Wagon Bed Formation on the north side (section $\mathbf{A}-\mathbf{A}^{\prime}$, pl. 1) has not been determined. Lithologically the formations have many differences, yet both are at least partly of middle Eocene age. H. D. Curry found the middle Eocene vertebrate fossils Helaletes nanus and Orohippus sp. (Radinsky, 1963, p. 46; P. O. McGrew, oral commun., 1962) at locality $1-\mathrm{V}$, pl. 1; section I-I', pl. 3) in the Bridger Formation about 11 miles west of well 21. These forms are considered to be equivalent to Bridger B-D of Wood and others (1941) in the Green River basin. At this same locality are abundant wellpreserved gastropods, ostracodes, and algae; the algae have a distinctive delicate chainlike growth pattern.

\section{ICE POINT CONGLOMERATE} NAME AND DEFINITION

The Ice Point Conglomerate is here named from exposures on a long boulder-covered ridge (fig. 14) that is the site of U.S. Coast and Geodetic Survey triangulation station ICE (VABM 7466), sec. 3, T. 28 N., R. $95 \mathrm{~W}$., Happy Spring quadrangle. This is designated as the type locality. The station is on a promontory known as Ice Point about three-fourths of a mile southwest of Happy Spring. The conglomerate was first recognized and studied by Bell (1955), who mapped it as "Eocene conglomerate." His work at Ice Point and at other outcrops to the west and south is the basis for many of the ideas presented here. $\mathrm{He}$ spent several days showing me localities where the relation of the conglomerate to older and younger rocks could be observed.

No completely exposed section is available, but the typical lithology of the conglomerate can be observed in slightly slumped outcrops in ravines on the steep north face of Ice Point.

The conglomerate is shown on the geologic map of Wyoming partly as "Conglomerate beds" and partly as Wind River Formation. Pipiringos (1961) mapped a small remnant on Flattop Butte as "Browns Park(?) Formation" of Miocene(?) and Miocene age.

\section{DISTRIBUTION AND THICKNEBS}

Plate 1 shows the distribution of the Ice Point Conglomerate in the type locality. Bell (1955) mapped additional exposures about 7 miles west-southwest of the Bison Basin oil field, near the Horsetrack anticline. The conglomerate is known only in the southwestern part of the Granite Mountains area and along the southeast margin of the Wind River Range. Only two subsurface section have been drilled. North of the type locality, well 27 penetrated 30 feet of conglomerate (sections $A-A^{\prime}$, pl. 1 and $S-S^{\prime}$, pl. 4 ). About 7 miles east of Ice Point, well 86 penetrated 20 feet of the conglomerate (sections $C-C^{\prime}$, pl. 1 , and $R-R^{\prime}$, pl. 4). Farther east and north, the conglomerate was apparently eroded away prior to deposition of the White River Formation.

The thickness of the Ice Point Conglomerate ranges from a maximum of about 200 feet in the type locality to an eroded edge. In many places it is little more than a lag gravel of resistant rock fragments that caps ridges and slopes, but even there it is a very conspicuous unit (figs. 14, 25, 26).

\section{LITHOLOGX}

The Ice Point Conglomerate in the type locality is composed of angular reddish-brown rock fragments, the larger of which are slabs of quartzitic Flathead Sandstone of Cambrian age. They range in size from pebbles to boulders 10 feet in diameter. Other less conspicuous boulers and smaller fragments are of Precambrian rocks, Cambrian limestone, Madison Limestone, Tensleep Sandstone, and cherts of Permion age. The conglomerate contains many rounded fragments of black petrified wood, the source of which has 


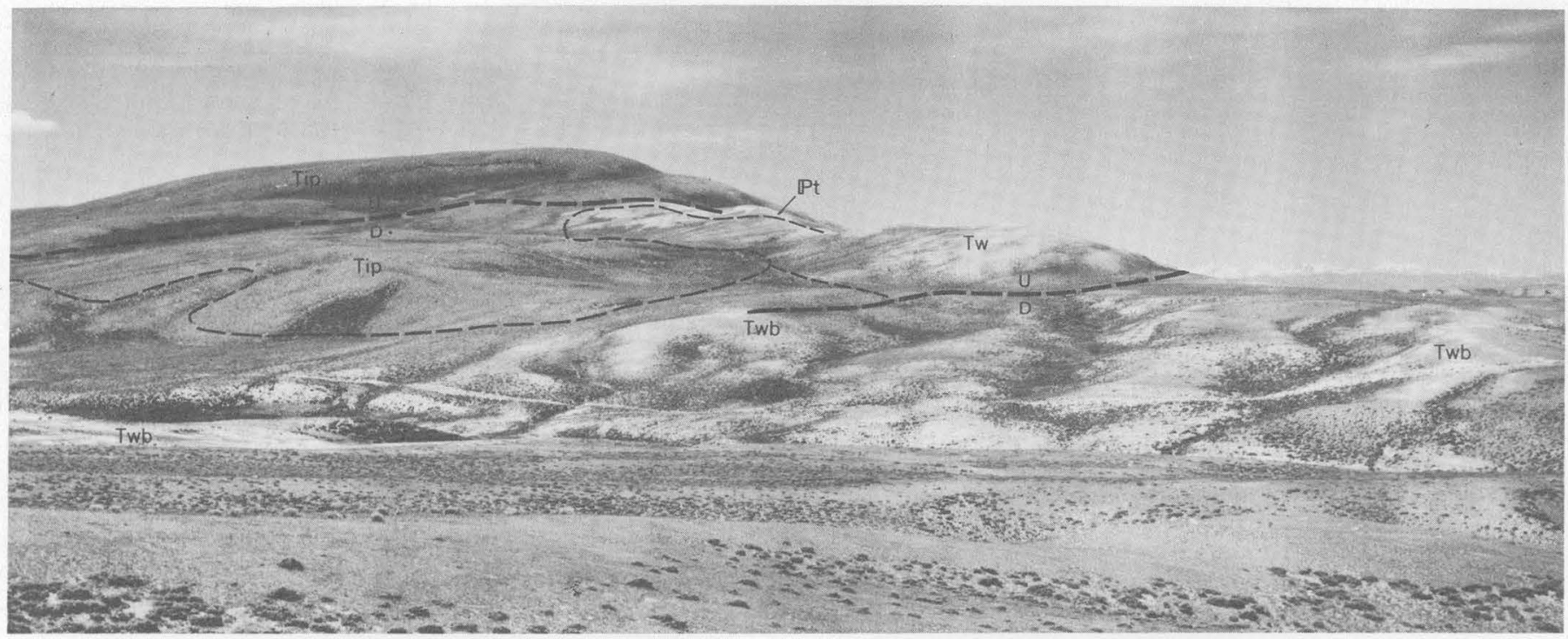

FIGURE 25.- Structural relations of Pennsylvanian and lower, middle, and upper Eocene rocks along the north marg in of the Great Divide basin. Vertical Tensleep Sandstone ( Pt) is overlapped by Wasatch and Battle Spring Formations ( $\mathrm{Tw}$ ) which dip about $45^{\circ} \mathrm{S}$. This sequence is overlapped by and faulted against the Wagon Bed Formation $(T w b)$ and the Ice Point Conglomerate (Tip). View is west across the Soap Holes at locality 34So, at lower left, in variegated bentonitic strata of the Wagon Bed Formation. Hills are in secs. 4 and 9, T. 28 N., R. 94 W. Snoweapped Wind River Range on right skyline is 60 miles away.

not been established. Similar wood however, is known in the Bridger Formation near well 21 (Pipiringos, 1961). Apple-green, pink, and black nephrite jade boulders of excellent quality were formerly common in the vicinity of Ice Point, but the exposures have been thoroughly combed by thousands of jade hunters during the last 20 years so that now even a pebble of jade is a rarity. The matrix of the conglomerate is a brown to golden-yellow arkosic poorly cemented sandstone.

The rock fragments decrease in size southeastward from Ice Point, but eastward along the ridge that overlooks the Soap Holes, the conglomerate is very coarse and resistant to erosion (fig. 25).

Southwest of Bison Basin oil field (pl. 1), the high flat hill capped by the Ice Point Conglomerate has abundant boulders of Flathead and Tensleep Sandstones, as much as 5 feet in diameter, associated with smaller fragments of other Paleozoic and Precambrian rocks. The adjacent Flattop Buttes are capped by a thin remnant of this conglomerate (section $S-S^{\prime}$, pl. 4).

I did not study the Ice Point Congolmerate west of the Bison Basin oil field; probably thin remnants of it are included in the area of outcrop of the Wagon Bed Formation. Bell (1955) described the conglomerate in some detail on the Horsetrack anticline and Cyclone Rim west and northwest of well 21 , beyond the mapped area shown on plate 1 .

The westernmost outcrop of the Ice Point Conglomerate in the Granite Mountains area is near well 20
(T. 29 N., R. 96 W.). This is an especially significant locality because the unconformable relations of the conglomerate to the underlying Wagon Bed and overlying White River Formations can be observed (fig. 26). In this area the Ice Point also consists of giant angular boulders of Paleozoic rocks and granite from the Wind River Range to the west.

\section{STRATIGRAPHIC AND STRUCTURAL RELATIONS}

In the type locality the Ice Point Conglomerate overlies pale-green to drab bentonitic claystone of the Wagon Bed Formation. Regional stratigraphic and structural relations are shown in sections $A-A^{\prime}, B-B^{\prime}$, C-C' (pl. 1), R-R', and S-S' (pl. 4). In the Soap Holes area, the conglomerate rests with $90^{\circ}$ uncomformity on Paleozoic and Mesozoic rocks; elsewhere the angular discordance is much less. On Flattop Butte, the conglomerate overlies the basal beds of the Wasatch and Battle Spring Formations; at Bison Basin, it is on the Cody Shale and Fort Union Formation; and in well 22, it overlies the Bridger Formation. The type and size of rock fragments indicate that uplift of the southeast end of the Wind River Range caused a flood of coarse debris from broad dip slopes of Paleozoic rocks to be transported eastward and southeastward and then deposited in a series of coalescing fans (fig. $10 F)$. The Wind River Range was the only source area of Paleozoic rocks large enough to supply boulders of the observed size, abundance, and lithology. The Sweetwater Crossing anticline was already buried to the Precambrian core by the Wagon Bed Formation 


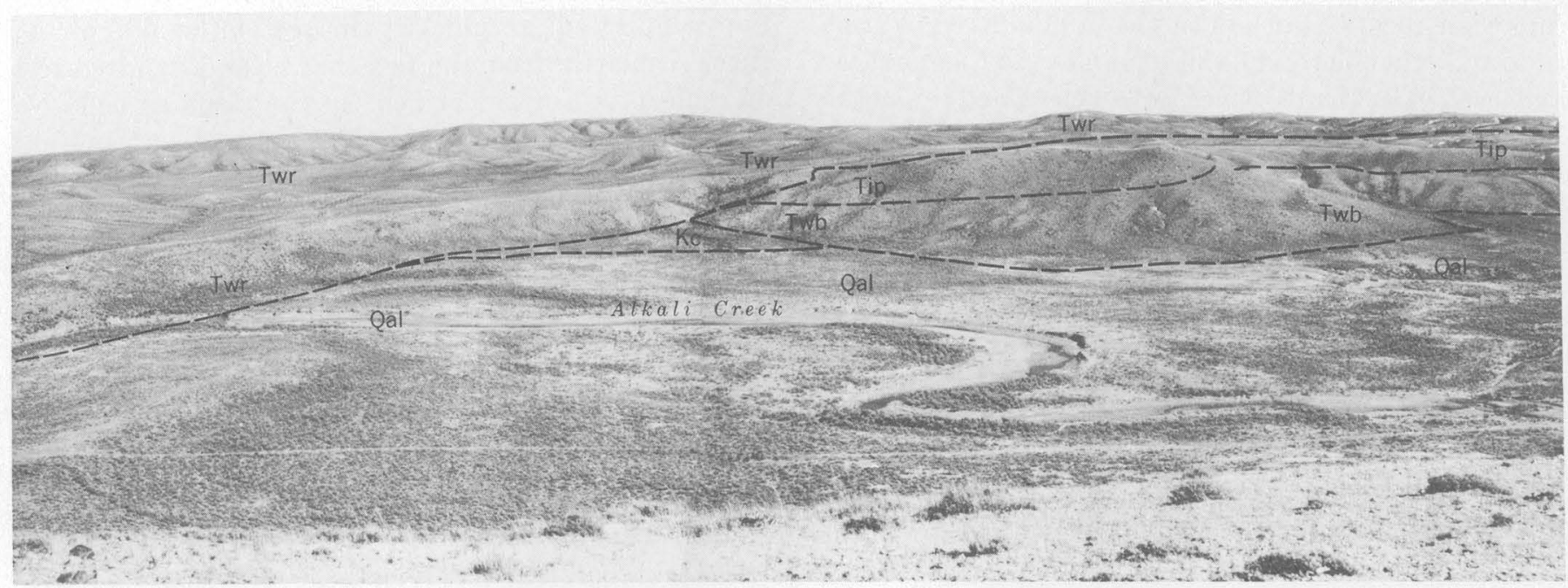

FIGURE 26.-View east across Alkali Creek, showing relations of Cretaceous, Eocene, and Oligocene rock units in sec. 24 , T. 29 N., R. 96 W. Cody Shale (Ko) dipping $55^{\circ}$ S.; Wagon Bed Formation (Twb); Ice Point Conglomerate (Tip); White River Formation (Twr); alluvium (Qal). The basal part of the White River Formation, which dips about $5^{\circ} \mathrm{NW}$. at the left margiu of the photograph, is a relatively fine-grained pebble and cobble conglomerate of granite fragments that contrasts with the Ice Point Conglomerate of giant boulders, some of which are visible in the upper right center, of Paleozoic and Precambrian rocks.

(pl. 1, $A-A^{\prime}, C-C^{\prime} ;$ pl. 4, $K-K^{\prime \prime}, M-M^{\prime \prime}, R-R^{\prime}$, $\left.S-S^{\prime}, U-U^{\prime}\right)$. The southwest flank of the Granite Mountains could not have furnished this debris, for the Paleozoic rocks had long since been overridden by the Emigrant Trail thrust plate or stripped away (pl. 7), and the Precambrian core had been overTapped by the Wagon Bed Formation (pl. $3, N-N^{\prime} ;$ pl. 4, $\left.M-M^{\prime \prime}, Q-Q^{\prime}, T-T^{\prime \prime}\right)$.

The presence of a 400 -foot-thick section of predominantly lacustrine strata making up the Laney Shale Member of the Green River Formation and the Bridger Formation in well 21 below the Ice Point Conglomerate, and the lack of such strata on Flattop Buttes 2 miles east (section $S-S^{\prime}$, pl. 4), suggests that movement on this segment of the Flattop fault caused stripping of the Laney and Bridger from the north block before the conglomerate was deposited. This movement could not have been directly related to the uplift of the southeast flank of the Wind River Range that triggered the flood of boulders now found in the Ice Point Conglomerate because there was no postBridger displacement along the Flattop fault on the Horsetrack anticline (section $I-I^{\prime}$, pl. 3 ), which is actually on the margin of the range.

Bell (1955) described a locality about 2 miles northwest of Bison Basin oil field where horizontal Brontopsbearing sandstone in the basal part of the White River Formation overlies the conglomerate with an angular discordance of $14^{\circ}$. At the type locality of the Ice Point and farther west, the unconformity at the top of the conglomerate is much less (section $S-S^{\prime}$, pl. 4 ; fig. 26).

\section{AGE AND CORRELATION}

No indigenous fossils have been found in the type locality of the Ice Point Conglomerate. Farther southwest, several miles northwest of well 21, Bell (1955) collected abundant crocodile scutes and fragments of mammal bones from the conglomerate. Crocodile remains are common in Eocene rocks elsewhere in the region but are rare in the Oligocene. The conglomerate overlies the Bridger Formation and middle Eocene part of the Wagon Bed Formation and unconformably underlies Brontops-bearing beds of early Oligocene (Chadron) age in the White River Formation. Therefore, the Ice Point Conglomerate is probably of late Eocene age. No rocks of similiar age are known in this part of Wyoming, except for the upper Eocene part of the Wagon Bed Formation on the Beaver Divide. The Continental Peak Formation of Nace (1939), previously thought to be of late Eocene age, has yielded middle Eocene vertebrate fossils (G. E. Lewis and H. D. Zeller, written commun., 1963).

Some geologists have raised the question as to whether the Ice Point Conglomerate is merely a facies of the Beaver Divide Conglomerate Member of the White River Formation. As discussed earlier, the only likely source of the Ice Point Conglomerate is the Wind River Range. The distribution of the basal conglomerate of the White River Formation is well known. From a point 3 miles northwest of the type Ice Point westward to the Wind River Range the White River Formation was penetrated in 27 wells and core holes. No Ice Point lithology was found in any well; some drilled sections contain a basal conglomerate of Pre- 
cambrian rock fragments in the White River Formation, and others have no conglomerate. To the northeast and east, the White River was penetrated in nearly 100 wells. Distribution of conglomerate in this part of the area is discussed in connection with the White River Formation. Broad outcrops of the White River are present west, southwest, and southeast of the type Ice Point Conglomerate. There is little lithologic similarity between the conglomerate in these two formations, and a comparison is easy because in many places they are juxtaposed or close together (figs. 14, 26). At these localities the older conglomerate has a large amount of Paleozoic rock fragments and a lesser amount of Precambrian; the younger is composed chiefly of granule- to pebble-sized fragments, almost entirely of Precambrian rocks. By the time deposition of the White River Formation began, the Ice Point Conglomerate had been deeply eroded and removed from many localities. The Paleozoic source area no longer contributed a significant amount of debris because it has been reduced to a low narrow belt (pls. 7, $10 F)$, whereas the Precambrian source area had been progressively expanded.

\section{OLIGOCENE ROCKS}

\section{WHITE RIVER FORMATION}

NAME AND DEFINTTION

The White River Formation was named by Meek and Hayden $(1858$, p. 119, 133) from exposures in South Dakota. Darton (1908, p. 463) extended the name to strata of Oligocene age along the east margin of the Granite Mountains area, and Granger (1910) used it for similar rocks on the Beaver Divide as a substitute for the lower part of Endlich's "Sweetwater group" (Endlich, 1879, p. 154-156).

Southwest of the Big Sand Draw oil and gas field, a local channel deposit, the Big Sand Draw Sandstone Lentil (Van Houten, 1954) and the overlying Beaver Divide Conglomerate Member (Nace, 1939), called Sweetwater Member by Bauer (1934), compose the basal units of the formation (table 3). Although there is general agreement as to the contact between the White River Formation and overlying Miocene rocks on most outcrops in the western part of the Granite Mountains area, two widely divergent interpretations of this contact is subsurface sections north of Happy Springs oil field have been published (Love, 1961b; Stephens, 1964). The disputed beds are 700-1,000 feet thick. In well 96, I interpret the contact to be at 1,612 feet, whereas Stephens (1964, p. 18) placed it at 930 feet. He thereby included nearly all of the lower three sequences of the Split Rock Formation in his White River. The difference in interpretation of this well sec- tion (indicated graphically in section $O-O^{\prime}, \mathrm{pl} .4$ ) stems primarily from the fact that several hundred feet of cement was misidentified by Stephens as tuff. No such tuff was found in any adjacent wells (there are three within $1,000 \mathrm{ft}$ and seven within $2,000 \mathrm{ft}$ ). An evaluation of data supporting each interpretation is presented in the discussion of lithology of the Miocene rocks.

\section{DISTRIBUTION AND THICKNESS}

The Big Sand Draw Sandstone Lentil has an areal extent of a very few square miles near its type locality and ranges in thickness from 0 to 75 feet. The Beaver Divide Conglomerate Member is somewhat more extensive. Its volcanic facies is a recognizable lithologic unit only along the western part of the Beaver Divide (pl. 5D) where the thickness is $50-150$ feet.

Plate $5 D$ shows the distribution and thickness of the White River Formation as a whole. A few features are notable. East of the Rattlesnake Hills, the formation is more than 800 feet thick and thickens toward the southeast arm of the Wind River basin. The original thickness in this area may well have been considerably more than 1,000 feet. No White River, however, has been identified in the Rattlesnake Hills, except along their west margin. An incomplete section of more than 600 feet is present in the syncline west of the Sweetwater Crossing anticline (pl. 7) and along the southeast margin of that uplift (section $C-C^{\prime}, \mathrm{pl} .1$ ).

In the syncline where well 21 was drilled south of the Bison Basin oil field, about 300 feet of disputed beds is present. The lower conglomeratic part and the upper part have been variously called White River Formation overlain by "Miocene" (Love and others, 1955), conglomerate of Oligocene (?) age overlain by beds of Miocene age (Sheridan and others, 1961), all Miocene (Bell, 1955), "Chadron Formation as used by Nace, 1939" (Wyant and others, 1956), and Browns Park(?) Formation of Miocene(?) and Miocene Age (Pipiringos, 1961). The rocks are shown as Miocene and Oligocene on figure 3.

Thin remnants of bentonitic red, brown, and green claystone and arkosic sandstone east of Crooks Gap were mapped as White River Formation by Stephens (1964) and as Wagon Bed Formation in this report.

N. M. Denson (written commun., 1962) suggested that the lower 1,000 feet of section in well 188 (T. 27 N., R. $86 \mathrm{~W}$.), as expressed by low resistivity in the electric $\log$, may be part of the White River Formation. Drill cuttings, however, show only loose rounded sand grains in this part of the section; these are characteristic of the Split Rock Formation but are sparse in the White River. 


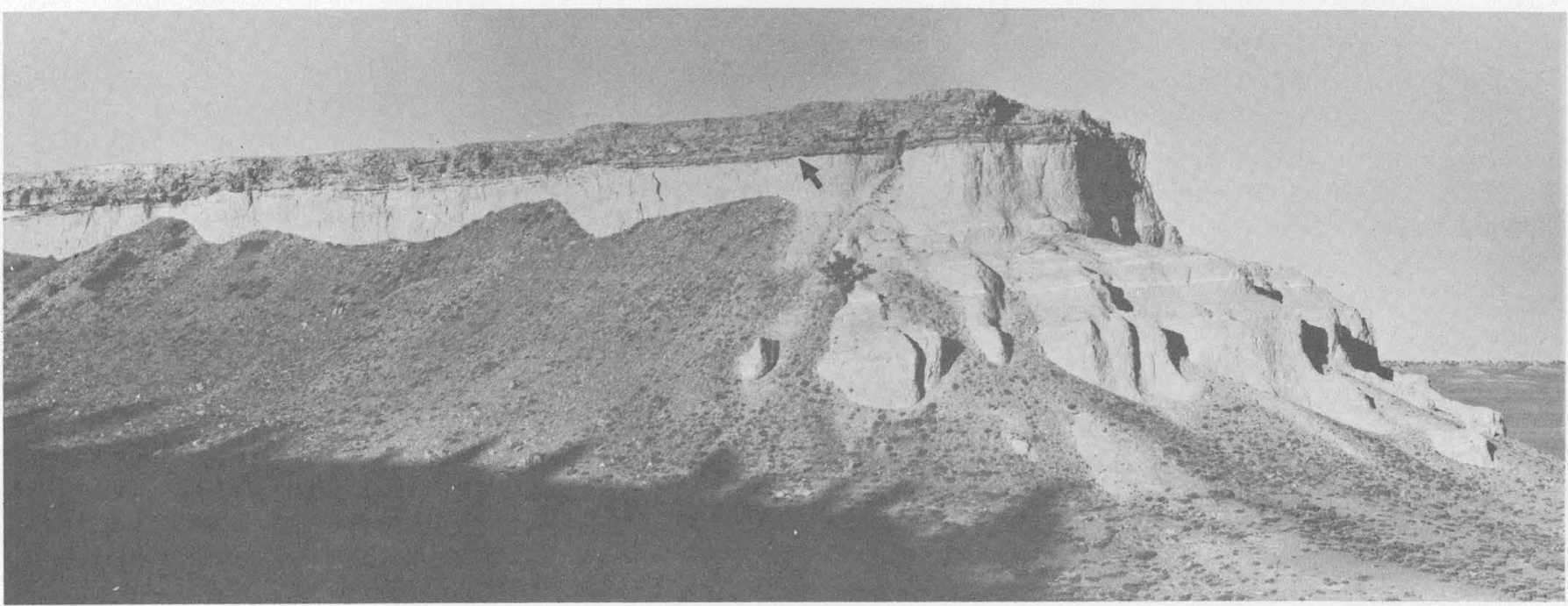

FIGURE 27.-Contact between basal conglomerate of Split Rock Formation and White River Formation, indicated by arrow. View is northeast in NE1/4 sec. 30 , T. $31 \mathrm{~N}$. R. $95 \mathrm{~W}$.

\section{LITHOLOGY}

The detailed lithology of the White River Formation has been studied along the Beaver Divide (Sinclair and Granger, 1911; Van Houten, 1954, 1955, 1964; this report, figs. $24,27,28$ ).

BIG SAND DRAW SANDSTONE LENTIL

The oldest strata form a local channel deposit about 2 miles wide, called by Van Houten (1954) the Big Sand Draw Sandstone Lentil. The type locality is south of the Big Sand Draw oil and gas field. The lentil consists of 0-75 feet of pale-greenish-yellow to yellowish-gray soft tuffaceous sandstone. Conglomerate lenses in the upper part contain fragments of Precambrian igneous and metamorphic rocks as well as brown and gray porphyritic andesite of a type found in the Absaroka Range 90 miles northwest. The sandstone contains blue-green hornblende, green-brown hornblende, and fibrous, colorless amphibole. The upper strata in the lentil grade into the overlying Beaver Divide Conglomerate Member.

\section{BEAVER DIVIDE CONGLOMERATE MEMBER}

The Beaver Divide Conglomerate Member consists of a facies of volcanic rock fragments that grades laterally into a facies of crystalline Precambrian rock fragments (Van Houten, 1954, 1964). The volcanic facies is best developed south of the Big Sand Draw oil and gas field (midway along the north line of $\mathrm{T}$. 31 N., R. 95 W.), where it forms cliffs $50-75$ feet high of light-gray volcanic conglomerate and tuff (fig. 28). Most of the lithic fragments are porphyritic brown and gray pyroxene-hornblende andesite, and porphyritic pumiceous rock, all of which are probably derived from the Absaroka Range. These fragments are less weathered, less well rounded, and much denser than those in the underlying Wagon Bed Formation. Some have a diameter of 8 feet (fiig. 29), but most are less than 2 feet. The volcanic facies is poorly bedded and poorly sorted; its rocks are characterized by augite, hypersthene, green-brown hornblende, red-brown hornblende, and andesine. These constituents are similar to those found in the underlying Wagon Bed Formation

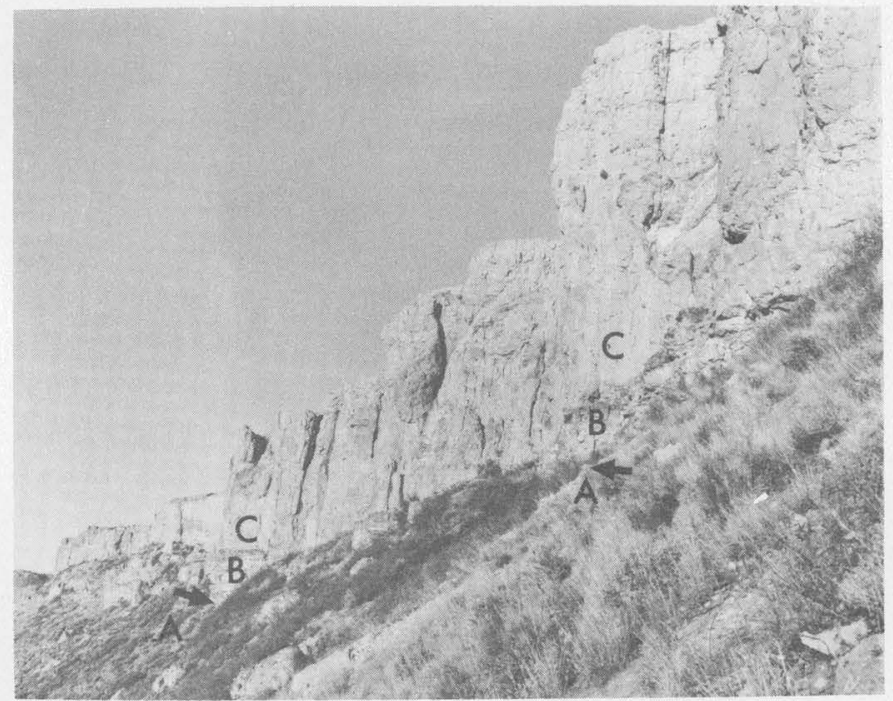

FIGURE 28-Outerop of Beaver Divide Conglomerate Member of White River Formation in the top 75 feet of the Beaver Divide escarpment in sec. $3, T .31$ N., R. $95 \mathrm{~W}$. View north along cliff. A, Uppermost strata of Wagon Bed Formation which are 60 feet above upper Eocene vertebrate fauna. B, Green chert and arkose included in Beaver Divide Conglomerate Member (basal contact marked by arrow). C, Main part of Beaver Divide Conglomerate Member, which in this area contains abundant boulders of andesite and basalt from Absaroka Range 90 miles northvest. At this locality, fossil mammal teeth were found in upper part of conglomerate (Van Houten, 1950, measured section 23). 


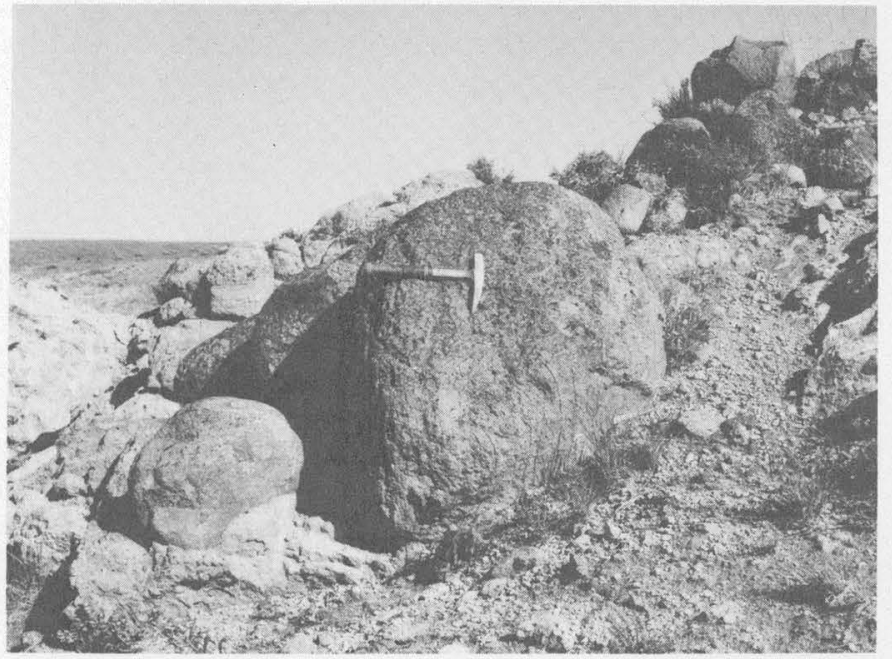

Figure 29.-Andesite boulders in Beaver Divide Conglomerate "Member of White River Formation near Wagon Bed Spring, SE1/4SW1/4 sec. 34, T. 32 N., R. 95 W. Boulders are from Absaroka Range, 90 miles northwest; most are of black, gray, or red coarse-grained porphyritic andesite and are 2-5 feet in diameter.

except that the hypersthene and red-brown hornblende are not as common as in the Wagon Bed. Silicified sandy green tuff, irregular beds of chalcedony, and masses of fibrous chert are present in some localities (fiig. 28). This facies thins westward from the type locality and grades into an arkosic gray sandstone that makes up the basal unit of the White River Formation. Eastward from Big Sand Draw, it intertongues with the crystalline facies in which the coarse fraction consists of gray and black Precambrian igneous and metamorphic rocks derived from the Granite Mountains.

Southward from the Big Sand Draw area, the volcanic facies has been recognized in all wells within the boundary shown on plate $5 D$. The crystalline facies thickens and becomes very arkosic east of the Emigrant Trail thrust fault. The basal conglomerate member grades up into massive white to grayish-orange cliffforming fine-grained silty sandstone and blocky hard siltstone and claystone that compose the major part of the White River Formation in the western Beaver Divide area (figs. 24, 27). Conspicuous thin beds of white tuff are present in the fine-grained massive facies in several localities.

\section{REMAINDER OF WHITE RIVER FORMATION}

The White River Formation as a whole is characterized by remarkably homogeneous massive white to grayish-orange sandy siltstone containing abundant shards and tiny black biotite flakes; the rock has a red- and black-flecked appearance under a binocular microscope. Thin, conspicuous, and persistent beds of moderately pure pumicite ${ }^{4}$ representing ash falls occur in many parts of the siltstone section (rock analyses are given in table 7). The siltstone weathers to hard conchoidally fractured fragments. From 80 to 90 percent of the size fraction of this lithology is between 0.062 and $0.004 \mathrm{~mm}$. Clay is a minor constituent, in contrast with the abundance of clay in the underlying Wagon Bed Formation. The bulk composition of the volcanic material in the White River is intermediate to mafic. Biotite, green-brown hornblende, and magnetite are the most common heavy minerals, and magnetite is less abundant than in the overlying Split Rock Formation. Angular grains are typical throughout the White River Formation, in contrast with the commonly rounded and frosted grains in the overlying Split Rock Formation. A detailed lithologic description and discussion of mineral suites in the White River Formation along the Beaver Divide is given by Van Houten (1964).

In many (fig. 24), but not all (fig. 27), localities along the western part of the Beaver Divide, the uppermost beds in the White River Formation consist of 50-80 feet of grayish-orange arkosic conglomerate which has a grayish-orange siltstone and claystone matrix. This unit rests with minor erosional unconformity on the massive siltstone and claystone sequence. The conglomerate becomes very coarse grained in the Long Creek Valley (east line of T. 31 N., R. 94 W.), and boulders $5-10$ feet in diameter are common. In many other places southeast of this locality, near and between granite knobs, the entire White River Formation is a conglomerate of Precambrian rock fragments embedded in a pink to grayish-orange siltstone matrix. These fragments represent locally derived fan deposits in valleys extending into the highest parts of the Granite Mountains.

In the Gas Hills area, two conspicuous north-trending channels were cut through the Wagon Bed Formation and into the Wind River Formation; they were then filled with sediment of the White River Formation (pls. 1, $5 C$ ). An unusual lithology is present in the western channel: the White River Formation contains red, green, and gray soft plastic bentonitic claystone similar to, and probably derived in part from, middle and upper Eocene rocks; the red debris was probably

${ }^{4}$ Pumicite as used in this report follows the definition of Stokes and Varnes $(1955$, p. 116), for a pumice that "has been blown to bits by force of volcanic explosion so that the cells are broken." Pumicite is objected to by many geologists on the grounds that it is a nontechnical term, although widely used in economic geology. Volcanic ash is hardly a suitable name for this material, as it is somewhat consolidated. Tuff has a broad spectrum of meaning unless modified by appropriate adjectives. This rock is a vitric crystal lithic tuff in some places, a vitric arenaceous tuff in others, and a vitric tuff in the purest parts. 
TABLE 7.-Rock analyses of pumicite and other tuffaceous strata of Cenozoic age, and of the Eocene and Precambrian age igneous rocks in central and northwestern Wyoming [Analyses of well-dated rocks from other areas closer to the Yellowstone-A bsaroka volcanic centers are included for comparison. Samples from each locality are arranged in stratigraphic order, with youngest at top. Lo-
cation abbreviations: SNL, south of north line; WEL, west of east line; NSL, north of south line; EWL, east of west line, etc. Rapid-rock analyses are by Lowell Artis, I. H. Barlow, S. D. Botts, Gillison Chloe,
P. L. D. Elmore, M. D. Mack, H. Smith, and K. E. White; methods used are simular to those described by Shapiro and Brannock (1956)]

\begin{tabular}{|c|c|c|c|c|c|c|c|c|c|c|c|c|c|c|c|c|c|c|c|}
\hline \multirow{2}{*}{$\begin{array}{l}\text { Formation } \\
\text { or lithology }\end{array}$} & \multicolumn{3}{|l|}{ Location } & \multirow{2}{*}{$\begin{array}{l}\text { Labo- } \\
\text { ratory } \\
\text { No. }\end{array}$} & \multicolumn{14}{|c|}{ Analyses (percent) } & \multirow{2}{*}{ Remarks } \\
\hline & Section & T.N. & R.W. & & $\mathrm{SiO}_{2}$ & $\mathrm{Al}_{2} \mathrm{O}_{3}$ & $\mathrm{Fe}_{2} \mathrm{O}_{3}$ & $\mathrm{FeO}$ & MgO & $\mathrm{CaO}$ & $\mathrm{Na}_{2} \mathrm{O}$ & $\mathrm{K}_{2} \mathrm{O}$ & $\mathrm{TiO}_{2}$ & $\mathrm{P}_{2} \mathrm{O}_{5}$ & Mno & $\mathrm{H}_{2} \mathrm{O}-$ & $\mathrm{H}_{2} \mathrm{O}+$ & $\mathrm{CO}_{2}$ & \\
\hline \multicolumn{20}{|c|}{ Pleistocene strata } \\
\hline $\begin{array}{l}\text { Ash near } \\
\text { Seminoe Dam. }\end{array}$ & $300 \mathrm{ft} \mathrm{NSL}, 2,400 \mathrm{ft}$ WEL 5 & 25 & 84 & 163197 & 73.1 & 12.0 & 0.55 & 1.0 & 0.30 & 0.76 & 2.3 & 5. 2 & 0.22 & 0.06 & 0.03 & 2.7 & 1.7 & 0.05 & $\begin{array}{l}\text { A verage lithology of 3-ft-thick } \\
\text { ash bed. }\end{array}$ \\
\hline \multicolumn{20}{|c|}{ Pliocene strata } \\
\hline \multirow[t]{10}{*}{ Moonstone ....... } & SW cor. NW1/434 & 30 & 89 & 154034 & 58.8 & 14.5 & 2.8 & 10.12 & 2.0 & 1.8 & 3.3 & 3.5 & 0.42 & 0.06 & 0.08 & $\ldots$ & 412.0 & 0.60 & $\begin{array}{l}\text { Type section, approximately } \\
90 \text { it below top of section } \\
\text { and } 450 \mathrm{ft} \text { stratigraphically }\end{array}$ \\
\hline & NW1/4NW1/4SE1/4 $17 \ldots \ldots$ & 30 & 89 & 147344 & 64.2 & 10.7 & 1.9 & .10 & 1.5 & 7.1 & 1.1 & 3.9 & .26 & .02 & .03 & 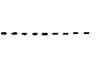 & 45.2 & 4.3 & $\begin{array}{l}\text { above 143219. } \\
\text { Type section, approximately } \\
60 \text { ft stratigraphically above } \\
147343\end{array}$ \\
\hline & NW1/4NW1/4SE1/4 $17 \ldots \ldots$. & 30 & 89 & 147343 & 70.7 & 11.4 & 1.8 & .15 & .79 & 2.8 & .97 & 5.4 & .29 & .05 & .03 & (n...... & -44.4 & 1.3 & $\begin{array}{l}\text { Type section, approximately } \\
35 \text { ft stratigraphically above } \\
143219 .\end{array}$ \\
\hline & NW1/4SE1/4 19 & 30 & 89 & 143219 & 62.3 & 14.2 & 3.5 & 1.2 & 1.0 & 2.2 & 2.6 & 3.6 & .86 & .36 & .10 & .......... & $-\quad 4.9$ & $<.05$ & $\begin{array}{l}\text { Dark-gray tuff marker bed } \\
\text { about } 800 \mathrm{ft} \text { above base of } \\
\text { of type section }\end{array}$ \\
\hline & $2,300 \mathrm{ft}$ EWL, $1,850 \mathrm{ft} \mathrm{SNL}$ & 26 & 85 & 163198 & 65.7 & 12.9 & 1.4 & .84 & 1.9 & 1.2 & 1.5 & 3.7 & .24 & .15 & .02 & 7.5 & 3.3 & $<.05$ & Pumicite bed. \\
\hline & $\begin{array}{l}2,350 \mathrm{ft} \\
\mathbf{3 6} .\end{array}$ & 27 & 85 & 163201 & 71.4 & 11.8 & .90 & 1.3 & .58 & 1.1 & 1.6 & 5.7 & .31 & .07 & .02 & 3.1 & 2.5 & .07 & $\begin{array}{l}\text { Pumicite, unit } 26 \text { in measured } \\
\text { section: bulk sample of bed. }\end{array}$ \\
\hline & & & & 164309 & 71.3 & 11.6 & .88 & 1.2 & .40 & .97 & 1.8 & 5.9 & .34 & .20 & .03 & .52 & 4.7 & .11 & $\begin{array}{l}1.5 \mathrm{ft} \text { above base of pumicite, } \\
\text { nnit }\end{array}$ \\
\hline & & & & 164308 & 72.1 & 11.6 & .77 & 1.3 & .30 & .80 & 1.7 & 5.8 & .31 & .20 & .03 & .35 & 4.1 & .10 & 6 in. above base of pumicite, \\
\hline & & & & 163202 & 71.4 & 11.8 & .86 & 1.4 & .42 & .97 & 1.7 & 5.6 & .32 & 0 & .02 & 3.1 & 2.1 & .07 & Pumicite, unit 20 in measured \\
\hline & 2,500 ft WEL 600 ft SNL $1 \ldots$ & 26 & 85 & 163200 & 71.4 & 11.8 & .86 & 1.4 & .33 & 1.0 & 1.7 & 5.6 & .33 & .13 & .02 & 3.2 & 2.4 & .06 & Pumicite, unit 16 in measured \\
\hline \multirow[t]{2}{*}{$\begin{array}{l}\text { Teewinot } \\
\text { (middle } \\
\text { Pliocene). }\end{array}$} & $\begin{array}{l}1,000 \mathrm{ft} \text { WEL, } 1,200 \mathrm{ft} \mathrm{SNL} \\
29 .\end{array}$ & 42 & 115 & 143222 & 72.1 & 11.8 & 1.1 & .86 & .18 & .84 & 1.6 & 6. 2 & .26 & .14 & .02 & $\ldots$ & 4.4 & .10 & $\begin{array}{l}\text { Pumicite, 20 it thick, type } \\
\text { section, limestone and pumi- } \\
\text { cite facies. }\end{array}$ \\
\hline & $\begin{array}{l}1,600 \mathrm{ft} W E L, 2,000 \mathrm{ft} \text { SNL } \\
26 .\end{array}$ & 42 & 115 & 143221 & 71.1 & 12.1 & 1.5 & .82 & .32 & 1.1 & 1.7 & 6.0 & .37 & .16 & .02 & $\cdots$. & 45.4 & $<.05$ & $\begin{array}{l}\text { Pumicite, lowest in 6,000-ft- } \\
\text { thick section. }\end{array}$ \\
\hline $\begin{array}{l}\text { Camp Davis } \\
\text { (early } \\
\text { Pliocene) }\end{array}$ & $\begin{array}{l}5,000 \mathrm{ft} \mathrm{EWL,} \\
2,500 \mathrm{ft} \text { NSL } \\
30 .\end{array}$ & 39 & 115 & 143220 & 71.8 & 12.6 & 1.2 & .40 & .30 & .80 & 2.0 & 5.8 & .24 & .14 & .02 & $\ldots$ & 45.9 & $<.05$ & $\begin{array}{l}\text { Pumicite, type section, } 413 \text { ft } \\
\text { above base. }\end{array}$ \\
\hline \multicolumn{20}{|c|}{ Miocene rocks } \\
\hline \multirow[t]{2}{*}{$\begin{array}{l}\text { Split Rock } \\
\text { (middle } \\
\text { Mícene part). }\end{array}$} & $\begin{array}{l}1,600 \mathrm{ft} \mathrm{EWL} \\
2,100 \text { ft SNL } 25 .\end{array}$ & 29 & 89 & 143218 & 72.0 & 1.1 & 12.1 & 0.90 & 0.19 & 0.81 & 2.1 & 6.0 & 0.22 & 0.14 & 0.02 & ..... & 44.9 & $<0.05$ & \multirow{3}{*}{$\begin{array}{l}5 \text { Pumicite, } 10 \mathrm{ft} \text { thick in uppe } \\
\text { part of type section, } 32 \mathrm{f} \\
\text { below horizon of "Devils } \\
\text { G ate vertebrate fossil zone.' } \\
\text { Pumicite, about } 20 \text { ft above. } \\
\text { sandstone containing } \\
\text { Mesogaulus praecursor. } \\
\text { Pumicite, in upper middle of } \\
\text { 7,000-ft-thick type section. }\end{array}$} \\
\hline & $\begin{array}{l}1,000 \mathrm{ft} \text { SNL, } \\
2,500 \mathrm{ft} W E \\
31 .\end{array}$ & 29 & 89 & 164305 & 69.4 & 11.4 & 1.6 & 1.2 & 1.4 & .75 & 2.0 & 5.4 & .27 & .10 & .10 & 1.2 & 4.9 & .08 & \\
\hline Colter............ & $\begin{array}{l}700 \mathrm{ft} \mathrm{SNL} \\
1,200 \mathrm{ft} \text { WEL } 29 .\end{array}$ & 46 & 114 & 143217 & 69.2 & 12.5 & 1.5 & .74 & .70 & 1.1 & 1.2 & 6.0 & .24 & .13 & .02 & ..... & 47.7 & $<.05$ & \\
\hline \multicolumn{20}{|c|}{ Oligocene rocks } \\
\hline White River & $\begin{array}{l}1,300 \mathrm{ft} \text { EWL, } \\
2,300 \mathrm{ft} \text { NSL } 4 .\end{array}$ & 29 & 96 & 161335 & 60.2 & 12.8 & 1.5 & 0.41 & 0.54 & 8.2 & 2.4 & 4.5 & 0.24 & 0.10 & 0.08 & 0.84 & 3.0 & 4.6 & $\begin{array}{l}\text { Pumicite, about } 300 \text { ft above } \\
\text { base of formation; has po- } \\
\text { tassium-argon age of } 32.2\end{array}$ \\
\hline & SW1/4 $22 \ldots$ & 32 & 89 & 143216 & 62.8 & 13.8 & 2.5 &. .42 & 1.9 & 2.4 & 1.5 & 3.2 & .36 & .22 & .06 & ........... & 410.5 & .28 & Pumicite. \\
\hline
\end{tabular}


TABLE 7.-Rock analyses of pumicite and other tuffaceous strata of Cenozoic age, and of the Eocene and Precambrian age igneous rocks in central and northwestern Wyoming-Con.

\begin{tabular}{|c|c|c|c|c|c|c|c|c|c|c|c|c|c|c|c|c|c|c|c|}
\hline \multirow{2}{*}{$\begin{array}{l}\text { Formation } \\
\text { or lithology }\end{array}$} & \multicolumn{3}{|l|}{ Location } & \multirow{2}{*}{$\begin{array}{l}\text { Labo- } \\
\text { ratory } \\
\text { No. }\end{array}$} & \multicolumn{14}{|c|}{ Analyses (percent) } & \multirow{2}{*}{ Remarks } \\
\hline & Section & T.N. & R.w. & & $\mathrm{SiO}_{2}$ & $\mathrm{Al}_{2} \mathrm{O}_{3}$ & $\mathrm{Fe}_{2} \mathrm{O}_{3}$ & $\mathrm{FeO}$ & $\mathrm{MgO}$ & $\mathrm{CaO}$ & $\mathrm{Na}_{2} \mathrm{O}$ & $\mathrm{K}_{2} \mathrm{O}$ & $\mathrm{TiO}_{2}$ & $\mathrm{P}_{2} \mathrm{Os}_{3}$ & Mno & $\mathrm{H}_{2} \mathrm{O}-$ & $\mathrm{H}_{2} \mathrm{O}+$ & $\mathrm{CO}_{2}$ & \\
\hline \multicolumn{20}{|c|}{ Oligocene rocks } \\
\hline \multirow[t]{2}{*}{ White River...- } & $\begin{array}{l}1,500 \mathrm{ft} \text { NSL, } \\
700 \mathrm{ft} \text { WEL } 3 .\end{array}$ & 30 & 96 & 143215 & 62.6 & 14.2 & 2.3 & .63 & 1.8 & 2.2 & 1.5 & 3.5 & .37 & .23 & .04 & .. & 410.4 & .12 & $\begin{array}{l}\text { Pumicite, in upper part of } \\
\text { formation; measured sec- } \\
\text { tion } 2 \text { of Van Houten (1950) }\end{array}$ \\
\hline & $\begin{array}{l}1,250 \mathrm{ft} \mathrm{WEL} \\
450 \mathrm{ft} \mathrm{SNL}_{2}\end{array}$ & 30 & 96 & 143214 & 62.3 & 13.5 & 2.6 & .44 & 1.6 & 3.8 & 1.7 & 3.4 & .38 & .22 & .06 & -.......... & 48.9 & 1.4 & $\begin{array}{l}\text { tion } 2 \text { of } \\
\text { Pumicite, } 50 \mathrm{ft} \text { above Be Beaver } \\
\text { Divide Conglomerate } \\
\text { Member and 90 ft above } \\
\text { base of formation, mesas- } \\
\text { ured section } 6 \text { of Van Houten } \\
\text { (1050) }\end{array}$ \\
\hline \multirow[t]{3}{*}{ Wiggins.... } & $\begin{array}{l}\text { 16,350 ft S of Mile Post } 29 \\
\text { along S boundary } \\
\text { Yellowstone Park. } 2\end{array}$ & $\cdots$ & ........ & 162362 & 56.7 & 14.5 & 4.5 & .16 & 3.3 & 3.1 & 1.0 & 1.6 & .65 & .34 & .10 & 7.7 & 6.7 & $<.05$ & $\begin{array}{l}\text { Tuff, near top of section, con- } \\
\text { taining Mink Creek verte- } \\
\text { brate launa of early oligo- } \\
\text { cene gao }\end{array}$ \\
\hline & & $\ldots$ & ........ & 164307 & 60.0 & 14.8 & 3.8 & .20 & 3.2 & 2.5 & 1.1 & 2.2 & .68 & .20 & .07 & 6.5 & 4.3 & .16 & Pumicite, $30 \mathrm{ft}$ above base of \\
\hline & & $\cdots$ & ........ & 164306 & 61.4 & 14.5 & 3.0 & .18 & 3.0 & 2.9 & 1.3 & 2.6 & .62 & .30 & .11 & 5.4 & 4.5 & .09 & $\begin{array}{l}\text { Pumicite, } 24 \text { ft above base of } \\
\text { measured section, inter- } \\
\text { bedded with tuff containing } \\
\text { Mink Creek vertebrate } \\
\text { fanna of early Oligocene } \\
\text { (Chadronian provincial age, } \\
\text { of Wood and others, 1941) } \\
\text { age. }\end{array}$ \\
\hline \multicolumn{20}{|c|}{ Opper and middle Eocene rocks } \\
\hline $\begin{array}{l}\text { Aegirine-augite } \\
\text { phonolite. }\end{array}$ & NE1/4NE1/4 $7 \ldots \ldots$ & 32 & 87 & RS-1 & 52.7 & 19.1 & 2.0 & 0.91 & 0.64 & 5.6 & 3.8 & 7.1 & 0.18 & 0.01 & 0.09 . & $\cdots$ & 46.2 & 1.3 & $\begin{array}{l}\text { Sample of Rattlesnake Hills } \\
\text { igneous rock collected by }\end{array}$ \\
\hline \multirow{3}{*}{$\begin{array}{l}\text { Aegirine-augite- } \\
\text { hauyne } \\
\text { phonolite. } \\
\text { Vogesite.......... } \\
\text { Early basalt } \\
\text { flows. }\end{array}$} & SE1/4SE1/4 7 & 32 & 87 & RS-2 & 54.9 & 18.7 & 2.3 & 2.8 & 1.5 & 3.6 & 8.3 & 5.7 & .59 & .16 & .16 & -......... & 41.3 & .07 & Do. \\
\hline & 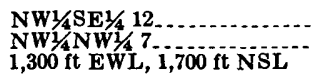 & $\begin{array}{l}32 \\
32 \\
\mathbf{4 9}\end{array}$ & $\begin{array}{r}88 \\
87 \\
103\end{array}$ & $\begin{array}{l}\text { RS-3 } \\
\text { RS-4 } \\
152083\end{array}$ & $\begin{array}{l}54.7 \\
5.7 \\
53.8\end{array}$ & $\begin{array}{l}19.8 \\
15.2 \\
19.6\end{array}$ & $\begin{array}{l}2.6 \\
5.7 \\
3.9\end{array}$ & $\begin{array}{l}1.1 \\
2.6 \\
1.8\end{array}$ & $\begin{array}{l}1.1 \\
3.6 \\
2.1\end{array}$ & $\begin{array}{l}2.8 \\
7.6 \\
4.8\end{array}$ & $\begin{array}{l}6.8 \\
\mathbf{3 . 0} \\
\mathbf{5 . 0}\end{array}$ & $\begin{array}{l}5.6 \\
\mathbf{5 . 2} \\
\mathbf{3 . 5}\end{array}$ & $\begin{array}{l}.45 \\
i .1 \\
.78\end{array}$ & $\begin{array}{l}.04 \\
.58 \\
.60\end{array}$ & $\begin{array}{l}.12 \\
.18 \\
.13\end{array}$ & ... & $\begin{array}{l}44.2 \\
42.8 \\
43.9\end{array}$ & $\begin{array}{l}.62 \\
1.2 \\
<.05\end{array}$ & $\begin{array}{l}\text { Do. } \\
\text { Do. } \\
\text { Basalt, directly underlying }\end{array}$ \\
\hline & 30 . & & & & & & & & & & & & & & & & & & $\begin{array}{l}\text { tuff that contains vertebrate } \\
\text { fauna of late Eocene age. }\end{array}$ \\
\hline \multirow{2}{*}{$\begin{array}{l}\text { Tepee Trail } \\
\text { equivalent. } \\
\text { Bridger....... }\end{array}$} & $\mathrm{SE} 1 / 4 \mathrm{SW} 1 / 4 \mathrm{NW} 1 / 436 . . . . . .$. & 42 & 90 & 161336 & 62.0 & 14.0 & .58 & .56 & 1.0 & 3.0 & 2.6 & 4.6 & .30 & .19 & .07 & .......- & 110.1 & .58 & $\begin{array}{l}\text { Tuff, has potassium-argon } \\
\text { gge of } 46.2 \text { m.y. }\end{array}$ \\
\hline & NE1/4SW1/4 10 & 28 & 105 & 163203 & 63.4 & 13.0 & 1.5 & .48 & 1.3 & 3.2 & 1.4 & 4.8 & .12 & .06 & .09 & 6.7 & 3.0 & 1.2 & $\begin{array}{l}\text { Pumicite, associated with late } \\
\text { Bridger fossils (late middle } \\
\text { Eocene) }\end{array}$ \\
\hline \multirow[t]{2}{*}{ Wagon Bed....... } & SW1/4NE1/4NW1/434......... & 32 & 95 & 158077 & 45.5 & 13.5 & 3.2 & .18 & 2.4 & 10.9 & 2.2 & 4.4 & .41 & 6.0 & .16 & $\ldots$ & 46.2 & 2.5 & $\begin{array}{l}\text { Siltstone, sample selected } \\
\text { because of uranium and } \\
\text { phosphate content; not } \\
\text { representative of composi- } \\
\text { tion of formation at this } \\
\text { locality. }\end{array}$ \\
\hline & \multicolumn{19}{|c|}{ Lower Eocene rocks } \\
\hline \multirow[t]{2}{*}{ Wind River..... } & $1,900 \mathrm{ft}$ NSL, $200 \mathrm{ft}$ EWL 2, & $-\quad 33$ & 96 & 161337 & 66.7 & 14.3 & 1.1 & 0.76 & 1.4 & 3.7 & 3.4 & 1.8 & 0.32 & 0.10 & 0.06 & 2.2 & 3.2 & 0.84 & $\begin{array}{l}\text { Type section of Halfway Draw } \\
\text { Tuff Member of Wind River } \\
\text { Formation. }\end{array}$ \\
\hline & (3) & & & .. & 65.62 & 13.07 & 1.89 & ...... & .95 & 2. 59 & 3. 39 & 1.13 & .18 & .32 & .01 & 2.71 & 7. 39 & 0 & $\begin{array}{l}\text { Analysis of Hallway Draw } \\
\text { Tuff Member by A.H. } \\
\text { Phillips (Sinclair and Grang. } \\
\text { er, 1911, p. 94). }\end{array}$ \\
\hline
\end{tabular}

Precambrian granite

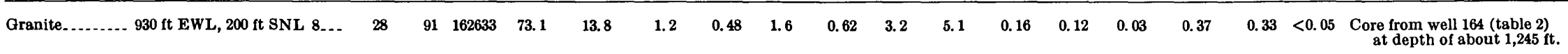


reworked from adjacent (now buried) outcrops of Triassic red beds. Fortunately, an abundant lower Oligocene vertebrate fauna is present in the variegated claystones; otherwise this outcrop could be mistaken for the Wagon Bed Formation. The eastern and larger channel contains a thick section of the White River Formation, the lower half of which is well exposed and very fossiliferous. (See following. measured section.)

Section of lower part of White River Formation at "Teacup Butte" vertebrate fossil locality near Cameron Spring, NW 34 sec. 1, T. 32 N., R. 90 W., Fremont County, Wyo.

[Measured by J. L. Weitz, M. J. Hough, and Robert DeMar in 1953, with additions by J. D. Love]

Split Rock Formation (basal beds):

27. Conglomerate, gray, arkosic, interbedded with thin pink siltstone lenses; poorly exposed.....

Erosional unconformity; overlying conglomerate deposited on an irregular surface cut in underlying strata.

White River Formation:

26. Sandstone, siltstone, and claystone, white and gray; intermittently exposed and not detailed. $250 \pm$

25. Claystone, light-chocolate-brown, weathers light olive gray; limy, blocky, soft, poorly exposed; forms steep slope; top of unit is top of "Teacup Butte" below lag gravel...................

24. Siltstone, light-gray with greenish cast, noncalcareous; laminated in part; forms steep

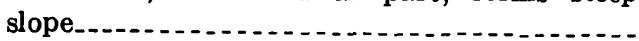

23. Siltstone "cannonball" concretion bed, light-gray, limy, sandy; weathers light tan; contains sporadic grains of angular quartz...........

22. Siltstone, light-gray to light-grayish-brown, mottled light green in part, limy, finely sandy in part, blocky; forms slope.................

21. Siltstone, light-gray, clayey; forms steep slope; weathers in part to concentrically spalling concretionary blocks about 6 in. in diameter; limy where concretions are developed; conspicuous concretion zone 4-5 $\mathrm{ft}$ above base and in top foot; concretions weather tan to gray.-

20. Claystone, light-olive-gray to light-gray; and light olive green in lower $3 \mathrm{ft}$; blocky, slightly limy in part, soft; forms slopes; contains five lenticular highly calcareous concretionary beds; $15 \mathrm{ft}$ above base is a 2-in.-thick bed of knobby-weathering light-gray to white tuffaceous noncalcareous siltstone; $8 \mathrm{ft}$ above base near top of middle butte is a hard coarsegrained sandstone from which a skull of $\mathrm{Men}$ odus heloceras was obtained; unit also yielded Mesohippus hyposiylus....................

19. Siltstone and silty claystone, light-olive-gray to light-brownish-pinkish-gray; contains concretion zone $6 \mathrm{ft}$ above base and two more zones in upper $2 \mathrm{ft}$; lower $6 \mathrm{ft}$ noncalcareous; remainder calcareous in part; concretions very calcareous; contains land snails Pupillidae, Polygyridae (2 species), and Helminthoglyptidae, and vertebrate fossils Oligoryctes cameronensis (Hough, 1956) Paleolagus tem-
Section of lower part of White River Formation at "Teacup Butte" vertebrate fossil locality near Cameron Spring, NW14 sec. 1, T. 32 N., R. 90 W., Fremont County, Wyo.-Continued

White River Formation-Continued Thick-
ness
(feet) nodon, Ischyromys sp., Cylindrodon of. $C$. fontis, Cylindrodon brownii, Pseudocylindrodon? wyomingensis, Leptumeryx esulcatus, Mesohippus hypostylus, a hoplophonid, and a turtle

18. Sandstone, light-gray, hard, coarse-grained to conglomeratic, limy; contains rounded pebbles of white tuffaceous sandstone and grains of quartz and feldspar; forms second bench below top of south butte: pinches out to west, thins to east............................

17. Siltstone, light-gray, blocky, hard, slightly limy; forms steep slope; weathers gray to tan in upper $3 \mathrm{ft}$; contains thin zones of light-gray concretions resembling bone fragments. . . . . . . . -

16. Siltstone, light-gray, blocky, hard; interbedded with brownish-gray claystone; upper $4 \mathrm{ft}$ forms cliff

1i. Claystone and silty claystone, olive-gray to lightgray, slightly limy in part; contains lenses of light-gray fine-grained limy concretionary sandstone; forms slope; yielded titanothere femur. -

14. Siltstone in upper $2 \mathrm{ft}$ is olive gray, blocky, and knobby; weathers to gray-buff polygonal blocks; forms slope; lower $4 \mathrm{ft}$ is light-gray knobby siltstone; upper part yielded skull of a

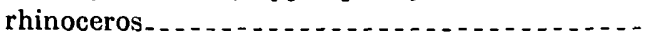

13. Sandstone, olive-gray, weathers smoky gray; changes color northward to light gray and white; very fine grained, biotitic, laminated greenish-gray silty claystone in middle; calcareous and concretionary claystone in lower part; forms most conspicuous marker bed in section

12. Sandstone, light-gray, coarse-grained, crossbedded, limy in part; contains beds of small pebbles as much as $2 \mathrm{ft}$ thick; forms ledges; lenses out to south and grades to concretionary light-olive-gray siltstone to north; contains abundant bone fragments. . . . . . . . . . . . . .

11. Siltstone and sandstone, light-olive-gray, blocky; sandstone is gray, coarse grained, and conglomeratic; unit contains abundant biotite

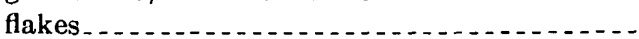

10. Claystone and siltstone, green and brown, slightly limy; lenticular sandstone forms top half of unit in places and crops out as prominent 5-ft-thick ledge near top of northwest buttes...................................

9. Claystone and siltstone, brownish-green to greenish-gray, slightly limy; more silty in upper part which weathers light gray; lower part weathers pale pink; forms slope; $20 \mathrm{ft}$ above base is a 1-ft thick bed of hard limy sandstone characterized by frosted grains; near top of unit are large brown mica flakes and frosted rounded quartz grains; lenses of hard limy sandstone at top. ...............

8. Claystone, light-greenish-gray, silty ............ 
Section of lower part of White River Furmation at "Teacup Butte" vertebrate fossil locality near Cameron Spring, NW1/4 Sec. 1, T. S2 N., R. 90 W., Fremont County, Wyo.-Continued

White River Formation-Continued:

7. Claystone, light-brownish-olive-gray, noncalcareous . . . . . . . .

6. Claystone, light-greenish-gray, silty, slightly

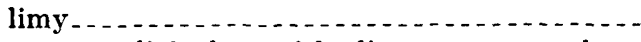

5. Claystone, light-brownish-olive-gray, noncalcareous. . . . . . . . . . .

4. Siltstone, light-greenish-gray to pale-olive, slightly limy; weathers to blocky conchoidally fractured fragments. . . . . . . . . . . . . . . . . .

3. Claystone, light-olive-gray, silty, weathers very light gray; limy, finely blocky, knobby; forms soft rounded slopes.......................

2. Partly covered interval; sporadic outcrops of gray soft arkosic sandstone and conglomerate containing rounded fragments of volcanic rocks from Rattlesnake Hills vents, as well as Precambrian igneous and metamorphic rocks..

Total approximate thickness of White River Formation

Unconformity. Contact poorly exposed, but regional relations indicate base of section is in bottom of a deep channel about 2 miles wide and several hundred feet deep which was cut entirely through upper and middle Eocene rocks prior to deposition of the White River Formation (fig. 22).

Wind River Formation

1. Sandstone, conglomerate, and siltstone, gray, red, and pale-green, soft; forms variegated low rolling hills . .

A check on the thickness of the White River Formation at this locality, where the measured section extends along 1 mile of outcrop, is provided by core hole 234. The interval penetrated, plus that from the drill collar to the top of the formation on the Beaver Divide 2,000 feet southeast, is 515 feet.

In the eastern part of the Gas Hills, conglomerates of the White River consist of angular to subrounded fragments of Precambrian igneous and metamorphic rocks and rounded pebbles, cobbles, and boulders of andesite porphyry. Some roundstones are white and light-gray soft sodic trachyte and tuff. All Tertiary igneous and pyroclastic rock fragments apparently were derived either directly by erosion of exposed volcanic cones and flows of middle and late Eocene age or indirectly from conglomerates in middle and upper Eocene rocks. There is no evidence that volcanos in the Rattlesnake Hills were active during Oligocene time. The few moderately pure white tuff beds are believed to be water-laid deposits representing ash falls whose source was in the Absaroka Range.
Thick and distinctive sections of the White River Formation are present in the northeast corner of the Granite Mountains area. These have been described by Rich (1962), who measured one section 843 feet thick. Potassium-argon ages were determined on four pumicite beds in this section by Evernden, Savage, Curtis, and James (1964; table 5, this report). Many subsurface sections are known from wells south of the unnamed escarpment that marks the south topographic boundary of the southeastern arm of the Wind River basin (pl. 1; section $H-H^{\prime}$, pl. 3). A thin bed of conglomerate is commonly present at the base in both surface and subsurface sections. The conglomerate consists predominantly of angular to subrounded fragments of Precambrian igneous and metamorphic rocks, sparse roundstones of dense andesite porphyry of Eocene age derived from the Rattlesnake Hills to the west, and hard siliceous fragments of Paleozoic and Mesozoic sedimentary rocks, all embedded in a gray coarse arkosic sandstone matrix.

Overlying the basal conglomerate in the easternmost exposures are soft bentonitic variegated red, green, brown, and white claystone, siltstone, and fine-grained sandstone that form badlands resembling those in the upper part of the Wind River Formation and in some sections of the Wagon Bed Formation. These strata, however, contain abundant vertebrate fossils which are of Oligocene age. The rest of the formation is chiefly white, light-gray, pinkish-gray, and tan tuffaceous siltstone and claystone interbedded with sparse lenses of gray conglomeratic sandstone and thin beds of light- and dark-gray tuff. The upper 50-100 feet in some localities is dull pink and white tuffaceous siltstone and claystone interbedded with arkosic sandstone and conglomerate. Similar beds occur locally in the basal strata in the overlying Miocene Split Rock Formation and probably were reworked from the White River Formation. In such places a precise contact is difficult to determine; in fact, this upper conglomerate is mapped by some geologists as part of the White River Formation (N. M. Denson, oral commun., 1963).

A unique occurrence of uraniferous pollen-bearing carbonaceous shale, siltstone, and sandstone was discovered by Rich (1962) in sec. 4, T. 31 N., R. 83 W., $300-400$ feet above the base of the formation. These are the only carbonaceous beds known in the Oligocene rocks of central Wyoming. Abundant vertebrate fossils in associated strata confirm the Oligocene age.

The White River Formation thins southward from 800 feet near Clarkson Hill (loc. $25 \mathrm{~V}$, pl. 1) to an edge northwest of Alcova, a distance of 5 miles, by overlapping on pre-Tertiary rocks that make up the north 
flank of the Granite Mountains. Probably no Oligocene strata occur in the Southeastern part of the Granite Mountains area.

The White River Formation underlies the entire area from the western part of Beaver Divide south to the South Granite Mountains fault system (pl. 5D). The formation in this area consists of light-gray to dully variegated tuffaceous slightly clayey siltstone and lenticular arkosic sandstone and conglomerate. Plate 8 shows typical electric-log characteristics. The lithology is very similar to that described in the western part of the Bea ver Divide. In general, locally derived arkosic sandstone and conglomerute are especially abundant in sections in wells along and east of the Emigrant Trail thrust fault, where the formation laps directly onto the Precambrian rocks of the Granite Mountains.

A small outcrop of the White River Formation along the South Granite Mountains fault system 6 miles west of Crooks Gap (pl. 1; figs. 17, 53) consists of palegreenish-white thin-bedded hard tuffaceous siltstone and fine-grained sandstone. Wells in this area (section $C-C^{\prime}$, pl. 1) penetrate 300-600 feet of the White River Formation. The strata mapped as White River by Stephens (1964) east of Crooks Gap, as previously discussed, are considered to be part of the Wagon Bed Formation.

The broad outcrops of the White River Formation in the extreme southwestern part of the Granite Mountains area, between the Sweetwater Crossing anticline (pls. $5 D, 7$ ) and the Wind River Range, are chiefly white and light-gray hard blocky coarsely bedded tuffaceous claystone and siltstone and finegrained dusty soft sandstone. The sandstone is superficially similar to a few in Miocene rocks. A critical comparison, however, shows that the sandstone in the White River Formation has fewer frosted rounded quartz grains, fewer hematite-coated grains, and a lower percentage of magnetic minerals. Many conspicuous white biotitic pumicite and pumiceous tuff beds are present. One of the most persistent of these, in the NW1 $1 / 4 N_{1} 1 / 4$ SW $1 / 4$ sec. $t$, T. 29 N., R. 96 W., about 300 feet above the base of the formation and perhaps 200 feet or more below the top, has such a concentration of hexagonal biotite flakes that a bulk sample was collected for potassium-argon age determination. The determined age is $32.2 \pm 2.0$ m.y. (table 5). Rock analysis of this sample is given in table 7. In this part of the area there are several hard and soft arkosic sandstone and conglomerate units 50-100 feet thick composed chiefly of angular to subrounded fresh fragments of Precambrian igneous and metamorphic rocks embedded in a tuffaceous matrix.
As mentioned in the discussion of the Ice Point Conglomerate, the presence of White River Formation along the Sweetwater River, directly east of the Wind River Range, is known from 27 wells and core holes. A basal conglomerate is present in some, but not all, sections and appears to follow a linear pattern extending eastward from Precambrian source areas in the Wind River Range. Nearly all rock fragments are Precambrian. An apple-green nephrite jade boulder was drilled through in core hole 1 at a depth of 400 feet. The thickness of the formation in the syncline adjacent to this core hole (pl. $6 C$ ) is, in places, at least 600 feet (pl. $5 D$ ).

The controversial beds in the vicinity of well 21 have already been mentioned. The basal conglomerate was mapped separately as the basal unit of the Browns Park(?) Formation of Miocene(?) and Miocene age and the overlying beds were included in the remainder of the Browns Park(?) by Pipiringos (1961). However, the lithology from the surface to a depth of $\mathbf{1 5 0}$ feet in well 21 and in adjacent outcrops suggests that these beds belong in the White River. The basal gray arkosic conglomerate, 10-20 feet thick, is overlain by 150-200 feet of gray to tan fine-grained tuffaceous sandstone, blocky hard siltstone, and tan claystone, all of which have tiny red and black flecks like those characteristic of the White River Formation on the Beaver Divide. Rounded frosted quartz grains are sparse. Overlying this sequence, and about 100 feet stratigraphically above the surface beds at the well site, is an arkosic gray conglomerate bed 5 feet thick that yielded astragali of horse and deer and abundant turtle bones. Above the conglomerate is 30 feet of greenish-white claystone and siltstone which has abundant tiny red flecks that resemble those in the lower strata. The size and type of preservation of the fossil bones are more like those in the White River Formation in fossiliferous areas to the north than like the Miocene vertebrate fauna in the Split Rock Formation at Hawks Nest (fossil loc. $3 \mathrm{~V}$ ), 3 miles to the southeast. The sequence penetrated in well 21 is shown on plate 1 as Miocene and Oligocene rocks undivided; time did not permit mapping of the contact in detail. On other maps it has been shown only as White River (Love and others, 19.55; Wyant and others, 1956).

\section{STRATIGRAPHIC AND STRUCTURAI RELATIONB}

Throughout the Granite Mountains area, an erosional, and in some places angular, unconformity exists between the White River Formation and upper Eocene and older rocks (fig. 22). Local relations are discussed above. Regionally, the extensive channeling and development of moderately rough topography occurred 
after Eocene deposition and before the basal strata of the White River Formation were laid down. Major drainage changes occurred at this time; powerful southeastward-flowing streams brought boulders, as much as 8 feet in diameter, 90 miles from the Absaroka Range (pl. 10G), and the drainage to eastern Wyoming, interrupted during middle and late Eocene time (pl. 10F), was reestablished (Love, 1960, p. 209).

Of special significance in the Gas Hills uranium district are two channels that were cut completely through the Wagon Bed Formation (pl. $5 C$ ) by north-flowing streams from the Granite Mountains prior to deposition of the White River Formation (fig. 22). The western channel is less than 1 mile wide and the eastern one is about 2 miles wide. Because of their suspected influence on the localization of some uranium deposits, they are discussed in more detail in the chapter on uranium.

Upper Eocene rocks were gently warped in parts of the Granite Mountains area prior to Oligocene deposition (compare pls. $6 B$ and $6 C$ ). The White River Formation was subsequently laid down across truncated edges of all older rocks on the flanks of the Wind River Range and the Granite Mountains. No evidence was observed of recurrent movement along either the North or the South Granite Mountains fault system during Oligocene time.

Van Houten (1964, p. 50 and figs. 12,13) discussed an anomalous occurrence of steeply dipping fractured strata in the Wagon Bed Formation in sec. 31, T. 31 N., R. 94 W., overlain by a thin horizontal remnant of White River and surrounded by the Miocene Split Rock Formation. He considered the feature to be either of tectonic origin or possibly a pre-Oligocene landslide and showed on his White River isopach map a sharp thinning to zero at this locality. A normal section $\left(300 \mathrm{ft}\right.$ ) of White River (section $K-K^{\prime \prime}, \mathrm{pl} .4$ ) is present, however, in well 63 , only 1,000 feet from this exposure, and the structure contour map (pl. $6 C$ ) shows no anomalous uplift affecting this section of any other in the adjacent wells $(63,64,65,66,67)$. In the absence of specific data on rocks beneath this feature, it is indicated on both the isopach and structure contour maps of the Wagon Bed and White River Formations (pls. $5 C, D ; 6 B, C$ ) with a question mark. A magnetometer investigation might evaluate the possibility of this being a pre-White River meteorite impact phenomenon.

Only the earlier half of Oligocene time is represented in the fossil record in the Granite Mountains area (table 8). In most places the fossils are Chadronian. Questionable Orellan fossils are present, but Whitneyan fossils are unknown. If the Whitneyan rocks were ever deposited in central Wyoming, they were removed without leaving any known fossil record. Therefore, possibly prior to deposition of the lower Miocene part of the Split Rock Formation, broad eastward or northeastward tilting and erosion stripped all upper and most middle Oligocene rocks from central Wyoming (pl. 10G). This interpretation is strengthened by the occurrence of channels that cut deeply into Oligocene rocks east of the Rattlesnake Hills; these subsequently were filled wth strata that Rich $(1957$, p. $278 ; 1962$, p. 503 ) and I consider to be the basal conglomerate of Miocene age.

\section{AGE AND CORRELATION}

The Big Sand Draw Sandstone Lentil was considered by Gazin $(1955$, p. 7$)$ to be of Oligocene age on the basis of the occurrence of Brachyhyops wyomingensis. If this age assignment is accepted, then the overlying Beaver Divide Conglomerate is likewise Oligocene. Van Houten $(1954,1964)$ considered both to be probably earliest Oligocene (Chadronian provincial age) in spite of the presence of several Eocene forms. Sparse vertebrate fossils occur in the type locality of the Beaver Divide Conglomerate Member. The remainder of the White River Formation on the Beaver Divide contains early Oligocene (Chadronian provincial age) and, possibly, middle Oligocene (Orellan provincial age) fossils (Wood and others, 1941; Wood, 1948; Van Houten, 1954, 1964).

Rich (1962) made extensive collections of vertebrate fossils throughout more than 800 feet of the White River Formation in the northeast corner of the Granite Mountains area. He reported that all were of early Oligocene (Chadronian) age. Sparse vertebrate fossils of early Oligocene (Chadronian) age have been found (Bell, 1955) in the area northwest of Bison Basin (locs. $6 \mathrm{~V}$ and $7 \mathrm{~V}$, table 10$)$.

Although vertebrate fossils are used to determine the age of the White River Formation, mollusks are present in several localities (table 10, locs. 17VI and 34DI) and pollen in one locality (Rich, 1962). In addition, at locality $19 \mathrm{VP}, \mathrm{NE} 1 / 4 \mathrm{NW}^{1} / 4 \mathrm{NE}^{1} / 4$ sec. 4 , T. $32 \mathrm{~N}$., R. $89 \mathrm{~W}$., the only fossil leaves thus far found in the Oligocene rocks of central Wyoming-Rhus obscura (Lesq.) MacGinitie and "Quercus" elwoyni Becker (this is a species of Acer) identified by J. A. Wolfe-are associated with Hyracodon cf. H. leidyanus, and other vertebrate fossils of early Oligocene (Chadronian) age. No pollen of Rhus or "Quercus" was recognized in the carbonaceous strata described by Rich (1962).

The White River Formation in the Granite Mountains area is equivalent to the Chadron Formation and possibly part of the Brule Formation of the White River Group in eastern Wyoming, to the caprock on Pumpkin Buttes in the middle of the Powder River basin (Love, 1954c, p. 7), and to the Wiggins Forma- 
tion in the Absaroka Range (Love, 1939), which has yielded remains of an early Oligocene (Chadronian) rhinoceros (identified by M. J. Hough, written commun., 1952). The "late basic breccia" of Hague (1896), along the south border of Yellowstone National Park, contains a large assemblage of vertebrate fossils of early Oligocene (Chadronian) age comparable to that on the Beaver Divide (Love, 1956a, p. 88; 1964, unpub. field notes on collections by M. C. McKenna).

Mollusks are sparse in the White River Formation. The following report includes all known collections in the Granite Mountains area and was prepared by D. W. Taylor (written commun., 1962) :

Occurrence of fossil mollusks in White River Formation

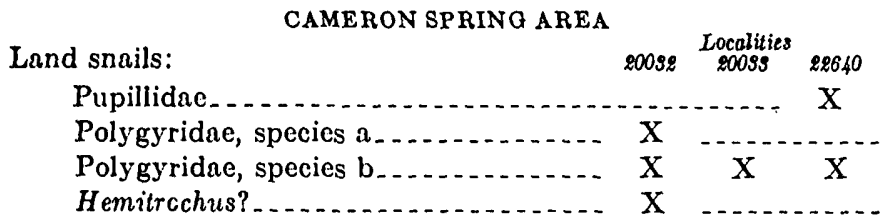

Locality, USGS 20032, Fremont County, Wyo. Gas Hills quadrangle (1952) 1:24,000. Sec. 11, T. 32 N., R. 90 W. M. J. Hough and others, 1951.

Localities, USGS 20033 and 22640. Fremont County, Wyo. Gas Hills quadrangle (1952) 1:24,000. NE $1 / 4 \mathrm{SW} 3 / 4 \mathrm{NW} / 4$ sec. $1, \mathrm{~T}$. 32 N., R. 90 W. "Teacup Butte." J. D. Love, 1944, 1961.

All the fossils are so poorly preserved that they cannot be identified even to genus. One of the species of Polygyridae is similar to the polygyrid from the Wind River Formation and might belong to the same genus. Possibly the other species in the White River Formation have a greater range, too, for the record of land snails is even more fragmentary than that of the aquatic forms.

Land snails :

OMERA MEADOW AREA

Pupllidae, four species in several genera Discus

Locality, USGS 21064. Fremont County, Wyo. Miners Delight quadrangle (1954) 1:24,000. Sec. 19, T. 30 N., R. 99 W. Tuffaceous deposits. E. J. McKay, (1947).

The fossils are not well enough preserved for precise identif. cation. Either an Oligocene or a Miocene age would be quite credible. So far as the very few known Oligocene and Miocene assemblages can be compared with this sample, an Oligocene age is more likely.

Fossil mollusks from Bcaver Divide Conglomerate Member of White River Formation

Fresh-water snails:

Lymnaca aff. $L$. similis Meek

Aplexa? n. sp.

Biomphalaria pscudoammonius (Schlotheim) Land snail :

Oreoconus n. sp.

Locality, USGS 22031 (11) and diatom locality 5416. Fremont County, Wyo. Center south side SE1/4 sec. 24, T. 32 N., R. 95 W. Measured section 31 of Van Houten $(1954 ; 1964$, loc. 12), $10 \mathrm{ft}$ above base of member. F. B. Van Houten (1951).

This assemblage is indistinguishable from that in the underlying Eocene rocks. It is in marked contrast to other known
Oligocene assemblages, admittedly few in number. This occurrence is the youngest known for all of the species.

K. E. Lohman and G. W. Andrews (written commun., 1965) found an abundant and well-preserved diatom assemblage in materials filling snail shells. These are the oldest known well-preserved fresh-water diatoms in North America, although as previously mentioned, poorly preserved forms are present in the underlying Wagon Bed Formation.

\section{MIOCENE ROCKS \\ SPLIT ROCK FORMATION S \\ NAME AND DEFINITION}

The Split Rock Formation was named from exposures in the vicinity of Split Rock in the Granite Mountains area (Love, 1961b). Prior to this, the names Browns Park Formation and Browns Park(?) Formation had been applied to these strata (McGrew, 1951, p. 56 ; Pipiringos, 1955 , p. $103 ; 1961)$. McGrew (1951) and Carey (1955) reviewed the problem of age of the type Browns Park Formation in northeastern Utah and northwestern Colorado, 130 miles southwest of Split Rock. Vertebrate fossils from a sandstone sequence called Browns Park near Maybell, Colo., 50 miles southeast of the type locality and in the Saratoga Valley (fig. 2), 85 miles south-southeast of Split Rock contain middle Miocene fossils. Detailed studies of the type Browns Park Formation by Hansen (1965), however, showed that its lithology is unlike that of the vertebrate-bearing beds, for the Browns Park is at least half claystone and tuff rather than nearly all sandstone. No specific evidence was found that any part of the Miocene(?) type Browns Park is equivalent to the lower and middle Miocene rocks in central Wyoming; so an extension of this name was considered inadvisable.

The Arikaree Group of western Nebraska was likewise considered as a possible correlative of the Miocene rocks in central Wyoming. Table 8 summarizes the nomenclature, ages, and correlations of rock units in and between these areas. A detailed review of the extraordinarily complex problems of Miocene nomenclature and faunas and the evolution of ideas of the workers involved was prepared by McKenna (1965); so the data are not repeated here. The Arikaree Formation has been considered by most geologists to be of early Miocene age.

Darton (1899) originally named both the Arikaree and Ogallala Formations in western Nebraska but

5 After the present report was submitted for publlcation Denson (1965) proposed that the formation named Split Rock be replaced by Arikaree, nnd his recommendation was adopted by the Geological Survey. My original reasons for not extending Arikaree to central Wyoming are, in my opinion, still valld. 

$\mathrm{T}_{\mathrm{ABLE}}$ 8.-Names and ages of Oligocene and younger Cenozoic rock units in the Granite Mountains and Wheatland areas, Wyoming,
and in western Nebraska

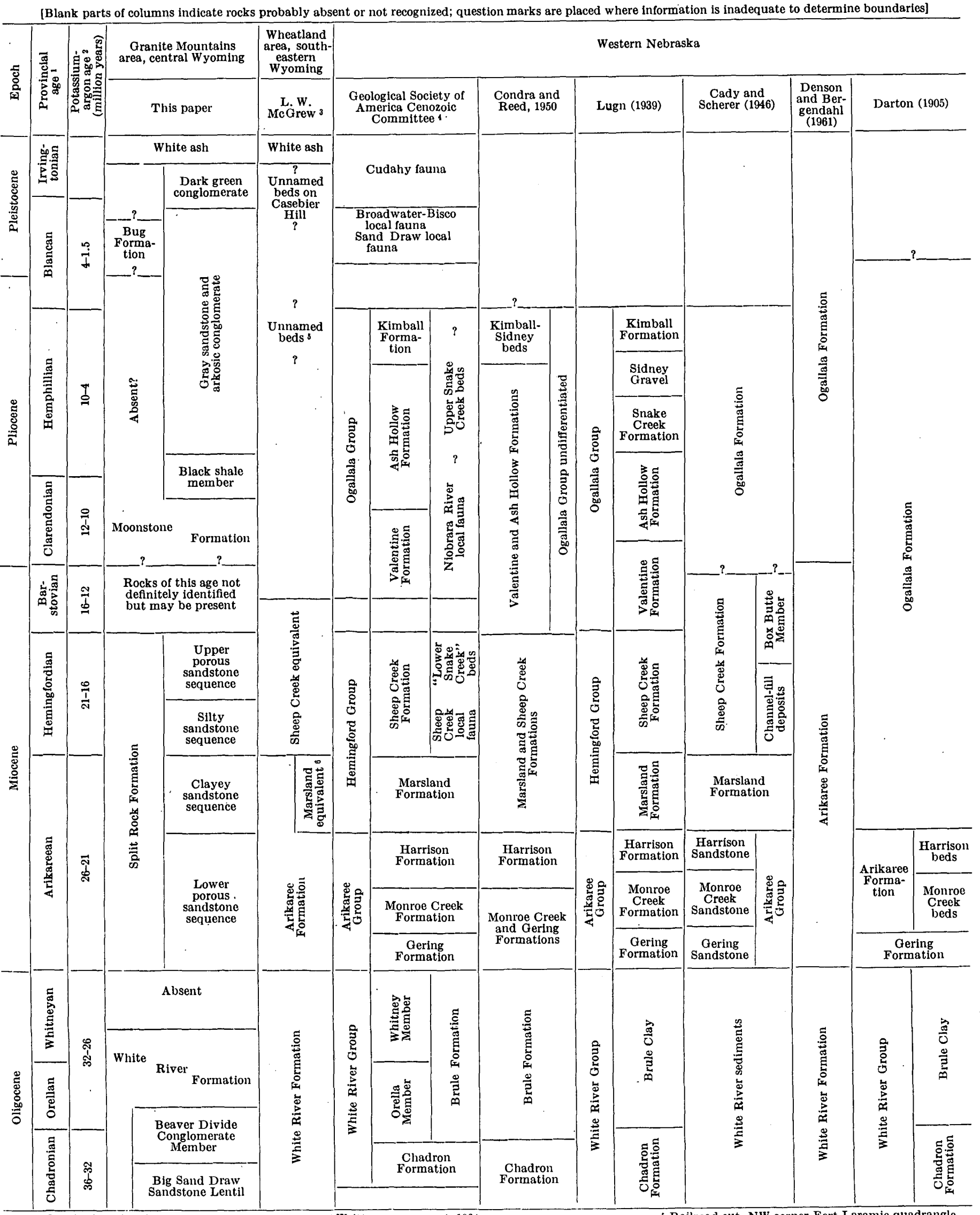

$\begin{array}{lll}\text { I Wood and others (1941). } & \text { 5 Railroad cut, NW corner Fort Laramie quadrangle. } \\ \text { 2 Ages reported by Evernden and others (1964). } & \text { 1 Gritten commun., 4. 1964. }\end{array}$ 
defined them rather loosely. Later he (1905; table 8, this report) specified that the Ogallala rested on the "Harrison beds" composing the upper part of the Arikaree Formation. Thus, the Ogallala included not only all the Pliocene rocks but most of those later found to be Miocene. Subsequently, the Ogallala was more or less restricted to Pliocene rocks and the postHarrison (for example, post-A rikaree of Darton, 1905) beds of early, middle, and late Miocene age were given other names. Denson and Bergendahl (1961) included all Miocene rocks in the Arikaree Formation and disregarded the complex sequence of mappable units, many of which have distinctive faunas that indicate time gaps associated with unconformities.

West of this controversial area and into eastern Wyoming, the geologist who uses Arikaree in an expanded sense would have to dispose of the Marsland Formation and the distinctive, partly lacustrine Sheep Creok equivalent. Presumably these would be lumped with the Arikaree, and the geologic episodes they represent would be ignored. West of this area Miocene rocks are absent from an area 30 miles wide that extends across the Laramie Mountains. Another area from which Miocene rocks have been stripped is that across the Shirley basin (fig. 2). Correlation of Miocene rocks across these gaps is not just a simple matter of matching up sandstone or conglomerate units, for E. N. Harshman (oral commun., 1961, 1964) found Oligocene fossils in arkosic sandstone previously thought to be Miocene on the west side of the Laramie Mountains.

All but one of the vertebrate fossils identified from the Split Rock Formation occur in the upper twothirds of the formation. They are of middle Miocene age (in the sense shown in table 8 and as used by McKenna, 1965) and are therefore younger than those in the type Arikaree Formation. Most of the fossils are found in the Sheep Creek Formation (table 8) and its equivalents. As with most Tertiary stratigraphic units of fluviatile origin, the Arikaree Formation in Nebraska has a considerable variety of rock types and little lateral continuity of individual units. For purposes of correlation of the Arikaree with rocks in eastern and central Wyoming, the presence of frosted rounded sand grains and abundant magnetite cannot be used, even in a broad sense, as distinguishing criteria, for they are likewise found in abundance in the Marsland, Sheep Creek, and Ogallala Formations in Nebraska and in lower, middle, and upper Miocene rocks and in Pliocene rocks in eastern, southeastern, and central Wyoming. Conglomerates are not necessarily valid marker beds, for they are lenticular deposits that are dependent on locally available source material; they become more abundant toward the mountains in nearly all sequences. The Sheep Creek equivalent is an anomaly, however, for along the east side of the Laramie Mountains it contains a thick sequence of laminated lacustrine claystone and shale that not only contains younger vertebrate fossils but lithologically is unlike the Arikaree in Nebraska.

In view of these considerations, only confusion would have resulted if an already controversial name were extended 300 miles westward from vaguely defined exposures to a different area of deposition in which rocks largely of a different age were derived from sources still farther west. Therefore, the name Split Rock was given to the Miocene strata in central Wyoming (Love, 1961b).

\section{DIBTRIBUTION AND THICKNEBS}

The Split Rock Formation is the most widely distributed (about 1,500 square miles) of any sedimentary sequence in the Granite Mountains area (pl. 1). It caps the Beaver Divide in most places (for examples, see fig. 24 and pl. 1) and forms the south-tilted dip slopes of the Sweetwater Plateau (frontispiece, foreground; pl.2; fig. 3); it buried the southeastern part of the Granite Mountains with about 3,000 feet of sand (frontispiece). Outcrops cover an additional 250 square miles east of the area shown on plate 1. Regional distribution of similar and probably partially equivalent rocks is shown on the geologic map of Wyoming (Love and others, 1955).

The thickness of the rocks assigned to the Split Rock Formation depends on interpretation of the formation's upper and lower contacts. One might assume from the following discussion that the Split Rock Formation is not a lithologically distinctive unit. It is very distinctive, however, in gross aspect and composition, but as in all formations containing locally derived sediments, more reworked debris is present in some places than in others. The different interpretations of the basal contact, involving 700-1,000 feet of beds, have already been discussed. The fundamental reason for this disagreement is that the subsurface data, chiefly drill cuttings coordinated with electric $\log \mathrm{s}$, have not hitherto been studied on a regional basis. The thickest sections of the Split Rock Formation are in the southern part of the Granite Mountains area; north of Crooks Mountain, for example, 25 wells penetrated from 1,000 to more than 2,000 feet of the formation (table $2 ; \mathrm{pl} .5 E$ ).

A problem exists regarding delineation of the contact between the Split Rock Formation and the overlying Moonstone Formation in the southeastern part of the Granite Mountains area. Uplift of the area south of the South Granite Mountains fault system caused 
sandstone from the Split Rock Formation to be eroded, carried northward, and then redeposited in the Moonstone. Fieldwork on this project was terminated before I could complete an adequate map of this contact; the geologic map (pl. 1) therefore, shows Pliocene and Miocene rock undifferentiated. Some data, nevertheless, are available on the minimum thickness of the Split Rock Formation in this part of the area. Well 188 ('T. 27 N., R. 86 W.) penetrated 2,732 feet of Tertiary rocks, the lower half of which has lithology typical of the Split Rock Formation. The bottom of well 187 (T. 28 N., R. 87 W.) is in the Split Rock Formation 1,675 feet below its contact with the Moonstone.

South of the South Granite Mountains fault system, the Split Rock Formation was completely removed by erosion except in the southwest corner of the mapped area. Southeast of well 21 , at least 200 feet is exposed in secs. 13 and 14, T. 26 N., R. 95 W. (loc. $3 \mathrm{~V}$, table $10 ;$ pl. 1), in the Cyclone Rim syncline. Three miles west of the southwest corner of the mapped area, the thickness increases to more than 1,000 feet.

Because so much of the formation has been eroded away (an example of this is known in section $D-D^{\prime}$, pl. 1), determination of its original maximum thickness, volume, and extent is difficult. A rough computation, based on surface, subsurface, and geophysical studies, indicates that the volume still present within the area shown on plate 1 is more than 250 cubic miles, of which perhaps 200 cubic miles is sandstone.

\section{LITHOLOGY}

In the western part of the Granite Mountains area, the part in which the most drill cuttings, electric logs, and radioactivity logs are available (pl. 1), the Split Rock Formation has been subdivided into four lithologic sequences (Love, 1961b). These are, from oldest to youngest, a lower porous sandstone, a clayey sandstone, a silty sandstone, and an upper porous sandstone. Data on the thickness, lithology, and fossil content of these rocks are summarized in table 3 ; electric-log characteristics are shown on plate 8. As mentioned previously, Stephens (1964) and N. M. Denson (written commun., 1962) put nearly all of the lower three sequences in the White River Formation (pl. 4, section $O^{-} O^{\prime}$, well 96) and considered them to be of Oligocene age. The areal extent of the four subdivisions is not completely known, but correlations are reasonably well established for the cross sections where adequate subsurface information is available (pl. $1, C-C^{\prime}, D-D^{\prime}$; pl. $3, N-N^{\prime} ;$ pl. 4 , $K-K^{\prime \prime}, M-M^{\prime \prime}, O-O^{\prime}$ through $\left.R-R^{\prime}, T-T^{\prime}, U-U^{\prime}\right)$.

Separation of the Split Rock into units is based on clay and silt content, presence or absence of widespread conglomerates, and electric-log characteristics. The sandstone in all four subdivisions is similar in physical appearance; it has the same high sphericity, frosting of grains, hematite coating of grains, abundance of brilliant quartz bipyramids, and abundance of magnetite. The units contain a mafic to intermediate mineral suite rich in augite, hypersthene, green-brown hornblende, calcic andesine, and sodic labradorite. Lesser amounts of sanidine, red-brown hornblende, and redbrown biotite are present. Curved or rectangular and pink to colorless glass shards are abundant. Analyses of the purest pumicite beds are given in table 7. These beds contain significantly more $\mathrm{SiO}_{2}$ and $\mathrm{K}_{2} \mathrm{O}$ than do the Oligocene pumicites but are similar to those of Pliocene age. Figure 35 and table 6 compare spectrographic analyses of the Split Rock Formation with those of other formations in the area. Sieve analyses show that 75 percent of the sandstone fraction is in the size range $0.05-0.35 \mathrm{~mm}$. All the clays that have been checked are mixed layer.

$$
\text { I.OWER POROUS SANDSTONE SEQUENCE: }
$$

The lower porous sandstone sequence is the coarsest grained and most widespread of the four subdivisions. Rocks described by Van Houten (1954) as Miocene (?) and by Van Houten and Weitz (1956) and Rich (1962) as Miocene, along the north margin of the Granite Mountains area, are part of this sequence. It thins from about 500 feet along some parts of the Beaver Divide to a featheredge against the Precambrian knobs in the central part of the Granite Mountains. Subsurface control in the southeastern part of the area is limited to well 188 , which may have penetrated as much as 250 feet of the sequence; this interpretation is based on the presence of a lithologically similar coarsegrained unit at the base of the section. In the western part of the area, the thickness ranges from 100 feet to more than 400 feet.

Outcrops of the lower porous sandstone sequence along the Beaver Divide are characterized by cliffs and steep slopes of conglomerate and sandstone (fig. 24). The roundstones are chiefly pebbles, cobbles, and boulders of granite and mafic igneous and metamorphic rocks of Precambrian age, except in the vicinity of the Rattlesnake Hills where fragments of Eocene andesite porphyry are common. The matrix is gray coarse-grained poorly cemented sandstone. Many beds of gray medium- to coarse-grained sandstone containing well-rounded frosted grains are interbedded with conglomerate. The conglomerate beds are thickest along the north flank of the Granite Mountains, and, in places, they make up the entire 400 feet of section, but commonly are much thinner. On the Sweetwater Plateau south of the Beaver Divide the lower porous sandstone sequence forms broad dip slopes (pl. 2; figs. $3,55)$. 
A hard gray arkosic conglomerate and sandstone as much as 50 feet thick and $300-400$ feet above the base of the lower porous sandstone sequence in sec. 16 , T. 31 N., R. 91 W. (loc. $18 \mathrm{U}, \mathrm{Ag}$, table 9 and pl. 1), contains agates 1-4 inches in diameter which have black manganese dendrites (fig. 30). These agates are radioactive and fluoresce brilliant yellow; many contain the yellow uranium mineral trögerite $\left(\left(\mathrm{UO}_{2}\right)_{3} \mathrm{As}_{2} \mathrm{O}_{8}\right.$ : $12 \mathrm{H}_{2} \mathrm{O}$; Theodore Botinelly, oral commun., 1963). They were formed in cavities after the conglomerate was deposited but apparently before deposition of the youngest sequence in the Split Rock Formation. The origin of these agates and their contained uranium are discussed later.

Intertonguing with and overlying the conglomeratic part of the lower porous sandstone sequence is massive to thick-bedded or cross-bedded gray medium- to coarse-grained sandstone. This sandstone is characterized by abundant colorless frosted rounded coarse quartz grains, some with a red hematite coating, and abundant tiny (about $0.1 \mathrm{~mm}$ ) subrounded black magnetite grains. Rounded well-sorted red hematitecoated quartz grains $(0.25-0.5 \mathrm{~mm}$ in diameter $)$ are so abundant in some sections (for example, wells 80 , $82,83,86,118,120$, and 170 ) that the sandstone is dull pink. In these localities, it has little fine matrix or cementing material and resembles dune sand. The volume of this pink sand comprises several cubic miles.

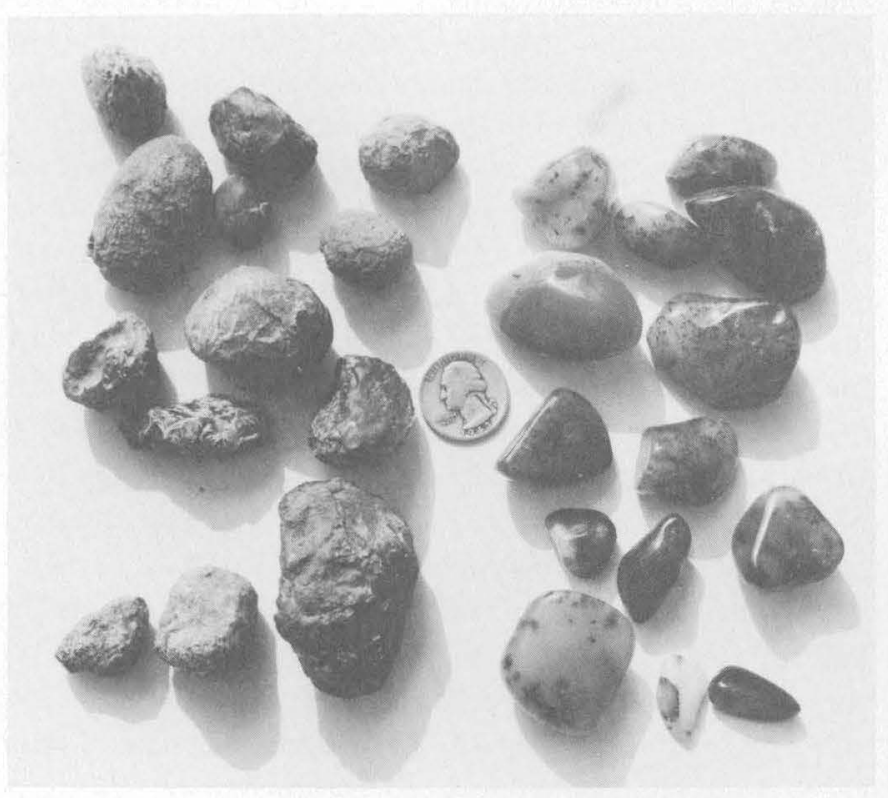

Figure 30 ,- Sweetwater moss agates from the lower porous sandstone sequence in the Split Rock Formation at loe. $18 \mathrm{U}, \mathrm{Ag}$. Those to left of coin are rough stones with brown opaque "bark" on surface, whereas those to the right have been tumbled sufficiently to remove the "bark" and expose black manganese dendrites in a chalcedony matrix. Smooth wind-faceted moss agates in the upper porous sandstone sequence are believed to have been derived from this source.
It is part of the sequence that Stephens (1964) and N. M. Denson (written commun., 1962) assigned to the White River Formation.

Glass shards, rounded grains of several varieties of pyroxene, angular grains of unaltered plagioclase, and slightly abraded quartz bipyramids are common, and in places abundant, in both the sandstone and the conglomerate. Pumicite beds are present but not common in this sequence. Van Houten $(1954,1964)$ reported that the sandstone contains abundant grains of magnetite and augite and moderate amounts of hypersthene and green-brown hornblende. In contrast, the sandstone in the underlying White River Formation contains abundant green-brown hornblende and less magnetite, augite, and hypersthene. Additional regional petrographic data are given by Houston (1964). Thin limestone beds are numerous in outcrops along the western part of the Beaver Divide (fig. 24) and in a few wells $(27,28,85$, and 127$)$ but are rare elsewhere. Studies of the isotopic composition of these limestones were summarized by Cheney (1964).

An unknown green and yellow hydrated chromium sulfate mineral occurs in the lower porous sandstone sequence in well 195 (sec. 9, T. 31 N., R. 84 W.). It impregnates gray conglomeratic arkosic sandstone in decreasing abundance from 10 feet below the surface to the base of the sequence at a depth of 460 feet. Traces are likewise present in the underlying White River Formation, not as cavings from above, but as actual impregnations of the claystone. Not enough material is present in the drill cuttings to permit adequate chemical analysis. The following statement was prepared by E. J. Young (written commun., 1959) :

The sample submitted is a silty fine-grained sandstone. It contains a very small amount of an apple-green mineral. There is also a smaller amount of a yellow mineral. The green mineral is apparently exceedingly fine grained since it does not show any obvious crystallinity under the petrographic microscope. It gives a negative U-flux test and gives no indication of radioactivity with the micro-alpha counter. It is not soluble in cold water, and gives no reaction in $\mathrm{H}_{2} \mathrm{O}_{2}$. It turns pale blue in $1: 5 \mathrm{HCl}$, and the solution surrounding it becomes yellow. It does not seem to go completely into solution. It effervesces in $1: 1 \mathrm{HNO}_{3}$, but does not readily dissolve. It gives a weakly positive test for $\mathrm{Fe}$. An $\mathrm{SO}_{4}$ test was positive, with a very fine precipitate. It turns dark brown in a platinum pan when heated to red heat, and then begins to lighten in color slightly.

A visual-are spectroscopic test showed $\mathrm{Cr}$ to be the only major cation. A small amount of $\mathrm{Ba}$ may be present. An X-ray diffractometer test of the mineral presents an unknown pattern. The three strongest lines, reported as $d$-spacings, are 3.24 , 3.01 , and 3.45 .

The lower porous sandstone sequence yielded one vertebrate fossil, a complete skull of Merycoides cursor, found by $\mathrm{E}$. I. Rich in the SW1/4 sec. 12 , T. 31 N., R. 85 
W. (loc. $23 \mathrm{~V}$, table 10 and pl. 1), approximately 400 feet above the base of the Split Rock Formation. G. E. Lewis, who identified the fossil, considered it to be of early Miocene age and representative of rocks "to be correlated approximately with" the Gering Sandstone of the Arikaree Group in Nebraska (table 8).

A silicified limestone between 100 and 150 feet above the base of the Split Rock Formation in the SW1/4 sec. 18 , T. 30 N., R. 95 W., in the western part of the Beaver Divide area contains the only gastropods found to date in Miocene rocks in the entire Granite Mountains area. D. W. Taylor (written commun., 1962) prepared the following report on this collection:

Fossil mollusks from split Rock Formation

Freshwater snail :

Pseudosuccinea sp.

Locality : USGS 20090. Fremont County, Wyo. SW1/4 sec. 18, T. 30 N., R. 95 W. Iower porous sandstone sequence of Split Rock Formation. Van Houten (1950).

This species was recorded previously by Van Houten (1954, sheet 2) as Lymnaca cf. L. meekiana and Lymmaea cf. L. shumarli. The same collection was recorded by Love (1961b, $p$. 111-I12) as Lymnaea (Pseudosuccinea) sp.

Few Oligocene mollusks, and virtually no other Miocene mollusks, are known from the region; hence, no precise correlations are possible. The living genus Preudosuccinea is first known from the early Miocene of Wyoming, where it appears here in the Split Rock Formation.

The other known occurrences in Wyoming are in Goshen County (USGS 21008, early Miocene or slightly younger) and in Platte County (USGS 22700, middle to late Miocene). Thus, the Split Rock occurrence of Pseudosuccinca is consistent with, but does not prove, a late Tertiary age.

\section{CLAYEY SANDSTONE SEQUENCE}

The clayey sandstone sequence, which is $100-300$ feet thick, consists almost entirely of very soft clayey gray sandstone. It is readily recognizable in most electric logs (pl. 8) from wells north of Crooks Mountain, but it is not as easy to distinguish from overlying and underlying sandstone units in drill cuttings because much of the clay washes out and only sandstone remains. The sand fraction is fine to medium grained and contains many frosted rounded quartz grains, hematite-coated quartz grains, and some slightly abraded quartz bipyramids. Gray to tan siltstone is common, and glass shards are numerous in all rock types. 'This unit was assigned to the White River Formation by Stephens (1964).

The eastern extent of the clayey sandstone sequence has not been determined. In the northeastern part of the area, bentonitic gray and pink claystone beds overlie conglomerate and sandstone of the lower porous sandstone sequence about 300 feet above the base of the Split Rock Formation (core hole 202). These claystone beds apparently occupy the stratigraphic position of the clayey sandstone sequence and may be a lateral equivalent.

Well 188, in the southeastern part of the Granite Mountains area, penetrated about 75 feet of creamcolored bentonitic clayey sandstone beginning at a depth of 2,325 feet. The clayey sandstone is between two thick units of a Split Rock type of sandstone composed of frosted rounded grains and abundant brilliant clear quartz bipyramids. This clayey unit may possibly be equivalent to the clayey sandstone sequence 40 miles to the west.

In the western part of the Granite Mountins area, the contact between the clayey sandstone and underlying lower porous sandstone sequence is at the lithologic change from coarse-grained conglomeratic sandstone below to silty and clayey fine-grained sandstone above.

No fossils have been found in the clayey sandstone sequence, but if the correlations presented here are correct, the sequence is underlain by lower Miocene rocks and overlain by rocks of middle Miocene age (section $O-O^{\prime}$, pl. 4).

\section{SILTY SANDSTONE SEQUENCE}

The silty sandstone sequence consists of fine- to coarse-grained light-gray sandstone, commonly with a silty matrix. It is sparsely pebbly in some areas. In all the rock types tuffaceous beds are present, and glass shards are abundant. Tiny $(0.1 \mathrm{~mm})$ rounded to subhedral magnetite grains, frosted rounded colorless quartz grains, and red hematite-coated quartz grains $(0.25-0.5 \mathrm{~mm})$ are abundant. Limestone is sparse.

This sequence is present in all the thicker subsurface sections in the western part of the Granite Mountains area, but its extent in the northern and eastern parts, where subsurface control is limited, has not been determined. In the area north and northwest of Crooks Gap, the thickness is commonly 300-600 feet in sections where no post-Miocene truncation has occurred. The base is probably gradational, although there is a gross lithologic change from silty (and in many places pebbly) sandstone above to clayey sandstone below.

I believe that the subsurface sections project to the outcrop (section $O-O^{\prime}$, pl. 4) where Stephens (1964) found, in the SW1/4 sec. 10, T. 29 N., R. 93 W. (loc. $10 \mathrm{~V}$, table 10 and fig. 3), the snout of a camel that G. E. Lewis hazarded was a Procamelus- or Hesperocamelus-like species of middle Miocene or younger age. Stephens, however, correlated the fossil-bearing strata with the stratigraphically higher upper porous sandstone sequence in surface and subsurface sections to 
the south and considered most of the silty sandstone to be the upper unit of the White River Formation.

Rachou (1951) found Oxydactylus ef. O. longipes in the SW1/4NE1/4 sec. 4, T. 31 N., R. 87 W. (loc. $21 \mathrm{~V}$, table 10 and pl. 1), and Oreodontoides ef. O. curtus and Cynodesmus cf. $C$. canarus in the $\mathrm{SE} 1 / 4 \mathrm{NE} 1 / 4$ sec. 10 , 'T. 31 N., R. 87 W. (loc. $22 \mathrm{~V}$ ). These fossils were collected from buff to white fine-grained sandstone interbedded with tuff and pumicite that may be part of the silty sandstone sequence. The fossils are considered to be of early middle Miocene age.

Correlation of the silty sandstone within the thick section of the Split Rock Formation in well 188 and elsewhere in the southeastern part of the Granite Mountains area has not been established.

LPPER POROUS SAXDSTONE SEQUENCE

The upper porous sandstone sequence is the thickest subdivision of the Split Rock Formation; it is as much as 1,000 feet thick in the western part of the area and probably is even thicker in the southeastern part. The unit is exposed in most of the outcrops in the deepest part of the Split Rock syncline between the Sweetwater River and the South Granite Mountains fault system (frontispiece; figs. 4, 6, 31, 54), east of R. 89 W. Farther to the southeast, it is overlapped in part by the Moonstone Formation.

A conglomerate and sandstone unit less than 100 feet thick, which is considered to be the basal bed of the upper porous sandstone sequence, forms broad dip slopes between the north edge of Agate Flats and the type section of the Moonstone Formation (frontispiece, A). No subsurface sections are available in this area, but data from isopach maps suggest that the conglomerate is 600-900 feet above the base of the Split Rock Formation. This conglomerate contains the Sweetwater moss agates that were described by Endlich (1879, p. 113). They are subrounded, frosted, and commonly less than 1 inch in diameter, and were apparently shaped by wind and streams before deposition as pebbles in the conglomerate. Most are translucent gray and contain black manganese dendrites, but some are red or brown. They are moderately radioactive (those analyzed contain about 0.01 percent uranium), and many fluoresce a brilliant yellow. In spite of having been collected by lapidaries for the last century, the agates are still abundant.

These agates are identical with but smaller than those previously described in the lower porous sandstone sequence (fig. 50) and likewise contain the uranium mineral trögerite. The only difference is that the older agates have a thick altered surface layer, whereas the younger ones have a fresh wind-abraded surface. If the older sequence was the source of the agates in the upper porous sandstone, the lower part of the Split Rock Formation must have been extensively eroded somewhere to the north or northwest of the Agate Flats (pl. 1). Furthermore, the uranium and silica were

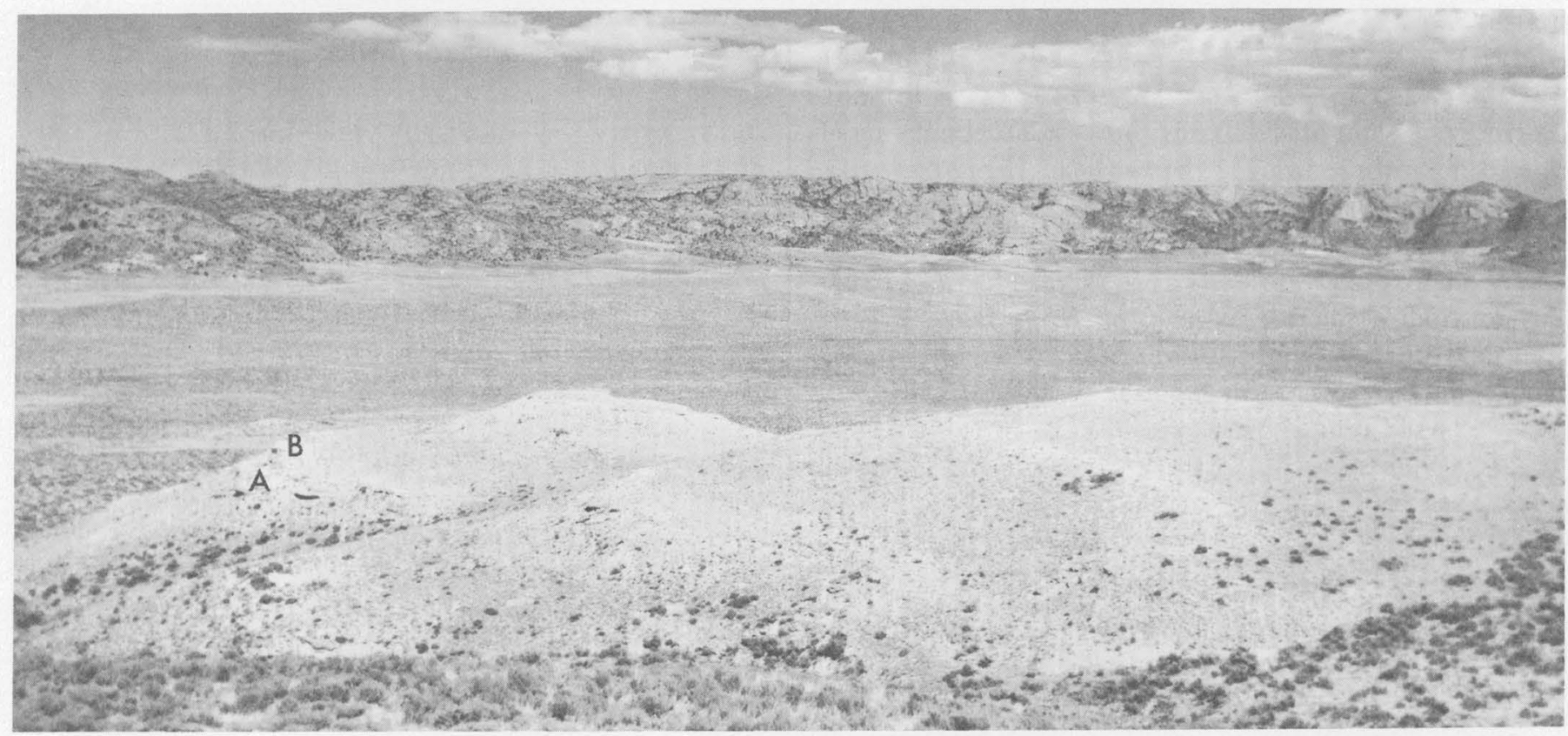

Figure 31.-View north at fossil locality 14P, showing upper part of Split Rock Formation at type locality (foreground) lapping onto Precambrian granite in distance. Beveled surface on crest of Granite Mountains on skyline marks approximate upper limit of deposition of Moonstone Formation. This surface probably also marks the upper limit of burial of the Granite Mountains. A, 10-foot-thick pumicite (Love, 1961b, p. 18, unit 20) is overlain by, B, a white pollen-bearing limestone (Love, 1961b, p. 17, unit 21). 
probably emplaced in the lower porous sandstone sequence during some part of early or middle Miocene time; subsequently, the agates were exposed, transported, abraded, and then redeposited in the upper porous sandstone sequence. The abundance of agates requires a prolific source, and no other source is known.

The dominant lithology in the upper porous sandstone sequence is medium- to coarse-grained gray to buff, massive to coarsely crossbedded sandstone (fig. $32)$. It resembles the sandstone in the underlying part of the Split Rock Formation because of the abundance of rounded frosted gray and clear quartz grains, red hematite-stained grains, brilliant clear slightly abraded quartz bipyramids, and abundant tiny $(0.1 \mathrm{~mm})$ black subrounded magnetite grains.

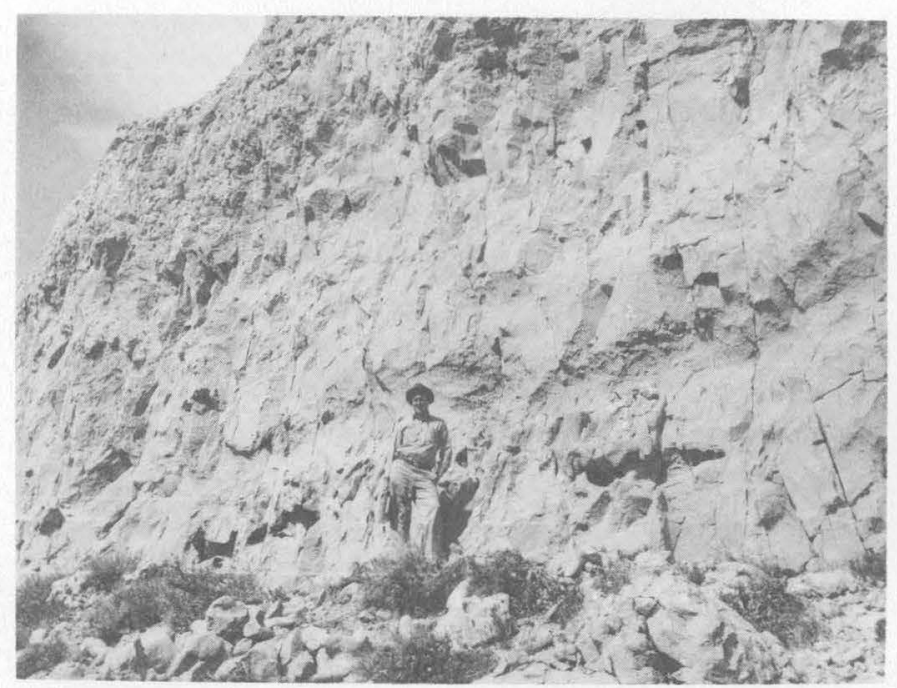

FIGURE 32.-Type locality of Split Rock Formation. Characteristic massive sandstone in upper porous sandstone sequence at site of "Split Rock local fauna" (fossil loc. 11V), SW $1 / 4 \mathrm{SW} 1 / 4 \mathrm{NW} 1 / 4$ sec. 36, T. 29 N., R. 90 W. Note tubular concretions several feet to right of man's left shoulder.

Many beds in both surface and subsurface sections contain so much magnetite that coherent chunks of sandstone can be lifted by a hand magnet. Twenty-five samples were studied in detail because of the possibility that they might be micrometeorites (extraterrestrial particles). Four samples representing magnetite-rich partings (not average rock samples) in a 16 -foot-thick stratigraphic interval at locality $6 \mathrm{M}$ (table 9 ; pl. 1) contained $0.36-5.1$ percent pure concentrate. Spectrographic analyses of the concentrate show maximums (in percent) of titanium, 7.0; chromium, 0.1 ; copper, 0.1 ; nickel, 0.1 ; scandium, 0.005 ; vanadium, 0.2 ; zine, 0.15 ; and zirconium, 0.05. Composite grains of quartz and magnetite are common. In addition to magnetite, the sandstone contains garnet, ilmenite, epidote, hornblende, and zircon. These and other samples were ex- amined by L. B. Riley, Theodore Botinelly, Charles Milton, D. J. Milton, and E. J. Young. Their unanimous conclusion (written communs., 1960, 1961, 1962, 1963) was that there is no compelling evidence that the magnetite had an extraterrestrial origin.

This leaves us with the problem of the source of a tremendous volume of magnetite. Many, but not all, of the grains are highly rounded. They are of relatively uniform size $(0.1 \mathrm{~mm})$ throughout several thousand square miles and 2,000 feet or more of section comprising all four units in the Split Rock Formation. They do not become conspicuously coarser grained or more abundant toward or even on Precambrian cores of mountains.

Magnetite crystals of about the same size compose much of the iron-formation (Bayley, 1963; Spencer, 1916) of Precambrian age at the south end of the Wind River Range. It is unlikely, however, that this 20square-mile area could be the source of magnetite that is distributed throughout many hundred cubic miles of Miocene sand and present in abundance as far away as Nebraska. Magnetite of this size should not only become progressively more abundant toward the southern Wind River Range, if it were the source, but should also be equally as common in the adjacent pre-Miocene Tertiary rocks. This pattern of distribution was not observed.

Modern sand dunes in the part of the Great Divide basin directly south of the Precambrian core of the Wind River Range and others south of the Ferris Mountains have much less magnetite, and it is more variable in size, shape, and appearance than that in the Split Rock. Thus, the evidence suggests that the local mountain uplifts exposed in Miocene time furnished no appreciable amount of magnetite to the Split Rock Formation. The 7,000-foot-thick section of pyroclastic rocks making up the Colter Formation of Miocene age in Jackson Hole is mafic and rich in magnetite (Love, $1956 \mathrm{~b}$; Houston, 1956, 1964); these rocks may be a possible source for part of the mineral suite in the Split Rock Formation.

Limestone beds, some of which persist for several miles, are common in the upper porous sandstone sequence. They occur most abundantly 100-200 feet above the base of the sequence (base of limy zone is indicated by a dashed line in section $D-D^{\prime}$, pl. $1 ; O-O^{\prime}, Q-Q^{\prime}$, $T-T^{\prime}$, pl. 4) in the deepest part of the depositional trough. They are present through several hundred feet of section and are interbedded with limy sandstone. The beds of limestone are commonly chalky white, soft, and finely sandy and contain abundant shards. In a few localities, the limestone is pink or white, dense, brittle, and hard. 
TABLE 9.-Numbered localities, other than fossil, indicated on geologic map and discussed in text

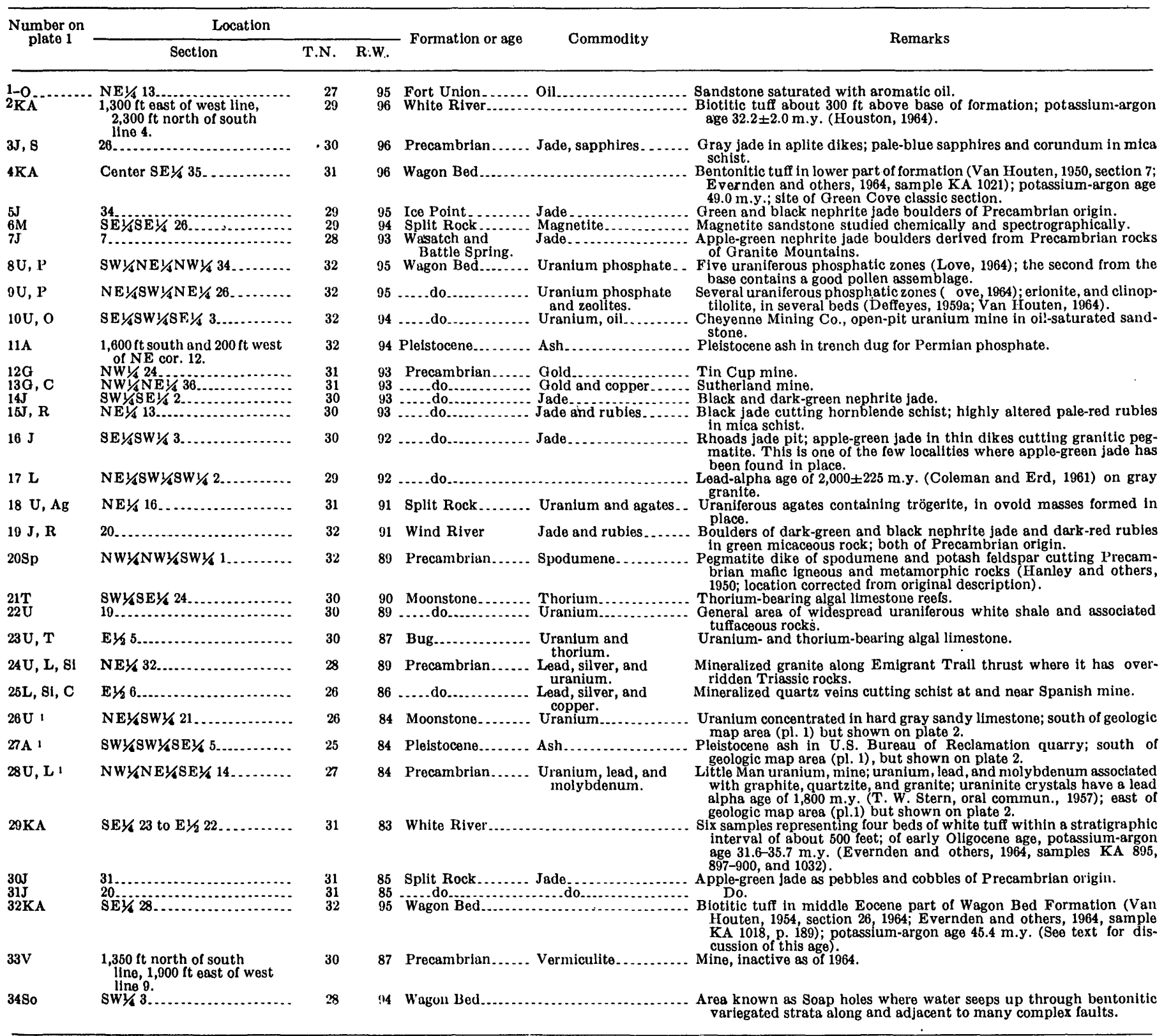

1 Number on pl. 2.

Algal reefs, 10-20 feet thick in places, occur at several localities (fig. 33A, $B$; Van Houten, 1964, fig. 18). Green and white soft waxy claystone is common in the upper part of the sequence at loc. 14P (pl. 1), and pink beds are present north of Green Mountain.

Remarkably pure bluish-white pumicite beds are present in the upper porous sandstone sequence (Love, $1961 \mathrm{~b}$, p. I18, unit 20 of section; this report, fossil localities $14 \mathrm{P}$ and $12 \mathrm{~V}$, table 10 , and figs. 31 and 34 ). 'The shards, which are the major constituent, are curved or rectangular and pink or colorless. Chemical analyses of the purest beds are given in table 7, and comparison of spectrographic analyses of these beds with those of tuffaceous rocks in other formations are given in figure 35. Sandstone beds in this sequence contain plagioclase (predominantly calcic andesine and sodic labradorite), sanidine, red-brown hornblende, red-brown biotite, and monoclinic pyroxenes. A 6-inch-thick zone of chalcedony nodules, locally called "angel agates," of secondary origin occurs in a gray medium-grained sandstone at locality $13 \mathrm{~V}, \mathrm{D}, 5$ feet below a 10 -foot-thick pumicite marker bed (same bed but east of photographed locality of unit 20 in Love, 1961b; this report, fig. 31). These nodules have an attractive pale-greenish-gray 


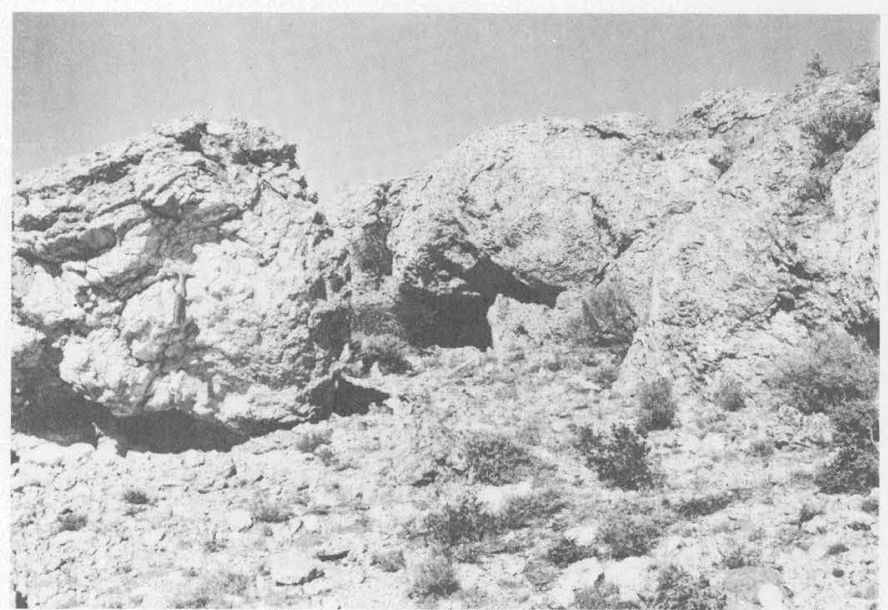

A

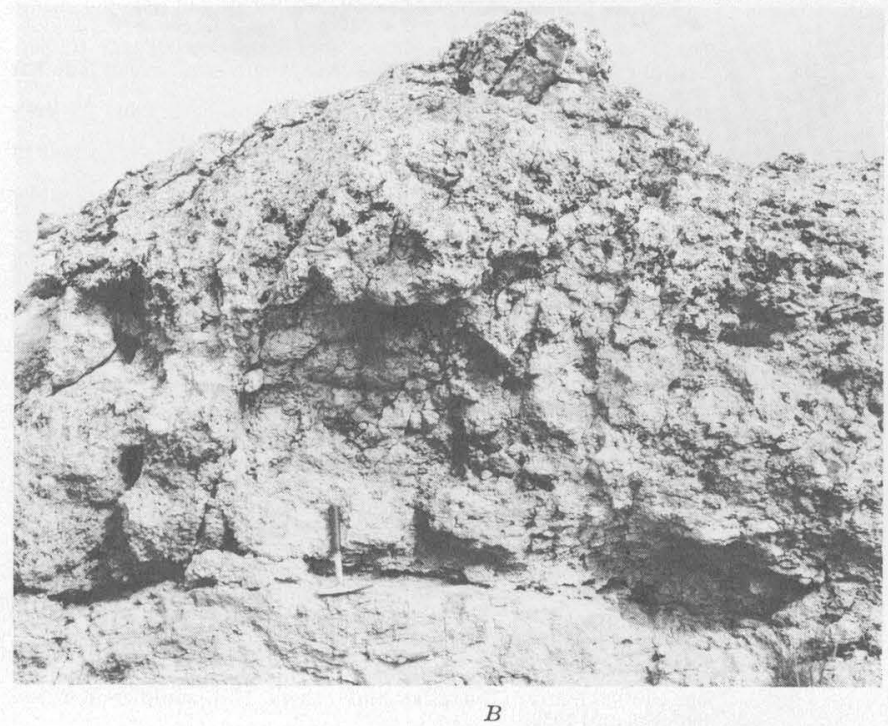

Figure 33.-Algal limestone reefs. $A$, Nonradioactive reef in upper porous sand stone sequence in Split Rock Formation. Reef caps an isolated knob 100 feet high in NE $1 / 4 \mathrm{SE} 1 / 4 \mathrm{sec} .30$, T. 29 N., R. 88 W. Note hammer at left for scale; $B$, Thoriumbearing reef in middle of Moonstone Formation; 1 in fig. 37; in NE cor. NW1/ sec. 25 , T. 30 N., R. $90 \mathrm{~W}$

color, are about 1-3 inches in diameter, are rounded, and have a chalky-white siliceous outer zone of alteration. They fluoresce a brilliant greenish yellow and contain a small amount of uranium (about 0.006 percent). Lapidaries quarry and polish them.

Measured sections, analytical data, sieve analyses, and fossil lists for the upper porous sandstone sequence have been published elsewhere (Love, 1961b, p. I15-I22). The base of the sequence is moderately well defined at most places in drill cuttings, electric logs, and outcrops. The contact is marked by a change from gray silty sandstone below to coarser grained, more porous, conglomeratic, and more limy sandstone above. This change may indicate an erosional unconformity if the inter-

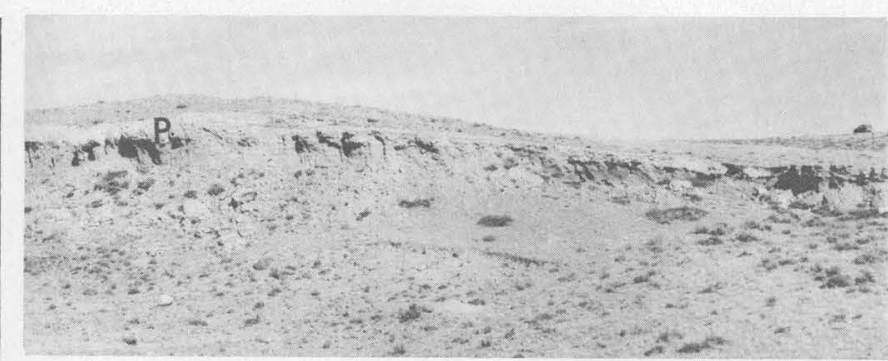

FIGURE 34.-Bluish-gray pumicite marker bed (P) in upper porous sandstone sequence in Split Rock Formation crops out as ledge 6 feet thick (rock analysis 164305 , table 7) and is underlain by soft massive tan sandstone containing fossil mammals (fossil loc. $12 \mathrm{~V}$, table 10 ). View east in $\mathrm{NW}^{1 / 4} \mathrm{NE}^{1 / 4} \mathrm{sec} .31$, T. $29 \mathrm{~N}$., R. $89 \mathrm{~W}$.

pretation regarding the source of uraniferous agates is correct. In subsurface sections north of Crooks Gap, Stephens (1964) considered this change to be the approximate contact between Oligocene and Miocene rocks. The top of the upper porous sandstone sequence is the present erosion surface except where the sequence is overlapped by Pliocene and Pleistocene(?) rocks in the central and southeastern parts of the Granite Mountains area.

The age of the upper porous sandstone sequence is middle Miocene in the sense used in table 8 and by McKenna (1965) for the time equivalent of the upper part of the Hemingford Group of Lugn (1939) in Nebraska. The diatoms identified are listed in table 12, and, in addition, the following fossils have been identified:

Pollen: USGS paleobotany locality D1309; 14P on plate 1; identified by E. B. Leopold.

Artemisia
Ephedra cf. E. nevadensis
Ulmus-Zelkova
Sarcobatus
Pinus
cf. Juniperus
Compositae
Chenopodiaceae

Vertebrate fossils: Localities $11 \mathrm{Y}, 12 \mathrm{~V}, 13 \mathrm{~V}, \mathrm{D}$ on plate 1 ; fossils from several horizons; list compiled from references cited by Love (1961b), Wilson (1960), Reed $(1960,1961)$, and Dawson (1965) and from unpublished data by C. C. Black (written commun. 1959).
Brachycrus rusticus
B. vaughani
B. sweetwaterensis
Metechinus marslandensis
Orcolagus nebrascensis
O. sp.
?Hypolagus sp.
?Desmatolagus schizopetrus
Mesogautus novellus
II. praecursor
Mesoscalops scopelotemos
Limnoecus? sp.
Mookomys sp. 
Gregorymys sp.

Aletomeryx sp.

Schaubeumys sabrae

Protospermophilus sp.

Tamias? sp.

Pleurolicus? sp.

Perognathus sp.

Peridomys sp.

Dikkomys sp.

Tomarctus rurestris

Leporid

Mustelid?

Lizards

Rubber boa

Locality $13 \mathrm{~V}, \mathrm{D}$ warrants some discussion. It was discovered by Schultz and Falkenbach (1940, p. 250), who stated that it was "about 11 miles west of Devil's Gate, Natrona County, Wyoming." This locality yielded the middle Miocene forms Brachycrus vaughani and B. sweetwaterensis (table 10), both of which occur in the "Split Rock local fauna." The precise location and stratigraphic position of the "Devils Gate fossil locality" are of special importance because some geologists have expressed the opinion that many of the strata in this general area appear to them to be
Pliocene in age. In 1944, I sent the late C. H. Falkenbach, the collector of these fossils, a planimetric map (scale 1:125,000; no topographic maps or aerial photogruphs were available at that time) of the region, and he marked the locality and commented on it (C. H. Falkenbach, written commun., May 15, 1944). I investigated this locality and found old pits, fragments of plaster, and many unidentifiable bone scraps (unit 34 of measured section, Love, 1961b, p. I17). Diatom collection 4718 came from bed 31 (table 12) at this locality. The diatom assemblage differs in important aspects from collections from Pliocene rocks in this area. It is true that some strata are thin bedded and clayey like those of Pliocene age, but floods of magnetite in many poorly consolidated sandstone beds composed chiefly of frosted rounded quartz and hematitecoated grains are, in my opinion, more typical of the Split Rock Formation. The appearance of these strata in outcrop (fig. 31) differs markedly from that of the Moonstone Formation of Pliocene age (figs. 38, 42). After evaluating all these factors, I have mapped the rocks common to localities $14 \mathrm{P}$ and $13 \mathrm{~V}, \mathrm{D}$ (pl. 1) as part of the Split Rock Formation.

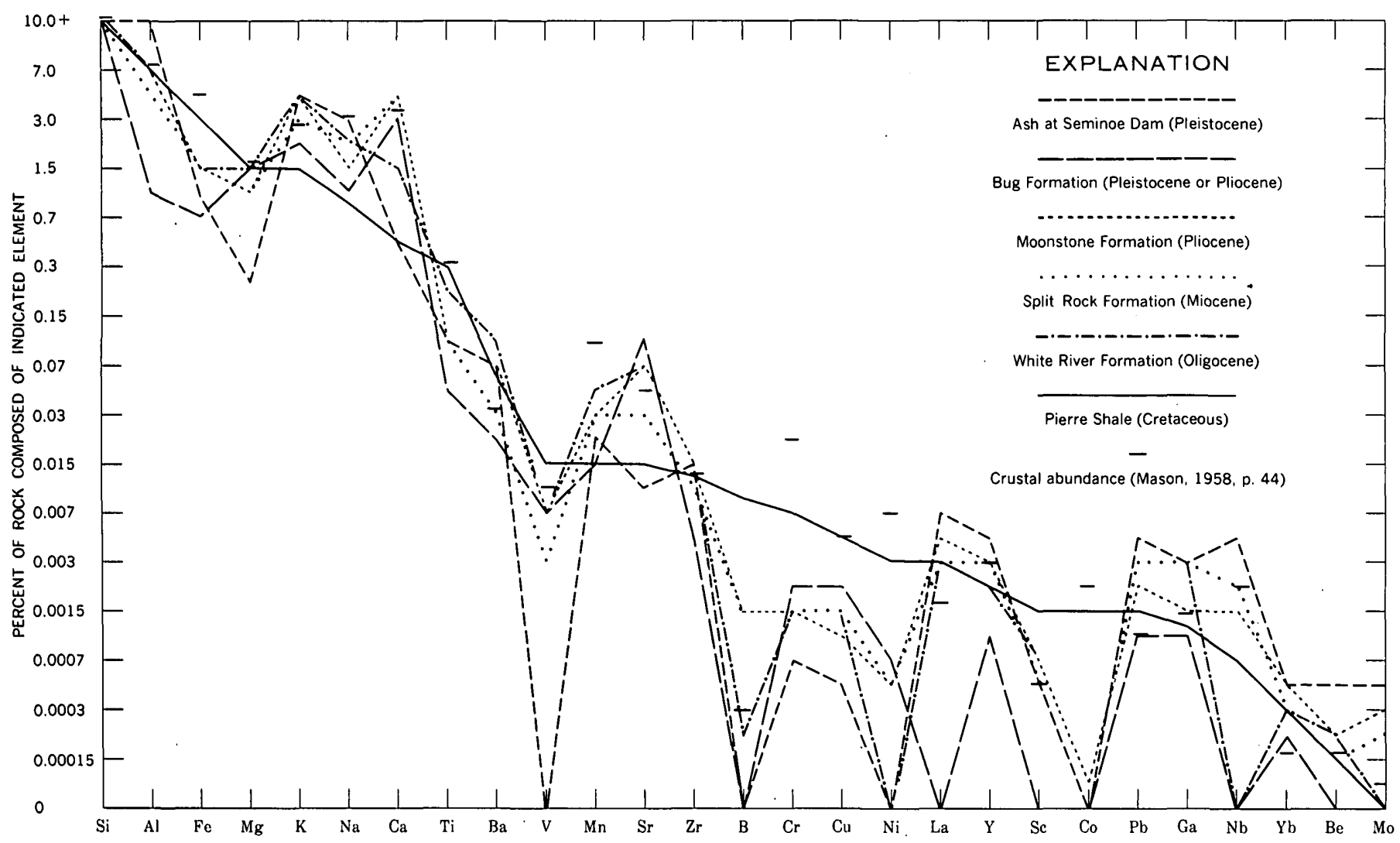

FiaURe 35.-Semiquantitative spectrographic analyses and distribution patterns of selected elements in Oligocene and younger strata in the Granite Mountains area contrasted with those of the Pierre Shale and other marine Cretaceous shales. Values are reported in percent to the nearest number in the series $7,3,1.5,0.7$, etc.; at least 60 percent of results are expected to be in the correct range. Data on Cretaceous shales are by Tourtelot (1962). Elements in Cretaceous shales are plotted in decreasing abundance from left to right to facilitate contrast with those in the younger rocks. 
TABLE 10.-Numbered fossil localities indicated on geologic map and discussed in text

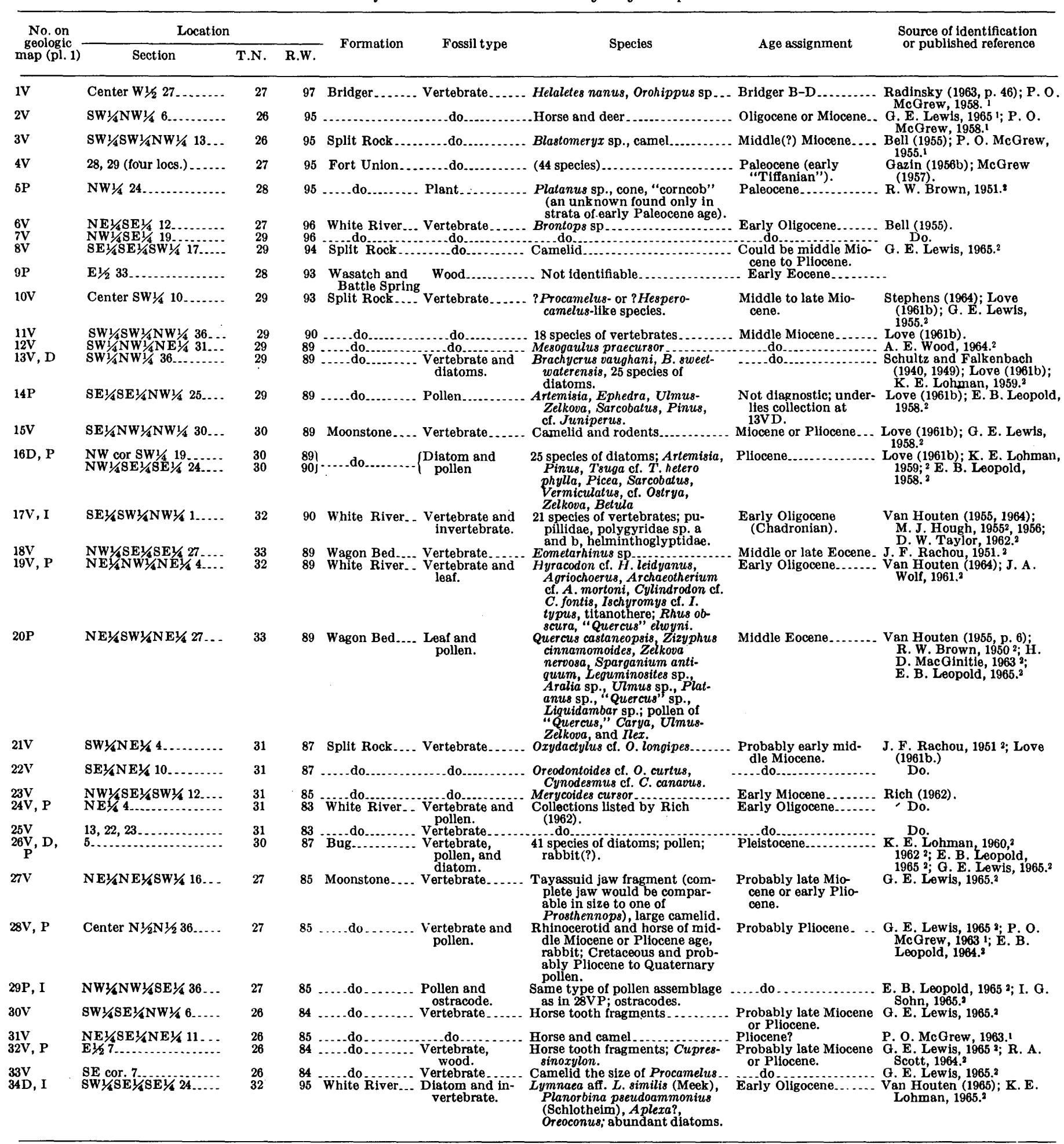

1 Oral commun.

Written commun. 
STRATIGRAPHIC AND STRUCTURAL RELATIONS

In most places in the mapped area, the Split Rock Formation overlies the White River Formation with a marked erosional unconformity. One conspicuous northeast-trending channel in T. 31 N., R. 83 W., cut well down into the White River Formation and subsequently was filled with the basal conglomerate and coarsegrained sandstone of the Split Rock Formation (Rich, 1956). East, south, and southwest of the Rattlesnake Hills, broad areas of the Split Rock Formation lie directly on the Wagon Bed Formation, and no Oligocene strata are present. Southeast of well 21, in the southwestern part of the area, the Split Rock Formation overlaps middle and lower Eocene rocks. At some localities along the Beaver Divide, strata of the White River Formation were extensively reworked into the basal deposits of the Split Rock Formation, and the contact is hard to determine. As previously mentioned, in parts of the area north of the Happy Springs oil field, there is a discrepancy in interpretation of the position of the contact amounting to about 1,000 feet.

The contact between the Split Rock Formation and Precambrian knobs of the Granite Mountains is truly remarkable. In many places, the sandstone overlaps steep unweathered faces of granite with no intervening talus or other coarse debris (fig. 36), and the sandstone extends many feet into joints and crevices. In places such as the one shown in figure 36 , the present topography of the Precambrian knobs now being exhumed is almost exactly that which was buried in middle Miocene time, about 17 million years ago.

The Split Rock Formation is preserved on and adjacent to the Granite Mountains because almost the entire

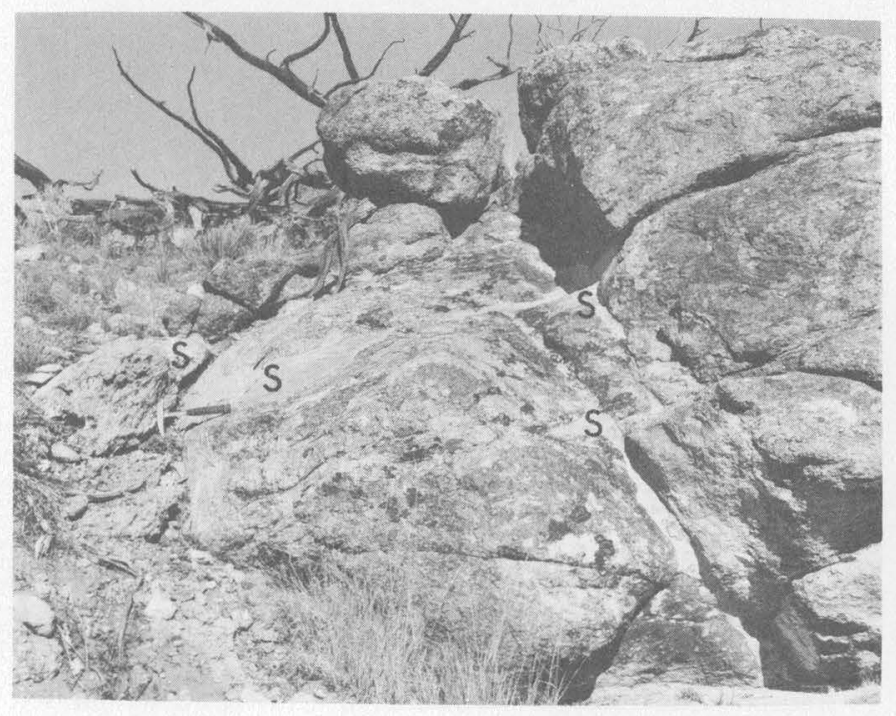

Frgure 36.-Nearly vertical contact between soft sandstone of the Split Rock Formation and hard unweathered Precambrian granite in Granite Mountains is marked by hammer. S, Sandstone also fills joints and crevices in granite. Locality is in NW cor. SW $1 / 4$ sec. 31, T. 30 N., R. 88 W. arch collapsed during post-Miocene time and the strata were downwarped in the Split Rock syncline (pls. $5 E$, $6 \mathrm{D}, 10 \mathrm{H})$. This downfold is broad, asymmetric, more than 70 miles long, and 30 miles wide; and it has a maximum structural relief of about 3,000 feet. The south flank is the steeper. Both sides are downdropped along normal faults (fig. 3, pl. 1), several of which are more than 20 miles long and have a few hundred to more than 1,000 feet of displacement. These are discussed in the section on structure.

\section{AGE AND CORRELATION}

The skull of Merycoides cursor (Rich, 1962) indicates that the lower porous sandstone sequence is of early Miocene age, equivalent to the Gering Sandstone in the lower part of the Arikaree Group of Nebraska (table 8 ). The vertebrate fossils from the upper porous sandstone sequence are of middle Miocene age, the same age as those occurring in the Hemingford Group and Sheep Creek Formation of Nebraska and in the Sheep Creek equivalent in eastern Wyoming.

The middle and upper parts of the Split Rock Formation contain a fauna similar to that of the Browns Park(?) Formation in the Saratoga area (Stephens and Bergin, 1959), 50 miles south of the southeastern part of the Granite Mountains area, where the sandstones have a similar lithology and are 1,500-2,000 feet thick (McGrew, 1951, 1953; Montagne, 1954). It also contains a fauna similar to that in the so-called Browns Park Formation in the Maybell area, northwestern Colorado, where Bergin (1957) and Wayne Chisholm (written commun., 1961) described as much as 2,000 feet of augite- and hypersthene-bearing conglomeratic tuffaceous sandstone somewhat similar to that of the Split Rock Formation. As previously mentioned, however, the formation in the Maybell area is different from the type Browns Park Formation, 50 miles northwest of Maybell; the type strata are more felsic and contain more hornblende and less pyroxene, more vitric tuff and claystone, and less sandstone. Diatoms of late Miocene or early Pliocene age occur in the lower middle part. It would seem, therefore, that the type Browns Park is a younger sequence of different composition not equivalent to the sandstone called Browns Park in northern Colorado and southern Wyoming or to the Split Rock Formation.

In the Cyclone Rim syncline southeast of well 21, south of Bison Basin, Bell (1955) found Blastomeryx sp. and several teeth of an artiodactyl in the Split Rock Formation (loc. 3V, table 10). P. O. McGrew (oral commun., 1959) stated: "The artiodactyl is a camel similar to one I collected from the Marsland formation in eastern Wyoming." 
Middle Miocene vertebrate fossils were found 4,150 feet below the top of the Colter Formation in Jackson Hole (fig. 2), 135 miles northwest of the Granite Mountains area. This formation is 7,000 feet thick, is coarse grained, and consists chiefly of locally derived basaltic and andesitic volcanic debris (Love, 1956b, p. 1904-1907). Vents in Jackson Hole may have furnished a large amount of the volcanic material to the Split Rock Formation; the composition is very similar (Houston, 1956, 1964).

\section{PLIOCENE ROCKS \\ MOONSTONE FORMATION \\ NAME AND DEFINTTION}

The Moonstone Formation was named and defined from exposures in the central part of the Granite Mountains area (Love, 1961b, p. I25-35; this report, pl. 1). It includes some of the strata described as Pliocene by Endlich (1879, p. 112-113). His lithologic description, although generalized, is remarkably accurate. From the date of his publication until 1961, with the exception of the Wyoming geologic map (Love and others, 1955) on which the strata were designated as Pliocene and Miocene rocks, the beds assigned to the Moonstone Formation were considered either as part of the White River Formation or as undifferentiated Miocene rocks.

The southeastern part of the area shown as Split Rock Formation in figure 2 of my 1961 report is now known to contain some strata of the Moonstone Formation. This had been suspected at the time (Love, 1961b, p. I15) but was not confirmed until later.

\section{DISTRIBUTION AND THICKNESS}

The type section of the Moonstone Formation is shown near the center of plate 1 . These soft strata were deposited around the high steep-sided granite knobs comprising the partly buried crest of the Granite Mountains and thus were protected from Quaternary erosion (frontispiece; figs. 8, 37, 38, 44). The type section (Love, 1961b), about 1,350 feet thick, is probably the thickest remnant of the formation. More extensive outcrops are present in the southeastern part of the mapped area. Fieldwork was terminated before these could be studied in detail and the contact with the Split Rock Formation mapped. Fossil localities $27 \mathrm{~V}$ to $33 \mathrm{~V}$ are in the Moonstone Formation.

An upper Tertiary arkosic sandstone sequence 200 feet or more thick overlying the Split Rock Formation west of South Pass at the south end of the Wind River Range, has long been known (Comstock, 1875). It was called Tertiary rocks undivided by Love, Weitz, and Hose (1955) and is probably a western equivalent of the Moonstone Formation.

\section{IITHOLOGY}

The details of lithology of the Moonstone Formation have previously been presented in the type measured section (Love, 1961b, p. I25-I29). A soft poorly cemented arkosic conglomerate and sandstone makes up the basal unit in valley areas; elsewhere, younger finegrained strata lap directly against granite knobs with little intervening talus or coarse conglomeratic debris. The basal unit contains distinctive brown and gray translucent waterworn agates, which were apparently derived from the underlying Split Rock Formation. They are associated with silicified wood and bone fragments.

About 1 mile west of the type section the lower 500 feet of the formation contains some remarkable agatepebble "reefs" that crop out in low ledges for a distance of about 1 mile (fig. 37, 9). Most of the agates are brown and translucent without manganese dendrites, but some Split Rock type of moss agates are present. Only a few are radioactive. The agates range in diameter from $1 / 4$ inch to $11 / 2$ inches; many are rounded but some are angular (fig. 39). Most apparently were formed in place in a tuffaceous light-greenish-gray sandstone matrix. Some bedded chalcedony occurs with the agates (fig. 40).

Conspicuous brown cliff-forming beds are present in the middle part of the Moonstone Formation. These contain bulbous masses as much as 10 feet in diameter of sandy tuffaceous rock (fig. 41) with a spongy texture and a radial internal structure. Richard Rezak (written commun., 1957) said these masses contain poorly preserved vegetative structures of chara. Table 7 lists two analyses of this rock (lab. Nos. 147343 and 147344). Euhedral crystal molds from which some soluble mineral, possibly an evaporite salt, was leached are abundant at several horizons within these beds, and one salt lick was observed. The salt lick is within a sandstone (unit 39 of the type section, Love, 1961b) and consists of a 10-foot-thick lens of greenish-white sandy tuff that contains 0.54 percent sodium and 0.94 percent chlorine.

Most of the strata in the middle third of the type section were deposited either in Moonstone Lake (Love, $1961 \mathrm{~b}$, p. I32 ; Love and others, 1963, fig. 9 ; this report, pl. 10I) or along its margins. Because of poor exposures and distribution of outcrops, there is no way to determine whether this was one lake or a series of separate or interconnected lakes. In the area of the type section, one lake existed, at least intermittently, during the deposition of at least 500 feet of strata, but it was probably shallow and saline, as is indicated by curled mud cakes, diatoms of saline habitat, salt content in the rocks, ripple marks, and absence of mollusks. Similar strata of lesser thickness are present in the southeastern 
part of the mapped area. The finest grained beds occur along the trough line of the Split Rock syncline (figs. $42,43)$. These data indicate that the Granite Mountains continued to sink along the syncline throughout deposition of the Moonstone Formation. The general area of the lake or lakes must have occupied several hundred square miles (pl. 10I).
Sandstone beds throughout the formation are characterized by angular grains of quartz and feldspar, some of which were derived from adjacent granites. However, many grains are fresh-appearing oligoclase or sodic andesine similar to the feldspar in Tertiary volcanic rocks in northwestern Wyoming. Some quartz grains do not have the strain shadows characteristic

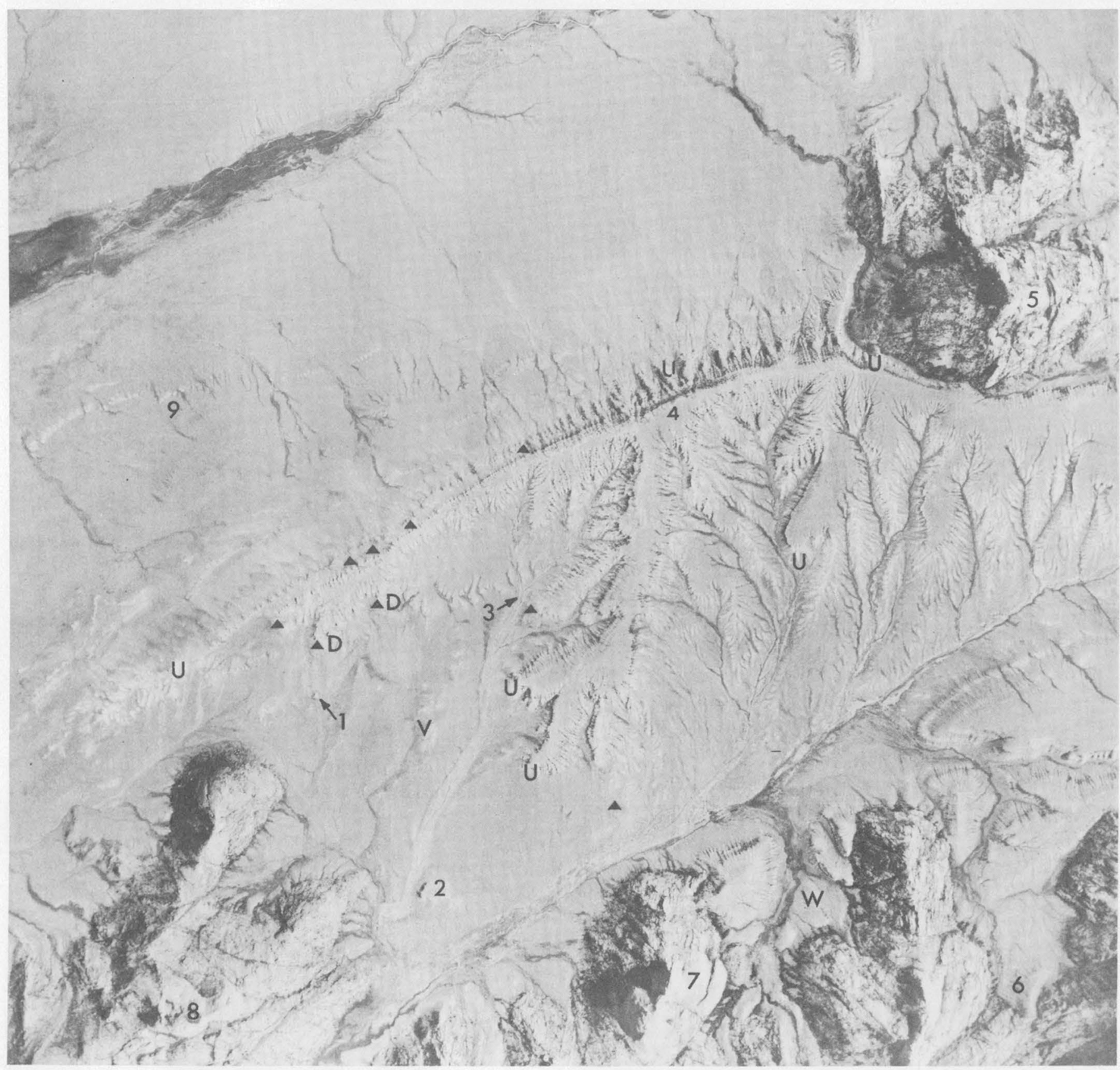

Figure 37-Type section of Moonstone Formation. Aerial photograph, width of view $51 / 4$ miles, north at top. 1 , Thorium-bearing limestone in Moonstone Formation. 2, Algal limestone, not thorium-bearing, in Moonstone Formation. 3, Location of well from which water containing $60 \mathrm{ppb}$ uranium was obtained (well 186 table 2). 4, A pex of White Ridge, composed entirely of strata of Moonstone Formation. 5, Lone Mountain, composed of Precambrian granite, 6, Youngest strat in type section of Moonstone Formation overlapping Precambrian granite. 7, The

Moonstone, a peak of Precambrian granite, the basal part of which is overlapped by lacustrine strata of the Moonstone Formation 8 Lankin Dome, a peak of massive Precambrian granite. 9, Agate "reef" in lower part of Moonstone Formation. D, Diatom locality. V, Vertebrate fossil locality. W, Fossil wood locality. $\Delta$, Localities where the uranium-bearing white shale marker bed was sampled (table 11), U Localities where uranium-bearing strata older or younger than the white shale marker bed were sampled (table 11). Photograph by Aero Service Corp. 


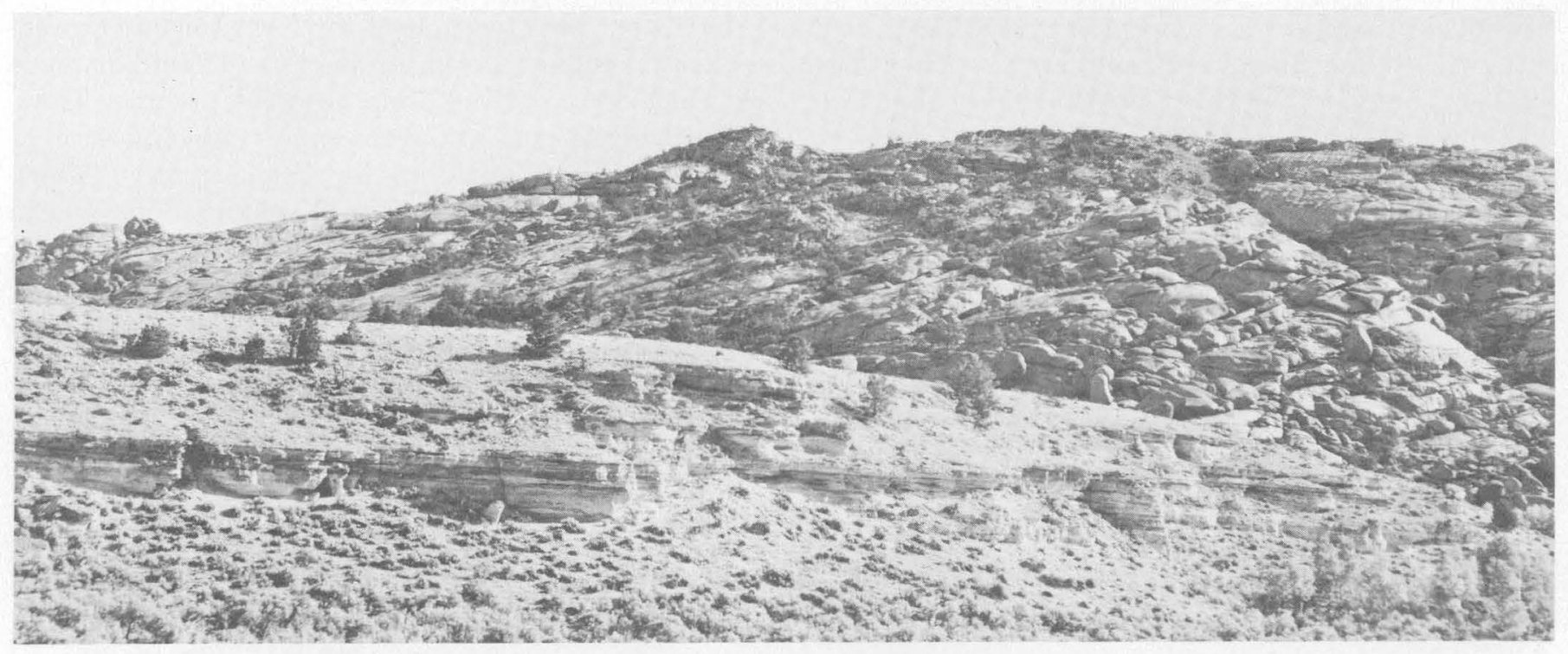

Figure 38.-Thin-bedded strata west of type section of Moonstone Formation. Strata contain abundant fossil wood and were deposited against steep-sided knobs of Precambrian granite. View east on east side of Miller Pocket, SW 144 sec. 28 , T. 30 N., R. 89 W.

of Precambrian quartz in this area. Red-brown biotite and green biotite are common. Orthopyroxene, augite, and oxyhornblende are present in a few thin sections but are rarely abundant. Glass shards may be pink or colorless and needle shaped, rectangular, or sickle shaped, and they are common to abundant in all thin sections studied. Sandstone beds in the southeastern part of the area contain rounded frosted quartz grains, hematite-coated grains, and abundant magnetite grains similar to those in the Split Rock Formation. These grains were probably derived from the Split Rock at

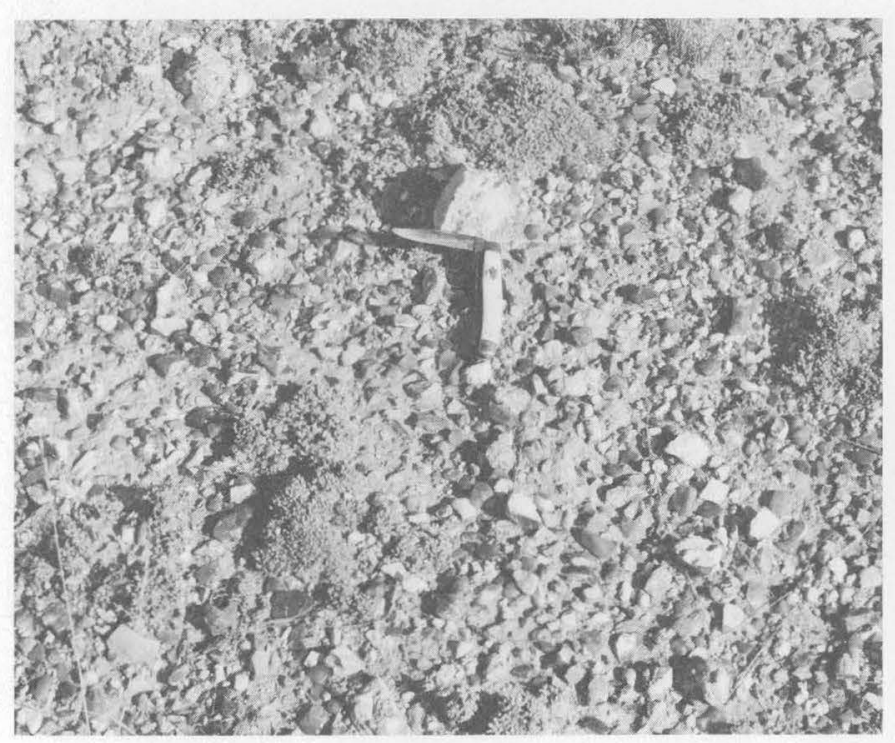

FIGURE 39.-Agates weathering out of tuff in lower part of Moonstone Formation, NW1/4 SE1/4 sec. 14, T. 30 N., R. 90 W. All fragments are of brown or black chalcedony but are not of the variety known as Sweetwater moss agates. the time of uplift and erosion of the area south of the South Granite Mountains fault system. This similarity of lithology makes the contact difficult to locate in many places. Houston (1964) compared the petrography of the volcanic debris in the Moonstone Formation with that of other formations in the Granite Mountains area.

Some of the brown ledges are locally radioactive and contain more than 0.01 percent uranium (table 11). In addition to the brown beds, seven other zones in the middle part of the Moonstone Formation contain uranium. Selected specimens of the most radioactive parts

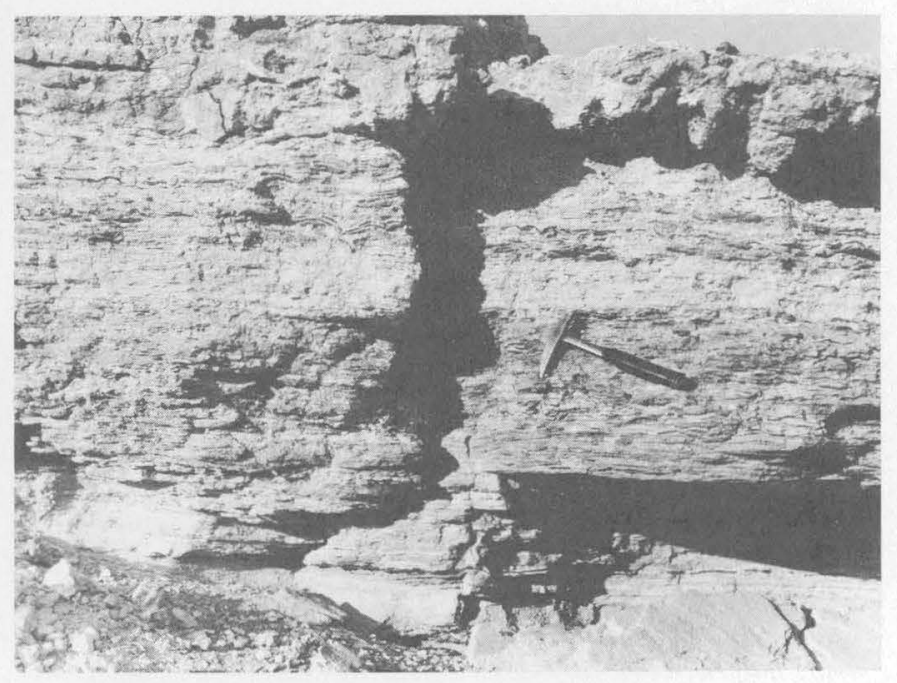

Figure 40.-Interlaminated white shale and datk-brown chalcedony in unit 21 of type section of Moonstone Formation (Love, 1961b). Exposure is on north side of White Ridge, NW 1/4 SE $1 / 4$ sec. 17, T. 30 N., R. 89 W. 


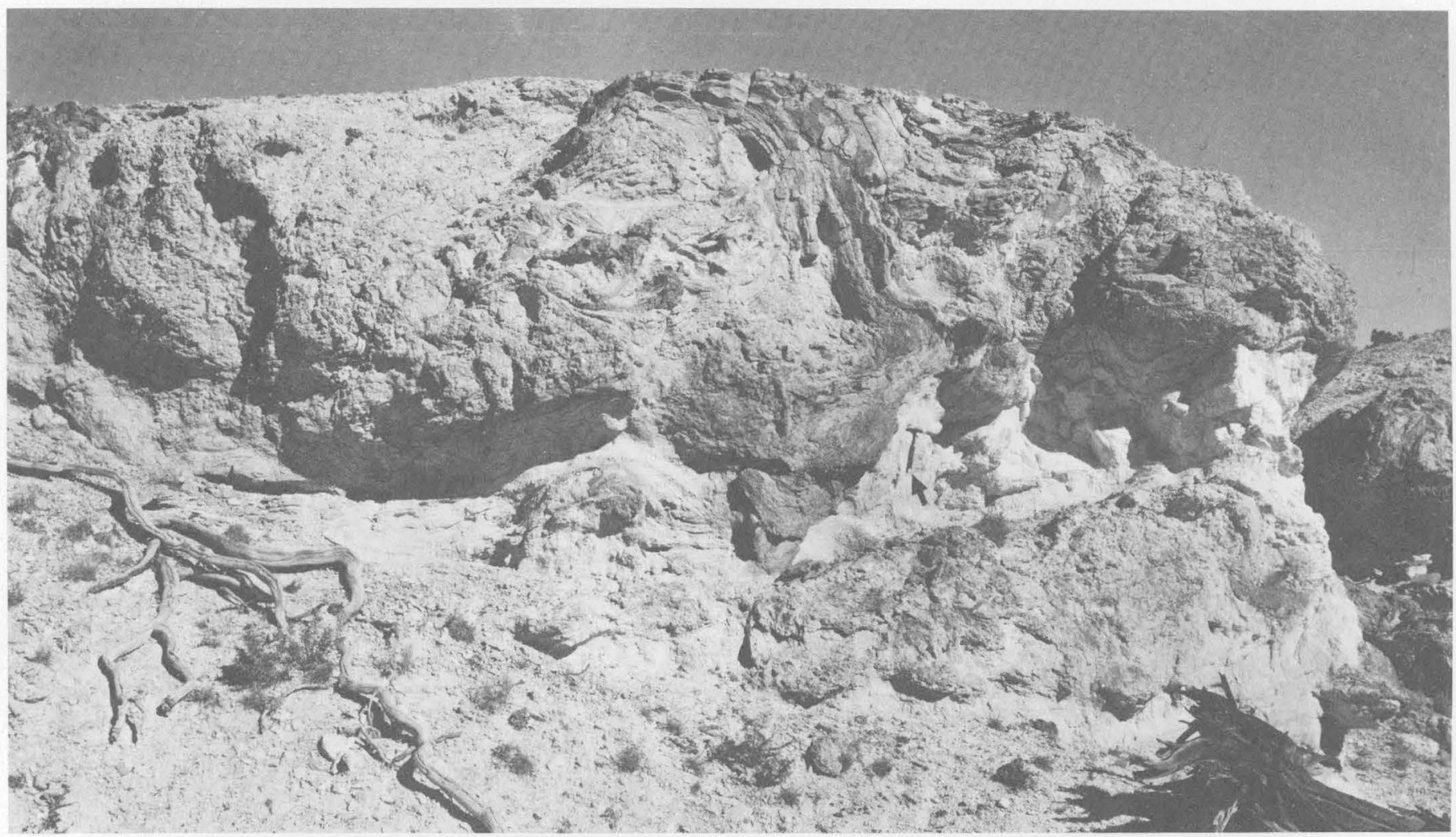

FigURE 41.-Bulbous masses of brown sandy tuffaceous rock, possibly algal reefs, interbedded with white tuff, unit 26, in type section of Moonstone Formation (Love, 1961b). View east on south side of White Ridge, NW1/4 SE1/4 SW1/4 sec. 17, T. 30 N., R. 89 W. Hammer (arrow) shows scale.

of these have a uranium content ranging from 0.003 percent to 0.034 percent. The uranium is present in a variety of rock types such as white shale, white claystone, relatively pure algal limestone, and brown and greenish-white tuff. The uranium-bearing beds range in thickness from 1 inch to several feet. None contains as much as 1 percent $\mathrm{P}_{2} \mathrm{O}_{5}$.

One persistent uranium-bearing white shale bed was sampled in an area of several square miles (figs. 37 and 60 ; table 11). This bed is discussed in the section on economic deposits. It occurs within a distinctive sequence of white shale (units 17-21, type section, Love, 1961b) about 60 feet thick that was deposited in Moonstone Lake, approximately 800 feet above the base of the formation. The shale is laminated, light weight, and extremely fissile. Black, brown, and varicolored chalcedony is interlaminated with the shale in many places (fig. 40). Glass shards are abundant in the coarser grained laminae. Individual beds 3-6 inches thick within the shale can be recognized throughout an area of 3 or more square miles, so conditions at the time of deposition must have been quiescent. The water was probably shallow, for curled mud cakes and mud cracks are common.
Contemporaneous with deposition of the white shale was the growth of five or more "reefs" of algal limestone. Eroded remnants of these range in size from 1,000 feet in diameter and 20 feet in thickness (figs. $33 \mathrm{~B} ; 37$, loc. 2 ) to 60 feet in diameter and 3 feet in thickness. 'The limestone is coarsely crystalline, gray, spongy, and soft. Some of it is structureless; other parts show crinkled bedding and outlines of barrel-shaped masses several feet in diameter. Four of these masses (fig. 60; three listed in table 11) contain uranium or thorium or both (Dooley and Hathaway, 1961). These are discussed in the section on economic deposits.

In the upper 30 feet of the white shale above the uranium bed on the southwest side of Lone Mountain (fig. 37 ), NE $1 / 4 \mathrm{NE}^{1} / 4 \mathrm{SW} 1 / 4$ sec. 16, T. 30 N., R. 89 W., abundant exceptionally well preserved agatized algal "water biscuits," as much as 8 inches in diameter, weather out in great profusion.

Nine samples of clay were studied. They are chiefly mixed layer with some montmorillonite. A white tuffaceous claystone in unit 44 of the type section (Love, 1961b) near the top of the formation contains an appreciable amount of phillipsite $\left(\mathrm{K}_{2} \mathrm{Ca}\right) \mathrm{Al}_{2} \mathrm{Si}_{4} \mathrm{O}_{12}$. $4 \frac{1}{2} \mathrm{H}_{2} \mathrm{O}$. 
TABLE 11.-Uranium analyses of samples from Bug and Moonstone Formations

Samples are arranged in approximate stratigraphic order. Analyses are by G. T. Burrow, E. J. Fennelly, D. L. Ferguson, M. Finch, L. M. Lee, H. H. Lipp, Wayne Mountjoy, W. W. Niles, J. N. Rosholt, D. Schafer, J. Wahlberg, J. Wilson. Equivalent uranium (eU) was determined by beta-gamma scaler, uranium was determined elements]

\begin{tabular}{|c|c|c|c|c|c|c|c|c|}
\hline \multirow{2}{*}{ Sample } & \multicolumn{3}{|l|}{ Location } & \multirow{2}{*}{$\begin{array}{l}\text { Labora- } \\
\text { tory No. }\end{array}$} & \multicolumn{3}{|c|}{ Analyses (percent) } & \multirow{2}{*}{ Remarks } \\
\hline & Section & T.N. & R.W. & & $\mathrm{eU}$ & $\bar{U}$ & $\mathrm{P}_{2} \mathrm{O}_{3}$ & \\
\hline \multicolumn{9}{|c|}{ Bug Formation } \\
\hline 1 & NW1/4NW1/4NE1/4 $5 \ldots \ldots \ldots \ldots \ldots$ & 30 & 87 & 270196 & 0.023 & 0.018 & 0.16 & \multirow{2}{*}{$\begin{array}{l}\text { Limestone, unit } 1 \text { in supplementary type section; contains } 0.046 \\
\text { percent } T \text { h ha23. } \\
\text { Same bed as sample } 1,100 \text { ft north. } \\
\text { Same bed as sample } 1,50 \text { ft north. } \\
\text { Limestone, unit } 6 \text { in type.section; no } \mathrm{Th}^{232} \text { present. }\end{array}$} \\
\hline $\begin{array}{l}2 \\
3 \\
4\end{array}$ & 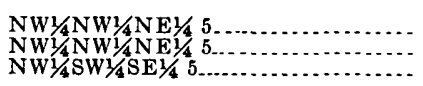 & $\begin{array}{l}30 \\
30 \\
30\end{array}$ & $\begin{array}{l}87 \\
87 \\
87\end{array}$ & $\begin{array}{l}252590 \\
297257 \\
292327\end{array}$ & $\begin{array}{l}.013 \\
.019 \\
.016\end{array}$ & $\begin{array}{l}.022 \\
.019 \\
.016\end{array}$ & .09 & \\
\hline
\end{tabular}

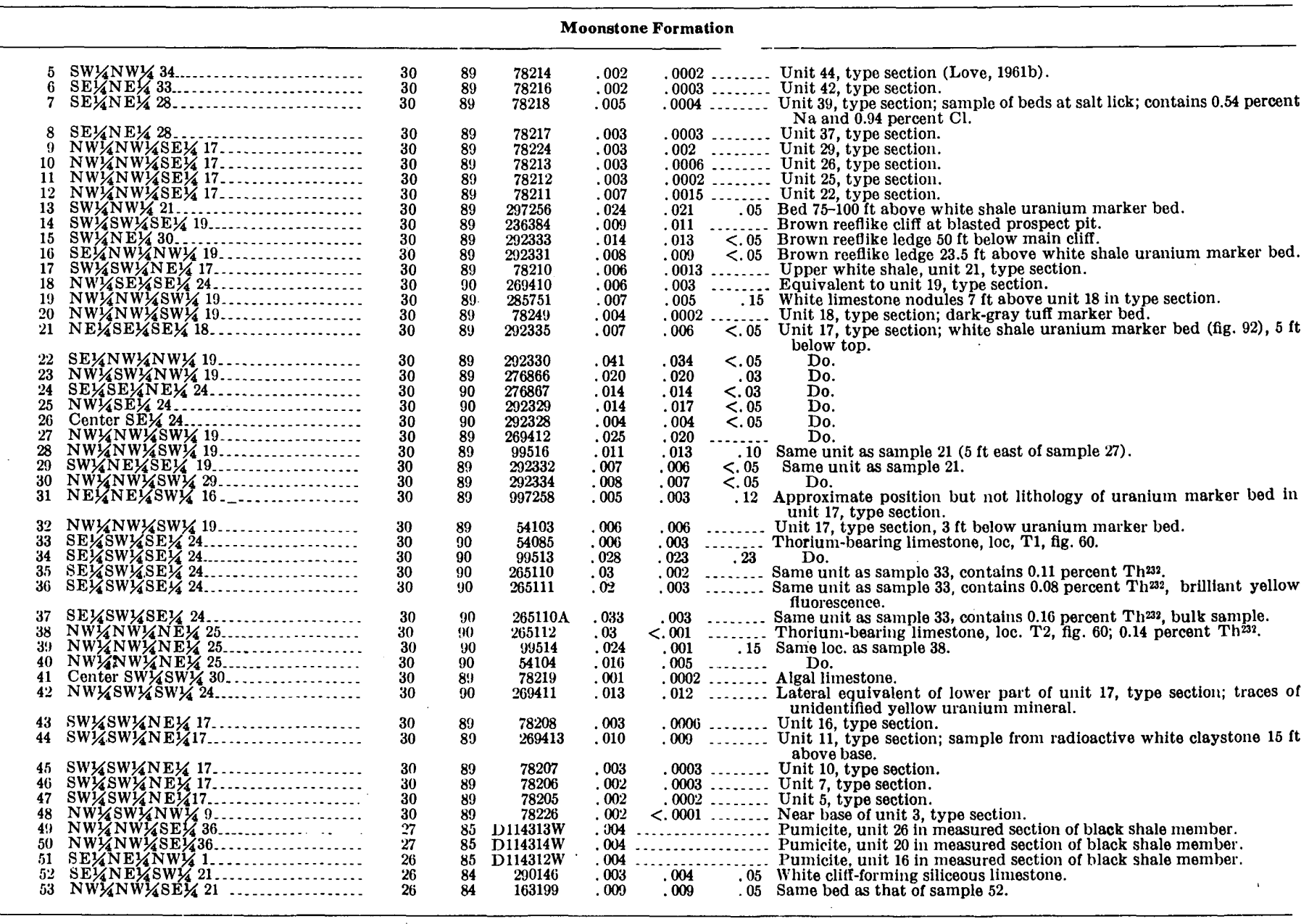

About 6 miles east of the type section is a remnant of the Moonstone Formation (pl. 1) that has approximately 50 feet of coarse-grained poorly cemented conglomeratic arkose with tan tuffaceous matrix at the base. This unit forms a slope and was deposited unconformably on tannish-gray medium-grained soft sandstone of the Split Rock Formation. Above the arkose is a hard ledge-forming massive tan tuff, arkose, and sindstone 30 feet thick. Overlying it is 50 feet of tan soft arkosic and conglomeratic tuff that forms rounded hills. This facies is like that in the lower part of the type Moonstone Formation.

The arkosic sandstone sequence that overlies the Split Rock Formation west of South Pass was described by Comstock (1875) and was mapped as Teritary rocks undivided by Love, Weitz, and Hose (1955). It is a locally derived greenish-gray arkosic sandstone which is cemented by conspicuous fluorescent silica and which contains agates, many of which are like those in the lower 500 feet of the type section of the Moonstone 
Formation. The strata have not yielded fossils as yet, so correlation is not possible, but the lithology is comparable to that in the lower half of the Moonstone Formation at its type section.

In the southeastern part of the Granite Mountains area, the Moonstone Formation is likewise a lightcolored sequence of soft sandstone, pumicite, limestone, and thin claystone beds similar in appearance to that of the type section (figs. 42, 43). Sandstone is much more abundant here than in sections to the northwest, and shale units are thinner, but claystones are common. The dominant lithology is light-gray to pale-greenishgray thin-bedded to massive soft porous medium- to fine-grained sandstone containing rounded frosted sand grains and some hematite-coated quartz grains similar to those in the Split Rock Formation. Magnetite, however, is less abundant in most beds in the Moonstone than it is in the Split Rock. Many conspicuous snowy white pumicite beds are present (fig. 42), as are white sandy tuffaceous soft limestones. Thin beds of white soft sandy shale identical (except for the absence of radioactivity) with those in the type section are present but are not abundant. Pale-green to tan soft silty to very fine grained claystone is common.

At locality $27 \mathrm{~V}(\mathrm{pl} .1)$ is a vertebrate-bearing sequence in the Moonstone Formation. At the base of the fossiliferous section is 50 feet of soft loose porous gray sandstone that looks very much like that in the Split Rock Formation. This is overlain by 3 feet of dull-green flaky soft silty shale that was sampled for pollen and diatoms. The lowest vertebrate fossil horizon overlies the shale and is in a 7 -foot-thick fine-grained homogeneous poorly cemented sandstone. The lower part of the sandstone is reddish brown because of the abundance of red hematite-coated quartz grains similar to those in the Split Rock Formation. The unit likewise contains abundant brilliant clear quartz grains and rounded frosted grains as does the Split Rock. A large leg bone, 27 inches long, of a camel and a fragmentary symphysis of the lower jaw of a pig were found near the top of the unit. The sandstone is overlain by a 3 -foot-thick dark-gray fissile flaky fine-grained shale.

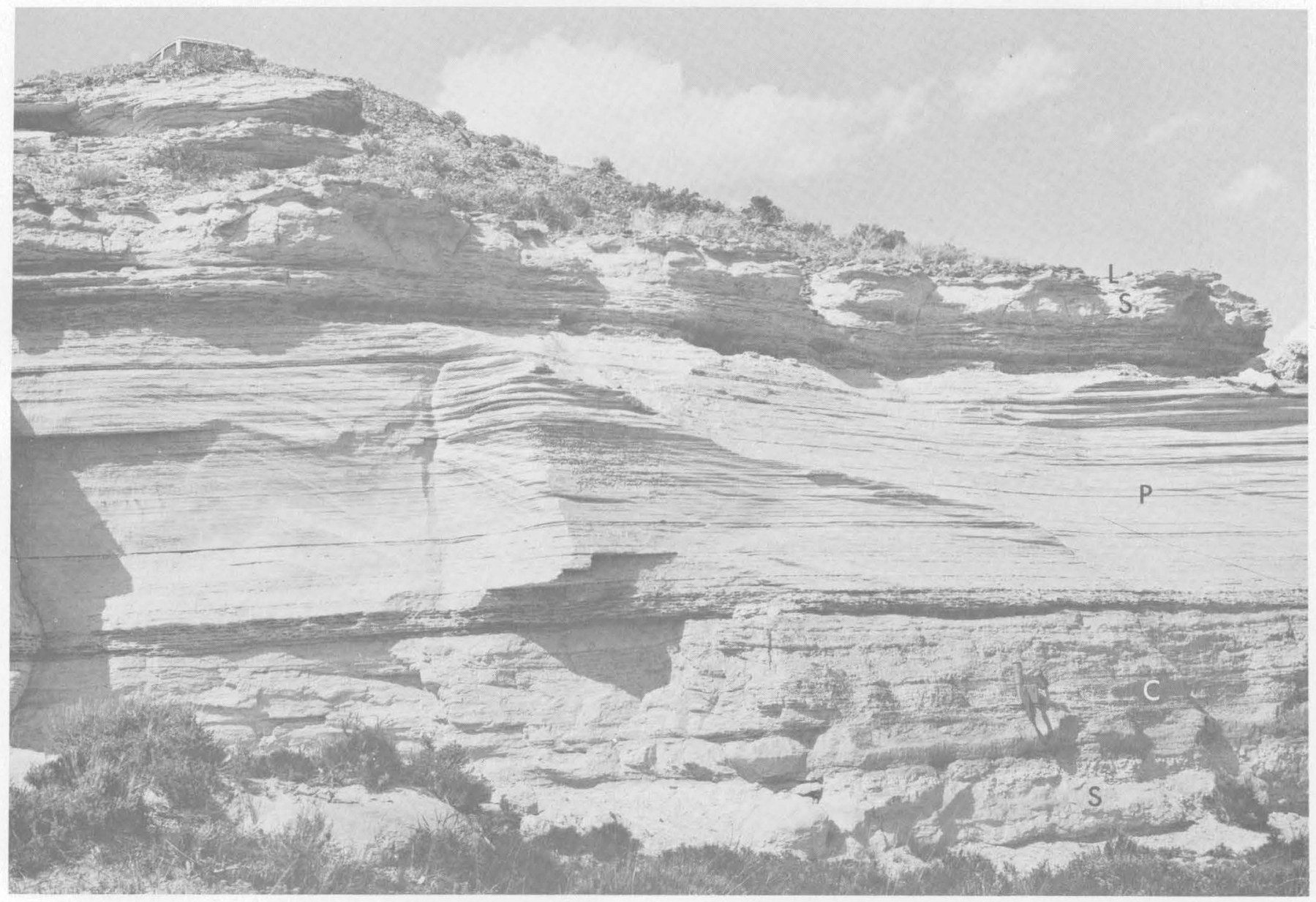

FigurE 42.-Pliocene strata half a mile south-southeast of well 225 in sec. 1, T. 26 N., R. 85 W. S, Sandstone; C, claystone and shale; P, widespread pumicite marker bed; $\mathrm{L}$, limestone. Height of lettered part of exposure is 20 feet. Scintillator at $\mathrm{C}$ gives scale. 
This is capped by 16 feet of light-gray soft sandstone with a hard limy ledge at the top.

Younger strata, 200-250 feet thick, in the sequence overlie this bed and extend to the top of the isolated hill (altitude, $6,466 \mathrm{ft}$ ) 2,200 feet west of locality $27 \mathrm{~V}$. The lower 150 feet is chiefly gray soft porous poorly consolidated sandstone interbedded with thin gray and green claystone. Vertebrate fossils, all nondiagnostic, were found at many horizons in the sandstone. The sandstone is overlain by a 10-foot-thick hard sandy limestone and limy standstone that caps the prominent spur on the northeast side of the high hill. Above the spur is 60 feet of pale-pink, brown, and grayish-green waxy smooth fine-grained claystone interbedded with siltstone and thin layers of sandstone. Unconformably overlying the claystone is about 50 feet of stratified gray arkosic conglomerate containing boulders of granite and Paleozoic rocks. These are discussed later.

Six miles northwest of locality $27 \mathrm{~V}$ (pl. 1), well 188 was drilled through 2,732 feet of Tertiary rocks, the lower half of which is typical sandstone of the Split Rock Formation. The top 130 feet has white claystone and limestone that looks like the Moonstone Formation, and it might extend to a depth of 670 feet or more where similar beds are present. Samples of cuttings examined for diatoms and pollen were barren. More well data are needed to determine the Split Rock-Moonstone contact with certainty.

Seven miles northwest of well 188, well 187 penetrated 400 to 520 feet of beds above beds lithologically similar to the Split Rock Formation. An excellent set of drill cuttings shows this upper sequence to consist of 150 feet of gray soft medium-grained loose sandstone containing frosted rounded grains, hematitecoated grains, some clear brilliant quartz bipyramids, and abundant shards; it is interbedded with green and white smooth fine-grained bentonitic claystone. Samples examined for pollen and diatoms were barren. Below this sequence is 250 feet of white very fine grained smooth claystone and some pumicite beds. Sand grains become increasingly abundant in the lower 150 feet. The underlying 120 feet ( $t o$ a depth of $520 \mathrm{ft}$ ) is white fine- to medium-grained sandstone in a white limy clayey matrix which contains abundant shards. This unit might belong to either the Split Rock Formation or the Moonstone Formation. Below it is more than 1,500 feet of sandstone typical of the Split Rock Formation; the base was not reached.

About 3 miles southeast of locality $33 \mathrm{~V}$ (just outside mapped area, pl. 1), a persistent hard siliceous gray limestone more than 50 feet thick form conspicuous cliffs (fig. 52). It is slightly radioactive; the maximum uranium content of samples I collected was 0.009 per- cent, but uranium operators have reported higher values. Spectrographic and rock analyses of this limestone show no unusual concentration of other elements.

BLACK SHALE MEMBER

Near the top of the Moonstone Formation at localities $28 \mathrm{~V}, \mathrm{P}$ and $29 \mathrm{P}, \mathrm{I}$ (pl. 1 and table 6 ) in the southeast corner of the area is a black shale facies (fig. 43) that is unique among Pliocene rocks of the Rocky Mountain region. It is overlain by strata containing fragmentary horse teeth of questionable Pliocene age and is underlain by strata containing Pliocene diatoms (table 12), as well as vertebrate fossils (locs. $30 \mathrm{~V}, 31 \mathrm{~V}, 32 \mathrm{~V}, \mathrm{P}$, and $33 \mathrm{~V}, \mathrm{pl} .1$ and table 10$)$. The following composite section illustrates the lithology of this sequence and its relations to overlying and underlying rocks.

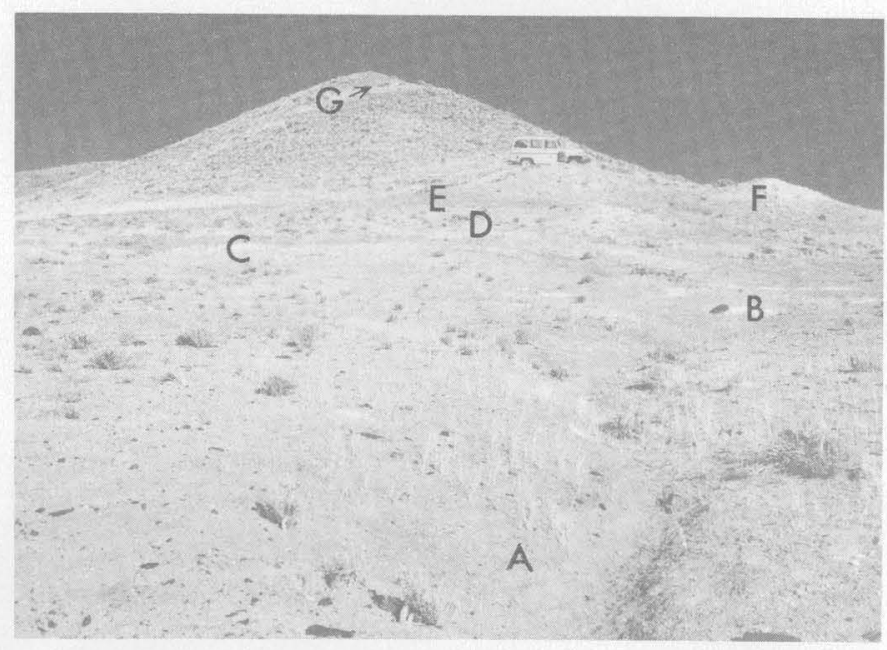

FIGURE 43.-Section of black shale member of Moonstone Formation at locality 28 V, P. View northeast in sec. 36, T. 27 N., R. 85 W. A, Black shale unit 30 containing late Cenozoic and reworked Upper Cretaceous pollen. B, White limestone concretions or algal growths in black shale unit 31. C, White limestone bed comprising unit 32. D, Yellow sandstone unit 36. E, Black shale unit 37. F, Arkosic sandstone unit 38 unconformably overlying black shale member and containing rhinoceros, horse, and rabbit bones. G, Unconformable contact between sandstone and conglomerate of unit 39 below and green and brown conglomerate of unit 40 above.

Section of black shate member and older strata in the Moonstone Formation and unnamed younger rocks

ITop of section is at locality $28 \mathrm{~V}, \mathrm{P}$ (pl. 1) 2,650 feet east of west line and 600 feet south of north line of sec. 36 , T. 27 N., R. 85 W., Pathfinder Reservoir quadrangle, Carbon County, Wyo., on the southwest-facing slope of hill 6251 (fig. 43). Section measured with steel tape by J. D. Love, Sept. 25 , 1963. Strata are nearly flat]

Pleistocene deposit:

Thick-

ness
$($ feet $)$

40. Conglomerate, dark-green to brown; composed largely of mafic igneous and metamorphic rocks and Seminoe iron from Seminoe Mountains 10 miles to the south; fragments angular to rounded, average size $3-6$ in.; locally has light-gray limy sand matrix that is hard enough in a few places to form ledges; could be a very old terrace deposit - the highest in the area. 
Section of black shale member and older strata in the Mroonstone Formation and unnamed younger rocks-Continued

Pleistocene or Pliocene deposits:

39. Sandstone, light-greenish-gray, mediumgrained, homogeneous, soft, almost uncemented; 1-ft-thick pale-green claystone $18 \mathrm{ft}$ above base; forms slope. -

38. Arkosic conglomerate and sandstone, light-gray, soft, poorly cemented, poorly sized; contains angular to rounded rock fragments, chiefly of pink and gray granite, in a coarsegrained sandstone matrix of rounded grains; absence of mafic rock fragments, in contrast to overlying Pleistocene conglomerate, indicates a different source area; unit forms a prominent bench paved with boulders of granite $1 \mathrm{ft}$ or more in diameter to northeast of line of section; yielded a shoulder blade and leg bones of rhinoceros, a leg bone of a rabbit, and a fragment of a horse tooth of Pliocenc aspect but too broken for generic identification; contains numerous oystershell fragments and Inoceramus(?) shell fragments................

Unconformity. Unit 38 was deposited on a relatively planc surface that bevels northeastward across units 37-30 within a distance of $200 \mathrm{yd}$.

Pliocene:

Moonstonc Formation:

Black shale member:

37. Shale; black in lower and middle parts, gray in upper $3 \mathrm{ft}$ bed $\mathrm{E}$ in fig. 43; homogencous where not fractured; fractures filled with sandstone; top 3 ft silty; white flattened limestone nodules and concretions and clear sclenite crystals abundant and conspicuous; pollen samples taken from basal $6 \mathrm{in}$. and another $5 \mathrm{ft}$ above base; pollen sample L63-11-A, USGS palcobotany loc. D3367-A from upper part contains both late Cenozoic and reworked Cretaccous pollen ....-

36. Sandstonc, rusty-tan, homogencous, soft, fine-grained; some rounded frosted grains; some magnetite grains .......

3j. Shale, black, soft, fissile, homogeneous; sampled for pollen

34. Sandstonc, light-rusty-tan, fine-grained, massive, homogencous, very soft and poorly cemented; angular grains; contains chalky white finc-grained limestone lenses or flattened nodules.....

33. Shalc, black, soft, homogeneous; sampled at basc and at top for pollen and diatoms; pollen sample L63-11$B$, USGS paleobotany Joc. D3367-B from top $1 \mathrm{ft}$; contains both late Cenozoic and reworked Cretaceous

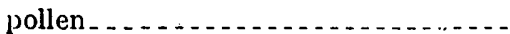

11

3. 7

6

1. 3

4. $\overline{3}$

Scction of black shale member and older strata in the Doonstone Formation and unnamed younger rocks-Continued

Pliocene-Continued

Moonstone Formation-Continued I' hick-

Black shale member-Continued

32. Algal(?) bed, white; composed of masses of chalky-whitc rounded "heads" or possibly flattened concretions as much as $6 \mathrm{in}$. thick and 3 ft long; forms a continuous conspicuous layer (bed $\mathrm{C}$ in fig. 43) .........

31. Shale, dark-gray to dark-brown, soft, fissile to slightly blocky; has thin silty partings; chalky-whitc algal(?) "heads" or flattened limestone concretions as in overlying unit; pollen and diatom samples taken from bottom $1 \mathrm{ft}$, from $6 \mathrm{ft}$ above base, and from top $1 \mathrm{ft}$; also pollen sample L63-11-C, USGS paleobotany loc. D3367-C taken from about middlc of this unit; contains both latc Cenozoic and reworked Cretaceous pollen; spectrographic analysis incorporated with other analyses of Moonstone Formation in table 6; sample SBR63-151X analyzed for oil by J. W. Smith, U.S. Bureau of Mincs (written commun., 1963); no oil found ...........................

30. Claystone and shale, dull gray to ocher, soft, plastic in part; exposed only on west side of hill (bed $A$ in fig. 43); pollen sample L63-11-D, USGS paleobotany loc. D3367-D from upper part contains both late Cenozoic and reworked Upper Cretaceous pollen . . . . . . . . . . . . . . . . . .

29. Sandstone, white, fine-grained, hard, slabby, very limy; almost a sandy limestone in places; forms ledges. . . -

Underlying beds measured in exposures on prominent south-facing hill $2,000 \mathrm{ft}$ south-southeast; offset on top of unit 29; at loc. 29P, I (pl. 1).

30. Same as unit 30 in section to north; sampled for pollen and lithology and described here in order to comparc with section to north. Shale, tan to gray in upper part; contains gypsum crystals and seams; very fine grained sandstone and siltstone partings; becomes progressively more limy in lower part; lower $5 \mathrm{ft}$ has enough oil content to float small chunks of shale in dilute acid; pollen samples taken at $18, .15,10,5$, and $1.5 \mathrm{ft}$ above base.

29. Sandstone, pale-pink to rusty-gray; very soft and structureless in part; thin bedded and rusty in top $6 \mathrm{ft}$, with weak slabby ledges; interbedded with dark-gray shale in top $1 \mathrm{ft} . . .$. 
Section of black shale nember and older strata in the Moonstone Formation and unnamed younger roclis-Continued

Pliocene-Continued

Moonstone Formation-Continued

Black shale member-Continued

28. Shale, dark gray in lower part, pale green from $3 \mathrm{ft}$ above base to top, soft, smooth, fissile, homogeneous, noncalcareous in lower part and very calcareous near top; numerous very tiny ostracodes in top $1 \mathrm{ft}_{\text {. - }}$

Total thickness of black shale member (using thickness of unit 30 in northern section) about.

Older strata:

27. Sandstone, pale-pink to tan, very soft; almost unlithified except for a weak ledge $18 \mathrm{ft}$ above base; poorly sized, with very fine grained sandstone and siltstone matrix; grades up to coarse sandstone with highly rounded and completely frosted quartz grains; many hematite-coated grains; sparse tiny black magnetite grains; looks like sandstone in Split Rock Formation except for poor sizing, abundance of silt, and sparse magnetite

26. Pumicite, snowy-white to gray, evenly bedded, relatively pure, very fine grained, poorly cemented; angular flat shards; rock analyses 163201, 164309 , and 164308 , table 7 ; spectrographic analyses $\mathrm{LW}-1205, \mathrm{LW}-1236$, and LW-1237; uranium analysis D114313W, table 11...............

25. Sandstone, pink to tan; mediumgrained with silty matrix; loose, almost uncemented, and noncalcareous; contains numerous coarse grains, rounded highly frosted grains, many coated with red hematite, many brown grains, many brilliant clear quartz grains; looks identical with sandstones in the Split Rock Formation except for poor sizing and sparse very small magnetite grains

24. Limestone, white, chalky, thin-bedded, hard; sandy in some parts; forms conspicuous slope dipping about $1^{\circ}$ north

23. Sandstone, gray, thin-bedded; soft but more completely cemented than unit 25; composed of rounded frosted grains and common hematite-coated quartz grains; matrix somewhat silty; forms slope broken by weak ledges; is approximate zone in which occur logs of opalized wood whose cell structure has been so completely destroyed that identification is not possible (R.A. Scott, oral commun., 1963)

22. Limestone, white, slabby, very sandy, thin-bedded
Scction of black shale member and older strata in the Moonstone Formation and unnamed younger rocks-Continued

Pliocene-Continued

Moonstone Formation-Continued

Thick-

(fect)

21. Sandstone, gray, tuffaceous, silty, porous; very soft in lower part; slabby and forms thin-bedded ledges in upper part; contains many large and small rounded frosted grains and hematite-coated grains; upper part very limy . . . . . . . . . . . . . . . . .

20. Pumicite, white, sandy, thin-bedded; rock analysis 163202, table 7; uranium analysis D114314W, table 11 _

19. Sandstone, brownish-gray, mediumgrained; contains frosted rounded grains and hematite-coated quartz grains as in the Split Rock Formation, and arkosic sandstone beds with pebbles up to 1/4-in. in diameter; soft gray claystone and limestone beds in lower part; unit was drilled through in well 225; sample from lower section submitted for diatoms but nonc found; thickness uncertain but probably fairly close

Underlying beds measured at locality of figure $42,2,500 \mathrm{ft}$ west of east line and $600 \mathrm{ft}$ south of north line of sec. 1, T. $26 \mathrm{~N}$., R. $85 \mathrm{~W}$., 2,000 ft south-southeast of well 225 .

18. Limestone, brownish-gray, hard, sandy; forms ledge ( $L$ in fig. 42) ..........

17. Sandstone, brownish-gray, massive to coarsely bedded (upper $S$ in fig. 42) - -

16. Pumicite, white, remarkably laminated (fig. 42); ripple marked near base; sandy in part; radioactive and shows yellow fluorescence near top; uranium analysis D114312W, table 11; spectrographic analysis LW-1204; rock analysis 163200 , table 7 .

15. Claystone, white, laminated, nonradioactive; contorted in part; some sandy and tuffaceous laminac (fig. 42); sampled for pollen and diatoms; spectrographic analysis LW-1197 (bed $\mathrm{C}$ in fig. 42)

14. Sandstone, brownish-gray, soft; massive in part; contains many rounded sand grains (lower $S$ in fig. 42) .......

13. Marl, snowy-white, fine-grained, blocky . . . . . . . . . . . . . . . . .

12. Sandstone, brownish-gray, very limy; massive in part; contains many rounded frosted sand grains . . . . . . . .

Underlying beds were drilled in well 225; section is offset on pumicite bed, unit 16, but units 15 to 12 are omitted to avoid duplication of description. 
Section of black shale nember und older strata in the Moonstone Formation and unnamcd younger rocks-Continued

Pliocene-Continued Moonstone Formation-Continued

11. Sandstone and conglomerate; pebbles of mafic Precambrian rocks and granite, up to $1 \mathrm{in.}$ in diameter, in gray soft tuffaceous sandstone matrix ........

10. Claystone, white, soft; contains biotite flakes; interbedded with white soft

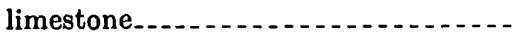

9. Marlstone, white, soft; sandy in part; interbedded with some layers of very fine grained limestone in lower part; samples collected from top, middle, and bottom parts were barren of diatoms........................

8. Sandstone, white, fine-grained, very limy; contains abundant shards in lower half . . . . . . . . . . . . . . . . .

7. Sandstone, white, fine-grained, very homogeneous, very limy; contains abundant shards; disintegrates rapidly in dilute $\mathrm{HCl}$ but does not decrepitate in water; some white fine-grained marly claystone in lower $15 \mathrm{ft}$; two samples from lower $35 \mathrm{ft}$ were barren of diatoms; this is believed to be the approximate part of the section that yielded horse teeth at localities 32 V, P and 30V (table 10) ...........

6. Sandstone, brownish-gray, coarsegrained, loose; contains abundant rounded frosted grains, hematitecoated quartz, and small round brown and black magnetic grains...........

5. Claystone, pale-green; pumicite, white, very fine-grained, and limy white fine-grained sandstone..............

4. Sandstone; pale pink because of abundant hematite-coated quartz grains; contains abundant white siliceous root casts. . . . . . . . . .

3. Claystone, white; interbedded with fine-grained limy sandstone; sample taken at $310-315 \mathrm{ft}$ contains abundant diatoms of Pliocene age (USGS loc. 5663, table 12) . . . . . . .

Total approximate thickness of Moonstone Formation. . . . . . . 480

Probable contact between Moonstone and Split Rock Formations.

Miocene:

Split Rock Formation:

2. Sandstone, pinkish-gray, medium- to coarsegrained, loose; white limy matrix in upper $75 \mathrm{ft}$; contains abundant hematite-coated quartz grains and abundant frosted rounded grains, magnetite common but smaller than that in Split Rock Formation farther west
Section of black shale member and older strata in the Moonstone Formation and unnamed younger rocks-Continued

Miocene-Continued ThickSplit Rock Formation-Continued (feet)

1. Sandstone, brownish-gray, medium- to coarse-grained, loose, rounded frosted grains with less fine-grained matrix than in overlying unit; some granules and pebbles 1 in. in diameter; clear brilliant quartz grains common................

Thickness of drilled part of Split Rock Formation

The unusual occurrence of Cretaceous-type black shale containing Cretaceous and Pliocene pollen (table 13), with arkosic sandstone containing oyster-shell fragments and Inoceramus (?) shell prisms at the top, in a sedimentary basin surrounded by Precambrian rocks warrants further comment.

Areas of Upper Cretaceous shale in central and south-central Wyoming that could have been exposed in Pliocene time are limited to the Hanna basin (fig. 2) south of the Seminoe Mountains. The state of preservation of the Cretaceous pollen is so excellent that it suggests they. were reworked from lumps of shale, rather than transported as individual grains. The fragments of marine megafossils such as oysters and Inoceramus (?) corroborate this interpretation, for it is unlikely that they could have been blown over the mountains by wind. Assuming, then, that the shale was water transported from south of the Seminoe Mountains, it had to be transported (1) by the North Platte River across the mountains through Black Canyon (fig. 46), (2) around the east or west ends of the Seminoe Mountains, or (3) across the Seminoe Mountains when they were buried by Miocene and Pliocene strata.

The distinctive Seminoe iron ore (Lovering, 1929) that is a conspicuous Precambrian rock in the eastern part of the Seminoe Mountains is absent from coarse clastics overlying the black shale. Thus, the possibility of a stream bringing the shale around the west end of the mountains is eliminated. A stream around the east end would have been possible, but if such did exist, it would be difficult to explain how the present course of the North Platte River could have been established at a later date across the middle of the mountains. If the stream transporting the black shale were funneled through Black Canyon, a narrow, twisting course flanked by precipitous walls of Precambrian rocks (fig. 46), we should expect soft black shale chunks to have been pounded to pieces and mixed thoroughly with coarse granite fragments. This did not happen. 
It seems most likely to me that the Hanna basin was uplifted in early Pliocene time, the Miocene and older Tertiary rocks were completely stripped from the uplift, and broad areas of black Cretaceous shale were thus exposed (pl. 10J). Then, as the Granite Mountains continued to sink along the Split Rock syncline, the ancestral northward-flowing North Platte River brought a flood of Cretaceous black shale directly across the buried Seminoe Mountains, and, at a later date, the mountains began to rise with respect to the basins on either side, and the river cut an antecedent course across them. Remnants of the Split Rock Formation, which are preserved in downfaulted blocks on the Seminoe Mountains west of Black Canyon, indicate that this formation once at least partly covered the mountains. A conspicuous erosion surface on Precambrian rocks on both sides of the canyon could be interpreted as the limit of burial of the mountains during Miocene or Pliocene time or as a surface cut immediately before the mountains began to rise in Pliocene time.

\section{STRATIGRAPHIC AND STRUCTURAL RELATIONS}

The Moonstone Formation overlies Precambrian and Paleozoic rocks and the Split Rock Formation. The topography which was cut on Precambrian rocks between Eocene and Pliocene time was mountainous. Many granite peaks near the type section of the Moonstone Formation have a relief of 1,000 feet or more in a horizontal distance of $1 / 4-1 / 2$ mile (frontispiece; figs. $8-11,37,38,44)$. As can be seen in these photographs, the ancient topography of this part of the Granite Mountains now being exhumed is almost unchanged from that which existed during deposition of the Moonstone Formation perhaps 10 m.y. ago (pl. 10), and of the Split Rock Formation 15-20 m.y. ago.

In the central part of the Granite Mountains area, the basal beds of the Moonstone were deposited in shallow channels cut in the underlying Split Rock. Contact relief is rarely more than 50 feet in a horizontal distance of 300 feet. The type Moonstone Formation dips about $1^{\circ}-2^{\circ} \mathrm{SSW}$., whereas the underlying Split Rock Formation dips about $2^{\circ}-4^{\circ}$ SSE. Two factors suggest that downwarping of the Split Rock syncline was in progress before deposition of the Moonstone Formation began: The strike of the Moonstone is slightly divergent from the average strike of the Split Rock, and the Moonstone dips less than the Split Rock.

Inasmuch as outcrops of the Moonstone Formation and the younger Bug Formation are no closer than 3 miles, their unconformable relation can only be inferred. This is discussed in connection with the Bug Formation.
As previously mentioned, the contact between the Moonstone and Split Rock Formations is difficult to determine in some localities in the southeastern part of the Granite Mountains because of the extensive reworking of sandstone from the Split Rock into the Moonstone. East of the North Platte River (outside the area shown on pl. 1), a conspicuous unconformity is present.

\section{AGE AND CORRELATION}

Assignment of a Pliocene age to the Moonstone Formation is based on occurrences of diatoms and vertebrate fossils. Diatoms were found about 800 feet above the base of the formation at several localities near the type section (table 12; fig. 37). A large collection was obtained from well 225 near the base of the formation in the southeast corner of the area. With references to collections 4695,4709 , and $4711, \mathrm{~K}$. E. Lohman (written commun., 1959) stated:

Five extinct species were found, all of which have been named and described in my manuscript on the Cenozoic nonmarine diatoms from the Great Basin. Anomoeoneis sp. A has been found previously only in the Esmeralda Formation of early Pliocene age in Nevada. The remaining four extinct species have known geologic ranges of late middle Miocene to middle Pliocene.

With the exception of the five extinct species, all others are still represented in living assemblages elsewhere, although nearly all have known geologic ranges from various parts of the late Tertiary to Recent. Ten of these species have known geologic ranges of late middle Miocene to Recent, four have ranges of middle Pliocene to Recent. Based upon this somewhat conflicting evidence, the best age assignment that can be made is approximately early to middle Pliocene. When present studies of the diatoms from the middle Pliocene Teewinot Formation are completed, a comparison of the two assemblages may sharpen this assignment.

All the diatoms in this assemblage are fresh-water lacustrine temperate species, although a few of them can also live in saline nonmarine waters. Both bottom-dwelling and pelagic species are present and this, coupled with the presence of large amounts of clastic material and volcanic glass, suggests that the lake was shallow and turbid.

Concerning collection 5663, K. E. Lohman and G. W. Andrews stated (written commun., 1965) :

This assemblage suggests deposition in a shallow fresh-water lake or in the littoral zone of a deeper one. A great majority of the diatoms present are littoral forms, many of which live attached to stones or aquatic plants and can prosper only in very shallow or very clear water. The large amount of finely divided clastic material suggests the water may have been turbid; hence, it could not have been deep. The Recent species are now living in cool to temperate water.

Four of the species found - Amphora sp. A, Gomphonema sp. A, Stauroncis sp. A, and Surirclla sp. A-were described from the lower Pliocene Esmeralda Formation of Nevada in $\mathrm{my}$ Great Basin paper. Only one of these, Gomphonema sp. A, has also been found in Miocene rocks, and also occurs in the Moonstone Formation. Although 21 species in this assemblage have 


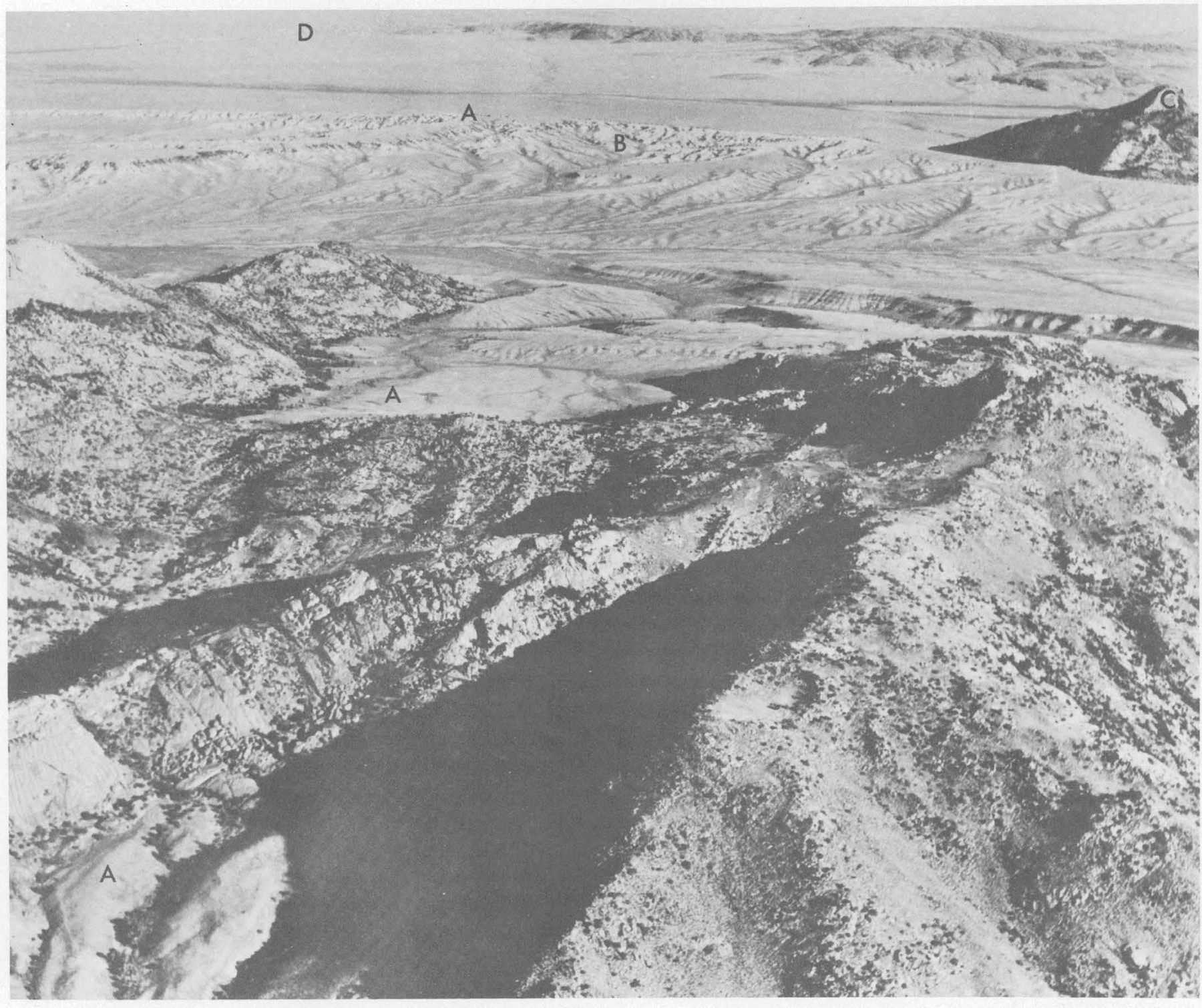

FIGURE 44.-Type section of Moonstone Formation, deposited on a surface of high relief that was developed on Precambrian rocks of Granite Mountains prior to and during Pliocene time. View north. A, Moonstone Formation. B, Position of middle part of type section indicated on White Ridge. C, Lone Mountain. D, Split Rock Formation. Photograph by P. T. Jenkins and L. P. House.

long ranges, middle Miocene to Recent, 16 species have shorter ranges from early Pliocene to Recent and in addition the three species mentioned above are known only from the early Pliocene. A total of 10 species also occur in your Moonstone Formation. Therefore, considerable confidence is felt in assigning this assemblage and the bed that contains it to the early Pliocene.

Pollen from the middle of the formation are listed in table 13. These indicate only a Miocene or Pliocene age. Fossil wood is abundant in several layers near the middle and a few hundred feet above the middle of the formation, but most of it is silicified, and the cell structure has been destroyed so that its identification is difficult or impossible.
The basal conglomerate southwest of the type section contains unidentifiable fragments of large mammal leg bones. At about the middle of the Moonstone Formation (approximate stratigraphic equivalent of unit 15, type section) in the NW1/4NW1/4 sec. $30, T .30$ N., R. 89 W. (fig. $37, \mathrm{~V}$ ), is a zone of white to light-gray tuffaceous sandstone $10-30$ feet thick that contains sparse mammal bones and teeth. One distal end of a camelid cannon bone was found. G. E. Lewis (written commun., 1958) stated: "Morphologically, it can be duplicated in the corresponding part of several upper Miocene and Pliocene genera of camels. I know of no way to determine [its] stratigraphic position." 
Several small teeth were collected from anthills in this same locality and zone. They were examined by R. W. Wilson (written commun., 1959), who identified the following items: A fourth upper premolar of an entoptychine rodent, a fragment of a tooth of a geomyoid rodent, incisors of at least three kinds of rodents, and the tooth enamel of a small unidentifiable ungulate(?) These were not sufficiently diagnostic to be used in age determinations.

Table 10 shows the vertebrate fossil assemblages from localities $27 \mathrm{~V} ; 28 \mathrm{~V}, \mathrm{P} ; 30 \mathrm{~V} ; 32 \mathrm{~V}, \mathrm{P}$; and $33 \mathrm{~V}$ in the southeast corner of the mapped area (pl. 1). These fossils indicate early Pliocene or late Miocene age. Fragmentary horse teeth from several localities are especially suggestive of Pliocene age (P. O. McGrew, oral commun., 1965); they come from several hundred feet above the Pliocene diatom assemblage (5663, table 12) in the same locality:

At locality $27 \mathrm{~V}$, the leg bone of a large camelid was uncovered, photographed, and measured. Lack of proper facilities prevented collection, but on the basis of the photograph and measurements, F. C. Whitmore (written commun., 1964) commented:

On the basis of size and general proportions, the bone fits into two species of Procamelus ( $P$. robustus Leidy and $P$. madisonius Douglass) and four species of Alticamelus (A. elrodi (Douglas), $A$. altus (Marsh), A. giraffinus Matthew, and A. stocki Henshaw). These species range in time from Barstovian (Mascall, Pawnee Creek, and Madison Valley) through Clarendonian (Esmeralda of California) and into Hemphillian (upper Snake Crook). There are also camels of this size in the later Pliocene and Pleistocene (Camelops, for instance).

\section{TABLE 12.-Diatoms in the Split Rock, Moonstone, and Bug Formations}

[Ident Ified by K. E. Lohman and G. W. Andrews. Explanation: R, rare; F, frequent; $\mathrm{C}$, common; A, abundant. Occurrence of listed diatoms is sparse if compared with that in samples of average diatomaceous rocks; therefore, the classification is relative only to abundance of diatoms in the seven samples]

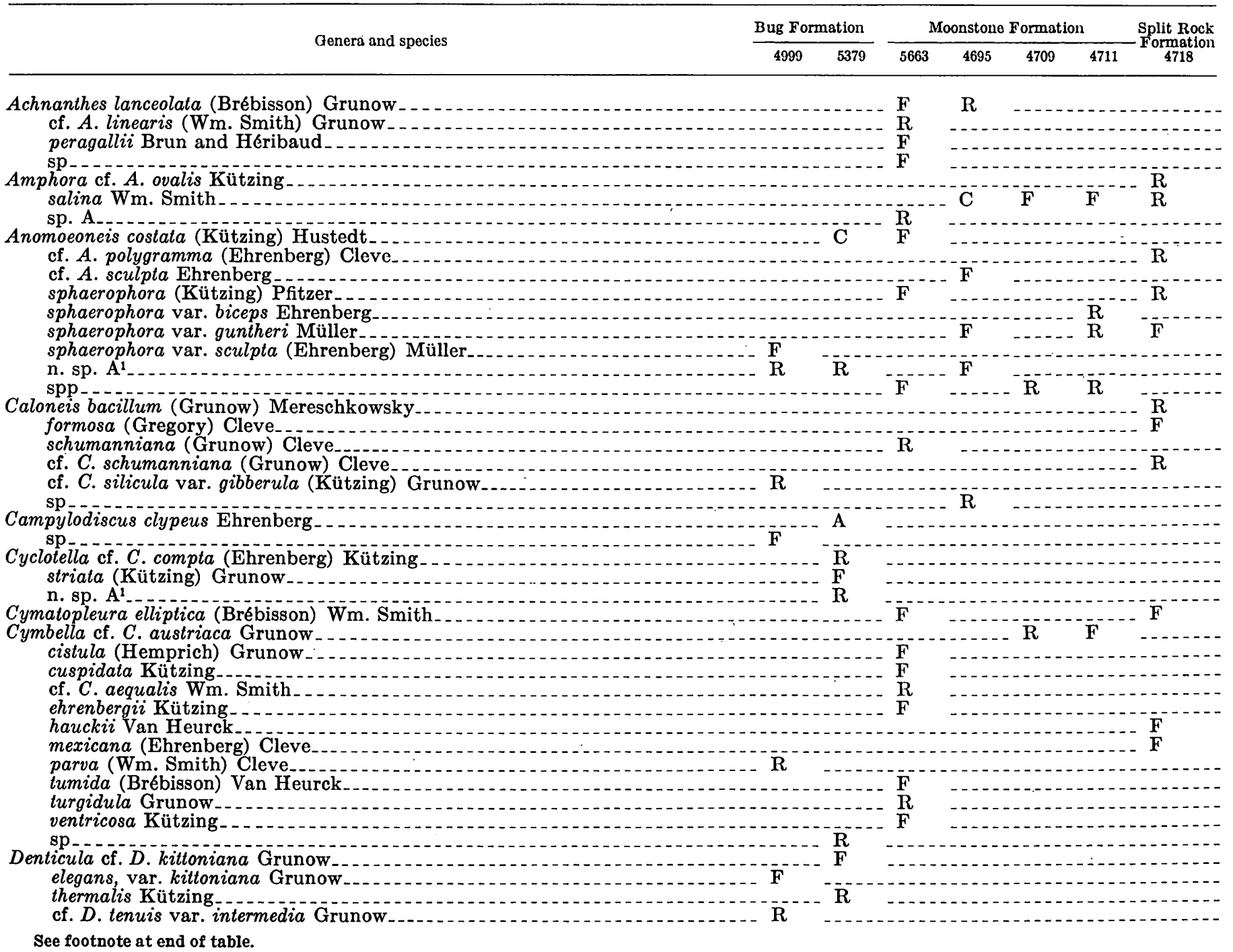


TABLE 12.-Diatoms in the Split Rock, Moonstone, and Bug Formations-Continued [Identlfied by K. E. Lohman and G. W. Andrews. Explanation: R, rare; F, frequent; C, common; A, abundant. Occurrence of listed diatoms is sparso if compared with that
in samples of average diatomaceous rocks; therefore, the classification is relative only to abundance of diatoms in the seven samples]

Genera and species

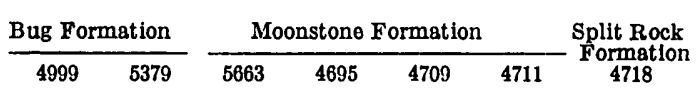

Diatoma cf. D. anceps Ehrenberg vulgare var. producta Grunow

$\mathbf{F}$

sp-- argus (Kützing) Ehrenberg

argus var. ocellata Kützing

sorex Kützing.
zebra var. porcellus Kützing

sp. $\mathrm{A}^{1}$. porcellus Kützing

sp. A

pectinalis var. minor (Kützing) Rabenhorst.

lunaris (Ehrenberg) Grunow

lunaris var. capitata Grunow

lunaris var. subarcuata (Naegli) Grunow

Fragilaria leptostauron (Ehrenberg) Hustedt.

pinnata Ehrenberg
cf. F. virescens Ralfs.

sp. A $\mathrm{A}^{1}$

Frustulia vulgaris Thwaites.

Gomphonema acuminatum var. trigonocephala (Ehrenberg) Grunow.

ingustatum (Kützing) Rabenhorst ${ }_{\text {intum Kützing }}$

longiceps var. subclavata Grunow

parvulum (Kützing) Grunow

Hantzschia amphioxys var. vivax (Hantzsch) Grunow

amphioxys (Ehrenberg) Grunow
sp
Mastogloia elliptica var. dansei (Thwaites) Cleve

Melosira cf. M. distans (Ehrenberg) Kützing

italica (Ehrenberg) Kützing
cf. $M$. italica (Ehrenberg) Kützing

cf. $M$. undulata (Ehrenberg) Kützing

sp. A1 $A^{1}$

sp.on circulare Agardh

Navicula amphibola Cleve.

cari Ehrenberg

cuspidata Kützing

cf. $N$. cuspidata Kützing

dicephala (Ehrenberg) Wm. Smith.

pupula var. rectangularis (Gregory) Grunow

semen Ehrenberg

simplex Krasske.
viridula Kützing -1.20

sp. A $A^{1} \ldots$ Neidium affine (Ehrenberg) Cleve
affine var. longiceps (Gregory) Cleve.

Nitzschia amphibia Grunow ${ }_{\text {sp }}$

balatonis Grunow
granulata Grunow
kitli Grunow

kittli Grunow

punctata (Wm. Smith) Grunow.

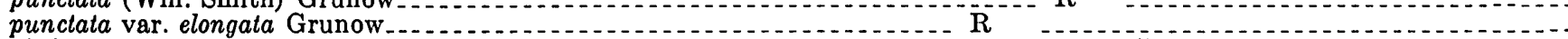

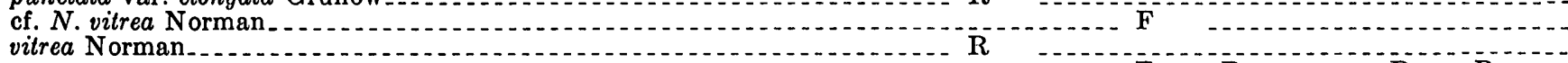

sp
Opephora martyi Héribaud
sp_

$\mathbf{R}$

See footnote at end of table. 
TABLE 12.-Diatoms in the Split Rock, Moonstone, and Bug Formations-Continued

IIdentified by K. E. Lohman and G.W. Andrews. Explanation: R, rare; F, frequent; C, common; A, abundant. Occurrence of listed diatoms is sparse if compared with that in samples of average diatomaceous rocks; therefore, the classification is relative only to abundance of diatoms in the seven samples]

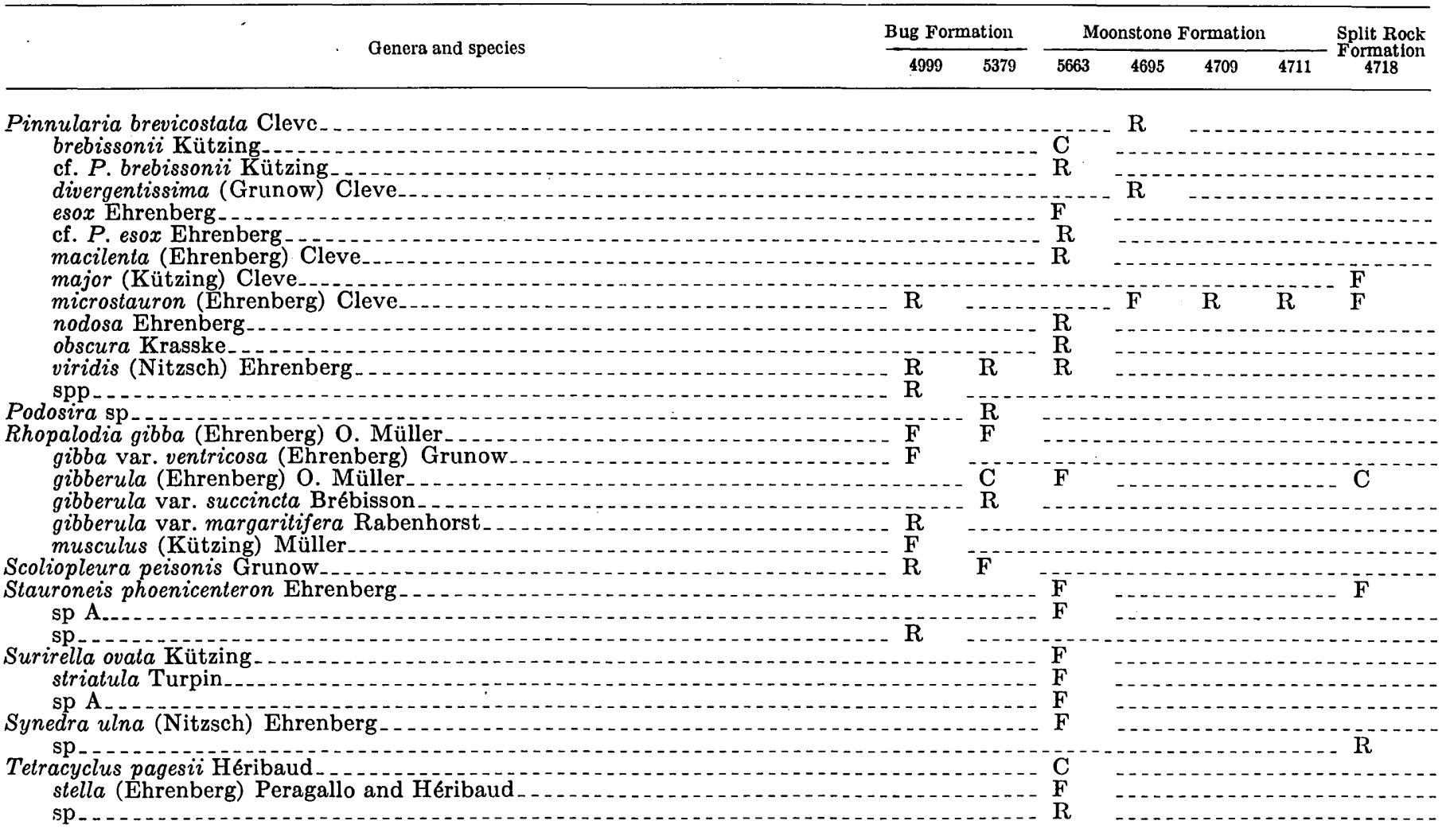

1 Extinct species.

LOCALITIES

4999. $400 \mathrm{ft}$ south of north line, 2,500 ft east of west line, sec. 5, T. 30 N., R. 87 W., Natrona County, Wyo. Pale-green claystone $50 \mathrm{ft}$ above úranium- and thorium-bearing limestone.
5379. $650 \mathrm{ft}$ north of south line, 2,000 ft west of east line, sec. 5, T. 30 N., R. 87 W., Natrona County, Wyo. Pale-green claystone, basal bed in type section of Bug Formation. 5663. Well No. 225 (pl. 1 and table 2), 1,900 ft east of west line, 1,200 ft north of south line, sec. 36, T. 27 N., R. 85 W., Carbon County, Wyo. White soft claystone near base of Moonstone Formation, at depth of $310-315 \mathrm{ft}$.
4695. NW cor. SWW 4 sec. $19, \mathrm{~T}, 30 \mathrm{~N}$. R . 89 W., Natrona County, Wyo. Laminated white uraniferous shale $6 \mathrm{ft}$ below dark-gray tuff marker bed, about $800 \mathrm{ft}$ above the base of

4709. Same locality as 4695 , but 1 ft stratigraphically higher in the Moonstone Formation.

4711. NW1/4SE1/4SE1/4 sec. 24, T. 30 N., R. 90 W., Fremont County Wyo. Laminated pink and white claystone, shale, and siltstone in the Moonstone Formation. Sample is from a very fine grained pale-pink claystone lamina in a white shale sequence overlying the dark-gray tuff marker bed. Thus, the horizon is slightly higher in the Moonstone Formation than locs. 4695 and 4709 , but the precise amount is not known because the marker bed is not exposed at this locality.

4718. NW1/4SE $1 / 4$ NW1/4 sec. 36, T. 29 N., R. 89 W., Natrona County, W yo. (pl. 1, loc. $13 \mathrm{~V}$, D). Fossils are in the upper part of the upper porous sandstone sequence in the Split Rock Formation at its type locality, about $2,000 \mathrm{ft}$ above the base. They are in unit 31 of the "Devils Gate fossil locality" measured section in a pale-breen waxy clay-
stone about $4 \mathrm{ft}$ below a vertebrate-fossil horizon.

Unit 28 in the section of the black shale member contains the only ostracodes found thus far in the entire upper Tertiary succession in central Wyoming. They are unusually small as compared with those from lower and middle Pliocene rocks in Jackson Hole (Sohn, 1956). The presence of ostracodes and fresh-water diatoms in the southeast corner of the Granite Mountains area indicates that the lacustrine environment during deposition of several hundred feet of the Moonstone Formation was not as saline as that in the type section.

Specific correlation of the Moonstone Formation with Pliocene rocks in adjacent areas must await more definitive collections as well as additional studies of the stratigraphic relations with older and younger rock units. In Jackson Hole, the Camp Davis Formation,
5,500 feet thick, of early Pliocene age contains felsic volcanic debris, as contrasted with the mafic to intermediate material in the Moonstone (Love, 1956b; Houston, 1964). The middle Pliocene Teewinot Formation, more than 6,000 feet thick, in the same area is likewise felsic in composition. The North Park Formation of late(?) Miocene age (Montagne and Barnes, 1957, p. 59) in the Saratoga area has volcanic debris of intermediate composition, more like that of the Moonstone Formation, but the vertebrate fossils suggests that at least part of it is older. The relations of these two formations, however, need much clarification.

The Moonstone Formation is probably a time equivalent of some part of the Ogallala Formation of Nebraska and eastern Wyoming, if that formation is 
TABLE 13.-Pollen from black shale member of Moonstone Formation

[Data prepared by E. B. Leopold (written commun., 1963); sample A is from bed 37 In measured soction, $B$ from bod $33, C$ from bed 31 , and $D$ from bed 30 ; USGS palcobotany loc. D3367]

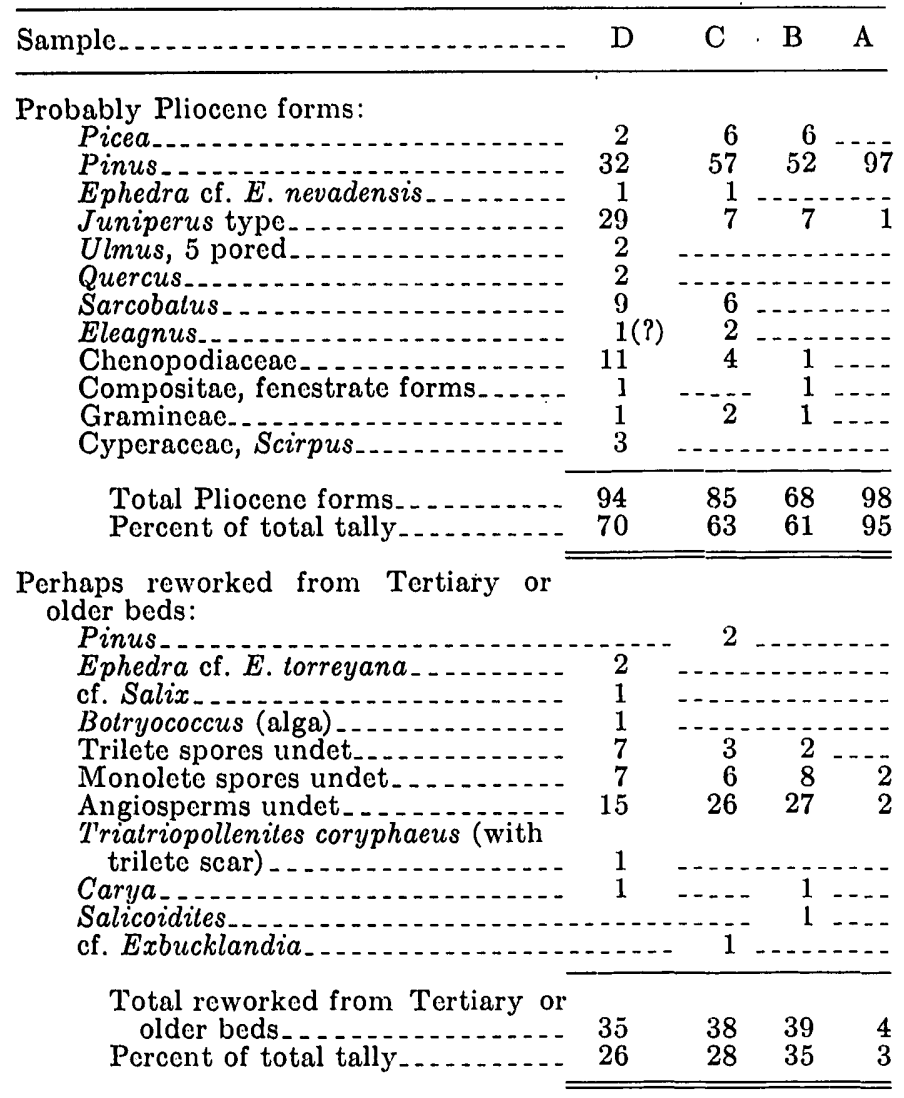

Definitely reworked from Cretaceous beds:

Cayloniapollenites.................

Cicatricosisporites

Gleicheniidites senonicus..........

Proteacidites

Appendicisporiles.

Sequoiapollenites.......................

Hymenozonotriletes reticulatus ...........

Aquilapollenites........................

Dinoflagellata.

Sporites arcifer

Pterospermopsis...

Total reworked Cretaceous forms $\ldots \begin{array}{lllll} & 4 & 12 & 5 & 1\end{array}$

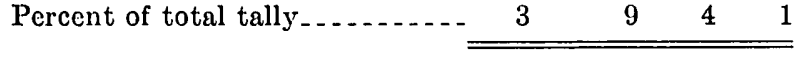

Total tally 133

$\begin{array}{lll}135 & 112 & 103\end{array}$

considered in a more restricted sense than was used by Darton (1905; table 8, this report) and Denson and Bergendahl (1961), who lumped Pleistocene strata with the Pliocene. In the locality of the black shale member (loc. $28 \mathrm{~V}, \mathrm{P}$ ) and west of locality $27 \mathrm{~V}$, younger unnamed strata containing fragmentary vertebrate fossils unconformably overlie the Moonstone Formation. When more extensive collections are obtained, they should help to determine the upper age limit of the Moonstone.
Strata in the type locality of the Browns Park Formation in northeastern Utah and northwestern Colorado resemble those in the Moonstone, for at least half are claystone and tuff. The middle part of the type Browns Park yielded late Miocene or Pliocene diatoms (Hansen, 1965). About one-third of the species are common to both formations. This sequence, as stated in discussion of the Split Rock Formation, is not to be confused with the middle Miocene so-called Browns Park Formation of the Maybell area of Colorado (Bergin, 1957) or the Browns Park(?) Formation of the Saratoga Valley of southeastern Wyoming (Stephens and Bergin, 1959).

\section{STRATIGRAPHY OF TERTIARY OR QUATERNARY ROCKS}

\section{PLIOCENE OR PLEISTOCENE ROCKS UNNAMED STRATA}

Units $38-40$ (p. 90-91) in the measured section at locality $28 \mathrm{~V}, \mathrm{P}$ (pl. 1) in the southeast corner of the mapped area represent two sequences of unnamed strata that may be of Pliocene or Pleistocene age (table 8). The lower one consists of about 35 feet of arkosic conglomerate and sandstone. The basal one-fourth is light-gray soft poorly cemented poorly sized arkosic conglomerate containing angular to rounded fragments of pink and gray granite in a matrix of coarse rounded sand grains. This bed crops out as a prominent bench paved with boulders of granite 1 foot or more in diameter. The remainder of the lower sequence is lightgreenish-gray medium-grained homogeneous almost uncemented sandstone, with 1 foot of pale-green claystone 18 feet above the base. This sequence was deposited on a relatively plane surface that bevels progressively northeastward across units 37-30 (35 ft) within a distance of 200 yards. The areal extent of these rocks has not been determined. The basal arkosic sandstone (fig. 43, F) yielded a shoulder blade and leg bones of a rhinoceros, a leg bone of a rabbit, a fragment of a horse tooth resembling Pliocene forms but too broken for generic identification, and many rounded waterworm granules of Inoceramus (?) shells and beaks that were apparently winnowed from the underlying black shale containing Cretaceous pollen and marine shell fragments.

Unconformably overlying this arkosic conglomerate and sandstone sequence is about 20 feet of dark-green and brown conglomerate composed largely of mafic igneous and metamorphic rocks and Seminoe iron ore (Lovering, 1929) of Precambrian age from the Seminoe Mountains 10 miles to the south. Fragments are angular to rounded, the average size is $3-6$ inches, and locally 
the strata are cemented by a light-gray limy sandstone matrix. These strata contrast sharply in both color and composition with the light-colored arkosic unit below and may represent the highest and oldest terrace deposit in the area.

About half a mile west of locality $27 \mathrm{~V}$ is a high hill (elev. 6,466 ft) capped by about 50 feet of stratified gray arkosic conglomerate containing boulders of granite and Paleozoic rocks. These strata resemble the lower sequence at locality $28 \mathrm{~V}, \mathrm{P}, 5$ miles southeast, in the paucity of Precambrian mafic rocks and Seminoe iron ore and the abundance of granite. The quantity of Paleozoic rock fragments warrants some attention, for their source had to be the Ferris and Seminoe Mountains 6 miles or more to the south and southwest, yet nearly all these rocks are in place on the south side of the mountains and were not directly available to the powerful streams that deposited this coarse conglomerate.

Other conglomerate-capped high hills are present in adjacent areas but have not been studied. By matching rock types in these localities with those in the source areas to the south, it is possible to reconstruct in a general way the post-Moonstone structural events and erosional history. This is considered in the latter part of the report.

\section{BUG FORMATION \\ NAME AND DEFINITION}

A new name, Bug Formation, is here used for a sequence of soft pale-green, pale-brown, and white claystone, tuff, limestone, sandstone, and conglomerate of Pliocene or Pleistocene age. The name is taken from the Bug Ranch headquarters (Beulah Belle Lake quadrangle), about 2 miles northeast of the type section, which is in the SW $1 / 4 \mathrm{SE}^{1} / 4$ sec. $5, \mathrm{~T} .30 \mathrm{~N}$., R. $87 \mathrm{~W}$. (Miller Spring quadrangle; pl. 1, loc. 26V, D, P fig.
45). The Bug Formation overlies the Split Rock Formation with an erosional, and probably angular, unconformity and comprises the youngest consolidated strata, excluding locally derived alluvial deposits and ash, in the east-central part of the Granite Mountains area. These rocks have not hitherto been described.

\section{DISTRIBUTION AND THICKNESS}

The Bug Formation in the vicinity of the type section has an areal extent of about 3 square miles (pl. 1). The thickness probably does not exceed 125 feet. Further paleontologic and stratigraphic work is needed to determine if any of the soft clayey and limy strata near well 187 and elsewhere along the trough line of the Split Rock syncline are part of the Bug Formation.

\section{IITHOLOGY}

The following type and supplementary sections of the Bug Formation illustrate its general lithology.

Type section of Bug Formation ( $p l$. 1, loc. $26 \mathrm{~V}, \mathrm{D}, \mathrm{P}$; fig. 45)

[Section is in the SW $1 / 4$ SE 14 sec. 5 , T. 30 N., R. 87 W., Miller Spring quadrangle, Natrona County, Wyo. Dip is $2^{\circ}-3^{\circ} \mathrm{WSW}$

Bug Formation:

17. Conglomerate, dark-gray, soft; at least 50 percent of rock fragments are of rounded porphyritic andesite and other volcanic rocks commonly 1-2 in. in diameter, from the Rattlesnake Hills; contains abundant dark-gray and amber agates, some of which fluoresce yellow; matrix is gray eoliantype highly rounded frosted coarse quartz sand grains, commonly loose but secondarily cemented in part by caliche; bed forms ridge top and dip slope to west; no exposures of younger beds; this and underlying part of formation dip west-southwest but there is no evidence as to what happens to these beds between this area and the closest outcrops of the Split Rock Formation to the west. .

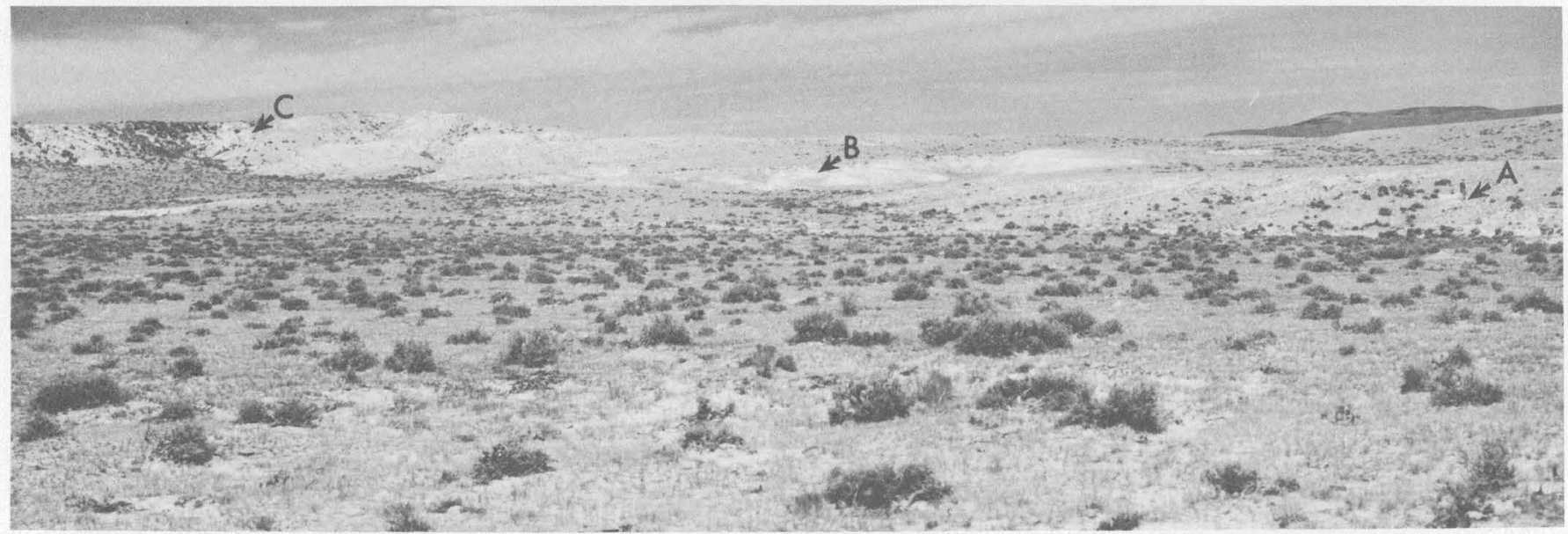

Figure 45.-Type section of Bug Formation, SW14SE1/4 sec. 5, T. 30 N., R. 87 W. View northwest shows man standing on A, contact between Bug Formation above and Split Rock Formation below. B, Uranium-bearing limestone. C, Conglomerate containing rock fragments from Cenozoic volcanos in Rattlesnake Hills. Diatom collection 5379 is from soft claystone at left of man. 
Type section of Bug Formation (pl. 1, loc. $26 \mathrm{~V}, D, P$; fig. 45)-Con.

Bug Formation-Continued

16. Siltstone, light-brownish-gray, very soft, thinbedded, dusty, sandy; interbedded with sparse thin gray hard limy sparkly sandstone beds...

15. Sandstone and conglomerate, brown to pale-tan; consists of medium- to coarse-grained loose sand with almost no cement; pebbles as much as 3 in. in diameter of subangular fragments of andesite and other porphyries from the Rattlesnake Hills; sand is composed of highly rounded frosted grains like those in Split Rock Formation but not as well sorted and with much fewer and smaller grains of magnetite and fewer red hematite-coated quartz grains.-...- -

14. Siltstone, light-brownish-gray, very soft, thinbedded, dusty, sandy; interbedded with sparse thin gray hard limy sparkly sandstone.......

13. Sandstone and conglomerate; lower $3 \mathrm{ft}$ is pebble bed consisting chiefly of gray, brown, and red porphyries from the Rattlesnake Hills, granite, and sparse brown agates; thin sections of volcanic pebbles (Wyo-796, 797, 798, 799) show they are principally andesite porphyry; remainder of unit is coarse-grained brown eoliantype sand, uncemented in lower part and becoming fine grained and more cemented near top; sand is composed of highly rounded frosted grains like those in Split Rock Formation but not as well sorted and with much less and finer grained magnetite and fewer red hematitecoated quartz grains........................

12. Claystone, clayey siltstone, and sandstone, palebrown, soft, weathers to badlands; forms lowest conspicuous stripe in badlands exposures; anthill at this horizon yielded one nondiagnostic tooth of a rabbit..............

11. Claystone and sandstone; at base is $1 \mathrm{ft}$ of greenish-gray limy hard slabby pebbly sandstone containing abundant tiny red and black grains and shards; in remainder of unit are similar slabby and hard or soft and silty sandstones interbedded with pale-green soft claystone and siltstone; thin section Wyo-800 of hard sandstone consists largely of angular grains of feldspar set in a calcareous cement.

10. Claystone, clayey limestone, and siltstone; in lower $6 \mathrm{ft}$ are three conspicuous 1-ft-thick beds of sandy white impure soft clayey limestone, the uppermost capped by 2 in. of white hard sandy limestone; these are separated and overlain by pale-green siltstone and claystone; upper half of unit is nearly all soft pale-green claystone. A sample checked for pollen and diatoms was barren............

9. Sandstone, light-greenish-gray and rusty, soft; waxy pale-green claystone matrix; contains abundant frosted rounded grains and sparse red hematite-coated quartz grains; thin section Wyo-801 has angular feldspar grains in clayey limy cement and sparse biotite and pyroxene
Thick$(f t)$

Type section of Bug Formation ( $p l .1$, loc. $26 \mathrm{~V}, D, P$; fig. 45)-Con.

Bug Formation-Continued

8. Claystone and siltstone, pale-green, very sof $\mathrm{t}$

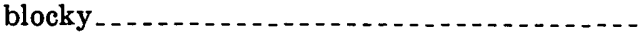

7. Limestone, white, hard; forms ledge in lower part and merges upward with pale-green very fine grained blocky siliceous rock (spectrographic analysis, table 6); contains abundant empty crystal molds that apparently once were occupied by a tabular soluble mineral; overlain by 2-3 $\mathrm{ft}$ of gray to white massive light-weight tuff(?) composed partly of masses and clusters of tiny clear gypsum and calcite crystals; top beds are a tangle of anastomosing thin-bedded basin fills of algal(?) deposits; radioactivity in this bed more than $0.05 \mathrm{mr}$ per hr.......

6. Variety of mixed lithologies; lower $3 \mathrm{ft}$ is interbedded pale-drab silty sandstone and siltstone and thin soft white clayey limestone; middle part is very soft pale-greenish-drab siltstone and claystone merging upward into about $5 \mathrm{ft}$ of soft white clayey limestone and dusty tuffaceous siltstone; clusters of small euhedral clear fragile gypsum and calcite crystals; about $4 \mathrm{ft}$ below top and extending to top are abundant basin-shaped structures composed of limestone and limy tuff; entire upper $5 \mathrm{ft}$ is radioactive, and a 1-in.-thick dark-gray limy tuff bed $4 \mathrm{ft}$ below top contains 0.019 percent uranium but no thorium (table 11); thin section Wyo-802 of this bed shows chiefly angular grains of feldspar and shards in a carbonate matrix; a soft smooth-feeling white blocky clayey limestone is $3 \mathrm{ft}$ below top. A sample checked for pollen and diatoms was barren...................................

5. Clayey limestone, white, soft, chalky, very fine grained; a sample checked for diatoms was barren .................................

4. Sandstone, olive-drab to gray, fissile, fine-grained, silty; contains abundant shards; splits into curled cakes.

3. Clayey limestone, white, soft, bedded, finegrained; forms a conspicuous stripe on slope; a sample checked for diatoms was barren. . . . . -

2. Claystone and siltstone, pale-green, very soft; forms bare slope; USGS diatom loc. 5379 (table 12)

\section{Thick-}

$(f t)$

5

Total measured thickness of Bug Formation_ $118+$

Contact between Bug and Split Rock Formations. Contact relations somewhat uncertain because of limited exposures, but regional relations indicate an erosional and probably a slight angular unconformity.

Split Rock Formation:

1. Sandstone, $\tan$ to gray and olive-drab, porous; very thin regular bedding; soft, almost uncemented at top; contains abundant black magnetite, red hematite-coated quartz, abundant frosted rounded quartz grains, and numerous brilliant clear subrounded quartz

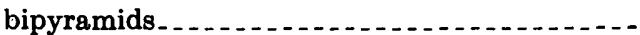


A generalized partial section of the Bug Formation was measured about three-eighths mile north of the type section and is presented here because it yielded several additional diatom zones and the limestones contain thorium as well as uranium.

Generalized supplementary section of Bug Formation ( $p l .1$, one-half mile north of loc. $26 V, D, P$ )

[Section extends up hill west of a point $200 \mathrm{ft}$ south of the quarter corner common to sec. 5 , T. 30 N., R. 87 W., and sec. 32 , T. 31 N., R. 87 W.]

Bug Formation:

5. Limestone, white, tuffaceous, hard, poorly bedded forms ragged ledge at top of hill; USGS pollen sample EL60-7D from top $1 \mathrm{ft}$

4. Claystone, green and brown, soft; forms slope below ledge; sample from top $1 \mathrm{ft}$ contains no pollen; sparse diatoms observed in pollen sample but none in split submitted for diatom study -

3. Claystone, pink to greenish-brown, soft; forms slope; contains sparse fragments of radioactive unidentifiable mammal bones (analysis 252591 shows 0.08 percent uranium); sample from top $1 \mathrm{ft}$ contains no pollen but does have sparse diatoms (USGS diatom loc. 5000, same forms as in underlying unit 2 so not listed separately in table 12) ...............................

2. Claystone, greenish-brown, soft; interbedded with soft white sandstone and tuff; forms gentle slope at foot of steeper one; contains sparse fragments of unidentifiable mammal bones; sample of claystone in top $1 \mathrm{ft}$ at break in slope contains no pollen but some diatoms (USGS diatom loc. 4999, table 12); USGS pollen sample EL60-7C is from green claystone $21 \mathrm{ft}$ above base; USGS pollen sample EL60-7B is from green claystone $18 \mathrm{ft}$ above base. . . . . . . . . . . . . . . .

1. Limestone, greenish-white, hard, finely sandy; porous in part and dense in part; locally silicified with dense pale-green silica; finely sandy, abundant shards; numerous cavities from which some tabular soluble crystals have been leached; locally impregnated with one or more paleyellow radioactive minerals; in part has bright yellow fluorescence (X-ray and mineral identification, lab. No. 150206 unsuccessful); numerous small laminated basin-shaped deposits of white tuffaceous algal limestone and (or) chemically precipitated limestone, similar to and probably equivalent to unit 6 in type section; USGS pollen sample EL60-7A; several uranium and thorium analyses (table 11) were made of radioactive beds within this unit and one spectrographic analysis; thin section Wyo-702 . ....

Total measured thickness of strata

The two sections described above indicate that the Bug and Moonstone Formations have many similar as well as dissimilar features. Both formations are soft, are generally light green to white, and have uraniumand thorium-bearing limestones, within which are numerous molds of unidentified soluble crystals; both contain abundant fine-grained tuffaceous debris, and the diatoms indicate similar saline lacustrine environments. Differences between these formations are: (1) The conglomerates in the Moonstone are composed of locally derived Precambrian rock fragments, whereas those in the Bug Formation are chiefly andesite and other porphyries from the Rattlesnake Hills vents 5-10 miles to the north; (2) strata in the Bug Formation are not conspicuously thin bedded, but those in the Moonstone are; (3) the Bug formation has more claystone but shale is rare, whereas the Moonstone has conspicuous white shale units and claystone is not as common; (4) the Moonstone Formation has a widespread basal arkosic conglomerate where it overlies the Split Rock Formation, but the Bug has a claystone at the base; (5) many beds other than limestone in the Moonstone Formation are radioactive, whereas only limestone is radioactive in the Bug; (6) the Moonstone Formation has abundant agates and chalcedony beds formed in place, but the Bug has only agate pebbles secondarily derived from older rocks and redeposited in conglomerate.

Faunal differences between the Bug and Moonstone Formations are shown in table 12 and are discussed later. The Bug contains shards, plagioclase of intermediate composition, potash feldspar, sanidine, volcanic quartz, biotite, oxyhornblende, clinopyroxene, green hornblende, amphibole, zircon, sphene, apatite, epidote, and garnet. Opaque minerals are not conspicuous in most samples.

The abundance of finely crystalline gypsum in some beds, the conspicuous crystal molds of a soluble mineral (unidentified) in the limestone and siliceous claystone, and the presence of diatoms of saline habitat suggest that the shallow lake in which some of the strata were deposited was alkaline and poorly drained (pl. 10J). The mixture of rock types in the clastic debris is to be expected, as the area is surrounded and underlain by sandstone of the Split Rock Formation through which knobs of Precambrian granite and metamorphic rocks project. The flood of pebbles of andesite prophyry from the Rattlesnake Hills, rare in the Split Rock Formation of this area, indicates either a major shift in drainage pattern during deposition of the Bug Formation or the possibility that not all the intrusives are of Eocene age.

\section{STRATIGRAPHIC AND STRUCTURAI RELATIONS}

The Bug Formation overlies the truncated edges of beds estimated to be in the lower third of the Split Rock (pl. $5 E$ ) with an erosional and probably slight angular unconformity. In the vicinity of the type section, the Bug dips about $2^{\circ} \mathrm{WSW}$ but between the type and the outcrops of the Split Rock Formation to the west is a 
broad valley with no exposures. Southward from the type section, the base of the Bug Formation is at an elevation equal to or lower than the base of the Moonstone Formation 3 miles farther south and 6 miles to the southwest. Therefore, it is probable that there was a broad area of southward tilting of the northern Granite Mountains into the subsiding Split Rock syncline and that this movement resulted in the removal of 1,300 feet or more of the Moonstone Formation before deposition of the Bug. No younger rocks are present in this area.

\section{AGE AND CORRELATION}

The age of the Bug Formation is based entirely on diatoms from the basal bed of the type section and from unit 2 in the supplementary section. Table 12 gives the list of genera and species as well as a list of those in the Moonstone and Split Rock Formations. Concerning assemblage 5379 in the type section, K. E. Lohman (written commun., 1962) stated:

All the species in this small assemblage are still living elsewhere, so that it is impossible to assign an age to the beds from which they came, except to suggest that they can hardly be older than Pliocene and more likely are Pleistocene.

It is possible to be much more definitive regarding the paleoecology suggested by this assemblage. Anomoeoneis costata and Campylodiscus clypeus, the only species that occur commonly in the assemblage, are both salt-loving species. Both, for example, are now living in Pyramid Lake, Nev., which has a salinity of 3,486 parts per million. Most species of Campylodiscus, including the present one, $C$. clypeus, are marine and brackish species and have never been reported from fresh (potable) water. Based upon a comparison with the diatoms from Pyramid Lake, the present lake must have been quite alkaline, as well as saline. Analyses of Pyramid Lake water by Clarke $(1924$, p. 160) indicate that the carbonate content is much higher than that of sea water.

With reference to collection 4999 in the supplementary section, K. E. Lohman (written commun., 1960) stated:

With the exception of one species, Anomoconeis sp. A, which is a new species and, hence, yields no stratigraphic information, all others are still represented in living assemblages elsewhere. Furthermore, a number of species in this assemblage are not known from pre-Pliocene rocks. The absence of extinct species makes it impossible to make a definite age assignment but the general aspect of the assemblage suggests that it can be no older than somewhere in the Pliocene and could be Pleistocene. Only one species in this assemblage, Nitzschia amphibia, occurs in the previous collection from the Split Rock Formation * * This species has a known geologic range of early Pliocene to Recent. ** Only three species in the whole assemblage are now known from middle Miocene beds *

Although bone fragments are present in several places, nothing diagnostic has been found. Unit 12 in the type section yielded one nondiagnostic tooth of a rabbit. No mollusks were noted and it is probable that this absence is accounted for by the saline environment indicated by the diatoms.
No regional correlations can be made until more definitive faunas or floras are discovered.

\section{QUATERNARY DEPOSITS}

\section{PLEISTOCENE AND RECENT DEPOSITS}

\section{ASH}

ASH NEAR SEMINOE DAM

A previously undescribed Pleistocene ash is present in the Seminoe Canyon cut by the North Platte River through Precambrian rocks of the Seminoe Mountains (pl. 2), about 200 yards downstream (north) from the Seminoe Dam, SW $1 / 4$ SW $1 / 4$ SE $1 / 4$ sec. 5 , T. 25 N., R. 84 W. (fig. 46). A remnant of about 60 feet of alluvial fill is exposed in a quarry wall on the west side of the canyon, 350 feet above the river level. A 3-foot-thick bed of white ash (table 7 ) is present 20 feet above the base of the fill and is overlain and underlain by coarsely to finely stratified sand and gravel (fig. 47). The lithology of this deposit and its relation to the present river level and to faulted remnants of the Split Rock Formation less than 1 mile to the west and much higher up on the mountains suggest that it is of Pleistocene age.

\section{ABH NEAR HEAD OF CONANT CREEK}

An ash, previously undescribed, occurs near the head of Conant Creek, along the north margin of the Granite Mountains area (loc. 11A, pl. 1; fig. 48). The locality is 1,600 feet south and 200 feet west of the NE cor. sec. 12, T. 32 N., R. 94 W. The ash was exposed in a deep bulldozer trench dug for phosphate (Conant Creek trench, Sheldon and others, 1953, p. 35). At the base of the alluvial section is 10 feet of talus grading up into 3 feet of brown structureless loess. Overlying this loess, a channel exposed for 15 feet north-south, 12 feet eastwest, and 2 feet in depth is filled with snowy white irregularly bedded moderately pure soft fine-grained ash. This is overlain by 3 feet of brown loess which is covered with 12 feet of talus up to the present ground surface.

A sample of the ash was submitted to Ada Swineford and J. C. Frye for lithologic comparison with Pleistocene ash deposits in Kansas and adjacent areas, which they had studied in considerable detail. Miss Swineford stated (written commun., 1951) :

I have compared it with our Pearlette material, and it is the nearest thing to Pearlette that $I$ have ever seen. The refractive index (checked with monochromatic light and Shillaber liquids of 0.002 intervals) is apparently identical with that of the Pearlette, and the color of the $<62$-micron fraction is also the same. The only marked difference is in the relative number of fibrous-type shards, the Wyoming ash having 30 to 40 percent fibrous shards, whereas none of the Pearlette has more than 5 percent. The little air holes in the Wyoming fibers are much smaller, and the glass is in general somewhat thicker. 


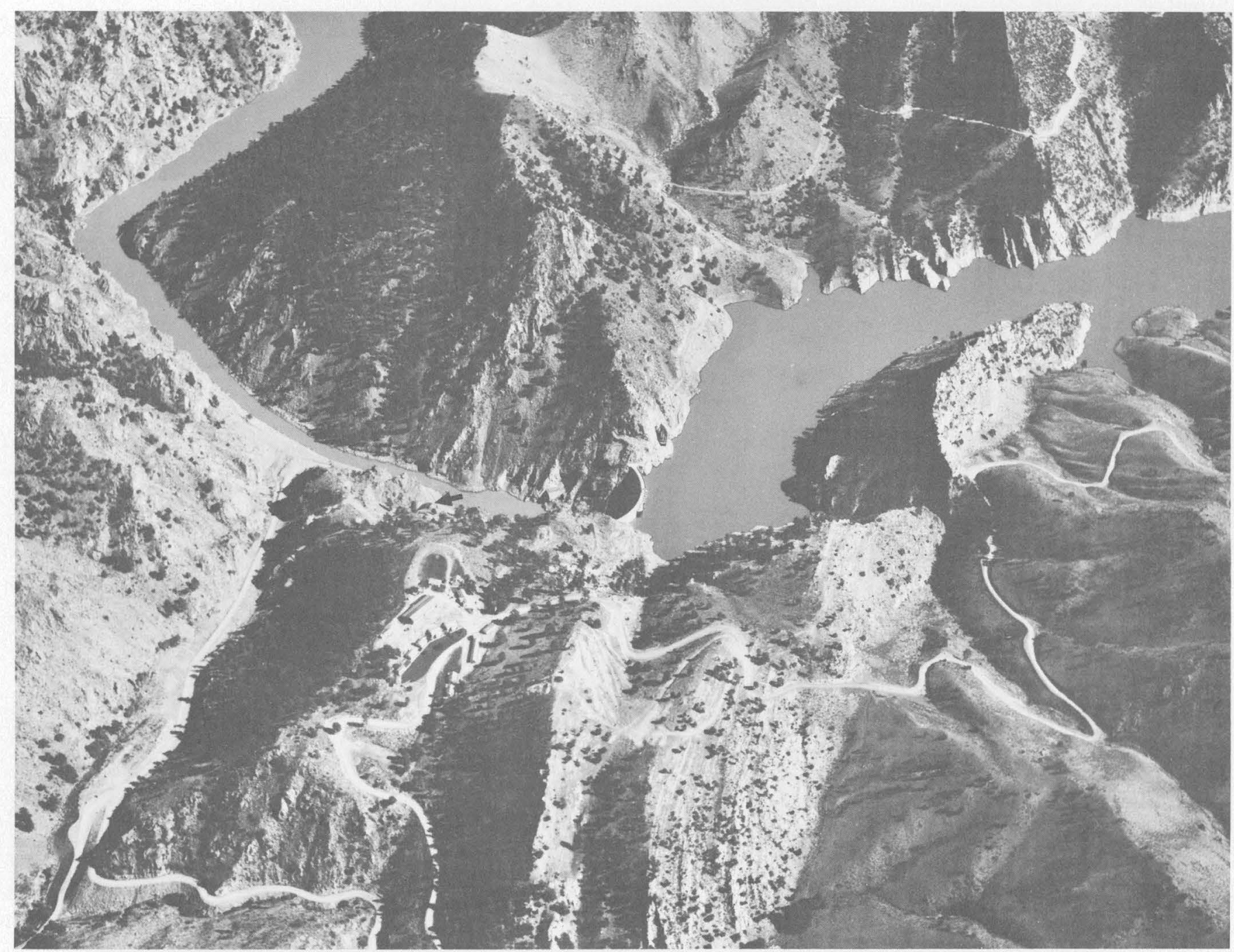

Figure 46.-View east across Seminoe Dam. Arrow downstream from dam indicates locality of Pleistocene ash shown in figure 47. Damsite and area to left of it are in Precambrian rocks; to right are steeply dipping Paleozoic strata. Gorge is Black Canyon cut by the North Platte River across Seminoe Mountains. Photograph by P. T. Jenkins and L. P. House.

The Pearlette Ash Member of the Sappa Formation is a widespread distinctive unit of the Kansan Glaciation in the Pleistocene of Kansas.

The purity of the ash in both the Seminoe and Conant Creek localities described here and the position of these deposits with respect to adjacent topography indicate that they are air-fall deposits. They are exposed in artificial cuts and have been protected from erosion by 12-60 feet of coarse debris.

\section{ALLUVIAL DEPOSITS}

Only a cursory examination was made of alluvial deposits, and they are not shown on the geologic map (pl. 1). Three general types are present: (1) sand and clay along the Sweetwater River valley and along major tributaries of the river, (2) pediment gravels, and (3) sand, in either stabilized or active dunes.
Because of the low gradient of the Sweetwater River (discussed in the introduction), alluvial deposits along the 80 miles of its course within the area are principally gray soft clay, silt, and sand. North of the river, few tributary streams have similar deposits because of generally steeper gradients, but south of the river, where gradients have been reduced by Quaternary downwarping of the Split Rock syncline, such deposits are more extensive.

Gravels, in places 50 feet or more thick, cap several inclined upland surfaces that extend north from Crooks, Green, and Ferris Mountains and south from the Rattlesnake Hills. The erosional and depositional history represented by these surfaces is very complex and is related to Quaternary movement on the North and South Granite Mountains fault systems and to 


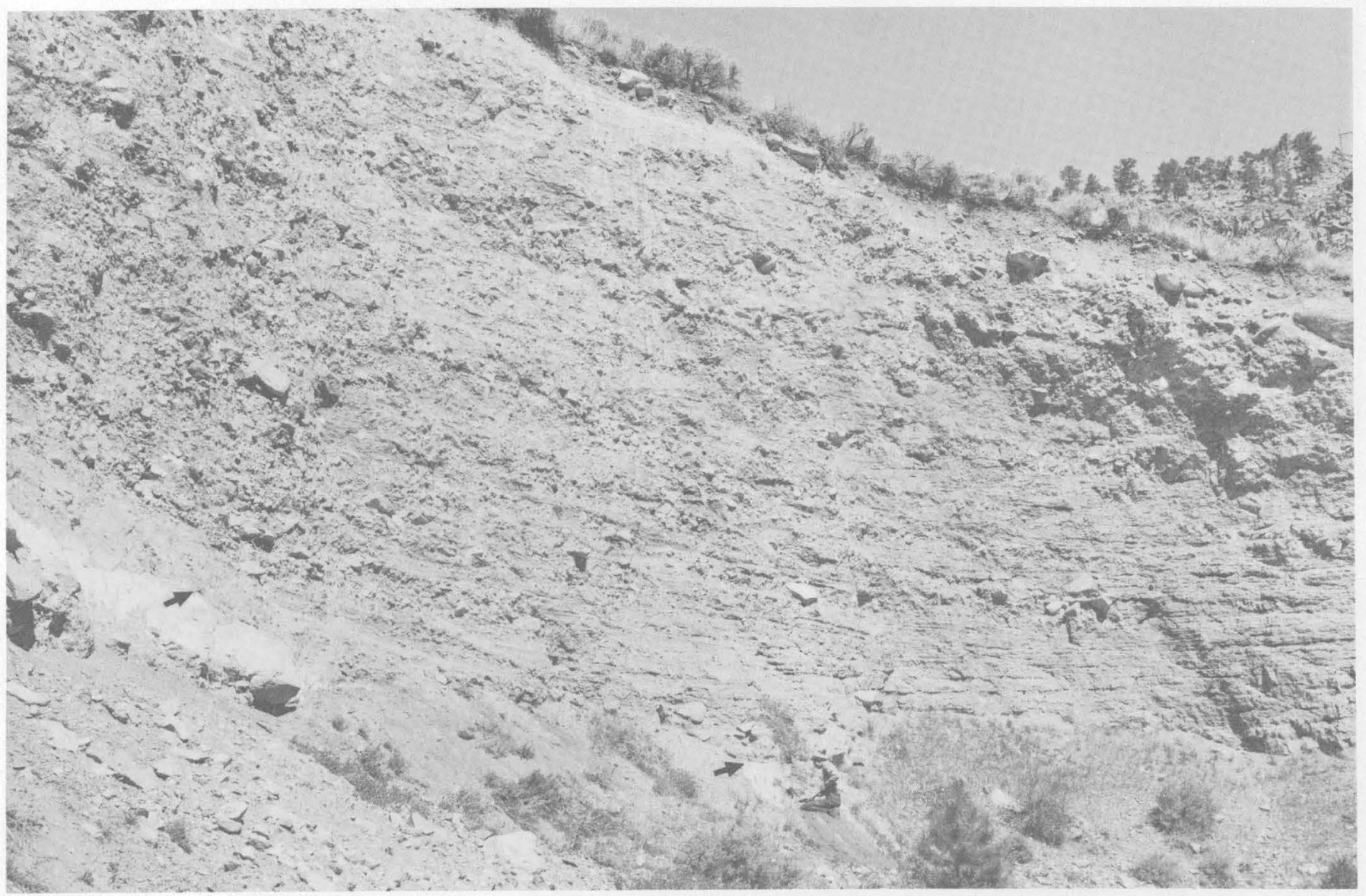

FIGURE 47.-Pleistocene ash bed near Seminoe Dam. Locality is in U.S. Bureau of Reclamation quarry, SW1/4SW1/4SE1/4 sec. 5, T. 25 N., R. 84 W. Ash bed, top of which is indicated by arrows, is 3 feet thick, is underlain by a boulder bed, and is overlain by silt and sand, then stratified gravel and sand. Height of cliff is 60 feet. Ash is approxmately 350 feet above river.

downwarping of the Split Rock syncline. Later faults offset the surfaces in several areas. In general, the debris on the surfaces is coarse sand, gravel, and boulders of locally derived material. In a few places, it is sufficiently consolidated to crop out as ledges. Some recent fans of giant boulders, representing deposits left by torrential floods, occur along the steep mountain fronts controlled by the South Granite Mountains fault system.

Small stabilized sand dunes are present in several places near the Sweetwater River. The source of the sand is the Split Rock Formation. In the southeast corner of the area, on the west side of the North Platte River, are large active sand dunes trending northeast (Weitz and Love, 1952). The sand was blown through Sand Creek Pass, between the Ferris and Seminoe Mountains (pl. 2), and is a continuation of the Ferris sand dune area (fig. 6). Much of this sand was apparently derived from the Wasatch and Battle Spring Formations south of Whiskey Peak and is, in general, much coarser grained and more arkosic than that derived from the Split Rock Formation.

\section{EOCENE IGNEOUS ROCKS}

Eocene igneous rocks are clustered in an area of about 125 square miles in the Rattlesnake Hills (pl. 1). They were mapped and studied in some detail by Carey $(1954,1959)$, who described 36 eruptive centers. Houston (1964) compared the Eocene igneous and pyroclastic rocks in the Rattlesnake Hills with those in other parts of Wyoming. R. G. Coleman loaned me his unpublished manuscript on the mineralogy and geochemistry of the Gas Hills uranium deposits, which contains a brief discussion of the Rattlesnake Hills volcanic rocks. Several analyses (table 7) are taken from his report.

Most of the volcanic centers are within or adjacent to Precambrian igneous and metamorphic rocks. Volcanism began in the middle Eocene and continued with increasing violence through much of the remaining Eocene time. It had ceased and the centers had been deeply eroded before the first Oligocene rocks were deposited. 


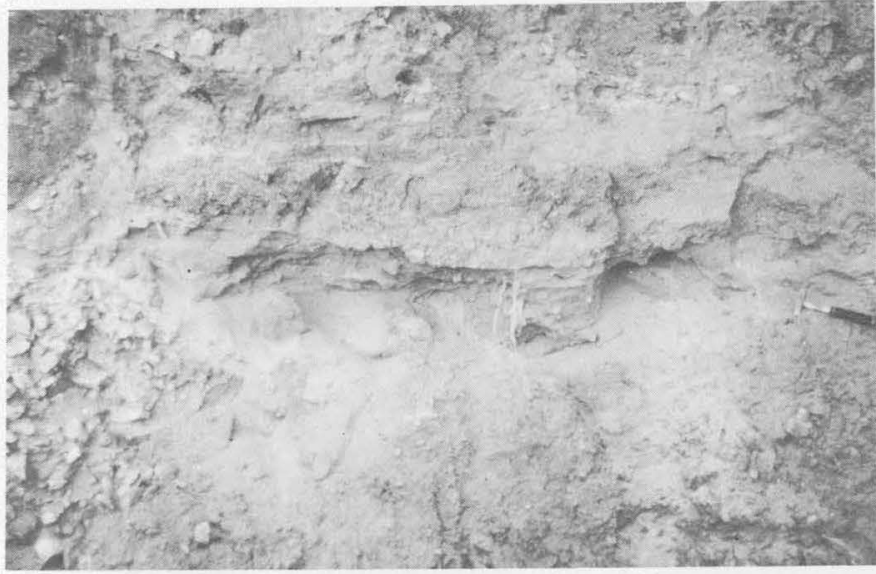

FIGURE 48.-Pleistocene ash bed in south wall of Conant Creek phosphate trench at a depth of 15 feet. Locality is 1,600 feet south and 200 feet west of NE cor. sec. 12, T. 32 N., R. 94 W. Soft undereut bed at level of hammer is ash and beds below and above are silt, sand, and gravel.

Houston (1964, p. 22) summarized data on the Rattlesnake Hills volcanic field as follows:

All intrusive rocks and flows are felsic and vary in composition from quartz latite to phonolites of different types. The earliest and quantitatively most important eruptives were biotite bearing quartz latites and soda trachytes. The most important phenocryst minerals in the quartz latites and trachytes are anorthoclase, aegirine-augite, biotite, magnetite, sphene, apatite, and oxyhornblende. Later eruptions were mostly phonolites that contained a great variety of undersaturated minerals as phenocrysts and, in general, had a very diagnostic mineralogy. The most important phenocryst minerals were nosean, aegirine, aegirine-augite, magnetite, green-brown hornblende, sanidine, hauynite, diopside, sphene, and anorthoclase. With the exception of the early eruptives the mineralogy of this province contrasts strongly with that of the Yellowstone-Absaroka province and distinctions between phenocrysts can be readily made.

Carey gave a detailed discussion (1959) of the volcanic rock types and associated structures and of his concepts of origin and emplacement. Houston (1964, tables 2 and 3) summarized the characteristics of volcanic debris in Tertiary sedimentary rocks elsewhere in Wyoming and compared them with the Rattlesnake Hills volcanic rocks. His data are discussed in connection with the Wagon Bed Formation.

Volcanic debris is a major constituent of all the middle Eocene and younger sedimentary rocks of central Wyoming; so the influence of the Rattlesnake Hills eruptive material on composition of the adjacent contemporary strata is of special interest. Surprisingly, the influence is extremely local and almost entirely confined to an area within 30 miles of the vents. Van Houten $(1955,1964)$ demonstrated the rapid westward gradation of volcanic conglomerate from the Rattlesnake Hills to fine-grained rocks and then to a complete absence of debris west of R. 93 W. Similarly, 10 miles east of the Rattlesnake Hills, the few thin remnants of this volcanic debris consist of fine-grained tuffaceous claystone. 'To the north and south the debris is buried or has been eroded away. The distinctive Rattlesnake Hills volcanic suites should easily be recognized, either as erosion products spread by streams from the vents or as ash falls, but they have not been found in other parts of Wyoming. A careful examination of thin sections of middle and upper Eocene rocks on the north side of the Wind River basin (Love, 1964; Houston, 1964) has failed to show anything but volcanic rocks from the Absaroka-Yellowstone National Park region. In the western part of the Beaver Divide and farther south in the Great Divide basin, and around the south end of the Wind River Range, the volcanic components are likewise of the Absaroka-Yellowstone National Park type. Either the volume of eruptive debris from the Rattlesnake Hills vents was small or it was eroded away prior to deposition of Oligocene rocks.

\section{SUMMARY DESCRIPTION OF STRUCTURAL FEATURES}

The following descriptive summary, keyed to the geologic map (pl. 1) and to the tectonic sketch map (pl. 9), is designed to guide the reader in the discussion of chronologic development of the most significant structures in the Granite Mountains area. These structural features are listed in alphabetical order.

\section{BARE RING BUTTE GRABEN}

The Bare Ring Butte graben is here named after Bare Ring Butte, a prominent topographic feature within the graben. This name is used by local residents because of a bare ring devoid of sagebrush tramped out on the otherwise brushy north side by cowboys trying to keep from freezing during a blizzard in the 1880's (Mrs. John Kirk, oral commun., 1963). It has also been called Barren Butte by oil geologists and is so designated on maps of anticlines in Wyoming (McGrew, 1956). The Bare Ring Butte graben is about 6 miles long, trends west, and involves the Bridger, Wasatch, and Battle Spring Formations. Displacement on the nearly vertical faults is not known but probably is several hundred feet. The age is post-Bridger but how much younger is not known.

\section{BEAVER CREEK THRUST FAULT}

The Beaver Creek thrust fault was named and first mapped by Bell (1955). It is a low-angle thrust fault about 16 miles long that trends northwest and forms the southwest margin of the Sweetwater Crossing anticline. Precambrian rocks in the core of the anticline were faulted onto strata of the Frontier Formation. 
The time of origin has not been determined precisely, but it is probably earliest Eocene.

\section{BISON BASIN-ANTELOPE-BARE RING (BARREN) BUTTE ANTICLINAL COMPLEX}

The anticlinal complex designated by this title began as a broad low uplift in pre-Tertiary time, and the crest was eroded to the Cody Shale prior to deposition of the first strata in the Fort Union Formation. Recurrent folding intensified the uplift after Paleocene time and before deposition of the Wasatch and Battle Spring Formations. Major folding occurred later and involved the Wasatch and Battle Spring and, near Bare Ring Butte, the Bridger. The structure of this anticlinal complex has been investigated in some detail by oil companies, and the anticline was drilled in many places during the last 40 years. A small amount of oil was found in the Bison Basin field and some gas at East Antelope, but not as much as might be expected for the size and age of the folds. The structure continues to be interpreted in many ways because poor exposures, several faults, and the presence of major unconformities complicate geophysical records.

\section{CASPER ARCH}

The Casper arch is a broad anticlinal uplift about 50 miles long that marks the east margin of the Wind River basin. Many oil and gas fields are along the crest of the fold; it has not been eroded below Jurassic rocks. The northeast flank is gentle and the southwest flank is overturned where the arch has overridden the northeast margin of the Wind River basin. Structural relief between the top of the arch and the bottom of the basin directly below the thrust is about 21,000 feet in some places. 'The major folding and thrusting occurred at about the end of deposition of the Indian Meadows Formation and before deposition of the Lysite Member of the Wind River Formation (Keefer, 1965, p. A57). Minor recurrent folding affected the Lysite and Lost Cabin Members.

\section{CONTINENTAL NORMAL FAULT}

The Continental normal fault was named by Nace (1939). It extends for about 60 miles along an arcuate course around the south (section I-I', pl. 3) and southwest margins of the Wind River Range; in most places the fault is slightly north of the Wind River thrust fault system, but apparently it intersects the system in the southwest corner of the Granite Mountains area. The mountain block was downdropped about 2,000 feet in some places, and movement was largely in Pliocene and Pleistocene time.

\section{CYCLONE RIM SYNCLINE}

The Cyclone Rim syncline (section B-B', pl. 1) was named by Bell (1955) for a 25-mile-long downwarp on the south side of, and parallel to, the Flattop fault. There is no specific evidence that the syncline existed as an entity separate from the Great Divide basin prior to middle Eocene time (section $\mathbf{A}-\mathbf{A}^{\prime}$, pl. 1). After deposition of the Bridger Formation but before that of the Ice Point Conglomerate, the syncline formed with the Flattop fault as the north margin. This downwarping and subsequent erosion are suggested by the distribution of lacustrine facies in the Laney Shale Member of the Green River Formation and the Bridger Formation, which are present below the Ice Point Conglomerate south of the Flattop fault but not to the north $\left(B-B^{\prime}\right.$, pl. $1 ; S-S^{\prime}$, pl. 4$)$. More downwarping occurred before deposition of the Oligocene(?) rocks, but the syncline then became nearly static until after deposition of the Split Rock Formation. Probably in late Miocene, Pliocene, or early Pleistocene time 500 feet or more of additional downwarping took place.

\section{EMIGRANT TRAIL THRUST FAULT}

The Emigrant Trail low-angle $\left(20^{\circ}-35^{\circ}\right)$ thrust fault (fig. 49), about 50 miles long and in places with a throw of more than 15,000 feet, developed along the south and west flanks of the Granite Mountains during earliest Eocene time. Six drill holes intersect the fault; so the dip and character of the fault plane are well known. Later normal faulting extensively modified the thrust plate east of Crooks Gap, but the part to the northwest has been essentially static since earliest Eocene time.

\section{FLATTOP FAULT}

The Flattop fault was named and mapped by Bell (1955). It has a sinuous 35-mile eastward course from the Wind River Range into the Great Divide basin. The western part is covered by middle Eocene rocks. This is a major fault, not only because of its enormous displacement in some localities, but because it represents several episodes of movement. The earliest episode had a significant effect on distribution and thickness of fluviatile and lacustrine facies in Eocene rocks. The actual time of first displacement on the fault is not known, but as is shown in section $\mathrm{B}^{-\mathrm{B}^{\prime}}$ (pl. 1), thinning caused by rising of the north block began in Paleocene time and continued until after the Cathedral Bluffs Tongue of the Wasatch Formation was deposited. Presence of the Laney Shale Member and Bridger Formation below the Ice Point Conglomerate in the syncline but their absence on Flattop Buttes is inter- 


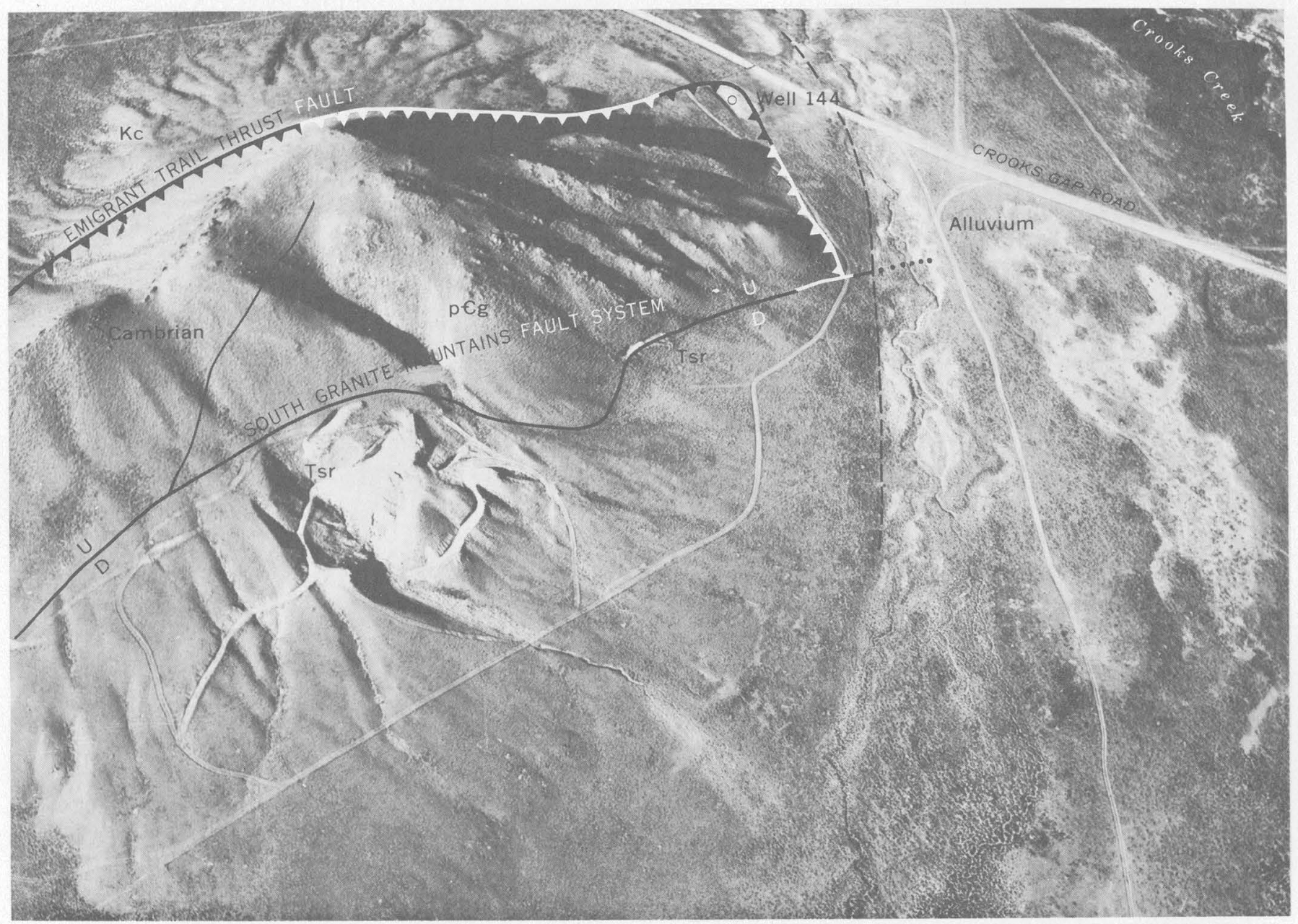

FIGURE 49.-View southwest toward northeast margin of Crooks Gap. Precambrian granite (p€g) and Cambrian rocks moved south along Emigrant Trail thrust fault onto Cody Shale $(K c)$ during early Eocene time. Well 144 penetrated 25 feet of granite and then into Cody Shale. Split Rock Formation (Tsr) was downfaulted against Precambrian granite along the South Granite Mountains fault system during post-Miocene time. Pit in left center is a uranium prospect. Photograph by P. T. Jenkins and L. P. House.

preted as evidence of post-Bridger but pre-Ice Point displacement and subsequent erosion along this segment of the fault ( $\mathrm{A}-\mathrm{A}^{\prime}$, pl. $1 ; \mathrm{S}-\mathrm{S}^{\prime}$, pl. 4). Intermittent movements during the time the Cathedral Bluffs, Laney, and Bridger sequences were being deposited south of the fault and the Wagon Bed Formation north of Flattop Buttes may account in part for the conspicuous differences in lithology on opposite sides of this area of disturbance. An interval of crustal quiescence followed deposition of the Ice Point Conglomerate, except for pre-Oligocene(?) sagging south of the fault, until post-Miocene time, when there was renewed movement along the Flattop fault and again the south block was downdropped, in places as much as 500 feet.

Farther west, in the vicinity of the Horsetrack anticline, the top of the Precambrian on the north side of the Flattop fault was 15,000 feet higher than that on the south side prior to deposition of the Laney Shale Member (section I-I', pl. 3). This does not necessarily mean that there was 15,000 feet of fault displacement; an unknown amount of this structural relief could be accounted for by folding. Much of the movement, as well as erosion of the rising block, may have preceded deposition of the Cathedral Bluffs Tongue, but several thousand feet of displacement and erosion are believed to have occurred between the time of deposition of the Cathedral Bluffs and Laney.

It is possible that this segment of the Flattop fault along which there was pre-Cathedral Bluffs movement may actually be continuous with the Wind River thrust fault. It would then represent the high-angle easttrending terminal part that is more of a tear than a thrust. No post-Laney displacement occurred along the fault in the Horsetrack area. 


\section{GRANITE MOUNTAINS}

The Granite Mountains, which have a Precambrian core about 85 miles long and are as much as 30 miles wide, comprise the major anticlinal uplift in the area. This uplift trends westward, has a gentle north flank and steep and in places thrust-faulted south and west flanks. The chief episode of folding and faulting was Laramide and occurred in earliest Eocene time; later structures (the North and South Granite Mountains fault systems and Split Rock syncline) were superimposed on the earlier ones, and they drastically modified the configuration of the mountain arch.

\section{GREAT DIVIDE BASIN}

The east half of the Great Divide basin bounds the southwestern part of the Granite Mountains. The basin trends west and is markedly asymmetric, with a gentle south flank and a steep north flank that was overridden by the Wind River Range, the Sweetwater Crossing anticline, and the Granite Mountains. Extending eastward from the southeast end of the Wind River Range into the northern part of the basin are the Wind River thrust fault (which coincides locally with the Continental normal fault), the Cyclone Rim syncline, the Flattop fault, the Bison Basin-Antelope-Bare Ring (Barren) Butte anticlinal complex, and the Mormon Trail reverse fault. The depth of the basin where it is overridden by the Granite Mountains just south of well 177 is about 18,000 feet. The basin is an old downwarp that began sinking in Late Cretaceous time. The major movement occurred in Paleocene and earliest Eocene times. Folding and faulting in late Cenozoic time have extensively modified the central northern margin.

\section{MORMON TRAIL FAULT}

The Mormon Trail fault was named and the western part was mapped by Bell (1955). From the junction with the Emigrant Trail thrust at Crooks Gap, it follows a sinuous generally westward course for 30 miles and dies out in Precambrian rocks of the Wind River Range. The Mormon Trail fault is probably a composite of several types. Certainly, it is a thrust at well 262, where Cody Shale overlies conglomerate of the Wasatch and Battle Spring Formations, and it is very likely a thrust from this well west for 7 miles. Along the north side of the Happy Springs oil field, it is a complex of thrust slices. Elsewhere it appears to be a high-angle reverse fault except in the western part, where it may be nearly vertical and indistinguishable from a normal fault. Maximum stratigraphic displacement is in the vicinity of section $\mathrm{R}-\mathrm{R}^{\prime}$ (pl. 4), where the Chugwater Formation overrides the Wasatch and Battle Spring. The age of the Mormon Trail fault is probably earliest or early Eocene, for at least part of the Wasatch and Battle Spring Formations has been overridden, whereas the Wagon Bed is not involved. Local configuration of this fault has been drastically modified by the younger South Granite Mountains fault system that parallels, displaces, and crosses it many times in an 8-mile-long segment extending west from Crooks Gap.

\section{NORTH GRANITE MOUNTAINS FAULT SYSTEM}

The North Granite Mountains fault system, 60 miles long, comprises a series of west-trending discontinuous nearly vertical normal faults near the north margin of the Granite Mountains. This fault system is remarkable in several respects. It is scarcely influenced by Laramide folds, for it cuts with little deviation from the deep southeast arm of the Wind River basin obliquely across Mesozoic, Paleozoic, and Precambrian rocks on the north flank of the Granite Mountains, through the Rattlesnake Hills volcanic field (fig. 50), and then from the Precambrian core of the mountains across Paleozoic, Mesozoic, and Tertiary strata in reentrants along the south margin of the Wind River basin.

The fault system was involved in two major episodes of movement. The first, and by far the greatest, occurred at about the end of early Eocene time, when the south (Granite Mountains) block was vertically uplifted several thousand feet. There is no way to determine the amount of movement along most of the fault system, but data from wells near the east end indicate it was about 5,000 feet. The system then lay dormant until Pliocene time, when the Granite Mountains began to subside and the fault system was reactivated. However, this time the direction of movement of the. blocks was reversed, for the mountain side went down. Again, the amount of movement is not known, but along the eastern and western parts it probably was only a few hundred feet. South of the Rattlesnake Hills it may have been 1,000 feet or more.

\section{RATTLESNAKE HILLS VOLCANIC FIELD AND ASSOCIATED STRUCTURES}

About 35 vents and intrusive bodies of middle and late Eocene age cut Precambrian, Paleozoic, Mesozoic, and lower Tertiary rocks in a 125-square-mile area of the Rattlesnake Hills. Of these, six are $1 / 2$ mile to more than 2 miles in diameter. Three of the largest, along the northeast margin of the field, were accompanied by intense concentric local folding and faulting of the Paleozoic and Mesozoic rocks; they hare been mapped in detail by Carey (1954). In addition to the North Granite Mountains fault system that crosses the volcanic field, there is a complex network of seemingly 


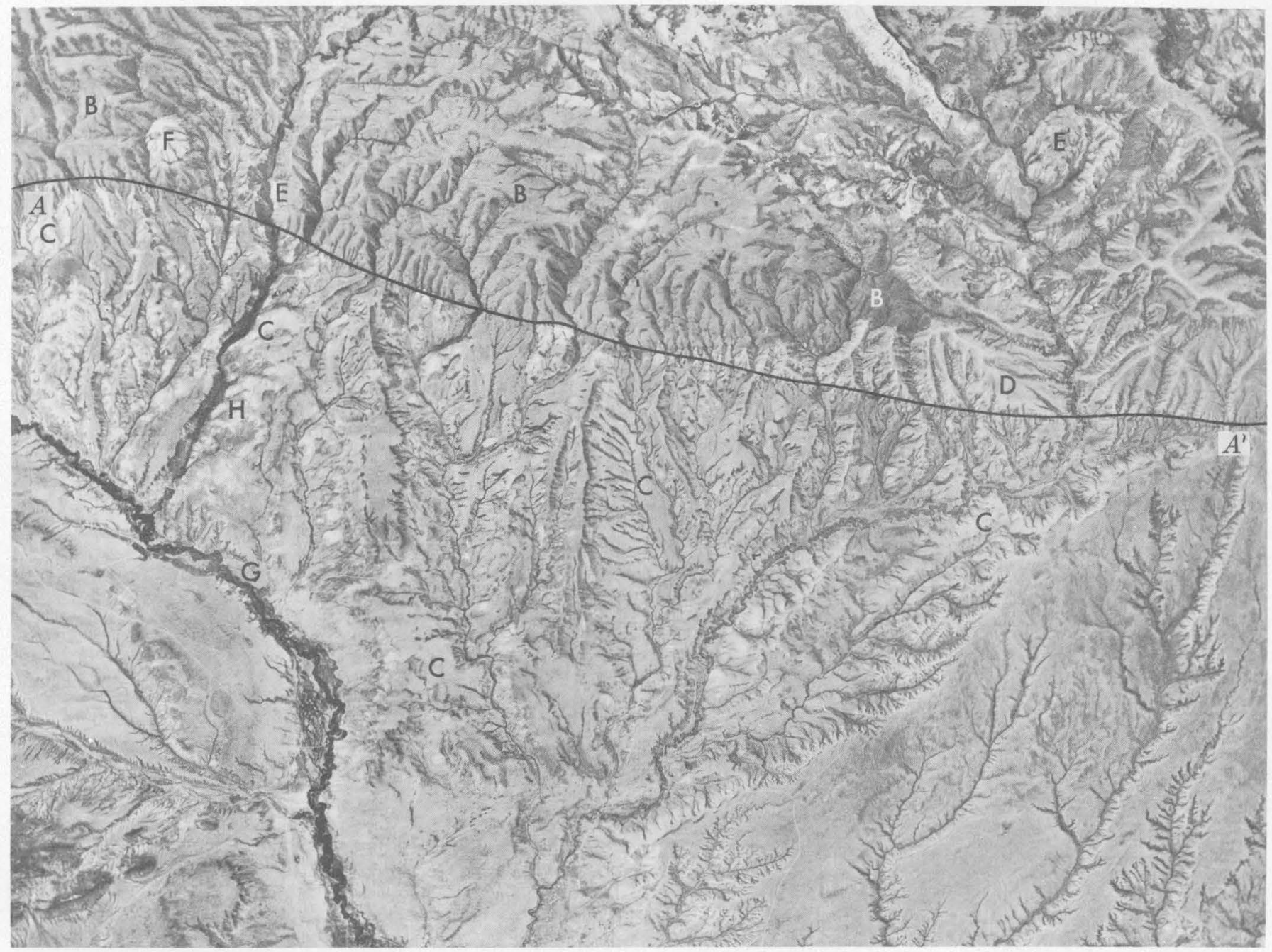

Figure 50,-North Granite Mountains fault system along south margin of the Rattlesnake Hills. Photograph shows area about 8.5 miles wide; north is at top. A-A', Major normal fault. B, Precambrian hornblende schist on the upthrown block. C, Split Rock Formation on the downthrown block. D, Wagon Bed Formation. E, Quartz latite intrusives. F, Aegirine nosean phonolite intrusive of Eocene age. G, Dry Creek. H, U T Creek. Geology from Carey (1954). Photograph by U.S. Army Map Service.

unoriented post-Miocene normal faults of relatively small displacement crossing or adjacent to many of the vents. Individual vents and the volcanic field as a whole show no obvious affinity for any particular type of older rocks, and the studies thus far do not indicate that they exploited any preexisting lines of structural weakness. Similarly, most of the late Cenozoic faults seem not to have been influenced by the vents and intrusives.

\section{SOUTH GRANITE MOUNTAINS FAULT SYSTEM}

The South Granite Mountains fault system (fig. 51), 80 miles long, is a southern counterpart of the northern fault system but is larger in nearly every respect, and much more precise information about it is available. The faults are more continuous and have greater displacement than those of the northern system, but they appear just as unaffected by the type of bedrock and the preexisting structures involving it. For example, the easternmost one-third of the southern system involves only the Precambrian core of the Granite Mountains (fig. 52) ; the central one-third involves the Emigrant Trail thrust plate (fig. 49) (where individual branches were named the Kirk and East Kirk normal faults by Stephens, 1964); and the western one-third leaves the Precambrian rocks and crosses soft Cretaceous strata in the Long Creek arm of the Wind River basin without change in trend or magnitude. This segment parallels the Mormon Trail fault and cuts indiscriminately across a variety of rock types and structures (figs. 53, $54)$.

This system was involved in the same two episodes of movement as the northern one. The first movement, but in this system not necessarily the greatest, occurred at about the end of early Eocene time when the Granite 


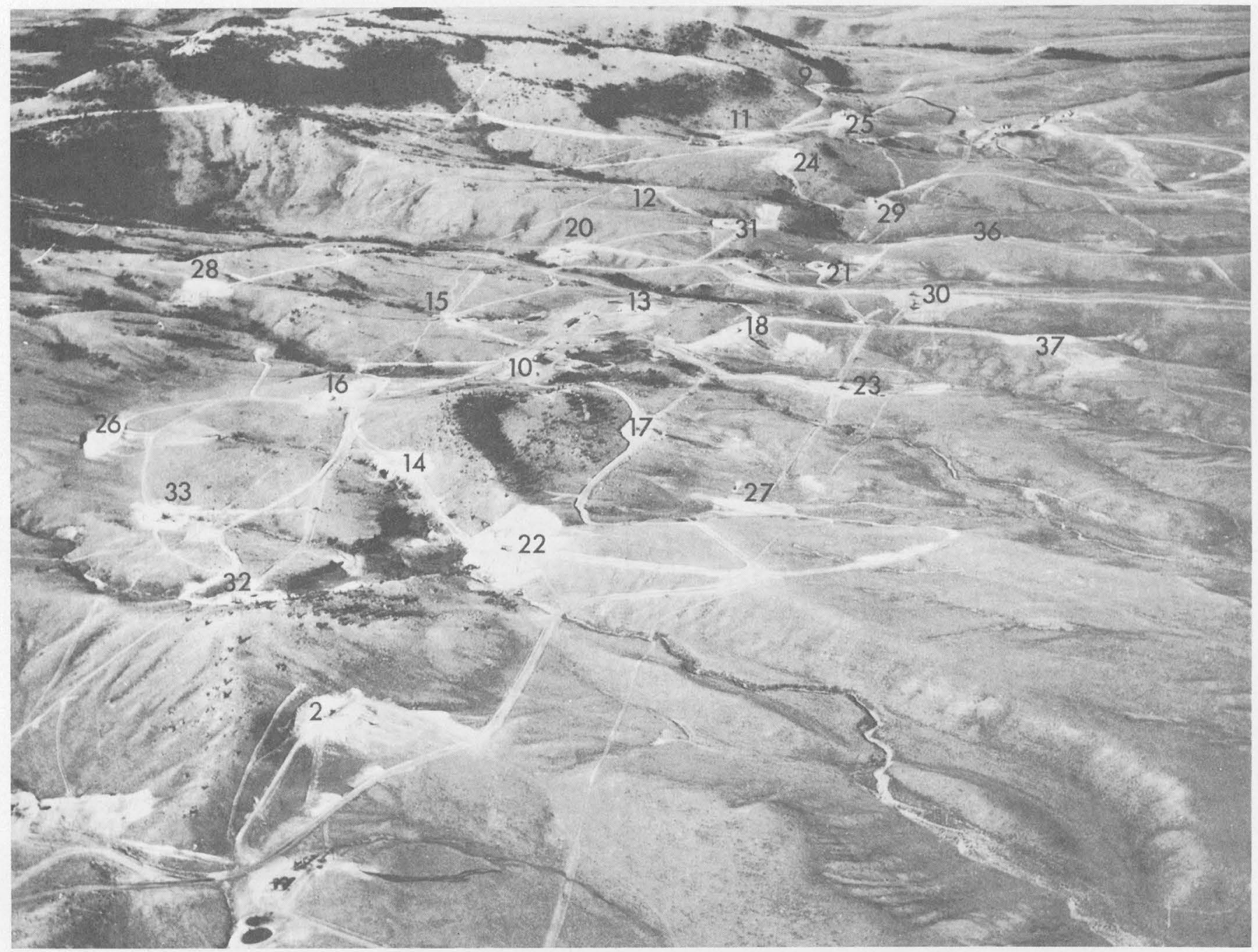

Figure 51.-View west along South Granite Mountains fault system, showing its relation to North Happy Springs oil field. Field well numbers (not arbitrary numbers used on geologic map and in table 2) are shown. Vertical fault is exposed in cut at site of well 22; dark conglomerate of Wasatch and Battle Spring Formations is at left and white Split Rock Formation is at right; post-Miocene downdrop of north block is more than 2,000 feet. (See $D-D^{\prime}, \mathrm{pl}, 1 ; O-O^{\prime}$, pl. 4.) Well 17 is on south

Mountains were uplifted. The vertical displacement was as much as 3,000 feet in places. Following this, the system lay dormant probably until Pliocene time. The second movement was the reverse of that during Eocene time. As the Split Rock syncline developed, the mountain block dropped; a minimum displacement of 2,000 feet can be demonstrated in several places. The maximum is not known.

\section{SPLIT ROCK SYNCLINE}

The Split Rock syncline is a west-northwest-trending major downwarp about 80 miles long, as much as 30 miles wide, and more than 3,000 feet in amplitude. It is asymmetric, with a steep south side. Almost the entire side of fault; 18 is on fault; 23 is in Split Rock Formation, which has a dip of $8^{\circ} \mathrm{N}$. 21 and 29 are on north side of fault; and 31,24 , and 25 are on south side, Area upslope from a line between wells 9 and 26 is Crooks Gap Conglomerate, and aren downslope to fault is Wasatch and Battle Spring Formations. Photograph by P. T. Jenkins and L. P. House.
Granite Mountains uplift subsided into it or was affected by it. However, like the North and South Granite Mountains fault systems, the syncline appears not to have been influenced by older structures or rock types. It crosses without deviation or variation in magnitude the Precambrian core of the Granite Mountains, the Emigrant Trail thrust sheet, the Long Creek arm of the Wind River basin, extends almost the entire length of the Sweetwater Crossing anticline, and dies out near the northwest terminus of that uplift.

Downwarping of the Split Rock syncline began in Miocene time and is still continuing. The most rapid movement, however, apparently occurred in Pliocene and early Pleistocene time. 


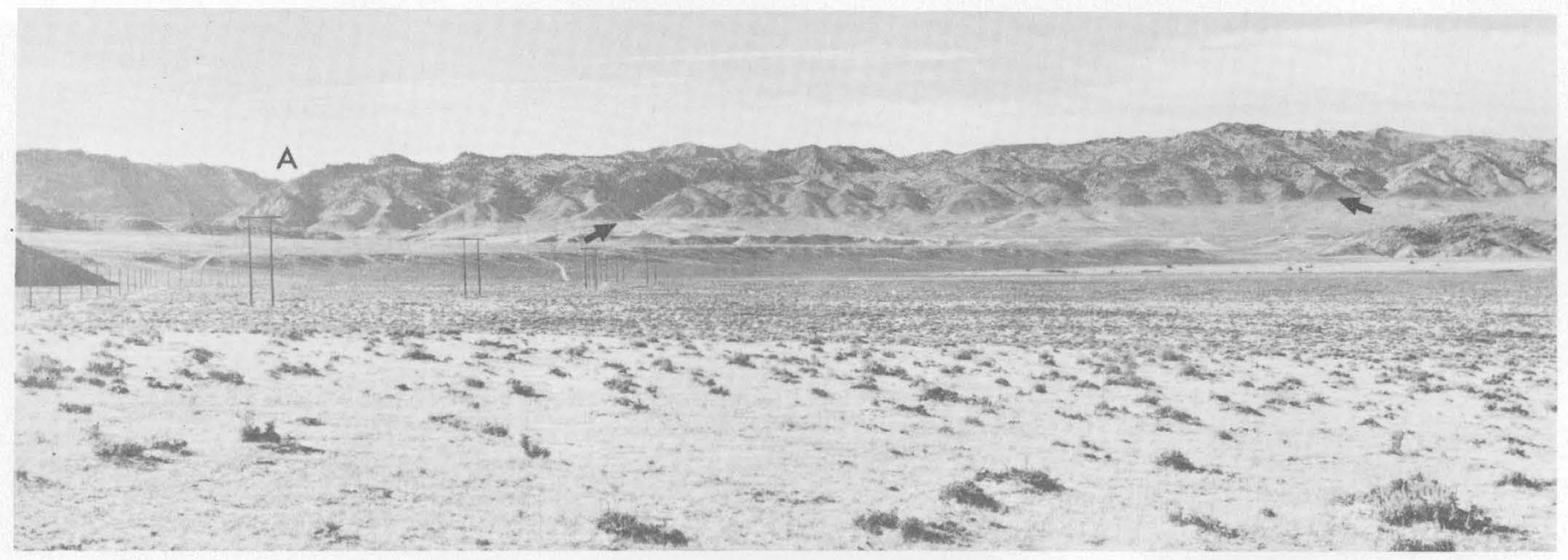

Figure 52.-View to south toward Seminoe Mountains. A, Black Canyon cut by the North Platte River. Arrows mark trace of South Granite Mountains fault system, along which Moonstone Formation in lower light-colored slopes is downdropped against vertical metasedimentary rocks of Precambrian age comprising higher part of Seminoo Mountains. Directly below left arrow is scarp of uranium-bearing limestone in Moonstone Formation.

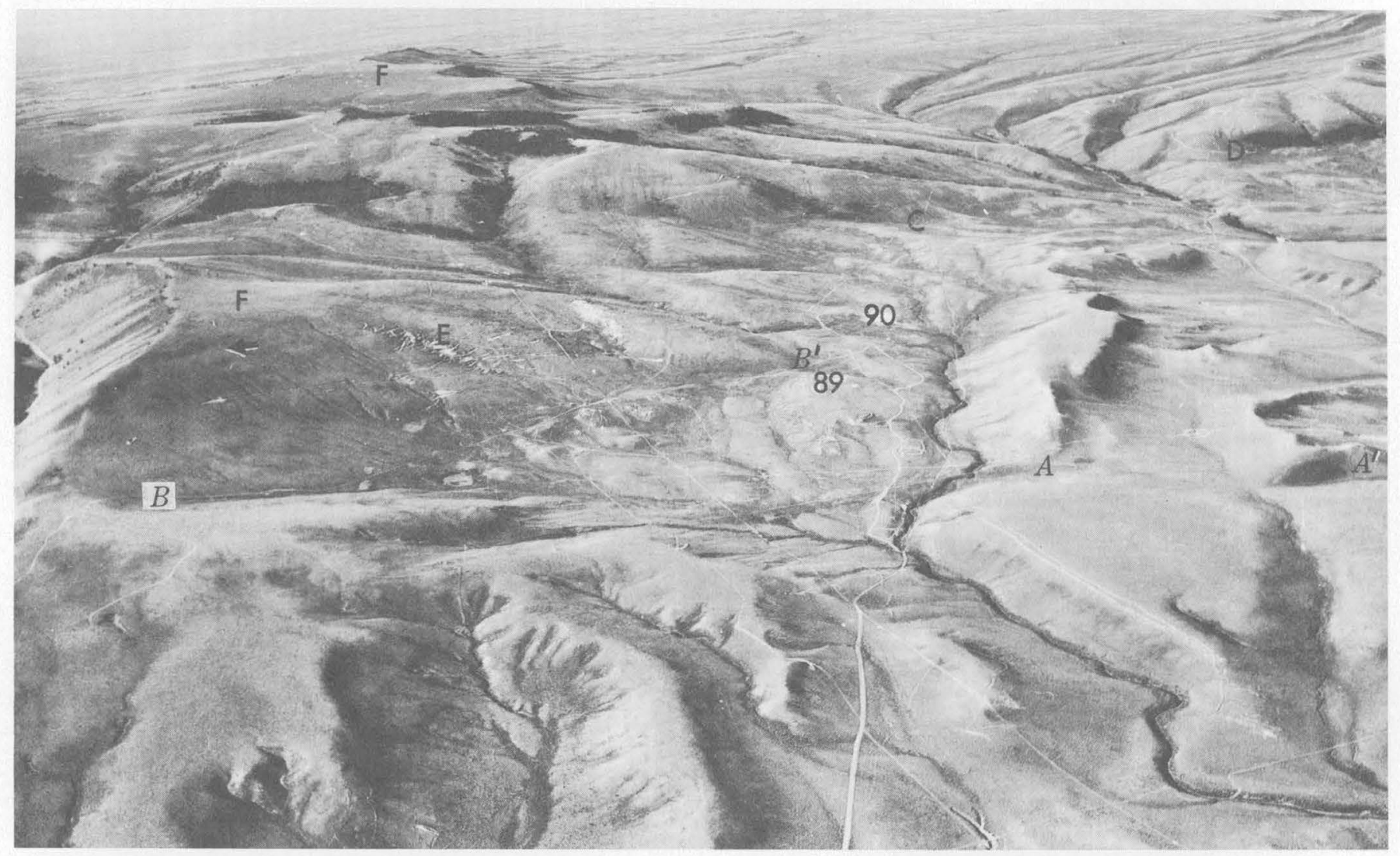

Figure 53.-View south showing complexly faulted west end of Crooks Mountain. Features indicated are wells 89 and 90 , Split Rock Formation (in foreground) downfaulted against White River Formation (fault trace along line $A-A^{\prime}$ ), and White River downfaulted against Wasatch and Battle Spring Formations (fault trace along line $B-B^{\prime}$ ). C, Wagon Bed Formation downfaulted against Wasatch and
Battle Spring Formations. D, Upper part of Wasatch and Battle Spring Formations downfaulted against lower part. E, Scarified jade area in Battle Spring Formation. F, Crooks Gap Conglomerate above arrow. Valley of Haypress Creek at upper right. Stratigraphic section $C-C^{\prime}(\mathrm{pl}, 1)$ crosses this area. Photograph by P. T. Jenkins and L. P. House. 


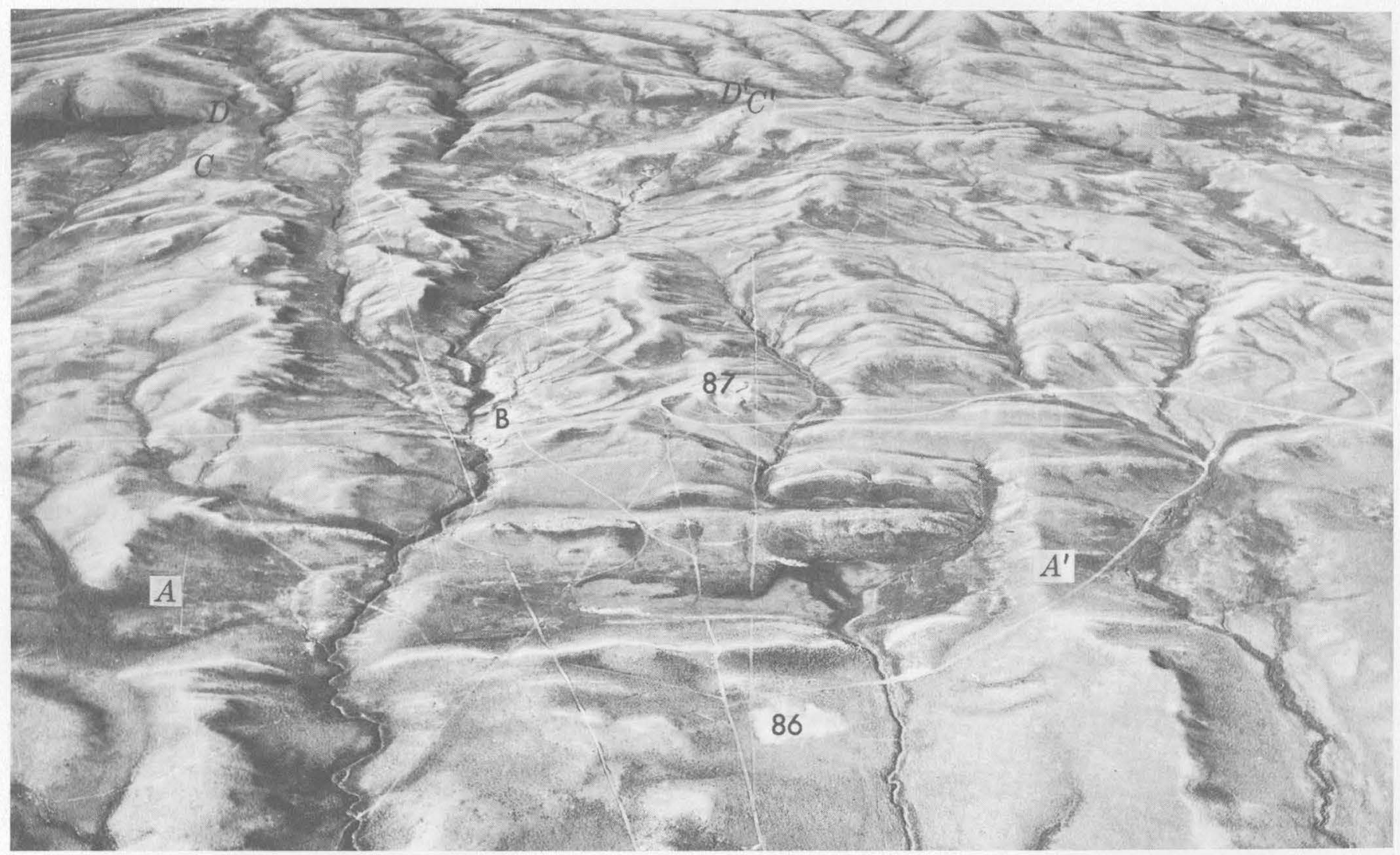

FIGURE 54,-View south in T, 28 N., R. 94 W., showing wells 86 and 87 . North-dipping Split Rock Formation in foreground is downfaulted against White River Formation (fault trace along line $\left.A-A^{\prime}\right)$. B, Variegated strata in Wagon Bed Formation at Soap Holes. Wagon Bed Formation is downfaulted against Wasateh and Battle Spring Formations (fault trace along line $C-C^{\prime}$ ); upper part of Wasatch and Battle Spring Formations is downfaulted against lower part (fault trace along line $D-D^{\prime}$ ). Stratigraphic and structure sections $C-C^{\prime}(\mathrm{pl}, 1)$ and $R-R^{\prime}(\mathrm{pl}, 4)$ cross this area. Photograph by P. T. Jenkins and L. P. House.

\section{SWEETWATER CROSSING ANTICLINE}

The Sweetwater Crossing anticline was named by Bell (1955), who recognized it as an independent uplift completely separated from both the Granite Mountains and the Wind River Range. It is a northwest-trending uplift with a gentle northeast flank and an overthrust southwest flank marked by the Beaver Creek thrust that shoved Precambrian rocks onto Upper Cretaceous. The Precambrian core is nearly 20 miles long and 4 miles wide. The Sweetwater Crossing anticline is the southernmost of a series, which is nearly 100 miles long, of anticlines en echelon east of the Wind River Range. It has been little-known until recently because it remains largely buried by Oligocene and Miocene rocks. Now, however, the knowledge gained from the few peripheral exposures is supplemented by abundant core-drill data, and the configuration of the anticline can be determined with some accuracy.

The Sweetwater Crossing anticline is presumed to be of approximately the same age, earliest Eocene, as the Wind River Range and the Granite Mountains. It was partly buried by the Wagon Bed Formation, almost completely by the White River Formation, and completely by the Split Rock Formation. Subsequently, the uplift subsided along the trough line of the Split Rock syncline, which cuts obliquely across it for 15 miles.

\section{WIND RIVER BASIN}

The Wind River basin is the major downwarp bounding the north flank of the Granite Mountains. The part of the southeast arm shown on plate 1 has an amplitude of about 25,000 feet, is asymmetric, with a gentle southwest flank, and is bounded by a thrust fault along the northeast flank. The Long Creek arm of the Wind River basin is directly west of the Granite Mountains. It is a structural downwarp that connects the Wind River and Great Divide basins. This arm is here named after Long Creek, a tributary to the Sweetwater River, that meanders for many miles across Tertiary rocks that bury this downwarp. The southwest flank of the Long Creek arm is gentle, whereas the northeast flank has been overridden by the Emigrant Trail thrust plate (pl, 7) in such a way that Precambrian rocks now rest on Cody Shale. The amplitude of 
the downwarped Long Creek arm is about 5,000 feet. It was first developed prior to deposition of the Indian Meadows(?) Formation, was overridden by the Emigrant Trail thrust plate during earliest Eocene time, and was downwarped again but not faulted after deposition of each of the following formations: Wind River, Wagon Bed, and White River.

\section{WIND RIVER RANGE}

Only the southeast margin of the Wind River Range is included in the Granite Mountains area, but the tectonic influence of this, the largest and highest range in Wyoming, must have been very significant. The Precambrian core of the range is nearly 120 miles long and has a maximum width of about 40 miles. Thus, it is only slightly longer and wider than the Granite Mountains. The anticlinal arch is asymmetrical, with a gentle northeast flank and a steep and overthrust southwest flank. Differential elevation on the Precambrian rocks from the highest part of the range to the directly adjacent, overridden part of the Green River basin is about 40,000 feet. Although the first upwarping began in Late Cretaceous time, major uplift and thrusting did not occur until earliest Eocene time. As was discussed in connection with the Flattop fault, additional uplift, faulting, and erosion occurred at the south end of the range after deposition of the Cathedral Bluffs Tongue and prior to deposition of the Laney Shale Member. Near the end of Eocene time, a sudden uplift of the southeastern part of the range released the flood of giant boulders that make up the Ice Point Conglomerate. Following this episode, the range was almost static until Pliocene time, when the south end subsided 1,000-2,000 feet along the Continental fault.

\section{WIND RIVER THRUST FAULT SYSTEM}

The southwest and south flanks of the Wind River Range are bounded by the Wind River thrust fault system which is more than 120 miles long and has a maximum throw of at least 35,000 feet (Berg, 1961). Nowhere is the southeastern part exposed; so its nature can be inferred only from geophysical and drill hole data. 'The small segment of the system that extends into the extreme southwest corner of the Granite Mountains area is a single fault, more likely a high-angle tear rather than a thrust. It apparently intersects the Flattop fault in the Horsetrack area (section $I-I^{\prime}$, pl. 3). Major movement on the fault occurred during earliest Eocene time, then decreased, and there has been little or no movement since the Laney Shale Member was deposited. The southeastern part of the Wind River thrust in places coincides approximately with, and was extensively modified by, the Pliocene and Pleistocene Continental normal fault.

\section{GEOLOGIC HISTORY AND ITS RELATION TO ECONOMIC POTENTIAL}

The ensuing discussion considers the history of the major structural features in the Granite Mountains area (pl. 9) in the following order: (1) The Granite Mountains uplift and associated lesser folds and faults, all of Laramide age; (2) the Wind River basin; (3) the Great Divide basin; (4) the Wind River Range; (5) the North Granite Mountains fault system; (6) the South Granite Mountains fault system; (7) the Split Rock syncline; (8) the Sweetwater Crossing anticline and the synclines on its northeast and southwest sides; and (9) the Flattop fault and the Cyclone Rim syncline south of it.

Those structural features involved in or affected by a tectonic event during a given interval of geological time are discussed in this numerical order as much as possible and are keyed to block diagrams (pl. 10A-J). Tectonic events are closely related to the origin and distribution of valuable economic resources in the Granite Mountains area. Therefore, an understanding of the geologic history is necessary for efficient development of the known resources as well as for the exploration for new ones.

When each of the enumerated structural features is studied critically, that feature is seen to be the product of a long, complex series of events; few features in any one locality are unrelated, either by cause or by effect, to those in another.

Reviews of the regional structure of the Granite Mountains and basins on the north and south sides were presented by Blackstone $(1948,1951)$ and by Osterwald (1961). An aeromagnetic map was made of the northwestern part of the Granite Mountains area by Dempsey, Stuart, and others (1962). The tectonic map of the United States (Cohee and others, 1961) gives the structural setting of central Wyoming on a small scale. Various detailed structure maps of areas around the margins of the Granite Mountains are available (Van Houten, 1964; Thompson and White, 1952, 1954; Bell, 1955).

\section{LATE BUT NOT LATEST CRETACEOUS}

The Lewis sea (late Campanian and early Maestrichtian) was the last extensive sea in which marine sediments were deposited in central Wyoming. It covered the east half of the Granite Mountains area. Prior to the advance of this sea, however, there had been local uplift and erosion directly south of the 
Granite Mountains in the area north of the Lost Soldier oil field (this report, pl. 1; Fath and Moulton, 1924; Weimer and Guyton, 1961; Zapp and Cobban, 1962) that resulted in abrupt truncation of the Mesaverde Formation and deposition of Lewis Shale on Cody Shale. Good traps for oil and gas may occur along this unconformity as sandstone 500 feet or more thick pinches out updip against an impervious shale. The sedimentary record across the Granite Mountains has been destroyed; so the configuration and extent of this initial uplift are not known. Plate $10 \mathrm{~A}$ shows my concept of the landscape at this time. It has been coordinated with a regional diagram representing this same time (Love and other's, 1963) and with a detailed one for the Wind River basin (Keefer, 1965).

The fragmentary sedimentary record shows no evidence that the Granite Mountains were being uplifted at this time. Sluggish streams originating along or west of the west border of Wyoming flowed eastward across a low-lying broad coastal plain and built a delta into the Isewis sea in central Wyoming. Coal swamps were abundant, the climate was warm and humid, and numerous ash falls from volcanos probably to the west contributed distinctive yellow, green, and white very fine-grained debris to the carbonaceous sediments of the coastal plain. These deposits comprise the Meeteetse Formation and intertongue eastward with its marine counterpart, the dark-gray soft Lewis Shale.

\section{LATEST CRETACEOUS}

The withdrawal of the Lewis sea from central Wyoming was interrupted by many broad oscillations; these influenced the type and thickness of deposits along the west shoreline. The retreat was caused by the first major movement of the Laramide Revolution ${ }^{6}$ - the uplift of a north west-trending area in central Wyoming that roughly coincided with the Granite Mountains and perhaps the south-central part of the Wind River Range (pl. 10B). This uplift lay between two easttrending rapidly sinking major downwarps of regional extent (Love, 1960; Love and others, 1963), and as the broad areas of soft Cretaceous strata were exposed, they provided a local source for an enormous amount of debris. Despite the magnitude of these downwarps, the general land surface in central Wyoming remained near sea level. In the northern downwarp, the deepest part of which coincided with the present trough line of the Wind River basin, 6,000 feet or more of the

\footnotetext{
"For the last 70 years, the name "Laramide Revolution" has been applied to a period of mountain bullding and erosion in the Rocky Mountuins region that began in Late Cretaceous time and ended in early Tertiary time (Dana, 1805; Wilmarth, 1938, p. 1149). As used here, it includes all tectonlc events that occurred in central Wyoming during latest Cretnceous Paleocene and Eocene times.
}

Lance Formation (latest Cretaceous, late Maestrichtian and Danian (?)) was deposited. In the southern downwarp, the deepest part coincided with the present trough of the Great Divide basin, and 6,000 feet or more fine-grained clastic strata was deposited in it. Brackishwater conditions lingered on through Lance time in eastern Wyoming but not, as far as is now known, in central Wyoming.

Differential uplift in the Lost Soldier area on the south flank of the Granite Mountains is indicated by a local angular unconformity at the base of the Lance Formation. The oil and gas potential is worth investigating in places where this unconformity is adjacent to porous and permeable rocks.

\section{PALEOCENE}

Deposition in the deepest parts of the Wind River and Great Divide basins probably was continuous from Cretaceous to Paleocene time. The Lance Formation, however, was stripped from the banks of the Granite Mountains and the Wind River Range as they continued to rise. Paleocene strata of the Fort Union Formation were deposited across the eroded edges of successively older strata on the uplifts. Conglomerates indicate that broad areas of Paleozoic rocks were being eroded early in Paleocene time; later, areas of Precambrian rocks were exposed (pl. 10C) and were sufficiently extensive to furnish a considerable amount of arkosic debris (section $B-B^{\prime}, \mathrm{pl} .1$ ).

Throughout Paleocene time, sedimentation kept pace with sinking; so despite the fact that the floors of the Wind River and Great Divide basins had sunk 10,000 feet or more after withdrawal of the Lewis Sea and onset of the Laramide Revolution, the altitude of the basin and mountain land surface remained nearly at sea level. The central part of the Wind River basin was occupied by Waltman lake, a large foul-bottomed body of water which contained sharks (Keefer, 1961; 1965 , p. A32-A33) and which probably connected with the Cannonball seaway east of Wyoming. No similar lake is known in the Great Divide basin.

The climate during Paleocene time was warm and humid. Coal swamps persisted during deposition of hundreds of feet of strata in the Great Divide basin but were more restricted to the area along the shores of Waltman lake in the Wind River basin. Thus, the most extensive Paleocene coal deposits in the region are along the north margin of the Great Divide basin. McGrew (1957) concluded from a study of the vertebrate fossils in the Fort Union Formation of the Bison Basin area (loc. $4 \mathrm{~V}, \mathrm{pl} .1$ )) that the environment was a savanna type but perhaps with some localized dense forests. 
A peculiar unexplained feature confined to Paleocene strata, and doubtless related to climate, is the characteristic absence of limestone fragments in conglomerates (Keefer, 1965, p. A30-A32), even though much of the debris was derived from broad exposures of Paleozoic rocks. Further, only two Paleocene mollusk localities have been found (D. W. Taylor, written commun., 1965) in central Wyoming, despite rather detailed studies of the Paleocene rocks. One of these is on the north side of the Wind River basin and one is on the south side. Most sandstones in the Fort Union Formation of the Granite Mountains area have abnormally small amounts of calcareous cement.

Plate $10 \mathrm{C}$ is a reconstruction of the landscape during late Paleocene time. The size and nature of rock fragments in conglomerates and the distribution of finegrained strata give clues as to the location of drainage systems, the outcrop patterns of pre-Tertiary rocks, and the position of the highest parts of the Granite Mountains.

The possibility of oil and gas traps occurring in lenticular sandstones of the Fort Union Formation along the north flank of the Great Divide basin is good. The straw-colored aromatic oil (described elsewhere in this report) in the Fort Union Formation at locality 1-O east of Bison Basin is evidence that oil can occur in these rocks near the margin of the basin. Farther south, out in the deeper part of the basin, well 278 was completed for 144 barrels of oil per day from the Transmountain sandstone of subsurface usage (B-B', pl. 1). Other areas of possible oil and gas traps, in addition to those within the Fort Union Formation, are the places where this formation laps progressively across the upturned strata of the Lance, Lewis, Mesaverde, Cody, and Frontier Formations in the northern part of the Great Divide basin.

\section{EARLIEST EOCENE}

The most violent paroxysms of the Laramide Revolution in central Wyoming occurred during earliest Eocene time. By the beginning of this epoch, all the major basins and most of the mountain ranges in Wyoming were delineated, and during this time the greatest amount of folding of oil- and gas-bearing structures took place. For the first time since the onset of the Laramide Revolution, uplift of the mountains (relative to sea level) predominated over subsidence of the basins. The Granite Mountains rose during the time of deposition of the Indian Meadows Formation almost certainly to an elevation of several thousand feet above sea level, and initial thrust movement occurred along the low-angle Emigrant Trail fault. The Precambrian core of the mountains was a broad area of rugged topography; its highest part was between the Pathfinder Reservoir and Split Rock. In this mountainous terrain lay the headwaters of two major drainage systems. These streams were very effective agents of erosion and transport because of wet climate and steep gradients.

One drainage system flowed northeast across the present southeast arm of the Wind River basin and on into the Powder River basin. Along the basinward part of its course, this stream deposited a giant arkosic fan as much as 6,000 feet thick that may have partly blocked the eastward drainage from the Wind River basin and caused Waltman Lake to persist into Eocene time (Love and others, 1963; Keefer, 1965, p. A56).

The other drainage system flowed southwest into the Great Divide basin and deposited an analogous arkosic fan, parts of which are at least 4,000 feet thick. During the early stages of deposition, this fan terminated along the north margin of extensive coal swamps that occupied the northern part of the Great Divide basin. These swamps persisted and many coal beds accumulated during deposition of 1,000 feet of strata. The coarse-grained arkosic part of the fan is the host rock for all the known uranium deposits in the Crooks Gap district as of 1965. The hypothetical positions of lesser drainages from the Granite Mountains are shown on plate 10D.

The Sweetwater Crossing anticline, west of the west end of the Granite Mountains (pl. 7) was folded and deeply eroded. The Wind River Range, still farther west, became prominent and for the first time broad areas of Precambrian rocks were exposed. Arkosic fans spread southward into the Green River and Great Divide basins from the southern, steep flank of the range. On the more gently folded southeast end, however, and along the northeast flank, broad dip slopes of Paleozoic rocks protected the Precambrian from erosion.

The most violent of all the episodes of thrusting in central Wyoming occurred after these fans had been deposited. It drastically altered the established drainage systems, destroyed parts of some major alluvial fans, and extensively modified others. Precambrian rocks of the Granite Mountains overrode the southern arkosic fan for more than 1 mile. The northern fan was overridden by the newly created Casper arch, a broad anticline that was thrust southwest onto the southeast arm of the Wind River basin (Keefer and Love, 1963; Keefer, 1965, p. A57). This movement temporarily disrupted eastward drainage from the Wind River basin.

The Mormon Trail reverse fault branched off the Emigrant Trail thrust at Crooks Gap (pls. 7, 9), and 
extended west to the Wind River Range. In most places it is a high-angle fault involving incompetent beds on both sides. Conglomerate in the Wasatch and Battle Spring Formations was overridden by Cody Shale in the vicinity of core hole 262 .

Arkosic fans that extended south and southwest from the Wind River Range were overridden by the Wind River thrust. The fault was a low-angle fault along the south west side of the uplift but became a high-angle tear fault near its southeast terminus. Vertical displacement along the south margin of the mountains ranged from 5,000 to more than 15,000 feet. This uplift launched a new episode of fan building into the Green River basin.

The Sweetwater Crossing anticline was thrust southwest along the Beaver Creek fault, and Precambrian rocks overrode Upper Cretaceous.

\section{EARLY EOCENE}

For several million years after the final major compressional movements of the Laramide Revolution in central Wyoming, the area was relatively stable. The Granite Mountains were deeply eroded, and several thousand feet of clastic strata was deposited in the Wind River basin to the north and in the Great Divide basin to the south. The thickness of these deposits indicates that the basins sank progressively during sedimentation, and by the end of this interval of time the oldest deposits must have been well below sea level in the deepest parts of both basins.

After the Lysite Member of the Wind River Formation was deposited in the Wind River basin, some warping and erosion occurred along the Casper arch, resulting in an angular unconformity between the Lysite and Lost Cabin Members. Major drainage in the Wind River basin was reestablished to the east over the Casper arch but was never again as vigorous as in earliest Eocene time. Volcanos in the Yellowstone National Park-Absaroka region furnished windblown and waterborne felsic ash to the western part of the Wind River basin during the latter part of early Eocene time but furnished little sediment to the eastern part.

Regional subsidence throughout much of southwestern Wyoming first caused local ponding and then sporadic expansion of lakes until they coalesced to form Gosiute Lake. This lake covered perhaps 12,000 square miles in the Green River, Washakie, and Great Divide basins, still had an outlet, and was the site of accumulation of major oil shale deposits (Bradley, 1930, 1948) during Luman and Tipton (late Lost Cabin) time. The north shore of the lake reached to, but probably not beyond, the present position of the Flattop fault, which could have been marked by either a flexure or a fault at that time.

Fluviatile strata may have extended uninterrupted from the Wind River basin to the Great Divide basin and perhaps overlapped the lower flanks of the Granite Mountains and Wind River Range. It is doubtful, however, that through drainage existed from the Wind River basin to the Great Divide basin at this time. The climate was warm and humid, and the deposition of widespread thin fine-grained lacustrine units in the Tipton Tongue indicates a remarkably tranquil episode in the history of at least the Great Divide basin part of south-central Wyoming.

\section{TRANSITION FROM EARLY TO MIDDLE EOCENE}

Late in early Eocene time the interval of quiescence ended. The Granite Mountains were uplifted along newly formed vertical lines of weakness, the North and South Granite Mountains fault systems. On the northern system, east of the Rattlesnake Hills, as much as 5,000 feet of displacement occurred, but the amount decreased progressively westward. Along the southern system, the displacement on the fault was about 3,000 feet. Both displacements must have been largely uplift of the mountain block, otherwise the basins would probably have been at or below sea level. There is no way to determine how much uparching of the mountain core took place between these fault systems, but it probably was of major proportions.

The South Granite Mountains fault system did not terminate at the west margin of the Granite Mountains but extended west from Crooks Gap for 10 miles to a point A on plate 10E. Southwest of that point it became a sharp faulted flexure that continued to the south end of the Wind River Range and joined the Flattop fault. The point of southwestward divergence coincides with the place where the late Cenozoic segment of the South Granite Mountains fault system trends northwest.

The Flattop fault started as a monocline flexed down on the south side. The time of initial displacement is not known, but later there were several episodes of movement on different parts of the fault. In the Horsetrack area, the combined displacement, caused by both folding and faulting, between the north and south crustal blocks was at least 15,000 feet prior to deposition of the Laney Shale Member. Several thousand feet of fault displacement and erosion are believed to have occurred after deposition of the Cathedral Bluffs Tongue and before the advance of Gosiute Lake northward across the site of the fault.

About two-thirds of the area of each of the regionally uplifted blocks had Precambrian rocks at the surface, 
and the remainder had sedimentary rocks of various types exposed. Another episode of fan development ensued. At least 1,500 feet of giant boulders, making up the Crooks Gap Conglomerate, accumulated directly south of the normal fault scarp on Green Mountain. Farther west, 1,000 feet or more of the Wasatch and Battle Spring Formations that buried the Long Creek arm of the Wind River basin was completely stripped off and carried south into the northern part of the Great Divide basin, where it was redeposited as the arkosic debris in the Cathedral Bluffs Tongue of the Wasatch Formation. During this process, the coarsest boulders remained in the vicinity of Crooks Mountain.

Boulder conglomerate and coarse-grained sandstone were deposited along the entire north flank of the Granite Mountains during and following vertical uplift along the North Granite Mountains fault system. The initial deposits comprise the upper coarse-grained unit in the Wind River Formation that is the host rock for all the major uranium deposits in the Gas Hills area. Overlying these deposits are reworked arkosic sandstone and conglomerate at the base of the Wagon Bed Formation. East of the Rattlesnake Hills, from Poison Spring Creek on south, several thousand feet of arkosic sandstone and conglomerate composing the Wind River and Indian Meadows Formations that lapped onto the Precambrian rocks was entirely stripped off. The debris from the initial stage of this stripping probably was deposited in the upper, coarsegrained unit in the Wind River Formation. However, the disposition of the remaining tremendous quantity of debris is a major enigma. No such deposits of the right age, lithology, and volume, that could have come from this locality are known in areas to the north, northeast, or southeast.

Northwest of the Granite Mountains and east of the Wind River Range, there is a marked decrease in arkosic debris in the younger strata of the Wind River Formation and the overlying Wagon Bed. The abundance of Paleozoic rock fragments in these formations decreases to the east, which indicates that the debris was derived from the broad dip slopes on the northeast flank of the Wind River Range.

Volcanic activity in the Yellowstone National ParkAbsaroka region increased and supplied a conspicuous quantity of very fine grained bentonitic debris to the reworked beds.

In the Green River and Great Divide basins, the time of transition from early to middle Eocene was marked by several major events. The climate became arid, and Gosiute Lake lost its outlet and shrank to less than half its original size (Bradley, 1964; Love, 1964). The lake became highly saline, and trona and salt beds were precipitated in the area west of the Rock Springs uplift. The magnitude and extent of the uplift of the Granite -Mountains at this time probably had a significant influence on the regional climate as well as on the nature and volume of sediment deposited in the Great Divide basin.

A characteristic of the strata deposited at this time in the Green River basin is the conspicuous excesses and deficiencies of many trace elements as contrasted with the trace-element contents in average sediments and in other Cenozoic rocks (Love, 1964). These excesses and deficiencies are probably related to primary composition of eruptive debris extruded from vents in the Yellowstone National Park-Absaroka region and perhaps from other vents in Utah.

\section{MIDDLE EOCENE}

Middle Eocene was another time of crustal stability in most of central Wyoming. The rate of deposition around the Granite Mountains slowed to the minimum for Tertiary time in central Wyoming. Fundamental changes in drainage took place. For the first time the Wind River basin was filled with sediment, and streams from the Absaroka volcanic area flowed southeast along the west margin of the Granite Mountains and out into the Great Divide basin. Drainage eastward from the Wind River basin was blocked, and one or more lakes of unknown size were impounded in central Wyoming. Very low grade oil shale accumulated in one lake directly west of the northwest end of the Granite Mountains.

A swarm of 35 or more volcanic vents opened in a 125-square-mile area of the Rattlessnake Hills and alkalic rocks of distinctive composition were extruded. Several vents more than 2 miles in diameter persisted through middle and late Eocene time, but their cumulative contribution of volcanic debris was astonishingly small. Their influence on the nature of sediments as little as 30 miles away was insignificant, whereas, by comparison, the Absaroka centers 90 miles away furnished a large amount of airborne and waterborne volcanic debris that is conspicuous throughout the western part of the Granite Mountains area. The pattern of excesses and deficiencies in trace elements, first noticed in beds transitional between early and middle Eocene in the Green River basin, is regional in middle and late Eocene strata.

The Cyclone Rim syncline south of the Flattop fault originated in middle Eocene time as a gentle downwarp along the northeast margin of Gosiute Lake. The climate became humid again, and the lake expanded to its maximum size, about 15,000 square miles, in southwestern Wyoming during deposition of the Laney Shale 
Member of the Green River Formation. The lake occupied the syncline, and in the vicinity of the Horsetrack anticline (section $\mathrm{I}-\mathrm{I}^{\prime}, \mathrm{pl} .3$ ) it crossed the fault and extended to the southeast margin of the Wind River Range (pl. 10F). Later, during deposition of the Bridger Formation, the lake separated into localized bodies of water, one of which intermittently occupied the Cyclone Rim syncline.

\section{LATE EOCENE}

Volcanic activity in the Rattlesnake Hills area continued through late Eocene time with increasing violence, but the volume of extruded debris was still comparatively small. Drainage from the Absaroka volcanic area continued, and mafic volcanic conglomerate and tuff were deposited by these southeastwardflowing streams west of the Granite Mountains. The Wind River basin remained filled with pyroclostic and lacustrine sediment. Apparently the outlet to the east that had been blocked after early Eocene time continued to be blocked. Fresh-water lakes extended into reentrants along the north flank of the Granite Mountains. Strata of the Wagon Bed Formation (whether the middle or late Eocene part has not been determined) lapped high on the south flank of the Granite Mountains north of Green Mountain. The same pattern of excesses and deficiencies in trace elements in these lake sediments continued from middle through late Eocene time.

An uplift of unknown extent occurred in the southern part of the Wind River Range and caused extensive erosion of middle Eocene rocks. The erosion was followed by deposition of three fans of torrential boulder debris composing the Ice Point Conglomerate that spread southeastward from the Wind River Range into the Great Divide basin. These fan deposits are composed of locally derived slabs torn from dip slopes of resistant Paleozoic rocks and contrast markedly with the conglomerate of rounded igneous rocks from the Absaroka Range deposited along the southeastwardflowing master drainage between the Wind River Range and the Granite Mountains.

Upward movement on the eastern part of the Flattop fault caused stripping of the middle Eocene strata from the north block before the Ice Point Conglomerate was deposited.

\section{OLIGOCENE}

Deposition of the first Oligocene rocks followed an interval of regional erosion during which rough topography was developed on Eocene and older rocks. This regional erosion probably was caused in part by downwarping of eastern Wyoming that allowed reestablish- ment of major eastward drainage from highland volcanic centers in the Absaroka Range.

In many ways, the history of sedimentation in the Granite Mountains during Oligocene time is in sharp contrast with that in late Eocene. The Eocene volcanos in the Rattlesnake Hills became extinct and there was no new (only reworked) locally derived pyroclastic debris. The upper Eocene mafic volcanic suites from the Absaroka centers changed to an intermediate type, color of sediments changed from green to white, lakes once again became rare, and the volume of fine-grained homogeneous pyroclastic debris increased tremendously --so much so that small streams were choked with debris, and local erosion of highlands in the Granite Mountains was significantly inhibited. However, a powerful river from the Absaroka Range continued to flow southeastward along the west margin of the Granite Mountains and into the Great Divide basin in about the same position as the one in late Eocene time. Boulders of Tertiary igneous rocks as much as 8 feet in diameter were carried 90 miles or more and deposited along the stream valley. The volume of water and the stream velocity and gradient necessary to move boulders of this size a distance of 90 miles should be investigated further. From the north margin of the Great Divide basin to the south the position of this river course has been obliterated. Tributary streams entering the river' from the west cut steep-sided canyons across the northeast flank of the Wind River Range. These canyons were subsequently filled with arkosic conglomerate, sandstone, and white tuffaceous siltstone.

Only the earlier half of Oligocene time is represented in the fossil record in the Granite Mountains area; therefore reconstruction of events in the remainder of the epoch is based on records of events in areas to the east and southeast. Younger Oligocene rocks probably once lapped higher on the Granite Mountains and Wind River Range than do the remnants now present. Deposits of Oligocene age almost certainly originally extended unbroken across the Wind River and Great Divide basins.

The late Eocene subtropical climate indicated by fossil breadfruits, figs, and magnolias changed gradually to a warm temperate climate favorable to oaks, beeches, and maples (Dorf, 1959). The general land surface rose higher and higher above sea level as the accumulation of pyroclastic debris became thicker; the mountains were progressively less prominent as the fill lapped farther up on their flanks.

\section{MIOCENE}

Prior to deposition of Miocene rocks, widespread erosion completely or partly removed Oligocene strata 
from large areas of southern and southeastern Wyoming, and elsewhere cut a surface of some relief on Oligocene and older rocks. Nearly everywhere in the Granite Mountains area the oldest Miocene rocks are conglomerates derived from adjacent uplands. Thus they contain locally abundant material reworked from the Oligocene and older Tertiary rocks.

The Miocene Epoch was a time of deposition of an enormous volume of tuffaceous sandstone across most of Wyoming. No similar deposits of this magnitude had accumulated previously, or would again, during the Cenozoic. The Granite Mountains were largely buried. Only a few square miles of the highest peaks projected above the sand plain. Early in the depositional history there were extensive areas of pink sand dunes, whose origin has not been determined. The crustal stability that was characteristic of Oligocene time in the Granite Mountains area was interrupted by the gradual sinking of the Split Rock syncline. Eastward drainage along what had been previously the highest part of the mountain range was established, but it was sluggish and became ponded in many places. Some lakes near the synclinal trough line were many miles long, and in them white limestone and algal reefs were deposited.

The origin of the vast quantity of sand-several thousand feet thick in large areas-is puzzling. The abundant mafic volcanic debris is similar to that in the thicker $(7,000 \mathrm{ft})$ Miocene sequence in Jackson Hole. Probably much of the sand originated from volcanic centers in the Jackson Hole-Yellowstone National Park region. The size and composition of sand grains in Cretaceous, older Tertiary, and Precambrian rocks are not like those in the Split Rock Formation. Furthermore, most of these possible sources are either inadequate in volume or were covered during Miocene time.

The history of deposition was probably little changed from middle Miocene to late Miocene time in the Granite Mountains area. The Split Rock syncline continued to subside. No late Miocene fossils have been identified, but some of the upper strata are similar to the 1,000-foot-thick section of upper Miocene rocks in the Saratoga area 40 miles to the south.

\section{EARLY TO MIDDLE(?) PLIOCENE}

Events of great magnitude and significance occurred in central Wyoming during early to middle(?) Pliocene time. The area south of the Granite Mountains, extending from the Great Divide basin to the Hanna basin, was uplifted, tilted northward, and then stripped of post-Eocene rocks by northward-flowing streams. In the Hanna basin, Cretaceous rocks were exposed, and black shale with marine Cretaceous fossils was trans- ported northward across the buried Seminoe Mountains and deposited on Precambrian knobs of the Granite Mountains. The Split Rock syncline continued to sag, and the western part of the South Granite Mountains fault system was reactivated, but movement was in a direction opposite to that in Eocene time, for the mountain block dropped at least 1,000 feet. Moonstone Lake formed, and in and adjacent to it more than 1,000 feet of tuffaceous strata accumulated. Some beds are unusually rich in uranium and thorium and are believed (Love, 1961b) to be source rocks for part of the uranium present in the Gas Hills and Crooks Gap uranium districts. Southward tilting of the Rattlesnake Hills area caused local exhumation of the highest knobs of resistant older rocks. Diatoms of saline habitat, salt concentrations, and the absence of mollusks suggest that Moonstone Lake had little or no external drainage.

\section{LATE PLIOCENE OR EARLY PLEISTOCENE}

Regional uplift started the present cycle of degradation in most of central Wyoming. In the Granite Mountains area, however, reactivation of movement along the North Granite Mountains fault system and more widespread movement along the South Granite Mountains fault system caused the mountain block to drop farther, so that the regional effect of a lowered base level was thus reduced. The easterly course of the Sweetwater River was established along the trough line of the Split Rock syncline, but continued sagging of the Granite Mountains reduced the ability of this stream to erode. Thus, only 1,000 feet of the buried crest of the mountains was exhumed. The sluggish river was trapped along a superimposed course across granite knobs, and as the trough line of the syncline migrated southward, north-flowing tributaries were not everywhere able to reach the river.

Recurrent movement along the Flattop fault was in the same direction as that in Eocene time. Elsewhere in Wyoming many other normal faults developed, commonly along or slightly on the mountainward side of buried Eocene thrusts, and invariably the mountain block collapsed. The south end of the Wind River Range dropped along the Continental fault (Nace, 1939). At least one highly saline lake was present south of the Rattlesnake Hills, and the Bug Formation accumulated in it. This formation contains thin beds of uranium- and thorium-rich limestone and clastic volcanic debris eroded from the adjacent vents. The North Platte River cut an antecedent course across the rising Seminoe Mountains. A broad east-trending upwarp in the southern part of the Wind River basin caused the Wind River to divert northward and its gradient to increase to several times that of the eastward-flowing 
Sweetwater River. Headward erosion by vigorous tributaries to the Wind River was responsible for development of the Beaver Divide. In the Gas Hills uranium district, the tilting of the south flank of this flexure was sufficient to reverse the normal northward downdip movement of uranium-charged ground water that otherwise would have gone into the Wind River basin. Instead, the ground water in some places became static and in others moved southward down the new dip and was trapped against faults and other barriers. Many of the known uranium ore bodies were probably formed or modified at this time.

\section{MIDDLE PLEISTOCENE TO RECENT}

The Split Rock syncline remained the dominant feature that influenced erosion and deposition in the Granite Mountains area; subsidence continued from middle Pleistocene time to Recent. Crooks Creek was unable to maintain a downhill course on the north side of the syncline and became ponded. Other streams were barely able to reach the river. Several erosion surfaces that crossed the South Granite Mountains fault system were offset by recurrent downdropping of the north block. Many small streams that cross the North Granite Mountains fault system were diverted by Recent downdropping of the south block (fig. 55). In the Gas Hills area, remnants of several erosion surfaces now tilt southward, although at the time they were cut they sloped northward into the Wind River basin. Some tributaries to the Sweetwater River west of Jeffrey City are barbed upstream, indicating more active subsidence in the western part of the Split Rock syncline than in the eastern. Vigorous erosion of the Beaver Divide by north-flowing streams with steep gradients caused it to retreat southward. In this way tributaries of the Wind River progressively captured more and more segments of sluggish streams in the Sweetwater River drainage system.

Volcanism, probably in Yellowstone National Park or Jackson Hole, provided wind-blown ash that was deposited in moderately pure beds, remnants of which are preserved in several widely separated localities.

No glaciers reached the Granite Mountains area during Pleistocene time, but remnants of permafrost persisted along Ice Slough (about 10 miles west of Jeffrey City) until the 1850 's. A combination of in-

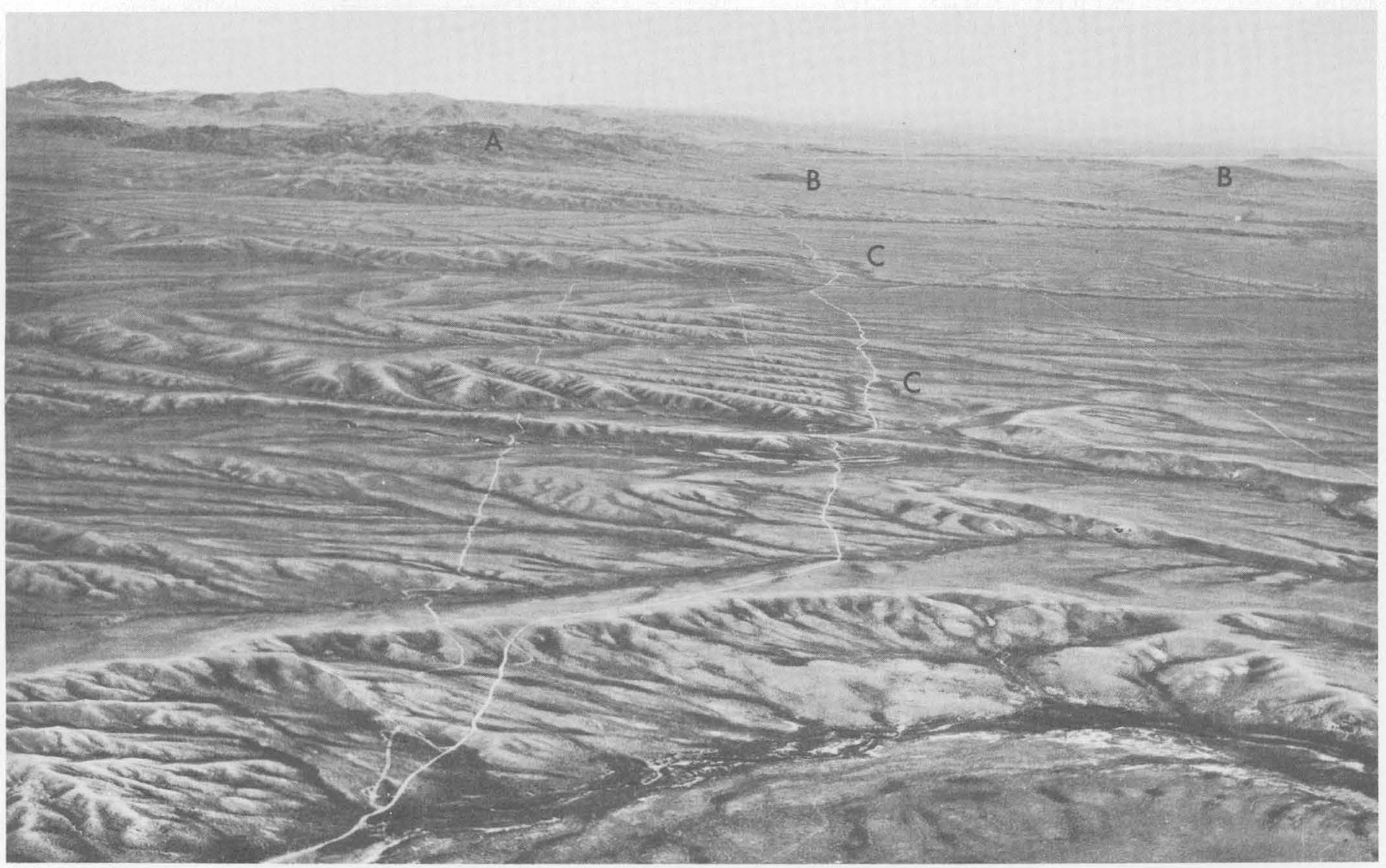

Figure 55.-View east along East Diamond Springs segment of North Granite Mountains fault system, T. 32 N., Rs. 89 and 90 W. Fault, up on north block, is on left side of prominent road and displaces the Split Rock Formation at surface. A, Precambrian knobs of Granite Mountains. B, Eocene igneous rocks. C, Modern drainage offset by fault. Photograph by P. T. Jenkins and L. P. House. 
creased precipitation and reduced temperature (during glaciations elsewhere in Wyoming) and southward tilting of the Gas Hills area undoubtedly affected the distribution of uranium during middle and late Pleistocene time. As the climate became more arid, wind erosion increased. Many undrained depressions were scooped out, and some were subsequently occupied by lakes in which sodium salts accumulated.

The end product of this long and complex Cenozoic greologic history is a landscape that, in itself, played an umusually prominent role in human history, first as a productive hunting ground, later as the easiest access route of the pioneers to the west coast, and finally as a fertile grassland for the livestock industry. On and beneath this landscape are economic deposits such as II'anium, oil and gas, coal, and jade of sufficient value that they more than justify the time, effort, and money required to obtain an understanding of their origin. In the realm of pure science, the extraordinary complete chronological record, preserved and now made available because of a fortuitous combination of tectonic events and economic incentives, will lead to a clearer understanding of fundamental geologic processes.

\section{SUMMARY OF STRUCTURAL PHASES IN THE DEVELOPMENT OF THE GRANITE MOUNTAINS}

The structural evolution of the Granite Mountains was not a continuous gradational process. The unusually complete record shows eight phases, most of which contrast sharply in significant respects. They are not all merely of local importance, for several can be recognized in adjacent mountain ranges where the record is fragmentary; therefore, they may be useful in reconstructing the missing parts of the regional story.

Phase 1.-Gradual vertical uplift of the mountain arch coincided with subsidence of paralleling basins to the north and south. Relative to sea level, the Granite Mountains arch rose about 7,500 feet, and the Wind River basin on the north and Great Divide basin on the south sank nearly the same amount, all during latest Cretaceous time. The crest line of the upwarp and the trough lines of the downwarps were nearly parallel; the downwarps were about 40 miles apart.

Phase 2.-Vertical uplift of the mountain arch increased in magnitude, and the subsidence of flanking basins decreased. During Paleocene time the Granite Mountains arch rose about 5,000 feet, the Wind River basin sank a maximum of 8,000 feet but an average of much less, and the Great Divide basin sank about 3,000 feet.
Phase 3.-Uplift of Granite Mountains predominated over subsidence of flanking basins; subsidiary folds with northwest trends, marginal to the uplift, were sharply defined; thrust faults developed along steep flanks of mountains and subsidiary anticlines. The climactic stage of the Laramide Revolution occurred in earliest Eocene time when the Granite Mountains rose 7,000 feet or more, the Wind River basin subsided a maximum of about 6,000 feet (in most places it was much less), and the Great Divide basin sank about 4,500 feet. Although the dominant movement at this time was vertical, the most active compressional force affecting the uplifts was in a southwest direction. Thus, major low-angle thrusts, as well as reverse faults, developed along the south and west sides of the Granite Mountains and Wind River Range; likewise smaller thrusts with a similar direction of overriding movement formed along the southwest sides of most subsidiary anticlines on both flanks of the Granite Mountains. The northwest trends of the subsidiary folds are nearly all at oblique or right angles to trends (commonly east or northeast) in Precambrian igneous and metamorphic rocks.

Phase 4.-Vertical uplift of the west-trending central part of the Granite Mountains and the anticlinal and synclinal complex to the west occurred along normal faults. At about the time of transition from early to middle Eocene, the Granite Mountains rose vertically as much as 3,000-5,000 feet along west-trending normal faults located parallel to but on the mountainward side of the uplift margins established in phase 3 . The normal faults are, in most places, independent of the thrust and subsidiary fold structures. In the eastern and central parts of the Granite Mountains, they parallel trends in Precambrian metamorphic rocks, but in the fold complex between the Granite Mountains and the Wind River Range the southern fault system is nearly at right angles to the Precambrian trends.

Phase 5.--Mountains and basins alike were relatively stable, except for a few local disturbances, for 20 m.y. This was a time of basin filling and mountain burial. About 35 vents opened in a 125 -square-mile area of the Rattlesnake Hills, but they show no close relation to Precambrian trends, Laramide folds, or normal faults. A local uplift of the southeastern part of the Wind River Range and intermittent movement along the eastern part of the Flattop fault were the only significant disturbances.

Phase 6.-The Granite Mountains arch and the anticlinal and synclinal complex to the west subsided as a single unit. During Miocene time, the Split Rock syncline was the dominant new structural feature; it 
developed along what had formerly been the highest part of the Granite Mountains. Subsidence of the mountains accelerated the rate of their burial. The completely filled Wind River and Great Divide basins remained high; therefore, the drainage system that controlled the deposition of nearly 3,000 feet of strata was centered along the east-trending trough line of the syncline on the mountains.

Phase 7.-Epeirogenic uplift occurred concomitantly with downfaulting of the core of the Granite Mountains, the anticlinal and synclinal complex to the west, and the south end of the Wind River Range. During late Pliocene time, epeirogenic uplift raised the general land surface of Wyoming several thousand feet. The north and south margins of the Split Rock syncline broke along normal faults that had been formed during phise 4. The movement in phase 7, however, reversed the direction of displacement on these faults, for the mountain block dropped. The Split Rock syncline continued to sink, the Great Divide basin rose so much that it was largely stripped of post-Eocene strata, and most of this debris was dumped on the foundering Granite Mountains. The south end of the Wind River Range subsided in like manner along the Continental fault. At this time the flanking basins stood higher than the adjacent parts of the mountains.

Pluase 8.-The Split Rock syncline continued to sink, minor faulting occurred along its margins, and antecedent and superimposed drainage systems were established; a broad gentle east-trending arch developed in the southern part of the Wind River basin. At the time (Pleistocene) that most of Wyoming was undergroing vigorous erosion as the result of epeirogenic IIplift, the Granite Mountains continued to subside along the Split Rock syncline. One result was the development of anomalous drainages, the largest and most interesting of which is the North Platte River, which apparently established an antecedent course across the Seminoe Mountains. Another result of continued subsidence was the preservation of a remarkably complete Cenozoic record of sedimentation and tectonism on and adjacent to the Granite Mountains.

The gentle east-trending arch in the southern Wind River basin was of considerable significance, for it caused the Wind River to divert to the north and to steepen its gradient; thus reexcavation of the basin was facilitated. This arch was the hinge between areas of northward regional tilting in north-central Wyoming and southward tilting into the Split Rock syncline. It had a profound effect on the rate and direction of flow of ground water in the southern Wind River basin, and this, in turn, affected the location, grade, and volume of uranium deposits in the Gas Hills district.

\section{DEPOSITS OF ECONOMIC OR SCIENTIFIC INTEREST}

The primary objective of the study of the Granite Mountains area was to work out the Cenozoic history rather than to make a thorough evaluation of the economic resources, but the two subjects are so closely interrelated that data from one can be of value in explaining problems pertaining to the other. Thus, the following economic discussion is a byproduct of the study of the geologic history and is not concerned with details of individual mines or oil fields.

\section{URANIUM}

Major uranium deposits occur in the Gas Hills and Crooks Gap districts, and, in addition, mineralization has been found elsewhere in the area in rocks ranging in age from Precambrian to Pleistocene(?)

\section{GAS HILLS DISTRICT}

The largest, most numerous, and most productive uranium mines in the Granite Mountains area are in the Gas Hills district (figs. 7, 56). Various aspects of the geology and geochemistry of these uranium deposits have been described in many papers, a few of which, in chronologic order, are those by Love (1954a), Zeller, Soister, and Hyden (1956), Grutt (1956), Zeller (1957), Soister (1958), Jensen, Field, and Nakai (1960), Jensen (1962), Guilinger (1963), Cheney and Jensen $(1963,1964)$, and Cheney (1964). Additional references are in bibliographies in these papers; the most complete is in Cheney (1964). Nearly all the large uranium deposits are in a coarse-grained arkosic sandstone sequence that makes up the upper unit in the Wind River Formation (fig. 56), directly below the reworked zone at the base of the Wagon Bed Formation. 'The source of the host rock was the granitic core of the Granite Mountains, directly to the south. The location of most ore bodies is controlled by porosity and permeability of the host sandstone, Quaternary faulting, and movement of ground water. Ore fronts observed in the mines are similar in many respects to those described by Harshman (1962), Melin (1964), and Bailey (1965) in the Shirley basin and likewise to those produced experimentally by Evseeva, Ivanov, and Kochetkov (1963). The age of the uranium ore is probably Pleistocene.

7 Many additional publicutions have appeared since this report was submitted in 1965 . 


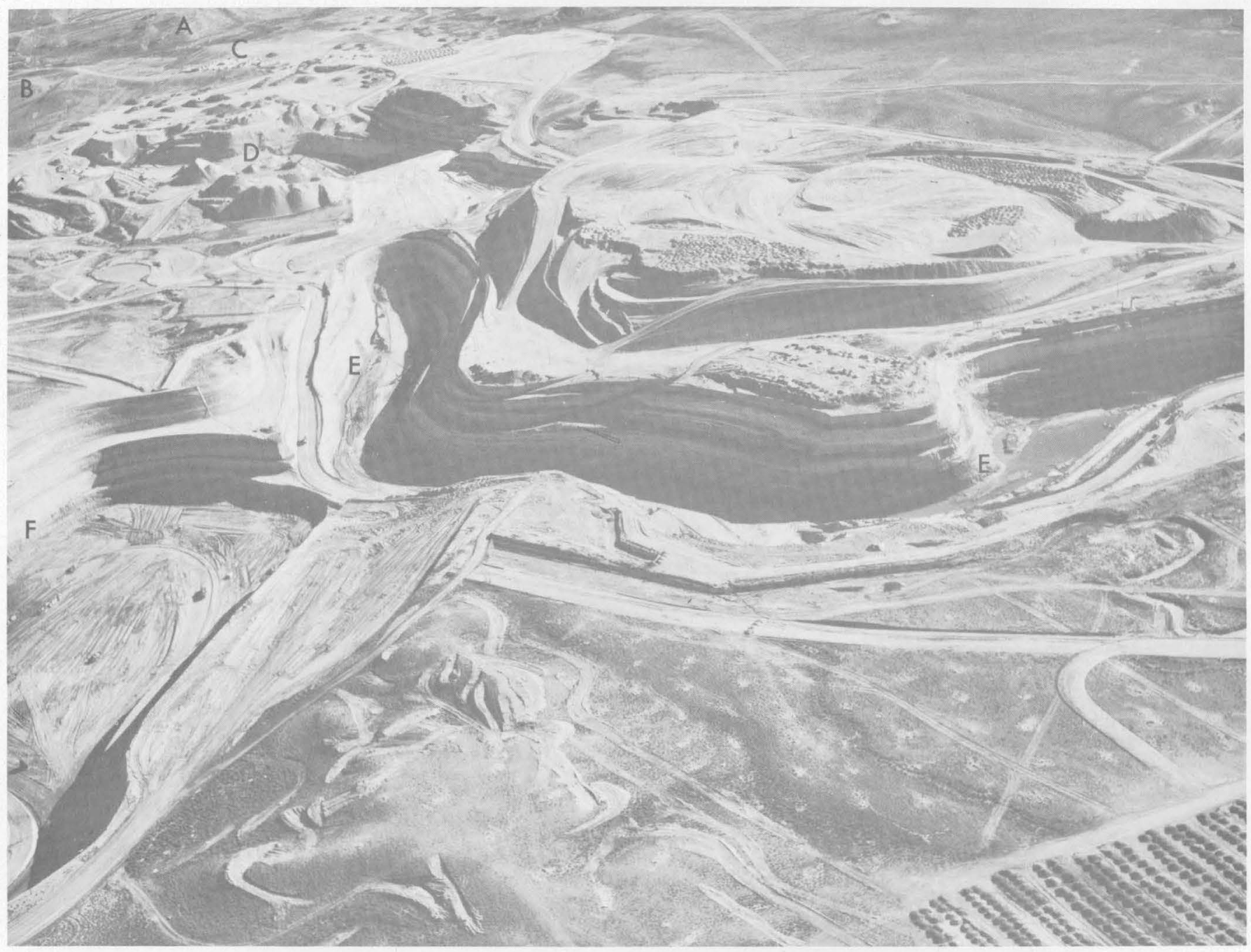

FiguRE 56.-View northeast showing uranium strip mines in Wind River Formation. A, Jurassic rocks dipping $20^{\circ}$ west on west flank of Dutton Basin anticline B, Lucky Mc camp. C, Vitro camp. D, Vitro strip mine. E, Lucky Mc strip mine showing horizontal Wind River Formation and dark ore zone at bottom of pit. F, FraserLemac strip mine. Mines are in sec. 26, T. 33 N., R. 90 W.; mounds are stockpiles. Photograph by P. T. Jenkins and L. P. House shows stripping as of August 13 , 1959.

\section{CROOKS GAP DISTRICT}

The Crooks Gap uranium district contains the second largest exploited uranium deposits in the Granite Mountains area. It has been discussed in some detail by Stephens (1964). The host rock for all the uranium being mined up to 1965 is in the Wasatch and Battle Spring Formations (fig. 16). This host rock is somewhat older than that containing uranium in the Gas Hills district, but its age is still early Eocene. The lithology of the host sandstones in both districts is very similar, however, and they had a common source in the granitic core of the Granite Mountains. In the Crooks Gap district, uranium occurs in conglomerate and in coarse- to fine-grained sandstone near the base of the Wasatch and Battle Spring Formations and in other zones in a section about 1,500 feet thick.

The ore-bearing beds are folded more but faulted less in the Crooks Gap area than in the Gas Hills. Minor amounts of uranium are in Paleozoic and Mesozoic rocks along the Emigrant Trail thrust fault; these occurrences were interpreted by Melbye (1957) as evidence of hydrothermal origin. Uranium ore is most abundant in the bottoms and along the flanks of the synclines in the Wasatch and Battle Spring Formations; all these synclines plunge south-southeast. There is some evidence that the pattern of ore fronts-the altered ground is updip and the unaltered ground is downdip-is similar to that in the Gas Hills and 
Shirley basin districts. The age of the uranium ore is probably Pleistocene.

\section{OTHER LOCALITIES}

Uranium mineralization occurs in Precambrian rocks and all the Cenozoic sequences, with the possible exception of the Fort Union Formation, outside the Gas Hills and Crooks Gap districts. These other localities are discussed in the order of age of the host rock, with the oldest first. This arrangement helps to emphasize the explanation of origin of both major and minor uranium occurrences in the Granite Mountains area.

Little Man mine-Uranium occurs in and adjacent to graphitic schist in Precambrian rocks at the Little Man mine (loc. 28U, L, table 9 and pl. 2). Several shipments of commercial-grade ore were made in 1954 and 1955. A brief reconnaissance study (Love, 1954b) indicated that a tabular layer of graphitic schist about
6 feet thick crops out for several hundred yards on the south side of Heath Peak in the eastern part of the Granite Mountains (pl. 2; fig. 57). The graphitic layer dips steeply to the east, has a thinly layered gray quartzite(?) along the west side, and has been intruded by gray and brown coarsely erystalline biotite granite. Within the weathered zone, which extends downward for about 15 feet below the ground surface, the yellow uranium mineral kasolite $\left(\mathrm{PbO} \cdot \mathrm{UO}_{3} \cdot \mathrm{SiO}_{2} \cdot \mathrm{H}_{2} \mathrm{O}\right.$; identified by W. F. Outerbridge and Jerome Stone, written commun., 1955) is abundant along fractures and is disseminated through the granite within 4-6 feet of the graphitic layer. A lesser amount of mineralization occurs in the quartzite (?), and the graphitic rock shows some finely disseminated fluorescence. Below the weathered zone is a concentration of sulfides, chiefly pyrite, but no significant increase in radioactivity was observed in this zone. The unweathered rocks contain

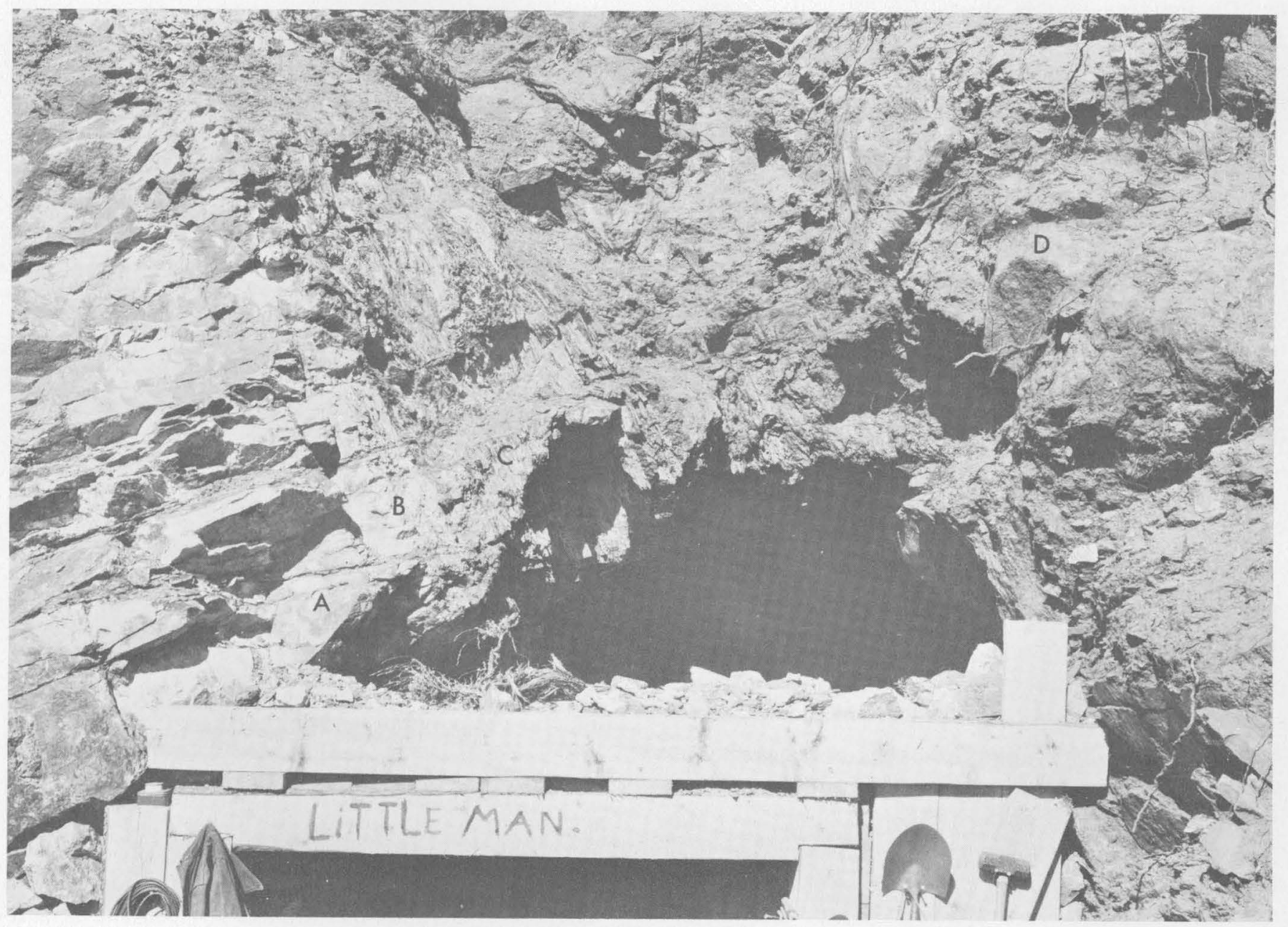

Figure 57.-Precambrian rocks at portal of Little Man uranium mine (loc. 28U, L, pl. 2), sec. 14, T. 27 N., R. 84 W. A, Brown granite containing uraninite. B, Gray thinly layered quartzite(?).C, Thinly layered siliceous graphitic schist 6 feet thick containing uraninite, molybdenite, and kasolite. D, Brown granite. Uraninite is 1.8 billion years old.

$356-3010-69-10$ 
finely disseminated uraninite, some of which is in euhedral crystals (identified by W. F. Outerbridge, written commun., 1955). Molybdenite is common in some samples. Granite 4 feet below the graphitic rock and 20 feet in from the portal contains 0.11 percent eThO ${ }_{2}$. The maximum amount of uranium in samples obtained during this investigation is 4.16 percent from granite 4 feet below the graphitic rock and 15 feet beneath the surface of the ground. Uraninite from this mine has a lead-alpha age of 1,800 m.y. (T. W. Stern, oral commun., 1957). The laminated character and continuity of the graphitic layer suggest that it may be of vegetal origin.

A small spring, locally known as Moonshiner's Spring, adjacent to the south terminus of the graphitic layer and 850 feet downhill from the mine portal has only $1 \mathrm{ppb}$ (part per billion) uranium; so apparently little uranium is being leached from the deposit at the present time. In contrast, the Slack Spring in Pliocene or Miocene sandstone in the valley fill south of Heath Peak has $26 \mathrm{ppb}$ uranium.

Twin Springs.-Six miles northeast of the Little Man mine on the west side of Twin Springs Creek $(1,900 \mathrm{ft}$ west of east line, $4,500 \mathrm{ft}$ south of north line, sec. 21, T. 28 N., R. 83 W.), uranophane (identified by Jerome Stone, written commun., 1955) is disseminated in a brown coarsely crystalline Precambrian granite and is concentrated along fractures. The granite is near the east margin of the Granite Mountains. The occurrence is small and has not been investigated underground. The maximum uranium content of samples analyzed is 0.075 percent.

Muddy Gap.-About 2 miles northwest of Muddy Gap (loc. 24U, L, Si, table 9 and pl. 1), uranium occurs with lead and silver in highly fractured Precambrian granite on the Emigrant Trail thrust block where it overrides Triassic rocks. This occurrence has not been investigated at depth. Maximum uranium content in a series of selected samples is 0.22 percent.

Clarkson Hill.-Small amounts of uranium occur in the Indian Meadows Formation along the northeast margin of the Granite Mountains area on the southeast side of Clarkson Hill (pl. 1), in sections 4, 9, and 17, T. 31 N., R. 82 W. The host rock is carbonaceous sindstone, siltstone, and shale, and the deposits have been described and sampled by Rich (1962). The grade is low, and although much exploration work has been done, little ore was mined.

Poison. Spider Creek-Willow Creek area.-Rich (1962) described low-grade uranium occurrences in the Poison Spider Creek-Willow Creek area (T. 32 N., R. $84 \mathrm{~W}$.) in the upper, coarse-grained facies of the Wind
River Formation. The surface and near-surface grade of the occurrences known as of 1965 is too low to be exploited. Radioactivity was reported at depth in drill holes, but no analyses are available.

Northern part of Great Divide basin.-Within an area 30 miles long and 8 miles wide paralleling the north margin of the Great Divide basin (exclusive of the Crooks Gap uranium district), lower Eocene rocks contain many uranium deposits or occurrences of mineralization. All these are in arkosic sandstone in the Wasatch and Battle Spring Formations. Mineralization occurs in several parts of the section, from directly above the base (in T. 27 N., R. 93 W.) to about 3,000 feet above it (in T. 27 N., R. 91 W.). No descriptions of the mineralized parts have been published. They are discussed further in connection with areas warranting additional exploration.

South of the area included on my geologic map (pl. 1) are many uranium-bearing coal beds in the Wasatch and Battle Spring Formations, which are shown in part on section $B-B^{\prime}$. Outcrops and subsurface sections of these beds to a depth of about 600 feet have been described in detail by Pipiringos (1961) and Masursky (1962). On the south margin of the Cyclone Rim syncline, along strike of the Cathedral Bluffs Tongue and about 3 miles east-southeast of well 268 , is an area containing many occurrences of schroeckingerite $\left(\mathrm{NaCa} 3\left(\mathrm{UO}_{2}\right)\left(\mathrm{CO}_{3}\right)_{3}\left(\mathrm{SO}_{4}\right) \mathrm{F} \cdot 10 \mathrm{H}_{2} \mathrm{O}\right)$. These have been described by Sheridan, Maxwell, and Collier (1961) and Wyant, Sharp, and Sheridan (1956).

Cyclone Rim.-The Cathedral Bluffs Tongue of the Wasatch Formation contains meta-autunite $\left(\mathrm{Ca}\left(\mathrm{UO}_{2}\right)_{2}\right.$ $\left.\left(\mathrm{PO}_{4}\right)_{2} \cdot 21 / 2-61 / 2 \mathrm{H}_{2} \mathrm{O}\right)$ along Cyclone Rim in sec. 15, 16,21 , and 22 , T. 26 N., R. $96 \mathrm{~W}$. The mineral is disseminated in soft poorly cemented conglomeratic sandstone. Some drilling and excavation have been done but no ore has been mined. In terms of origin of uranium in central Wyoming, discussed elsewhere, it is significant that mineralization on Cyclone Rim is on the topographically highest eminence, 200-600 feet above the general land surface to the north and south, and along a narrow west-trending ridge.

Big Sand Draw.-Uranium phosphate beds occur in the Wagon Bed Formation in several places near the Big Sand Draw oil and gas field (locs. $8 \mathrm{U}, \mathrm{P}$ and $9 \mathrm{U}, \mathrm{P}$, table 9 and pl. 1). These have been described in some detail (Love, 1964). Maximum uranium content is 0.042 percent, and maximum $\mathrm{P}_{2} \mathrm{O}_{5}$ content is 5.67 percent. The occurrences here and in strata of similar age elsewhere in central and southwestern Wyoming suggest a syngenetic origin. 
Conant Creek.-The Wagon Bed Formation is the host rock for a uranium deposit exposed in a strip mine at the head of Conant Creek (loc. 10U, O, table 9 and pl. 1 ; figs. 58, 59). Some of the uranium is in an oil-saturated tuffaceous arkosic sandstone (figs. 58, 59 ), and the remainder is in adjacent slightly petroliferous sandstone. Van Houten (1964) mapped this and adjacent occurrences of oil-stained sandstone along 4 miles of outcrop extending northwest along the Beaver Divide. A brief description of the rocks in the strip mine was given by K. G. Bell (1960, p. B60), who called the host sandstone White River Formation. The Cheyenne Mining and Uranium Co. produced approximately 2,000 tons of ore averaging 0.20 percent uranium. The occurrence is about 300 feet above the base of the Wagon Bed Formation. A stratigraphic section and a descrpition of the oil are given in the discussion of oil-saturated sandstone at this locality. Apparently the oil migrated into the host rock after late Eocene time and then was followed by the uranium. About 50 drill holes within 1 mile of this pit show both oil-saturated sandstone and radioactivity, but the pit is the only place that has produced ore. Bell (1960) identified carnotite as the uranium mineral. A random sample of the petroliferous sandstone contained 0.007 percent $\mathrm{V}_{2} \mathrm{O}_{5}$ and 30 ppm selenium.

Another occurrence of uranium in the Wagon Bed Formation 3 miles west of this pit, in sec. 6, T. 32 N., R. 94 W., is mentioned by Van Houten (1964, p. 88).

Poison Spring Creek.-Rich (1962, p. 522-524) described an occurrence of uranium in carbonaceous siltstone about 300 feet above the base of the White River Formation (loc. $24 \mathrm{~V}$, P, table 10, pl. 1) near the head of Poison Spring Creek. The uranium mineral

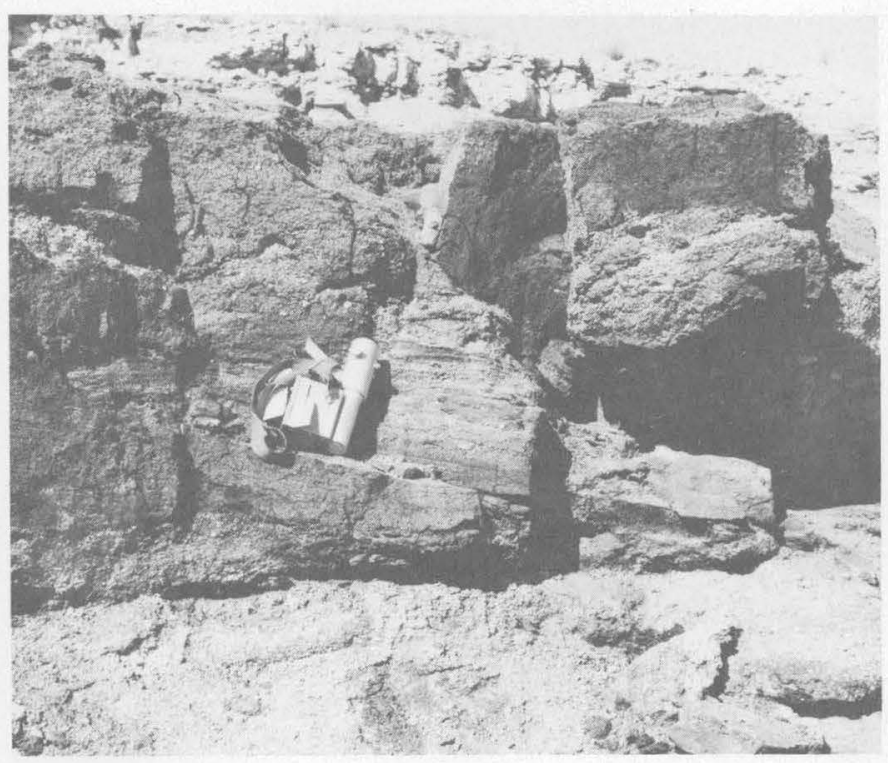

FiGURE 59.-Oil-saturated arkosic sandstone comprising the uranium ore bed in the Cheyenne Mining Co. strip mine, SE $1 / 4$ sec. 3 , T. 32 N., R. 94 W. This photograph shows detail of outerop at central left margin of figure 58 .

was identified as meta-autunite or uranocircite. No commercial production was obtained.

Bear Spring.-A small noncommercial amount of a yellow uranium mineral, possibly carnotite, was obtained from the lower part of the White River Formation along the western part of the Beaver Divide east of Bear Spring (SE1/4 sec. 24, T. 32 N., R. 95 W.). It occurs in an arkosic sandstone and blocky tuffaceous light-gray siltstone at the top of the Beaver Divide Conglomerate Member.

Dry Lakes.-Yellow uranium-bearing agates containing trögerite $\left(\left(\mathrm{UO}_{2}\right)_{3} \mathrm{As}_{2} \mathrm{O}_{8} \cdot 12 \mathrm{H}_{2} \mathrm{O}\right)$ occur about

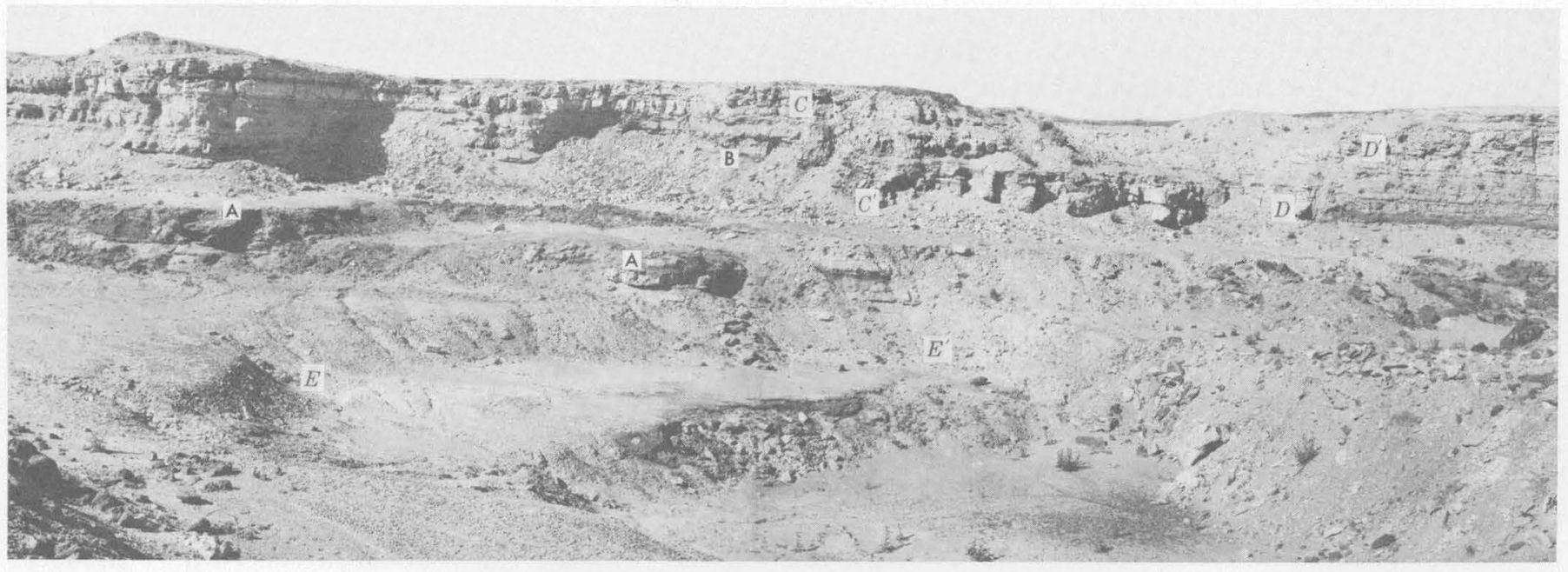

FIGURE 58.-Cheyenne Mining Co. uranium strip mine in upper part of Wagon Bed Formation. View to north in SE1/4 sec. 3, T. 32 N., R. 94 W. A, Black uraniferous oilsaturated sandstone 7 feet thick. B, A thinner similar bed. A small graben is of bounded by faults $C-C^{\prime}$ and $D-D^{\prime}$. Lower oil-saturated sandstone is downfaulted on floor of pit between $E$ and $E^{\prime}$. Height of cliff at far edge of pit is 20 feet. 
1 mile south of the Dry Lakes (loc. $18 \mathrm{U}, \mathrm{Ag}$, table 9 and pl. 1) in the lower porous sandstone sequence of the Split Rock Formation. The host rock is a hard gray arkosic conglomerate and sandstone 50 feet thick and $300-400$ feet above the base of the formation. The agates are 1-4 inches in diameter, have a rough outside coating, manganese dendrites (fig. 30) inside, and fluoresce brilliant yellow, but only a few contain trögerite. The agates were formed in cavities in the conglomerate, apparently before deposition of the upper porous sandstone sequence in the Split Rock Formation. (See discussion of Agate Flats locality.) Although the uranium content averages only about 0.01 percent, the occurrence is important to an understanding of the genesis of uranium deposits; here, the uranium-bearing water that supplied trögerite to the agates as they were being formed was percolating through this part of the Split Rock Formation, probably in early middle Miocene time.

Agate Flats.-The Agate Flats comprise an area of broad dip slopes about 12 miles long and 5 . miles wide in the Split Rock Formation between the Precambrian knobs of the Granite Mountains and the Beaver Divide. The agates are pebbles in a conglomerate and sandstone unit less than 100 feet thick that is the basal bed of the upper porous sandstone sequence, 600-900 feet above the base of the Split Rock Formation. The agates are about one-fourth the size of those in the Dry Lakes locality and are waterworn and wind faceted, whereas the Dry Lakes agates have a thick altered surface layer and have not been transported. Agates from both localities are identical in uranium content, fluorescence, manganese dendrites, and presence of trögerite. If the agates on Agate Flats were derived by erosion from the zone containing similar agates in the lower porous sandstone sequence, and no other source is known, it means that between early and middle Miocene time there was uplift, extensive erosion of the agate-bearing part of the lower porous sandstone sequence, transport to Agate Flats, and sufficient time of exposure to accomplish wind faceting of many agates prior to their burial.

White Ridge.-Small amounts of uranium occur in eight zones in the middle of the Moonstone Formation at the type section (figs. 37,60 ; loc. $22 \mathrm{U}$, table 9 and pl. 1 ; table 11). In no place does the uranium content exceed 0.034 percent, but analyses of 0.01 percent are common. (See, for example, samples 5-32, table 11). No uranium mineral has been identified, and the uranium apparently is finely disseminated in shale and tuff in the same manner as that in lacustrine beds in the Green River Formation and its equivalents (Love, 1964). The continuity of several of these thin beds throughout distances of several square miles, the extreme porosity and permeability of the Moonstone Formation as a whole, the absence of carbonaceous material, the position of the uranium-bearing beds on a high ridge, and the absence of younger or higher strata from which the uranium could migrate laterally indicate to me that most or all the uranium in the formation in this area is syngenetic.

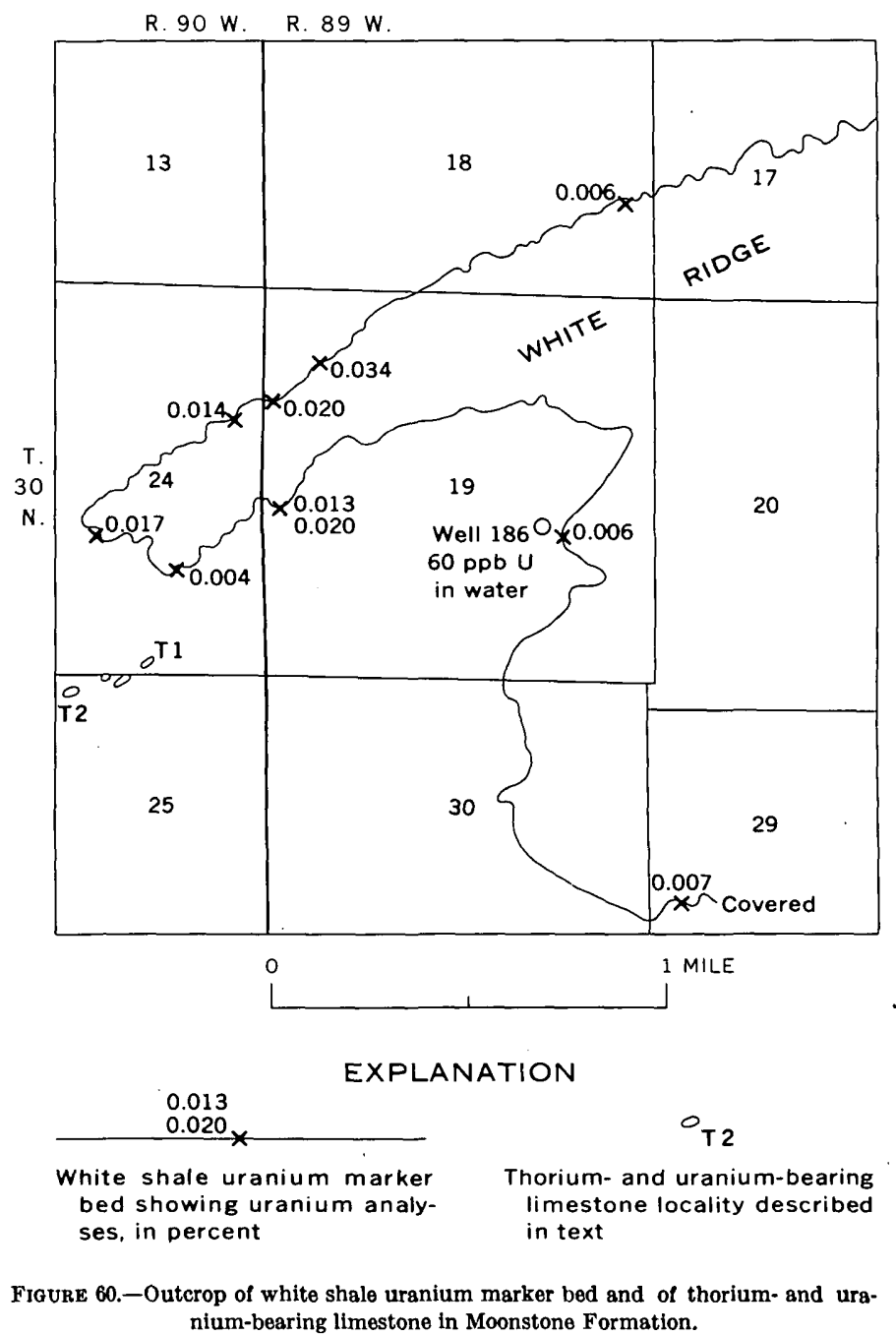

A white shale bed 6-12 inches thick (unit 17, type section, Love, 1961b) was sampled in nine places along 5 linear miles of outcrop (fig. 60). The average grade is 0.013 percent, which is probably low because none of the samples was taken more than 2 feet below the surface, whereas the zone of weathering is about 25 feet. This figure for average grade is used in computing the amount of uranium per square mile, however, on 
the assumption that the higher values below the zone of weathering are offset by the use of a thickness of 1 foot, which includes bordering strata of lesser uranium content. In round figures, this one zone has about 200 tons of uranium per square mile. The outcrops of other zones are not now as continuous, perhaps because of Quaternary leaching, but a few of them originally may have had a uniformly high uranium content at the time of deposition. Several lower grade zones are much thicker than 1 foot. Subsurface uranium content below the weathered zone could be determined, in part at least, by drilling a core hole on the top of White Ridge directly east of where the sample containing 0.034 percent was taken (fig. 60) in sec. 19.

Water wells and springs in the Moonstone Formation of this area contain an average of $34 \mathrm{ppb}$ uranium, more than three times that in the underlying Split Rock Formation. The maximum uranium content is $60 \mathrm{ppb}$, in well 186 (fig. 60). Unfortunately, no drill cuttings from this well were saved and no radioactivity $\log$ was run.

Kortes area.-A weakly radioactive siliceous limestone as much as 50 feet thick, in the Moonstone Formation, crops out as a prominent escarpment about 1 mile northwest of the Kortes Dam camp (loc. 26U, pl. 2 ; fig. 52). Radioactivity is distributed unevenly in this rock, and the highest value in a sample that I collected is 0.009 percent uranium (sample 53, table 11). Prospectors have reported higher values.

Bug Ranch.-Siliceous limestone in two adjacent localities near the type section of the Bug Formation yielded as much as 0.022 percent uranium (table 11), but the average is much less, and the deposits extend laterally for only a few hundred yards. They are significant, however, because they represent the youngest strata containing probable syngenetic uranium deposits in the Granite Mountains area.

\section{ORIGIN OF URANIUM DEPOSITS}

Numerous papers have been published on the origin of uranium deposits in general and many more have described specific districts in Wyoming. The papers most pertinent to this region are cited in the following discussion, but no attempt is made to assemble a complete bibliography. The hypotheses of source and accumulation of uranium, although with multiple variations, include four general categories (Denson, 1959, p. 3; Pipiringos, 1961, p. A64-A65 ; Masursky, 1962, p. B91-B96 ; Stephens, 1964, p. F50F51): (1) syngenetic, in which uranium accumulates at. the same time as the host sediments, (2) diagenetic, in which uranium accumulates after deposition of host sediments but before lithification, (3) epigenetic, in which uranium accumulates after the host rocks have been lithified, (4) a combination of the preceding three methods.

The primary source of uranium has been considered by various geologists to be (1) Precambrian granite of the Granite Mountains, with uranium leached directly from it or from arkoses derived from it; (2) Precambrian vein deposits of hydrothermal origin (Guilinger, 1963) ; (3) uraniferous tuff of Tertiary age (Love, 1954a ; Pipiringos, 1961) ; and (4) uraniumbearing hydrothermal solutions from deep-seated mineral belts (Melbye, 1957; Gabelman and Krusiewski, 1963). A variety of mechanisms of entrapment and concentration have also been proposed. Among these are invasion of porous sandstones by hydrothermal solutions coming up along faults (Melbye, 1957), multiple migration-accretion (Gruner, 1956), entrapment by hydrogen sulfide from natural gases (Grutt, $195 \%$ ), and creation of a favorable environment of precipitation by the introduction of biogenic sulfur (Cheney, 1964; Jensen, and others 1960; Jensen, 1962). The geochemical aspects of concentration and migration have been reviewed by Rosholt, Harshman, Shields, and Garner (1964).

The broad regional aspects of the geology of uranium deposits involving origin, location, and enrichment are discussed in reports (and references cited) by McKelvey, Everhart, and Garrels (1955), Denson (1959, p. 10), Osterwald and Dean (1961), and Gabelman and Krusiewski (1963).

All these studies contributed important data and ideas, many of them conflicting, that are pertinent to the origin of uranium deposits in the Granite Mountains area. Thus, the interpretation presented here is a synthesis of published research by many other workers, in addition to my own.

Rosholt, Garner, and Shields (1964) and Masursky $(1962$, p. B95) discussed the low uranium content of some granite in central Wyoming; their findings are compatible with a rock analysis of representative granite from a core at a depth of about 1,245 feet in well 164 (table 7 ). This core has 0.006 percent equivalent uranium and 0.0003 percent uranium. Well 164 is about 3 miles northeast of the Crooks Gap uranium district, and the core is from the source rock that furnished arkose to the Wasatch and Battle Spring Formations, the host rocks for uranium in the district.

In addition to widely disseminated minute amounts of uranium in Precambrian granite, local concentrations do occur, as is shown at the Little Man mine and other described localities. Guilinger (1963) discussed 
a core fragment of a uraninite-bearing cobble of quartz diorite or granodiorite of Precambrian age in the Wind River Formation of the Gas Hills area. He considered the rock to be from a Precambrian primary vein deposit. Cheney and Jensen $(1963,1964)$ questioned this origin on the basis of biogenic pyrite in a suite of similar Precambrian cobbles from the same locality.

Of 10 water samples from springs in Precambrian rocks of this area, five contain $1 \mathrm{ppb}$ uranium and only two have more than $6 \mathrm{ppb}$. Of particular interest is the Moonshiner's Spring, previously mentioned, 850 feet downhill from the Little Man mine and directly adjacent to the south terminus of the uranium-bearing graphite layer. The water contains $1 \mathrm{ppb}$ uranium, which indicates that no uranium is currently entering the ground water system, even in an area of known uranium concentration. Although many more analyses are needed to confirm this, the data from all samples suggest that granite is not readily yielding uranium to ground water in this area, even where uranium is locally available.

From this we can see that Precambrian rocks might have provided all or part of the uranium in the Gas Hills and Crooks Gap districts, but, as will be pointed out in the ensuing discussion, most of the uranium could have been derived much more easily from younger source rocks.

Uranium analyses of the arkosic host rock in the Wasatch and Battle Spring Formations (Masursky, 1962 ; Stephens, 1964, fig. 17) show an average uranium content of less than 0.005 percent in the vicinity of Crooks Gap uranium deposits and lesser amounts elsewhere. The uranium content of water in the Wasatch and Battle Spring Formations averages less than $5 \mathrm{ppb}$, which is about the same as that from water in Eocene and older rocks in areas of no known uranium mineralization (Denson and others, 1956). The somewhat younger upper part of the Wind River Formation, though likewise derived from the same segment of the Granite Mountains but on the opposite side of the drainage divide in the Gas Hills district, has an average uranium content in water of $16 \mathrm{ppb}$ uranium (exclusive of the actual mine localities). The Wind River Formation on the northeast margin of the Granite Mountains has $8.8 \mathrm{ppb}$ uranium in water (Rich, 1962).

When considered with respect to geographic and stratigraphic settings, the rock and water analyses neither disprove nor support the hypothesis that nontuffaceous lower Eocene arkosic sandstones derived from the Precambrian core of the Granite Mountains are a source for all or part of the uranium in the Gas
Hills and Crooks Gap districts. These rocks are not here considered to be the most logical source.

Turning our attention to the younger Tertiary rocks, all of which contain appreciable amounts of volcanic debris, we can see from the localities described earlier that uranium is in localized concentrations in strata of many ages and in widely separated areas. These concentrations are not clustered in the vicinity of either the Crooks Gap or Gas Hills uranium districts or near middle and late Eocene vents in the Rattlesnake Hills. This wide range in geologic age of host rocks, from middle Eocene to Pliocene and Pleistocene, broad geographic distribution of the host rocks, and variety of relations to underlying strata and structure indicate very strongly that uranium in the post-lower Eocene rocks did not have a hydrothermal origin. The simplest and most applicable explanation is that the deposits were formed by leaching of readily available uranium from the youngest rocks, probably largely the Pliocene Moonstone Formation, that once blanketed the areas.

The uranium occurrence in a topographically high exposure in the Cathedral Bluffs Tongue of the Wasatch Formation on Cyclone Rim is near a deep well $\left(21\right.$, table 2 ; section $\left.B-B^{\prime}, \mathrm{pl} .1\right)$ that penetrated many coal beds and beds of arkosic carbonaceous sandstone less than 2 miles south of the Flattop fault. This well is likewise near surface accumulations of schroeckingerite and uraniferous coals (Wyant and others, 1956; Sheridan and others, 1961; Pipiringos, 1961). The subsurface coals and carbonaceous sandstones should have attracted some of the uranium if it had come up from depth along the faults. This origin was postulated by Sheridan and others to account for the nearby schroeckingerite and uraniferous coals on the surface. Excellent gamma ray-neutron and gamma ray-sonic logs of well 21 show no abnormally radioactive zones from the surface to a total depth of 6,779 feet. Other deep wells to the southeast, southwest, and northeast likewise show no abnormally high radioactivity in the lower coal zones; those zones in the upper 100 feet of section are the most radioactive. 'Therefore, Pipiringos' explanation that the uraniferous coal and schroeckingerite derived their uranium by leaching of tuffaceous strata that once overlay the area seems to agree with the subsurface data. If uranium had been syngenetic in the surface coals as postulated by Wyant and others, it would still have had to migrate upward, both stratigraphically and topographically, to form concentrations in the Cathedral Bluffs Tongue. This appears less likely than downward leaching, especially in the light of the late Cenozoic history of 
sedimentation and tectonism outlined in the preceding part of this paper.

The thin hard uranium phosphate beds in the middle Focene part of the Wagon Bed Formation in the Big Sand Draw localities (locs. 8U, P and 9U, P, table 9 and pl. 1) are believed to be syngenetic (Love, 1964) and to have been little affected by later events. Twentyfive water samples from springs emerging from the Wagon Bed Formation north of the Beaver Divide werage $6 \mathrm{ppb}$ uranium, and these include samples from the Gas Hills uranium district (Zeller, 1957). Only two samples contain more than $7 \mathrm{ppb}$ uranium, and 11 contain $1 \mathrm{ppb}$ or less. From this, it would seem that little uranium is being leached out of the Wagon Bed Formation or is passing through it.

'The uranium deposit in the upper Eocene part of the Wagon Bed Formation at the Conant Creek locality is not underlain by lower Eocene rocks but rests directly on Paleozoic and Mesozoic strata. The locality is topographically high. The distribution of uranium is quite different from that of the stratigraphically lower syngenetic uranium phosphate in the lower part of the Wagon Bed to the southwest, and appears to have migrated into the porous arkosic tuffaceous sandstone after emplacement of the oil. I think that the uranium was leached from younger tuffaceous strata that have since been stripped off', and that the uranium was concentrated at this locality because of the abundant hydrocarbons in the host rock.

Water from 18 springs and wells in the White River Formation in the northeastern part of the Granite Mountains area has a uranium content of only $4 \mathrm{ppb}$ (Rich, 1962) except at the mineralized carbonaceous shale locality near the head of Poison Spring Creek. In that area, the water contains an average of $61 \mathrm{ppb}$ uranium. This is a topographically high area that was tilted southward in Pliocene and Pleistocene time, and I suspect that the uranium came down from overlying rocks and was trapped by the carbon. In the Gas Hills urea and farther west, water from 10 wells and springs in the White River Formation averages $12 \mathrm{ppb}$ uranium.

The only appreciably high amounts of uranium found in Miocene rocks are trapped in agates. The oldest of these agates were formed in place in the lower porous sundstone sequence in the Split Rock Formation at the Dry Lakes locality and apparently were reworked, wind fuceted, and then deposited as pebbles in the middle Miocene upper porous sandstone sequence. If this order of events is correct, and I can find no evidence for an alternative interpretation, uraniferous ground water must have supplied uranium to the agates being formed in place during early Miocene time.

Eighteen water samples from wells and springs in the Split Rock Formation in the central and western parts of the Granite Mountains area average $10 \mathrm{ppb}$ uranium (Stephens, 1964; more detailed mapping indicates that age designations of rocks at several sampled localities in his table 7 are in error). Excluded from this average are four wells downstream from the Crooks Gap area, near where Crooks Creek becomes intermittent, that average about $35 \mathrm{ppb}$ uranium. The water in these wells is undoubtedly enriched by uraniferous water draining from the Crooks Gap uranium deposits. Five samples of water from the Split Rock Formation in the northeastern part of the Granite Mountains area, average $11 \mathrm{ppb}$ uranium.

The Moonstone Formation is the most interesting of all the Cenozoic sequences from the standpoint of origin of uranium deposits in the Gas Hills and Crooks Gap districts. As mentioned previously, eight uraniferous zones are known in the middle part of the formation, and others may be present in the subsurface. Although outcrops are undoubtedly leached, as is indicated by the erratic distribution of uranium in some beds and the extreme porosity and permeability of most strata, the less permeable white shales contain units with more constant uranium values. A bed 1 foot thick, sampled in nine places along 5 miles of outcrop averages 0.013 percent uranium and has a maximum of 0.034 percent (fig. 60). In the absence of a more logical explanation, I have postulated a syngenetic origin for the uranium in these strata.

If we assume a syngenetic origin for the uraniferous zones in several hundred feet of lacustrine beds in the middle part of the Moonstone Formation, the original extent of Moonstone Lake in which the strata were deposited becomes important. Plate 10I shows a hypothetical reconstruction of this lake, based in part on lithology and in part on the regional pattern of tectonism and sedimentation. These data suggest that the lake probably extended to, but not north of, the Gas Hills district and southwest into Crooks Gap. The southwestern extension is based on an interpretation of the time of cutting of Crooks Gap by a northward-flowing stream.

Uranium is now in solution and moving within the Moonstone Formation; water samples from all wells and springs in the outcrop area of the type section average $34 \mathrm{ppb}$ uranium, three or more times the amount in any of the older Tertiary rocks. $A$ bed 1 foot thick with an average grade of 0.013 percent uranium, such as the one shown in figure 60 , extending north for 
15 miles from White Ridge to the Gas Hills district, with the same width as that district (18 miles), would contain about 54,000 tons uranium. If it extended a like distance southwest to Crooks Gap, a similar tonnage would be available. There is, of course, no way to determine how many zones were originally present, or how thick, how rich, or how persistent they were, but it is reasonable to assume that we are not now seeing either the best or the only uraniferous part of the original deposit. The middle part of the type section of the Moonstone Formation contains more uranium per unit volume than any other Tertiary formation outside the uranium districts.

Inasmuch as the tonnage of uranium ore produced through 1964 from both the Gas Hills and Crooks Gap districts plus the tonnage of estimated ore reserves as of 1965 is slightly less than 50,000 tons, it is apparent that there is or has been an adequate amount of uranium locally available from this one part of the Moonstone Formation alone to supply all that both districts are known to have.

The following chronological interpretation of origin of the uranium deposits in these districts synthesizes all types of data and is presented with the hope that it will be useful in future search for new deposits and that it will stimulate research whose objective is to confirm or correct the inadequately known parts of this story. It can likewise be used to account for the occurrences of uranium in middle and upper Eocene, Oligocene, Miocene, and Pliocene strata.

Events in central Wyoming leading up to the formation of Moonstone Lake have already been discussed. A concept of the regional setting at this time has been presented elsewhere (Love, 1961b; Love and others, 1963, fig. 9). Fine-grained ash deposited in the lake probably came from vents in the Yellowstone National Park-Jackson Hole region. The lake was highly alkaline, and alteration of ash was rapid and extensive, as is shown by the spectacular abundance of chalcedony in the Moonstone Formation. The uranium is concentrated in several hundred feet of the finest grained, most chalcedonic middle part of the formation (table 11). At the time of deposition of these beds and subsequently, the porous and permeable arkosic sandstone host rock of the Wasatch and Battle Spring Formations was probably exposed in the Crooks Gap area (pl. 10I), and uraniferous water draining from the Moonstone Formation could readily penetrate it. In the Gas Hills area, the record of events is less complete, but large uranium deposits are concentrated near the two conspicuous pre-White River channels cut through the Wagon Bed Formation and into the Wind River (pl.
1). These may have been conduits along which uraniferous water from the Moonstone Formation flowed to the arkosic sandstone host rock in the Wind River.

In post-Split Rock time, abundant pyrite was introduced into both the Gas Hills and the Crooks Gap districts. This episode needs more study because the reason for it is not well understood. It seems to be related in part to oil migration into Tertiary rocks. The magnitude and areal extent of this oil migration have not generally been recognized by those studying origin of uranium deposits. The oil migration apparently occurred at about the time of maximum thickness, and therefore the time of maximum load pressure, of Tertiary sediments in the region and may have been triggered by epeirogenic uplift and the more localized subsidence of the Granite Mountains. Much, but not all, of the oil is a high-sulfur type derived from rocks of late Paleozoic age. (See discussion of oil-saturated sandstone, p. C135-C136.) This was an episode of widespread oil movement involving most of the Tertiary units, as is indicated by the following examples: (1) The entire 220 feet of the Split Rock Formation in well 261 is oil stained; (2) the Split Rock and White River Formations contain abundant pyrite, and the White River has spotty oil staining in core holes 112 and 113, 3 miles northwest of the Crooks Gap uranium district, and adjacent to several oil fields; (3) beds of pyritic sandstone are oil stained in the Wagon Bed and Wind River Formations in well 139; the White River has pyrite in core hole 169 ; (4) spotty oil staining occurs in places scattered through 600 feet of the Wind River Formation and in the underlying Permian rocks in well $167 ;(5)$ a concentration of pyrite occurs at the contact of the Wagon Bed Formation and Triassic rocks in well $258 ;(6)$ pyrite and oil staining occur in tuffaceous sandstone of the Wagon Bed Formation in most of the 45 or more core holes and wells in the north half of T. 32 N., R. 94 W., near the Conant Creek uranium deposit. In the Gas Hills uranium district, oil-stained sandstones of 'Triassic and Late Cretaceous ages occur in eight or more places along the Dutton Basin anticline directly below the Wind River Formation. Sulfur isotopes in the oil-stained parts of the Tertiary rocks have not been studied in detail.

Sulfur from the oil probably reacted with the abundant iron in the Tertiary rocks, especially in the porous lower Eocene sandstones, to form pyrite. This reducing environment would have facilitated precipitation of uranium. After the creation of a favorable environment is accounted for, the next step is to 
explain how and when uranium in quantity entered that environment.

Cheney and Jensen (1964) postulated that the ground water containing uranium moved north into the Wind River basin, perhaps during late Tertiary time, and that subsequently the direction of flow was reversed by collapse of the Granite Mountains so that the water funneled back south again into the Gas Hills area. As mentioned on pages $\mathrm{C} 120\lrcorner \mathrm{C} 121$, however, a broad gentle upwarp, developed in late Pliocene and early Pleistocene time and extended west from the northern part of the Gas Hills. This barrier separated the southwardsagging Split Rock syncline from the region of northward tilting that involved the major part of the Wind River basin and the areas to the north. Uranium-bearing water from the Moonstone Formation may never have been able to flow into the deeper part of the Wind River basin north of the Gas Hills. This water could not escape to the east because of the exposed pre-Wind River upland barrier or to the west because of permeability pinchouts in the host rocks. With a rich local source like that of the Moonstone Formation, sufficient uranium is directly available without having to postulate that any of it flowed back southward from a large area containing uraniferous water in the Wind River basin.

The general pattern of convexity of ore fronts, especially in the western part of the Gas Hills district, sugrests fanning out of northwestward- and northward-moving uranium-bearing solutions from several areas of dispersal. Concentrations of molybdenum minerals have been observed on the apices of some fronts. Many fronts are similar to those described in the Shirley basin by Harshman (1962), Rosholt, Harshman, Shields, and Garner (1964), and Bailey (1965) and to those produced experimentally by Evseeva, Ivanov, and Kochetkov (1963).

Because most of the unoxidized ore is in radioactive equilibrium (Coleman, 1956, 1957; Cheney, 1964), extensive mineralization may have occurred more than 500,000 years ago. However, the presence of rich ore out of equilibrium (high chemical and low radiometric values-the "no count" ore of miners) above, below, and at the water table (Grutt, 1957; Zeller, 1957) shows that secondary enrichment has occurred recently and is probably still going on. This is likewise indicated by the distribution of uranium in ground water (Denson and others, 1956). Radiometric ages of the ore range from 11,000 to 170,000 years (Zeller, 1957; Coleman, 1957; Rosholt, 1958). The Pleistocene or Recent episode of southward tilting probably has not redistribu- ted large tonnages of uranium ore for any great distances.

The Crooks Gap area likewise has ore fronts similar to those in the Gas Hills and in the Shirley basin, and they were probably formed in the same manner. The localization of uranium in the vicinity of Crooks Gap may be related to the existence of the gap in Pliocene time and to the availability of the host rock to uraniferous water draining out of the Moonstone Formation. Emplacement of uranium deposits in ore fronts and other types of concentration could have occurred at any time from the end of deposit of the Moonstone Formation to Recent.

\section{AREAS WARRANTING FURTHER EXPLORATION 8}

If my interpretation of origin of uranium deposits in the Granite Mountains area has merit, several localities where no major uranium ore bodies have yet been discovered may warrant detailed investigation.

Area 1.-Area 1 trends east, is 30 miles long and 10 miles wide, extends from well 221 to well 178 , south of Crooks Gap, and is underlain by porous and permeable host rocks in the Wasatch and Battle Spring Formations, the same as those at Crooks Gap. Small amounts of uranium are present near the base of the host rocks in the western part and 3,000 feet above the base in the. eastern part. As is shown on plate $6 A$, this area has a closed hydrodynamic system from which no uraniferous water could have escaped after early Eocene time. One of the most promising parts of this area is Willow Creek Gap, 12 miles east of and very similar to Crooks Gap. Small amounts of uranium have been found at shallow depths, but no mining is going on, and no deep drilling had been done as of 1964 . The Wasatch and Battle Spring Formations are estimated to be about 4,000 feet thick. Well 177, 2 miles northwest of Willow Creek Gap, penetrated beds containing abundant pyrite in about 600 feet of the Battle Spring Formation and more in the underlying Fort Union, beneath the Emigrant Trail thrust (section $F-F^{\prime}$, pl. 3), but a gamma ray-neutron log shows no significant amount of radioactivity. This could be because the rocks were protected from penetration of uranium-bearing water by 2,000 feet of overlying granite.

Several synclinal troughs trending southeast from Crooks Gap (pl. 6A) into the major downwarp have not been explored at depth. There again, about 4,000 feet of host rock is present within the closed hydro-

SThis report was submitted for publication In 1965 ; beginning in 1967, exploration for uranium was carried on in parts of areas 1 and 3. 
dynamic system. Ore fronts are commonly convex downdip, and additional uranium probably will be found in this direction, inasmuch as none of it could escape.

Area 2.-Area 2, comprising the Niland Basin in the northern part of the Great Divide basin, is south of the geologic map area (pl. 1) and has been mapped by Pipiringos. He recommended it (1961, p. A73) for additional prospecting. Subsurface data obtained by me in connection with the construction of section $B-B^{\prime}$ (pl. 1) indicate the desirability of reemphasizing the potential importance of this area. It is a closed hydrodynamic system containing a much thicker coal-bearing section than was indicated by Pipiringos. The exposed radioactive coal beds and others not exposed extend downdip into the basin to depths of perhaps 2,000 feet. Lost Creek, which drains the schroeckingerite area to the northeast, flows along the east margin of this basin. Pipiringos noted that the outcropping radioactive coals were associated with coarse sandstones.

Area 3.-Area 3 is on both sides of the North Granite Mountains fault system west of the Rattlesnake Hills and extends from the faults south to the granite knobs and north to the Beaver Divide. A few core holes show thin ore beds in widely separated spots, but, unfortunately, adequate records were not kept of the rocks penetrated. The area is a closed subsurface hydrodynamic system, downdip from major uranium deposits in the Gas Hills district. The host rocks extend southward along pre-Eocene valleys cut in the Granite Mountains and eventually wedge out against the Precambrian core of the uplift.

Area 4.-Area 4 is the area of oil-stained radioactive tuffaceous sandstone in the Wagon Bed Formation south of the Conant Creek uranium deposit and is of potential interest for both oil and uranium. Here again, however, failure to keep detailed records on 50 or more holes has made impossible an adequate evaluation of the potential of this area.

Area 5.-Area 5 is the deepest part of the Split Rock syncline (pl. $6 D)$. It has been a closed hydrodynamic system since Miocene time and contains 2,000-3,000 feet of porous and permeable Miocene and Pliocene tuffaceous rocks, some of which are known to contain uranium. Streams have flowed into it from the Crooks Gap area and the type section of the Moonstone Formation since Pliocene time. Abundant pyrite is present in some well sections. Only one gamma ray $\log$ of the entire Tertiary section (from well 188) is available for an area of more than 250 square miles. It did not show anomalous radioactivity.

\section{THORIUM}

Small amounts of thorium have been found in Precambrian, Pliocene, and Pliocene or Pleistocene rocks. No exploitation has been attempted. Uraninite-bearing Precambrian granite in the Little Man mine contains 0.11 percent equivalent thorium. One spectrographic analysis of siltstone from the Wagon Bed Formation shows 0.03 percent thorium. Several radioactive algal reefs in the Moonstone Formation (fig. 60) contain significant quantities of thorium (samples $35-38$, table 11). Chemical analysis shows a maximum of 0.16 percent $\mathrm{Th}^{232}$. A thorium mineral with an $\mathrm{X}$-ray pattern similar to that of rhabdophane was described from this deposit by Dooley and Hathaway (1961). A total of about 10,000 tons of thorium-bearing limestone may be present in the three largest reefs.

One sample of limestone from the Bug Formation (loc. $23 \mathrm{U}, \mathrm{T}$, pl. 1 and table 9 ; sample 1, table 11) contains 0.046 percent $\mathrm{Th}^{232}$. The only other sample of this limestone analyzed for thorium was from half a mile south and was barren (sample 4, table 11).

\section{OIL AND GAS}

All the oil and gas fields in the Granite Mountains area are shown on plate 1 . Descriptions of the oil and gas, producing horizons, and history of production are given in publications by Biggs and Espach (1960) and the Wyoming Geological Association (1962). No production has been from Tertiary rocks. During the process of working out the Late Cretaceous and Cenozoic history, it became apparent that two areas have more than average oil and gas potential. The largest of these extends from Bison Basin to Lost Soldier, in the northern part of the Great Divide basin, and the other is in the Long Creek arm of the Wind River basin southwest of the Long Creek gas field.

Some parts of the northern Great Divide basin have greater oil and gas potential than others. Section $F-F^{\prime \prime}$ (pl. 3) shows a broad anticlinal area between wells 160 and 177. There is little control on this area other than surface dips, but it is in the direction of trend of the adjacent Wirtz and Lost Soldier fields and may not be just one anticline but a series en echelon. West of this locality is the Bison Basin-Antelope-Bare Ring (Barren) Butte anticlinal complex. It is a large and old feature that may have begun to rise in Cretaceous time, and involves all the formations that produce oil in the Lost Soldier field. The anticlinal complex is on the updip side of a major sedimentary basin and has oil fields on the east, west, and north sides, but it has produced much less oil and gas than could reasonably be expected from such a large upfold in this structural position. I 
think this area warrants further investigation to look for not only structural traps but also traps in facies and along unconformities on the flanks of these folds. The beveling of 500 feet or more of sandstone in the Mesaverde Formation west of Lost Soldier and the overlap of the Fort Union Formation across Lance, Lewis, Mesaverde, Cody, and Frontier Formations on the updip side of the Great Divide basin suggest possibilities of major traps.

In the Long Creek arm of the Wind River basin, all the formations productive in the Big Sand Draw oil and gas field are present. An area larger than a township (T. 31 N., R. 95 W.) north, northeast, and northwest of well 46 has not been drilled and seismic records are poor. 'This area is directly west of the Emigrant 'Trail thrust, in front of which pre-Wind River anticlines might occur, and the Fort Union and younger 'Tertiary strata unconformably overlap the Cody Shale and younger Cretaceous rocks, thereby creating a possibility of traps below the unconformity.

$A$ third small undrilled synclinal area lies north of Bison Basin and south of well 20. This is a moderately shallow downwarp with Cody Shale directly below Tertiary rocks. The structural details are not known, but anticlines involving Paleozoic and Mesozoic. rocks could be present.

\section{OIL-SATURATED SANDSTONE}

Oil-saturated sandstone of Tertiary age crops out in several places in the Granite Mountains area. By far the most important occurrence is that in the Wagon Bed Formation in a 12-square-mile area near the Cheyenne Mining and Uranium Co. strip mine (loc. $10 \mathrm{U}, \mathrm{O}, \mathrm{pl} .1$ and figs. 58, 59; table 9) near the head of Conant Creek. Van Houten (1964) mapped surface occurrences of hydrocarbon residue from near the mine to a point about 5 miles west-northwest along the Beaver Divide. South and southwest of the mine, within an area of about 5 square miles, 46 shallow holes were drilled for uranium and several deep wells for oil and gas (all the deep wells, but only a few shallow holes, are listed in table 2 and plotted on pl. 1). I studied all available logs and cuttings. Unfortunately, most logs are sketchy, and all but six sets of cuttings had been discarded. The data indicate that about 35 holes penetrated from 5 to 100 feet of oil-stained sandstone, much of it radioactive, at depths ranging from surface to 500 feet. The limits of the area of oil staining have not been determined.

The following section of oil-bearing strata was measured in the uranium strip mine (figs. 58, 59) :

Section of oil-bearing strata measured in the uranium strip mine, SE1/4 sec. 3, T. 32 N., R. 94 W. (figs. 58, 59)

Wagon Bed Formation:

Thick-
ness

ness
$(f t)$

Top of north rim of pit.

8. Sandstone, brown and green, soft; contains 1 ft oil-saturated sandstone in lower part. ....

7. Arkosic sandstone, light-rusty-tan, hard, pebbly; forms ledge...................

6. Claystone, pale-green; contains abundant limy nodules; very irregular bed. . . . . . . . . . 0. 5-1. 0

5. Limestone, light-greenish-gray, hard, dense, fine-grained, clayey, silicified in part....... 1. 5-3.0

4. Arkosic sandstone, brown, coarse-grained; appears moderately even bedded when viewed from a distance; forms cliff in pit; has $2 \mathrm{ft}$ of irregular oil-saturated arkosic grit in lower

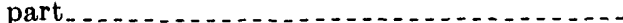

3. Claystone, sandstone, arkosic grit, and tuff, thin-bedded; claystone is green; arkosic grit and sandstone are brown and coarse grained; tuff is white and fine grained..............

2. Arkosic grit, gray to rusty-brown; con tains oilsaturated layers in lower half; top half is completely saturated and highly radioactive (fig. 59); gummy oil oozes out on surface and drips off ledge in globs; contains 0.12 percent $\mathrm{eU}, 0.28$ percent $\mathrm{U}, 0.007$ percent $\mathrm{V}, \mathrm{O}_{5}$, and $30 \mathrm{ppm}$ selenium. (See also statement by W. J. Wenger on characteristics of oil) .......

1. Claystone, rusty-brown in lower part, bright green at top, very sandy, very soft, bentonitic, plastic; weathers to a puffy rounded

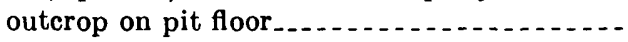

Approximate thickness of measured beds..

A simple of oil from unit 2 was submitted to W. J. Wenger of the U.S. Bureau of Mines for analysis; he reported (written commun., January 14, 1963) :

A sample (1161 grams) of the bituminous sand was extracted with chloroform in a soxhlet extractor and yielded 10.3 weight percent bitumen. Properties of the recovered bitumen were as follows :

\begin{tabular}{|c|c|}
\hline \multirow{2}{*}{\multicolumn{2}{|c|}{$\begin{array}{ccc}\text { Property } & \text { Value } \\
\text { Yield, weight percent_. }\end{array}$}} \\
\hline & \\
\hline ercent. & \\
\hline ent & 4. \\
\hline ercent & .4 \\
\hline & \\
\hline & \\
\hline & \\
\hline
\end{tabular}

The properties of the recovered oil or bitumen indicate that it originated in formations older than Cretaceous-probably from formations of Permian, Pennsylvanian, or Mississippian agebecause they resemble properties of oils from formations of these time periods in Wyoming. The oil is extremely asphaltic, with high sulfur and nitrogen contents and a low ratio of nitrogen to carbon residue. In contrast, the oils from Tertiary and Cretaceous formations are usually waxy (sometimes naphthenic) and nonasphaltic. They contain less than 0.50 percent sulfur 
and less than 0.20 percent nitrogen. Their ratios of nitrogen to carbon residue are about $0.0 \leqslant 0$.

The bitumen-free sand was analyzed qualitatively by X-ray diffraction. It contained three major minerals-quartz, feldspar, and illite, of which quartz was the most abundant. Qualitative analysis by $\mathrm{X}$-ray fluorescence showed that the uranium content was too low to detect in the bitumen-free sand (less than 0.001 percent). Other elements detected, and in descending order of their abundance, were iron, potassium, calcium, strontium rubidium, molybdenum, arsenic, titanium, barium, chromium, vanadium, and manganese.

The recovered bitumen was anlayzed qualitatively by X-ray fluorescence. Trace elements detected, in descending order of their abundance, were molybdenum, iron, arsenic, and uranium.

Ash from the recovered bitumen also was analyzed by X-ray fluorescence. Elements detected, in descending order of their abundance, were iron, molybdenum, vanadium, calcium, nickel, uranium, arsenic, barium, titanium, manganese, and potassium.

The oil was introduced either upward into the Wagon Bed Formation or almost horizontally from low-lying Paleozoic rocks along the eroded west flank of the Conant Creek anticline (pl. 9). These rocks had been exposed for a long time prior to burial by the Wagon Bed Formation; so they presumably should already have been drained of their oil. An estimated several million barrels of oil, however, was released by some mechanism into the Eocene strata and spread along horizontal bedding planes for distances of several miles. Small-scale normal faulting occurred (fig. 58) after emplacement of the oil, but no oil moved along the fault planes. A program of drilling, sampling, and radioactivity logging of the northwest half of T. 32 N., R. 94 W., should give an evaluation of both oil and uranium potentials. Any deposits would probably be within feasible limits of stripping.

Well 261 penetrated 220 feet of oil-stained sandstone in the Split Rock Formation. The oil is light, volatile, and not merely an asphaltic residue. The areal geology of pre-Tertiary rocks indicates a fault near here (pl. 7) along which the oil probably migrated in post-Miocene time. The extent and chemical nature of the oil and the volume of the deposit have not been determined.

East of Bison Basin is an oil-saturated sandstone about 500 feet above the base of the Fort Union Formation on the Bison Basin-Antelope anticlinal complex (loc. 1-0, table 9 and pl, 1). The oil is straw colored and highly aromatic. It has not been investigated in detail, and the only chemical studies, started in the early 1930's by the research chemistry department at the University of Wyoming, were never completed (O. A. Beath, oral commun., 1963). This oil-stained sandstone is of special interest because it is the only one known in the Fort Union Formation near the north margin of the Great Divide basin. The occurrence of oil is on an anticline, and the relations suggest that under favorable condi- tions the formation may contain accumulations of indigenous oil downdip in this part of the basin, as it does in well 278 (section $B-B^{\prime}$, pl. 1 ) to the southeast.

Oil staining occurs in the Wagon Bed and Wind River Formations in well 139. About 600 feet of the Wind River Formation has spotty oil staining in well 167 and this continues into the underlying Permian rocks. As discussed in connection with uranium deposits, oil migrated into Tertiary rocks at about the time of maximum thickness and maximum load pressure (post-Split Rock) and may have been triggered by epeirogenic uplift concomitant with subsidence of the Granite Mountains. Certainly, the oil must have been extremely fluid to have migrated the observed distances in horizontal strata.

\section{COAL}

Paleocene and lower Eocene rocks contain coal deposits of economic significance in the northern part of the Great Divide basin. Outcropping and near-surface coal beds in the Wasatch Formation have been described by Masursky (1962) and Pipiringos (1961), but the deeper subsurface coal beds have not previously been described.

In well 21 , the lower coal zone (section $B-B^{\prime}, \mathrm{pl} .1$ ) contains six coal beds 5 feet or more in thickness and the upper zone has 11 coal beds 5-30 feet thick. Four miles southeast, well 269 penetrated 20 coal beds 5-30 feet thick in the Paleocene part of the section. This same general sequence in well 233,15 miles to the east, contains about 25 coal beds 5-20 feet thick. Lesser amounts of coal are present in well 160, still farther east.

In well 278 (section $B-B^{\prime}$ ), and north, south, and east of it, is an undescribed coal-bearing sequence 1,000 1,500 feet thick and 1,500-2,000 feet below the surface that contains 10-17 coal beds 5-40 feet thick.

Near well 269 and below the Tierney 5 coal that was a structure-contour horizon for Pipiringos (1961, pl. 1) is an additional 800 feet of coal-bearing rocks, the lower part of which has not been described. The number, thickness, and areal extent of these lower coal beds are incompletely known, but there are at least six of minable thickness.

Regional well data in the northern part of the Great Divide basin show the presence of an east-trending area of coal deposition that persisted from Late Cretaceous time through Paleocene and into early Eocene time. No analyses are available on the quality of subsurface sections of coal in this area. A conservative estimate of the amount of hitherto undescribed coal above a depth of 6,000 feet in the major area of coal deposition would be considerably more than 1 billion tons. 


\section{PUMICITE AND ASH}

Pumicite is the name here used for consolidated deposits consisting primarily of shards and very small pumice fragments in which cell structure has been almost completely blown apart. Ash is the name used for unconsolidated beds of the same material.

The White River Formation contains many beds of pumicite. They are most common in the northeastern and western parts of the Granite Mountains area. Those in the northeastern part are rarely more than 4 feet thick; some are moderately pure, and others are sandy or contain abundant biotite flakes. The beds of pumicite in the western part are somewhat thicker but are rarely more than 6 feet thick. Analyses and localities of simpled beds are given in table $\tau$. Additional localities of vitric tuff and less pure pumicite from which potassium-argon dates were obtained are given in table 5.

Beds of pumicite in the Split Rock Formation are more abundant, thicker, and less consolidated than those in the White River. They are most numerous in the upper porous sandstone sequence, where some outcrops extend for several miles. Two beds 5-10 feet thick in the vicinity of localities $13 \mathrm{~V}, \mathrm{D}$ and $14 \mathrm{P}$ (table 10 and pl. 1) have a combined estimated total of at least 15 million tons of pumicite per square mile. (See analysis 143218 , table 7.)

By far the thickest and most widespread pumicite beds are in the Moonstone Formation in the southeast corner of the Granite Mountains area. (See beds in measured section of the black shale member; fig. 42.) Many are sandy but some are moderately pure. They have considerable lateral continuity and can be mapped in detail. In the vicinity of well 225 , beds $2-10$ feet thick of pumicite of varying purity have a combined estimated total of more than 15 million tons of pumicite per square mile. Rock analyses of six representative sumples from this locality are given in table 7 .

Pleistocene ash is known only from the Conant Creek (loc. 11A, table 9 and pl. 1 ; fig. 48 ) and Seminoe Dam (loc. $27 \mathrm{~A}$, table 9 and pl. 1 ; fig. 47) localities. Rock analysis of ash from the latter locality is given in table $i$. The ash from these localities is of considerable scientific interest but is thin, lenticular, and covered with thick overburden. 'It is not of economic interest because of these factors and the abundance of much larger deposits of older pumicite in adjacent localities.

\section{ZEOLITES AND OTHER CLAY MINERALS}

Bedded deposits of heulandite, clinoptilolite, and erionite are known at locality $9 \mathrm{U}, \mathrm{P}$ (table 9 and pl. 1) and have been described. (See Deffeyes, 1959a, b; Van Houten, 1964; Love, 1964, measured section on p. E42.)
The extent, tonnage, and economic significance, if any, of these deposits have not been determined.

Samples of clay from all the younger formations were examined. Nearly all are montmorillonite or mixed layer. Many from the Moonstone Formation contain clinoptilolite. One white tuffaceous claystone in unit 44 near the top of the type section (Love, 1961b) of the Moonstone Formation contains an appreciable amount of phillipsite. This was not found in any other samples.

\section{SODA LAKES}

Six soda lakes half a mile or more in diameter ( $\mathrm{pl} .1$ ) and many smaller ones (not shown) occupy windscooped depressions in the upper porous sandstone sequence of the Split Rock Formation northwest and east of Split Rock Peak. Another small soda lake is about $1 \frac{1}{2}$ miles south of locality $3 \mathrm{~V}$ (table 10 ), south of the mapped area. This lake is likewise in a windscooped depression in the Split Rock Formation along the trough line of the Cyclone Rim syncline.

Chemical and spectrographic analyses were made of evaporite samples from three of the lakes. Sample 1 is from the soda lake in the Cyclone Rim syncline, NE $1 / 4$ SW $1 / 4$ sec. 24 , T. 26 N., R. $95 \mathrm{~W}$.; sample 2 is from the easternmost of the Seventy-One soda lakes, SW cor. sec. 26 , T. 30 N., R. $91 \mathrm{~W}$.; and sample 3 is from the Turkey Track soda lake, center sec. 20, T. 29 N., $R$. $88 \mathrm{~W}$.

Analyses of evaporites from soda lakes

\begin{tabular}{|c|c|c|c|c|c|c|c|c|}
\hline \multirow{2}{*}{ Sample No. } & \multirow{2}{*}{$\begin{array}{c}\text { Lab. } \\
\text { No. }\end{array}$} & \multicolumn{7}{|c|}{ Weight percent on basis of total sample } \\
\hline & & $\mathrm{Na}_{2} \mathrm{O}$ & $\mathrm{K}_{2} \mathrm{O}$ & $\mathrm{CaO}^{\circ}$ & $\mathrm{MgO}$ & $\mathrm{Cl}$ & so, & $\begin{array}{l}\text { Total } \\
\text { solids }\end{array}$ \\
\hline $\begin{array}{l}1 \ldots \\
2 \ldots \\
3 \ldots\end{array}$ & $\begin{array}{rr}304303 \\
\therefore-\quad 304 \\
. \quad & 305\end{array}$ & $\begin{array}{l}14.6 \\
15.1 \\
15.6\end{array}$ & $\begin{array}{r}0.51 \\
3.04 \\
.31\end{array}$ & $\begin{array}{r}0.40 \\
<.01 \\
.02\end{array}$ & $\begin{array}{l}0.04 \\
<.01 \\
<.01\end{array}$ & $\begin{array}{l}0.98 \\
.61 \\
.43\end{array}$ & $\begin{array}{r}22.9 \\
4.1 \\
24.0\end{array}$ & $\begin{array}{l}36.5 \\
34.1 \\
37.3\end{array}$ \\
\hline
\end{tabular}

$\mathrm{Na}_{2} \mathrm{O}$ and $\mathrm{K}_{2} \mathrm{O}$ were determined by flame photometer by Wayne Mountjoy. $\mathrm{CaO}$ and $\mathrm{MgO}$ were determined volumetrically and gravimetrically, respectively, by E. J. Fennelly.

$\mathrm{Cl}$ and $\mathrm{SO}_{4}$ were determined volumetrically and gravimetrically, respectively, by Ardith Bartel.

Total dissolved solids were determined by evaporation and by weighing of 100 milliliter aliquots of the sample solutions.

For determination of specific conductance and pH, 5 milliliters of each of the original solutions were diluted to 200 milliliters volume:

\begin{tabular}{|c|c|c|c|}
\hline Sample No. & $\begin{array}{l}\text { Grams of } \\
\text { original sample } \\
\text { in } 200-\mathrm{ml} \\
\text { volume }\end{array}$ & $\begin{array}{c}\text { Specific } \\
\text { conductance } \\
\left(K \times 10^{\circ}\right)\end{array}$ & pH \\
\hline 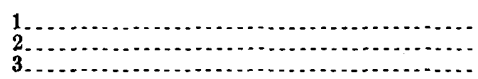 & $\begin{array}{r}0.74 \\
1.12 \\
.96\end{array}$ & $\begin{array}{l}2,007.8 \\
3,220.5 \\
2,581.5\end{array}$ & $\begin{array}{r}8.0 \\
10.1 \\
9.3\end{array}$ \\
\hline
\end{tabular}

Spectrographic analyses (in percent) of total solids obtained by evaporation show little similarity in traceelement content (elements not listed were not found in 
any sample or were not looked for, in the case of the rarer elements) :

\begin{tabular}{|c|c|c|c|}
\hline Sample No_....... & 1 & 2 & 3 \\
\hline $\mathrm{Si}_{-}$ & 0.015 & 0.3 & 0.07 \\
\hline Al $\ldots$ & .015 & .015 & .0015 \\
\hline $\mathrm{Mg}$ & .1 & 0 & .0007 \\
\hline $\mathrm{Ca}_{-}$ & 1.5 & .02 & .02 \\
\hline $\mathrm{Na}_{-}$ & 10 & 10 & 10 \\
\hline$K_{-}$ & 2. 0 & 10 & 2. 0 \\
\hline $\mathrm{Ti}_{-}$ & 0 & .001 & .0005 \\
\hline$B$ & 0 & .02 & 0 \\
\hline $\mathrm{Ba} \ldots \ldots$. & .0003 & 0 & 0 \\
\hline $\mathrm{Cr}_{\ldots} \ldots \ldots \ldots$ & .0003 & 0 & 0 \\
\hline Mo $\ldots . . .$. & 0 & .01 & .001 \\
\hline Sr $\ldots \ldots \ldots$ & .1 & 0 & .002 \\
\hline$V_{\ldots} \ldots \ldots$ & .001 & .002 & 0 \\
\hline
\end{tabular}

The presence of 0.01 percent molybdenum in sample 2 is worth noting. Osterwald, Osterwald, Long, and Wilson (1959, p. 147-149) summarized the rather sketchy analytical data on the eastern soda lakes. The composition of the evaporite differs somewhat from one lake to another but all samples that have been analyzed contain $\mathrm{Na}_{2} \mathrm{SO}_{4}, \mathrm{NaCl}$, and $\mathrm{Na}_{2} \mathrm{CO}_{3}$, and lesser amounts of $\mathrm{NaHCO}_{3}$. The thickness of the salts is reported to range from 0 to 20 feet. Little exploration, sampling, or mineralogic work has been done on the salts within the last 50 years, and no recent estimates of tonnage have been made.

The Moonstone and Bug Formations probably were the source of much of the evaporite. This interpretation is based on the presence, in one or both of the formations, of diatoms of saline habitat, salt licks, molds from which soluble minerals have been leached, and abundant gypsum, and on the absence of mollusks. Evaporite may have been leached from the Split Rock Formation at the locality of sample 1 in the Cyclone Rim syncline where no rocks younger than the Split Rock are present. Perhaps the different chemical composition of the evaporite at this locality is related to derivation from these older source rocks.

\section{JADE}

Nephrite jade occurs in many places in the Granite IIountains area. Some deposits are in reins in Precambrian rocks (locs. $3 \mathrm{~J}, \mathrm{~S}, 14 \mathrm{~J}, 15 \mathrm{~J}, \mathrm{R}$, and $16 \mathrm{~J}$, table 9 and pl. 1), others are boulders in strata of Tertiary age $(5 \mathrm{~J}, 7 \mathrm{~J}$, and $19 \mathrm{~J}, \mathrm{R})$, and still others are in Quaternary lag gravels (30J and 31J). Colors range from black through dark green, emerald green, light green, to amber. Several popular articles on jade in the Granite Mountains area have appeared in hobby magazines and newspapers, but, except for a summary by Keenan (1964, p. 10-11), no technical studies of the geologic occurrence, geochemistry, mineralogy, or petrography have been published.

Jade was first recognized in central Wyoming during the 1930 's, and large quantities were collected by the early discoverers, B. A. Rhoads, Al Branham, William Marion, and others. As word spread in lapidary circles, the hunt for jade in the Granite Mountains area intensified until, during the 1950 's, thousands of people participated each summer. The success ratio declined sharply, and the jade correspondingly increased in price so that by the early 1960 's the value of a boulder of good-quality jade, such as the boulders shown in figure 61 , was considerable.

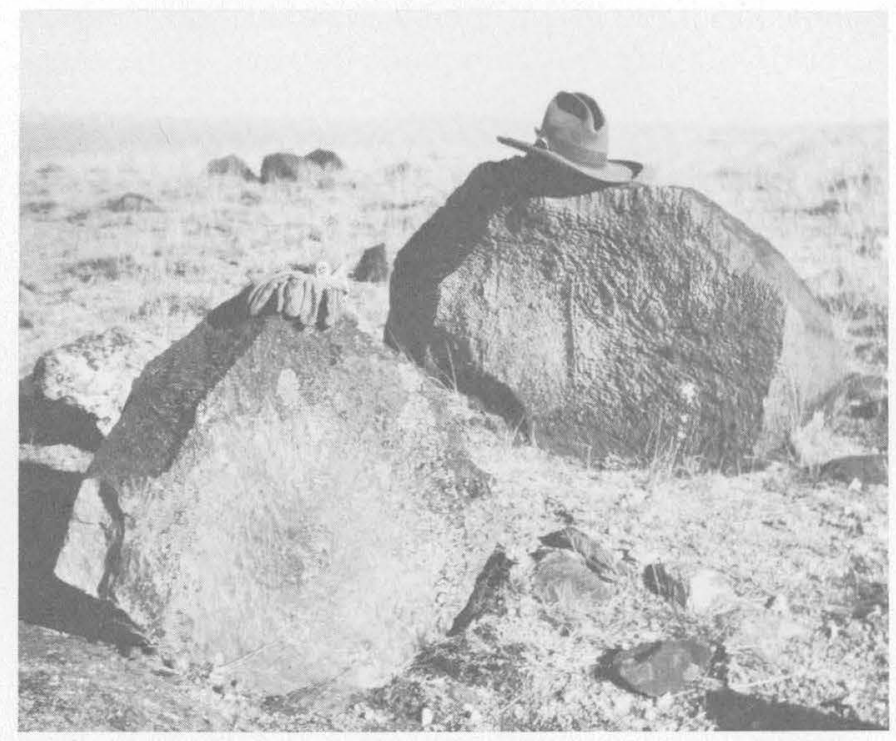

Figure 61.-Wind-faceted nephrite jade boulders eroded from the Wasateh and Battle Spring Formations and deposited on a pediment surface in sec. 1, T. 28 N., R. 94 W. They were discovered and photographed by Bert A. Rhoads in 1944; at 1965 prices, their combined worth is more than $\$ 200,000$.

Keenan (1964, p. 10-11) gave an excellent brief account of the occurrence of jade in place in Precambrian rocks, as follows:

Of fifty-five veins and pods of nephrite jade found up to the present time, two are apple green or contain some apple green veinlets, thirteen are black, and the remaining forty are olive and dark green in color. All thirteen of the black deposits occur in diabase dikes, apparently the dikes do not contain other colors.

Many linear fractured zones extend outward from the dikes into the adjacent granite and gneiss country rock. These zones are hydrothermally metamorphosed to mineral mixtures that might be termed epidosite. The most abundant minerals are quartz, epidote, zoisite, and altered feldspars, with lesser amounts of clinozoisite, thulite, saussurite, piedmontite, and other, unidentified minerals. The lighter green nephrite jade varieties are found in these fractured zones, occurring as vein and fracture fillings. 
It might be natural to assume a deep seated origin for the nephrite. But the selectivity of the different colors for specific host rock - black in the diabase dikes, other colors in the veins, rules out this explanation of origin. Rather, it appears that the magmatic source contributed only lydrothermal waters and/or gases and that the nephrite was reconstituted from some other mineral very near its place of final deposition.

The most abundant mineral associated with the green nephrite is altered feldspar, grading to zoisite, clinozoisite, thulite, Ind piedmontite. Often the nephrite is penetrated by abundant clear quartz prisms. The most usual country rock enclosing the green nephrite is green and light grey epidosite containing considerable pistachio green epidote.

Minerals commonly associated with the black nephrite in the diabase dilies are clear quartz prisms and coarse crystals of medium to dark brown common epidote. Often the epidote occurs pseudomorphic after the quartz.

In a few locations green nephrite has been found pseudomorphic after quartz, strongly supporting a hydrothermal origin for the nephrite deposits.

No study of the origin of the jade boulders has previously been published. A reconstruction of the sedimentation and tectonism in the areas of jade boulders shows that the boulders had a rather complex history and one that was quite different from one locality to another. I believe that by working out this history the general sources can be delimited and perhaps much fruitless searching of barren areas can be uvoided.

Jade boulders on the west end of Crooks Mountain are in the Crooks Gap Conglomerate and the Wasatch and Battle Spring Formations (figs. 24, 69, 88). This locality yielded the largest tonnage and the largest individual boulders (some more than 3,000 pounds) of apple-green jade in the entire Granite Mountains area. The boulders in the lower sequence came from the now-buried southwest flank of the Granite Mountains on the overriding block of the Emigrant Trail thrust, were transported southwestward by torrential streams, and then were deposited in a giant boulder fun. Later, near the end of early Encene time, that part of the fan between the mountain source area and Crooks Mountain was destroyed by vertical uplift along the South Granite Mountains fault system. This movement caused the uplifted segment of the fan to be washed southward, and a second fan deposit, the Crooks Gap Conglomerate, was deposited on the southern part of the older fan. 'Thus, the larger reworked boulders of jade were carried the shortest distance and were concentrated directly south of the fault trace. The area was then buried by middle and upper Eocene, Oligocene, Miocene, and Pliocene strata and subsequently reexposed in late Pliocene and Pleistocene time by faulting that caused the downwarping of the Split Rock syncline $\left(D-D^{\prime}\right.$, pl. $1 ; P-P^{\prime}$, pl. 4). During the
Recent erosion cycle many jade boulders were carried northward back toward the mountain source, which was now lower than the basin margin, and were redeposited on pediment surfaces which cut Miocene rocks.

The Bull Canyon apple-green jade boulders (loc. $5 J$, table 9 and pl. 1) had quite a different history and source from those just described. The jade was derived from the south end of the Wind River Range during late Eocene time. A sudden uplift caused powerful streams to transport fanglomerate debris (Ice Point Conglomerate) eastward. Jade boulders were incorporated in the northernmost of three fans. These deposits were covered by 1,000 feet or more of Oligocene, Miocene, and probably Pliocene strata and then were reexposed by the downfaulting of the Split Rock syncline in late Pliocene and early Pleistocene time ( $S-S^{\prime}$, pl. 4). Tater, Pleistocene and Recent erosion spread the boulders northward onto Miocene rocks.

Some of the most prized of all the jade is the scarce emerald-green variety found chiefly in Quaternary lag gravels in the northeastern part of the Granite Mountains area between the Grieve oil field and locality $30 \mathrm{~J}$ (table 9 and pl. 1). The history of these boulders has not been determined. They are on (and perhaps in) conglomerate of early Eocene, Oligocene, and Miocene ages. The original source was probably in Precambrian rocks southeast of the Rattlesnake Hills.

Dark-green jade in and west of the Gas Hills area (loc. 19J, R, table 9 and pl. 1) is in the Wind River Formation and was deposited by north-flowing streams from a Precambrian source in the Granite Mountains. Dark-green jade has also been found in Precambrian rocks and in pediment gravels derived from them on the north sides of the Ferris and Seminoe Mountains.

\section{AGATES}

'The Sweetwater moss agates, described in conmection with the Split Rock Formation, occur principally as lag gravels that weather out of the basal conglomeratic sandstone of the upper porous sandstone sequence in the Split Rock Formation. They are exposed on and adjacent to about 50 square miles of dip slopes in the north-central part of the Granite Mountains area (frontispiece and pl. 1). They have been collected for about 100 years, but small specimens are still moderately abundant. They were waterworn and wind faceted before deposition in the conglomerate. The original source is thought to have been the lower porous sandstone sequence in a now-destroyed outcrop area north or northwest of the present Beaver Divide. To have provided the agates. the source area must have been up- 
lifted and eroded between early and middle Miocene time. The agates which formed in place in the lower porous sandstone sequence at locality $18 \mathrm{Ag}$ (presumably a southern remnant of the source deposit), must have received their unique components from circulating water rich in silica, uranium, arsenic, and manganese derived from decomposed volcanic ash in the host rock during early Miocene time. A few small flakes of darkgreen jade, rarely more than 1 inch in diameter occur with the agates.

"Angel agates" were formed in place in the upper part of the upper porous sandstone sequence of the Split Rock Formation at locality 13V, D (table 8 and pl. 1). These are translucent and pale greenish-gray, fluoresce a brilliant greenish yellow, and contain a small amount (about 0.006 percent) of uranium. They occur in individual ovoid masses 1-3 inches in diameter and have a chalky-white soft siliceous outer zone of alteration. The host rock is a gray medium-grained sandstone, and the agates occur along a 6-inch-thick zone of bedding within it. These agates are confined to this one locality, as far as is now known; they have been quarried along the outcrop for about 200 feet.

Extensive agate "reefs" and bedded chalcedony occur in the middle part of the Moonstone Formation on and adjacent to White Ridge (pls. 1, 9 ; figs. 37, 39, 40, 44). These agates are not as popular with lapidaries as the Sweetwater moss agates and, so, have not been exploited.

\section{RUBIES, SAPPHIRES, AND COLORLESS CORUNDUM}

Rubies have been found in mica schist of Precambrian age at locality $15 \mathrm{~J}, \mathrm{R}$ and in boulders of soft green micaceous rock in the Wind River Formation at locality $19 \mathrm{~J}, \mathrm{R}$. At locality $19 \mathrm{~J}, \mathrm{R}$ some are as much as 1 inch in diameter but are badly fractured. No detailed study of the rubies in either locality has been made. Some of gem quality have been reported from locality 15J, R (Osterwald and others, 1959, p. $60)$.

Pale-blue sapphires and colorless corundum occur as rounded nodules about 1 inch in diameter in a mica schist surrounded by gray-brown granite at locality $3 J, \mathrm{~S}$ (table 7 and pl. 1). They are abundant but badly shattered on outcrop and in prospect pits; no exploration at depth has been done.

\section{SPODUMENE}

One occurrence of spodumene (loc. $20 \mathrm{Sp}$, table 9 and pl. 1) is known in Precambrian rocks of the Granite Mountains. It has been described by Hanley, Heinrich, and Page (1950, p. 121; note corrected location in table $9)$. No commercial exploitation has been attempted.

\section{CHROMIUM}

Chromium was found in well 195 ; its description is included in the discussion of the lower porous sandstone sequence in the Split Rock Formation. Additional drilling is needed to determine more about this occurrence. It is of considerable scientific interest, but commercial possibilities are unknown.

\section{IRON}

Drill cuttings from well 190 contain numerous fragments of dark-red crystalline bedded magnetic iron-rich rock at a depth of 140-160 feet in the Wagon Bed Formation. Outcrops of Precambrian and Paleozoic rocks to the south and southwest in the Rattlesnake Hills should be checked to determine the source of these fragments. No iron deposits with this lithology have been reported in the region.

\section{GOLD, SILVER, LEAD, COPPER, AND MOLYBDENUM}

Gold mines operated sporadically during the early part of the 20th century in Precambrian rocks at and near localities $12 \mathrm{G}$ and $13 \mathrm{GC}$ in the western part of the Granite Mountains area. A brief description of the district, known both as the Tin Cup mining district and as the Black Rock-Long Creek mining district was given by Beeler (1907). I have not been able to find any reliable data on tonnages of gold, silver, and copper produced, or on the grade of the ore in various mines. No detailed geologic studies of any of the mineralized localities have been published.

The Red Boy mine, in sec. 36, T. 31 N., R. 93 W., operated intermittently for about 20 years and closed about the time of World War II. A shaft was sunk to a depth of more than 130 feet. Gold values are reported to range from $\$ 1.40$ to $\$ 16.00$ per ton, and silver values are reported to be as much as $\$ 15.00$ per ton at 130 feet (prospectus accompanying incorporation papers, June 15, 1938). Pyrite is abundant below 120 feet. No production figures for either gold or silver are available.

Sparse mineralized nodules occur in prospect pits at locality $24 \mathrm{U}, \mathrm{L}, \mathrm{Si}$ (table 9 and $\mathrm{pl} .1$ ), about 2 miles northwest of Muddy Gap, in highly fractured Precambrian granite on the Emigrant Trail thrust block where it overrides Jurassic and other Mesozoic rocks. This occurrence has not been investigated at depth. The most radioactive of four selected nodules contains 0.22 percent uranium. Maximum spectrographic values, in percent, of other elements in these samples are: silver, 0.1 ; cobalt, 0.02 ; copper, 0.15 ; gallium, 0.01 ; lead, $10+$; antimony, 0.3 ; yttrium, 0.015 ; and neodymium, 0.01 . 
The Spanish mine in Precambrian rocks at the northeast margin of the Ferris Mountains has had a long and poorly recorded history. Endlich (1879) made brief but vague mention that mining was going on at that time. According to unconfirmed legend, the area was first prospected by Spanish explorers; underground workings (all caved) of unknown extent and remains of an old mill are still in evidence. No reliable data on production or grade of ore are available. Apparently the ores were copper, silver, lead, and gold. Brief summaries of the geology of this locality and adjacent prospects to the northwest were given by Osterwald, Osterwald, Long, and Wilson (1959, p. 40, 112-113). Molybdenite occurs with kasolite and uraninite in the Little Man mine (loc. 28U, L, table 9 and pl. 2; a description of the deposit is in the section on uranium) but has not been commercially exploited.

\section{VERMICULITE}

A vermiculite mine was opened at locality $33 \mathrm{~V}$ in Precambrian rocks and was operated intermittently during the 1940 's. No data are available on production or quality of the product, and the geology of the deposit has not been described.

\section{SAND AND GRAVEL}

Sand is almost ubiquitous in the Granite Mountains area. The Split Rock Formation alone contains nearly 200 cubic miles of tuffaceous, porous permeable poorly cemented fine-grained to coarse-grained sandstone. The Wasatch and Battle Spring Formations on the south side of the mountains and the Wind River Formation on the north side have arkosic sandstones which are several hundred to more than 1,000 feet thick. Active sand dunes in the southeastern part of the area were mapped by Weitz and Love (1952), and by Weitz, Love, and Harbison (1954). Some of this sand came from the Split Rock and Moonstone Formations, but most of it was derived from the Wasatch and Battle Spring Formations and is much coarser grained and more arkosic than that in the Split Rock.

Gravel deposits are less abundant than sand deposits but are locally present in all Tertiary formations. Those in the Fort Union Formation are composed of rounded fragments of chert and quartzitic sandstone and a little limestone, either in fragments or in the matrix, and are most abundant in Crooks Gap and in the northern part of the Great Divide basin. Poorly consolidated conglomerate of siliceous rock fragments is likewise present in the Ice Point Conglomerate; it is most abundant in the vicinity of Bison Basin. Other formations have lenticular arkosic conglomerates locally derived from Precambrian rocks of the Granite
Mountains. An exception is a conglomerate in the Wagon Bed Formation in the Rattlesnake Hills area which contains coarse and fine fragments of igneous rocks from adjacent volcanic vents.

\section{GROUND-WATER POTENTIAL}

A discussion of ground water in this region was included in a report on a Statewide study by W. C. Knight (1900). No detailed modern studies have been made of any large parts of this area in spite of the perennial water shortage and the excellent water potential in the underlying rocks. The amount of information that could be assembled on ground water is staggering to contemplate. For example, in addition to the 278 wells listed in table 2, several hundred core holes have been drilled for uranium, and others were drilled by and for ranchers. Oil companies have drilled from 10,000 to 20,000 seismograph shot holes, most of which went to or below the water table. Some of these shot holes do not have logs or notations on water levels, but many do. One company, for example, logged more than 3,000 shot holes between Green Mountain and the Sweetwater River, and these logs were made available for my study. Small flows of artesian water were encountered in many of these shallow drill holes.

From the data obtained during the progress of this study, several generalizations can be made as to the ground-water potential of the Granite Mountains area. The Fort Union Formation is a poor to fair aquifer; it is best near the north margin of the Great Divide basin. Lower Eocene rocks are good aquifers near both north and south flanks of the Granite Mountains but become progressively poorer and have more dissolved solids farther out in the basins. The Wagon Bed and White River Formations are generally poor aquifers, both in quality and quantity of water, with local exceptions where coarse-grained facies are present near granite knobs or Eocene volcanic vents in the Rattlesnake Hills. The high bentonite content in these two formations makes maintenance of the wells difficult.

The Split Rock Formation is almost everywhere a good aquifer with excellent-quality water and few dissolved solids except near soda lakes. The sandstone, however, is so porous and permeable that in many places the water table is several hundred feet below the surface. The same is true of the Moonstone Formation. Analyses of four bulk samples from the Wasatch, Battle Spring, Split Rock, and Moonstone Formations were given by Stephens (1964, table 8). Jeffrey City, the only town in the area, gets sufficient water from .wells in the Split Rock Formation to supply 1,000 or more people. In that area, the water-bearing sandstone is about 1,000 feet thick, but only the upper 250 feet 
is tapped. Several pumping wells for the Western Nuclear Corp. uranium mill north of Jeffrey City obtained yields of more than 1,000 gallons per minute at depths of 150-250 feet in the Split Rock Formation. The geological record of well 166 indicated water saturation throughout the upper 830 feet of the Split Rock Formation.

In places on the south-sloping Sweetwater Plateau where the water table is not too deep, flowing artesian wells probably could be drilled. In most other places the water probably would have to be pumped. In an area with average precipitation of 8-12 inches and with only one major stream that is almost dry during the height of the irrigating season, the tremendous groundwater potential of the Split Rock syncline should be recognized. Its water resources could then be developed under geologic guidance and according to conventional hydrologic practices.

\section{REFERENCES CITED}

Bailey, R. V., 1965, Applied geology in the Shirley Basin uranium district, Wyoming: Wyoming Univ. Contr. Geology, v. 4., no. 1 , p. $27-35$.

Barlow, J. A., Jr., 1961, Almond Formation and lower Lewis Shale, east flank of Rock Springs uplift, Sweetwater County, Wyoming, in Wyoming Geol. Assoc. Guidebook 16th Ann. Field Conf., Symposium on Late Cretaceous rocks, Wyoming and adjacent areas, 1961: p. 113-115.

Barwin, J. R., and Espach, R. H., Jr., 1957, Geologic map of the southwestern part of the Wind River basin, Wyoming, in Wyoming Geol. Assoc. Guidebook 12th Ann. Field Conf., Southwest Wind River Basin, 1957: map in pocket.

Bauer, C. M., 1934, Wind River Basin [Wyo.]: Geol. Soc. America Bull., v. 45, no. 4, p. 665-696.

Bayley, R. W., 1960, Precambrian taconite deposits near Atlantic City, Fremont County, Wyoming, in Wyoming Geol. Assoc. Guidebook 15th Ann. Field Conf., Overthrust belt of southwestern Wyoming and adjacent areas, 1960: p 222-225.

- 1963, A preliminary report on the Precambrian iron deposits near Atlantic City, Wyoming: U.S. Geol. Survey Bull. 1142-C, 23 p.

Beeler, H. C., 1907, Prospecting in the Black Rock-Long Creek vicinity, near the Sweetwater River, Fremont County, Wyoming: Cheyenne, Wyo., State Geologist's Office, 12 p.

Bell, K. G., 1960, Uranium and other trace elements in petroleums and rock asphalts: U.S. Geol. Survey Prof. Paper 356-B, p. B45-B65.

Bell, W. G., 1954, Stratigraphy and geologic history of Paleocene rocks in the vicinity of Bison Basin, Wyoming [abs.] : Geol. Soc. America Bull., v. 65, no. 12, p. 1371.

1955, Geology of the southeastern flank of the Wind River Mountains, Fremont County, Wyoming: Laramie, Wyoming Univ., Ph.D. thesis, 204 p.

1956, Tectonic setting of Happy Springs and nearby structures in the Sweetwater uplift area, central Wyoming, in Am. Assoc. Petroleum Geologists, Geological Record, Rocky Mountain Section, 1956: p. 81-86.
Berg, R. R., 1961, Laramide tectonics of the Wind River Mountains, in Wyoming Geol. Assoc. Guidebook 16th Ann. Field Conf., Symposium on Late Cretaceous rocks, Wyoming and adjacent areas, 1961: p. 70-80.

Bergin, M. J., 1957, Maybell-Lay area, Colorado, in Geologic investigations of radioactive deposits-Semiannual progress report, Dec. 1, 1956 to May 31, 1957 : U.S. Geol. Survey TEI-690 (book 2), p. 280-291, issued by U.S. Atomic Energy Comm. Tech. Inf. Service, Oak Ridge, Tenn.

Biggs, Paul, and Espach, R. H., 1960, Petroleum and natural gas fields in Wyoming: U.S. Bureau of Mines Bull. 582, $538 \mathrm{p}$.

Blackstone, D. L., Jr., 1948, The structural pattern of the Wind River Basin, Wyoming, in Wyoming Geol. Assoc. Guidebook 3d Ann. Field Conf., Wind River Basin, 1948: p. 69-78.

- 1951, An essay on the development of structural geology in Wyoming, in Wyoming Geol. Assoc. Guidebook 6th Ann. Field Conf., South-central Wyoming, 1951: p. 15-28, and tectonic map in pocket.

Bogrett, J. W., 1954, Geologic map and structure sections of the northwestern end of the Rattlesnake Hills, Natrona County, Wyoming, in Wyoming Geol. Assoc. Guidebook 9th Ann. Field Conf., Casper area, 1954 : map in pocket.

Bradley, W. C., 1963, Large-scale exfoliation in massive sandstones of the Colorado Plateau: Geol. Soc. America, v. 74, no. 5 , p. 519-527.

Bradley, W. H., 1930, The varves and climate of the Green River epoch : U.S. Geol. Survey Prof. Paper 158-E, p. 87-110.

_ 1948, Limnology and the Eocene lakes of the Rocky Mountain region: Geol. Soc. America Bull., v. 59, no. 7, p. $635-648$.

1964, Geology of Green River Formation and associated Eocene rocks in southwestern Wyoming and adjacent parts of Colorado and Utah: U.S. Geol. Survey Prof. Paper 496-A, p. A1-A86 [1965].

Cady, R. C., and Scherer, O. J., 1946, Geology and groundwater resources of Box Butte County, Nebraska: U.S. Geol. Survey Water Supply Paper 969, 102 p.

Cannon, R. S., Jr., 1957, Isotope geology of lead, in Geologic investigations of radioactive deposits-Semiannual progress report, Dec. 1,1956 to May 31, 1957 : U.S. Geol. Survey TEI-690 (book 2), p. 558-561, issued by U.S. Atomic Energy Comm. Tech. Inf. Service, Oak Ridge, Tenn.

Carey, B. D., Jr., 1954, A brief sketch of the geology of the Rattlesnake Hills, Natrona County, Wyoming, in Wyoming Geol. Assoc. Guidebook 9th Ann. Field Conf., Casper area, 1954: p. 32-34 and map.

- 1955, A review of the Browns Park formation [Colo.], in Intermountain Assoc. Petroleum Geologists Guidebook 6th Ann. Field Conf., 1955: p. 47-49.

1959, Geology of the Rattlesnake Hills Tertiary volcanic field, Natrona County, Wyoming: Laramie, Wyoming Univ., Ph.D. thesis, $247 \mathrm{p}$.

Cheney, E. S., 1964, Stable isotopic geology of the Gas Hills uranium district, Wyoming: New Haven, Conn., Yale Univ., Ph.D. thesis, 342 p.

Cheney, E. S., and Jensen, M. L., 1963, Bearing of stable isotopic geology on the origin of the Gas Hills, Wyoming, uranium district [abs.] : Mining Eng., v. 15, no. 11, p. 60. 1964 , Bearing of stable isotopic geology on the origin of the Gas Hills, Wyoming, Uranium district: New York, Am. Inst. Mining, Metall., and Petroleum Engineers, Preprint No. $64 \mathrm{~L} 19,37 \mathrm{p}$. 
Clarke, F. W., 1924, The data of geochemistry : U.S. Geological Survey Bull. 770, 841 p.

Cohee, G. V., chm., and others, 1961, Tectonic map of the United States, exclusive of Alaska and Hawaii: U.S. Geol. Survey and Am. Assoc. Petroleum Geologists, scale $1: 2,500,000$ [1962].

Coleman, R. G., 1956, Mineralogic studies, Gas Hills area, Fremont and Natrona Counties, Wyoming, in Geologic investigations of radioactive deposits-Semiannual progress report for June 1 to Nov. 30, 1956: U.S. Geol. Survey TEI-640, p. 119-120, issued by U.S. Atomic Energy Comm. Tech. Inf. Service, Oak Ridge, Tenn.

1957, Mineralogy and geochemistry of uranium deposits in the Gas Hills district, Wyoming, in Geologic investigations of radioactive deposits-Semiannual progress report, Dec. 1, 1956 to May 31, 1957: U.S. Geol. Survey TEI-690 (book 2), p. 50S-512, issued by U.S. Atomic Energy Comm. Tech. Inf. Service, Oak Ridge, Tenn.

Coleman, R. G., and Erd, R. C., 1961, Hydrozircon from the Wind River Formation, Wyoming, in Short papers in the geologic and hydrologic sciences: U.S. Geol. Survey Prof. Paper 424-C, p. C297-C300.

Comstogk, 'T. B., 1875, Geological report, in Jones, W. A., Report upon the reconnaissance of northwestern Wyoming including Yellowstone National Park, made in the summer of 1873 : Washington, U.S. Govt. Printing Office, p. 85-292.

Condra, G. E., and Reed, E. C., 1950, Geologic map of Nebraska : Nebraska Geol. Survey.

Dana, J. D., 1895, Textbook of geology [4th ed.]: American Book Co., 1088 p.

Darton, N. H., 1899, Geology and water resources of Nebraska west of the one hundred and third meridian: U.S. Geol. Survey 19th Ann. Rept., pt. 4, p. 719-785.

- 1905, Preliminary report on the geology and underground water resources of the Central Great Plains: U.S. Geol. Survey Prof. Paper 32, 433 p.

1908, Paleozoic and Mesozoic of central Wyoming: Geol. Soc. America Bull., v. 19, p. 403-470.

Dawson, M. R., 1965, Oreolagus and other lagomorpha (mammalia) from the Miocene of Colorado, Wyoming, and Oregon: Colorado Univ. Studies Ser. Earth Sci. 1, p. 1-36.

Deffeyes, K. S., 1959a, Zeolites in sedimentary rocks: Jour. Sed. Petrology, v. 29, no. 4, p. 602-609.

1959b, Erionite from Cenozoic tuffaceous sediments, central Nevada : Am. Mineralogist, v. 44, nos. 5-6, p. 501509 .

Dempsey, W. J., Stuart, D. J., and others, 1962, Aeromagnetic map of south central Wyoming: U.S. Geol. Survey Map GP-393.

Denson, N. M., 1959, Introduction, chap. A. of Denson, N. M. and others, Uranium in coal in the western United States: U.S. Geol. Survey' Bull. 1055, p. 1-10 [1960].

Denson, N. M., 1965, Miocene and Pliocene rocks of central Wyoming, in Cohee, G. V., and West, W. S., Changes in stratigraphic nomenclature by the U.S. Geological Survey, 1964: U.S. Geol. Survey Bull. 1224-A, p. A70-A77 [1966].

Denson, N. M., and Bergendahl, M. H., 1961, Middle and upper Tertiary rocks of southeastern wyoming and adjoining areas, in Short papers in the geologic and hydrologic sciences: U.S. Geol. Survey Prof. Paper 424-C, p. C168C172.
Denson, N. M., Zeller, H. D., and Stephens, J. G., 1956, Water sampling as a guide in the search for uranium deposits and its use in evaluating widespread volcanic units as potential source beds for uranium, in Page, L. $\mathbf{R}$., Stocking, H. E., and Smith, H. D., compilers, Contributions to the geology of uranium and thorium by the United States Geological Survey and Atomic Energy Commission for the United Nations International Conference on Peaceful uses of Atomic Energy, Geneva, Switzerland, 1955 : U.S. Geol. Survey Prof. Paper 300, p: 673-680.

Dickey, M. L., 1962, Upper Cretaceous and Cenozoic history of the Green Mountain-Whiskey Peak area, Fremont County, Wyoming: Laramie, Wyoming Univ., Master's thesis, $85 \mathrm{p}$

Dooley, J. R., Jr., and Hathaway, J. C., 1961, Two occurrences of thorium-bearing minerals with rhabdophane-like structure, in Short papers in the geologic and hydrologic sciences; U.S. Geol. Survey Prof. Paper 424-C, p. C339-C341.

Dorf, Erling, 1959, Climatic changes of the past and present: Michigan Univ. Mus. Paleontology Contr., v. 13, no. 8 , p. 181-210.

Endlich, F. M., 1879, Report on the geology of the Sweetwater district, in Hayden, F. V., Eleventh annual report of the United States Geological and Geographical Survey of the Territories, embracing Idaho and Wyoming, being a report of exploration for the year 1877: Washington, U.S. Govt. Printing Office, p. 3-158.

Evernden, J. F., Savage, D. E., Curtis, G. H., and James, G. T. 1964, Potassium-argon dates and the Cenozoic mammalian chronology of North America: Am. Jour. Sci., v. 262, no. 2, p. 145-198.

Evseeva, L. S., Ivanov, K. E., and Kochetkov, V. I., 1963, Some laws of the formation of epigenetic uranium ores in sandstones, derived from experimental and radiochemical data Atomnaya Energiya, v. 14, no. 5, p. 474-481.

Fath, A. E., and Moulton, G. F., 1924, Oil and gas fields of the Lost Soldier-Ferris district, Wyoming: U.S. Geol. Survey Bull. 756, $57 \mathrm{p}$.

Gabelman, J. W., and Krusiewski, S. V., 1963, The application of hydrothermal zoning to Wyoming uranium deposits: Am. Inst. Mining, Metall., and Petroleum Engineers 8th Ann. Uranium and Minerals Symposium, p. 11-41.

Gazin, C. L., 1955, A review of the upper Eocene Artiodactyla of North America: Smithsonian Misc. Colln., v. 128, no. 8, $96 \mathrm{p}$.

1956a, Paleocene mammalian faunas of the Bison Basin in south-central Wyoming: Smithsonian Misc. Colln., v. 131, no. 6, $57 \mathrm{p}$.

1956b, The Mammalian fauna of the Badwater area, Pt. 2 of The geology and vertebrate paleontology of upper Eocene strata in the northeastern part of the Wind River basin, Wyoming: Smithsonian Misc. Colln., v. 131, no. 8, 35 p.

1961, Occurrences of Paleocene Mammalia in Tertiary basins of Wyoming, in Wyoming Geol. Assoc. Guidebook 16th Ann. Field Conf., Symposium on Late Cretaceous rocks, Wyoming and adjacent areas, 1961: p. 47-52.

Gooldy, P. L., 1948, Geologic map of Beaver Creek-South Sheep Mountain area, in Wyoming Geol. Assoc. Guidebook 3d Ann. Field Conf., Wind River Basin, 1948: map in pocket.

Granger, Walter, 1910, Tertiary faunal horizons in the Wind River Basin, Wyoming, with descriptions of new Eocene mammals : Am. Mus. Nat. History Bull., v. 28, p. 235-251. 
1914, On the names of lower Eocene faunal horizons of Wyoming and New Mexico: Am. Mus. Nat. History Bull., v. 33, p. 201-207.

Gruner, J. W., 1956, Concentration of uranium in sediments by multiple migration-accretion: Econ. Geology, v. 51, no. 6, p. 495-520.

Grutt, E. W., Jr., 1957, Environment of some Wyoming uranium deposits, in Dunning, J. R., and Prentice, B. R., eds.; Advances in nuclear engineering: Nuclear Eng. and Sci. Cong., 2d, Philadelphia 1957, Proc., v. 2, p. 313-323.

Guilinger, R. R., 1963, Source of uranium in the Gas Hills area, Wyoming: Econ. Geology, v. 58, no. 2, p. 285-286.

Guyton, J. W., 1960, Geology of the Lost Soldier area, Sweetwater, Fremont, and Carbon Counties, Wyoming: Laramie, Wyoming Univ., M.A. thesis, 70 p.

Hague, Arnold, 1896, Yellowstone National Park [Wyoming]: U.S. Geol. Survey Geol. Atlas, Folio 30.

Hanley, J. B., Heinrich, E. W., and Page, L. R., 1950, Pegmatite investigations in Colorado, Wyoming, and Utah, 1942-44: U.S. Geol. Survey Prof. Paper 227, 125 p.

Hansen, W. R., 1965, Geology of the Flaming Gorge area, UtahColorado-Wyoming: U.S. Geol. Survey Prof. Paper 490, $196 \mathrm{p}$.

Hares, C. J., 1916, Anticlines in central Wyoming: U.S. Geol. Survey Bull. 641-I, p. 233-279.

Hares, C. J., and others, 1946a, Geologic map of the southern part of the Wind River basin and adjacent areas in central Wyoming: U.S. Geol. Survey Oil and Gas Inv. Prelim. Map 60.

- 1946b, Geologic map of the southeastern part of the Wind River Basin and adjacent areas in central Wyoming: U.S. Geol. Survey Oil and Gas Inv. Prelim. Map 51.

Harshman, E. N., 1962, Alteration as a guide to uranium ore, Shirley Basin, Wyoming, in Short papers in geology, hydrology, and topography: U.S. Geol. Survey Prof. Paper 450-D, p. D8-D10.

- 1964a, Geologic map of the Bates Creek Reservoir quadrangle [Shirley Basin area], Wyoming: U.S. Geol. Survey open-file map.

- 1964b, Geologic map of the Chalk Hills quadrangle [Shirley Basin area], Wyoming: U.S. Geol. Survey openfle map.

1964c, Geologic map of the Horse Peak quadrangle [Shirley Basin area], Wyoming: U.S. Geol. Survey openfile map.

- 1964d, Geologic map of the Measel Spring Reservoir quadrangle [Shirley Basin area], Wyoming: U.S. Geol. Survey open-file map.

1964e, Geologic map of the Moss Agate Reservoir quadrangle [Shirley Basin area], Wyoming: U.S. Geol. Survey open-file map.

- 1964f, Geologic map of the Mud Springs quadrangle [Shirley Basin area], Wyoming: U.S. Geol. Survey openfile map.

- 1964g, Geologic map of the Wild Irish Reservoir quadrangle [Shirley Basin area], Wyoming: U.S. Geol. Survey open-file map.

Hay, R. L., 1956, Pitchfork formation, detrital facies of early basic breccia, Absaroka Range, Wyoming: Am. Assoc. Petroleum Geologists Bull., v. 40; no. 8, p. 1863-1898.

Hayden, F. V., 1869, Geological report of the exploration of the Yellowstone and Missouri Rivers, 1859-60: U.S. 40th Cong., 2d sess., Senate Executive Doc. 77, 174 p.
1871, Preliminary report of the United States geological survey of Wyoming and portions of contiguous Territories, being a second annual report of progress for 1870: Washington, U.S. Govt. Printing Office, 511 p.

- 1883, Twelfth annual report of the U.S. geological and geographical survey of the Territories; a report of progress of the exploration in Wyoming and Idaho for the year 1878, Part I: Washington, U.S. Govt. Printing Office, $809 \mathrm{p}$.

Hough, M. J., 1956, A new insectivore from the Oligocene of the Wind River Basin, Wyoming, with notes on the taxonomy of the Oligocene Tenrecoidea: Jour. Paleontology, v. 30, no. 3, p. 531-541.

Houston, R. S., 1956, Preliminary report on the petrography of Tertiary volcanic rocks of the Jackson Hole area, Teton County, Wyoming, in Wyoming Geol. Assoc. Guidebook 11th Ann. Field Conf., Jackson Hole, 1956: p. 133-139.

- 1964, The petrographic calendar, Pt. 3 of Parker, R. B., ed., Non-paleontological methods of correlation of rocks of Tertiary age in Wyoming: Wyoming Univ. Contr. Geology, v. 3, no. 1, p. 15-26.

Irwin, Cynthia, Irwin, Henry, and Agogino, George, 1962, Wyoming muck tells of battle-Ice age man vs. mammoth: Natl. Geog. Mag., v. 121, no. 6, p. 828-837.

Jaffe, H. W., Gottfried, David, Waring, C. L., and Worthing, H. W., 1959, Lead-alpha age determinations of accessory minerals of igenous rocks (1953-1957) : U.S. Geol. Survey Bull. 1097-B, p. 65-148.

Jensen, M. L., 1962, Biogenic sulfur and sulfide deposits, in Jensen, M. L., ed., Biogeochemistry of sulfur isotopes: U.S. Natl. Sci. Foundation Symposium Proc., Yale Univ., 1962, p. 1-15.

Jensen. M. L., Field, C. W., and Nakai, N., 1960, Sulfur isotopes and the origin of sandstone-type uranium deposits, in U.S. Atomic Energy Comm., Biennial progress report for 19591960 : Yale Univ. Dept. Geology, 281 p., available on microfilm from University Microfllms, Ann Arbor, Mich.

Keefer, W. R., 1960, Progressive growth of anticlines during Late Cretaceous and Paleocene time in central Wyoming, in Short papers in the geological sciences: U.S. Geol. Survey Prof. Paper 400-B, p. B233-B236.

1961, Waltman Shale and Shotgun Members of Fort Union Formation (Paleocene) in Wind River Basin, Wyoming: Am. Assoc. Petroleum Geologists Bull., v. 45, no. 8 , p. 1310-1323.

- 1965, Stratigraphy and geologic history of the uppermost Cretaceous, Paleocene, and lower Eocene rocks in the Wind River Basin, Wyoming: U.S. Geol. Survey Prof. Paper 495-A, p. A1-A77.

Keefer, W. R., and Love, J. D., 1963, Laramide vertical movements in central Wyoming: Wyoming Univ. Contr. Geology, v. 2 , no. 1, p. 47-54.

Keefer, W. R., and Rich, E. I., 1957, Stratigraphy of the Cody shale and younger Cretaceous and Paleocene rocks in the western and southern parts of the Wind River Basin, Wyoming, in Wyoming Geol. Assoc. Guidebook 12th Ann. Field Conf., Southwest Wind River Basin, 1957: p. 71-78.

Keefer, W. R., and Troyer, M. L., 1964, Geology of the Shotgun Butte area, Fremont County, Wyoming: U.S. Geol. Survey Bull. 1157, 123 p.

Keefer, W. R., and Van Lieu, J. A., 1966, Paleozoic formations in the Wind River basin, Wyoming: U.S. Geol. Survey Prof. Paper 495-B, $60 \mathrm{p}$. 
Keenan, J. E., 1964 Common gemstones of Wyoming, in Highway geology of Wyoming: Wyoming Geol. Assoc., p. 9-11.

Kieslinger, Alois, 1960, Residual stress and relaxation in rocks, in Pt. 18, Structure of the earth's crust and deformation of rocks: Internat. Geol. Cong., 21st, Norden 1960, Rept., p. 270-276.

King, P. B., 1944, Tectonic map of the United States, 1944: Am. Assoc. Petroleum Geologists.

Knight, S. H., 1937, Origin of the giant conglomerates of Green Mountain and Crooks Mountain, central Wyoming [abs.] : Geol. Soc. America Proc., 1936, p. 84.

Knight, W. C., 1900, A preliminary report on the artesian basins of Wyoming: Wyoming Univ. Experimental Sta. Bull. 45, p. 107-251.

1901, The Sweetwater mining district, Fremont County, Wyoming: Wyoming Univ. Geol. Survey Bull., 35 p.

Love, J. D., 1939, Geology along the southern margin of the Absaroka Range, Wyoming: Geol. Soc. America Spec. Paper 20, $134 \mathrm{p}$.

- 1948, Mesozoic stratigraphy of the Wind River Basin, central Wyoming: Wyoming Geol. Assoc. Guidebook 3d Ann. Field Conf., Wind River Basin, 1948: p. 96-111.

- 1954a, Preliminary report on uranium in the Gas Hills area, Fremont and Natrona Counties, Wyoming: U.S. Geol. Survey Circ. 352, 11 p.

- 1954b, Pedro Mountains, in Geologic investigations of radioactive deposits-Semiannual progress report, June 1 to Nov. 30, 1954 : U.S. Geol. Survey TEI-490, p. 229-230, issued by U.S. Atomic Energy Comm. Tech. Inf. Service, Oak Ridge, Tenn.

- 1954c, Uranium in the Mayoworth area, Johnson County, Wyoming-a preliminary report: U.S. Geol. Survey Circ. 358, 7 p.

1956a, Cretaceous and Tertiary stratigraphy of the Jackson Hole area, northwestern Wyoming, in Wyoming Geol. Assoc. Guidebook 11th Ann. Field Conf., Jackson Hole, 1956 : p. 76-94.

- 1956b, New geologic formation names in Jackson Hole, Teton County, northwestern Wyoming: Am. Assoc. Petroleum Geologists Bull., v. 40, no. 8, p. 1899-1914.

- 1957, Stratigraphy and correlation of Triassic rocks in central Wyoming, in Wyoming Geol. Assoc. Guidebook 12th Ann. Field Conf., Southwest Wind River Basin, 1957 ; p. $39-45$.

- 1960, Cenozoic sedimentation and crustal movement in Wyoming: Am. Jour. Sci., v. 258-A (Bradley Volume), p. 204-214.

1961a, Definition of Green River, Great Divide, and Washakie basins, southwestern Wyoming: Am. Assoc. Petroleum Geologists Bull., v. 45, no. 10, p. 1749-1755.

- 1961b, Split Rock Formation (Miocene) and Moonstone Formation (Pliocene) in central Wyoming: U.S. Geol. Survey Bull. 1121-I, p. I1-I39.

— 1964, Uraniferous phosphatic lake beds of Eocene age in intermontane basins of Wyoming and Utah: U.S. Geol. Survey Prof. Paper 474-E, p. E1-E66.

Love, J. D., Johnson, C. O., Nace, H. L., Sharkey, H. H. R., Thompson, R. M., Tourtelot, H. A., and Zapp, A. D., 1945, Stratigraphic sections and thickness maps of Triassic rocks in central Wyoming: U.S. Geol. Survey Oil and Gas Inv. Prelim. Chart 17.
Love, J. D., McGrew, P. O., and Thomas, H. D., 1963, Relationship of latest Cretaceous and Tertiary deposition and deformation to oil and gas in Wyoming, in The backbone of the Americas-Tectonic history from pole to pole-a symposium: Am. Assoc. Petroleum Geologists Mem. 2, p. 196-208.

Love, J. D., Thompson, R. M., Johnson, C. O., Sharkey, H. H. R., Tourtelot, H. A., and Zapp, A. D., 1945, Stratigraphic sections and thickness maps of Lower Cretaceous and nonmarine Jurassic rocks of central Wyoming: U.S. Geol. Survey Oil and Gas Inv. Prelim. Chart 13.

Love, J. D., Tourtelot, H. A., Johnson, C. O., Sharkey, H. H. R. Thompson, R. M., and Zapp, A. D., 1945, Stratigraphic sections and thickness maps of Jurassic rocks in central Wyoming: U.S. Geol. Survey Oil and Gas Inv. Prelim. Chart 14.

Love, J. D., Tourtelot, H. A., Johnson, C. O., Thompson, R. M., Sharkey, H. H. R., and Zapp, A. D., 1947, Stratigraphic sections of Mesozoic rocks in central Wyoming: Wyoming Geol. Survey Bull. 38, 59 p.

Love, J. D., and Weitz, J. L., 1951, Geologic map of southcentral Wyoming, in Wyoming Geol. Assoc. Guidebook 6th Ann. Field Conf., South-central Wyoming, 1951: insert map.

Love, J. D., Weitz, J. L., and Hose, R. K., 1955, Geologic map of Wyoming: U.S. Geol. Survey.

Lovering, T. S., 1929, The Rawlins, Shirley, and Seminoe iron-ore deposits of Carbon County, Wyoming: U.S. Geol. Survey Bull. 811-D, p. 203-235, 5 pls., 1 fig.

Lugn, A. L., 1939, Classification of the Tertiary System in Nebraksa: Geol. Soc. America Bull., v. 50, no. 8, p. 12451275.

McGrew, L. W., 1956, Map of Wyoming showing test wells for oil and gas, anticlines, oil and gas fields, and pipelines: U.S. Geol. Survey Oil and Gas Inv. Map OM-175.

McGrew, P. O., 1951, Tertiary stratigraphy and paleontology of south-central Wyoming, in Wyoming Geol. Assoc. Guidebook 6th Ann Field Conf., South-central Wyoming, 1951 : p. 54-57.

- 1953, Tertiary deposits of southeastern Wyoming, in Wyoming Geol. Assoc. Guidebook 8th Ann. Field Conf. Laramie Basin, Wyoming, and North Park, Colorado, 1953 : p. 61-64.

1957, The Bison Basin mammal fauna, in Wyoming Geol. Assoc. Guidebook 12th Ann. Field Conf., Southwest Wind River Basin, 1957 : p. 94-96.

1961. The Rawlins mammoth, in Wyoming Geol. Assoc. Guidebook 16th Ann. Field Conf., Symposium on Late Cretaceous rocks, Wyoming and adjacent areas, 1961: p. 315-317.

McGrew, P. O., and Roehler, H. W., 1960, Correlation of Tertiary units in southwestern Wyoming, in Wyoming Geol. Assoc. Guidebook 15th Ann. Field Conf., Overthrust belt of southwestern Wyoming and adjacent areas, 1960: p. 156-158.

McKelvey, V. E., Everhart, D. L., and Garrels, R. M., 1955 , Origin of uranium deposits, in Pt. 1 of Bateman, A. M., ed., Economic geology, 50th anniversary volume, 19051955: Urbana, Ill., Econ. Geology Pub. Co., p. 464-533.

McKenna, M. C., 1965, Stratigraphic nomenclature of the Miocene Hemingford Group, Nebraska: Novitates, no. 2228, 21 p. 
Mallory, W. W., 1962, Pathfinder uplift of Pennsylvanian age in southern Wyoming, in Short papers in geology, hydrology, and topography: U.S. Geol. Survey Prof. Paper 450-E, p. E57-E60.

Marshall, C. H., 1959a, Photogeologic map of the Crooks Creek SE quadrangle, Fremont and Sweetwater Counties, Wyoming: U.S. Geol. Survey Misc. Geol. Inv. Map I-304. 1959b, Photogeologic map of the Crooks Creek SW quadrangle, Fremont and Sweetwater Counties, Wyoming: U.S. Geol. Survey Misc. Geol. Inv. Map I-305.

1959c, Photogeologic map of the Split Rock SW quadrangle, Fremont and Sweetwater Counties, Wyoming: U.S. Geol. Survey Misc. Geol. Inv. Map I-306.

Mason, Brian, 1958, Principles of geochemistry [2d ed.] : New York, John Wiley \& Sons, Inc., $310 \mathrm{p}$.

Masursky, Harold, 1962, Uranium-bearing coal in the eastern part of the Red Desert area, Wyoming: U.S. Geol. Survey Bull. 1099-B, p. B1-B152.

Meek, F. B., and Hayden, F. V., 1858, Descriptions of new species and genera of fossils, collected by Dr. F. V. Hayden in Nebraska Territory **; with some remarks on the Tertiary and Cretaceous formation of the north-west * * : Philadelphia Acad. Nat. Sci., Proc. 1857, v. 9, p. 117-148.

1862, Descriptions of new Lower Silurian (Primordial), Jurassic, Cretaceous, and Tertiary fossils, collected in Nebraska Territory, with some remarks on the rocks from which they were obtained: Philadelphia Acad. Nat. Sci., Proc., 1861, v. 13, p. 415-447.

Melbye, C. E., 1957, Structural control of Crooks Gap $\mathrm{U}_{8} \mathrm{O}_{8}$ gives clues for Wyoming prospectors: Mining World, v. 19, no. 12, p. 54-57, 108-109.

Melin, R. E., 1964, Description and origin of uranium deposits in Shirley Basin, Wyoming: Econ. Geology, v. 59, no. 5, p. 835-849.

Montagne, John de la, 1954, Tertiary structure, fauna, and lithology in the upper Saratoga Valley-Big Creek Park area, Wyoming and Colorado [abs.]: Geol. Soc. America Bull., v. 65, no. 12, pt. 2, p. 1384.

Montagne, John de la, and Barnes, W. C., 1957, Stratigraphy of the North Park Formation in the North Park area, Colorado, in Rocky Mountain Assoc. Geologists Guidebook to the geology of North and Middle Parks basins, Colo., 1957 : p. 55-60.

Nace, R. L., 1939, Geology of the northwest part of the Red Desert, Sweetwater and Fremont Counties, Wyoming: Wyoming Geol. Survey Bull. 27, 51 p.

Oriel, S. S., 1962, Main body of Wasatch . Formation near La Barge, Wyoming: Am. Assoc. Petroleum Geologists Bull., v. 46, no. 12, p. 2161-2173.

Osterwald, F. W., 1961, Critical review of some tectonic problems in Cordilleran foreland: Am. Assoc. Petroleum Geologists Bull., v. 45, no. 2, p. 219-237.

Osterwald, F. W., and Dean, B. G., 1961, Relation of uranium deposits to tectonic pattern of the Central Cordilleran Foreland: U.S. Geol. Survey Bull. 1087-I, p. 337-390.

Osterwald, F. W., Osterwald, D. B., Long, J. S., Jr., and Wilson, W. H., 1959, Mineral resources of Wyoming: Wyoming Geol. Survey Bull. 50, $259 \mathrm{p}$.

Pipiringos, G. N., 1955, Tertiary rocks in the central part of the Great Divide Basin, Sweetwater County, Wyoming, in Wyoming Geol. Assoc. Guidebook 10th Ann. Field Conf., Green River Basin, 1955 : p. 100-104.
1961, Uranium-bearing coal in the central part of the Great Divide Basin: U.S. Geol. Survey Bull. 1099-A, 104 p. [1962].

- 1968, Correlation and nomenclature of some Triassic and Jurassic rocks in south-central Wyoming: U.S. Geol. Survey Prof. Paper 594-D, $26 \mathrm{p}$.

Rachou, J. F., 1951, Tertiary stratigraphy of the Rattlesnake Hills, central Wyoming: Laramie, Wyoming Univ., Master's thesis, $70 \mathrm{p}$

Radinsky, Leonard, 1963, Origin and early evolution of North American Taperoidea: Peabody Mus. Nat. History Bull. $17,106 \mathrm{p}$.

Ray, R. G., 1960, Aerial photographs in geologic interpretation and mapping: U.S. Geol. Survey Prof. Paper 373, 230 p.

Reed, K. M., 1960, Insectivores of the middle Miocene Split Rock local fauna, Wyoming: Breviora, no. 116, p. 1-11. 1961, The proscalopinae, a new subfamily of talpid insectivores: Harvard Univ. Mus. Comp. Zoology Bull., v. 125 , no. 14, p. 473-494.

Reeside, J. B., Jr., chm., and others, 1957, Correlation of the Triassic formations of North America, exclusive of Canada: Geol. Soc. America Bull., v. 68, no. 11, p. 14511513.

Renaud, E. B., 1932, Archaeological survey of eastern Wyoming, summer 1931: Denver Univ, and Wyoming Univ. $91 \mathrm{p}$.

Rich, E. I., 1956, Hiland-Clarkson Hill area, Natrona County, Wyoming, in Geologic investigations of radioactive deposits-Semiannual progress report, June 1 to Nov. 30 1956 : U.S. Geol. Survey TEI-640, p. 121-125, issued by U.S. Atomic Energy Comm. Tech. Inf. Service, Oak Ridge, Tenn.

1957, Hiland-Clarkson Hill area, Wyoming, in Geologic investigations of radioactive deposits-Semiannual progress report, Dec. 1, 1956 to May 31, 1957: U.S. Geol. Survey TEI-690, p. 276-279, issued by U.S. Atomic Energy Comm. Tech. Inf. Service, Oak Ridge, Tenn. 1962, Reconnaissance geology of Hiland-Clarkson Hill area, Natrona County, Wyoming: U.S. Geol. Sarvey Bull. 1107-G, p. 447-540.

Riva, J. P., Jr., 1959, The geology of the Sheep Creek-Middle Cottonwood Creek area, Fremont County, Wyoming: Laramie, Wyoming Univ., Master's thesis, $82 \mathrm{p}$.

Robinson, Peter, Black, C. C., and Dawson, M. R., 1964, Late Eocene multituberculates and other mammals from Wyoming: Science, v. 145 , no. 3634, p. 809-811.

Rosholt, J. N., 1958, Radioactive disequilibrium studies as an aid in understanding the natural migration of uranium and its decay products, in United Nations, Survey of raw material resources: Internat. Conf. Peaceful Uses of Atomic Energy, 2d, Geneva, 1958, Proc., v. 2, p. 230-236.

Rosholt; J. N., Garner, E. L., and Shields, W. R., 1964, Fractionation of uranium isotopes and daughter products in weathered granite and uranium-bearing sandstone, Wind River basin region, Wyoming, in Geological Survey research 1964: U.S. Geol. Survey Prof. Paper 501-B, p. B84-B87.

Rosholt, J. N., Harshman, E. N., Shields, W. R., and Garner, E. L., 1964, Isotopic fractionation of uranium related to roll features in sandstone, Shirley Basin, Wyoming: Econ. Geology, v. 59, no. 4, p. 570-585.

Schultz, A. R., 1920, Oil possibilities in and around Baxter Basin, in the Rock Springs uplift, Sweetwater County, Wyoming : U.S. Geol. Survey Bull. 702, 107 p. 
Schultz, C. B., and Falkenbach, C. H., 1940, Merycochoerinae, a new subfamily of oreodonts: Am. Mus. Nat. History Bull., v. 77, p. 213-306

1949, Promerycochoerinae, a new subfamily of oreodonts: Am. Mus. Nat. History Bull., v. 93, p. 69-198.

Shapiro, I.eonard, and Bramnock, W. W., 1956, Rapid analysis of silicate rocks: U.S. Geol. Survey Bull. 1036-C, p. 19-56.

Sheldon, R. P., Waring, R. G., Warner, M. A., and Smart, R. A., 1953, Stratigraphic sections of the Phosphoria Formation in Wyoming: U.S. Geol. Survey Circ. 307, $45 \mathrm{p}$.

Sheridan, D. M., Maxwell, C. H., and Collier, J. T., 1961, Geology of the Lost Creek schroeckingerite deposits, Sweetwater County, Wyoming: U.S. Geol. Survey Bull. 1087-J, p. 39.1-478 [1962].

Sinclair, W. J., and Granger, Walter, 1911, Eocene and Oligocene of the Wind River and Bighorn Basins [Wyo.] : Am. Mus. Nut. History Bull., v. 30, p. 83-117.

Smith, E .E., 1909, The eastem part of the Great Divide basin coal fleld, Wyoming, in Coal fields of Wyoming: U.S. Geol. Survey Bull. 341-B, p. 220-242.

Sohn, I. G., 1956, Pliocene ostracodes from Jackson Hole, Wyoming, in Wyoming Geol. Assoc. Guidebook 11th Ann. Field Conf., Jackson Hole, 1956 : p. 120-122.

Soister, P. E., 1958, Preliminary stratigraphy of Wind River Formation in Gas Hills area [Wyo.], in Geologic investigations of radioactive deposits-Semiannual progress report, Dec. 1, 1957 to May 31, 1958: U.S. Geol. Survey TEI-740, p. 112-120, issued by U.S. Atomic Energy Comm. Tech. Inf. Service, Oak Ridge, Tenn

Spencer, A. C., 1916, The Atlantic gold district, Fremont County, Wyoming: U.S. Geol. Survey Bull. 626, p. 9-45.

Stephens, T. G., 1964, Geology and uranium deposits at Crooks Gap, Fremont County, Wyoming, with a section on Gravity and seismic studies in the Crooks Gap area, by D. I. Healy : U.S. Geol. Survey Bull. 1147-F, 82 p.

Stephens, J. G., and Bergin, M. J., 1959, Reconnaissance investigation of uranium occurrences in the Saratoga area, Carbon County, Wyoming: U.S. Geol. Survey Bull. 1046-M, p. 321-338.

Stokes, W. I., and Varnes, D. J., 1955, Glossary of selected geologic terms, with speciul reference to their use in engineering: Colorado Sci. Soc. Proc., v. 16, 165 p.

Swain, B. W., 1957, Fort Union Formation, west flank of the Sierra Madre, Carbon County, Wyoming [abs.]: Geol. Soc. America Bull., v. 68, no. 12, pt. 2, p. 1874.

Thompson, R. M., Love, J. D., and Tourtelot, H. A., 1949, Stratigraphic sections of pre-Cody Upper Cretaceous rocks in central Wyoming: U.S. Geol. Survey Oil and Gas Inv. Prelim. Chart 36.

Thompson, R. M., and White, V. L., 1952, Geology of the Conunt Creek-Muskrat Creek area, Fremont County, Wyoming: U.S. Geol. Survey open-flle report. - 1954, Geology of the Riverton area, central Wyoming: U.S. Geol. Survey Oil and Gas Inv. Map OM-127.

Tourtelot, H. A., 1957, Geology, Pt. 1 of The geology and vertelinte puleontology of upper Eocene strata in the northenstern part of the Wind River basin, Wyoming: Smithsonian Misc. Colln., v. 134, no. 4, p. 1-27.

- 1962, Preliminary investigation of the geologic setting and chemical composition of the Pierre Shale, Great Plains region: U.S. Geol. Prof. Paper 390, 74 p.
Trumbull, L. W., 1914, Atlantic City gold mining district, Fremont County [Wyo.]: Wyoming Geol. Survey Bull. 7, ser. B, p. 72-100.

U.S. Geological Survey, 1958, Suggestions to authors of the reports of the United States Geological Survey: 5th ed., U.S. Govt. Printing Office, 255 p.

U.S. Weather Bureau, 1960, Climatography of the United States, Wyoming: U.S. Weather Bureau, no. 60-48, 16 p.

Van Houten, F. B., 1950, Geology of the western part of the Beaver Divide area, Fremont County, Wyoming: U.S. Geol. Survey Oil and Gas Inv. Map OM-113.

- 1954, Geology of the Long Creek-Beaver Divide area, Fremont County, Wyoming: U.S. Geol. Survey Oil and Gas Inv. Map OM-140.

- 1955, Volcanic-rich middle and upper Eocene sedimentary rocks northwest of Rattlesnake Hills, central Wyoming: U.S. Geol. Survey Prof. Paper 274-A, 14 p.

- 1964, Tertiary geology of the Beaver Rim area, Fre mont and Natrona Counties, Wyoming: U.S. Geol. Survey Bull. 1164, 99 p. [1965].

Van Houten, F. B., and Weitz, J. L., 1956, Geologic map of the eastern Beaver Divide-Gas Hills area, Fremont and Natrona Counties, Wyoming: U.S. Geol. Survey Oil and Gas Inv. Map OM-180.

Weimer, R. J., and Guyton, J. W., 1961, Geology of the Muddy Gap-Lamont area, Wyoming, in Wyoming Geol. Assoc. Guidebook 16th Ann. Field Conf., S.mposium on Late Cretaceous rocks, Wyoming and adjacent areas, 1961: p. 139-147.

Weitz, J. L., and Love, J. D., 1952, Gcologic map of Carbon County, Wyoming: Wyoming Geol. Survey.

Weitz, J. L., Love, J. D., and Harbison, S. A., 1954, Geologic map of Natrona County, Wyoming: Wyoming Geol. Survey.

Wheat, C. I., 1958, Mapping the Trans-Mississippi West, 15401861: Grabhorn Press, San Francisco Inst. Hist. Cartography, v. 2, 281 p. ; v. 3, 349 p.

Wilmarth, M. G., 1938, Lexicon of geologic names of the United States (including Alaska): U.S. Geol. Survey Bull. 896, 2396 p.

Wilson, R. W., 1960, Early Miocene rodents and insectivores from northeastern Colorado: Kansas Univ. Paleont. Contr., art. 7, $92 \mathrm{p}$.

Wood, H. E., 2d, 1934, Revision of the Hyrachyidae: Am. Mus. Nat. History Bull., v. 67, p. 181-295.

- 1948, Section at Beaver Divide, in McGrew, P. O., ed., Society of Vertebrate Paleontology Guidebook 3d Ann. Field Conf., Southeastern Wyoming, 1948: p. 37-41.

Wood, H. E., and others, 1941, Nomenclature and correlation of the North American continental Tertiary: Geol. Soc. America Bull., v. 52, no. 1, p. 1-48.

Wyant, D. G., Sharp, W. N., and Sheridan, D. M., 1956, Reconnaissance study of uranium deposits in the Red Desert, Sweetwater County, Wyoming: U.S. Geol. Survey Bull. 1030-I, p. 237-308.

Wyoming Geological Association, 1962, Wyoming oil and gas fields: Wyoming Geol. Assoc., 579 p., with supplement.

Yenne, K. A., and Pipiringos, G. N., 1954, Stratigraphic sections of Cody shale and younger Cretaceous and Paleocene rocks in the Wind River Basin, Fremont County, Wyoming: U.S. Geol. Survey Oil and Gas Inv. Chart OC-49. 
Zapp, A. D., and Cobban, W. A., 1962, Some Late Cretaceous strand lines in southern Wyoming; in Short papers in geology, hydrology, and topography: U.S. Geol. Survey Prof. Paper 450-D, p. D52-D55.

Zeller, H. D., 1957, The Gas Hills uranium district and some probable controls for ore deposition, in Wyoming Geol.
Assoc. Guidebook 12th Ann. Field Conf., Southwest Wind River Basin, 1957 : p. 156-160.

Zeller, H. D., Soister, P. E., and Hyden, H. J., 1956, Preliminary geologic map of the Gas Hills uranium district, Fremont and Natrona Counties, Wyoming: U.S. Geol. Survey Mineral Inv. Map MF-83. 


\section{INDEX}

[Itallc page numbers indicate major references]

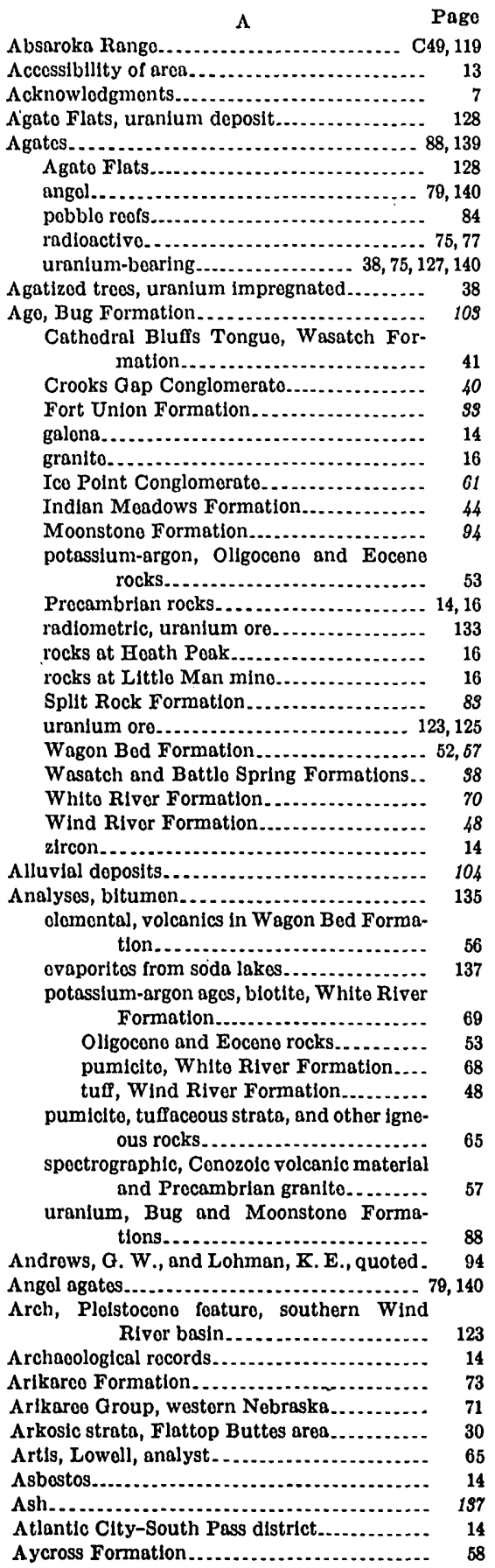

\section{B $\quad$ Page}

Badlands ....................... $12,46,50,68$ elephant-back

Bare Ring Butte. ....................................

Bridger Formation.

Bare Ring Butte graben

Barlow, I. H. analyst

Barren Butte_............................... 100

Bartel, Ardith, analyst. Battle Spring Formations.

Bear Spring, uranium deposit............... 127

Beaver Creek thrust fault

Beaver Creek thrust fault.................. 106, 117

Beaver Divide................................

River Formation.............. 62, 63, 70

Bentonite.................................. 46

Big Sand Draw, uranium deposits $\ldots \ldots . . . .126$

Big Sand Draw Sandstone Lentil, White River Formation............. 62, 63, 70

Blotite, White River Formation, potassiumargon ages........................

Bison Basin .

Fort Unjon Formation................

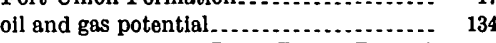

Bison Basin-Antelope-Bare Ring (Barren) Butte anticlinal complex ......... 107, 134

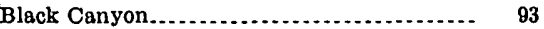

Black Mountain, pegmatite spodumene...... 14

Black shale member, Moonstone Formation.. 90, 99

Botts, S. D., analyst..................... 65

Boulders, giant.......................... 39, 54, 118

Breccia, late basic......................... 71

Bridger formation, Cyclone Rim............ 33

Bridger Formation. ................. 50, 58,61

Browns Park Formation.................. 71, 83, 99

Bug Formation........................... 100

age .................................... 109

compared with Moonstone Formation... 102

correlation................................. 108

distribution. . ................................ 100

lithology ............................. 100

source of evaporite....................... 138

stratigraphic and structural relations..... 102

stratigraphic section................... 100, 102

thickness $\ldots$

thorium........................ 100, 102,134

uranium.......................... 100, 102, 129

uranium analyses. 88

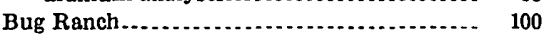
uranium deposit............................ 129

Bull Canyon, jade boulders.................. 139

Cameron Spring area, fossil mullusks........ $\quad 71$ Cannonball seaway......................... $\quad 115$ Carbonaceous bed, Oligocene................ 68 Carnotite................................. 127 Carter Mountain. ........................... 58 Casper arch........................ 44, 107,116, 117 Cathedral Bluffs Tongue, Wasatch Formation...................... 40, 41,126
Battle Spring Formation. See Wasatch and
Page

Chappo Member, Wasatch Formation....... C39 Chloe, Gillison, 8nalyst.................... 65

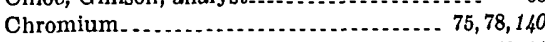
Clarkson Hill.................................. 43,44 uranium deposit. ...................... 126

Clay minerals. . ........................... 197

Climate.................................... 14 Eocene............................. 116, 117, 118, 119 Late Cretaceous........................ 115 Oligocene............................... 119 Paleocene.................................. 115 Pleistocene............................ 122

Clinoptilolite.............................. 49, 53, 137

Coal, Fort Union Formation. . . ............. occurrence and amount................... 196 radioactive. ............................... 134 uraniferous. ............................... 130 Wasatch and Battle Spring Formations..- $\quad 35$

Wasatch and Battle Spring Formations...
Colter Formation............................... 78,84 Conant Creek, Pleistocene ash near head.... 103, 137 uranium depositConant Creek anticline, oil.................... 136 Conklin, N. M., analyst..................... 57 Continental normal fault................ 107, 120, 123 Continental Peak Formation of Nace.......... 61

Copper................................... 14, 78, 141

Correlation, Bug Formation................. $10 s$ Cathedral Bluffs Tongue, Wasatch Formation..........................

Crooks Gap Conglomerate.................

Fort Union Formation. .................

Ice Point Conglomerate...................

Indian Meadows Formation...............

Moonstone Formation.....................

Oligocene and younger Cenozoic rocks....

Split Rock Formation

Wagon Bed Formation.

Wasatch and Battle Spring Formations. -

White River Formation...............

Wind River Formation.....................

Corundum

Cretaceous, Late, geologic history ........... 114

Crooks Gap, geologic column in reverse....... $\quad 35$ gravel..................................... 141 uranlum................................. 7,124

Crooks Gap Conglomerate................... age ................................................... correlation.......................................... distribution

jade boulders

lithology

stratigraphic and structural relations.

(ns.....

thickness....................................

Crooks Gap district, uranium.............. 37, 124

Crooks Mountain............................. 38, 39 jade boulders ............................. 139

Crystalline facies, Beaver Divide Conglomerate Member, White River Formation.-... 63

Cyclone Rim..................................... Bridger formation............................ meta-autunite. 
Page

Cyclone Rim syncline............... C74, 83, 107, 118 soda lake ............................ 137

D

Devils Gate fossil locality

Dikes, mafic.

pegmatite.

Distribution, Bug Formation

Cathedral Bluffs Tongue, Wasatch Formation...........................

Crooks Gap Conglomerate...............

Fort Union Formation. -

Ice Point Conglomerate..................

Indian Meadows Formation

Moonstone Formation.

Split Rock Formation.

Wagon Bed Formation.

Wasatch and Battle Spring Formations.

White River Formation

Wind River Formation

Drainage.

Dry Lakes, uranium deposit.

Dune coal zone.

Dune sand, pink

Dysprosium...........................................

$\mathbf{E}$

East Kirk normal fault Elemental excesses and deficiencies...... 56,118, 119

Elmore, P. L. D., analyst.................. 65

Emigrant Trail thrust fault..... 40,45, 48, 69,107, 116 mineralization............................ 140 uranium along

Endlich, F. M., quoted................. 8,15

Eocene geologic history..................... 116

Eocene rocks igneous. ..................... 105 sedimentary

Erbium

Erionite ..................................... 49, 53, 137

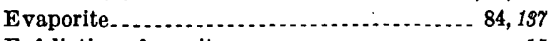

Exfollation of granite....................... 15

Exploration, uranium, further warranted..... 199

$$
\text { F }
$$

Fennelly, E. J., analyst. $\ldots . \ldots \ldots \ldots \ldots \ldots \ldots \ldots$

Ferris Mountains, dark-green jade........... 139

Flattop Butte.............................. 60

Flattop Buttes area arkosic strata ........... 30

Flattop fault............ 42, 58, 107, 117, 119, 120, 122

Fort Union Formation, age.................. $s 8$ Bison Basin.

coal.

Fort Union Formation, corretion

defined

distribution.............................. 17

fossils.................................. 17, 30, 33

glauconite.............................. 35

gravel.................................. 141

ground-water potential.................. 141

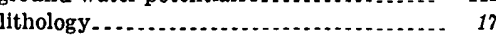

oil....................................... 136

possible oil and gas traps................ 116

stratigraphic and structural relations.....

thickness................................

Tiffanian provincial age fauna.

unconformities. ................

Fossils, Acer.

Achnanthes lanceolata...................

linearis...

peragallii..................................... sp....

Alangium.

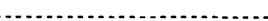

Aletomeryx sp...............................

algae.

Alnus.
Fossils-Continued

Alticamelus altus

elrodi

giraffinus............................

stocki...

Amphora ovalis

sp. A............................. 94

Anomoeoneis costata. .................... 96, 103

polygramma..

sculpta.......

sphaerophora

biceps.

guntheri.

sculpta.

sp. A

spp

Aplexa................................ 58,71

Appendicisporites...................... 99

Aquilapollenites....................... 99

spinulosus ........................... 30

Artemisia......... 80

Betulaepollenites....................... 30

Biomphalaria pseudoammonius............ 58, 71

Blastomeryx sp........................ 81

Botryococcus........................... 99

Brachycrus rusticus................... 80

sweetwaterensis . ...................... 80,81

vaughani.......................... 80,81

Brachyhyops wyomingensis............... 70

Brontops............................... 61

Caloneis bacillum.......................... 96

formosa.

schumanniana...................... 96

silicula gibberula....................... 96

camel.....................................

Camelops................................. 96

Campylodiscus clypeus. . . . . . . . . . . . . 96, 103

sp................................ 96

Carya

(30,

Caytoniapollenites.......................... 99

Chenopodiaceae....................... 30,80, 99

Cicatricosisporites....................... 99

Compositae. .......................... 80, 99

crocodile scutes.

Cyclotella compta......................... 96

(triatampla-

Cylindrodon brownii

$$
\text { fontis. }
$$

Cymatopleura elliptica

Cymbella aequalis.

austriaca

cistula.-

cuspidata..

ehrenbergii.

hauckii.

mexicana

parva

tumida:

turgidula

ventricosa.

sp...

Cynodesmus canavus.

(n)

Denticula elegans kittoniana

kittoniana...

tenuis intermedia.

thermalis.

Desmatolagus schizopetrus

Diatoma anceps. vulgare producta...................... 96 sp...

diatoms...

oldest fresh-water

Dikkomys sp...

Dinoflagellata.

Discus.
Fossils-Continued Page

Eleagnus............................... C98

Eometarhinus ervayensis.................. 58

Ephedra nevadensis. ...................... 80,98 torreyana............................ 99

Epithemia argus..........................

argus ocellata..............................

zebra porcellus.

sp. A sp.

Eunotia lunaris..

lunaris capitata.. subarcuat

pectinalis.

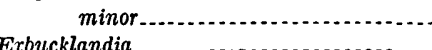

Fort Union Formation.................... fruits and nuts.

Fragilaria leptostauron. pinnata.

virescens

sp. A

$\mathrm{spp}$

Frustulia vulgaris

Gastrocopta

gastropods.

Gomphonema acuminatum trigonocephala. angustatum

intricatum

longiceps subclavata. ..................

parvulum...........................

sp.A.............................. 94, 97

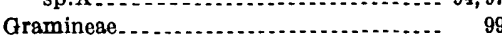

Gregory mys sp..........................

Hantzschia amphioxys

amphioxys vivax

sp..

Helaletes nanus.

(1)

hoplophonid

horse tooth . ......................... 91,99

Hymenozonotriletes reticulatus.............. 99

Hypolagus sp...............................

Hyracodon leidyanus.......................

Ice Point Conglomerate. ................. 6

Inoceramus. ............................ 83,99

Ischyromys sp............................. 67

Juglans.................................. 58

Juniperus. . ............................. 80,99

Lambdotherium popoagicum............... 48

Leporid................................. 81

Leptomeryx esulcatus.

Limnoecus sp.

lizards.

Lymnaea.

meekiana.

shumardi.

similis

(Pseudosuccinea) sp.

Mastogloia elliptica dansei

Melosira distans

italica.

undulata

sp.A

sp.

Menodus heloceras.

(n)

Meridion circulare

Merycoides cursor......................... 75,83

Mesogaulus novellus. .................... 80

praecursor........................ 80

Mesohippus hypostylus....................

Mesoscalops scopelotemos.................. 80

Metarhinus............................ 58

Metechinus marslandensis................ 80 


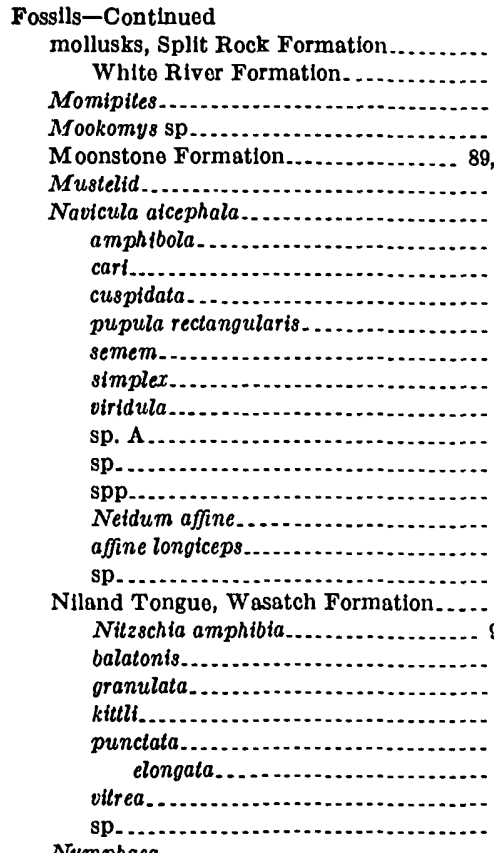

Nymphaea.

Oligoryctes cameronensis

(l)

Opephora martyi................................... sp.

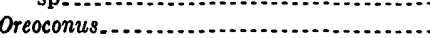

Oreodontoides curtus. .....................

Oreolagus nebrascensis......................

Orohippus sp............................. 59

ostracodes............................. 42, 58, 58, 88

Oxydactylus longipes...................... 77

oysters............................... 93

Paleolagus temnodon...................... $\quad 67$

Parahyus vagus................................ 58

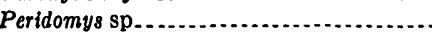

Perognathus sp...............................

Picea.

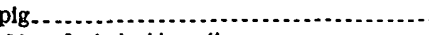

Pinnularia brebissonii.....................

brevicostata.

divergentissima..........................

macilenta............................. 98

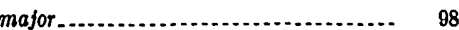

microstauron................................

nodosa.

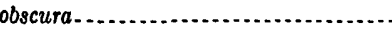

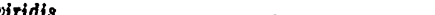

spp.................................... 98

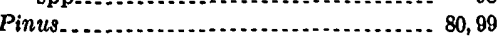

Pinuspollenites _......................... $\quad 30$

Pistillipollenites............................ $\quad 30$

Platycarya......

Pleurolicus sp........................... 81

Podosira sp.

pollen, black shale member, Moonstone Formation.....................

Paleocene

Polygyridac.............................. 67,71

Procamelus madisonius.................... 96

Procamelus robustus...................... 96

Proteacidites............................ 30,99

Protospermophilus sp.................... 81

Pseudocylindrodon wyomingensis........... $\quad 67$

Pseudosuccinea sp........................ $\quad 76$

Pterospermopsis........................ 99

Pupillidae............................... 67,71

Quercus.................................. 58,99

elwyni.

70
Fossils-Continued

Page

rabbit

$\mathrm{C} 91,9$

Red Desert Tongue, Wasatch Formation.

Rhopalodia gibba

gibba ventricosa

gibberula.

margaritifera

succincta

Rhus.

musculus

obscura

rodent.

rubber boa

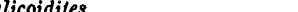

Salix -

Sarcobatus 80,99

Schaubeumys sabrae....................... 8

Scirpus.............................................

Scoliopleura peisonis

Sequoiapollenites.

Split Rock Formation

Sporites arcifer...........................

Stauroneis phoenicenteron. ................

sp. A............................. 94, 98 sp.-. 98

Surirella ovata................... 98 striatula............................ 98 sp. A ................................. 94, 98

Synedra ulna........................... 98

sp..............................................

$\mathrm{sp}$

Tamias sp

Taxodiaceae.

Tetracyclus pagesii.

stella

$$
\text { sp.... }
$$

titanothere...

Tomarctus rurestris.

Triatriopollenites coryphaeus

Tricolporopollenites sat zyvensis............

turtle.................................... 47,67

Ulmipollenites......................... 30

Ulmus..................................... 58, 99

Ulmus Zelkova.

unnamed Pliocene or Pleistocene rocks.

Wagon Bed Formation.

Formation

Wind River Formation....................

wood

black petrified.........................

Zelkova

a

Gadolinium............... 49, 52

Gadolinima, 14

Galena, age.................................... 14

areas of potential interest...............

Gas Hills area, dark-green jade............... 139

Gas Hills district, uranium ................. 7, 129

Geographic setting of area.................. 4

Geologic features, nomenclature problems.... 8

Geologic history ............................. 114

Geologic setting of Granite Mountain

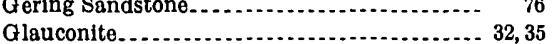

Glauconite $\ldots \ldots \ldots \ldots \ldots . . .142,35$

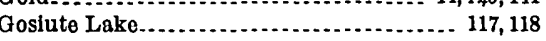

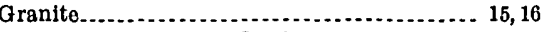

Granite Mountains, defined

discussion.

deologic setting

phases of structural evolution............. 128

Granite Mountains arch..................... 122

Gravel..................... 141

Great Divide basin ...................... 9, 109 northern part, uranium............... 126 oil and gas potential......................... 134

Green Cove beds............................ 49

Green Cove section......................... 50,52
Page

Green Mountain........................ C39

Green River Formation, Laney Shale Member. ............................ 48,61

Ground water, potential..................... 141 Gypsum..................................... 102, 138

\section{$\mathbf{H}$}

Halfway Draw Tuff Member, Wind River Formation..

Hamilton, J. C., analyst..................... 40

Hanna basin..................... 57

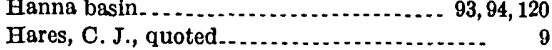

Harris, J. L., analyst. ..............................

Havens, R. G., analyst

Hawks Nest.

Hazel, K. V., analyst............................... 57

Heath Peak................................. 16, 125

Hemingford Group..................... 83

Hendry Ranch Member, Tepee Trail Formation $\ldots \ldots \ldots \ldots$

Heulandite.............................. 49, 53, 137

Historical data.

Houston, R. S., quoted....................... 106

Hydrodynamic system, relation to uranium.. 134

$$
\text { I }
$$

Ice Point Conglomerate

age

correlation.

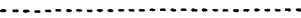

fossils.

jade boulders. ........................... $\begin{array}{r}139 \\ 59\end{array}$

stratigraphic and structural relations...... 60

thickness............................... $\quad \sigma 9$

Ice Slough, permafrost remnants............. 121

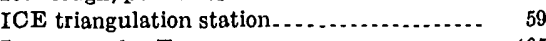

Igneous rocks, Eocene................... 105

Indian Meadows Formation.............. 38, 43, 126

Industry in area........................... 13

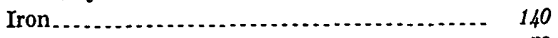

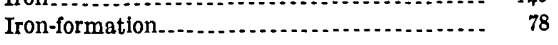

$\mathbf{J}$

Jackson Hole. .............................. 78, 84 Jade............................... 14, 37, 40,60,69, 188

K

Kasolite, Little Man mine.................. 125

Keenan, J. E., quoted..................... 138

Kirk normal fault.......................... $\quad 110$

Kortes area, uranium deposit............... 129

L-datum of Barlow. ........................ 33

Landscape, relation to human history and economic deposits................

Laney Shale Member, Green River Formation............................. 42,61

Lankin Dome............................... 16 Laramide orogeny............................. 48 Laramide Revolution.......................... 115, 116

Latites, quartz. . . . . . . . . . Lead Lead-alpha age determinations, Precambrian rocks............................. 14, 10 Lowis, G. E. quoted....................... 95

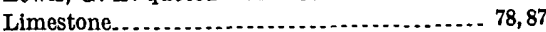
Lithology, Bug Formation................ 100 Cathedral Bluffis Tongue, Wasatch Formation..............................

Crooks Gap Conglomerate................ 89

Fort Union Formation................. 17 
Lithology-Continued Page

Ice Point Conglomerate................ C59

Indian Meadows Formation............... 49

Moonstone Formation

Split Rock Formation..................... 74

Wagon Bed Formation.................. 49

Wasatch and Battle Spring Formations...

White River Formation.................. 69

Wind River Formation................. $\quad 45$

Littlo Man mine, age of rocks....... 16 molybdenite........................... 126, 141 uranium....................................... 125

Lohman, K. E., quoted. . . . .

Lohman, K. E., and Andrews, G. W., quoted. 94

Lone Mountain

Long Creek arm, Wind River basin $\ldots . . . . . . \quad 44$,

Long Creek Valley ......................... 64

Lost Cabin Member, Wind River Formation. 38,

40,117

Lost Soldier, oil and gas potential............. 134

Lysite Member, Wind River Formation.... 38,

Lysite Mountain area

$44,45,117$

\section{M}

MacGinitie, H. C., quoted

McGrew, P. O., quoted

McIntosh Peak.

Mack, M. D., analyst.

Magnetite....

(n)...........................

Marsland Formation

Masursky, Harold, quoted.................. 33, 34

Meta-autunite, Cathedral Bluffs Tongue, Wasatch Formation.............. 126

Poison Spring Creek.................... 127

Micrometeorites............................ 78

Miocene geologic history....... .119

Mlocene rocks............................... 71

Molybdenite

Little Man mine...................... 126

Molybdenum...................... 133, 138

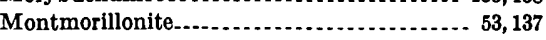

Moonshiners Spring......................... $\quad 126$

Moonstone Formation, agate reefs .......... 140

age .................................... 94

algal limestone........................... 87

black shale member........................ 90 pollen............................. 99

clay .................................. 137

compared with Bug Formation........... 102

correlation...................................

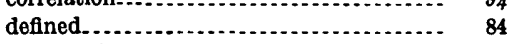

distribution............................ 84

fossils................................ 89,90,94

ground-water potential................... $\quad 141$

lithology.................................... 84

pumicite.................................. 137

salt licks.................................. 138

source of evaporite

stratigraphic and structural relations..... 94

thickness................................. 84

thorium................................... 87, 134

uranium......................... 86, 128, 129, 132 analyses............................ 88

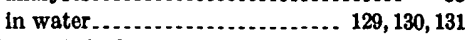
white shale bed........................ 87 Moonstone Lake. . . ........................... 120, 131

Moonstone Peak........................... 15

Mormon Trail fault.................... 57, 109, 116

Mountjoy, Wayne, analyst............... 137

Muddy Gap, uranium deposit............... 126

Mudstone marker zone.................... 30, $\$ 4,41$

$$
\mathbf{N}
$$

Nickel............................... 78

Niland Basin, uranium possibilities.. 78
134

Niland Tongue, Wasatch Formation.
Puge

North Granite Mountains fault system. C57, 109, 120 North Platte River, antecedent course... 93, 120, 123

Ogallala Formation....................... 73

Oil. ............................ 7,194

areas of potential interest................ 194

Conant Creek anticline

Fort Union Formation................. 116

migration................................... 132

Transmountain sandstone.............. 35,116

Oil and gas traps, potential ............... 115,116

Oil shale............................... 53, 117, 118

Oil staining, related to uranium.

Oligocene geologic history ................. 119

Oligocene rocks....

Omera Meadow area, fossil mollusks.......... 7

Oregon Trail.............................. 14

Oriel, S. S., quoted.

\section{$\mathbf{P}$}

Paleocene and Eocene rocks

Paleocene geologic history

Paleocene rocks.

Pearlette Ash Member, Sappa Formation.... 104

Pegmatite dikes............................ 14

Phillipsite

Phosphate, Green Cove section........... 50, 52 uraniferous............................. 49 Wagon Bed Formation.................. 126

Pipiringos, G. N., quoted................. 33, 34, 41

Pleistocene deposits............. 103

Pleistocene geologic history .................. 120

Pliocene geologic history.................$\quad 120$

Pliocene or Pleistocene rocks. . . . . . . . .

Pliocene rocks................................ 84

Poison Spider Creek, uranium deposit........ 126

Poison Spring Creek, uranium deposit........ 127

Pony Express route......................... 14

Powder River basin........................ 70

Precambrian rocks........................... 14

age........... 14,

fragments, facies of White River Formation.

nephrite jade.

precious minerals

thorium

uranium.............................. 14, 125, 126

in water. $\ldots \ldots \ldots \ldots \ldots \ldots \ldots \ldots \ldots \ldots . \ldots 14,125,126$

primary source..................... 129, 190

vermiculite........................... 141

Precious minerals, Precambrian rocks......... 140

Pre-Tertiary sedimentary rocks. ............... 17

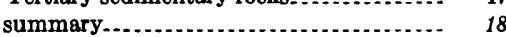

Previous investigations..................... 5

Pumicite...................................... 187

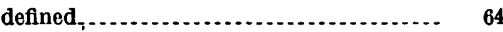

Moonstone Formation................ 89

Split Rock Formation. ................. 75,79

White River Formation, potassium-argon

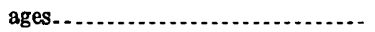

Pumpkin Buttes............................. $\quad 68$

Pyrite.............. 132, 140

Q

Quaternary deposits......................... 103

lag gravels, emerald-green jade............ 139

R

Radioactivity, coal. ........................ 35

Rattlesnake Hills, Eocene igneous rocks...... $\quad 105$ volcanic activity...................... 118, 119 volcanic centers ......................... 48

volcanic field..........................54,109

Recent geologic history

Red Boy mine, gold and silver
Page

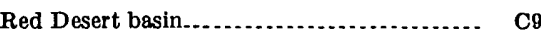

Red Desert Tongue, Wasatch Formation..... 38

Reefs, algal .................................. 79

References cited............................. 148

Reworked beds................................ 54,57

Rhabdophane.......... 134

Rubies. ......................................... 140

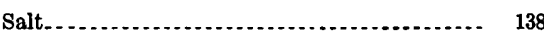
Sand ........................................ 141

Split Rock Formation, origin. ........... 120

Sand dunes.......................... 105, 120, 141

Sandstone, oil-saturated..................... 49,195 oil-saturated, uraniferous.................. 127

oil-stained radioactive. . .................. 134

volume, Split Rock Formation.......... 74

Sappa Formation, Pearlette Ash Member.... 104

Sapphires................................. 14, 140

Scandium................................. 78

Schist, graphitic............................. 125

Schroeckingerite.......................... 126, 130

Sedimentary rocks, Pre-Tertiary ............ 17

Selenium, Conant Creek. . . . . . . .

Seminoe Dam, Pleistocene ash near.......... 103, 137

Seminoe iron ore.......................... 93

Seminoe Mountains....................... 93, 139

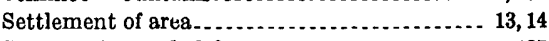

Seventy-One soda lakes........................ 137

Shale, oil. See Oil shale.

radioactive carbonaceous................. 54

white, Moonstone Formation............. 87

Sheep Creek Formation.................... 73,83

Shirley basin................................ 73

Silica, fluorescent........................... 88

Siliceous marker bed of Van Houten.......... $\quad 59$

Silver................................... 126, 140, 141

Smith, H., analyst.

Soap Holes.

Soda lakes................................ 187

South Granite Mountains fault system....... 40,41, $57,69,110,117,120$

South Pass.

South Pass area, agates in Moonstone equivalent............................ 88

South Pass-Atlantic City district............ 14

Spanish mine................................ 141

Spanish mine area........................... 14

Split Rock................................. 15

Split Rock Formation, agates................. 189

age...................................... 89

chromium ........................... 75, 140

clayey sandstone sequence................ 76

correlation.............................. 89

defined...................................... 71

distribution............................ $7 S$

fossils_................................... 71,73, 75

ground-water potential. ................... 141

limestone beds............................. 78

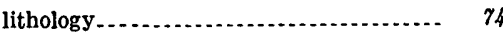

lower porous sandstone sequence.......... 74

oil........................................ 136

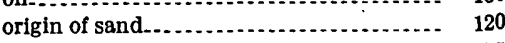

pink dune sand.......................... 75

pumicite................................ 75, 137

sand....................................... 141

silty sandstone sequence.................... 76

soda lakes................................... 137

source of evaporite......................... 138

stratigraphic and structural relations..... 89

thickness.................................. 79

upper porous sandstone sequence.......... 77

uranium............................... 128

in water ............................. 129, 130, 131

volume of sandstone.................... 74

Split Rock syncline . .... 85, 103, 111, 120, 121, 122, 123

Spodumene.............................. 14,140 
Stratigraphic and structural relations, Bug Formation...................... C10 Oathedral Bluffs Tongue, Wasatch Formation............................

Crooks Gap Conglomerate. Fort Union Formation.

Ico Polnt Conglomerate.

ws Formation...............

Moonstono Formation

Split Rock Formation.

Wagon Bed Formation

Formations.-

Wind River Formation section, black shale member Moonstone Formation.............

Bug Formation....................... 100, 102

oll-saturated strata of Wagon Bed Formatíon........................ 135

type, Halfway Draw Tuff Momber, Wind River Formation.

White River Formation, lower part.....

Structural evolution, phases...................

Structural features, summary.......................

Sulfur isotopes

Sweotwater Crossing anticline $48,60,62,119,116,117$

Sweetwater moss agates................... 77, 139

Sweetwater Plateau.......................... 12,73

Sweetwater Rlver.......................... $\quad 9,12$

Sweotwater uplift, nomenclature problem..... 8

Swinolord, Ada, quoted..................... 103

Taylor, D. W., quoted........................... Teacup Butto, partlal section of White River Formation.......................

Tepee Trail Formation, Hendry Ranch Mem ber.

Tertlary strats, depositional surface

Thickness, Bug Formation

Oathodral Bluffs Tongue, Wasatch Formation....................................

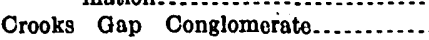

Fort Unlon Formation.

Ice Polnt Conglomerate

Indian Meadows Formation.............

Moonstono Formation.

Split Rock Formation.

gagon Bed Formation....................

Whito River Formatlon.

WInd River Formation....................

Bug Formation..................... 100, 102, 134

Moonstone Formation.................... 87, 134

Wagon Bed Formation. .................. 134

Tiernoy 5 coal................................... 136

Titanlum.

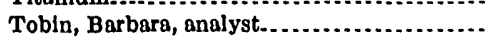

Topography...

Trachytes, soda................................. 108

Transition beds of Van Houten................. 48

Transmountain sandstone.................... 35,116

Trögerito.............. 75, 77

Agate Flats............................. 128

Dry Lakes................................ 127

Trona............. 118

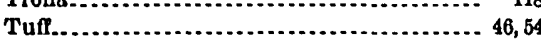

lapilll................................... 55

Tortlary, primary sourco of uranlum. .. 129, 190

vitrlc....................................

Wind Rivor Formation, potassium-argon age...
Page

Turkey Track soda lake..................... C137

Twin Springs, uranium deposit

$\mathrm{U}$

Unconformities, base of Bug Formation...... 100 base of Indian Meadows Formation...... base of Lance Formation.................. base of Laney Shale Member, Green River Formation...........................

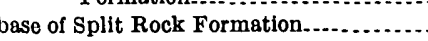
base of Wagon Bed Formation............. base of Wasatch and Battle Spring Formations.............................. base of White River Formation........... Fort Union Formation.

possible oil and gas traps...................

top of Ice Point Conglomerate...

top of Wasatch and Battle Spring Formetions........................... 38,40

White River Formation................. 64

Wind River Formation................... 45

Uplift, epeirogenic.......................... 123

Uranium, availability from Moonstone Formation on White Ridge........... 132

Bug Formation 100, 102, 129

Crooks Gap district...................... 124 derived from Precambrian rocks..... 14, 129, 190 discovery...

Gas Hills district 7,189

Green Cove section...................... 50,52

hydrothermal origin....................... 124

in agates......................... $38,75,127,140$

in water ............................. 129, 180

Indian Meadows Formation ............ 43, 126

localization......................... 123

mechanisms of entrapment and concentration...

Moonstone Formation........... 86, 128, 129, 132

Precambrian rocks $14,125,126$

prevlous studies. ......................... 123, 128

primary source. .......................... 129

production

radiometric age of ore

related to oll staining..................... 132

related to pyrite........................... 132

relation of distribution to tectonism....... 121

relation to hydrodynamic system......... 134

Split Rock Formation................... 128

syngenetic............................. 126, 128, 131

Wagon Bed Formation ........... 49, 50, 53, 126

Wasatch and Battle Spring Formations.. 37,

124,126

Wind River Formation $. . . . . . . . . . .45,123,126$

White River Formation. ................ 127

Uranium deposits, Agate Flats.............. 128

areas warrenting further exploration...... 198

Bear Spring............................ 127

Big Sand Draw.............................. 126

Bug Ranch............................ 129

Clarkson Hill. . . . . . . . . . . . . .

Conant Creek 127

Cyclone Rim. ............................. 126

Dry Lakes................................. 127

Great Divide basin, northern part........ 126

Kortes area ............................. 129

Little Man mine........................ 125

Muddy Gap.................................. 126

origin................................ 129

Polson Spider Creek-Willow Creek area.. 126

Poison Spring Creek. ..................... 127

Twin Springs. .......................... 126

White Ridge ......................... 128, 132

Uranocircite, Poison Spring Creek............ 127

Uranophane, Twin Springs.................. 126
V

Page

Van Houten, F. B., quoted.................. C49

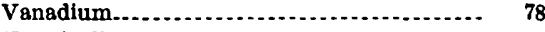

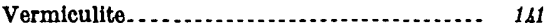

Volcanic facies, Beaver Divide Conglomerate Member, White River Formation 63

Volcanism......................... 46,118, 119, 121

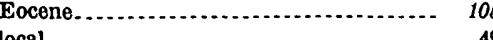

Yellowstone National Park-Absaroka re-

gion. $\ldots \ldots \ldots \ldots \ldots \ldots \ldots \ldots . .117,118$

W

Wagon Bed Formation, age................ 52,57 channels through $\ldots \ldots \ldots \ldots \ldots \ldots .6 .64,70,132$ correlation. defined.

distribution...

elemental analyses of volcanic material

fossils.

gisnt boulders.......................... 54

ground-water potential................. 141

iron..................................... 140

lithology ............................... 49

minerals.................................. 49

oll...................................... 136

oil-saturated sandstone................... 135

phosphate.............................. 126

radioactive carbonaceous shale........... 54,57

reworked beds............................ 54,57

stratigraphic and structural relations...... 56

thickness................................ 49

thorium

units, between Gas Hills and Rattlesnake Hills............................ $\sigma_{4}$

western Beaver Divide area.......... 60

uranium........................... 126, 127

Wagon Bed Spring......................... 48

Waltman Lake............................ 115, 116

Wasatch and Battle Spring Formations, age.coal......................................... 35 correlation.

defined............. 33

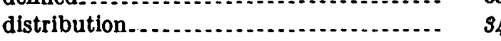

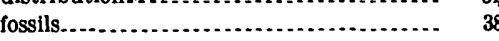

glauconite................................ 32, 35

jade boulders............................ 139

lithology

sand....................................... 141

stratigraphic and structural relations...... 38

thickness................................. 34

unconformity at base.................... 38

unconformity at top..................... 38,40

uranium.............................. 37, 124, 126

in water ........................... 130

Wasatch Formation, Cathedral Bluffs Tongue. 40,41

coal...................................... 136

Chappo Member.......................... 39

Niland Tongue......................... 38

Red Desert Tongue...................... 38

Water, ground, potential. .................... 141

uraniferous........................... 129, 130

Water biscuits................................ 87

Wenger, W. J., analyst quoted............ 135

Whiskey Peak, conglomerates................. 31

White, K. E., analyst. ...................... 65

White Ridge, uranium deposit. . . . ......... 128, 132

White River Formation, age................ 70

Beaver Divide conglomerate Member. 62, 63, 70

Big Sand Draw Sandstone Lentil...... 62, 63, 70

biotite, potassium-argon ages............. 69

channels filled by................... 69,70,132

correlation................................ 70

deffned...................................... 62

distribution. . . . 


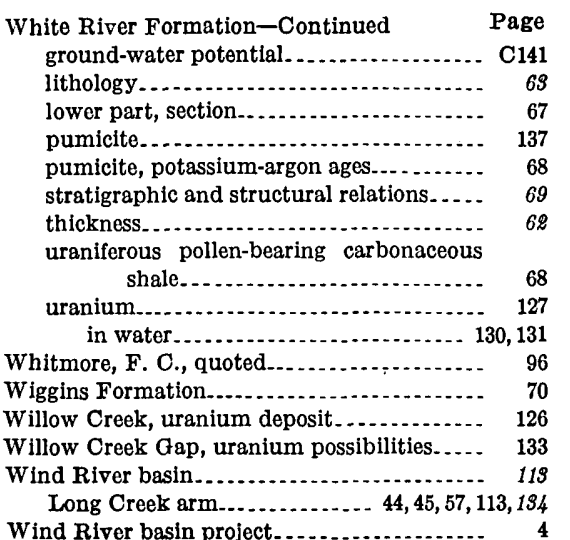

\begin{tabular}{|c|c|}
\hline & Page \\
\hline Formation & $\mathrm{C} 44$ \\
\hline age & 48 \\
\hline correlation. & 48 \\
\hline distribution. & 44 \\
\hline fossils............. & 48 \\
\hline Halfway Draw Tuff Member.. & 46 \\
\hline jade bc & 139 \\
\hline litholog & 45 \\
\hline Lost Cabin Member & 0,117 \\
\hline Lysite Member............... & \\
\hline 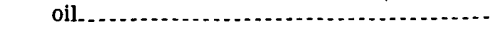 & 136 \\
\hline rubies... & 140 \\
\hline (.................... & 141 \\
\hline stratigraphic and structural relations. .... & 48 \\
\hline (2) & 44 \\
\hline uranium.......... 45 , & \\
\hline
\end{tabular}

Page

Wind River Range..................... C114, 116

Wind River structural basin defined.........

Wind River thrust fault system........... 114, 117

$\mathbf{Y}$

Yellowstone National Park-Absaroka region

volcanos

Young, E. J., quoted...................... 75

Z

Zeolites............................... 49, 53,197

Zinc......................................... 78

Zircon, age

Zirconium................................... 78 